MINISTERIE VAN ONDERWIJS, KUNSTEN EN WETENSCHAPPEN

\title{
RIJKSINSTITUUT VOOR OORLOGSDOCUMENTATIE
}

MONOGRAFIEËN Nr 2

\section{DE APRIL-MEI-STAKINGEN VAN 1943}

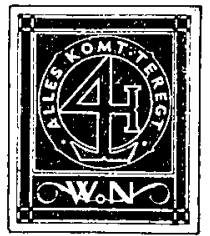

'S-GRAVENHAGE

MARTINUS NIJHOFF

1950 


\title{
DE APRIL-MEI STAKINGEN VAN 1943
}

\author{
DOOR \\ Dr P. J. BOUM A N \\ hoogleraar aan de Rijksuniversiteit \\ te Groningen
}

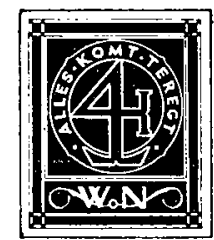

'S-GRAVENHAGE

MARTINUS NIJHOFF

1950 
Copyright I950 by Netherlands State Institute for War-Documentation, Amsterdam, Netherland

All rights reserved, including the right to translate or to reproduce book or parts thereof in any form this 


\section{N H O U D}

blz.

INLEIDING

\section{DEEL I: ALGEMEEN OVERZICHT}

Hoofdstuk 1: Voorgeschiedenis van de April-Meistakingen 1943

Hoofdstuk 2: De gebeurtenissen van 29 April tot 7 Mei 1943 en de gevolgen van de stakingsactie . . . . 18

Hoofdstuk 3: Het standpunt van de regering te Londen . . . 38

DEEL II. DE STAKING IN DE PROVINCIEN

Hoofdstuk 1: Overijsel . . . . . . . . . . . . . . 47

Hoofdstuk 2: Gelderland . . . . . . . . . . . . . 67

Hoofdstuk 3: Drente . . . . . . . . . . . . . . . 81

Hoofdstuk 4: Friesland . . . . . . . . . . . . . . 92

Hoofdstuk 5: Groningen . . . . . . . . . . . . . 105

Hoofdstuk 6: Limburg . . . . . . . . . . . . . . 119

Hoofdstuk 7: Noord-Brabant . . . . . . . . . . . . 132

Hoofdstuk 8: Zeeland . . . . . . . . . . . . . . 148

Hoofdstuk 9: Zuid-Holland . . . . . . . . . . . . 152

Hoofdstuk 10: Utrecht . . . . . . . . . . . . . . 172

Hoofdstuk 11: Noord-Holland . . . . . . . . . . . . 178

NABESCHOUWING . . . . . . . . . . . . . 187

BIJLAGEN

Bijlage I: B. A. SIJES: DE APRIL-MEI-STAKINGEN IN TWENTE . . . . . . . . . . . . . . 191 Inhoudsopgave . . . . . . . . . . . . . . . 192

Bijlage II: DOCUMENTEN . . . . . . . . . . . . 297

Lijst van afgedrukte documenten . . . . . . . . . 299

ENGLISH SUMMARY . . . . . . . . . . . . . . . . 435

REGISTER VAN GEOGRAFISCHE NAMEN . . . . . . . 457

REGISTER VAN PERSONEN EN INSTELLINGEN . . . . . 467 


\section{N L E I D I N G}

In de geschiedenis van de bezettingsjaren vormen de gebeurtenissen van eind April-begin Mei 1943 een merkwaardige episode: het eerste massale verzet van het Nederlandse volk. Er werd in grote delen van het land spontaan gestaakt, soms heftig en verbitterd, dikwijls ook enigszins aarzelend en weinig demonstratief. Het besluit van Generaal Christiansen van 29 April 1943, dat terugvoering in krijgsgevangenschap van het voormalige Nederlandse leger inhield, lokte in ieder geval verschillende reacties uit. Juist dit maakte het onderzoek moeilijk. Bij navraag bleken de herinneringen dikwijls verbleekt, vooral in de streken, waar weinig gebeurd was. En zoals het gewoonlijk gaat, de getuigenissen weerspreken elkander. De waarheid kon slechts bij benadering worden vastgesteld. Wij verwachten dus critiek en aanvullende gegevens, die het mogelijk zullen maken, in een eventuele herdruk van dit boek verschillende onnauwkeurigheden te verbeteren.

Ik moet hier afzien van een lange reeks van dankbetuigingen mijnerzijds. Velen hebben inlichtingen gegeven, dikwijls uitvoerig en vertrouwelijk; enkelen deden meer: zij bleken bereid, voor het Rijksinstituut voor Oorlogsdocumentatie mee te werken in het tijdrovend onderzoek en rapporten te schrijven over enkele delen van het land, die ik zelf niet bereisde. In de eerste plaats noem ik het nauwkeurige, uiterst gedetailleerde en verantwoorde verslag van de heer B. A. Sijes, medewerker van het Rijksinstituut, over de stakingen in Twente (men vindt het grotendeels als Bijlage I opgenomen). Belangrijke rapporten werden ook ingediend door de heren W. H. Bouman (Zuid -Holland), Dr Alb. van de Poel (Noord-Brabant) en K. Leyenaar (Friesland). Ik mag hiervoor nog wel eens mijn bijzondere erkentelijkheid betuigen.

Geven wij ons rekenschap van het materiaal dat voor het schrijven van deze geschiedenis der April-Meistakingen kon worden verzameld, dan komen wij tot de volgende indeling:

a. Duitse archiefstukken: in Duitsland opgespoorde documenten, 
rapporten van de Beauftragten, verschillende geheime memories, diensttelegrammen, enz. Het leek ons ongewenst de Duitse documenten voortdurend te citeren, maar het is misschien niet overbodig te verklaren, dat de Duitse archivalia op zichzelf reeds een vrij duidelijk beeld van de staking geven. Vooral de brieven en telegrammen, gewisseld tussen verschillende Nazi-autoriteiten, bezitten een hoge zelfstandige waarde, zowel door het inzicht dat zij schenken in de psychologie van de overheersers, als door de wijze waarop zij opheldering verschaffen over de achtergrond der gebeurtenissen. In de gevallen, waarin de tekst de betekenis van de Duitse documenten niet voldoende tot haar recht doet komen, geven de bijlagen verdere informatie.

b. Schriftelijke herinneringen van Nederlandse zijde: dagboeken, krantenartikelen, illegale bladen, aanplakbiljetten, pamfletten enz.. Hiertoe rekenen wij ook enige honderden brieven, ontvangen naar aanleiding van een radiorede, die de Chef van het Rijksinstituut voor Oorlogsdocumentatie op 20 April 1946 uitsprak. Aan degenen, die aan zijn opwekking gehoor gaven om schriftelijke getuigenissen te zenden, moge van deze plaats nogmaals dank worden betuigd.

c. Een in samenwerking met het Rijksinstituut georganiseerde enquête, die gelegenheid schonk, een vergelijkend en systematisch onderzoek in te stellen naar vele vragen die ons interesseerden. Enquêteformulieren van drie verschillende typen werden gezonden naar de burgemeesters van alle Nederlandse gemeenten, naar directeuren van bedrijven en hoofden van dienst van overheidsinstellingen en naar particulieren, van wie mocht worden verwacht, dat zij waardevolle inlichtingen zouden kunnen geven.

d. Mondelinge informaties ter plaatse, vooral waar het overige materiaal tekort schoot. Met medewerking van de hierboven genoemde personen is veel tijdrovend locaal onderzoek verricht, waardoor het mogelijk werd, dieper inzicht te verwerven in de motieven tot staken en in het gedrag van de verschillende bevolkingsgroepen. Voorts konden noodzakelijke correcties worden aangebracht op onjuiste mededelingen in genoemde enquêteformulieren of aanvulling worden gegeven op onvolledige informaties. Wij moeten tot onze spijt constateren, dat zelfs een aantal burgemeesters bij het invullen of doen invullen van de enquêteformulieren van geringe belangstelling blijk gaf. Alle vragen werden in zulke gevallen door hen kortaf met "ja" of "neen" beantwoord. Ook van particuliere zijde werd te 
dikwijls het antwoord ontvangen, dat men geen tijd en geen lust had, aan de gestelde vragen aandacht te schenken. Daartegenover staat de hulpvaardigheid van velen, die tijd noch moeite ontzagen om ons nauwkeurig in te lichten over een van de spannendste weken uit de geschiedenis der bezettingsjaren.

Het hier boven onder $\mathrm{a}-\mathrm{d}$ bedoelde bronnenmateriaal berust thans bij het Rijksinstituut voor Oorlogsdocumentatie te Amsterdam. Men zal deze bronnen t.z.t. in het Algemeen Rijksarchief kunnen terugvinden.

Het stakingsonderzoek leverde meer op dan een chronologischgeordend stuk geschiedenis uit de bezettingstijd. Het vormt ook een bijdrage tot de kennis van het Nederlandse volk. Waar men spontaan staakte en het verzet soms volhield, ook na afkondiging van het standrecht, kwamen temperament en karakter aan het licht niet alleen van personen, maar ook van groepen. Vooral van grote groepen, want in de regel vond het verzet in groepsverband plaats. Het rijk-gevarieerde beeld van deze groepsreacties vormt m.i. een bijdrage tot ons sociologisch en sociaal - psychologisch inzicht stellig tot onze kennis omtrent de streek - en volkskarakters in Nederland, waarover weliswaar reeds een vrij uitgebreide literatuur bestaat, doch concrete gegevens schaars zijn. Moge verder onderzoek aanvullen, wat ik in het vage moest laten. Er valt nog veel te doen!

P. J. BOUMAN 
DEEL I

ALGEMEEN OVERZICHT 


\section{HOOFDSTUK I}

\section{VOORGESCHIEDENIS VAN DE APRIL-MEI- STAKINGEN 1943}

In de eerste maanden van 1943 nam de spanning waaronder het Nederlandse volk leefde, aanmerkelijk toe. De druk, die de bezettende macht uitoefende, werd heviger, naarmate Duitsland met groter moeilijkheden te kampen kreeg. Reeds in Januari kon de nederlaag bij Stalingrad niet meer verborgen worden gehouden. In dezelfde maand vonden hevige luchtaanvallen op Berlijn plaats en maakte het geallieerde offensief in Noord-Afrika enige vorderingen. Nijpend gebrek aan arbeidskrachten noopte de Duitsers tot verder ,uitkammen" van de bezette gebieden, desnoods door middel van razzia's (die in Nederland in begin Februari 1943 op grote schaal plaats vonden).

Een kanselboodschap van de Aartsbisschop en van de Nederlandse bisschoppen, die op 21 Februari in alle katholieke kerken werd voorgelezen, gaf uiting aan de groeiende ongerustheid. De Duitsers draaiden de schroef echter nog wat steviger aan. De 1 ste Maart werd bekend gemaakt, dat voortaan alle aanstellingen en ontslagen gecontroleerd moesten worden door de Gewestelijke Arbeidsbureaux. Op 11 Maart volgde de bekende "ordening" van het Hoger Onderwijs. Voor alle universiteiten en hogescholen gold voortaan een numerus clausus. De studenten moesten een loyaliteitsverklaring tekenen en zich verplichten, na het volbrengen van hun studie een jaar in Duitsland te gaan werken.

Tegelijkertijd werd de Landwacht-Nederland als onderdeel van de Waffen-SS opgericht.

De razzia's en de maatregelen tegen de studenten veroorzaakten verbittering in vele huisgezinnen, die tot dusver nog weinig rechtstreeks van de oorlog te lijden hadden gehad. Naarmate de nood steeg, nam ook het ongeduld toe. Men volgde met groter spanning de oorlogsgebeurtenissen. De symptomen van collectief verzet werden talrijker, zowel in de ondergrondse organisaties (vorming van een "Landelijke Raad van Verzet" en van het Nationaal Comité) als in de openlijke afwijzing van Duitse pressie. Op 24 Maart 1943 legden bijvoorbeeld de Nederlandse artsen hun bevoegdheid neer als protest tegen de maatregelen van de Artsenkamer.

De oorlog ontwikkelde zich in de vroege lente van 1943 voor de Geallieerden voorspoedig. Terwijl de Russen aan het Oostelijke front vorderingen bleven maken, werd Rommel in Noord-Afrika steeds verder teruggedrongen. Aan de 
invasie-verwachtingen van het Nederlandse volk was nieuw voedsel gegeven, toen Churchill na de Casablanca-conferentie al op 11 Februari in het Lagerhuis aankondigde dat de Geallieerden ,nu volgens een vast plan werkten, dat in de eerstvolgende negen maanden ten uitvoer zou worden gebracht". De broeierige stemming van begin April vindt men voortreffelijk beschreven in een artikel van Pieter 't Hoen in Het Parool van 5 April 1943. Belangrijker dan de meeste beschouwingen achteraf, is in het artikel van Pieter 't Hoen de voorspelling, dat de ingehouden woede van het volk zich zou kunnen ontladen in een algemene staking. Wij citeren:

\begin{abstract}
„Wie terugdenkt aan het grootse morele effect van de Amsterdamse Februaristaking, kan hunkeren naar het ogenblik, waarop heel werkend Nederland het hoofdstedelijk voorbeeld van toen volgt en de bijltjes erbij neerlegt. Indien wij voor bepaalde categorieën van gevallen „verticaal verzet" of "onderduiken" aanbevelen, zo doen wij dat niet, omdat wij het stakingsmiddel minder dienstig zouden achten. Neen, veeleer is het zo, dat wij, zetten hier en daar acties van andere aard in, van harte hopen, dat $z \mathrm{ij}$ de opmaat tot een algemene staking zullen zijn. Lamleggen van heel het Nederlandse leven zou immers het meest afdoende antwoord zijn op de schanddaden, waaraan de Duitsers met hun gore trawanten van de NSB thans bezig zijn zich schuldig te maken. Maar zulk een algemene staking gelukt alleen dan, indien de Duitsers één kapitaal feit stellen, dat iedere Nederlander zó diep in het hart grijpt, dat allen als één man voelen: dit is het ogenblik! (cursivering van de schrijver). Dàn zouden de handen tegelijk zakken, de machines tegelijk stoppen, de pennen tegelijk weigeren. Dat weten de Duitsers, en $z$ ij trachten listig, een dergelijk sprekend feit te vermijden. $Z_{i j}$ lopen handig om het psychologisch ogenblik heen, in de hoop dat zij, voetje voor voetje verder gaand, ons verzet zullen uithollen, onze geest zullen verlammen en vermurwen. Maar dat zullen zij niet! Het volk is lang genoeg getergd en gesard, genegerd en geringeloord om de maat vol te weten; het staat gereed; het is bereid tot handelen. Maar - dat handelen vergt organisatie. Een staking, die mislukt, is erger dan een staking die op het laatste ogenblik achterwege blijft. Ook hier is overleg het halve werk. Kleine vertrouwenscommissies in elke onderneming en in elk bedrijf, in elk corps en elk bureau moeten de staking voorbereiden en contacten leggen, die het mogelijk maken om te vertrouwen, dat het eenmaal uitgegeven parool zal worden opgevolgd."
\end{abstract}

Pieter 't Hoen beoordeelde de toestand, wat de stemming betreft, volkomen juist. Hij overschatte echter de mogelijkheid, op korte termijn een stakings organisatie op te bouwen. Ongemotiveerd was ook zijn opinie, dat de Duitsers er voor zouden terugdeinzen, door ,één kapitaal feit" de geest van het verzet tot het uiterste te prikkelen. Er waren reeds geruime tijd plannen in de maak, waarover wij door archiefvondsten te Berlijn en elders tot in finesses zijn ingelicht.

Reeds in November 1942 kreeg de Generalbevollmächtigte für den Arbeitseinsatz in den Niederlanden bericht, dat de deportatie van arbeiders naar Duitsland moest worden versneld. De oorspronkelijke eis bedroeg 100.000 arbeiders gedurende het tijdvak 1 September 1942-30 April 1943, maar door het toenemend gebrek aan arbeidskrachten besloot men, de jacht op mensen nog wat intensiever te organiseren. Voor de beide maanden November en December 
1942 werd op telkens 25.000 man gerekend, voor de tijd van 1 Januari 1943 tot 30 April 1943 op 100.000 man.

Het bekende Führererlass van 13 Januari 1943 over de totale oorlog en de algemene Arbeitseinsatz, voorspelde ook voor Nederland niet veel goeds. Men kon een verhoging van het reeds vastgestelde contingent verwachten. De vraag was slechts, hoe massale deportatie van Nederlandse arbeiders technisch uitvoerbaar zou zijn.

Onder deze omstandigheden was het niet verwonderlijk, dat de gedachte werd geopperd, het voormalige Nederlandse leger in krijgsgevangenschap terug te voeren. Het leek niet alleen de eenvoudigste weg om beslag te leggen op enige honderdduizenden arbeiders, doch men meende er ook uit militair oogpunt voordelen in te zien. Bij het dreigend invasiegevaar kon de aanwezigheid van een groot aantal oud-militairen in het kustgebied wel eens een voor de Duitsers minder gewenst effect hebben.

Uit aantekeningen, die Himmler maakte over gesprekken met de Führer blijkt, dat de gevreesde Reichsführer-SS zich met deze materie bemoeide. In zijn Niederschrift über Besprechung mit dem Führer am Sonnabend den 13 Februar 1943 in der Wolfschanze 1) um $17 \mathrm{Uhr}$, vindt men de passage: .Ich trug dem Führer meinen Gedanken vor, dass man aus den Niederlanden 300.000 Landeseinwohner als Kriegsgefangene nach Deutschland zum Arbeitseinsatz abschieben könne. Der Führer fand das notwendig und richtig und beauftragte mich, sofort mit dem Reichskommissar Verbindung aufzunehmen".

Seyss-Inquart toonde zich niet geestdriftig over Himmlers plan. Nadat Rauter hem er over had ingelicht, schreef de rijkscommissaris een brief aan Himmler, waarin hij enige bezwaren liet doorschemeren: „Rauter teilte mir auch mit. dass der Führer die Einziehung der demobilisierten Niederländer begrüsst und ich will in dieser Richtung mein möglichstes tun. Allerdings mïssen wir diese Angelegenheit mit einiger Vorsicht vorbereiten, denn einerseits kann ein solcher Entzug zu einer schweren Störung unserer Rüstungswirtschalt usw. Führen, andererseits könnte die Nichtbefolgung einer solchen Einberufung durch die Betroffenen zu einer schweren Schädigung unserer Autorität führen, da wir ja zu wenig deutsche Kräfte haben um die Leute einzelweise herauszufangen, und die niederländische Polizei in diesen Dingen kaum voll einsatzfähig ist. Aber wir werden schon alles machen, was möglich ist, zu einem guten Ende zu kommen" (zie Bijlage II, 3).

De 22ste Februari 1943 vond te Berlijn (zie Bijlage II, 4 en 5), onder voorzitterschap van staatssecretaris Kritzinger een bespreking plaats ,,über die Frage, ob und in welcher Weise dem Führererlass vom 13. Januar 1943 entsprechend Massnahmen in den Niederlanden zur Durchführung gelangen können". Seyss-Inquart had zich door staatssecretaris Fischböck, tevens commissaris-generaal voor economie en financiën in bezet Nederland, laten vertegenwoordigen. Deze liet duidelijk blijken, dat naar zijn mening ,aus

x) Wolfschanze was het codewoord voor Hitler's hoofdkwartier in Oost-Pruisen. 
Gründen der militärischen Sicherheit" werd gehandeld. Men moest echter wel bedenken, dat het bedrijfsleven in Nederland niet te veel kon worden bedreigd. Men kon een aantal luxe-winkels enz. sluiten, doch het was de vraag of daardoor meer dan 17.000 arbeidskrachten zouden vrijkomen.

Fischböck verzette zich ook tegen een "Meldepflichtverordnung” zoals deze voor het Duitse rijk gold. In de bezette gebieden waren dergelijke verordeningen veel moeilijker door te voeren. Men kwam tenslotte tot de conclusie, dat het voormalige Nederlandse leger in krijgsgevangenschap zou terugkeren, doch dan in voor de oorlog belangrijke bedrijven zou worden te werk gesteld. De beslissing daarover lag echter bij veldmaarschalk Keitel.

In een ander verslag van dezelfde bijeenkomst (Bijlage II, 5) komt nog het argument naar voren, dat de Nederlandse bevolking voor militaire maatregelen meer begrip zou tonen dan voor een massale burgerlijke mobilisatie van arbeidskrachten. Dat echter de behoefte aan arbeidskrachten in het Duitse rijk de doorslag gaf, kon men lezen uit een artikel van 5 Maart 1943 in de Deutsche Allgemeine Zeitung: ,Totaler Kriegseinsatz auch in der holländischen Wirtschaft" (Bijlage II, 8). Het artikel is interessant door de vaststelling, dat reeds 300.000 Nederlanders in Duitsland werkten. Er moesten echter nog belangrijke reserves van arbeidskracht aanwezig zijn. Op terugvoering in krijgsgevangenschap werd niet gezinspeeld.

Intussen vonden besprekingen plaats met het Oberkommando der Wehtmacht, dat zich allerminst geneigd toonde, zich in dienst te stellen van de burgerlijke instanties, die jacht maakten op arbeidskrachten. Wanneer er een geldig motief was voor het zwaarwegend besluit, het voormalige Nederlandse leger weer gevangen te zetten, zou dit een militair motief moeten zijn. Het OKW meende dat er inderdaad militaire gronden aanwezig waren om tot krasse maatregelen over te gaan. Bij een invasie zou de bevolking zeker steun verlenen aan de geallieerde troepen; hiertegen moest worden gewaakt. Uit verhoren van Rauter en van Generaal Christiansen is gebleken, dat er inderdaad in militaire kringen vrij grote ongerustheid bestond over de toenemende ondergrondse actie van Nederlandse militairen.

Op 23 Maart 1943 gaf het OKW Generaal Christiansen, de militaire bevelhebber in Nederland, het bevel „die Angehörigen der ehemaligen nieder ländischen Wehrmacht erfassen, festnehmen und abschieben zu lassen". Er heerste nog wel enige twijfel over de methode, waarop dit zou moeten gebeuren. Verder mengde het Ministerie van Butitenlandse Zaken te Berlijn zich in de discussie. Zou het te werk stellen van krijgsgevangenen niet te veel door de buitenlandse propaganda worden uitgebuit? In ieder geval in mindere mate dan massale deportering van burgerbevolking (Bijlagen II, 13, 16, 17). Het Ministerie van Buitenlandse Zaken drong er op aan, de bekendmaking van het besluit zo zorgvuldig mogelijk te redigeren, liefst in overleg met het Ministerie zelf.

Inmiddels beklaagde Sauckel zich er over, dat de correspondentie tussen het $\mathrm{OKW}$ en het Ministerie van Buitenlandse Zaken vertraging veroorzaakte 
en dat hij geen antwoord kreeg op zijn vragen (Bijlagen II, 10. 11, 12). Eerst 24 April stond de proclamatie vast. Vermoedelijk is $z \mathrm{ij}$ door Ritter van het Ministerie van Buitenlandse Zaken opgesteld. De tekst werd door de Führer goedgekeurd. Uit een te Berlijn opgespoorde brief blijkt wel duidelijk, dat Generaal Christiansen niet ten volle aansprakelijk kon worden gesteld voor het besluit, dat hij de 29ste April uitvaardigde. Hij handelde als militair op bevel van veldmaarschalk Keitel. De proclamatie, die met zijn ondertekening verscheen, was te Berlijn opgesteld. Ware Generaal Christiansen een krachtiger figuur met meer politiek en psychologisch inzicht geweest, dan had hij er de heren te Berlijn op kunnen wijzen, dat de verordening door haar onvolledigheid (het weglaten van uitzonderingsbepalingen) een consternatie zou veroorzaken, die, van Duits standpunt beschouwd, ongewenst was. Hij hield zich echter zonder commentaar aan de hem gegeven instructies. „Befehl ist Befehl".

De reactie liet niet op zich wachten. 


\section{HOOFDSTUK II}

\section{DE STAKINGEN VAN 29 APRIL TOT 7 MEI 1943}

Op Donderdag 29 April 1943, in het begin van de middaguren, kwam in de redactiebureaux van de dagbladen die bij de telexdienst aangesloten waren, het bericht binnen, waarbij de Wehrmachtbefehlshaber in den Niederlanden, de General der Flieger Fr. Christiansen liet bekend maken:

„Na de capitulatie van het Nederlandse leger in Mei 1940 heeft de Führer en Opperbevelhebber van de Duitse Weermacht bevel gegeven tot onmiddellijke invrijheidsstelling van de Nederlandse soldaten uit de krijgsgevangenschap. Deze maatregel werd vanzelfsprekend genomen op voorwaarde, dat de Nederlandse officieren en manschappen deze grootmoedige handelwijze met een dienovereenkomstige houding ten aanzien van de Duitse bezettende macht, zouden beantwoorden. Een groot ge deelte van hen heeft aan deze verwachting voldaan; in vele gevallen is echter onder invloed van onverantwoordelijke ophitsers een tegenovergestelde ontwikkeling gevolgd. Reeds in Mei 1942 moesten derhalve de voormalige beroepsofficieren opnieuw in krijgsgevangenschap worden weggevoerd. De Duitse weermacht heeft sindsdien bijna een vol jaar laten verstrijken in de verwachting dat deze duidelijke waarschuwing zou worden verstaan. In feite hebben echter afzonderlijke leden van het voormalige Nederlandse leger door hun vijandig gedrag telkens opnieuw het vertrouwen dat bij hunne vrijlating in hen werd gesteld, geschonden. Dit misbruik van een volkomen vrijwillig teruggeschonken vrijheid wordt thans niet langer meer geduld.

De Wehrmachtbefehlshaber in den Niederlanden beveelt derhalve, dat de leden van het voormalige Nederlandse leger terstond opnieuw in krijgsgevangenschap worden weggevoerd. Hij zal de betrokken personen in de dagbladpers tot persoonlijke aanmelding oproepen. Wie an de oproep van de Wehrmachtbefehlshaber geen gevolg geeft of tracht zich op andere wijze aan de krijgsgevangenschap te onttrekken, moet op de strengste maatregelen rekenen. Dit geldt eveneens voor personen, die de betrokkenen bij dergelijke pogingen ondersteunen. Allen, die thans in krijgsgevangenschap moeten terugkeren, hebben dit uitsluitend aan de ophitsers te danken, die door hun misdadig gedrag deze maatregel noodzakelijk maakten."

Een van de hulpmiddelen der moderne techniek stelde de Duitse militaire overheid in staat de Nederlandse dagbladpers in volledige ",gelijkschakeling" als orgaan van publiciteit te gebruiken. Deze keer namen de provinciale kranten het bericht niet uit "de grote pers" over. Er was evenmin sprake van een ambtelijke hiërarchie in de verstrekking van instructies, die op verschillend niveau van variërend commentaar konden worden voorzien. Snel en overrompelend werd het Nederlandse volk voor het harde feit geplaatst. De bezetter had een nieuw wapen gevonden tot verdere ondermijning van onze 
volkskracht, een methode tot bespoediging van de deportatie van de mannelijke bevolking, welke door de opeenvolgende besluiten over de Arbeitseinsatz al vele aderlatingen had ondergaan.

Wij schreven reeds over de heersende spanning en over de groeiende ontevredenheid. Kenmerkend voor de verbitterde stemming en de algemene neerslachtigheid was de overvloed van alarmerende geruchten, die zich telkens als een lopend vuurtje over het gehele land verbreidden. Men hechtte geen geloof meer aan krant en radio. Het was algemeen bekend, dat de Duitsers voortdurend speculeerden op de onwetendheid van het publiek; hun belangrijkste besluiten werden menigmaal in gecamoufleerde vorm bekend gemaakt. Vooral vele economische maatregelen, gericht op de plundering van het land, vertoonden in hun uitvoering een zekere geheimzinnigheid. Dit gold ook voor de Arbeitseinsatz, waarvoor uitzonderingsbepalingen golden, die dikwijls onder de Duitse instanties zelf aanleiding gaven tot een verbitterde strijd achter de schermen.

Van geheel andere aard was de proclamatie van Generaal Christiansen, de 29ste April 1943. Zij was scherp en duidelijk gesteld. Over uitzonderingen werd niet gerept. Voorzover hier sprake kon zijn van een strafmaatregel, liet deze aan duidelijkheid niets te wensen over. Wij zouden ons aan geforceerde beeldspraak schuldig maken, indien wij in dit geval spraken van de druppel, die de emmer deed overlopen. De Duitsers wierpen veeleer met geweld een $z$ ware steen in het water. En het Nederlandse volk reageerde spontaan op hun uitdaging. De illegaliteit was nog niet voldoende ontwikkeld, geheime groepsvorming vergde tijd, van gewapend verzet kon geen sprake zijn. Voor massale sabotage was het juiste moment nog niet gekomen. Zo kon het spontaan reageren van ons volk slechts één vorm aannemen; het neerleggen van het werk, in alle nuances van een kortstondige protestactie tot verbitterde pogingen, de stakingen het karakter van een volksopstand te geven.

Zoals in een psychotechnisch laboratorium individuen zeer verschillend reageren op een electrische schok bij een bepaalde stroomsterkte, zo zag men eind April 1943 een merkwaardige variatie in het gedrag van de bevolkingsgroepen, waaruit het Nederlandse volk is samengesteld. Millioenen Nederlanders namen op één dag kennis van een besluit, dat heftige verontwaardiging wekte: in de eerste plaats onder degenen, die voor hernieuwde krijgsgevangenschap in aanmerking kwamen. Wanhoop en verbittering heersten eveneens onder de vrouwen en verloofden, bloedverwanten en vrienden van de bedreigde militairen. Maar ook bij anderen ontwaakte het gevoel, dat de Duitse bezettingsmacht te ver was gegaan en openbaarde zich een verlangen tot demonstratieve agitatie. Waar de drang tot verzet tot daden overging, speelden protestacties $z$ ich meestal in groepsverband af. Wie de geschiedenis van de April-Mei-stakingen van 1943 wil beschrijven, zal zich daarvan terdege rekenschap moeten geven. Als men niet met een chronologie der gebeurtenissen meent te kunnen volstaan, komt men tot de veel moeilijker te doorgronden sociaal-psychologische en sociologische aspecten van de weerspannigheid, die 
op zo gevarieerde wijzen tot uiting kwam. Het wezen van deze emotionele episode uit de geschiedenis onzer bezettingsjaren benadert men dan ook niet in een relaas van de algemene staking als nationale demonstratie van verzet, doch slechts in een poging. regionale verschillen zo goed mogelijk te verklaren. Dit boek geeft dan ook veel meer de beschrijving van een groot aantal stakingen dan van de ,algemene" staking in de April-Meidagen 1943. Het zwaartepunt van ons betoog ligt in de hoofdstukken over het verzet in de provincies, die ieder ook weer een sterke regionale verscheidenheid te zien geven.

"Spontaan" mag men de stakingen noemen, die zonder voorafgaande organisatie Donderdagmiddag 29 April 1943 in Twente begonnen en zich daarna als een olievlek uitbreidden. Voor de spontaneiteit van het handelen pleit ook, dat Vrijdagochtend 30 April in vele streken van het land het werk werd neergelegd, zonder dat overleg tussen de verschillende stakingskernen kan worden aangetoond. Toch vereist het begrip ,,spontaan" wel enige opheldering. Wij vestigden er reeds de aandacht op, dat de stakingen zich in groepsverband, bijvoorbeeld onder de arbeiders van bedrijven, afspeelden. De sociologie leert evenwel, dat iedere groep eigen groepsnormen heeft en leiding niet kan ontberen. De vraag dringt zich op, of zelfs bij het meest ",spontane" handelen niet aanmoediging door enkele, door de groep als leiders erkende personen, de doorslag heeft gegeven. Inderdaad geldt ook voor de meeste spontane stakingen in de April-Meidagen van 1943 de regel, dat het persoonlijk prestige van leidinggevende figuren invloed heeft uitgeoefend op het collectief handelen. Weliswaar organiseerden zij de staking niet, maar enkele woorden van goedkeuring, een korte opwekking, een ostentatief gegeven voorbeeld, waren meestal voldoende om de solidariteit van de groep tot gelding te brengen.

Voor zover er leiding in het spel was, dient te worden opgemerkt dat deze in vele gevallen van informele aard was. De oude vakverenigingen en de politieke partijen waren ontbonden, de meeste landbouwmaatschappijen bevonden zich in een toestand van liquidatie. Slechts de kerken hadden zich organisatorisch kunnen handhaven. Verder vormden coöperaties en gezelligheids- of sportverenigingen kernen van contact. Kerkelijke groeperingen vielen veelal samen met formeel ontbonden politieke verenigingen. $Z_{i j}$ gaven dikwijls ook beschutting aan jonge illegale organisaties. Het bleek daardoor zelden mogelijk, achteraf vast te stellen, of de leiding bij sommige "spontane" stakingen uitging van kerkelijke, politieke of illegale vertrouwensmannen. Hun leiding beperkte zich in deze phase van het verzet trouwens meer tot goedkeuring en aanmoediging van stakingen dan tot een zorgvuldige organisatie daarvan. Degenen, die door hun positie nog organisatorisch werkzaam hadden kunnen zijn, voelden zich trouwens zelf ook verrast door het felle reageren van de bevolking. Toen zij eenmaal voor het feit waren geplaatst, dat het volk niet meer in toom was te houden, toonden de meesten voldoende verantwoordelijkheidsbesef om tot voorzichtigheid aan te manen. Men moest trachten een bloedbad te voorkomen.

Bij de beoordeling van het voor de April-Mei-stakingen zo gecompliceerde 
probleem van leiding en volgzaamheid, organisatie en spontaneïteit dient men in aanmerking te nemen, dat bij het neerleggen van het werk bedrijfsorganisatorische omstandigheden eveneens van betekenis waren. Vooral onder de arbeiders van bedrijven van middelmatige grootte, in het bijzonder indien zij aan de disciplinaire kracht van vakverenigingen gewend waren, kon zich de solidariteit van de groep gemakkelijk manifesteren. Leiders van inmiddels ontbonden afdelingen van vakverenigingen namen gewoonlijk nog een informeel toonaangevende positie in. Het staat dan ook wel vast, dat $z \mathrm{ij}$ in het eerste overleg over de vraag, welke houding men zou aannemen tegenover het besluit van Generaal Christiansen, Donderdagmiddag, Donderdagavond of Vrijdag in de vroege ochtend meer rechtstreeks aanwijzingen hebben kunnen geven dan de voormannen van kerkelijke zijde of van voormalige politieke groeperingen.

Deze groepsdiscipline van de arbeiders manifesteerde zich bijzonder duidelijk in de metaalnijverheid. Het was stellig niet louter toeval dat de stakingsbeweging Donderdagmiddag in Twente, te Hengelo bij de Machinefabriek Gebr. Stork \& Co., N.V. begon. Voor bijzonderheden moge worden verwezen naar het verslag van de stakingen in Overijsel en naar het veel gedetailleerder rapport van B. A. Sijes, dat als Bijlage I in dit boek is opgenomen.

In Twente was de structuur van het bedrijfsleven voor de stakingsactie even gunstig als het streekkarakter van de bevolking met haar tradities van collectief handelen en de neiging, één lijn te trekken. Tegenover de passieve inslag, die de volksaard hier vertoont, staat een zekere mate van onverzettelijkheid, zodra men zich te sterk belaagd voelt 1 ).

De massa arbeiders, die Donderdagmiddag 29 April 1943 tussen twee en drie uur de fabrieksterreinen van de N.V. Stork te Hengelo verliet, veroorzaakte in de straten van deze industriestad, ondanks haar rustig optreden, een verkeersstagnatie, welke algemeen de aandacht trok. Het personeel van naburige bedrijven kwam in rep en roer. Er waren slechts enkele woorden van overleg voor nodig om het voorbeeld van de eerste stakers te volgen.

Door de vele arbeiders, die in naburige steden of dorpen woonden, verbreidde het gerucht van de staking zich in de gehele omgeving.

Ook de telefoon heeft veel bijgedragen tot het spoedig bekend worden van de staking in andere Twentse industrieplaatsen. Overal ontwaakte het solidariteitsgevoel en haastte men zich instemming te betonen met het demonstratief verzet van de bevolking van Hengelo. Nog voor de middag ten einde was, had het personeel van een groot aantal bedrijven te Almelo, Enschede, Borne, Oldenzaal, Nijverdal, Haaksbergen, Rijssen en Vriezenveen het werk neergelegd.

Reizigers, die Twentse stations passeerden, en telefonische mededelingen, gaven verdere bekendheid aan de gebeurtenissen in het Twentse industriegebied. Donderdagmiddag begon ook reeds de eerste staking te Zwolle. In de

1) Dit is duidelijk gebleken in vroegere stakingen, die, nadat zij enigszins aarzelend waren begonnen, met grote hardnekkigheid werden voortgezet. 
Gelderse Achterhoek en in de industriestreek langs de Veluwezoom vertoonden $z i c h$ eveneens tekenen van onrust. Te Kampen en in naburige plaatsen kwamen gereformeerde illegale kernen in actie. Bij de N.V. Philips' Gloeilampenfabrieken te Eindhoven verliet het personeel Donderdagmiddag weliswaar het bedrijf niet, maar werden uit verschillende afdelingen toch sit-down-stakingen gemeld, die op toenemende spanning wezen. Zeer krachtig was de agitatie ook in het Zuid-Limburgse mijngebied, waar reeds Donderdagavond druk over de mogelijkheid van staken werd gesproken.

Donderdagavond drong het gerucht over de stakingen in Twente bijna overal in den lande door. Vele arbeiders, die Donderdagmiddag nog aarzelden, moeten in de loop van de avond tot de conclusie gekomen zijn, dat het ogenblik gekomen was om de Duitse maatregelen te saboteren. Hier en daar werden door illegale groepjes pamfletten met een opwekking tot staken verspreid. Waar nog aarzeling bestond, zag men dat velen er de voorkeur aan gaven, Vrijdagochtend 30 April nog naar de werkplaats of de fabriek te gaan voor verder overleg. Langzamer reageerden de plattelanders, die eerst Vrijdag nadere berichten ontvingen over de ,algemene staking", welke in feite allerminst algemeen was en het ook in de volgende dagen niet zou worden.

Het phaseverschil tussen de verschillende stakingen kwam de bezettingsmacht goed te stade. De Duitse politie-autoriteiten konden daardoor hun aandacht verdelen over de meest bedreigde gebieden. Donderdag troffen zij maatregelen voor een krachtdadig optreden in Twente. De ervaring leerde immers, dat een enkel afschrikwekkend voorbeeld grote volksmassa's in toom kon houden. Men zag evenwel, dat de Sicherheitspolizei de 29ste April 1943 niet klaar stond om het eerste verzet in de kiem te smoren. Rauter heeft Christiansen later verweten ${ }^{1}$ ) - het verwijt werd in 1943 reeds door vele Duitsers geuit dat de proclamatie, die Donderdagmiddag door de telexberichtendienst aan de dagbladen werd bekend gemaakt, slecht en onvolledig was geredigeerd. Waarom waren er geen uitzonderingsbepalingen in opgenomen en waarom had men Rauter niet gekend in het moment van de publicatie?

Merkwaardig was ook, dat de Rijkscommissaris, dr Arthur Seyss-Inquart, zich bij de uitvaardiging van het decreet van Generaal Christiansen niet in het land bevond. Hij reisde in Duitsland; men wist op het critieke ogenblik niet eens zijn adres. Zo kwam de volle verantwoordelijkheid voor het handhaven van de orde neer op Rauter, de Höhere SS- und Polizeiführer.

Donderdagmiddag 29 April, nadat Rauter bericht had ontvangen over het uitbreken van ongeregeldheden in Twente, telegrafeerde hij dringend naar Himmler, zijn hoogste chef in de SS. Hij meldde, dat hij van plan was, het politiestandrecht af te kondigen, doch hiervoor feitelijk toestemming nodig had van de op het moment onvindbare Rijkscommissaris Seyss-Inquart. "I Ich habe die Absicht, das Polizeistandrecht in den Streikgebieten sofort zu prokla-

1) $\mathrm{Bij}$ verhoren, die Rauter en Christiansen in de gevangenis ondergingen, bleek duidelijk, hoe sterk het antagonisme tussen de verschillende organisaties gedurende het Derde Rijk kon zijn. 
mieren. Blanko-unterschriften des Reichskommissars, die der Reichskommissar für diese Zwecke immer bei mir deponiert hat, liegen bei mir vor. Nur benötige ich die grundsätzliche Genehmigung des Reichskommissars, da er ja das Standrecht verfassungsmässig proklamiert" (het volledige telegram vindt men als Bijlage II, 20 afgedrukt).

Er was voor de Duitsers veel aan gelegen, het verzet zo spoedig mogelijk te breken. Als de stakingsactie verder om zich heen greep en tot een algemene staking uitgroeide, dreigde het gevaar voor een verplaatsing van deze vorm van sabotage naar gebieden buiten de Nederlandse grenzen. De arbeiders van België en Frankrijk zouden zich met de Nederlandse stakers solidair kunnen verklaren. Denemarken was ook niet betrouwbaar. En in Duitsland zelf was men niet geheel zeker van het katholieke Westfalen, waar onder bisschop Von Galen te Münster illegale bewegingen terrein schenen te winnen. Kwam een gedeelte van West-Europa in rep en roer, dan zou dit voor de Geallieerden de aantrekkelijkheid van een vervroegde invasie verhogen.

Rauter besloot dus nog Donderdagavond een SS-regiment uit Arnhem naar Hengelo te dirigeren. Deze troepen kregen instructie, in afwachting van het standrecht, krachtdadig op te treden. Indien het nodig mocht blijken, zouden ook uit Westfalen versterkingen aanrukken. Twente was gemakkelijk bereikbaar voor troepen uit verschillende richtingen.

De illusie, dat men de staking tot Twente zou kunnen beperken, werd echter verstoord door de berichten, die Vrijdagochtend 30 April in het hoofdkwartier van de Duitse politie te 's-Gravenhage binnenkwamen. Van uur tot uur, in de loop van die morgen, werden de telegrammen verontrustender: stakings haarden in de Zuid-Limburgse mijnen, stakingen te Eindhoven en in andere Brabantse industriegebieden, langs de Merwede en de Noord, in het NoordHollandse industriegebied, te Arnhem en langs de Veluwezoom, in Friesland - tenslotte vrijwel overal, met uitzondering van Amsterdam, waar slechts enkele bedrijven staakten. Ook te 's-Gravenhage, Rotterdam, Utrecht, en Haarlem bleef het betrekkelijk rustig.

Rauter wist, dat hij niet over voldoende troepen beschikte om over het gehele land voldoende patrouille-activiteit te ontwikkelen. Hij begreep ook wel, dat hij van de NSB onder deze omstandigheden niet veel steun mocht verwachten. Slechts militair vertoon, massale arrestaties en doodvonnissen zouden in staat zijn, de bevolking te intimideren.

Nadat Rauter enigermate een overzicht van de verwarde situatie had verkregen, kondigde hij Vrijdag 30 April het politiestandrecht af voor de provincies Overijsel, Limburg, Noord-Holland en Gelderland; voor de vier provincies dus, waaruit de meest alarmerende berichten werden gemeld.

"Ik verbind daarmede het bevel, dat zich een ieder heeft te onthouden van iedere beroering, die de openbare orde en de veiligheid van het openbare leven kan verstoren of in gevaar brengen, en zich heeft te volegen naar mijn speciale beschikkingen, die ik uitvaardig onder uitdrukkelijke verwijzing naar de gestrengheid van het politiestandrecht. 
Wie handelt in strijd met dit bevel, wordt standrechtelijk veroordeeld.

De Höhere SS- und Polizeiführer treft alle maatregelen, die hem tot instandhouding of herstel van de openbare orde of de veiligheid van het openbare leven noodzakelijk voorkomen.

De Höhere SS- und Polizeif̌rihter kan bij de uitvoering van zijn opdracht afwijken van het geldende recht."

Verder bevatte het besluit de aanwijzing van enige bijzondere gemachtigden. $\mathrm{Na}$ een opsomming van verbodsbepalingen werd vastgesteld:

1. „De aan mij ondergeschikte SS- en Polizei-eenheden schieten onverwijld zonder waarschuwing, wanneer samenscholingen van welke aard ook voorkomen of wanneer zich meer dan 5 personen op openbare wegen of pleinen verzamelen. Uitgezonderd zijn door de Duitse politie goedgekeurde bedrijfsvergaderingen.

2. Verboden is het oponthoud buitenshuis in de tijd van 20 uur tot 6 uur 1 ). Uitzonderingen staat de Duitse politie toe.

3. Verboden is het schenken en gebruiken van brandewijn en andere alcoholische dranken in openbare lokalen en het afleveren en verkopen van dergelijke dranken.

4. De werkgevers is de uitbetaling van lonen en salarissen aan stakers verboden voor dagen, waarop geheel of gedeeltelijk is gestaakt.

5. De Duitse veiligheidspolitie neemt alle zaken in beslag, die tijdens de duur van het politiestandrecht op de voorgeschreven of ter plaatse gebruikelijke tijden niet open zijn.

Wie handelt in strijd met een van de onder 2 tot 4 genoemde verboden wordt gestraft met gevangenisstraf en boete tot een onbeperkte hoogte of met een van deze straffen, voor zover niet volgens andere bepalingen een strengere straf is verbeurd.

Maatregelen der veiligheidspolitie blijven voorbehouden."

Dezelfde dag liet Generaal Christiansen bekendmaken, welke groepen van het beroepspersoneel van ons voormalige leger zich zouden moeten melden op 7, op 10 en op 13 Mei 1943. In dezelfde bekendmaking werden ook uitzonderingsbepalingen genoemd voor:

1. leden van de Nederlandse politie, van de brandweer, van de vaste kern van de luchtbeschermingsdienst, enz.;

2. voormalige administrateurs-onderofficieren;

3. personen, die als hoofdberoep een functie bij de Nederlandse Arbeidsdienst uitoefenen;

4. in Duitsland werkende personen.

Men vraagt zich af, waarom deze uitzonderingsbepalingen niet eerder werden gepubliceerd. Nog vreemder is het, dat over verdere uitzonderingsbepalingen voor economisch onmisbare personen in het geheel niet werd gerept, hoewel Duitse hoofdambtenaren uit Den Haag reeds ondershands hadden doen weten, dat het zeker in de bedoeling lag aan mijnwerkers, boeren, enz. Ausweise te geven.

1) De vrienden van de Duitsers waren zó slecht van het Duits op de hoogte, dat zij "Aufenthalt" vertaalden door "oponthoud"! 
Uit rapporten van Seyss Inquarts provinciale Beauftragten, als Bijlagen II 48 t.e.m. 58 opgenomen, blijkt, dat de meesten van hen zich over de onvolledigheid van Generaal Christiansen's proclamatie hadden verbaasd. Was een vermelding van uitzonderingsbepalingen de eerste dag met opzet achterwege gelaten? Wilde men het op een krachtproef laten aankomen en de Nederlanders de laars op de nek eens flink doen voelen? Of vermengde zich ook in dit geval gebrek aan psychologisch inzicht met een zekere bureaucratische slordigheid of onverschilligheid? Generaal Christiansen kon zich later weliswaar beroepen op het bevel van de Reichsführer-SS Himmler — "Befehl ist Befehl" - , maar het is niet gebleken, dat hij Himmler heeft gewezen op mogelijk ongunstige gevolgen van het bewuste decreet. Himmler zelf leefde te veel in de sfeer van het bruut geweld om zelfs maar te kunnen veronderstellen, dat zijn bevel spontaan en massaal verzet zou uitlokken.

De telegramwisseling tussen de hoofden van dienst der Sicherheitspolizei - de stukken zijn grotendeels teruggevonden - geeft een goede indruk van de snelheid, waarmede de staking zich Vrijdag 30 April uitbreidde. De belangrijkste stakingshaarden waren:

1. Twente, de streek van het eerste verzet, waar de Duitse maatregelen nog niet veel indruk hadden gemaakt. In de loop van de 30ste April breidde de staking in dit gebied zich nog verder uit tot de meeste overheidsdiensten, terwijl op het platteland in toenemende mate de melkleverantie tot stilstand kwam.

2. Eindhoven, waar o.a. het personeel van de Philipsfabrieken het werk neerlegde. Voorts naburige industriesteden, vooral Helmond.

3. Zuid-Limburg, waar Donderdagavond 29 April de nachtploeg van de Staatsmijn Maurits, het grootste en modernste bedrijf in deze streek, het voorbeeld gaf. De bekende solidariteit der mijnwerkers kwam Vrijdagochtend tot uiting. De ene ploeg na de andere viel uit, zowel bij de Staatsmijnen als bij de particuliere mijnen. Ook het kantoorpersoneel in het hoofdgebouw der Staatsmijnen te Heerlen legde het werk neer. Te Maastricht gaven rijks en gemeente-ambtenaren bij de staking de toon aan.

4. Delft en het industriegebied langs de Noord en langs de Merwede.

Te Delft droeg de staking een vrijwel algemeen karakter. Evenzo in het $Z$ uid-Hollandse industriegebied ten Zuid-Oosten van Rotterdam waar de bevolking met een zekere hartstocht haar geest van verzet demonstreerde. Het was voor de Duitsers een voordeel dat het te Rotterdam rustig bleef; zij konden zodoende de nodige politietroepen aan de Maasstad onttrekken.

5. Het Westland, waar de bevolking met de demonstratieve neiging tot sabotage reeds Vrijdag in de vroege ochtenduren tot staking overging.

6. Velzen en Wormerveer in Noord-Holland, waar men in zekere zin het spiegelbeeld zag van Zuid-Holland. Gering verzet in de grote stad - er bestonden voor de Amsterdammers redenen te over om voorzichtigheid in acht te nemen - naast heftige agitatie in naburige kleinere industrieplaatsen. In 
het Noord-Hollands industriegebied werkten vertrouwensmannen uit de voormalige vakverenigingen samen met illegale kernen, welke ten dele uit de vroegere Communistische Partij waren voortgekomen. Op het platteland, vooral in de katholieke en gereformeerde gemeenten in de Kop van Noord-Holland, kon men daarentegen vooral kerkelijke invloeden waarnemen.

\section{Arnhem en de Veluwezoom.}

Met veel élan staakten de arbeiders van de ijzergieterijen van Vaassen en vrijwel alle groepen van de bevolking in het naburige Epe en Heerde. Van veel grotere omvang waren evenwel de stakingen te Arnhem, waar de arbeiders van de A.K.U. en de E.N.K.A. Vrijdagochtend de fabrieksterreinen verlieten. Te Renkum werd het werk neergelegd door het personeel van Van Gelder's Papierfabrieken en door de arbeiders van de Rubberfabrieken "Hevea" te Doorwerth.

8. De Groninger Veenkoloniën, met Hoogezand, Oude en Nieuwe Pekela, Veendam en Wildervank als centra van verzet.

9. Friesland, waar de stakingsbeweging zich het snelst over het gehele platteland uitbreidde - vlugger dan de Duitsers konden overzien, zodat zij over dit gebied in de eerste dagen van de staking onvoldoende waren ingelicht.

In de kaarten, aan dit boek toegevoegd, zijn de gemeenten waar de staking een vrijwel algemeen karakter droeg, in donker getint. De drie nuanceringen voor ,,algemene staking", ,talrijk voorkomende stakingen" en ,,lichte sta kingen" kunnen geen aanspraak maken op absolute nauwkeurigheid. Toch demonstreren de kaarten duidelijk uitbreiding en afloop van de stakingsbeweging. Vrijdag, in de uren vóór de afkondiging van het standrecht, bereikte het verzet zijn grootste omvang, althans in de steden. Waarschijnlijk naderde de stakingsactiviteit op het platteland eerst Zaterdagmorgen $1 \mathrm{Mei}$ haar hoogtepunt.

In de beschrijving van de gebeurtenissen in de verschillende provincies zal nader aandacht worden geschonken aan de vraag, waarom in sommige steden en landbouwgebieden niet of weinig werd gestaakt. Het was voor de Duitsers bijvoorbeeld een grote geruststelling, dat de bevolking van onze grootste steden in het gareel bleef. De Amsterdammers hadden hun kruit reeds verschoten bij de staking van Februari 1941; in de jaren daarna droegen de steeds verder opgeschroefde maatregelen tegen de Joden bij tot een verlammend gevoel ván onmacht in alle lagen der bevolking. Men leerde berusten. Rotterdam was een gehavende en uiteengereten stad, waar vele inwoners naar de buitenwijken waren geëvacueerd. Bovendien lag het havenbedrijf, doorgaans het middelpunt van arbeidersagitatie, stil. Een aantal van de voormalige bootwerkers waren tewerk gesteld bij de aanleg van verdedigingslinies in de buurt van Hoek van Holland. Den Haag, het centrum van de bezettingsbureaucratie, meer onder contrôle dan enige andere stad, bood ook niet veel gelegenheid tot demonstratief verzet. Utrecht kende weinig grote bedrijven en kenmerkte zich door een bevolking, die nooit veel élan aan de 
dag had gelegd. De stad bleef evenwel belangrijk als middelpunt van spoorwegbeheer.

Het niet staken van het spoorwegpersoneel heeft vermoedelijk het meest bijgedragen tot het verloren gaan van de illusie, dat de stakingsactie tot een werkelijk nationale staking zou uitdijen. Overal letten de stakers scherp op de spoorwegen. Vrijdagochtend nog hoorde men algemeen beweren, dat het spoorwegpersoneel in de loop van de dag het werk zou neerleggen. Men vermoedde, dat er eerst over beraadslaagd moest worden. Toen de treinen ook Zaterdagochtend volgens de gewone dienstregeling bleven rijden, begreep men in de stakingsgebieden wel, dat men te lichtvaardig in de algemene staking had geloofd. Velen vonden er een aanleiding in om van voortgezette actie af te zien. Welke motieven in het contact tussen de directie van de Nederlandse Spoorwegen en het dagelijks bestuur van de personeelsraad de doorslag hebben gegeven, kan hier buiten beschouwing blijven. Het Rijksinstituut voor Oorlogsdocumentatie hoopt immers een afzonderlijke studie over het spoorwegverzet te publiceren. Wij mogen echter vaststellen, dat de aard van het spoorwegbedrijf spontane groepsvorming en groepsleiding in de weg stond. De landelijk gecentraliseerde leiding werkte te traag om aan de eerste impuls van verzet gehoor te geven, en toen men op de tweede stakingsdag de situatie eens wikkend en wegend bezag, kwam men tot de overweging, dat ieder onberaden avontuur latere stakingsacties, op een sein van de regering te Londen, ernstig zou kunnen belemmeren.

Bij het noemen van de regering te Londen stuiten wij op een afzonderlijk aspect van de negatieve tendenties, die het stakings-élan verzwakten. RadioOranje kwam achter de feiten aan en muntte in deze critieke dagen nu niet bepaald uit door juiste berichtgeving of door het geven van goed gefundeerde adviezen. Het gedeeltelijk en verklaarbaar falen van onze overzeese voorlichtingsdienst gedurende de April-Mei-staking zal in een afzonderlijk hoofdstuk worden toegelicht.

Een van de grootste moeilijkheden, die ons het volgen van de gebeurtenissen op Vrijdag 30 April belemmert, is de snelle uitbreiding van de staking in agrarische gebieden. Bij industriële bedrijven kon bijna altijd het ogenblik van het uitbreken van de staking worden vastgesteld. "Staken" betekende daar het neerleggen van het werk en het verlaten van de werkplaatsen. Geheel anders op het platteland, waar men soms niet naar de akker ging, doch wel lichte werkzaamheden in stal of schuur bleef verrichten. Tenslotte moest het vee toch worden gemolken; het bedrijf kon nooit geheel stagneren. De duidelijkste demonstratie van verzet was in vele streken, vooral in de weidegebieden, het staken van melkleveranties aan de zuivelfabrieken. Hier en daar is de herinnering aan de April-Mei-staking 1943 als de "melkstaking" blijven voortleven.

Nader onderzoek naar het karakter van deze „melkstakingen" bewees opnieuw hoe moeilijk het is, de historische werkelijkheid min of meer schematisch 
samen te vatten. Stagnatie in de levering en verwerking van melk kon zich op drie manieren voordoen:

1. indien de boeren geen melk meer aan de fabrieken leverden, hun melkbussen niet meer buiten zetten en de overtollige melk clandestien of openlijk aan het publiek verkochten( soms tegen de gewone detaillistenprijzen, soms tegen „,zwarte" prijzen);

2. wanneer de melkrijders het vervoer staakten, zodat de boeren wel gedwongen werden, hun leveranties aan de fabrieken stop te zetten;

3. in het meermalen voorkomende geval, dat de zuivelfabrieken zelf het sein tot staken gaven (soms op initiatief van de directies, soms op aandrang van arbeiders of van de melkleveranciers).

Onduidelijk was dikwijls ook de situatie in de dorpen, waar men zoveel vreemder stond tegenover het begrip ,staken" dan in de brandpunten van handel en bedrijf. Eerst de razzia's 'van doortrekkende Duitse patrouilles deden de dorpelingen de ernst van de situatie beseffen. Waar slachtoffers vielen, weet men nog genoeg van de gebeurtenissen te verhalen. Voor het overige bleven de plattelandsstakingen te diffuus om er achteraf nog een duidelijk beeld van te kunnen reconstrueren. Wanneer men begon, en hoe of wanneer deze stakingen eindigden, is zelfs ooggetuigen veelal niet duidelijk geworden. Slechts bij benadering bleek het beschikbare materiaal toereikend om het verloop van de staking voor alle Nederlandse gemeenten in kaart te brengen.

Dadelijk na afkondiging van het politiestandrecht - in Twente al eerder sloegen de Duitsers hard toe. $Z_{\mathrm{ij}}$ waren vastbesloten, de staking desnoods in bloed te smoren. De 1ste Mei 1943 werd het politiestandrecht tot het gehele land uitgebreid en kregen de Beauftragten bijzondere volmachten tot handhaving van de orde. Vrijdag was de stemming in het hoofdkwartier van de Sicherheitspolizei nog wel vrij nerveus, maar begon men daar in de loop van de dag toch wel in te zien dat het effect der getroffen maatregelen zich reeds deed gevoelen. De voordelen van de betrekkelijke kalmte in de grote steden en het niet staken van het spoorwegpersoneel konden worden uitgebuit om alle kracht te concentreren op de geïsoleerd gelegen stakingshaarden.

In Twente werden Vrijdag 30 April burgemeesters en bedrijfsleiders aansprakelijk gesteld voor het niet hervatten van het werk door het personeel, dat onder hun toezicht stond. De Beauftragte in de provincie Overijsel eiste, dat Zaterdagochtend de normale toestand zou zijn hersteld. Hij was er van overtuigd, dat de stakingsbeweging op instigatie van enkele stakingsleiders begon en verlangde nu een even snel beëindigen van het verzet als het in het leven was geroepen. Toen zijn bevelen Zaterdagochtend nog niet tot het gewenste resultaat hadden geleid, vielen er slachtoffers. Wilde schietpartijen op straat, arrestaties van fabrieksdirecteuren en andere methoden van intimidatie brachten de bevolking tot het inzicht, dat men een bloedbad kon verwachten, indien men voet bij stuk trachtte te houden. 
Te Eindhoven vonden Zaterdag arrestaties plaats. Evenzo in andere Brabantse industriesteden, zonder dat de Duitse politie-autoriteiten daar direct tot executies overgingen. $Z_{i j}$ probeerden liever eerst pressie uit te oefenen op burgemeesters en fabrikanten.

In Zuid-Limburg hadden de Duitsers het voordeel, dat zij in het goedgeorganiseerde bedrijf der Staatsmijnen de leidinggevende figuren aansprakelijk konden stellen voor een verdere voortzetting van de staking. Minder overzichtelijk was voor hen de situatie te Maastricht en in Midden-Limburg, waar de katholieke geestelijkheid (vooral te Roermond) in samenwerking met verschillende illegale groepen aanvankelijk de staking aanmoedigde, later evenwel tot voorzichtigheid aanmaande. In het algemeen mag worden gezegd, dat de Limburgse geestelijkheid zich in de stakingsdagen actiever toonde dan de Brabantse clerus, die langer in een afwachtende houding volhardde.

Te Delft trachtte de Duitse politie personeelshijsten van de stakende bedrijven in handen te krijgen. Zaterdag vonden er massale arrestaties plaats. Langs de Merwede en de Noord opereerden Vrijdag politieafdelingen uit Rotterdam, die er door intimidatie in slaagden, enkele ploegen arbeiders tot hervatting van de werkzaamheden te bewegen. De meeste stakers bleven echter ook Zaterdag thuis. $\mathrm{Na}$ afkondiging van het standrecht op de 1 ste Mei, besloot de Duitse politie, onder aanvoering van de beruchte Kriminalsekretär Hoff mann uit Rotterdam, represailles toe te passen. Te $Z$ wijndrecht, Kinderdijk, Alblasserdam, Bolnes, en in andere plaatsen, werden vele bedrijfsleiders en arbeiders gearresteerd. Hierbij zij opgemerkt dat in deze streek krachtig tegenstand werd geboden door directeuren en bedrijfsleiders, die in de meeste gevallen weigerden personeelslijsten uit te leveren.

De bevolking van het Westland, vooral in de dorpen De Lier, 's-Gravenzande en Naaldwijk, volhardde ook Zaterdag in haar houding van verzet en verontrustte de Duitsers door het stilleggen van het veilingbedrijf. $\mathrm{Na}$ de afkondiging van het standrecht en door het bericht dat de fabrieksarbeiders te Delft het voornemen hadden, Maandagochtend het werk te hervatten, besloten de Westlandse tuinders en arbeiders niet veel meer te riskeren. Aarzelend keerden zij naar hun velden en kassen terug. Duitse represailles bleven hier achterwege.

In het stakingsgebied Velzen-Wormerveer-Krommenie concentreerde de Duitse politie haar aandacht het meest op Krommenie, waar zij een krachtige communistische agitatie vermoedde, speciaal onder het personeel van de N.V. Verenigde Blikfabrieken. Zaterdagmiddag werden twaalf arbeiders uit hun huizen gehaald en op transport gesteld naar Amsterdam, waar zij voor het Standgericht moesten verschijnen. Te Velsen en Beverwijk werden Zaterdag 1 Mei tachtig personen gearresteerd; slechts tien van hen werden voor de bijzondere rechtbank gedaagd. Het was duidelijk, dat hier slachtoffers zouden vallen. De Duitsers lieten doorschemeren, dat een aantal van de gearresteerden nog kon worden gered, als de arbeiders Zaterdagmiddag een bewijs van hun 
goede wil gaven door nog enkele uren te werken. De meesten toonden zich daarop bereid, hun weerspannige houding te laten varen.

Te Arnhem en in de kleinere industrieplaatsen langs de Veluwezoom trad de Duitse politie eerst Zaterdag krachtdadig op. Door talrijke arrestaties en $z$ ware pressie op fabrieksdirecteuren en bedrijfsleiders werd ook hier gesuggereerd, dat verder verzet op een bloedbad zou uitlopen indien men niet het hoofd in de schoot legde. Velen zouden Zondag 2 Mei voor het Standgericht Gelderland moeten verschijnen. Geen wonder dat de meeste stakers liever niet het risico wilden lopen, Maandagochtend te worden gearresteerd.

In de Veenkoloniën maakte de afkondiging van het standrecht op Zaterdagmorgen 1 Mei wel indruk. Reeds Vrijdag waren vele arbeiders gearresteerd, o.a. te Ouder en Nieuwe Pekela. Van Groningen uit patrouilleerde de Sicherheitspolizei (waarvan in de provinciehoofdstad een sterk detachement lag) door alle dorpen, waar stakende arbeiders woonden. Een complicatie in dit gebied, evenals in sommige andere streken, was de traditionele 1-Meiviering. De Duitse politie had echter gewaarschuwd, dat hierin geen argument mocht worden gezien om Zaterdagochtend thuis te blijven. Zaterdag en Zondag vonden besprekingen plaats tussen vertegenwoordigers van verschillende groepen stakers; evenzo tussen directies van bedrijven en vertrouwensmannen van de arbeiders. De Duitsers bleken in het algemeen bereid te zijn, genoegen te nemen met de verklaring, dat het werk Maandagochtend 3 Mei zou worden hervat.

In Friesland nam de staking Zaterdag het karakter aan van een sterk emotionele volksbeweging. Geen ander gebied van Nederland vertoonde een dergelijke solidariteit. De hele provincie verkeerde in een toestand van opwinding. Het was voor de Duitse politie dan ook uitermate moeilijk, haar houding te bepalen, omdat duidelijk bleek, dat patrouille-activiteit in de dorpen weinig indruk maakte.

Wat voor Friesland gold, gold ook voor andere agrarische gebieden waar men soms geen bepaalde brandpunten van tegenstand kan aanwijzen. Op de kaart die de situatie op Zaterdag 1 Mei 1943 weergeeft, zijn slechts drie nuances van stakingsintensiteit aangegeven. De schakeringen van verzet bleken voor het platteland nog moeilijker vast te stellen dan voor de steden. $B i j$ vergelijking van de kaarten, die de toestand op 30 April en 1 Mei illustreren, zien wij, dat vooral in Zuid-Holland en in de Gelderse Achterhoek op Zaterdag minder werd gestaakt dan op de voorafgaande dag. In de vele gebieden, die op beide kaarten gelijk getint zijn, konden nog wel verschillen voorkomen. In het algemeen waren de plattelandsstakingen Zaterdag 1 Mei iets heviger dan op Vrijdag 30 April.

De afkondiging van het standrecht, eerst voor Overijsel, Limburg, Noord. Holland en Gelderland, daarna voor de overige provincies, betekende voor de Duitsers het meest effectieve middel tot intimidatie van de bevolking. Kranten-, radioberichten en aanplakbiljetten brachten ieder er van op de hoogte 
dat verder staken zonder pardon zou worden gestraft. De Sicherheitspolizei wist, dat zij niet talrijk genoeg was om hardnekkig volgehouden massaal verzet reeds in de eerste dagen van de staking te breken. De Duitse politiechefs hadden echter voldoende ervaring om te weten, dat zware bedreigingen altijd een wig drijven tussen de aarzelenden en de vastberadenen.

Een zekere matiging bij het ten uitvoer leggen van de standrechtsmaatregelen kan de Duitsers niet worden ontzegd. $Z_{\text {ij }}$ hebben een vrij groot aantal gearresteerden, die na afkondiging van het standrecht hadden doorgestaakt, spoedig vrijgelaten. Velen werden enige maanden naar Vught gezonden; een minderheid hoorde de doodstraf eisen. De leiders van de Standgetichte beseften heel goed, dat de politie slechts een willekeurige greep had gedaan uit honderdduizenden ",schuldigen". $Z_{\mathrm{ij}}$ wisten evenwel, dat hun de taak was opgelegd, voor afschrikwekkende voorbeelden te zorgen. Snelle publicatie daarvan was hoofdzaak; het publiek moest de indruk krijgen, dat de Duitse politie tot het uiterste zou gaan. Inderdaad heeft de publicatie van een aantal doodvonnissen op Zondag 2 Mei - bekendmaking geschiedde vooral door middel van aanplakbiljetten - veel bijgedragen tot het neerslachtige gevoel, dat men voor het geweld zou moeten zwichten.

Valt in sommige opzichten de matiging van de Duitse Sicherheitspolizei te prijzen, dan dienen daar vele gevallen van nodeloze ruwheid tegenover te worden geplaatst. Vooral bij het patrouilleren op straat werd meermalen slechts geschoten om de bevolking te intimideren. Als twee schanddaden moeten het bloedbad bij Marum in het Zuid-Westen van de provincie Groningen en het neerschieten van gevangenen bij Haaksbergen worden vermeld.

De NSB betoonde haar verontwaardiging over de staking, die natuurlijk aan het stoken van Joden en communisten en van de regering te Londen werd toegeschreven. Actieve steunverlening aan de Duitsers kwam in de AprilMeidagen echter slechts bij uitzondering voor. Sommige NSB-burgemeesters (te Krommenie enz.) waren de Duitse politie behulpzaam bij het opsporen van „raddraaiers". Voorts beschikken wij over enige rapporten van de Landstand in Noord-Brabant en van het Arbeidsfront te Apeldoorn (gedeeltelijk als Bijlagen II 37, 43 opgenomen), die er op wijzen, dat NSB-ers aan Duitse autoriteiten aanwijzingen gaven over het ontstaan en het verloop van de stakingen. Hier en daar werkten NSB-politie-ambtenaren samen met leden van de Sicherheitsdienst. Maar in het algemeen toonden de aanhangers van de NSB zich in de dagen van de staking niet bijzonder actief. Vooral op het platteland durfden $z \mathrm{ij} z$ ich niet te veel tegenover de groepssolidariteit van de dorpsbewoners te plaatsen. Waar zij het wèl deden, werd door de bevolking met enige van de meest gehate tegenstanders afgerekend. In Friesland en in Drente gingen enkele boerderijen van NSB-ers in de vlammen op.

Uit onzé summiere schets van de gebeurtenissen op 30 April en 1 Mei in enige stakingsgebieden blijkt, dat op beide dagen door honderdduizenden arbeiders, boeren en ambtenaren werd gestaakt. Het overheidspersoneel staakte 30 April in grotere getale dan op de 1 ste Mei. Ambtenaren konden ge- 
makkelijker tot de orde worden geroepen en handelden meestal minder spontaan dan de grote massa, die minder verantwoordelijkheid droeg. Ook begrepen de intellectuelen eerder, dat de staking in de eerste plaats een demonstratief karakter diende te dragen en bij het ontbreken van een werkelijk nationale solidariteit niet tot iedere prijs moest worden gerekt. Zaterdagmiddag $1 \mathrm{Mei}$ waren de meeste stakers er wel van overtuigd, dat $z$ ij verstandig deden, Maandagochtend weer op het appèl te verschijnen. Intussen hoorde men toch ook nog veel uitlatingen van verbitterde onverzettelijkheid. Hoe men zich zou gedragen, hing meer af van het groepsverband dan van ieders individueel wilsbesluit.

Geven de manier waarop men Donderdag en Vrijdag met de staking begon en de wijze van verzet in deze critieke dagen inzicht in de aard der verschillende bevolkingsgroepen in hun regionale verscheidenheid, dan geldt dit nog in versterkte mate voor het collectieve handelen in de volgende stakingsdagen.

Het eerste verzet kon, sociaal-psychologisch beschouwd, als een toetssteen gelden voor de spontaneiteit van het handelen in diverse lagen der bevolking in haar geografische verbreiding. $\mathrm{Na}$ afkondiging van het standrecht en na de eerste maatregelen van terreur, die er op gericht waren het publiek te intimideren, viel waar te nemen, hoe sterk verbittering en de neiging tot verdere tegenstand in het land varieerden.

De sociale psychologie, die laboratorium-experimenten moet ontberen, beschikt zelden over voldoende waarnemingsmateriaal om een vergelijkende studie te maken van gevarieerd collectief handelen. De Nederlanders, die op dezelfde dag waren opgeschrikt door het fatale besluit van Christiansen, reageerden op verschillende wijze. Uit onze beschrijving van de stakingsgebeurtenissen in de elf provincies zal blijken, in welke mate het streekkarakter, het groepstemperament en de beroepsorganisatie bijdroegen tot de aard van het demonstratief verzet. Interessanter nog is het collectief gedrag in de tweede phase. Toen de eerste, demonstratieve, phase, achter de rug was, brak het moment aan van de keuze tussen onderwerping (met erkenning dat de staking in feite verloren was) en verder verzet. Redelijk inzicht tegenover fanatisme, berusting tegenover koppigheid, overleg tegenover collectieve verbetenheid.

Het groepshandelen dat de triomf der hardnekkigheid tegen beter weten in demonstreert, vindt men afgebeeld op de derde kaart (toestand op Maandag 3 Mei 1943). In de eerste plaats zij opgemerkt, dat het platteland later in beweging kwam dan de steden en alleen reeds daardoor de neiging vertoonde, het verzet iets langer vol te houden. Bovendien profiteerde men in afgelegen agrarische streken, bijvoorbeeld op Noord-Beveland, van de afwezigheid van een Duitse bezetting. Sommige plattelandsstakingen werden uit zorgeloosheid gerekt. Het kwam ook voor, dat illegale groepen de toon aangaven en voortgezette weerspannigheid aanmoedigden. Het is evenwel geen toeval, dat Maandag 3 Mei de stakingen in Friesland nog in volle gang waren, vooral in de gereformeerde gemeenten van Noord-Friesland. Evenmin, 


\section{(y) \\ ERLAS S}

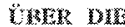

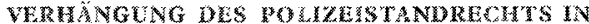
DWN

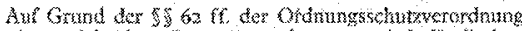

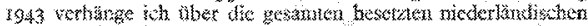
Gelvise mil shondor witkeng das

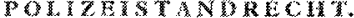

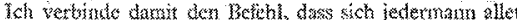

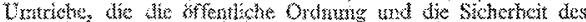

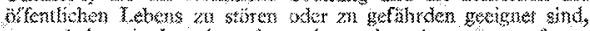

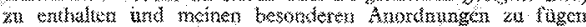

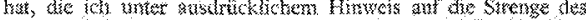

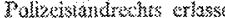

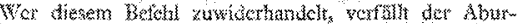

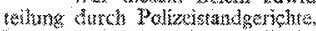

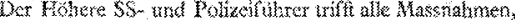

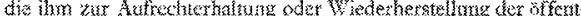

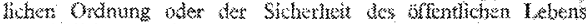
whorderlich exomeinizen.

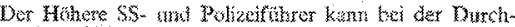

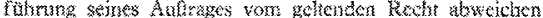

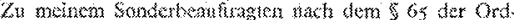

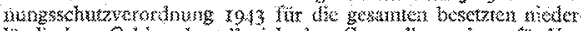
landishen Geblete kesple oh den Generallemmsso fir Ver

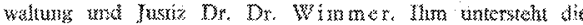

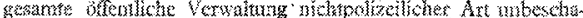

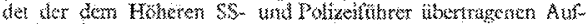
gyane.

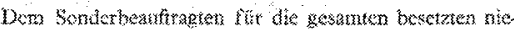

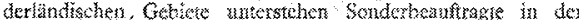

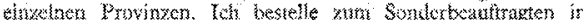
der $P$ roving

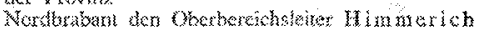

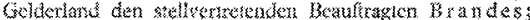

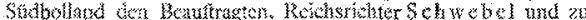

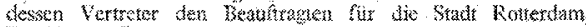

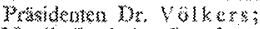

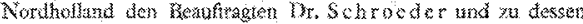

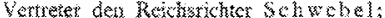

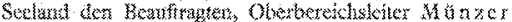

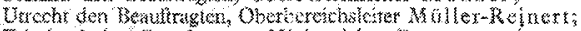

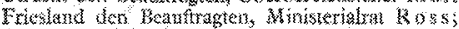

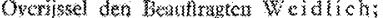

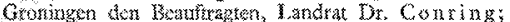

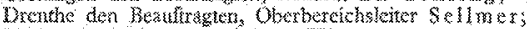

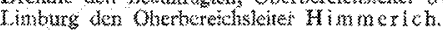

Dox

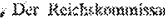

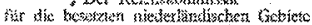

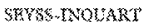

\section{BISONDERE ANORDNUNG.}

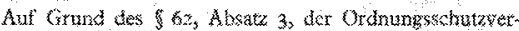

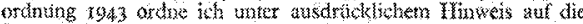

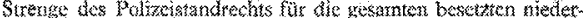
Jundischer Gebiots an:

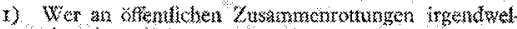
cher Ari teifrimm;

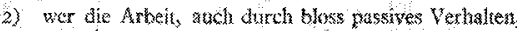
verwelyert,

wer strolkt ods?

Fer Arbitnchmer ausspetw:

3) Wer uncranbe Schuss, Theb- oder Stichwaffen trà oder besitzi:

4) wer Fugblatter hersellt, verbreitel oder besilzt, die

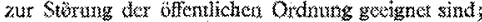

5) wer der ofentichen (xewall Widerstand leistet

verfalt der standgerichlhelen Aburteihng wnd witd baher ge-

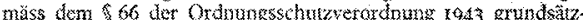
lich mis derta Tode bestrat

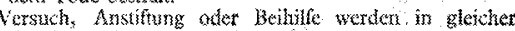

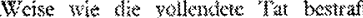

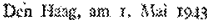

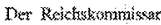

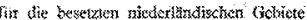
SEYSS-INOUNKT.

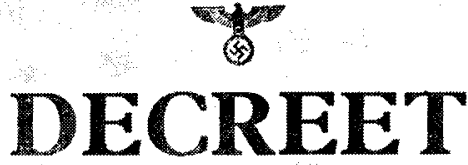

GEYTRYYTENDE DE

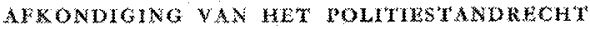

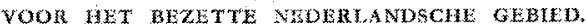

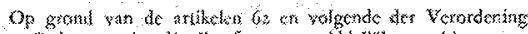

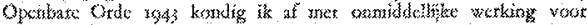

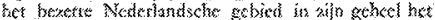

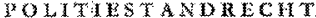

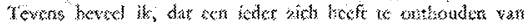

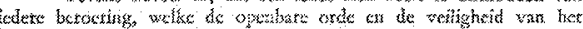

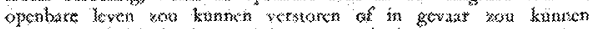

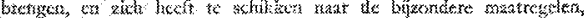

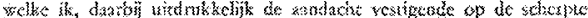

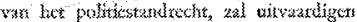

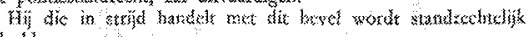
vecourdats.

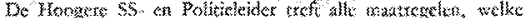

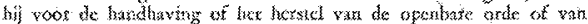

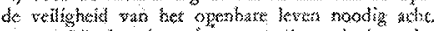

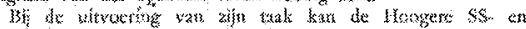

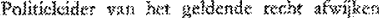

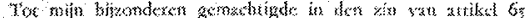

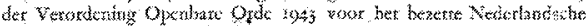

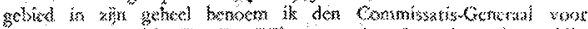

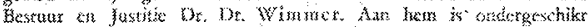

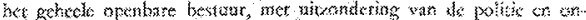

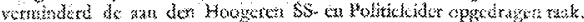

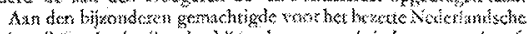

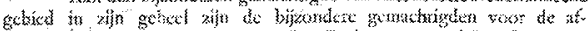

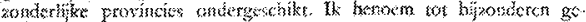

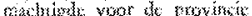

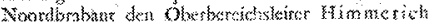

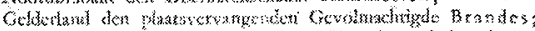

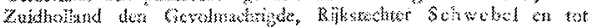

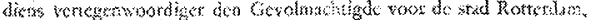
Prendeat D: Yolkets:

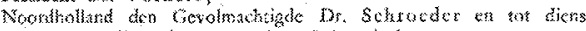

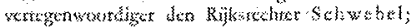

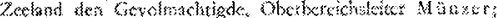

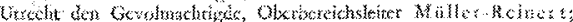

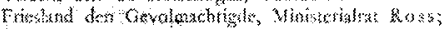

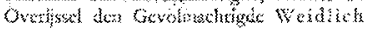

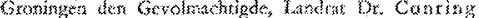

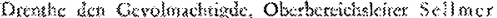

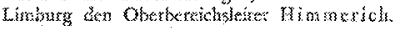

s.

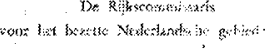

$$
\begin{aligned}
& \text { MPNY-13GAR }
\end{aligned}
$$

BUZONDERE BESHIKKING.

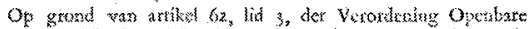

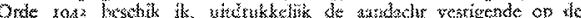

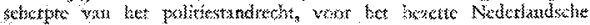
gehied in the gehed he whonds:

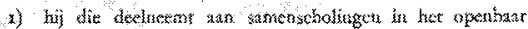
wat welk ond ook

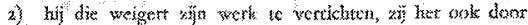

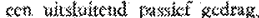

die stake of

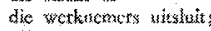

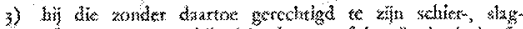

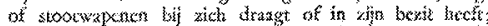

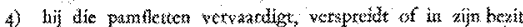

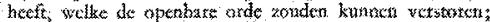

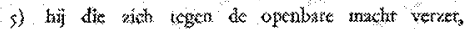

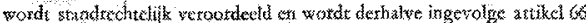
der Yexurdening Openbare Ode $x_{943}$ in het algensen gestrats met den towd.

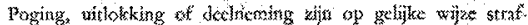
har als het volucoids mraflarat teit

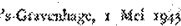

13. Re

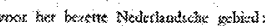

BEX IMUUART. 
dat een groot gedeelte van Noord-West-Brabant donker gekleurd bleef - men staakte er tot 5 of $6 \mathrm{Mei}$, soms tot $7 \mathrm{Mei}$. Ook de bevolking van Vaassen, Epe, en Heerde, van Haaksbergen en Genemuiden, van de gemeente Slochteren in Groningen en van enkele veenkoloniale gebieden kon er niet gemakkelijk toe komen, voor de Duitse druk te zwichten.

Voor een beschrijving van het Friese volksverzet en van de opstandige beweging in Noord-West-Brabant kan naar de afzonderlijke hoofdstukken over Friesland en Noord-Brabant worden verwezen.

$\mathrm{Bij}$ het raadplegen van de drie aan het boek toegevoegde kaarten zij nog opgemerkt dat deze niet alleen zekere leemten en onvermijdelijke onnauwkeurigheden vertonen, doch ook verder niet zoveel indices voor het stakingsverzet geven als wij wel zouden wensen. Men hoede zich voor voorbarige conclusies. Kennis van locale omstandigheden is noodzakelijk om bijvoorbeeld de passiviteit van de bevolking in bepaalde gemeenten te verklaren. Dit geldt o.a. voor de meeste Zeeuwse eilanden, die onder zware Duitse militaire bezetting zuchtten en voor het gehele duingebied van Cadzand tot Den Helder en de Waddeneilanden. Waar de bevolking gedeeltelijk was geëvacueerd en brede stroken grond in militaire verdedigingslinies waren herschapen, kon bezwaarlijk worden gestaakt.

$\mathrm{Na}$ de talrijke arrestaties, die Zaterdagochtend en Zaterdagmiddag $1 \mathrm{Mei}$ 1943 plaats vonden en na de voltrekking van de eerste doodvonnissen, meende de Sicherheitspolizei er zeker van te zijn, dat de overgrote meerderheid van de stakers Maandagochtend wel weer aan het werk zou gaan. In ieder geval rekende ze er op, met geïsoleerde gevallen van voortgezette staking te doen te krijgen en deze waren gemakkelijker te behandelen dan massaal verzet van een anonieme massa.

Zondag 2 Mei kon worden gebruikt om de intimidatiepolitiek ten top te voeren ten einde de hervatting van het werk op Maandagmorgen te bespoedigen. Er heerste de hele dag grote bedrijvigheid bij alle Duitse instanties.

Volgens een instructie, dd. 1 Mei van de centrale Duitse politiedienst te Den Haag, gericht ,an alle Aussenstellen”, moest des Zondags vooral contrôle worden uitgeoefend op alle godsdienstoefeningen. Het bevel luidde: "Soweit möglich, bitte ich die morgigen Gottesdienste in den Kirchen überwachen zu lassen und fernschriftlich hier zu berichten. falls irgendwelche Äusserungen im Hinblick auf die augenblickliche Lage gemacht werden." (Bijlage II, 30).

Bij alle kerkdiensten werd echter grote voorzichtigheid in acht genomen. Ieder wist, dat er spionnage dreigde. Bovendien zagen de geestelijken wel in, dat het niet verantwoord zou zijn, verder olie op het vuur te werpen. $Z_{i j}$ kozen soms teksten, die betrekking hadden op bange nood, maar niemand achtte zich na de afkondiging van het standrecht geroepen, voortgezette tegenstand te stimuleren.

De Standgerichte, die hun taak Zaterdag begonnen, zetten de verhoren in geforceerd tempo voort. Doodvonnissen werden in de meeste gevallen direct 
bekend gemaakt en voltrokken. Door aanplakbiljetten en radioberichten met opsommingen van slachtoffers moest het publiek overtuigd worden van de ernst van de toestand. Er werd overal geducht gepatrouilleerd en menigmaal in het wilde weg geschoten. Schrik en ontsteltenis veroorzaakten ook talloze nachtelijke arrestaties, zowel in de nacht van Zaterdag op Zondag als Zondagnacht.

Maandagochtend werd gecontroleerd, of deze maatregelen tot het voor de Duitsers gewenste resultaat hadden geleid. In het algemeen had de Duitse politie zich daarover niet te beklagen. $Z_{i j}$ kon haar aandacht bepalen tot kernen van geisoleerd verzet. Dit verklaart het grote aantal slachtoffers, dat de na Zondag voortgezette stakingen eisten.

In Twente, het gebied waar reeds Donderdagmiddag algemeen werd gestaakt, had het personeel van de meeste fabrieken reeds Zaterdagmorgen het werk hervat. Het weerspannigst toonde zich de bevolking van Haaksbergen. Toen de Duitse politie Maandagochtend voor contrôleritten uitrukte, bleken in Haaksbergse fabrieken, o.a. bij de N.V. D. Jordaan \& Zoon's Textielfabriek, nog vele arbeiders te ontbreken. 's Middags werd nagegaan, welk gedeelte van het personeel in dit bedrijf eerst na de middagschafttijd was verschenen. Vier-en-twintig personen werden in arrest gesteld en weggevoerd. Negen van hen moesten plaats nemen in een politie-auto, die men in de richting Hengelo zag wegrijden. Later bleek dat onderweg zeven van dit groepje arrestanten zonder vorm van proces waren neergeschoten: „op de vlucht dood geschoten", zoals de Duitse terminologie luidde.

Tegenover dit voorbeeld van politieterreur staat, dat de Duitsers Maandagochtend $3 \mathrm{Mei}$ een aantal nog stakende Genemuider mattenvlechters zeer clement behandelden. Van de 126 arbeiders, die zich te Genemuiden, na omsingeling van het dorp, moesten melden, werden 23 gearresteerd. $Z_{i j}$ kwamen echter de volgende dag weer op vrije voeten.

Een van de treurigste gebeurtenissen uit de geschiedenis der April-Meistakingen speelde zich af in de omgeving van Marum in de Zuid-Westhoek van de provincie Groningen. Op een bericht dat bij Marum barricades zouden zijn opgericht - in werkelijkheid was slechts een omgehakte boom over de weg gevallen - werden Maandag 3 Mei vele personen uit de omgeving lukraak gearresteerd en opgesloten in een barak van de "stelling Trimunt" bij het gehucht van dezelfde naam. Later op de dag verschenen leden van de Sicherheitspolizei uit Groningen. $Z_{\mathrm{ij}}$ haalden de gevangenen in groepjes van vier te voorschijn en schoten de een na de ander neer - in het geheel 17 personen. Indien men een slachtoffer van een wilde schietpartij op straat in Marum meerekent, kostte het bloedbad van Marum 18 mensenlevens.

Ongeveer op hetzelfde ogenblik, dat te Marum zoveel slachtoffers vielen, arresteerden de Duitsers een drietal stakers in de nabijheid van de Coöperatieve Aardappelmeelfabriek "De Woudbloem" te Scharmer in de gemeente Slochteren (een uitgestrekte landbouwgemeente ten Oosten van Groningen). Dinsdagmiddag 4 Mei fusilleerden Duitse politiemannen deze gevangenen op 
het fabrieksterrein van ,De Woudbloem”; een poging tot intimidatie, die inderdaad tengevolge had, dat stakers uit naburige fabrieken weer naar hun werk terugkeerden. Voordien had de Duitse politie trouwens Maandagavond ook al enige arrestanten bij een fabriek te Hoogezand neergeschoten. Woensdag was het verzet in de Veenkoloniën gebroken.

Verwonderlijk is, dat de lang-volgehouden staking in Friesland niet meer slachtoffers heeft geëist. De Friezen lieten zich door de publicatie van doodvonnissen niet intimideren. In de meeste Friese dorpen was de staking, het standrecht ten spijt, Maandag dan ook nog in volle gang. Tegenover de solidariteit van de bevolking beschikte de Duitse politie over geen ander middel dan uitbreiding van patrouille-activiteit. Waar sabotage voorkwam, kon men gijzelaars arresteren, waar men samenscholingen bespeurde, zou onmiddellijk worden geschoten. Op deze wijze vielen er op 3 en 4 Mei nog slachtoffers te Dokkum, te Noord-Bergum, te Buitenpost, te Munnikeburen, enz. De ,melkstaking" werd door de Friese boeren ook zo lang mogelijk volgehouden, ondanks alle moeilijkheden, die het niet-afleveren van melk aan de zuivelfabrieken, voor het bedrijf veroorzaakte. Door contrôle op de melkleverantie kon de Duitse politie gemakkelijk te weten komen, welke boeren hun verzet het langst volhielden. Te Suameer werd een boer doodgeschoten, die zich niet wilde buigen voor de Duitse aanmaning, zijn verkoop van melk aan particulieren stop te zetten. Eerst heel geleidelijk, veelal pas na Dinsdag of Woensdag, gaven de boeren aan de op hen uitgeoefende pressie toe.

In Gelderland kostte het voortzetten van de staking op Maandag 3 Mei het leven aan een aantal arbeiders van de Hevea-Rubberfabriek te Renkum en van de beide ijzergieterijen te Vaassen ("Industrie" en "Vulcanus”). Voor bijzonderheden zij ook hier verwezen naar het hoofdstuk Gelderland in het gedeelte dat aan de stakingsbeweging in de verschillende provincies is gewijd.

In het Zuid-Limburgse mijngebied uitte de groepssolidariteit van de ondergrondse mijnwerkers zich in een voortgezet saboterende houding op Maandag 3 Mei. Weliswaar was Zondag voortdurend beraadslaagd over de hervatting van het werk en scheen men wel geneigd het advies van de directie der Staatsmijnen te volgen - rustig aan het werk te gaan op conditie dat Duitse represailles achterwege zouden blijven - doch de dagploegen, die Maandagochtend verschenen, bleken allerminst volledig.

De Duitse politie arresteerde hierop in de loop van de dag enige ingenieurs en een aantal arbeiders. $\mathrm{Na}$ de reeds eerder gepubliceerde doodvonnissen kon het ergste worden verwacht. Inderdaad veroordeelde het Standgericht te Maastricht een tiental personen van de nieuwe groep gevangenen tot de kogel. Dinsdag 4 Mei werd evenwel bekend gemaakt, dat gratie mogelijk was, indien alle stakers hun verzet opgaven, een mededeling die er toebijdroeg, de tegenstand te breken.

Te Eindhoven constateerde de Sicherheitspolizei, dat het personeel in vele bedrijven, o.a. in de fabrieken van de N.V. Philips, slecht was opgekomen. Het Standgericht voor Noord-Brabant installeerde-zich in het hoofdkantoor 
van Philips en liet het aan de politie over, een keuze te doen uit het grote aantal arrestanten, dat die dag door overvalwagens van alle kanten werd aangevoerd. Maandagmiddag werden zeven arbeiders op een der fabrieksbinnenplaatsen gefusilleerd. Deze poging tot intimidatie had voor Eindhoven wel effect, zij maakte evenwel weinig indruk op de bevolking van Noord-WestBrabant. Dinsdag was te Breda de staking bij de N.V. Hollandse Kunstzijde Industrie en bij de N.V. Hero nog in volle gang. De Duitse politie trad hier gematigd en tactvol op, zodat de staking te Breda zonder bloedvergieten eindigde.

Merkwaardig was het langdurig verzet in de dorpen van het Noord-Westelijk kleigebied van Brabant, in de omgeving van de Langstraat en langs de randen van het Land van Altena. De staking kwam in deze buturten eigenlijk eerst Maandag goed op gang. Hier en daar nam de bevolking een zeer opstandige houding aan en kwam sabotage voor. Patrouilles van de Duitse politie, schietpartijen en arrestaties schenen weinig indruk te maken. In sommige dorpen bleef men tot 6 of 7 Mei doorstaken.

Dezelfde geest van min of meer roekeloze hardnekkigheid trof men in Zuid-Holland in het gebied langs de Merwede en de Noord aan. Vele arbei ders van scheepswerven te Hardinxveld verschenen Maandag niet op hun werk, hoewel zij wisten, dat de Duitse politie contrôle zou uitoefenen. Maandagmiddag werden twintig van hen gearresteerd. Vier stakers kregen 's avonds de kogel. Ook langs de Noord, te Kinderdijk, Alblasserdam en Bolnes bestond de derde Mei nog niet veel animo om de werkzaamheden te hervatten.

In Noord-Holland duurden de stakingen het langst voort in het Noordelijke landbouwgebied, waar de West-Friese bevolking in haar wijze van reageren overeenstemming vertoonde met de felheid van de Friese boeren en arbeiders.

In het algemeen was in de industriesteden het laatste verzet op Dinsdag $4 \mathrm{Mei}$, in de meest opstandige landbouwstreken op Donderdag 6 Mei gebroken.

9 Mei 1943 kon Himmler uit Berlijn aan Rauter telegraferen:

\section{Lieber Rauter!}

Ich spreche Ihnen und Ihren Männern für das umsichtige und tatkräftige Dutchgreifen bei dem von einer verbrecherischen Emigrantenrlegierung angezettelten Generalstreik und die rasche Niederschlagung desselben meine volle Anerkennung aus.

Ich trete mit grösstem Nachdruck für die Einziehung der Radiogetäte ein. Seien Sie sich darüber klar, dass eine Unterlassungssünde, die jetzt in diesem psychologisch günstigen Zeitpunkt nach Niederschlagung des Generalstreiks begangen wünde, so leicht nicht wieder gutzumachen wäre.

Berlin, den 9. Mai 1943.

Heil Hitlet!

Ihr

gez. H. Himmlet.

Het hier in extenso afgedrukte telegram is niet in de eerste plaats als gelukwens merkwaardig. Het is vooral interessant door de opwekking om op het 
psychologisch gunstig moment tot vordering der radiotoestellen over te gaan. Verder bevat het een belangwekkend voorbeeld van de voor het nationaalsocialisme typische phraseologie. Himmler kon heel goed weten, dat de staking niet door de regering te Londen was aangemoedigd; ook diende zijn telegram niet voor propaganda-doeleinden. Uit de macht der gewoonte moest echter de formule van de "verbrecherische Emigrantentegierung" (vermoedelijk werd er niets meer bij gedacht) worden opgenomen.

Inderdaad heeft Rauter in het zegevierende gevoel, dat hij de Nederlanders had klein gekregen, niet geaarzeld, de enigszins geïntimideerde bevolking direct na de staking hard aan te pakken. Op 5 Mei werd zijn beschikking gepubliceerd, dat de studenten niet-tekenaars zich de volgende dag moesten melden. 7 Mei stond het besluit van de "arbeidsinzet" in de kranten: alle mannen van 18 tot 35 jaar moesten zich melden bij een der gewestelijke arbeidsbureaux. 13 Mei volgde het bevel tot inlevering van de radiotoestellen.

Uit de door de provinciale Beauftragten ingezonden rapporten blijkt duidelijk, hoe de schrijvers onder de indruk waren gekomen van de kracht van het volksverzet. Sommige van hen waren van mening, dat de stakingen als een vorm van georganiseerd verzet moesten worden opgevat; anderen veronderstellen, dat ze spontaan waren uitgebroken. Maar zonder uitzondering eisten zij krachtdadige maatregelen om een herhaling van dergelijke gebeurtenissen te voorkomen. Vooral op het moment van de Geallieerde invasie mocht men niet het risico lopen van een nieuwe algemene staking. Men had nu duidelijk gezien, uit welke groepen van de bevolking tegenstand te verwachten viel. Het was ook duidelijker geworden, hoeveel ambtenaren en bedrijfsleiders op een voor de Duitsers ongunstig ogenblik een saboterende houding zouden aanmoedigen; het werd daarom volgens de Beauftragten hoog tijd, nog meer onbetrouwbare figuren door NSB-ers te vervangen.

Interessant zijn ook de beschouwingen over de oorzaken en de gevolgen van de stakingen in enige Stimmungsberichte (zie Bijlage 59 en 60), berustend op informaties, ingewonnen door Legationsrat Wickel, die dikwijls bij niet-NSB-ers te rade ging. Ze werden opgesteld ter voorlichting van Generalkommissar Fritz Schmidt en van het Auswärtige Amt te Berlin. Of deze Stimmungsberichte, waaruit meermalen wel enig gezond verstand spreekt, enige invloed hebben uitgeoefend op het beleid van Seyss-Inquart, Christiansen en Rauter moet worden betwijfeld. 


\section{HET STANDPUNT VAN DE REGERING TE LONDEN}

Vrijdagochtend 30 April 1943 ving de Britse luisterdienst een Duits radiobericht op (in het Engels gesteld), bestemd voor Japan, waarin mededeling werd gedaan van hernieuwde krijgsgevangenschap van het voormalige Nederlandse leger. Radio-Hilversum gaf op geen enkele wijze bevestiging; wèl de Berlijnse correspondent van een $Z$ witserse courant.

De opgevangen berichten leken belangrijk genoeg om er dadelijk de Minister-president, prof. mr P. S. Gerbrandy, van in kennis te stellen. Terwijl in Nederland de stakingen reeds in volle gang waren, aarzelde de Nederlandse regering te Londen nog, op welke wijze zij zou reageren op de binnengekomen verontrustende informaties. De uitzending van Radio-Oranje, die om 1 uur n.m. zou plaats vinden, stond reeds op papier. Minister Gerbrandy gaf echter opdracht, in de middaguitzending op voorzichtige wijze het standpunt van de regering kenbaar te maken. De tijd, besteed aan gelukwensen voor Prinses Juliana, die op deze fatale datum haar verjaardag vierde, kon iets worden ingekrompen. Ingelast werd een korte beschouwing over de „Registratie van gemobiliseerden in Nederland", uitgesproken door H. J. van den Broek (,De Rotterdammer", toenmaals hoofdredacteur van Radio-Oranje). Dit geschiedde in de volgende bewoordingen: „Berlijn meldt dat alle Nederlandse officieren, onder-officieren en manschappen opdracht hebben gekregen zich bij de Duitse autoriteiten aan te melden. $Z_{i j}$ zouden hun belofte hebben verbroken om niets tegen Duitsland te ondernemen en daarom alsnog krijgsgevangen worden gemaakt. In de laatste 24 uur zouden reeds 18.500 gedemobiliseerden door de Duitsers zijn opgepakt. De gedragslijn van iedere Nederlander, die onder deze nieuwe maatregel valt, moet zijn: Niet aanmelden!, een raad, die de Nederlandse regering te Londen geeft".

In het hierop volgend commentaar vertelde Van den Broek dat het bericht uit ,een tot dusverre nog niet met zekerheid geïdentificeerde bron" kwam. Het genoemde getal van 18.500 gedemobiliseerden was ontleend aan een telegram van de Berlijnse correspondent van een $Z$ witsers blad. Vrij uitvoerig ging de spreker op de vraag in, wat de Duitsers met hun jongste maatregel beoogden: „De eerste mogelijkheid is, dat zij, die zich aanmelden, direct of na een poosje naar de Duitse krijgsgevangenkampen zullen worden overgebracht. De tweede is, dat deze slachtoffers onmiddellijk of later in Duitsland zullen worden te werk gesteld. De derde mogelijkheid is tenslotte, dat de Moffen uit de Nederlandse gedemobiliseerden een troepenmacht zouden 
willen vormen, die onder leiding en toezicht komt te staan van Duitse officieren en in Nederland geboren landverraders. Deze troepenmacht zou dan of naar de fronten worden gestuurd of, op verafgelegen plaatsen in Europa, politiediensten moeten verrichten."

Bij een registratie van namen zou het niet blijven. "Dat stippelt als vanzelf de gedragslijn uit van iedere Nederlander, die onder de nieuwe maatregel valt. Die gedragslijn moet zijn: ,, ,Niet aanmelden, zich rustig houden; alle oproepen en alle bevelen doodgewoon negeren"."

En even later: „Wij zijn er van overtuigd, dat verreweg de meeste, zo niet alle Nederlanders dit bij zichzelf reeds als de enig juiste houding hebben vastgesteld. $Z_{\mathrm{ij}}$ hebben waarschijnlijk, op dit gebied, geen raad meer nodig."

„Daarom nogmaals: „, ,Meldt U niet aan; negeert de oproepen; steekt zelf niet $U w$ hoofd in de muil van de tijger; houdt U rustig en, als het absoluut noodzakelijk is, tracht $U$ onvindbaar te maken"."

Uit deze vrij vage raad blijkt wel duidelijk, dat men te Londen die Vrijdagochtend slecht geïnformeerd was. Men kende er de strekking van het besluit van Christiansen, doch wist nog niets af van de spontaan uitgebroken stakingsbeweging. In Nederland was de allesoverheersende vraag, hoe de regering op de staking zou reageren. Het is psychologisch verklaarbaar dat het publiek, vooral degenen die het werk hadden neergelegd, zich gedurende enkele dagen nog meer voor de staking als zodanig dan voor het decreet van Generaal Christiansen interesseerde. Velen waren er van overtuigd, dat tal van illegale organisaties over geheime zenders beschikten, die een geregelde verbinding met Londen mogelijk maakten. Men verbaasde er zich over, dat Radio-Oranje een kennelijke onjuiste mededeling deed over het gevangen nemen van 18.500 gedemobiliseerden en met geen woord over de stakingsactiviteit repte.

In de avonduitzending, 30 April om kwart over acht, van Radio-Oranje, vatte $H$. J. van den Broek het advies van de Londense regering samen in de slagzin: „Niet aanmelden! Alle oproepen negéren! Desnoods onderduiken!" Het is begrijpelijk dat deze "goede raad" door de Nederlanders, die in de gelegenheid waren, naar Radio-Oranje te luisteren, met ironie en scepsis werd ontvangen. Van den Broek erkent in zijn boek Hier Radio-Oranje, dat de formulering ,,desnoods onderduiken" als slagzin fout was ${ }^{1}$ ). De Nederlandse Voorlichtingsdienst te Londen heeft wel meer de fout begaan onuitvoerbare voorstellen te doen. Begreep men dan niet, dat het niet mogelijk was, op korte termijn een organisatie tot stand te brengen, die het onderbrengen van honderdduizenden onderduikers kon regelen? Ieder advies, dat niet met de realiteit te rijmen viel, wekte bij velen wrevel op.

Het kan de regering te Londen echter niet worden aangerekend, dat zij, onkundig van het inmiddels uitgevaardigde standrecht en de vele arrestaties, welke in verband met de staking plaats vonden, de avonduitzending grotendeels wijdde aan de verjaardag van de Prinses. Eerst sprak Hare Koninklijke Hoogheid zelf. Daarna hoorde men het stemmetje van Prinses Beatrix.

1) H. J. van den Broek, Hiet Radio-Oranje, Amsterdam 1947, blz. 150. 
De volgende dag, Zaterdag $1 \mathrm{Mei}$, werd de radiorede van Prinses Juliana opnieuw uitgezonden. Vervolgens sprak in de middaguitzending $A$. den Doolaard onder de titel: „Nederlanders! Niemand melde zich vrijwillig!” $Z_{\text {ijn }}$ gloedvol betoog kon weinig indruk maken op het moment dat de stakingsbeweging hier en daar haar dramatisch hoogtepunt naderde en de eerste slachtoffers vielen.

In de avonduitzending van Zaterdag sprak Ir J. W. Albarda, Minister van Waterstaat, over: „De één-Meidag, een dag van bezinning en idealisme”. Intussen was het Nederlandse volk reeds tot het smartelijk besef gekomen, dat de algemene staking geen kans van slagen had. Men moest zich onderwerpen. Opnieuw richtte zich nu de aandacht op de vraag, hoe en binnen welke termijn onze voormalige militairen naar Duitsland zouden worden afgevoerd.

Zondagmiddag 2 Mei sprak H. J. van den Broek over "Het masker valt". Hij kwam tot de conclusie: „De vrijheid - en waarschijnlijk erger - van honderdduizenden Nederlanders wordt bedreigd. Talloos zijn de misdaden, die de barbaarse schenders van ons grondgebied reeds tegen ons volk hebben begaan. Het is moeilijk, de ernst en de draagwijdte van elk dezer misdaden tegen elkaar af te wegen. Maar de aanslag, die thans op ons volksleven wordt beraamd, is waarschijnlijk het ernstigste feit, dat zich sedert de $10 \mathrm{de}$ Mei 1940 heeft voorgedaan. Thans willen de Moffen de Nederlanders weer als gezworen vijanden beschouwen en handelen zij daarnaar. Het masker valt af!"

Dezelfde dag echter kwam de Londense regering door een illegaal telegram op de hoogte van de stakingsactiviteit, die het land gedurende de voorafgaande dagen in beroering had gebracht. Men had er reeds een vermoeden van, dat zich bijzondere gebeurtenissen hadden afgespeeld. Een berichtje van Radio-Hilversum, Zaterdagochtend, dat geen 1-Meiviering was toegestaan en dat men het werk niet mocht neerleggen, gaf te denken. Bovendien vroeg men zich af, wat Ir Mussert, die de 1ste Mei een radiorede hield, bedoelde met zijn toespeling op ,onbezonnenheden".

$\mathrm{Nu}$ Londen enigermate wist wat zich in het vaderland had afgespeeld, maakte zich een sombere stemming van de Nederlanders in de Britse hoofdstad meester. Men kon verwachten, dat de Duitsers hard zouden toeslaan; sommigen opperden zelfs de veronderstelling, dat het bevel van Christiansen als provocatie moest worden opgevat om bij eventuele tegenstand van de bevolking een waar bloedbad te kunnen aanrichten.

Maandagochtend, de 3de Mei, vergaderde de ministerraad ten huize van de Minister-President. Prof. Gerbrandy had van Churchill vernomen, dat voorlopig niet aan een invasie kon worden gedacht. De geallieerde legers waren gebonden door de strijd in Noord-Afrika. Een Amerikaans plan tot een vervroegde invasie in 1943 leek te riskant. Dit betekende evenwel dat het niet verantwoord zou zijn, de bevolking van de bezette West-Europese gebieden tot gewapend verzet op te wekken. De regering had nu wel ge- 
adviseerd, dat niemand zich voor hernieuwde krijgsgevangenschap zou melden, maar tot aanmoediging om te staken kon zij niet besluiten. $Z_{i j}$ bevond zich wel in een moeilijk parket. Enerzijds wist $z \mathrm{ij}$, dat geen geallieerde militaire hulp beschikbaar was om een volksopstand te steunen, anderzijds viel het haar ook niet gemakkelijk om tot spoedige beëindiging van alle stakingsactie te manen. De regeringsverklaring, die Maandagmorgen in de ministerraad werd opgesteld, was dan ook een poging om de kool en de geit te sparen. $Z_{i j}$ werd in de Maandagmiddaguitzending van Radio-Oranje door Prof. mr P. S. Gerbrandy persoonlijk voorgelezen:

Landgenoten,

Gij hebt allen kennis genomen van de nieuwe aanslag van de Duitse overweldiger

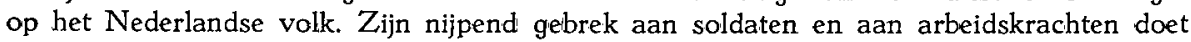
de vijand grijpen naar allerlei middelen om zijn eigen tanende macht te versterken ten koste van de Nederlandse volkskracht. $G i j$ weet, wat $U$ dienaangaande reeds door Radio-Oranje is meegedeeld en welke raad U namens de Nederlandse Regering heeft bereikt.

De Nederlandse Regering roept allen, die door het Duitse aanmeldingsbevel getroffen zouden worden, met de meeste nadruk op, in geen geval aan dat Duitse bevel gehoor te geven en zich te onttrekken aan iedere Duitse poging om zich van hen meester te maken.

Daarbij doet de Nederlandse Regering een dringend beroep op de gehele bevolking, om alles te doen teneinde het welslagen van de Duitse poging te verhinderen en om de voorbestemde slachtoffers te helpen en bij te staan.

De Nederlandse Regering herinnert uitdrukkelijk aan de opdracht van 4 Februari 1943 aan alle leden van het personeel in overheidsdienst. Deze opdracht gelastte: betmoeilijking en tegenwerking van alle maatregelen van den bezetter, die het Duitse oorlogspotentieel zouden verhogen ten koste van het Nederlandse volk. Geen geval is, in dit opzicht, duidelijker dan wat zich thans voordoet. Geen enkele uitzondering op de opdracht tot bemoeilijking en tegenwerking kan dan ook, minder dan ooit in de huidige omstandigheden, worden toegestaan.

Meer in het bijzonder geldt dit voor wat de identificatie, de opsporing, de aanhouding en de wegvoering van de slachtoffers van de Duitse maatregel betreft. Ik herhaal: identificatie, opsporing, aanhouding en wegvoering van de slachtoffers.

Tevens wens ik echter nadrukkelijk te verklaren, dat dit geen oproep tot algemeen gewapend verzet betekent. Als het ogenblik daarvoor gekomen is, zal de Nederlandse Regering $U$ dat op overduidelijke wijze laten weten.

Voor het ogenblik geldt het alleen, de Duitse aanslag op de Nederlandse weerbare mannen af te slaan. Daarbij rekenen Koningin en Regering op de volle medewerking, de offervaardigheid en de vastheradenheid van alle Nederlanders."

Deze regeringsverklaring muntte niet uit door duidelijkheid en zal zeker door slechts weinig luisteraars zijn begrepen. Waarop sloeg de zin: „Geen geval is, in dit opzicht, duidelijker dan wat zich thans voordoet"? Duidelijk was slechts de nadrukkelijke verklaring ,,dat dit geen oproep tot algemeen gewapend verzet betekende".

De radiorede van Prof. Gerbrandy werd 's avonds herhaald. Even later sprak A. den Doolaard over het onderwerp ,Algemeen verzet: ja! Algemeen gewapend verzet, neen!", waarin hij opnieuw het accent legde op het niet 
aanmelden, maar toch ook een toespeling maakte op het begrip dat ons volk toonde voor ",de totale oorlog".

Ook in de volgende dagen bracht Radio-Oranje de staking niet rechtstreeks ter sprake. De Londense regering wilde, zo lang zij niet volledig op de hoogte was van de stand van zaken, geen aanwijzingen geven, die de Duitsers gelegenheid zouden schenken gearresteerde stakers als door Londen opgehitste personen te beschouwen.

Woensdag 5 Mei liet L. de Jong de oproep klinken: „Meldt U a.s. Vrijdag niet!" Tegen de tijd dat de eerste transporten krijgsgevangenen naar Duitsland zouden vertrekken, mocht niets worden verzuimd om het effect van de Duitse maatregelen zo gering mogelijk te maken. De trouwe luisteraars naar RadioOranje verbaasden er $z$ ich over dat Londen nog maar steeds over de stakingen bleef zwijgen. Hier en daar had zich een diepe neerslachtigheid van het volk meester gemaakt. De verbittering was gestegen, de neiging tot verzet toegenomen, maar tegelijkertijd kon men moeilijk verkroppen dat tijdens een van de meest critieke momenten van de bezettingsjaren de stemmen uit Londen hadden gezwegen over het eerste massale volksverzet. Slechts enkelen begrepen de toespelingen, bijvoorbeeld in de Dinsdagavond-uitzending van de "Rotterdammer" (H. J. van den Broek). Hij sprak toen over dit grote principe: ,alle middelen van strijd en vooral alle middelen van verweer moeten zodanig gekozen worden, dat zij aangepast zijn aan het karakter niet alleen, maar ook aan de waarschijnlijke duur van de strijd, waarin zij nodig zijn. Het is, om het maar kort te zeggen, de oude waarheid dat men zijn kruit niet ontijdig moet verschieten, maar het droog moet weten te houden tot het juiste ogenblik."

En , de Rotterdammer" vervolgde: „Na het bekend worden van de nieuwe Duitse schanddaad, hebben zich onmiddellijk, zoals $U$ weet, even spontane als scherpe reacties van de Nederlandse bevolking gemanifesteerd, vrijwrel op ieder gebied; reacties, die op hun beurt gevolgd zijn door nieuwe maatregelen van de vijand. De houding van de bevolking was een duidelijke aanwijzing, wat betreft de aard van haar gevoelens."

Voor de goede verstaander behoefde er geen twijfel over te bestaan dat „Londen" toen op de hoogte was van de April-Meistakingen. Des te meer verbaasde het velen, dat geen aanwijzingen werden gegeven en de gevolgen van de staking verder niet ter sprake kwamen.

Achteraf beschouwd, vragen wij ons dan ook af, of Radio-Oranje, in overleg met de regering, niet beter open kaart had kunnen spelen. Wanneer men Maandag had meegedeeld, dat men eerst Zondag berichten over de staking had ontvangen en daarop de demonstratieve kracht van de staking in het licht had gesteld, gevolgd door de goede raad van "het kruit droog houden", enz., zou dit in brede kringen van ons volk beter opgevat zijn dan het onderduikadvies en de "voorlichting" vol bedekte toespelingen, die de luisteraars in dagen van nood en verwarring te horen kregen.

Niet zonder bittere bijgedachten ving menigeen Donderdagavond $6 \mathrm{Mei}$ de woorden van H. J. van den Broek op: „Toen ik er over nadacht, wat ik 
vanavond zeggen zou, maakte ik bij mijzelf deze opmerking: de radio is een mooi ding, maar zij heeft een groot gebrek. En wel dit. De een moet altijd spreken, de ander moet altijd luisteren. Gedachtewisseling is niet mogelijk". Als een verontschuldiging klonk de opmerking, dat het voor de sprekers te Londen zo moeilijk was, vrijuit te spreken. Ieder woord moest op een goudschaaltje worden gewogen.

"Soms hindert dat absoluut niet, integendeel is het wel goed, dat de tegenstander dan hoort wat we zeggen. Maar soms is ook de allergrootste waakzaamheid geboden. En dat geldt wel speciaal voor bepaalde raadgevingen, instructies en oproepen uit Londen. $Z_{i j}$ moesten, aan de ene kant, aan duidelijkheid niets te wensen overlaten voor hen, wie ze aangaan, aan de andere kant mogen $z$ ij ook niet zo gedetailleerd en precies zijn, dat zij de vijand gelegenheid geven tot onmiddellijke tegenactie."

Zou het niet beter zijn geweest, indien dit Zondag, Maandag en Dinsdag herhaalde malen met veel nadruk was medegedeeld?

Geleidelijk ontving de regering nauwkeuriger inlichtingen: niet uit de Nederlandse couranten uit het bezette gebied, die haar meestal 16 à 18 dagen na het verschijnen bereikten, maar uit illegale rapporten, o.a. een verslag van de staking door de geheime agent "Wim", die op de 9de Mei een samenvatting van de gebeurtenissen overseinde. Dit rapport berustte echter op niet altijd even nauwkeurige waarnemingen van agenten in verschillende delen van het land.

Een jaar later, Zaterdagavond 29 April 1944, herdacht Radio-Oranje de April-Meidagen van 1943. Op grond van commentaren uit Nederlandse ondergrondse bladen werd door een drietal sprekers nog eens een overzicht gegeven van de voornaamste gebeurtenissen. Het regeringsbeleid uit die dagen bleef verder buiten beschouwing. 
DEEL II

DE STAKING IN DE PROVINCIËN 


\section{HOOFDSTUK I}

\section{OVERIJSEL}

Het is een vaststaand feit, dat na Generaal Christiansen's bekendmaking van Donderdagmiddag 29 April 1943, de eerste stakingen hier te lande in Twente begonnen. Wij kunnen het begin van de staking zelfs nog nauwkeuriger localiseren: het werk werd het eerst neergelegd bij de Machinefabriek Gebr. Stork \& Co. N.V. te Hengelo, kort na de schafttijd, 's middags tussen twee uur en half drie.

Moeilijker is het, vaststaande feiten te verklaren. Heeft het toevalselement een rol gespeeld bij het uitbreken van de staking in Twente of moet het heftig verzet van de Twentse arbeiders worden toegeschreven aan een of meer oorzaken, die zich elders niet of in veel zwakkere mate voordeden? Dit is niet met volledige zekerheid vast te stellen. Min of meer hypothetisch meen ik echter op het samentreffen van verschillende factoren in Twente, met name te Hengelo, te mogen wijzen:

1. de sterke concentratie van industriële bedrijven. Niet alleen in ieder bedrijf afzonderlijk, maar ook in iedere opeenhoping van fabrieken was het aantal arbeiders groot genoeg om een massaal optreden mogelijk te maken. De bedrijven waren evenwel niet zó omvangrijk, dat eerst moeizaam overleg nodig was tussen ver uiteengelegen afdelingen. Sociologisch beschouwd, ziet men in bedrijven van 1000 tot 4000 arbeiders (de N.V. Stork telde in 1943 ruim 3000 arbeiders) een zeker evenwicht tussen massale tendenties en de solidariteit van niet al te grote groepen. Amerikaanse sociologen gebruiken gaarne de uitdrukking "face-to-face group", de groep waarin men elkander althans naar het uiterlijk kent. Het is de vraag of men de gezamenlijke arbeiders van Stork's Fabrieken een .face-to-face group" zou mogen noemen; de arbeiders in iedere werkplaats afzonderlijk zeker wèl. In iedere werkplaats-groep reageerde men na onderling overleg, vrij snel. Ook het contact met het personeel van naburige afdelingen behoefde niet veel tijd te kosten;

2. de invloed van het volkskarakter. Hoewel de vage term ,,volkskarakter" altijd de nodige omzichtigheid vereist, mag toch voor de Twentse bevolking wel enige homogeniteit in aard en aanleg worden vastgesteld: een neiging tot materialisme, geslotenheid, plichtsbesef met een ietwat fatalistische inslag, vredelievendheid, vasthoudendheid en doorzettingswil, meegaandheid, echter slechts tot een bepaalde grens (met een plotselinge omslag naar koppig verzet), 
rechtvaardigheid en solidariteit - dat zijn de eigenschappen, die door kenners van de Saksisch-Twentse volksaard worden genoemd ${ }^{1}$ ).

Het is evenwel de vraag, in hoeverre deze karaktertrekken ook nog een industriële bevolking kenmerken, die door huwelijk met personen van andere afkomst en door migratie veel van haar oorspronkelijk karakter heeft verloren. De bekende karakternivellering, die men gewoonlijk ziet in stedelijk-industrieel gebied, heeft $z$ ich in de jonge Twentse industrie-centra nog slechts in beperkte mate doen gelden. Geoefende waarnemers wezen er op, dat het Twentse stadsleven dikwijls nog in zijn groepskarakter een agrarische inslag vertoont. Zo schreef Blonk: „Toch is ook in een stad als Enschede niet de grote-stadsatmosfeer geheel doorgedrongen. De mening van familie, buurt en groep weegt er nog zwaar" 2).

Indien men de volksaard in het geding brengt dient ook te worden onderzocht, waarom in een bepaald gebied de bevolking van het platteland anders reageerde dan de bevolking van gelijke volksaard in de steden. Dit bewijst, dat naast de volksaard het massaal karakter van de stedelijke samenleving en de grotere beweeglijkheid daarvan als afzonderlijke factoren moeten worden genoemd;

3. Uit de volgende hoofdstukken zal blijken, dat overal in den lande de metaalbewerkers in de stakingsbeweging een bijzondere activiteit vertoonden. Ook wat dit betreft, had het oplaaiend verzet in de eerste stakingshaard, Stork's Fabrieken te Hengelo, een symptomatische betekenis. De metaalnijverheid, speciaal de machine-industrie, neemt, wat het intelligentiepeil en het organisatievermogen van haar arbeiders betreft, een vooraanstaande plaats in. Deze arbeiders weten, wat zij willen; zij zijn actief en gewend aan solidair optreden. In de April-Meidagen van 1943 trokken de metaalbewerkers in Twente dan ook veel duidelijker één lijn dan de textielarbeiders;

4. In het georganiseerd verzet vóór de staking, hadden de Twentse arbeiders reeds van een zekere onverzettelijkheid blijk gegeven. Of de Duitse druk in Twente sterker was dan elders, valt te betwijfelen (veeleer mag worden gezegd, dat Twente minder te lijden had van militaire bezetting en van het Duitse contrôle-apparaat dan de steden in het Westen), maar zeker is, dat er vroegtijdig vrij resoluut weerstand werd geboden. Dit blijkt bijvoorbeeld uit de opheffing van de Hengelose "Concertvereniging", nadat in November 1941 de Kultuurkamer was ingesteld, en uit het verzet tegen de "gelijkschakeling" van de afdeling Hengelo van „Het Groene Kruis" (in Juli 1942). Evenzo uit de sabotage van vele Duitse maatregelen door het Gewestelijk Arbeidsbureau te Hengelo en uit de belangstelling voor illegale politieke bijeenkomsten (waar o.a. de religieus-socialist J. H. Scheps, bekend door zijn verzetskrant $\mathrm{O} p$ korte golf, dikwijls sprak). Maar bovenal uit het verzet tegen de gelijkgeschakelde vakbeweging. Het optreden van de door de Duitsers be-

1) Vgl. G. J. ter Kuile Sr, Twlente en Oost-Salland. In P. J. Meertens en Anne de Vries, De Nederlandse Volkskarakters, 1938.

2) A. Blonk, Fabrieken en Mensen. Diss. Amst. 1929. 


\section{T \\ ANORDNUNG}

Auf Grund des 64 der Ordnungschwtzrerordrung 1943 ordne ich unter Hinweis auf das yom Reichskommissar für die besetzten niederländischen Gebiete verhäng Polizein standrecht fü die gesanten besetzten niederländischen Gebiete an:

1) Die mir unterstehenden SS- und Folizei-Yerbănde schiessen othe Warnung unverzüglich, wenn $Z_{u}$. sammentotrongen irgendwelcher Art arfolgen oder went sich mehr als funf Personen aut offentlichen Strassen ader Plätzen ansammela. Ausgenommen sind von der deutschen Polizei genehmigte Betriobsvarsamminatson.

2) Verboten izt der Aufenthalt in Freien in der Zeit von 20 Whr bis 6 Uhr. Ausnahmen genehmigt die deutsche Polizei.

3) Verboten ist der Ausschank und Genust van Branntwein und sonstigen alkoholischen Getränken in offentlichen Lokalen sowie die Abgabe und der Verkzuf solcher Getranke.

4) Den Arbeitgebern ist die Auszahlumg von Lobhnen und Gehaltern an Streikende für Tage verboten, an denen ganz oder teilweise gestreikt wurda.

5) Die datsche Sicherheitspolize beschlagnahnt alle

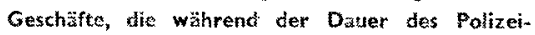
standrechts $z u$ den vorgeschriebsnen oder orts. üblichen Zeiten nicht offenhalten.

Wer einem der unter den ziffern 2 bis 4 genannten Verbote zuwiderhandelt, wird mit Gefängnis und Geldstrafe in unbeschränkter Möhe oder mit einer dieser Strafen bestraft, sofern nicht nach amberen Bestimmungen eine strengere Strafe verwirkt ist.

Sicherheitspolizeiliche Massnahmen bleiben vorbehatten.

Den Hasg, am t, Mai 1943.

$$
\begin{aligned}
& \text { Der Mohere SS- und Polizeiftithrer } \\
& \text { boim Reichskomsissar für die } \\
& \text { bcsetzten nieder } \\
& R \text { R } \cup T \mathbb{R}_{1} \\
& \text { S\$Gruppentihtrex und Generalleutrant } \\
& \text { der Poltzei. }
\end{aligned}
$$

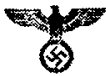 \\ BESCH IKKING}

Op grond van artikel 64 der Vetordening Omenbarc Orde 1943 besthik ik in verband net hot door don fijkscomtrissaris voor het beratte Noderlandsche gebled afgokondigde politicstanx-

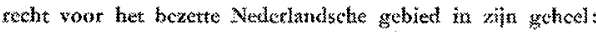

1) De atan mij ondergeschikte SS- an politienconeden schicter owwerwifld zotder watsehwway, wamneet

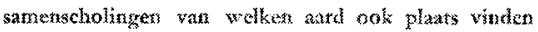

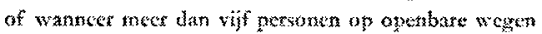
of pleinen samenkomen. Woor te Doukche politie

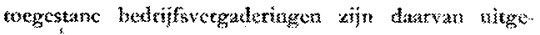
zonderd.

2) Het is verbotwo zich tusschen 20 en 6 uar in de open luche op te houden. Viczondcringen worden denr de Duxische politic togestata.

3) Verboden is het schenkst ex hat gebraiken san brandswijn en andere acoholhoudende dratem in openkare localiteiten, alswede bet afferen an het verkospen van zoodanige drataken.

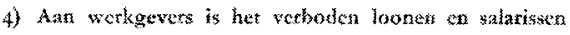
wit to betalca aan stakers roor dagen, watarop getwe t of sedectelijk werd gestiakt.

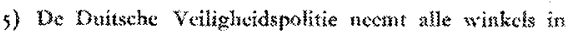
bestag, welke gedurende den tijd dat bet politicstandrecht van kxacht is, nier geopend tijn or de root geschreven of op de ter platse geluraikelike nijden.

Hii die in strijd handelt mat ea der wathoden, pronowm? onder 2 tor en met 4, worde gestedt met gevangenisstraf wan

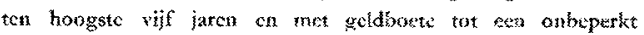

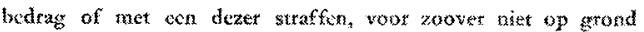
wan andere bepalingen ecf zwatade straf is verhourd.

Fict nemen van naatrogclen op fict gobiea det veilig. heidspolitie blifft onaangetast.

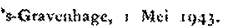

De Hoogere ss. kn plitieleidec

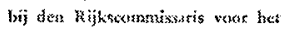

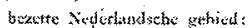
$\mathrm{R} A \mathrm{ETE}$,

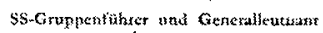
dis polizai, 


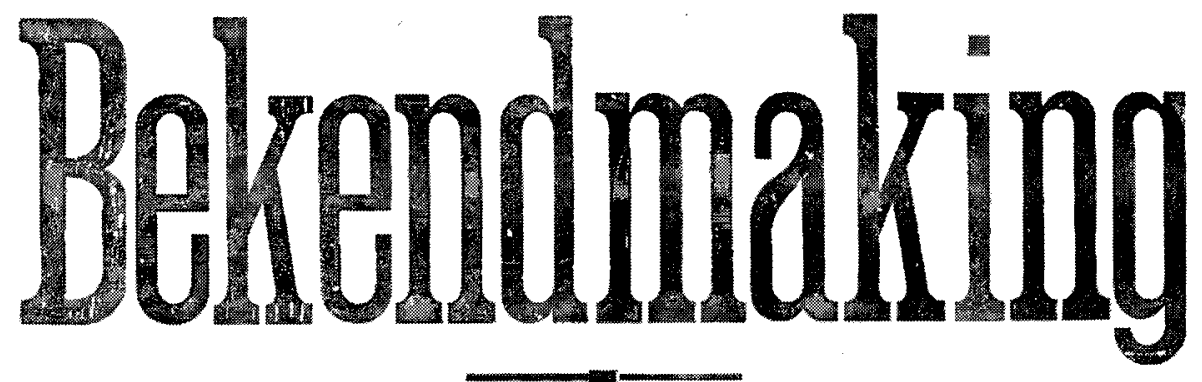

De Höhere SS en Polizeiführer maakt bekend:

Het Politiestandgerecht Overijssel heeft op grond van het Decreet en van de Bijzondere Verordening van den Rijkscommissaris over de inwerkingtreding van het Politiestandrecht van 30-4-1943,

\section{ter dood veroordeeld:}

1.) den Nederlander

FREDERIK MARTINUS LOEP,

geboren 31 Augustus 1906 in Stad Doetinchem. LOEP heeft als leidend bedrijfsingenieur der firma Stork te Hengelo (O.) door passief gedrag de staking bewust en gewild gesteund.

2.) den Nederlander

ANTONIUS HASENBEKKE,

geboren 17 October 1917 in Tubbergen.

HASENBEKKE, heeft als leider van het distributiekantoor te Tubbergen aan een staking zooals omschreven in $\$ \$ 40,42$ der Ordnungsschutzverordnung 1943, deelgenomen.

De vonnissen zijn door de hoogste rechterlijke instantie bekrachtigd en daarna voltrokken.

Den Haag, 4 Mei 1943. 
noemde commissaris van het N.V.V., Woudenberg, lokte van begin af veel critiek uit; men weigerde in de bestuursorganisatie van de vakbonden het leidersprincipe te aanvaarden. Notulen van de vergaderingen van 10 en 23 Februari 1941 werden naar afdelingen in andere provinciën gezonden om het Twentse standpunt in ruime kring bekend te maken. Ook de confessionele vakorganisaties boden tegenstand. Na de maatregelen, door Woudenberg genomen, verlieten de arbeiders in grote getale hun vakverenigingen: het ledental daalde tot ongeveer $1 \%$ van het oorspronkelijke aantal.

Het N.A.F. had met zijn propaganda-actie in Twente bitter weinig succes, ook bij de ondernemers, die door de nood gedreven, steeds meer buiten iedere organisatie om, overleg pleegden met enkele vertrouwensmannen uit hun bedrijven. Waar het N.A.F. het houden van z.g. bedrijfsappèls wist te forceren, liepen deze meestal op een mislukking uit.

Op deze wijze deed zich het ene conflict na het andere voor. De spanning steeg, regionaal en in het gehele land. Wij kunnen niet voor iedere provincie herhalen, wat in de inleidende hoofdstukken werd medegedeeld over de algemene voorgeschiedenis van de staking. In het vroege voorjaar van 1943 was de atmosfeer zó geladen, dat ieder ogenblik spontaan verzet kon uitbreken. Dat Twente in de stakingsbeweging het voorbeeld gaf, is in het licht van bovenbeschreven omstandigheden niet verwonderlijk.

Keren wij terug tot de fatale datum, Donderdag 29 April 1943. Uit een minutieus onderzoek van B. A. Sijes, van wiens uitstekend rapport over de Twentse staking een groot gedeelte als Bijlage I is opgenomen, is gebleken, dat enkele ingewijden te Hengelo de 29ste April reeds vroegtijdig wisten dat er onheil dreigde. Ongeveer 9 uur v.m. werd namelijk de drukkerij $\mathrm{H}$. Smit \& $\mathrm{Zn}$. opgebeld door de N.V. Drukkerij en Uitgeverij v/h M. J. van der Loeff te Enschede met de mededeling, dat via de telex een bericht was binnengekomen omtrent een te verwachten persbericht over de terugvoering van Nederlandse militairen in Duitse krijgsgevangenschap: het zou in de loop van de dag verschijnen. Dit telex-bericht werd door het personeel van beide drukkerijen aan verschillende personen bekend gemaakt. Als ,gerucht" ging het snel rond, doch er waren meer geruchten in omloop, zodat degenen die het hoorden, een zekere reserve in acht namen.

Eerst omstreeks 12 uur kwam bij de drukkerij Smit te Hengelo telefonisch bericht binnen. Direct begon men toen met het opmaken van vier, met grote blauwe letters geschreven bulletins, die - in het schaftuur van passerende arbeiders - voor de ramen van de drukkerij kwamen te hangen. In andere steden is de bekendmaking omstreeks dezelfde tijd op dergelijke wijze geschied, in de meeste gevallen echter iets later, na het schaftuur. Ik geloof niet, dat het moment van publicatie zó beslissend was voor het snelle reageren van de Hengelose arbeiders. Bijna overal in het land is 's avonds beraadslaagd en vielen de beslissingen eerst Vrijdagochtend.

Vele arbeiders, die na de middagpauze weer naar hun werk gingen, bleven even stilstaan bij de drukkerij $\mathrm{H}$. Smit, die vrijwel midden in Hengelo ligt, 
slechts enkele tientallen meters verwijderd van de drukke Enschedesestraat. Daar had zich een menigte verzameld, die druk commentaar op het bericht leverde. Wanordelijkheden vielen echter niet voor. Voor de arbeiders, die gedurende de schafttijd op de fabrieksterreinen waren gebleven, was het bericht dat hun collega's van buiten af meebrachten, nog geheel nieuw. Om het te controleren, zond men hier en daar enkele personen naar de drukkerij Smit, die natuurlijk allen bevestigden, dat de onheilstijding waar was.

In de fabrieken van Stork werden na de schafttijd de machines wel aangezet, maar van werken kwam niet veel. Overal stond men met elkander te beraadslagen. Men mag aannemen dat degenen, die zich het meest door de nieuwe maatregel bedreigd gevoelden, de grootste verontwaardiging hebben getoond. In sommige afdelingen gaf men arbeiders, die gevaar liepen, opnieuw in krijgsgevangenschap te geraken, de keus tussen vacantie nemen of heengaan zonder opgave van redenen. Steeds meer arbeiders verlieten de fabrieks gebouwen en zetten hun overleg in de fabrieksstraat voort. Het was nu maar de vraag - inmiddels was het kwart over twee, half drie geworden - of men het terrein zou verlaten.

In de aarzeling, welke zich van een massa meester maakt, indien men voor belangrijke beslissingen staat, wordt het verlossende woord gewoonlijk gesproken door enkelen, die door de suggestieve kracht van hun vastberaden oordeel imponeren. Enige chefs fietsten van de ene afdeling naar de andere. Waar men hen vragend aankeek, zeiden ze: „Weten jullie nu nòg niet wat jullie moeten doen?" Ook in de meest ",spontane" actie zijn gangmakers onontbeerlijk. Misschien moet men spontane actie van een massa zelfs omschrijven als het in beweging komen van een massa onder invloed van het spontaan reageren van degenen, van wie leidinggevende invloed wordt verwacht (bij georganiseerde actie vindt overleg plaats tussen de leiders onderling en tussen de leiders en hun volgelingen).

Tegen half drie was het pleit ten gunste van de staking beslecht. De ene afdeling na de andere werd verlaten, in brede stroom bewoog men zich naar de uitgangen van de fabrieksterreinen, rustig en zwijgzaam - feitelijk niet anders dan het dagelijks bij het beëindigen van het werk toeging. Alleen de bewakingsdienst, de luchtbeschermingsdienst en enkele leden van het secretariaat bleven achter.

Intussen was het in de omgeving van Stork's fabrieken druk geworden op straat. Het personeel van het metaal-bedrijf, G. Dikkers \& Co, N.V. ongeveer 720 arbeiders, dat eveneens in rep-en-roer was en gedeeltelijk reeds op de binnenplaats van de fabriek stond verzameld, aarzelde niet langer, toen het de arbeiders van Stork zag langs trekken. In de onmiddellijke nabijheid van Stork staat de Koninklijke Nederlandse Katoenspinnerij N.V. (omstreeks 430 arbeiders). Ook de arbeiders en arbeidsters van dit bedrijf volgden spontaan het voorbeeld van het personeel van Stork en Dikkers. Tegen kwart voor drie had de demonstratie van het stakend fabriekspersoneel reeds zo'n omvang aangenomen, dat vrijwel de gehele stad er van op de hoogte was. De stakers 
hielden zicn rustig; zij stonden in groepjes te praten of gingen naar huis. Maar het aantal stakers bleek op zichzelf reeds indrukwekkend genoeg om de gedachte ,algemene staking" ingang te doen vinden.

Het ene bedrijf na het andere werd verlaten: de Kant- en Kousenfabriek De Jong \& Van Dam N.V. (300 arbeiders), de Kon. Nederlandsche Zoutindustrie (480 arb.), N.V. Heemaf (1000 arb.) enz.. Bij de N.V. Heemaf verliet men eerst de fabrieken na een bijeenkomst van het voltallige personeel, waarin de directeur op de ernstige consequenties van een eventuele staking wees. Ook deze groep arbeiders sloot zich echter bij de andere stakers aan.

Slechts één groot bedrijf te Hengelo werd die Donderdagmiddag niet in de staking betrokken, althans niet in de openlijke stakingsdemonstratie: N.V. Hazemeyer's Fabriek van Signaal apparaten, een fabriek met een Duitse directie. Onder het 1179 man sterke personeel bevonden zich 129 Duitsers en 59 NSB ers. Toen enige arbeiders deserteerden, plaatsten de Duitsers een wacht voor de poort. De directie deelde mede dat de Duitse maatregel niet voor Hazemeyers fabriek gold. Niemand mocht het bedrijf verlaten; er werd die dag echter vrijwel niet meer gewerkt.

Halverwege de middag ging nagenoeg het gehele gemeentepersoneel in staking (o.a. het personeel van de gemeentesecretarie, de distributiedienst, gemeentewerken en -bedrijven, enz.). Het personeel van het telefoondistrict Hengelo droeg veel bij tot vroegtijdige verbreiding van het stakingsbericht door alle abonné's, die Stork opbelden, mede te delen dat het personeel daar in staking was gegaan. Verder werden andere telefoonkantoren in het land op de hoogte gesteld van de gebeurtenissen in Hengelo. Op aandrang van de directeur bleven de telefonistes echter zelf wel aan het werk.

Zoals reeds werd opgemerkt, gingen de meeste stakers rustig naar huis. Velen woonden in naburige steden of dorpen en maakten het uitbreken van de staking wijd en zijd bekend, evenwel zonder pogingen, anderen in het verzet te betrekken. De meeste opwekkingen tot solidariteit werden telefonisch tussen de bedrijven onderling doorgegeven. Slechts bij uitzondering gingen groepjes arbeiders op pad om anderen tot meestaken te bewegen. Enige arbeiders van Stork begaven zich bijvoorbeeld naar de locomotievenloods te Hengelo. Het spoorwegpersoneel, dat gaarne bereid was, zich solidair te verklaren, gaf er na rijp beraad toch de voorkeur aan, nadere instructies af te wachten.

De telefonische mededelingen, die door heel Twente heengingen, veroorzaakten spoedig een algemene stakingspsychose. Het is soms nauwkeurig na te gaan, langs welke weg de berichten binnenkwamen. Zo belde de hoofdtelefoniste van Stork uit Hengelo even na half drie de telefoniste van Palthe's Textielveredelingsbedrijven N.V. te Almelo op. Deze gaf het bericht door aan de personeelsafdeling, maar belde ook Bendien's Confectiefabrieken N.V. op. Intussen had de drukkerij Van der Loeff te Enschede reeds met een dertigtal bedrijven telefonisch contact gezocht. De meest effectieve opwekking tot meestaken ging echter uit van de Hengelose arbeiders, die naar alle kanten 
uitzwermden. Van de arbeiders, werkzaam in de acht grootste fabrieken te Hengelo woonden er destijds 239 te Almelo, 434 te Borne, 200 te Delden, 896 te Enschede, 108 te Goor, 101 te Haaksbergen, 23 te Losser, 321 te Oldenzaal en 97 te Weerselo.

Er behoefde op het fabriekspersoneel van naburige plaatsen niet veel aandrang te worden uitgeoefend om zich solidair te verklaren met de Hengelose arbeiders. Donderdagmiddag begonnen te Enschede stakingen bij Van Heek E Co. N.V. (omstreeks 1140 arb.), N. J. Menko N.V. (1000 arb.), Nico ter Kuile \& Zn. N.V. (700 arb.), Gerhard Jannink \& Zn. N.V. (500 arb.), Gebr. van Heek (800 arb.), J. F. Scholten \& Zn. (540 arb.), Blijdenstein \& Co. N.V. (250 arb.), N. V. Rigtersbleek v/h G. J. van Heek \& Zn. (570 arb.). Vrijdagochtend volgden nog enkele andere bedrijven.

Te Almelo breidde de staking zich uit over grote aantallen arbeiders van de N.V. Katoen Mij. v/h Gebr. Scholten \& Co. (260 arb.), H. ten Cate Hzn. \& Co. N.V. (700 arb.), Palthe's textielveredelingsbedrijven N.V. (1000 arb.), enz.. Vrijdagochtend werd het werk neergelegd bij de N.V. Leeuwarder Textiel Mij N.V. (350 arb.), Bendien's Confectiefabrieken N.V. (1000 arb.), de N.V. Stoomspinnerij "Twenthe" (210 arb.) en de N.V. Almelose Confectiefabriek v/h Smits \& Co. (450 arb.).

In andere plaatsen begonnen de stakingen eveneens vrijwel zonder uitzondering Donderdagmiddag: te Borne bij de N.V. Stoomspinnerijen en -weverijen $v / h$ S. J. Sparijaard (900 arb.), te Oldenzaal bij H. P. Gelderman \& Zn. N.V. ( 800 arb.), te Rijssen bij Ter Horst \& Co. N.V. (1300 arb.), te Haaks bergen bij de N.V. D. Jordaan $\mathcal{E} \mathrm{Zn}$. (945 arb.), te Vtiezenveen bij Jansen $\mathcal{E}$ Tilanus N.V. (560 arb.) en te Nijverdal bij de Kon. Stoomweverij N.V. (1150 arb.).

Van de 41 grootste bedrijven in Twente, met een personeel van in het geheel ruim 25.000 personen, waren Donderdagmiddag reeds 28 fabrieken, met totaal ongeveer 21.000 mannen en vrouwen, in staking. Doch eerst Vrijdagochtend droeg de staking een algemeen karakter, ook op het Twentse platteland.

Het begrip ,platteland" is op de Twentse dorpen en buurtschappen slechts in beperkte mate van toepassing. Verschillende dorpen liggen onder de rook van één of meer fabrieken en voor zover zij zelf geen industrieplaats zijn, bieden zij toch huisvesting aan een groot aantal arbeiders en arbeidsters in naburige fabriekscentra. De vraag of in een bepaald dorp werd gestaakt, kan dus op twee manieren worden verstaan: het dorp kon de woonplaats zijn van stakende forenzen en het is ook mogelijk dat dorpelingen in hun plaats van inwoning het werk neerlegden.

In het algemeen toonde de agrarische dorpsbevolking of de verspreid wonende bevolking van gehuchten zich bereid tot staken - echter met een wat vertraagde reactie. Hier en daar vond overleg plaats tussen boeren. Als manifestatie van verzet werd gewoonlijk besloten, geen melk aan de zuivelfabrieken te leveren, maar in dit opzicht toonde men zich weinig solidair. 
Het is bijzonder moeilijk zich een voorstelling te vormen van de motieven, die zich in de stakingsbeweging op het platteland deden gelden. Met termen als "verzet" en ,protest" benadert men de werkelijkheid niet voldoende. Ook het veelomvattende woord "melkstaking" vereist nadere opheldering.

Het kon voorkomen, dat de boeren hun melkbussen niet meer met de vrachtrijders meegaven en tot detailverkoop overgingen - soms zelfs tot het laten wegvloeien van melk waarvoor zij niet dadelijk een bestemming wisten.

Menigmaal wierpen voorbijgangers melkbussen omver van boeren, die de leverantie aan de fabriek nog wel dachten voort te zetten. Dikwijls namen de melkrijders zelf het initiatief; waar zij staakten, kwamen de fabrieken vanzelf tot stilstand. In enkele gevallen ging de leiding uit van de directies der zuivelfabrieken.

Reeds Vrijdag sloot een aantal zuivelfabrieken (b.v. te Boekelo, Rijssen, Vriezenveen en Hengelo), zonder dat duidelijk was wie daartoe het initiatief namen. Het personeel van een aantal zuivelfabrieken ging Vrijdag in de loop van de dag in staking (Almelo, Denekamp), of het moest naar huis worden gestuurd, omdat de melkrijders te weinig aanvoerden (Haaksbergen, Wierden en Ambt-Delden). Van elf zuivelfabrieken in Twente nam het personeel niet aan de staking deel.

De beslissing over de zuivelproductie lag uiteindelijk toch in de handen van de boeren. Uit de cijfers van de aangevoerde melk blijkt, dat de boeren in overgrote meerderheid inderdaad op Vrijdag hebben "gestaakt". Ook Zaterdag was de aanvoer nog gering, Zondag aanzienlijk meer en Maandag $3 \mathrm{Mei}$, toen het verzet vrijwel overal was gebroken, zelfs boven het normale. De dagcijfers van de 19 Twentse zuivelfabrieken, die hierover gegevens verstrekten, vermelden totale aanvoercijfers van $132.016 \mathrm{~kg}$ op Donderdag 29 April, 22.862 op 30 April, 52.594 op 1 Mei, 79.308 op Zondag 2 Mei en 177.010 op Maandag 3 Mei.

Ook landarbeiders, dorpswinkeliers e.a., hebben aan de staking deelgenomen, doch hun actie zonk, wat Twente betreft, geheel in het niet bij de gebeurtenissen in de naburige steden. Wie het verzet van de agrarische streken in Overijsel wil nagaan, kan daarvoor beter voorbeelden zoeken in de „Kop van Overijsel" of in het Noord-Westelijk weidegebied van de provincie. Alvorens hierover nadere bijzonderheden mede te delen, moet eerst nog de aandacht worden gevestigd op het staken van de grensgangers, d.w.z. de in het Nederlands grensgebied wonende arbeiders, werkzaam in Duitse fabrieken te Nordhorn, Gronau, enz.

De grensgangers, die Donderdagavond naar huis reisden, hoorden reeds aan de grens dat er overal stakingen waren uitgebroken. Veel tijd voor overleg hadden zij niet meer. Vrijdagochtend vertrokken dan ook op de gewone wijze arbeiderstreinen naar Duitsland, echter niet met voltallige bezetting. Menigeen had besloten thuis te blijven. Arbeiders, die in de tweede, naar Gronau vertrekkende trein hadden plaatsgenomen, kwamen al gauw tot de conclusie, dat $z \mathrm{ij}$ beter deden, ook in staking te gaan. Zij trokken aan de noodrem en 
verlieten de trein. Lang hebben zij hun verzet niet volgehouden, want toen in de loop van de dag de Duitse tegenmaatregelen bekend werden, hervatten bijna alle grensgangers Zaterdag het werk.

De teleurstelling over het niet-staken van de spoorwegen was in Overijsel goed merkbaar. De desorganisatie van het verkeer beperkte zich tot een stagnatie van het vervoer op enkele autobuslijnen, namelijk de diensten van de T.E.T. (Twentse Electrische Tramwegmaatschappij) te Enschede, het Reisbureau "Twenthe" te Enschede en de N.V. "Wato" te Wierden. Het spoorwegpersoneel was weliswaar in hevige beroering, maar het slaagde er niet in, voldoende overleg te plegen. Eerst Vrijdagmiddag wist het met voldoende zekerheid, dat de centrale leiding een staking afraadde.

Begrijpelijk is, dat het platteland meer aandacht aan de spoorwegen schonk dan de steden. Vele overigens geïsoleerde streken worden door spoorlijnen doorsneden. De langsrijdende treinen vormen een stukje buitenwereld. Waar $z \mathrm{ij}$ volmaakt regelmatig verschenen en verdwenen, lieten de dorpelingen zich niet wijs maken, dat de staking ,algemeen" was. Aan de andere kant hoorde men genoeg over de gebeurtenissen in naburige steden en voelde men zich volkomen solidair met de stakende stedelingen. Ook op het platteland was de spanning in de loop van de tijd zo toegenomen, dat men bereid was, een demonstratie van verzet te steunen.

In de regionale aspecten van de stakingen op het platteland spelen de streekkarakters stellig een rol. Daarnaast andere omstandigheden, b.v. kerkelijk verzet of de aanwezigheid van onafhankelijke illegale groepen in hun eerste opkomst. Dikwijls gaf een enkele energieke figuur, een dorpsarts of een gepensionneerd oud-militair de doorslag. Een dergelijke verscheidenheid van stemmingen en gebeurtenissen geeft het platteland van Noord $\sim$ en NoordWest-Overijsel te zien. Van de plaatsen langs de Oostgrens, Oldenzaal enz., waar met enthousiasme werd gestaakt, tot in het veengebied ten Zuid-Westen van Koevorden en verder langs de Vecht, droegen de stakingen een gevarieerd karakter. Het meest principieel waren zij waarschijnlijk in de gereformeerde plaatsen in de Noord-West hoek en in het Noord-Oostelijk veengebied.

Het is bij plattelandsstakingen evenwel niet altijd mogelijk, met voldoende zekerheid vast te stellen, in welke mate het werk werd neergelegd. Een fabrieksarbeider verlaat de fabriek, een boer blijft echter rondlopen op zijn erf en kan nog enige lichte werkzaamheden doen in zijn schuur. De koeien worden in ieder geval gemolken, doch daarmede is niet gezegd, dat de melk naar de naburige zuivelfabriek wordt gevoerd. In menig dorp ,staakten" de winkels door rolgordijnen neer te laten, maar klanten werden wel geholpen - soms door een achterdeur. Al deze grensgevallen bemoeilijken het onderzoek.

Als voorbeeld kies ik Hardenberg, een typisch-agrarische gemeente van ongeveer 5000 inwoners, met o.a. vele verspreid wonende landbouwers, veen en landarbeiders, en middenstanders in de plaats zelf. Deze overwegend orthodox-protestantse bevolking staakte Vrijdag spontaan. Het verkeer kwam stil te liggen, de zuivelfabriek "Salland" werd stopgezet, veel landarbeiders 
bleven thuis en een aantal winkeliers sloot de zaken. Een der voormannen van de latere illegale beweging, zelf winkelier, verklaarde: „de staking droeg een volkomen algemeen karakter". De burgemeester daarentegen: „de staking droeg hier geen algemeen karakter". De een oordeelde, dat de staking de illegale beweging heeft bevorderd, omdat de solidariteit van de bevolking nu wel heel duidelijk was gebleken; de ander meende, dat de gebeurtenissen van eind April 1943 te Hardenberg ,niet van invloed zijn geweest op de versterking van het verzet". Mondeling getuigenverhoor lokt soms eveneens tot tegenstrijdige verklaringen uit. Een aanwijzing voor de omvang en de intensiteit van een staking kan men dikwijls zoeken in het optreden van de Duitse politie. Waar deze, zoals te Hardenberg het geval was, vijf gijzelaars arresteerde en naar $V$ ught vervoerde, mag de betekenis van het verzet niet worden onderschat. De maatstaf van het aantal arrestaties kan echter zeer onzuiver zijn, indien zich de invloed deed gelden van een actieve Duitse politie-officier of wanneer plaatselijk bijzonder felle NSB-ers de Duitsers op de hoogte brachten van alle gebeurtenissen (of namen noemden!). Toch kan men zich door combinatie van alle gegevens - soms nog het best uit enkele details, b.v. het staken van bakkers - wel een voorstelling van de stakingsactiviteit vormen.

Ook in de omgeving van Hardenberg is druk gestaakt, vooral te Den Ham en Heemse, waar o.a. het gemeentepersoneel het werk neerlegde. De bevolking in deze streek hechtte echter bijzondere betekenis aan het niet-staken van de spoorwegen. Teleurgesteld hervatte men reeds Zaterdag $1 \mathrm{Mei}$ het werk. Een vrijwel algemeen karakter droeg de staking te Gramsbergen, eveneens een bolwerk van orthodox protestantisme. Er zijn uit deze streek slechts vage berichten over aanmoediging van de staking door predikanten, doch dit doet weinig af aan het feit, dat in het gehele Noord-Oostelijke gedeelte van Overijsel geloofsijver en kerkelijke saamhorigheid een stimulerende invloed op het verzet hebben uitgeoefend, ondanks de aangeboren lijdelijkheid van de Saksische bevolking. Niet veel anders was de situatie te Dedemsvaart en te Ommen, waar de boeren en arbeiders vermoedelijk feller reageerden dan de middenstanders, doch na afkondiging van het standrecht toch ook al gauw het hoofd in de schoot legden. Men liet zich in deze streek trouwens intimideren door de nabijheid van het Duitse strafkamp "Erika".

Zuidelijker, in de buurt van Dalfsen, Raalte of Hellendoorn of in het stroomgebied van de IJsel ten Zuiden van Zwolle, schijnt de stakingsbeweging gematigder te zijn gebleven, dan in de „Kop van Overijsel" of in de „NoordWest Hoek". Het Sallandse streekkarakter is wat flegmatisch en voorzichtig. Doch ook hier mag men niet teveel generaliseren, omdat ons telkens opvalt, hoe verschillend de reacties van enige dicht bij elkander gelegen plaatsen konden zijn. Te Raalte bijvoorbeeld staakte het personeel van de zuivelfabriek en van de houtzagerij Gebr. Douma, en sloot ook de gemeentesecretarie Vrijdag 30 April haar deuren, zonder dat dit een betoging van solidariteit uitlokte van de te Raalte zo talrijke winkeliers. Te Olst en te Wijhe concentreerde de 
staking zich in de gemeentelijke diensten, in het zuivelbedrijf en in de vleesconservenfabrieken en enige ander industrieën (te Olst Bakhuis' Vleeswarenfabriek en Aberson's IJzerfabriek, en te Wijhe Hunnink's Vleeswarenfabriek en Withold's Mandenmakerij). Eerst Maandag 3 Mei - met uitzondering van de gemeentediensten, die Zaterdag weer werden geopend - werd hier het verzet opgegeven. Z wakker reageerde de bevolking in het grensgebied van Overijsel en de Gelderse Achterhoek. Te Bathmen en bij Diepenheim was de staking niet algemeen.

Noordelijker vormde Dalfsen een stakingshaard van enige betekenis. De staking droeg er door sluiting van gemeentelijke instellingen, de zuivelfabriek en de cichoreifabriek en van een aantal winkels een algemeen karakter - doch verliep er minder heftig dan in de Noord-West Hoek.

In Noord-West Overijsel staakten bijna alle zuivelfabrieken. Van de bevolking maakte zich een zekere opwinding meester door de massale uittocht van arbeiders uit de Noord-Oostpolder. Op het platteland bestaat slechts weinig gelegenheid tot dergelijke demonstraties. In dit geval kwam het massaal effect wel bijzonder duidelijk tot uiting, omdat de Noord-Oostpolder slechts door weinig uitgangen kon worden verlaten. Van de 3700 arbeiders, die onder de Directie van de Noordoostpolderwerken stonden, bleven slechts enkele in de polder achter. De anderen trokken weg: enkele ploegen Vrijdagmiddag, de meeste Vrijdagavond of Zaterdagochtend in alle vroegte. Men moet hierbij niet uit het oog verliezen, dat de Polder altijd Vrijdagsavonds door het merendeel van de arbeiders werd verlaten, zodat het voor de Duitsers niet gemakkelijk was, het staken in dit geval van het gewone naar huis gaan te onderscheiden.

Het staat wel vast, dat de stakingen in de Noord-Oostpolder reeds Vrijdag 30 April in de loop van de dag begonnen. Vermoedelijk werden berichten over de gebeurtenissen op ,het oude land" verspreid door een motorordonnans van een of andere illegale groep. Wilde geruchten deden de ronde, waardoor vooral een grote ongerustheid ontstond onder arbeiders, die in militaire dienst waren geweest. Wie zich bedreigd gevoelde wilde naar huis. In ieder geval werd het isolement in de Polder als iets ondragelijks beschouwd en legde men op tal van plaatsen overhaast het werk neer. Paarden werden uitgespannen; wagens bleven op het land staan, ieder zocht langs binnenwegen een goed heenkomen. Eerst na de ervaring, dat de stakingsbeweging op , het oude land" toch geen kans op succes bood, kwamen de arbeiders geleidelijk terug. Maandag 3 Mei gingen van de 3700 arbeiders 2800 weer aan het werk. Het duurde nog enige dagen, eer de Directie van de polderwerken kon melden, dat de toestand geheel normaal was.

Plaatsen, waar met vastberadenheid werd gestaakt - na afkondiging van het standrecht met aarzeling en toenemende voorzichtigheid - waren Kuinre, Vollenhove, Steenwijkerwold, Steenwijk, Hasselt, Giethoorn, enz. Hier en daar kwamen daden van geweld voor, b.v. in de buurt van IJsselmuiden, waar boeren en arbeiders een melkwagen op de Kamperzeedijk aanhielden en 
melkbussen lieten leeglopen. Een landwachter, die deze wagen bewaakte. liep enige klappen op en deed hiervan zijn beklag bij de Duitse politie te Kampen. De Duitsers arresteerden toen Vrijdagnacht een zestal personen, die in de omgeving woonden van de plaats, waar deze overval plaats vond. Vijf van de arrestanten werden op transport gesteld naar Vught, één moest als afschrikwekkend voorbeeld dienen (frJvan Oene te Kamperzeedijk) en hoorde de 2de Mei te Hengelo het doodvonnis uitspreken. Nog dezelfde dag werd hij terechtgesteld.

Te Wanneperveen werd de boerderij van de plaatselijke leider van het Agrarisch Front in brand gestoken (in de nacht van 2 op $3 \mathrm{Mei}$ ); twee dagen later gingen in de buurt van Barsbeek (bij Vollenhove) zes boerderijen in vlammen op. Zeer onrustig was het ook in de omgeving van Staphorst. In het gemeentelijk distributiebureau kwam inbraak met brandstichting voor; een andere inbraak vond plaats bij de plaatselijke Bureauhouder, waarbij kaarten voor zelfverzorgers werden gestolen. $\mathrm{Bij}$ het station Meppel werd de lijn van een voorsein doorgesneden.

Te Hasselt waren Vrijdag de handles voor het opendraaien van de brug over het $Z$ wartewater zoek. Dit veroorzaakte de nodige opschudding, toen een Duits munitieschip de brug wilde passeren. Een tiental personen, onder wie de brugwachters, werd opgepakt, doch na een langdurig verhoor weer losgelaten, toen zij aannemelijk maakten, dat de handles door een of andere schipper moesten zijn gestolen. Te $Z$ wartsluis makkte men de gasgenerator van een bus onklaar. Al deze daden van sabotage wekten de woede van de Duitse politie op. $Z_{i j}$ nam hier en daar gijzelaars mede (te Staphorst zelfs 20), hetgeen op de bevolking inderdaad een deprimerende invloed uitoefende.

Alleen de stakende mattenvlechters van Genemuiden lieten zich niet intimideren. $\mathrm{Zij}$ weigerden zelfs Maandagochtend $3 \mathrm{Mei}$, toen bijna overal in de provincie de staking reeds ten einde was, het werk te hervatten. Omstreeks 9 uur 's morgens werd de burgemeester door de Duitse politie uit Zwolle opgebeld. Op de vraag of in zijn gemeente nog werd gestaakt, antwoordde de burgemeester, dat de zuivelfabriek weer werkte, dat ook de melktoevoer bevredigend was en dat de arbeiders van de mattenfabrieken geleidelijk aan de gang gingen. De Duitsers antwoordden, dat zij om elf uur zouden komen controleren en voegden er bedreigingen aan toe voor ieder, die dan nog staakte. Enige stakende arbeiders, van dit bericht in kennis gesteld, trachtten hun collega's nog te overreden, het werk te hervatten. $Z_{i j}$ hadden daarmede geen succes. Precies om elf uur reden zes overvalwagens het dorp binnen. Mannen van de Grüne Polizei begonnen in het wilde weg te schieten. Een aantal arbeiders probeerde de mattenfabrieken door achteringangen te bereiken, toen de Duitsers aanstalten maakten, nauwkeurig na te gaan, wie zich niet aan het bevel hadden gehouden, dat het werk Maandag moest zijn hervat.

Duitse politieofficieren gaven de burgemeester bevel, alle fabrikanten op het gemeentehuis te ontbieden. Onder grote verwarring werd het dorp afge- 
zocht, 126 arbeiders moesten zich melden, van wie er 23 in arrest werden gesteld. Hun vrouwen of bloedverwanten kregen bevel, dekens en brood te brengen; daarna begon de uittocht van de politietroepen met hun gevangenen. Ieder vreesde het ergste, doch de Duitsers toonden zich clement. Het standrecht werd deze keer niet toegepast. Reeds de volgende dag mochten de 23 Genemuiders naar huis gaan, tot vreugde van de bevolking, die hen met gejuich ontving.

Tenslotte enige opmerkingen over het verloop van de staking in de Overijselse steden langs de benedenloop van de IJsel: Kampen, Zwolle en Deventer. $\mathrm{W}_{\mathrm{ij}}$ vinden daarover bijzonderheden in een rapport Nederland's fier protest, dat vermoedelijk is samengesteld door de later gefusilleerde verzetsleider Dr R. J. van Dam (uit de illegale "Trouw"-groep). De schrijver geeft in dit verslag ook een samenvatting van berichten uit andere provincies, maar overzag het best, wat in zijn omgeving gebeurde, vooral in Kampen, waar hij zo'n werkzaam aandeel nam in het verzet.

Te Kampen, vanouds een bolwerk van de Gereformeerde Kerken, droeg het saboteren van Duitse maatregelen uiteraard veelal een principieel-religieus karakter. Zo ook in sommige andere gedeelten van de Noord-West Hoek. In de groepen, waarin men elkander geheel kon vertrouwen, durfde men wel wat meer wagen dan in het algemeen het geval was. Zo werden te Kampen in opdracht van $\mathrm{Dr}$ van Dam bij de Firma Zalsman strooibiljetten gedrukt, die een opwekking tot staking inhielden. Vertrouwde koeriers brachten deze papieren naar Apeldoorn. Arnhem en Enschede, waar intussen al stakingen waren uitgebroken. Te Kampen bracht men een gestencilde oproep tot staking in omloop.

Aan het verslag van Dr van Dam over de gebeurtenissen te Kampen, dat bij verificatie geheel in overeenstemming bleek te zijn met de feiten, ontleen $i k$ de volgende bijzonderheden.

„Kampen kreeg Vrijdagmorgen, nadat reeds vele geruchten de ronde hadden gedaan, de eerste goede stakingsberichten, die onmiddellijk het sein tot deelneming waren. Op het gemeentehuis, het postkantoor en verschillende fabrieken legde het personeel het werk neer en goed anderhalf uur later was de staking algemeen en heerste er een ongewone drukte op straat. In de Berkfabrieken werd 'smiddags het werk niet hervat, de zuivelfabriek lag stil, grote grossiersbedrijven en nagenoeg alle middenstandszaken hadden de deuren gesloten. De kantoren van de Directie van de Noord-Oostpolder waren voor driekwart leeggestrocmd. Gasfabriek en Waterleiding evenwel werkten door (ze werden door een NSB-luitenant onder bedreiging met zijn revolver op gang gehouden. - Noot van de auteur van dit deel). De eerste maatregelen werden door de gemeentepolitie onder leiding van de NSB-opperluitenant, genomen tegen het postkantoor, waarvan de deur aanvankelijk demonstratief was gesloten. Twee postbeambten werden gearresteerd en later onder politietoezicht op hun plaatsen achter de loketten gezet. Het merendeel der bevolking maakte die dag echter van het postkantoor geen gebruik meer. Een W.A.-man werd op post gezet op het telefoonkantoor. De tegenmaatregelen bleven in handen van de gereorganiseerde surrogaat-politie, versterkt met de krijgshaftige W.A. De marechaussee moest de winkeliers aansporen, hun zaken te heropenen, wat maar zeer ten dele de volgende dag geschiedde. De gehele Vrijdag 
werd de staking algemeen gehandhaafd. Wonderlijk genoeg verscheen er geen Duitse politie. Van de maatregelen, die door de Duitsers in het land werden genomen (politiestandrecht, om 8 uur binnen), kwam de bevolking maar ten dele en zeer gebrekkig op de hoogte, vooral door het feit, dat er geen couranten werden bezorgd. Ze bleken na aankomst op het station zoek te zijn. De omroeper maakte eerst omstreeks 6 uur bekend, dat men die avond om 8 uur binnen moest zijn. Decreten werden niet voor Maandag aangeplakt.

Enige verwarring brachten Zaterdagmorgen de berichten dat de staking in het land niet algemeen was, hetgeen werd versterkt door het feit, dat het politiestandrecht voor lopig maar voor vier provincies werd afgekondigd. Voorts verzwakte de staking die morgen onmiddellijk, doordat de treinen bleven rijden. Het secretarie-personeel verscheen weer op het stadhuis. Berk bleef nog gesloten. Maandagmorgen werd in de hele stad het werk hervat. In de nacht van Zaterdag op Zondag werd een twintigtal personen, bestuursleden der kiesverenigingen en vakbonden, van hun bed gelicht. Verschillende kwamen Zondag weer op vrije vceten, doch als gijzelaars werden 6 per sonen (A.R., S.D.A.P. en R.K.) weggevoerd. Vergeleken met andere plaatsen verliep de staking in Kampen nogal rustig. Het feit, dat politie en W.A. zonder directe steun van de Duitse politie moesten handelen, is hieraan misschien niet vreemd. 's Avonds na 8 uur, toen de straten er slechts voor de W.A.-ordehandhavers en de politie waren, klonken uit de huizen de oude volksliederen. " "Zo is het volk van Nederland", enz." "

Tot zover Dr van Dam, wiens verslag duidelijk maakt, wat een goedgeïnformeerd man van de staking in zijn eigen woonplaats waarnam. Het is niet moeilijk, enige aanvullende bijzonderheden te verzamelen, b.v. over het aantal ambtenaren, dat in verschillende takken van dienst staakte (in hoofdzaak alleen Vrijdagmiddag!), maar het beeld, dat men zich van de gebeurtenissen vormt, verandert er weinig door. Wat zich te Kampen afspeelde, was in het algemeen ook kenmerkend voor de andere provinciesteden in het Westen van Overijsel: $Z$ wolle en Deventer.

Te $Z$ wolle begon de eerste staking reeds Donderdagmiddag 29 April. Onder de indruk van de berichten uit Hengelo - ik wees reeds op het levendig telefonisch contact - staakte het personeel van de N.V. Erven Tijl, uitgeefster van de Prov. Overijsselse en Zwolse Courant. Het werk werd op een wenk van de directie om tien minuten over vijf neergelegd; de volgende dag verscheen niemand van het lagere personeel. Een dergelijk voorbeeld heeft altijd een duidelijk effect. Men gaf zich meer rekenschap van de algemene situatie. Donderdagavond hoorde men steeds meer bijzonderheden over de gebeurtenissen in de Twentse industriesteden.

Vrijdagochtend begaven arbeiders, kantoorbedienden en ambtenaren zich naar hun werk om overleg te plegen. Ieder had nu tijd genoeg gehad om zich een voorstelling te vormen van de betekenis van het staken als vorm van verzet, doch juist daarom wilde men elkander nog graag even ontmoeten om een besluit te kunnen nemen. Tegen 10 uur 's morgens stroomden kantoren, bureaux en werkplaatsen leeg. Het werd druk op straat. Busdiensten staakten. Velen begonnen water af te tappen met het oog op een eventuele staking van het waterleidingbedrijf, anderen haastten zich, om voor enige dagen brood en andere levensmiddelen in te slaan. Het élan ging echter al gauw verloren, vooral toen men door het niet-staken van de spoorwegen (op het spoorweg- 


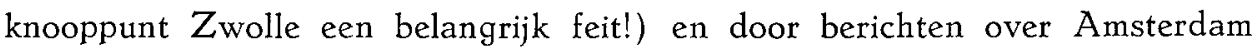
en Utrecht tot de conclusie kwam, dat er geen sprake was van een nationale algemene staking. Met dezelfde bedachtzaamheid, waarmede men het werk had neergelegd, werd het ook weer opgevat. Zaterdag liepen vrijwel allen weer in het gareel. De Duitse tegenmaatregelen beperkten zich tot het wegvoeren van enige gijzelaars.

Ook te Deventer concentreerde de stakingsactiviteit zich op één dag Vrijdag 30 April. De staking droeg een algemeen karakter: banken, kantoren, fabrieken en vele winkels werden gesloten; evenzo rijks $\sim$ en gemeentediensten (het postkantoor, enz.). Toen echter Vrijdag in de loop van de middag de afkondiging van het standrecht tot de stakers doordrong, maakte zich een aarzeling van het publiek meester. Weliswaar bleven de arbeiders van enkele kleine bedrijven ook nog Zaterdagochtend thuis, maar in overgrote meerderheid zwichtte men toch voor de Duitse dreigementen. De Duitse politie beperkte zich tot het ontslaan van de directeur van het postkantoor; verdere represailles bleven te Deventer achterwege.

$\mathrm{Na}$ ons overzicht van de gebeurtenissen in de provincie, richten wij opnieuw onze aandacht op de grote stakingshaard van het Twentse industriegebied. Daar had het verzet zo overrompelend-snel een grote omvang aangenomen, dat de Duitsers zich overbluft gevoelden en niet direct wisten hoe zij op het grote aantal stakingen zouden reageren. Uit een rapport van de Beauftragte in de provincie Overijsel blijkt, dat de Duitse autoriteiten er van begin af van overtuigd waren, dat de staking was georganiseerd. Juist omdat zij er zoveel meer in zagen dan een spontane demonstratie, meenden zij streng en hard te moeten optreden. $Z_{i j}$ begrepen echter ook wel, dat de proclamatie van Generaal Christiansen, waarin niet werd gerept van uitzonderingsbepalingen, niet bepaald tactvol was opgesteld. Reeds Donderdagmiddag vond te Hengelo een bespreking plaats tussen een bedrijfsleider van Stork en een officier van de Rüstungsinspektion. Op bevel van de Duitsers moest in de werkplaatsen van Stork een briefje worden opgehangen - het makte in de verlaten fabrieksruimten niet veel indruk - van de volgende inhoud:

„In opdracht van de Rüstungs-inspectie delen wij mede, dat van de opkomst in krijgsgevangenschap zijn vrijgesteld alle mannen, die werkzaam zijn in de Rüstungsbedrijven, dus ook in ons bedrijf en die geboren zijn in de jaren 1898 tot en met 1925."

Hgl. 29.4.'43.

De Directie.

In afwachting van de komst van de Beauftragte voor Overijsel, Weidlich, lieten plaatselijke Duitse politie-autoriteiten te Hengelo door middel van luidspreker-wagens bekend maken, dat de bevolking na acht uur 's avonds moest binnenblijven. Een SS-regiment uit Arnhem, dat naar Hengelo werd verplaatst, kwam ongeveer half acht 's avonds aan. 's Nachts arriveerden nog versterkingen. Indien het nodig mocht blijken, zouden de Duitsers ook troepen uit Westfalen - te Münster lag een groot garnizoen - naar Twente dirigeren.

Dit militaire machtsvertoon imponeerde wel, doch niet zodanig, dat de be- 
volking weer aan het werk ging. Veeleer breidde de staking zich nog verder uit: zelfs het personeel van het door Duitsers gecontroleerde bedrijf Hazemeyer's Fabriek voor Signaalapparaten N.V. - vrijwel de enige fabriek te Hengelo, die Donderdagmiddag niet had gestaakt - legde het werk neer. Het personeel van de telefoondienst keerde op aandrang van de directeur van deze dienst wel terug, maar het bleef een saboterende houding aan nemen.

Op straat was het Vrijdagmorgen betrekkelijk stil, vooral in de wijken waar Duitsers patrouilleerden. Men had echter wel een zekere bewegingsvrijheid. Er werd die ochtend druk beraadslaagd tussen directies en fabriekskernen. De directies wezen er op, dat berichten uit andere delen van het land niet bijzonder hoopvol klonken en dat men wel moest begrijpen, dat plaatselijke stakingen niet veel uitzicht op succes boden. De arbeiders zagen dit in en lieten doorschemeren, dat zij Maandagochtend vermoedelijk het werk zouden hervatten.

Vrijdagmiddag werd het politiestandrecht afgekondigd. Deze dreiging en de zekerheid dat het spoorwegpersoneel zich niet bij de staking aansloot, veroorzaakte plotseling een neerslachtige stemming. In de loop van de middag werden vele Twentse burgemeesters naar Hengelo ontboden voor een onder houd met Beauftragte Weidlich. Zij kregen te horen, dat zij er voor aan sprakelijk waren, dat het gemeentepersoneel Zaterdagochtend overal aan het werk zou gaan. Wie niet kwam, zou "met de kogel of met de strop" worden gestraft. De Duitsers hoopten kennelijk verdeeldheid te zaaien door hun eerste aanval te richten op de groepen waarop men het gemakkelijkst vat kon krijgen: het ambtenaren-apparaat. De burgemeesters moesten ook zorgen voor een snelle afkondiging van het standrecht in hun gemeenten.

Vrijdagavond vond op het gemeentehuis te Hengelo op Duits bevel een samenkomst van fabrikanten plaats. Nadat men een uur op Weidlich had gewacht, kon de bespreking beginnen. Weidlich toonde zich zeer nerveus en opende de vergadering met een toespraak vol dreigementen. De bedrijfsleiders werden aansprakelijk gesteld voor de gang van zaken. Verder deelde de Beauftragte mede dat Zaterdag een Ueberfallkommando van de Grüne Polizei een onderzoek in de fabrieken zou instellen en alle arbeiders, die niet op hun werk waren verschenen, van huis zou halen om hen terstond door het stand gerecht te doen vonnissen. De fabrikanten moesten dit mededelen aan hun bazen en deze zouden dan moeten rondgaan om de arbeiders te waarschuwen.

Ir Keus, directeur van de N.V. Heemaf, wees Weidlich er op, dat het al te laat was geworden om aan deze eis te voldoen. Hij vroeg wat meer tijd om de arbeiders in te lichten. Weidlich zag in de stakingsactie nog steeds een georganiseerde beweging van verzet en was daarom van mening, dat men haar even georganiseerd snel kon doen aflopen. Tenslotte zwichtte hij echter voor de argumenten en beloofde hij, dat met het optreden der Grüne Polizei zou worden gewacht tot Zaterdagochtend 10 uur. Nog Vrijdagavond laat werd begonnen, de arbeiders te waarschuwen; de meesten kon men echter 
eerst Zaterdag in de vroege ochtend bereiken. Degenen, die op het platteland woonden, kregen aanzegging, in ieder geval Maandag te verschijnen.

De Duitsers hielden zich niet aan hun belofte, de arbeiders Zaterdag gelegenheid te geven om tien uur in de fabriek aanwezig te zijn. De Grüne Polizei rukte vroeger uit en opende om half tien het vuur in de straten. Deze eerste schietpartij kostte twee personen het leven (G. J. Weyenborg en $H$. W. Varvik). Ook werden voorbijgangers opgepakt en in overvalwagens weggevoerd. Gelukkig, dat het geloei der sirenes voor een luchtalarm de Duitse actie even onderbrak en vele personen gelegenheid gaf, zich uit de voeten te maken.

Intussen was de inspectie van de Duitse politie in de fabrieken begonnen. Reeds bij vluchtig onderzoek bleek, dat slechts een gedeelte van het personeel aanwezig was. De Duitsers eisten toen van de directies inlevering van lijsten met namen van stakende arbeiders en employé's. In hoeverre aan dit verzoek is voldaan, valt niet nauwkeurig na te gaan. De directies leverden in het alger meen de verlangde lijsten wel in, maar zo laat mogelijk en met de toevoeging dat $z \mathrm{ij}$ voor de juistheid van de lijsten niet instonden. Het was immers in de algemene verwarring niet mogelijk te controleren, hoeveel arbeiders tijdig waren verschenen. Onder de afwezigen waren ook zieken, terwijl degenen, die buiten de stad woonden, zich er op konden beroepen, geen waarschuwing te hebben ontvangen.

Zaterdagmiddag verschenen Duitse officieren bij de directie van Stork om een onderzoek in te stellen naar het uitbreken van de staking. Als een der hoofdaanstichters noemden zij Ir F. M. Loep en hoewel de directie met nadruk verklaarde, dat hier een vergissing in het spel moest zijn, werd Ir Loep gearresteerd en korte tijd later gefusilleerd (Dinsdagavond $5 \mathrm{Mei}-$ zijn lijk is tot op heden niet gevonden).

In de nacht van Zaterdag en Zondag vonden te Hengelo verdere arrestaties plaats (o.a. van enige directeuren van grote fabrieken, b.v. C. F. Stork). Uit verschillende plaatsen in Twente werden gevangenen naar café "Haverkate" te Hengelo gebracht, waar zij tot Zaterdagavond moesten verblijven. Sommigen werden op transport gesteld naar Vught, anderen herkiegen hun vrijheid.

Maandagochtend waren alle Hengelose fabrieken weer in vol bedrijf, al werd er ook langzamer gewerkt dan gewoonlijk. Aan de Dienststelle van de Sicherheitspolizei moest worden opgegeven, welke arbeiders ontbraken. Men stelde wel lijsten samen, doch kon voor ieder van de genoemde personen een of ander excuus bedenken.

Te Enschede vonden Donderdagmiddag op straat besprekingen plaats van stakende arbeiders. Ook het personeel van enige gemeentediensten ging die middag reeds in staking. Bij bakkers en kruideniers ontstonden oplopen van mensen, die levensmiddelen wilden inslaan. Het gerucht dat ook ,,de water leiding" zou staken, leidde tot het aftappen van water op grote schaal, met het gevolg dat de druk op de leiding verminderde en ook dit stakingsgerucht 
algemeen ingang vond. In tegenstelling met Hengelo was het wel toegestaan, zich 's avonds op straat te begeven.

Vrijdagochtend kwam de Duitse politie te Enschede al vroeg in actie. Blijkbaar was het de bedoeling de arbeiders door schietpartijen op straat zó te imponeren, dat zij zich naar hun werk zouden spoeden. De methode leverde echter niet veel resultaat op.

In de loop van de dag vond in de directiekamer van Van Heek \& Co N.V. een vergadering plaats van 15 à 20 fabrikanten. Dit overleg was nodig om een gemeenschappelijk standpunt te bepalen tegenover de Duitse eis, dat lijsten van het stakend personeel moesten worden ingeleverd. Men besloot al het mogelijke te doen om de inlevering van lijsten te voorkomen. Wèl zou men trachten de arbeiders ervan te overtuigen dat zij verstandig deden, Zaterdagochtend weer aan het werk te gaan.

Tegen het eind van de middag liet de politie de decreten van het standrecht aanplakken; men wist nu ook, dat men Vrijdagavond na acht uur binnen moest zijn. Met hun bekende onbetrouwbaarheid saboteerden de Duitsers hun eigen maatregelen. Reeds lang vóór acht uur schoten zij links en rechts door de straten. Ook hier vielen slachtoffers (J. B. J. Steinmeyer en H. Slotboom). Toch bleven in stadswijken, waar de Duitsers niet direct verschenen, groepjes mensen ook na acht uur voor de deur staan praten. Intussen waren enige fabrikanten reeds begonnen hun personeel te laten waarschuwen, dat men verstandig deed, het werk Zaterdagochtend te hervatten. $E_{r}$ waren ook fabrikanten, die deze oproep eerst Zaterdag verspreidden, met de opwekking, Maandagmorgen in de fabriek te verschijnen. Na verdere schietpartijen en vele arrestaties (vooral in de nacht van Zaterdag op Zondag) eindigde ook te Enschede het verzet. Maandag was de rust hersteld.

Te Almelo werd een uit Hengelo ontvangen telefoonbericht over het uitbreken van de staking door de telefoniste van Palthe doorgegeven aan andere bedrijven. Men reageerde te Almelo echter wat minder fel dan in de naburige industriesteden: van de negen grootste fabrieken gingen er slechts vier terstond in staking (in het geheel Donderdag 2100 arbeiders). Bijzondere demonstraties kwamen niet voor. De arbeiders verlieten rustig de fabrieken en gingen naar huis. Enkele winkeliers begonnen hun winkels te sluiten. 's Avonds was het stil op straat. Eerst laat in de avond, tegen elf uur, kwamen twee grote vrachtauto's met Duitse politietroepen te Almelo aan. Deze politiemacht kon echter niet verhinderen, dat de staking zich Vrijdag verder uitbreidde. De overige fabrieken werden nu eveneens gesloten; ook de winkelsluiting nam een algemener karakter aan. Vele onderwijzers zonden schoolkinderen naar huis. Op sommige plaatsen hadden de Duitsers zwaarbewapende wachtposten voor fabrieken geplaatst, waardoor zij er zelf toe meewerkten dat de arbeiders wegbleven. De fabrikanten kregen te horen, dat zij aansprakelijk waren voor een hervatting van de werkzaamheden op Zaterdagochtend.

Zaterdag was de toestand zeer onoverzichtelijk. De meeste arbeiders waren thuisgebleven. Sommigen kwamen eens informeren naar de stand van zaken 
en verdwenen weer. De Beauftragte riep Zaterdagmiddag de Almelose fabrikanten op het gemeentehuis bijeen en eiste, dat zij lijsten zouden inleveren van de arbeiders, die het werk niet hadden hervat. Of dit is gebeurd, is mij niet bekend.

Maandagmorgen waren in de meeste fabrieken de arbeiders voltallig aanwezig. Bij Palthe bleken echter nog zoveel arbeiders en arbeidsters te ontbreken, dat het bedrijf niet kon functionneren; ook bij Bendien ontbrak een aantal meisjes. Tot Duitse represailles gaf dit echter geen aanleiding.

Te Borne was Donderdagmiddag de staking bij de N.V. Stoomspinnerijen en -weverijen $v / \mathrm{h} \mathrm{S}$. J. Spanjaard het belangrijkste evenement. 's Avonds is er nog een bijeenkomst geweest van arbeiders van de bewakingsdiensten van dit bedrijf. Daarbij gaf de bedrijfsleider C. Brasser nog eens duidelijk te kennen, dat men er goed van moest zijn doordrongen, aan een algemene staking deel te nemen. Dat men dit terdege begreep, bleek Vrijdag. Ondanks alle Duitse dreigementen en de toenemende contrôle ontbrak zelfs Zaterdag het merendeel van de arbeiders op de fabriek. De Duitse politie heeft bloedig wraak genomen door Maandagavond twee bedrijfsleiders van Spanjaard's Fabrieken te arresteren: M. G. Neurdenburg en C. Brasser. $Z_{i j}$ werden in een auto weggevoerd en op perfide wijze uit de weg geruimd, d.w.z. ergens neergeschoten - "op de vlucht doodgeschoten", luidde de formule.

Te Oldenzaal was de staking Donderdag begonnen bij H. P. Gelderman $\&$ Zonen N.V. Vrijdagochtend staakte ook de morgenploeg van de N.V. Kon. Oldenzaalse Stoomweverij v/h J. Molkenboer Jr. Dit voorbeeld werd gevolgd door de gemeentebedrijven; zelfs door het personeel van de douanedienst. Na afkondiging van het standrecht en na aankomst van Duitse troepen maakte zich ook hier een aarzeling van de bevolking meester. Men liet zich echter niet te gauw intimideren. Zaterdagmorgen verschenen voor de fabriek van de N.V. v/h J. Molkenboer slechts weinig arbeiders. Om Duitse contrôle te voorkomen, werden tegen halfelf de motoren aangezet en gingen enkele bazen rond om nog wat meer arbeiders te verzamelen.

Bij H. P. Gelderman \& Zn. kwamen Zaterdag de Duitsers kijken of alles in orde was. De directeur en een bureauchef werden met het geweer in de rug gedwongen, enige namen van ontbrekende employés op te geven. Zaterdagavond en Zondag volgde te Oldenzaal de arrestatie van 21 personen. De Duitse politie bracht hen naar Hengelo, doch liet de meesten al gauw vrij. Negen van deze arrestanten kwamen in Vught terecht. De uitgeoefende druk was voldoende om ook de Oldenzaalse arbeiders te bewegen Maandagochtend het werk te hervatten.

Te Haaksbergen begon de staking Donderdagmiddag bij de N.V. D. Jordaan $\mathcal{E}$ Zoon's Textielfabriek en bij J. P. Odink \& Koenderink N.V. Ook het personeel ter gemeentesecretarie legde het werk neer. Vrijdagmorgen breidde de staking te Haaksbergen zich uit tot het personeel van de N.V. Twentse Kabelfabriek en de firma D. J. ten Hoopen $\& \mathrm{Zn}$. In het geheel staakten hier 400 à 500 arbeiders. De Duitse politie kwam eerst Zaterdag- 


\section{Bekanntmachung.}

\section{Der Höhere SS- und Polizeiführer gibt bekannt:}

Das Polizeistandgericht im SS and Polizei= sicherungsbereich für die Provinzen Limburg und Nord Brabant in MAASTRICHT verurteilte am 2.5.1943 die nachstehend genannten nieder= ländischen Staatsangehörigen zum Tode :

1.) Den Hauptkontrolleur des C.C.D. Martinus B o u m a n aus Roermond, geboren am 5.5.1899.

2.) Den Adjunkt=Hauptkontrolleur des C.C.D. Leo R u y t ers aus Maastricht/Heer, ge= boren am 10.10.1892,

3.) Den Distriktsleiter des C.C.D. Leo B r o u = wer aus Maastricht, geboren am 1.6.1007,

4.) Den Chemiker Johannes B o o ge rd aus Roermond. geboren am 24.8.1906,

5.) Den Elektromonteur Renier S a v e Is be rg aus Heerlerheide, geboren am 27.4.1895.

6.) Den Bergschïler Servatius $T$ ous s a in $t$ aus Amstemrade, geboren am 22.12.1914,

7.) Den Bergmann Meinardus $\mathrm{T}$ e $\mathrm{m}$ p e $\mathrm{la}$ a $\mathrm{rs}$ aus Heerlerheide, geboren am 6.6.1904.

Die Verurteilten zu 1 bis 3 haben bei den Beamten des Zentr.-Controll=Dienstes Unter= schriften gesammelt, wonach sich diese zum Streik verpflichteten. Die Verteilung der hierzu hergestellten Formulare wurde am 1.5.1943 vorgenommen, die entsprechenden Unterschrif= ten wurden am gleichen Tage abgegeben. Alle 3 Verurteilten hielten enge Verbindung und haben durch Organisieren eines Streiks der Beamtenschaft des Zentr."Controll-Dienstes die öffentliche Ordnung und Sicherheit gefährdet.

Die Verurteilten za 4 bis 7 haben trotz Kennt= nis yom Standrechterlass gestreikt. Sie haben die Arbeit trotz öffentlicher Aufforderung nicht aufgenommen und sind ihr auch am 1.5.1943 ferngeblieben.

Die 7 Urteile wurden durch Erschiessen vollstreckt.

\section{Bekendmaking.}

\section{De hoogere S.S.- en Politieleider maakt bekend:}

Het Politiestandgerecht van het $S . S .=$ en Polizeibesicherungsbereich voor de Provincies Limburg en Noord Brabant te MAASTRICHT, veroordeelde den 2 Mei 1943 de navolgende Nederlandsche Staatsonderdanen ter dood door den kogel:

1.) De hoofdcontroleur van den C.C.D. Martinus B o $11 \mathrm{~m}$ a $\mathrm{n}$ te Roermond, geboren $5 \times 5 \times 1899$,

2.) De adjunct=hoofdcontroleur van den C.C.D. Leo Ruyters uit Maastricht/Heer, ge= boren $10=10=1892$,

3.) De districtsleider yan den C.C.D. Leo Brouwer uit Maastricht, geboren 1 $=6-1907$,

4.) De scheikundige Johannes $\mathrm{B}$ o o g e r d uit Roermond, geboren 24.8 .1906 ,

5.) De electromonteur Renier $S$ a v e Is berg uit Heerlerheide, geboren 27=4-1895,

6.) De leerling aan de Mijnschool Servatius Tous a int uit Amstenrade, geboren $22=12=1914$,

7.) De mijnwerker Meinardus $\mathrm{T}$ e $\mathrm{m}$ p e la a rs uit Heerlerheide, geboren $6=6=1904$.

De veroordeelden yan 1 tot 3 hebben bii de C.C.D. $=$ ambtenaren handteekeningen verzameld, waarbij zich deze tot staking verplichtten. De verdeeling der vervaardigde formulieren ge* schiedde op 1 Mei 1943, de handteekeningen zijn eveneens op dezen dag afgegeven. De drie veroordeelden stonden steeds met elkaar in contact en hebben door het organiseeren eener staking de openbare orde en veiligheid in gevaar gebracht.

De veroordeelden van 4 tot 7 , kennis genomen hebbende van het Politiestandrechts* Decreet, zijn toch in staking gebleven, hebben hun werk, ondanks openliiken oproep niet hervat en rijn ook op 1 Mei 1943 niet op hun werk verschenen.

De zeven vonnissen zijn voltrokken. 


\section{Bekanntmachung}

Der Hobere SS. und Polizeifuhrer Nordwest gibt folgentes bekannt:

Das in Sicherungsbereich Nordholland in Amsterdam tagende Polizeistandgericht hat auf Grund des Erlasses und der besonderen Anordnung des Reichskommissars über die Verhängung des Polizeistandrechtes in der Provinz Nordholland yom 30.4.1943 nachstehende Todesurteile gefallt, die nach Bestãtigung durch den Gerichtsherrn vollstreckt worden sind. Es wurden verurteilt: die niederlàndisclien Staatsangehörigen
1) Johan y $a$ Lemmoren, geboren am 15.11.1902, Amsterdam,
2) Gerard Wiersma, geboren am 12.2.1905, Amsterdam.
3) Theodorus Rijkhoft, geboren am 11. 6.1914, Assendelft,
4) Hendrik $\mathbf{B} / \mathrm{a} n \mathrm{k}$, geboren am 4. 11.1888, Krommenie,

wegen massgeblicher Streikbeteiligung in den "Ver* einigten Blechwarenfabriken" in Krommenie:
6) Theodorus $H$ endrikso, geboren am 5. 4.1907, Beverwilk,
6) Nicolaas Nieuwkoop, geboren am 10.11.1912, Velsen,
7) Jacob Wijker, geboren am 2,10.1893, Egmond az.

wegen massgeblicher Streikbeteiligung in den Hochofen- und Walzwerken in Velsen-IImuiden:
8) Pleter Houthooper. geboren am 30.1.1898, Oudorp,
9) Hendrik Stratíng, geboren am 11.2 .1905 , Haarlem

wegen massgeblicher Streikbeteiligung in der Papierfabrik van Gelder und Sohn in Velsen-lImuiden:

10) Herman Pieter de Noo, geboren am 18.3.1887, Utrecht, Bahnhofsvorsteher in Velsen-IJmuiden,

wegen offentticher Sympathiebekundung zum Streik.

Eine Reihe wegen Streikbeteiligung Mitangeklagtor wurde freigesprochen, weil sie glaubhaft nachgewiesen haben, dass sie sich wiederholt ernstlich um die Wiederaufnahme der Arbeit bemüht haben.

Weitere Fälle, die in dem standgerichtlichen Verfahren nicht zweifelsfrei geklärt werden konnten, wurden der Sicherheitspolizei zur Klarstellung ubergeben.

Das Standgericht tagt weiter.

Den Haag, den 2. Mai 1943.

\section{Bekendmaking}

De Höhere SS- und Polizeifubrer Nordwest maakt het volgende bekend:

Het in het beveiligingsgebied Noord Holland in Amsterdam dagende Politiestandgerecht heeft op grond van het decreet en de bijzondere beschikking van den Bijksconmissaris over het instellen van het Politiestandrecht in de "provincie Noord Holland van 30.4 .1943 de navolgende doodvonissen geveld en na bevestiging door de hongste rechtelijke macht ten uitvoer gelegd. Veroordeeld werden de Nederlanders
1) Johan y n Lemmeren, geboren op 15.11.1902 te Amsterdam,
2) Gerard Wiersma, geboren op 12.2.1905 te Amsterdam,
3) Theodorus Rijkhoff, geboren op 11.6,1914 te Assendeltt,
4) Hendrik Blank, geboren op 4.11,1888 te Krommenie,

wegens vergaande deelname aan de staking in de "Vereenigde Blikfabrieken" in Krommenie:
6) Theodorus Hendrikse, geboren op 5.4.1907 te Beverwilk,
6) Nicolaas Nieuwkoop, geboran op $10,11,1912$ to Velsen.
7) Jacob Wijker, geboren op 2.10.1893 te Egmond a. Zee,

wegens vergaande deelname aan de staking in de hoogovens en walsfabrieken te Velsen-Ifmuiden:
8) Pieter Houtkooper, geboren op 301.1898 te Oudorp.
9) Hendrik Strating, geboren op It. 2.1905 te Haarlem,

wegens vergaande deelname aan de staking in de papierfabrizk Van Gelder \& Zonen te Velsen-IJmuiden:

\footnotetext{
10) Herman Pieter de Noo, geboren op 18.3.1887 te Utrecht, stationschef te Veisen-1umuiden;
}

wegens opentijke symphatiebetuiging met de stáking.

Een aantal andere beklaagden. die aan de staking hadden deelgenomen, werden vrijgesproken, omdat zij op steekhoudende wijze konden aantoonen, dat zij herhaaldelijk ernstig gepoogd hebben de arbeid to hervatten.

Andere gevallen, die tijdens de procedure van het Standgerecht niet volkomen konden worden opgehelderd, werden ter afdoening aan de Sicherheitspolizei overgedragen.

De zitting van het Standgerecht duurt voort.

Den Haag, 2 Mei 1943. 
morgen controleren en ging vreselijk te keer, toen zij bemerkte, dat de arbeiders nog geen aanstalten makkten aan het werk te gaan. Zondagmiddag riep de bedrijfsleider van de N.V. Jordaan de bazen bijeen en verzocht hun zoveel mogelijk arbeiders te waarschuwen Maandag weer aan het werk te gaan. Dit gebeurde, doch nu bleek wel duidelijk welk een weerbarstig slag deze groep arbeiders was. Maandagmorgen bleek slechts een gedeelte van de arbeiders te bewegen de fabriek binnen te gaan - sommigen liepen er weer uit. Eerst in de loop van de dag kwam er enige regelmaat in de werkzaamheden.

Maandagmorgen half elf kwam de Duitse politie bij de N.V. Jordaan controleren. De directie werd gedwongen, 's middags een lijst in te leveren van de arbeiders, die om 12 uur nog niet aanwezig waren. Toen de Duitsers omstreeks 4 uur weer verschenen, dwongen $z \mathrm{ij}$ alle arbeiders, die pas na de middagschafttijd waren gekomen, bij elkaar te gaan staan. $\mathrm{Na}$ een voorlopig onderzoek werden 24 personen, onder wie 9 meisjes, apart gehouden en naar Enschede vervoerd. Van deze arrestanten mochten er 's avonds 15 naar Haaksbergen terugkeren. Negen arbeiders moesten plaats nemen in een auto, die richting Hengelo wegreed. Ter hoogte van "Den Broeierd" kregen deze arrestanten bevel de auto te verlaten. Daarna werd het vuur op hen geopend; zeven werden "op de vlucht doodgeschoten". Twee arbeiders wisten te ontsnappen. Eén van hen werd de volgende dag weer gearresteerd, zijn makker ( $H$. Goering geheten) dook onder en heeft naderhand bijzonderheden kunnen meedelen over het drama, dat zich 3 Mei 1943 tussen Enschede en Hengelo afspeelde. De slachtoffers van dit bloedbad waren J. Oltwater, W. Th. J. van Sark, J. H. Asbroek, W. Barends, J. H. Geuvers, B. H. Bos en G, J. Holterman, allen uit Haaksbergen afkomstig. Degene, die aanvankelijk ontsnapte, was A. B. Wijlens. Hij werd Dinsdag $4 \mathrm{Mei}$ in de tuin van het klooster Dolphia, tussen Enschede en Glanerbrug, gefusilleerd.

Stakingen bij de Koninklijke Stoomweverij N.V: te Nijverdal en bij de Koninklijke Stoomblekerij in dezelfde plaats, lokten eerst Zaterdag Duitse tegenmaatregelen uit. Maandagmorgen werd het werk hervat te Hellendoorn, Nijverdal en Rijssen. Te Rijssen gebeurde dit onder intimidatie door de Duitse politie (hier vonden Maandag niet minder dan 30 arrestaties plaats). Eerst Maandagmiddag werd het werk bij Ter Horst $\mathcal{E}$ Co N.V. te Rijssen geheel hervat.

Soms kwam ook in de stakingsactiviteit van de Twentse randgebieden de solidariteit van de Twentse arbeiders tot uiting. Wij noemden als stakings haard reeds het dorp Vriezenveen, waar Donderdagmiddag het personeel van Jansen $\mathcal{E}$ Tilanus N.V. de fabrieken had verlaten. Een afdeling Sicherheitspolizei uit Arnhem kwam hier Donderdagavond controleren en scheen zich bijzonder te interesseren voor de vraag, hoe men te Vriezenveen te weten was gekomen, dat elders werd gestaakt. Meestal kon men op zulke vragen wel misleidende antwoorden geven. Vrijdag breidde de staking zich over geheel Vriezenveen, een langgerekt dorp van $6 \mathrm{~km}$ lengte, uit. De zuivelfabriek werd stopgezet, omdat de melkaanvoer stagneerde. Winkels sloten; er was zelfs 
geen brood meer te krijgen. Ruim 1000 veenarbeiders legden die dag het werk neer. Vrijdagavond patrouilleerde de staatspolitie. Hier en daar vielen schoten. Het personeel van Jansen $\mathcal{E}$ Tilanus zwichtte Zaterdagmorgen voor de aandrang het werk te hervatten. Men wist, het spel was toen toch verloren. Onder toezicht van de Duitse politie werd Zaterdagmiddag tot 4 uur doorgewerkt.

Te Delden staakten de arbeiders van de N.V. Chemische Fabriek "Servo" (138 arbeiders). De staking begon er Donderdagmiddag na terugkeer van een aantal Deldense arbeiders, die te Hengelo werkten. Te Denekamp was de zuivelfabriek het middelpunt van de staking, te Wierden de Wierdense Exportslachterij. Te Goor begon de staking in de fabriek van de N.V. Eternit v/h Martinit (waaruit destijds slechts 60 arbeiders werkten); daags daarna bij de N.V. Katoenfabriek v/h Arntz. Jannink \& Co (60 arbeiders). Evenals elders was de rust te Goor Maandagochtend hersteld. Onder Duitse pressie kwamen op het platteland Zaterdag ook de meeste zuivelfabrieken weer op gang.

Het verzet was Maandag overal gebroken; wat dit betreft, konden de Duitsers tevreden zijn. Maar als manifestatie van verzet mag de betekenis van de staking niet worden onderschat. Voor het eerst had men op grootse wijze gedemonstreerd en laten blijken, waartoe men in staat was. De algemene opinie luidt dan ook, dat het saamhorigheidsgevoel onder invloed van de gebeurtenissen van 29 April tot 3 Mei was toegenomen, evenals de bereidwilligheid, aan illegale acties deel te nemen. Helaas werd hiervoor een hoge prijs betaald: kostbare mensenlevens gingen verloren; in enkele gevallen nog na de stakingsdagen, toen de Duitsers zonder verdere tegenstand strafmaat regelen konden doorvoeren.

Het Standgericht dat te Hengelo zetelde, veroordeelde in de week na $2 \mathrm{Mei}$ de reeds genoemde slachtoffers Ir F. M. Loep en Joh. van Oene. Verder de leider van het plaatselijk distributiebureau te Tubbergen: A. Hasselbeke en daarna nog enige beschuldigden, die buiten Overijsel waren gearresteerd: de student A. L. Frederiks, de boekdrukker W. A. van der Veer en de kantoorbediende E. A. van der Veer, allen uit Nijmegen.

Door patrouillerende Duitsers werden op straat zeven personen doodgeschoten. Verder zijn in het geheel elf gearresteerden ,op de vlucht doodgeschoten", d.w.z. lafhartig, zonder vorm van proces vermoord. De namen van degenen, die tot "tuchthuisstraf" werden veroordeeld (eveneens elf personen) zullen wij maar niet noemen. Het belangrijkste is, dat zij de hun opgelegde straffen niet volledig hebben ondergaan ${ }^{1}$ ).

1) Bijzonderheden over het lot van alle slachtoffers van de April-Meistaking in Twente vindt men in het niet-afgedrukte gedeelte van het rapport van B. A. Sijes, dat in het archief van het Rijksinstituut voor Oorlogsdocumentatie (later: het Algemeen Rijksarchief) wordt bewaard. 


\section{HOOFDSTUK II}

\section{GELDERLAND}

In de provincie Gelderland, die geografisch evenals in aard en afkomst van de bevolking zo weinig een eenheid vormt, is in April-Mei 1943 eigenlijk alleen langs de Oostelijke Veluwezoom met verbetenheid gestaakt. Daar vielen ook de meeste slachtoffers.

De reeds meermalen aan de orde gestelde vraag in hoeverre het gedrag bij de staking het streekkarakter tot uiting bracht, is voor Gelderland moeilijk te beantwoorden, omdat de toevloed van vreemdelingen hier een grote omvang heeft aangenomen - vooral in de industriële randgebieden. Slechts voor de "melkstaking" op het platteland zijn enige conclusies te trekken. Bij de beoordeling van het gedrag der stakende fabrieksarbeiders staan wij voor de moeilijkheid, zelfs niet bij benadering te kunnen vaststellen, in welk percentage zij zich met de inheemse bevolking vermengd hebben. Alleen in de streek van Vaassen tot Heerde vertoont het fabriekspersoneel een sterke inslag van bevolking, in die buurt geboren en getogen. Op het vroegtijdig uitbreken van de staking aan de Oostelijke Veluwezoom kan evenwel het contact met Twente ook van invloed $z$ ijn geweest.

Te Vaassen zijn twee grote industrieën gevestigd: de IJzergieterij "Industrie" (in 1943 ruim 600 arbeiders) en de IJzergieterij "Vulcanus” (400 arbeiders). Als een voorbeeld van snelle verspreiding van geruchten of berichten kan worden vastgesteld, dat het fabriekspersoneel in de beide genoemde fabrieken reeds Donderdagmiddag, één uur na het uitbreken van de staking bij Stork te Hengelo, op de hoogte scheen te zijn van de gebeurtenissen in Twente. Is er getelefoneerd? Het bleek achteraf niet meer vast te stellen, maar onwaarschijnlijk is het niet, indien men weet, dat de ijzergieterijen te Vaasen meestal grote orders ontvangen van Stork en van Heemaf te Hengelo. In ieder geval was de stemming in de fabrieken van Vaassen Donderdag tegen het einde van de middag reeds zeer onrustig.

De volgende ochtend, Vrijdagmorgen, zag men de arbeiders als gewoonlijk de fabriekspoort binnenkomen. Men ging echter niet aan het werk; er werd beraadslaagd. Toen de arbeiders uit de Noordelijker gelegen plaatsen om half acht niet met de werkliedentrein meekwamen, stroomden de fabrieken leeg. De staking breidde zich snel uit over het gehele dorp: winkels sloten, zelfs de schoolkinderen werden naar huis gestuurd. Op verzoek van de dorpspolitie vonden geen samenscholingen plaats. Zaterdag werd het standrecht 
afgekondigd en verschenen Duitse patrouilles in het dorp. Berichten, dat stakingen elders begonnen te verlopen, werkten enigszins ontmoedigend, maar men besloot vol te houden. De bevolking is in deze streek vrij koppig en wantrouwig. Adviezen van directeuren en bedrijfsleiders om het werk te hervatten, werden niet gevolgd. Zondagochtend vertelde men, dat enige oudgemeenteraadsleden en oud-vakverenigingsleiders zich alleen door overhaaste vlucht aan arrestatie hadden kunnen onttrekken. Men moest op verdere represailles rekenen, temeer omdat een Duitse bedrijfsleider, een zekere Schuhmacher van de fabriek "Vulcanus”, de Duitsers alle gewenste inlichtingen kon geven. Er waren trouwens ook Duitse arbeiders in dienst. Inmiddels waren door een illegale groep stakingsmanifesten verspreid. De kans op een bloedige afloop van dit conflict nam toe.

In de nacht van Zondag op Maandag vonden nieuwe arrestaties plaats, doch slechts als inleiding tot een Duitse actie op Maandag 3 Mei. Die ochtend was namelijk slechts een gedeelte van de arbeiders op hun werk verschenen. Om half-elf verschenen drie Duitse overvalwagens, waarvan de manschappen de fabrieken omsingelden en contrôle begonnen uit te oefenen op het aantal aanwezige arbeiders. Degenen die na elf uur binnenkwamen, werden op binnenplaatsen van de beide fabriekscomplexen tegen de muur gezet. Vooral bij "de Vulcanus" traden de Duitsers onbeschoft op. Men trachtte de arbeiders te pressen elkander te verraden, door op te geven wie Vrijdag het eerst de fabriek had verlaten. Niemand noemde echter namen. 's Nachts bleven honderden arbeiders opgesloten.

Nadat Zondag reeds een twintigtal arbeiders en employé's uit Vaassense bedrijven naar Vught waren gezonden ${ }^{1}$ ), velde het Standgericht Maandag vier doodvonnissen: $H$. Proper, $H$. J. van Werven en $H$. Eilander kregen de kogel; de vierde, een zekere W. v. Norel, wist bij het transport naar Apeldoorn uit een vrachtauto te springen en aan zijn bewakers te ontsnappen. Woensdag 5 Mei was de rust in Vaassen weer hersteld.

Te Epe droeg de staking een even algemeen karakter als te Vaassen. De talrijke arbeiders, die in het naburige Vaassen hun werk hebben, bleven Vrijdagochtend thuis of keerden na enkele uren terug. Daarna sloten de gemeentebureaux, o.a. de distributiedienst, het postkantoor, enz. De ambtenaren hervatten Zaterdag - ten dele ook Maandag - hun taak. Van de metaalbewerkers, die Maandag op verkenning uitgingen om te zien hoe te Vaassen de zaken stonden, ontsnapten slechts enkele aan de Duitsers.

De bevolking van Heerde gedroeg zich niet anders dan die van de naburige plaatsen. Het schijnt, dat hier in de nacht van Donderdag op Vrijdag pamfletten verspreid zijn. In ieder geval was men Vrijdagochtend 30 April op alle gebeurtenissen voorbereid. Het staat ook vast, dat arbeiders uit Heerde zich Vrijdagochtend vroeg bij de naburige spoorweghalte posteerden om arbeiders van de trein $Z$ wolle-Apeldoorn tot staken aan te manen. Te Heerde

1) Een gedeelte van deze groep bleef zes weken in Vught, de anderen werden na drie weken vrijgelaten. 
zelf, een plaats met vrij veel industrie, bleven de arbeiders thuis of verlieten zij Vrijdagmorgen na enig overleg hun werkplaatsen (Zeepfabriek „De Klok”, Arck's Beschuitfabriek en Berghuizer Papierfabriek). Ook de zuivelfabriek kwam tot stilstand, terwijl het personeel van de gemeentesecretarie en van het distributiekantoor eveneens in staking ging ${ }^{1}$ ). De staking hield aan tot Maandag. 's Morgens 3 Mei verschenen de arbeiders wel voor de fabrieken, maar na enig overleg gingen zij naar huis. Nadat echter de SS was aangekomen, gaven de meesten toe aan de aandrang van de directie om zo spoedig mogelijk aan het werk te gaan. Maandagmiddag waren de bedrijven weer op gang, maar de Duitsers namen achteraf nog wraak. Een aantal arbeiders uit Heerde, o.a. H. Eilander en W. van Norel, werd naar Vaassen gebracht om daar voor het Standgericht te verschijnen. Wij deelden de vonnissen reeds mede.

Bij het overzien van deze gebeurtenissen lijkt het toch niet waarschijnlijk, dat het heftig karakter van de stakingen te Vaassen, Epe en Heerde - vooral de weigering, Maandagochtend aan het werk te gaan - toe te schrijven is aan invloeden van buitenaf. De meer lijdzame bevolking van de Gelderse Achterhoek, die toch ook van de gebeurtenissen in Twente op de hoogte was, reageerde veel kalmer. Dus toch invloed van het streekkarakter in de industrieplaatsen Vaassen, Epe, Heerde? De bevolking staat hier bekend als eigengereid, weerbarstig en wantrouwig. Symptomatisch is, dat de vakverenigingsleiders hier niet gemakkelijk invloed op de arbeiders kunnen uitoefenen. Onaantastbaar sterk daarentegen is de invloed van de predikanten op het rechtzinnig-orthodoxe deel van de bevolking. Het staat wel vast, dat enkele gereformeerde predikanten veel gedaan hebben om de geest van verzet aan te wakkeren. $Z_{i j}$ stonden ook in relatie met illegale kernen, die Vrijdag pamfletten begonnen te verspreiden. De gereformeerde predikant uit Epe bracht pamfletten over naar Wezep. Te Wapenveld trokken de gereformeerde en de hervormde predikant er samen op uit om de staking te propageren. Te Wezep werd Zondagochtend in de gereformeerde kerk in gebed en preek rekening gehouden met de heersende spanning.

In de beide agrarische gemeenten Wezep en Hattum was de houding van de bevolking echter niet bijzonder fel. Er begon een melkstaking, maar deze eindigde reeds na enkele dagen - vooral toen men zag, dat de treinen bleven rijden. Hetzelfde geldt voor andere dorpen van de Noord-Veluwe.

Te Nunspeet was de staking Vrijdag 30 April vrij algemeen (Zuivelfabriek, een kleine staalfabriek en een kinderwagenfabriek, postkantoor en distributiedienst). Zelfs de meeste winkels werden hier gesloten. Indien wij juist zijn ingelicht, zou het verzet vooral zijn uitgegaan van de niet-inheemse bevolking. Nadat de Duitse politie Vrijdag enige malen gepatrouilleerd had en de teleurstelling over het niet-staken van de spoorwegen ook de Nunspeetse bevolking had aangegrepen, verliep de staking snel. Maandag $3 \mathrm{Mei}$ was ieder weer

1) De Duitse politie stelde burgemeester $\mathrm{Mr}$ J. D. Koster hiervoor aansprakelijk en arresteerde hem om een voorbeeld te stellen. 
aan het werk. Te Elburg, waar de staking op dezelfde wijze verliep, ging men zelfs de 1ste Mei alweer aan de arbeid. Te Harderwijk begon de staking bij de zuivelfabriek en geraakte de bevolking in opwinding door het stagneren van de watervoorziening (het pompstation werkte wel, maar er werd teveel water getapt). Hoewel de toestand in het stadje reeds Zaterdag rustig was, werden Zondag zes gijzelaars weggevoerd.

Te Putten gaf een melkstaking - het stopzetten van de coöperatieve zuivelfabriek - de NSB-burgemeester Klinkenberg gelegenheid, gevoelens van wraak te koelen op persoonlijke tegenstanders. In de nacht van 1 op 2 Mei liet hij elf dorpsgenoten arresteren, die naar Vught werden gebracht. Brandpunt van de staking te Nijkerk was de uitgeverij en drukkerij van de firma Callenbach. Het verzet was hier wat feller dan elders op de Noord-Veluwe, vermoedelijk door de werkzaamheden van een illegale kern, die pamfletten vervaardigde. Helaas werden bij het aanplakken van stakingspamfletten enige onvoorzichtigheden begaan, waardoor de Duitse politie op het spoor kwam van vier daders. Deze werden naar de strafgevangenis te Scheveningen vervoerd. Eén van hen, M. Slort, uit Amsterdam afkomstig, werd gefusilleerd. De drie anderen kwamen in Duitse concentratiekampen om het leven. (Het waren: W. Bouwman, Joh. Pijpers en J. T. Sietsma, allen uit Nijkerk).

Langs de Gelders-Utrechtse grens werd met bijzondere felheid gestaakt te Scherpenzeel, waar alle wolspinnerijen enz. hun deuren sloten. De staking droeg in deze gemeente een algemeen karakter: bakkers, winkeliers, allen legden het werk neer. Eerst nadat Zaterdag een aantal arrestaties plaats vond, toonde de bevolking zich bereid het werk te hervatten.

Het treinverkeer tussen Apeldoorn en Amersfoort was de 30ste April een halve dag gestremd door een bomaanslag op een trein, die daar in de vroege ochtend passeerde. Deze trein werd slechts licht beschadigd. Een tweede springlading, bestemd voor een Duitse trein met verlofgangers, die even later zou passeren, kwam niet tot ontploffing. De Duitsers slaagden er niet in, de daders op te sporen. Vermoedelijk waren zij afkomstig uit Apeldoorn waar de geest van verzet vrij sterk was. Er werd tenminste daar de 30ste April algemeen gestaakt. De meeste ambtenaren en arbeiders waren die dag 's morgens nog verschenen, maar vernamen al gauw, dat te Vaassen, Epe, enz. gestaakt werd. In de loop van de morgen gingen de meesten naar huis. Uit een NSB-rapport, dat wij als Bijlage II, 37 afdrukken, blijkt, dat de stakingen vrijwel gelijktijdig begonnen bij de Papierfabriek Van Gelder \& Zonen, bij Rocarto's cartonnagefabriek, de Apeldoornse Coöp. Fabriek van Zuivelproducten, de Nieuwe Apeldoornse Courant, Buiscar en de Apeldoornse Machinefabriek. In de middaguren breidde de staking zich verder uit en kwamen ook enige busdiensten tot stilstand. Van de gemeentelijke instellingen staakten de distributiedienst en het waterleidingbedrijf. Ondanks de verspreiding van stakingsmanifesten met de woorden: „Arbeiders, volgt het voorbeeld van Hengelo", maakte zich al gauw een aarzeling van de bevolking meester. Zaterdag werd in de meeste fabrieken het werk hervat. Het bleef 
de hele dag nog onrustig, vooral door vele geruchten over stakingsgebeurtenissen en doodvonnissen in andere plaatsen. Het standrecht maakte indruk. Maandag 3 Mei waren de omstandigheden uiterlijk weer normaal.

Op de Zuid-Veluwe was Arnhem het middelpunt van de stakingsbeweging. In hoeverre men daar op de hoogte was van de gebeurtenissen in Twente, blijft een open vraag, maar het staat wel vast, dat in de arbeidersbuurten van Arnhem, met hun talrijke kernen van voormalige S.D.A.P.-groepen reeds Donderdagavond geageerd werd om het werk neer te leggen. Sommige arbeiders gingen Vrijdagochtend 30 April wel naar werkplaats of fabriek, maar ook in dit geval kennelijk om overleg te kunnen plegen. Tussen negen en tien uur begon de staking vrijwel gelijktijdig in enige grote fabrieken, o.a. bij de Algemene Kunstzijde Unie en bij de gemeentebedrijven (ruim 500 arbeiders).

Voor het grote publiek was de uitschakeling van de stroomlevering en het ophouden van de watervoorziening wel het duidelijkste bewijs, dat er gestaakt werd. Ook het gemeentelijk trambedrijf kwam tot stilstand. Men zag de trams zeer ordelijk naar de remise rijden. Op het Velperplein stond een man met een wisselijzer het binnenrijden van de trams te regelen; hij had er van niemand opdracht toe ontvangen en er was ook niemand, die hem in zijn taak hinderde. Het meest imposant was de uittocht van de arbeiders van de A.K.U. en de E.N.K.A., in het geheel ongeveer 5000 man, waarbij zich nog enkele duizenden bouwvakarbeiders voegden, die op de A.K.U.-terreinen bezig waren met de bouw van vijf nieuwe fabrieken. Een aantal busdiensten staakte eerst, nadat het transport van de buiten Arnhem wonende arbeiders grotendeels was verzorgd.

In de loop van de ochtend breidde de staking zich zo snel uit, dat zij wel algemeen mocht worden genoemd. Het personeel van talrijke kleine bedrijven verklaarde zich solidair met de stakers van de E.N.K.A. en de A.K.U. en van de gemeentebedrijven. Bij de sleephelling Prins, bij de Verffabriek van Ommeren, bij Van Gend $\mathcal{E}$ Loos, enz. - overal werd het werk neer gelegd. Winkels sloten. De Duitse politieautoriteiten voelden zich overrompeld. Hun contact met Den Haag werd verbroken, toen tegen 11 uur ook nog het personeel van het post- en telegraafkantoor deserteerde. De stemming op straat werd onrustiger. In het begin van de middag werd bij de Geitenkamp een bijwagen van lijn 4 door het publiek omver geworpen. Patrouillerende Duitsers losten hier en daar schoten.

Door zware pressie op de burgemeester en op het politiecorps slaagden de Duitsers er in, hun dreigementen bekend te maken onder het gemeentepersoneel en onder de rijksambtenaren. Reeds 's middags kwamen verschil lende overheidsdiensten weer op gang. Zelfs de gemeentetram hervatte haar dienst. Dit was voor het publiek - met de zekerheid dat ook de spoor wegen waren blijven rijden - aanwijzing voor de gedeeltelijke mislukking van de stakingsbeweging. De directies van de kunstzijdefabrieken moesten maatregelen nemen om ook hun arbeiders tot hervatting van werkzaamheden 
te brengen. Hun proclamaties maakten echter niet veel indruk, evenmin als de afkondiging van het standrecht, 30 April 's avonds laat. Het was trouwens ook niet gemakkelijk, de verspreid wonende arbeiders van de kunstzijdefabrieken te bereiken. Vermoedelijk kwam het de meesten niet eens ter ore, dat Zaterdag een twaalftal arbeiders van de A.K.U. werd gearresteerd (waarschijnlijk noemde een NSB-er hun namen). $Z_{i j}$ werden na één of twee dagen hechtenis in vrijheid gesteld. Het was wel duidelijk, dat de Duitsers te Arnhem met enige matiging optraden. Voorbeelden waren elders gesteld; in de hoofdplaats van de provincie behoefde het zover niet te komen. Arnhem's bevolking schikte zich in het onvermijdelijke. Maandagochtend vertoonde de stad een normaal aanzien. De heersende spanning kwam evenwel tot uiting in een daad van sabotage: brandstichting in de zolderverdieping van het gebouw van het Gerechtshof. Het vuur werd geblust, maar de Duitsers behoefden er niet aan te twijfelen, dat het smeulend verzet wel weer opnieuw zou oplaaien.

Langs de Zuid-Oostelijke Veluwezoom werd eveneens gestaakt. In de gemeente Rheden legde het personeel van de meeste overheidsdiensten (gemeentewerken, distributiedienst, enz.) Vrijdagochtend 30 April het werk neer. Ook vele winkels sloten. Het stop-zetten van de tramdienst Arnhem-De Steeg en berichten over stakingen te Arnhem en in andere grote plaatsen veroorzaakten een opgewonden stemming. De duidelijkste manifestatie van verzet vormden uiteraard ook in dit geval de stakingen aan enkele grote bedrijven: N.V. Betonfabriek De Meteoor (240 man personeel) en de Machinefabriek Thomassen in De Steeg ( \pm 340 man). Gaat men de details van deze stakingen na, dan blijkt evenwel niet, dat zij begonnen door directe navolging van stakingen in de naburige grote stad. Weliswaar wisten het kantoorpersoneel en de arbeiders bij geruchte dat er reeds verschillende stakingen waren uitgebroken, maar het besluit, dat Vrijdagochtend na kort overleg werd genomen, droeg in het algemeen een "spontaan" karakter. Door het gehele land zijn er trouwens Vrijdagsochtends personeelsbijeenkomsten gehouden, waar men in volle eensgezindheid tot daden van protest besloot - practisch onafhankelijk van elkander. Slechts in enkele gevallen is van navolging sprake geweest.

De stakingen in De Steeg lokten dadelijk maatregelen van Duitse zijde uit. Manschappen van de naburige SS-opleidingsschool te Avegoor-Ellecom kregen nu gelegenheid om te tonen, wat door terreurmaatregelen kon worden bereikt. SS-troepen bezetten de fabrieken en arresteerden enige arbeiders. Toen des Zaterdags nog gestaakt werd, kon het standrecht worden toegepast. Zondag 2 Mei arresteerden de Duitsers drie arbeiders van de Machinefabriek Thomassen in De Steeg (ze werden naar Vught vervoerd) en Maandag $3 \mathrm{Mei}$ nogmaals drie leden van het personeel van deze fabriek. Dit laatste drietal verscheen voor het Standgericht en hoorde het doodvonnis tegen zich uitspreken. De lijken van deze slachtoffers (J. Tjalkens en B. Pessink, beide te Velp en J. A. Versteeg te Arnhem) werden eerst Februari 1949 teruggevonden in een massagraf op de Galgenberg bij Arnhem. 
In de overheidsbedrijven in de gemeente Rheden is het werk onder zware pressie van de SS reeds Vrijdagmiddag hervat, in de fabrieken was het personeel eerst Maandag weer voltallig.

Te Dieren begon de staking Vrijdag 30 April in de N.V. Gazelle-Rijwiel fabriek, het eerst onder het kantoorpersoneel. Spoedig verlieten ook de arbeiders het fabrieksgebouw; korte tijd later volgden de arbeiders van naburige kleinere fabrieken hun voorbeeld. (Zadelfabriek v/h Van der Kloot Meyburg, enz.). Zelfs het personeel van de N.V. Leppers fabrieken trotseerde de druk van de Duitse bedrijfsleiding van deze onderneming. Maar ook te Dieren toonde de Waffen SS van het naburige Avegoor zich zeer actief. Er werd een ultimatum gesteld: vóor 4 uur moest het werk hervat zijn. De directie van de Gazelle-Rijwielfabriek verzocht toen het gehele personeel om 2 uur 's middags aanwezig te zijn om $z$ ich te beraden over mededelingen, die de directie zou doen. De stemming was op deze vergadering reeds vrij neerslachtig, o.a. door de zekerheid, dat de spoorwegen de staking niet zouden steunen. Men gaf dus gevolg aan het bevel van de directie om diezelfde dag nog de werkzaamheden te hervatten. Doch niet zonder protest! Degene echter, die zich openhartig toonde en zich tot tolk maakte van de gevoelens van alle collega's, C. de Reus te Dieren, moest later ervaren, het vertrouwen van de directie te hebben verspeeld. Dergelijke voorbeelden van gebrek aan psychologisch inzicht en gebrek aan waardering voor een principiële houding zouden wij in vrij groten getale kunnen geven. Onze beschrijving zou daardoor op vele plaatsen een aanklacht worden en dat is het doel van deze studie niet. Evenmin kan het onze taak zijn, waardering te uiten voor alle gevallen van vaderlandslievende samenwerking tussen directies en personeel. Enkele illustratieve voorvallen in verschillende nuances tussen licht en donker werden echter wèl geregistreerd.

Te Loenen en te Eerbeek staakten de papierfabrieken en enige grote wasserijen. De houding van de directies van de papierfabrieken was in het algemeen zeer standvastig. Dit blijkt o.a. uit hun bereidwilligheid, papier te leveren voor illegale bladen. De Duitse informatiedienst was goed op de hoogte: men wist, dat de directies van de papierfabrieken zich eind April 1943 niet tegen de staking verzetten. Er vonden arrestaties plaats en er viel een slachtoffer door het Standgericht: Ir D. W. van Vreeswijk te Eerbeek.

Te Renkum staakte het personeel van de papierfabriek Van Gelder \& Zonen N.V. (ook hier begon de staking bij het kantoorpersoneel!), evenzo de ambtenaren van de P.T.T., gemeentewerken enz. De volle woede van de Duitsers richtte zich evenwel tegen de arbeiders van de N.V. Verenigde Ned. Rubberfabriek "Hevea" te Doorwerth in de gemeente Renkum, die bleven doorstaken, nadat het standrecht was afgekondigd. De bevolking van Heveadorp toonde zich solidair en had besloten, zich niet te laten intimideren. Maar berichten over het mislukken van de stakingen in andere plaatsen brachten aarzeling en verdeeldheid teweeg. Maandag 3 Mei staakte nog slechts een gedeelte van het personeel der Hevea-Rubberfabrieken door. Zeven van hen moesten 
dit met de dood bekopen (H. C. Munter, J. Kleefsman, J. M. Z. Quadvlieg, P. Dijkstra, C. W. Knipscheer, W. Weimar en G. Peters). Voor de Duitsers was er veel aan gelegen de arbeiders van een der grote Gelderse bedrijven (de Heveafabrieken telden destijds ongeveer 800 man personeel) aan hun gezag te onderwerpen. Het staat wel vast, dat deze reeks doodvonnissen een grote indruk op de bevolking heeft gemaakt. Men onderwierp zich, doch de bereidheid tot illegaal werk was gestegen. Evenals in andere delen van de provincie, was het langs de Zuidelijke Veluwezoom goed merkbaar, dat na de AprilMei-stakingen de verzetsorganisaties snel groeiden. Het offer der gefusilleerden was niet tevergeefs geweest!

Te Wageningen staakte het personeel van de N.V. Gebr. Zomer \& Keuning's Uitg. Mij, het personeel van het Scheepsbouwkundig Proefstation en van een aantal instituten van de Landbouwhogeschool. Voorts gemeentewerken, het kantoor van de Prov. Geld. Electriciteits Mij. Ook het gemeentehuis werd verlaten. Toen de druk op de waterleiding verminderde, werd dit door de bevolking opgevat als een signaal voor een werkelijk algemene staking. Voor de bakkerswinkels vormden zich lange rijen, er ontstond een geduchte opwinding. Maar de volgende dag reeds was de geest van verzet geluwd. De overheidsinstellingen gaven het sein tot terugkeer tot normale toestanden.

In naburige dorpen nam de bevolking een afwachtende houding aan. Tot vrij omvangrijke stakingen kwam het in die streek slechts te Ede, waar het stakingssignaal werd gegeven door het personeel van de A.K.U. De arbeiders van de grote kunstzijdefabrieken hadden vermoedelijk al vernomen van stakingsplannen te Arnhem. Het is zelfs niet uitgesloten, dat door voortdurend telefonisch contact tussen Arnhem en Ede de stakingscampagne volgens een gemeenschappelijk plan werd voorbereid. Bij nader onderzoek bleken hierover tegenstrijdige berichten in omloop te zijn. De goede verstaanders hadden slechts een half woord nodig. Zo braken de stakingen in de fabrieken van het kunstzijdeconcern te Arnhem en te Ede vrijwel gelijktijdig uit. In de loop van de dag ging te Ede ook het personeel van het gemeentehuis, van de gemeentewerken enz. in staking. Na enige arrestaties ging men echter reeds 1 Mei weer aan het werk. Van georganiseerd verzet was geen sprake. Ook de geestelijkheid gaf in dit geval geen leiding. In het algemeen mag men de invloed van de predikanten der verschillende protestantse kerkgenootschappen in Gelderland gedurende de April-Meidagen niet hoog aanslaan. Slechts in de Noord-Oosthoek van de Veluwe hebben, gelijk reeds vermeld, predikanten door woord en daad de stakingsactie aangemoedigd. De berichten over hun activiteit in andere streken lopen nogal uiteen. De meeste predikanten, vooral de gereformeerde predikanten, geraakten eerst later in de verzetsbeweging betrokken of namen daarbij zelf het initiatief. De onverwacht uitbrekende stakingen van eind April 1943 schiepen een situatie waarop men niet berekend was. Vóór men voldoende contacten had kunnen leggen, waren de stakingen reeds grotendeels onderdrukt. Het standrecht vormde een sombere dreiging. Geen wonder, dat de meeste predikanten in hun preken van Zondag 
2 Mei weinig toespelingen maakten op de gebeurtenissen, die de kerkgangers die dag zo in spanning hielden.

Wat voor de predikanten der verschillende geloofsrichtingen geldt, is ook van toepassing op hun volgelingen en op de groepen der onkerkelijken. Op de Veluwe met zijn sterk orthodox -protestantse groeperingen heeft de orthodoxie het verzet niet in bijzondere mate aangemoedigd. Min of meer incidenteel kon een moedig optreden van sommige predikanten worden gesignaleerd. Bij de beoordeling van het verband tussen kerkelijke overtuiging en verzetsgeest moet er voorts rekening mee worden gehouden, dat op de Veluwe de Christelijk-Gereformeerden met hun neiging om alle gezag als "wettig" (of als straf Gods) te erkennen, veel aanhang hadden.

In de stakingshaarden in de industriecentra Arnhem, Heveadorp en Ede hebben resterende bestanddelen der ontbonden S.D.A.P. en van het N.V.V. ongetwijfeld organisatorische kracht getoond, meer door het prestige der voormalige leiders dan door voorbereiding van enige stakingsactie.

In de Achterhoek kenmerkt de inheemse bevolking zich door een zekere lijdzaamheid. Kenners van deze streek spreken van een neiging tot slapheid en beginselloosheid 1). Men is goedig en meegaand. Vooral op het platteland ziet men nog de nawerking van de onderworpenheid aan een kleine bevoorrechte bovenlaag. Eeuwenlang leefde men hier onder de druk van feodale rechten. Een en ander kwam ook wel tot uiting in de houding van de Achterhoekse plattelandsbevolking gedurende de April-Meidagen. Er werd hier en daar gestaakt, fel gestaakt zelfs, maar in de meeste gevallen waren het slechts kleine groepjes, die weerstand boden. Voor zover de melkleveranties werden stopgezet, gebeurde dit slechts gedurende een of twee dagen. De meeste zuivelfabrieken werkten door.

De stakingsgolf ging ook langs vele rustige provincieplaatsen heen. Te Doesburg b.v. viel geen enkel incident voor. In sommige dorpen bleef de protestactie beperkt tot de sluiting van enige winkels gedurende enkele uren (Lochem, Vorden, Ruurlo, enz.). Bij navraag bleken de herinneringen reeds te zijn vervaagd, maar vrij algemeen luidde het antwoord, dat de een zich achter de ander verschool en dat de algemene houding slap was - ook in kerkelijk-orthodoxe kringen. Bij uitzondering, o.a. te Didam, liet de plattelandsbevolking zich van een principiëlere zijde kennen.

Toch waren er wel enige brandpunten van verzet: verschillende kleine industrieplaatsen, waar de concentratie van arbeiders een zodanige omvang had bereikt, dat mogelijkheden voor een massale actie aanwezig bleken. Waren het "vreemdelingen", die daarbij het initiatief namen? Of mogen we in het afwijkend gedrag van de grotendeels van het platteland afkomstige industriearbeiders het bewijs zien van de invloed, die werk en omgeving op het sociaal gedrag kunnen uitoefenen? Ik ben geneigd laatstgenoemde mogelijkheid als

1) G. J. Klokman, in P. J. Meertens en Anne de Vries, De Nederlandse Volkskarakters, 1938, blz. 132. 
de beslissende factor te beschouwen. Industriearbeid leidt tot groepsvorming, een wennen aan discipline, maar tevens tot een verhoogde emotionaliteit in dagen van spanning en strijd.

Berichten over de stakingen in Twente waren in de fabrieken in de Achterhoek niet alleen eerder bekend dan op het platteland, ze maakten ook meer indruk en prikkelden tot navolging. Het eerste bedrijf, waarin de arbeiders een demonstratieve houding van verzet aannamen, was in de Achterhoek de ijzergieterij van de firma Diepenbrock \& Reigers te LIfft bij Zevenaar. Het personeel (omstreeks 600 man) verliet Donderdagmiddag 29 April, een kwartier voor het einde van de normale werktijd, de fabriek. Onder pressie van de Duitse politie en van de directie werd het werk echter reeds de volgende dag hervat.

De fabrieksbevolking van Winterswijk, Aalten, Lichtenvoorde, Zevenaar, Neede en Eibergen liet zich minder gauw intimideren. In alle genoemde plaatsen werd Vrijdag het werk neergelegd, in de meeste gevallen na overleg, welke houding men zou innemen t.a.v. het Twentse voorbeeld. Te Winterswijk begon de staking in de bontweverij "De Batavier", waar het personeel Vrijdagsochtends gewone tijd (half acht) op het werk verscheen, doch daarna na kortstondig overleg de fabriek verliet. De staking breidde zich spoedig uit tot andere bedrijven. Ook het overheidspersoneel (distributiedienst, gemeentewerken, gas- en waterleidingbedrijven) ging in staking (alleen Vrijdagmiddag). Te Neede, dicht bij de grens van Overijsel, staakten de textielfabrieken van N.V. v/h A. J. ten Hoopen \& Zn. en Ter Weeme \& Zonen N.V. Ook in de omgeving van dit dorp werd met meer volharding en heftigheid gestaakt dan in vele andere plaatsen. Met uitzondering van Eibergen, dat zich eveneens naar Twente richtte en bijna het beeld van een algemene staking toonde (staking van de Lederwaren- en kettingkastenfabriek, de Stoomzuivelfabriek „Eibergen", de Eibergse Stoomblekerij, met haar groot personeel van 350 personen, N.V. Gebr. Prakke, alle gemeentediensten, enz.).

In het algemeen krijgt men de indruk, dat juist in de kleinere Achterhoekse fabrieken de directies getracht hebben, de stakers enigermate in het gareel te houden. Waar zij het vertrouwen van de arbeiders genoten, slaagden zij daarin wonderwel. Het kwam echter ook voor, dat de stakers er van overtuigd waren, dat staken door de directie werd gewaardeerd. Zo werden bij de N.V. Gimborn's Inktfabrieken te Zevenaar de loonzakjes Vrijdagochtend uitgereikt in plaats van Vrijdagmiddag, zoals gewoonte was. Bij Pannerden en andere dorpen langs de rivieren staakten vrijwel alle steenbakkerijen. Te Lichtenvoorde werd Vrijdagochtend nog gewerkt, maar kwamen de machines Vrijdagmiddag algemeen tot stilstand (Firma H. B. Sterenborg Schoenfabriek, Schoenfabriek Gelria, Lederfabriek $\mathrm{Fa}$ Boschker, Leder- en metaalwarenfabriek Hulshof, N.V. Herwalts Tassenfabriek, Confectiefabriek Fa Westerman). De staking verliep er na een dag, waarbij zich een zekere neerslachtigheid van de bevolking meester maakte naar aanleiding van het niet-staken der spoor wegen. Te Terborg werd het werk neergelegd in een ijzergieterij en in een 
emaillefabriek. Te Aalten staakten de gasfabriek, het personeel van gemeentewerken en de arbeiders van enige grote bedrijven (Textiel Mij N.V. v/h Gebr. Driessen, de N.V. Dutch Button Works, N.V. Herm. Driessen). Ook hier gingen de meeste arbeiders Zaterdagmorgen weer aan het werk, toen was gebleken, dat de treinen bleven rijden.

Tenslotte nog enkele gegevens over Zutphen, dat in gedrag meer overeenstemming toonde met plaatsen als Doesburg, Doetinchem of Lochem, dan met de industriële randdorpen Aalten, Lichtenvoorde, Zevenaar, Eibergen, Neede, enz. De Zutphense bevolking was uiteraard op de hoogte van de gebeurtenissen in Twente, doch kwam langzaam in beweging. Van een felle spontane activiteit was geen sprake. Aarzelend begonnen Vrijdagmiddag de eerste stakingen (personeel van de Gemeente Gasfabriek, Ind. Mij „Zutphen”, H. J. Reesink \& Co N.V., Fa Wöhrman, Spruyt \& Co). Ook in dit geval sloegen de Duitsers niet toe op het punt, waar de stakingen het hevigst waren. $Z_{i j}$ wisten, dat zij meer bereikten met intimidatie van degenen, die niet al te vast in hun schoenen stonden. Zo beperkten zij zich in de Achterhoek tot een eenzijdig op Zutphen gerichte actie: een dertigtal personen uit verschillende bedrijven werd naar Vught gezonden. Zaterdag was de rust hersteld. Maandag viel in de gehele Achterhoek geen verzet meer te bespeuren.

In het Gelderse rivierengebied vertonen de gebeurtenissen in de April-Meidagen nogal variatie. Hier zien wij geen duidelijk verschil tussen de houding van stedelingen en plattelanders. Opvallend was de kalmte van de Nijmegenaren, terwijl soms juist in kleine dorpen in het land van Maas en Waal een krachtige neiging tot tegenstand tot uiting kwam.

Te Nijmegen bleef de stakingsbeweging zo beperkt, dat men slechts met moeite de namen van enige bedrijven kan opsporen, waarvan het personeel een halve dag thuisbleef (180 man van de Stijfselfabriek „Hollandia" en 90 man van de papierfabriek "Gelderland"). Van gevoel voor humor getuigt een geslaagde grap van het personeel van het Sportfondsenbad, dat Vrijdagmiddag deserteerde na alle maatregelen te hebben getroffen, het grote bassin te laten leeglopen. Het water zakte snel, terwijl Duitse militairen aan het baden waren! Men kan zich de woede van de Feldwebels in zwembroek voorstellen.

In de omgeving van Nijmegen werd heel wat resoluter gestaakt. Te Millingen staakten de N.V. Scheepswerven v/h H. H. Bodewes en de Gloeilampenfabriek Gebr. van der Velden. Te Lubbergen lagen de terreinen van een drietal steenfabrieken enige dagen verlaten. Hier en daar reageerde men - in overeenstemming met de Betuwse volksaard - vrij langzaam, b.v. in een aantal steenfabrieken, waar de arbeiders eerst 3 Mei van hun werk wegbleven.

Vraagt men zich af, of men in het riviergebied van de uitgestrekte provincie Gelderland inderdaad anders reageerde dan in de Achterhoek of op de Veluwe, dan aarzelt men om tot enige conclusie te komen. Men verlieze niet uit het oog, dat voor het gehele Gelderse gebied als kenmerken van de platte- 
landsbevolking traagheid en individualisme worden genoemd. In welk opzicht verschilt het Betuwse streekkarakter dan van andere streekkarakters? Volgens Lautermans zou in de Betuwe een sterke nawerking van het katholicisme te bespeuren zijn, ook in de protestantse gedeelten van het gebied 1). Men laat zich gaarne leiden, men aanvaardt autoriteit.

In de geschiedenis van de April-Mei-stakingen komt dit, wat de Betuwe betreft, inderdaad tot uitdrukking in de leiding, die in vele dorpen uitging van predikanten en Rooms-katholieke geestelijken. Hier en daar, b.v. te Tiel, waren kernen van de voormalige vakbeweging zeer actief. Maar in het algemeen bleef de bevolking vrij rustig en bedachtzaam. Van ,spontaan" handelen was slechts in beperkte mate sprake. Men werkte liever achter de schermen. Van het staken werd weinig ophef gemaakt en toen men een dag later de treinen zag rijden en berichten binnenkwamen over de passieve houding van de stadsbevolking in Noord- en Zuid-Holland, ging men weer aan het werk op grond van de verstandelijke overweging, dat verder staken weinig zin had.

Er waren uitzonderingen, die de regel bevestigden. Zo heerste er een felle geest van verzet in het Land van Maas en Waal (dat ook in andere opzichten eigen trekken vertoont), o.a. in de dorpen Wamel en Leeuwen. Vrijdagmiddag 30 April begonnen stakingen in de talrijke kleine industrieën, gevestigd in de gemeente Beneden-Leeuwen: vier meubelfabrieken, de meelfabriek van de $\mathrm{Fa}$. van der Zande, twee scheepswerven, een zuivelfabriek en een mandenfabriek.

Zaterdag 1 Mei plakten de werkgevers van genoemde bedrijven proclamaties aan, waarin de arbeiders geraden werd, zo spoedig mogelijk aan het werk te gaan. De politie waarschuwde ook de boeren, dat zij verstandig zouden doen, de melkleveranties te hervatten. Alle aanmaningen en het standrecht ten spijt, bleek de stakingsactie Maandagmorgen nog weinig te zijn geluwd. De Duitse politie, die hiervan lucht had gekregen, stuurde een detachement uit Tiel. Aan de door de Duitsers gestelde eis, dat Maandag iedereen om twee uur 's middags aan het werk zou zijn, werd voldaan. Inmiddels was in de gehele provincie de rust hersteld, maar voor de Duitsers kon dit geen motief zijn ook hier en daar bloedige wraak achterwege te laten. In dit geval moesten Wamel en Leeuwen het ontgelden. Na een groot aantal arrestaties vond Dinsdag 4 Mei een zitting van het Standgericht plaats met het resultaat dat vijf arbeiders ter dood werden veroordeeld, een vijftal zou 15 jaar tuchthuisstraf moeten ondergaan, terwijl de fabrieksdirecteur, een fabrieksboekhouder en elf arbeiders naar een strafwerkkamp werden overgebracht. $Z_{i j}$, die in deze affaire het leven lieten, waren J. Walraven, L. H. Hendriks en C. van Emmerloot uit Beneden-Leeuwen, A. Wijman uit Wamel en G. van Kampen uit Boven-Leeuwen. Helaas vielen ook de vijf arbeiders die tot 15 jaar tuchthuisstraf werden veroordeeld ten prooi aan de Duitse wreedheid: twee van hen (W. Fijnagel en $\mathrm{H}$. de Kok) stierven in een concentratiekamp; van de

1) K. Lautermans: De Betuwenaars in: P. J. Meertens en Anne de Vries, De Nederlandse Volkskarakters, 1938, biz. 151. 
drie anderen, die naar Duitsland werden gevoerd, heeft niemand meer iets vernomen.

In het naburige Druten, waar de arbeiders van de N.V. Scheepswerf Janssen en van de N.V. Steenfabriek Terwindt eveneens drie-en-een-halve dag staakten - ook de ,melkstaking" was er zeer algemeen - is ieder Maandagochtend haastig aan het werk gegaan, zodra men iets vernam van het drama, dat zich in het nabije Leeuwen afspeelde.

Vrij belangrijk was de stakingsbeweging te Tiel, dat in die critieke dagen meer invloed op zijn omgeving heeft uitgeoefend dan Nijmegen. Het was Vrijdag 30 April al vroeg rumoerig in de stad. De nerveuze stemming nam toe door vermindering van druk op de waterleiding, hetgeen door velen aan staking van het personeel werd toegeschreven. Ieder wachtte op een sein het werk neer te leggen. Twee vertrouwensmannen van de Kon. Metaalwarenfabriek $v / h$ Daalderop $\& \mathrm{Zn}$ gingen in het middagschaftuur de stad door, hier en daar een wenk gevend, dat men van plan was te staken. Zo deed het gerucht "Daalderop staakt" de ronde. Korte tijd later waren de meeste fabrieken en werkplaatsen verlaten (o.a. de N.V. Maatschappij „De Betuwe” 550 personen). Zelfs het personeel van verschillende overheidsdiensten (belastingkantoren en een gedeelte van de ambtenaren van het distributiebureau) legde het werk neer. Van de winkels sloten slechts enkele. Zaterdagochtend maakte zich een grote teleurstelling van de bevolking meester, toen men merkte dat de treinenloop op de gewone manier voortgang vond. De ambtenaren togen weer aan de arbeid, maar de fabrieken bleven leeg.

De afkondiging van het standrecht veroorzaakte verdere aarzeling. Zaterdagmiddag vergaderden fabrikanten met $B$. en $W$., 's avonds verscheen een Sonderkommando van de SS uit Arnhem en begonnen de arrestaties. Het verzet was toen feitelijk reeds gebroken. 's Zondags lieten de fabrikanten hun personeel zoveel mogelijk aanzeggen, Maandag weer aan het werk te gaan. De waarschuwing was overbodig: men was voldoende geïntimideerd, nadat zestien arbeiders naar Vught waren gezonden en twee andere door het Standgericht te Arnhem ter dood waren veroordeeld ( $T$. Campagne en $D$. van Zetten). Maar de verzetsgeest leefde op. Evenals elders had men de mogelijkheden van een massaal verzet leren overzien.

Te Geldermalsen werd een halve dag gestaakt door het personeel $( \pm 460$ man) van de N.V. Chamotte-Unie. Ook naburige steenfabrieken staakten enige uren - sommige anderhalve dag - maar men kan toch niet zeggen, dat de stakingsbeweging in dit gedeelte van de Neder-Betuwe van algemene aard was. Ook te Zalt-Bommel werd aarzelend gestaakt (o.a. N.V. Van de Garde \& Co's Drukkerij en van N.V. Meyers Scheepswerf). Iets krachtiger bleek het verzet te Culemborg. De fabrieken liepen Vrijdagsmiddags leeg (N.V. Gispen, met 180 man personeel en N.V. Mosterdfabriek W. A. Spoor met 35 man personeel), doch na enige arrestaties, Zaterdagnacht, dacht men er niet aan, verder tegenstand te bieden.

Korte stakingen werden gemeld uit Elst (gemeentepersoneel en het personeel 
van Taminiau's Jamfabriek - enkele uren, Vrijdagmorgen) en uit een aantal dorpen, waar steenfabrieken waren gevestigd. Voegt men hierbij nog de "melkstaking", die in alle schakeringen voorkwam, dan kan men zich voorstellen, hoe moeilijk het valt, uit de veelheid van gegevens tot een algemeen overzicht te komen. Hier en daar - b.v. in de gemeente Dodewaard staakte men in enkele bedrijven zonder de fabrieken te verlaten. Er zijn gevallen bekend van een tot Woensdag voortdurende boerenstaking (Beusichem). In de Tielerwaard, b.v. te Herwijnen, kwam het tot samenscholingen van de opgewonden bevolking. Uit sommige dorpen (Ammerzoden, Dreumel) wordt een afzijdige houding van de geestelijkheid gemeld, terwijl in andere plaatsen de kerkelijke vertegenwoordigers weer door een veel actievere houding opvielen. In de omgeving van Arnhem, b.v. te Huissen, waar veel fabrieksarbeiders wonen, die gewoonlijk in de A.K.U.-fabrieken werken, was de stakingsbeweging uiteraard geheel afhankelijk van de gang van zaken in de grote stad.

Maandag 3 Mei deden zich in de Betuwe geen ongeregeldheden meer voor. Maar de korte stakingsepisode liet een spoor na van wrok en verbittering. Men had het gevoel, een voorlopige krachtmeting achter de rug te hebben. Vele krachtige en kordate figuren waren naar voren gekomen, van anderen was de karakterzwakheid bewezen. Zo hadden de gebeurtenissen als een zeef gewerkt. Het tijdperk der illegaliteit was ook voor Gelderland aangebroken. 


\section{HOOFDSTUK III}

\section{DRENTE}

In de Drentse steden en dorpen heeft de staking een uiterst gevarieerd beeld vertoond, waarin men niet gemakkelijk algemene lijnen kan ontwaren. Mijn eerste onderzoek was gericht op de vraag, in hoeverre in ,het Oude Land", in de traditionele sfeer van de ten dele reeds ontbonden Drentse dorpsgemeenschappen, een krachtige solidariteit tot uiting kwam. De vraag op zichzelf zou reeds tot een te schematische beschouwingswijze aanleiding kunnen geven, indien men zich niet van begin af voor ogen hield, dat op het streekkarakter van alle kanten inbreuk wordt gemaakt door migratie en kolonisatie. Doch met dergelijke constateringen ,verklaren" wij weinig. Slechts een diepgaand onderzoek naar de sociale geschiedenis van ieder dorp afzonderlijk zou iedere locale situatie kunnen verduidelijken - met alle speelruimte, die wij moeten laten aan de "toevallige" factor van de geestkracht en vrijheidszin van enkele onafhankelijke figuren.

$\mathrm{Nu}$ is wel gebleken, dat de neiging tot individueel verzet, de krachtigste stimulans voor de ontwakende illegale beweging, zich het duidelijkst openbaarde in de betrekkelijk jonge bevolking van de veengebieden, vooral langs de Zuidelijke rand van de provincie, waar zich bovendien nog een sterk calvinistische inslag vertoonde. Een figuur als Johannes Post - in ruime kring bekend geworden door zijn door Anne de Vries geschreven "levensroman" stond niet alleen. Hij vertegenwoordigde een groep, waarin zich de pioniersgeest van de jonge veenkoloniale bevolking (van zeer verschillende herkomst) verbond met een religieus en emotioneel gekleurde vaderlandsliefde. Hier en daar kwam ook Noordelijker op de zandgronden illegale groepsvorming voor (te Pesse in de buurt van Eursinge bijvoorbeeld), doch veel meer als uitzondering en dan nog meestal van van buitenaf binnengekomen personen.

In de meeste oude Drentse dorpen was men gewend aan collectieve reacties. Er werd soms gestaakt zonder veel persoonlijk élan, eigenlijk meer omdat "iedereen het deed" en soms ook op aanraden van een of andere dorpsleider, van wien men de adviezen gewoonlijk volgde. Het was bijvoorbeeld niet gemakkelijk, in sommige oude dorpen onderduikers onder te brengen: de burenrelaties waren er te hecht, de beslotenheid van het gezinsverband kende men er te weinig, en wanneer men dan ook nog verraad te duchten had van een aantal dorps-NSB-ers, bestond er niet veel animo om voor onderduikers 
te zorgen. In de "nieuwe dorpen" (als voorbeeld noem ik Hooghalen in tegenstelling met het naburige Hijken) was het onderbrengen van een onderduiker meer een beslissing, die ieder individueel had te nemen en die men voor buren verborgen kon houden.

De neiging tot illegaal verzet en de bereidwilligheid om hulp te verlenen aan onderduikers houdt echter generlei rechtstreeks verband met de stakingsactiviteit in de April-Meidagen. Veeleer zag men menigmaal, dat de voorstanders van het individueel verzet het minst geestdriftig waren voor een massaal verzet, dat weinig uitzicht op succes bood, terwijl vrij slappe en weinig principiële dorpsgroepen soms direct te vinden waren voor een gemeenschappelijk demonstratief optreden.

Het meest kleurloos en aarzelend was het gedrag van de bevolking in de grote plaatsen zonder hecht groepsverband: vooral te Assen, Hoogeveen en Emmen. Daar tegenover staat, dat Meppel fel staakte. Dit zou m.i. zijn toe te schrijven aan het feit dat Meppel krachtiger locale tradities kent dan de andere genoemde plaatsen en aan de politieke geschooldheid van vrij brede arbeidersgroepen.

Indien de informaties van de Duitse politie juist zijn, zou de eerste staking (van zeer beperkte omvang) in Drente in de vroege ochtenduren van Vrijdag 30 April 1943 zijn uitgebroken in de $W_{i j k}$, in een grensgemeente waar de invloed van de gebeurtenissen in Overijsel zich deed gelden. Onmiddellijk daarop werd echter een staking onder de veenarbeiders te Odoorn gemeld. Tegen het eind van de ochtend gaf het personeel van het postkantoor te Meppel het voorbeeld, dat spoedig in het hele stadje navolging vond. Uit naburige Overijselse plaatsen als Dedemsvaart, Gramsbergen, enz. drongen stakingsberichten door, die vooral in het Zuid-Drentse veengebied tussen Hoogeveen en Coevorden een grote opwinding veroorzaakten. Het staat ook vast, dat stakende arbeiders uit Overijsel fietsend rondtrokken om het stakings parool door te geven.

Zoals reeds werd opgemerkt, liet de veenkoloniale bevolking zich gemakkelijker in beweging brengen dan de dorpsbewoners van het centraal-Drentse diluviaal gebied 1). Volgens getuigenverklaringen uit Valthermond, Emmer Erfscheidenveen, Nieuw-Buinen, Schoonebeek en Zuidwolde reageerde de bevolking daar vrij snel. Arbeiders uit de veenderijen gingen naar huis, soms nadat locomobielen uit veenbedrijven een fluitsignaal hadden gegeven. Boeren bleven binnen en weigerden melk af te leveren aan naburige zuivelfabrieken. De staking bereikte eerst Zaterdag 1 Mei haar volle omvang en duurde in de meeste dorpen tot 3 of 4 Mei. De afkondiging van het standrecht geschiedde in de meest geïsoleerde dorpen eerst Zaterdagavond, toen iedereen toch al min of meer overtuigd was van de slechte vooruitzichten voor het verzet. Als een lopend vuurtje ging door heel Drente het bericht, dat de spoorwegen

1) „Over het algemeen kan worden vastgesteld, dat de bevolking in het veengebied spontaner is en sneller reageert, in gunstige of in ongunstige zin, dan die van het zandgedeelte", G. Th. Kempe en J. Vermaat, Criminaliteit in Drenthe, 1939, blz. 73. 
normaal functionneerden. Van betekenis was ook, dat juist enkele van de belangrijkste illegale groepen (Joh. Post e.a.) al gauw tot de overtuiging waren gekomen dat de staking geen kans op succes bood en dat men beter deed, de krachten voor later te sparen $\mathbf{1}$ ).

In ieder geval trok men nergens één lijn. Er bestond telefonisch contact tussen de verschillende gemeentesecretarieën, maar iedere centrale leiding ontbrak. Het duidelijkst waren de berichten uit Meppel, doch ook deze bleken telkens door de gebeurtenissen achterhaald. Uit de gegevens waarover wij beschikken, komt ook niet naar voren, dat er overleg plaats vond tussen de dorpspredikanten. $Z_{i j}$ namen in het algemeen een afwachtende houding aan, met uitzondering van een aantal gereformeerde voorgangers, die een actief aandeel hadden in de vorming van illegale kernen. Te Valthermond werden pamfletten verspreid, doch het valt thans niet meer na te gaan, wie daartoe het initiatief hadden genomen.

Op de plattelandsbevolking maakte vooral het sluiten van de zuivelfabrieken veel indruk. Drente bezit echter ook verspreide industriële bedrijven, b.v. een glasfabriek te Nieuw-Buinen, aardappelmeelfabrieken, enz. Ook het personeel van deze industrieën legde aanvankelijk bijna overal het werk neer, o.a. de 650 arbeiders van de N.V. Nieuw-Buiner Glasfabriek v/h Meursing \& Co. De mannen schoolden Zaterdag op straat samen. Enige gereformeerde en communistische groepen juichten de staking het meest toe en zullen er ook wel het meest toe hebben bijgedragen, dat het werk zelfs na afkondiging van het standrecht Maandagochtend 3 Mei niet ineens werd hervat.

In verschillende plaatsen verschenen Maandag 3 Mei Duitse overvalcommando's. Te Nieuw-Amsterdam kostte dit W. Emmens en K. Gorter het leven.

Te Coevorden beperkte het verzet zich tot een korte staking op 1 Mei van het personeel van de zuivelfabriek, van de aardappelmeelfabriek en van verschillende gemeente-instellingen (distributiedienst, gemeentesecretarie, enz.). Even weinig geprononceerd was de stakingsactiviteit te Emmen en Hoogeveen. Des te opvallender waren de gebeurtenissen te Meppel, waar het moment van het uitbreken van de staking nauwkeurig te bepalen valt.

Te Meppel, waar reeds Donderdagavond geruchten over de staking te Hengelo in omloop kwamen, heerste Vrijdagochtend een zenuwachtige stemming. Op het post- en telegraafkantoor ontving men bevestiging van de juistheid van een aantal alarmerende berichten. Enige leden van het personeel kwamen zich toen om tien uur's morgens bij de directeur van het postkantoor melden met het verzoek, het werk te mogen neerleggen. De directeur verzocht hun, nadere informatie uit andere plaatsen af te wachten, maar keurde toch goed, dat het postkantoor 's middags niet zou worden heropend. Zodra dit in de stad bekend werd, maakte zich een gevoel van solidariteit van de bevolking meester. Vrijdagmiddag werd het werk neergelegd in de fabrieken van Brocades-Stheeman (300 personen), bij de Coöperatieve Landbouwersbank en Handelsvereniging, bij de N.V. Rijwiel Industrie v/h F. en J. van

1) Anne de Vries, De levensroman van Johannes Post, z.j., blz. 144 e.v. 
Werven, maar eveneens bij de gemeentesecretarie en alle gemeentebedrijven. De kracht van de staking manifesteerde zich ook in een bijna algemene winkelsluiting. Een Duits bevel, dat de bevolking zich niet 's avonds na 8 uur op straat mocht vertonen, werd vele malen overtreden.

Zou Meppel inderdaad een haard van verzet worden? Spoedig bleek, dat de staking zou worden gebroken door de deprimerende zekerheid dat de spoorwegen in vol bedrijf bleven. Conducteurs van passerende treinen wisten trouwens mede te delen, dat Den Haag. Amsterdam en Utrecht zich niet bij de stakingsactie hadden aangesloten. $\mathrm{Na}$ dit teleurstellend bericht maakte zich van de Meppelse bevolking een aarzeling meester, die tot uiting kwam in besprekingen welke Vrijdagavond werden gehouden. Velen bepleitten een hervatting van de werkzaamheden op Zaterdagochterid, anderen verklaarden $z$ ich daar tegen. Het gevolg van dit verschil van inzicht was, dat de volgende dag niet veel meer van een algemene gedragslijn viel te bespeuren. In enkele bedrijven keerden het kantoorpersoneel en de arbeiders terug, evenwel zonder aan het werk te gaan. Slechts bij de overheidsbedrijven en -instellingen kon van een hervatting van werkzaamheden worden gesproken. Verder werden bijna alle winkels weer heropend. Bij Brocades-Stheeman bleek Zaterdag het personeel nog niet voltallig aanwezig; het bedrijf kwam eerst weer Maandag 3 Mei geheel op gang. De Duitse politie-autoriteiten schreven het verflauwen van de stakingsactie geheel toe aan de intimidatie, die zij door hun maatregelen en bekendmakingen hadden willen veroorzaken. $Z_{i j}$ waren tevreden over het resultaat en namen achteraf geen wraak door massale arrestaties; deze bleven echter niet achterwege in de onmiddellijke omgeving van Meppel, bijvoorbeeld te Nijeveen, waar de bevolking even spontaan het werk neerlegde als in Meppel zelf. Waarom de Duitsers te Nijeveen wèl streng optraden en daar een vijftiental personen in arrest stelden (van wie er vier naar Vught werden gezonden) is moeilijk te doorgronden.

Aarzelend en besluiteloos was de houding van de bevolking in het Noordelijk deel van de provincie, o.a. te Assen, Vries, Beilen, enz. Uit Assen vallen zelfs nog minder bijzonderheden te vermelden dan uit Hoogeveen en Emmen: een korte staking bij Van Gorcum $\mathcal{E}$ Co's Uitgeversbedrijf (stellig aangemoedigd door de directie). Hier en daar bleven enige arbeiders thuis, maar in het algemeen was de stemming in de provinciale hoofdstad merkwaardig passief. In de omgeving van Assen leverden de meeste boeren enkele dagen geen melk af, maar zowel de Coöp. Zuivelfabriek te Assen als de zuivelfabriek in het iets Noordelijker gelegen Vries bleven bereid, de aangevoerde melk te verwerken. Wel staakte te Vries het personeel van de gemeentesecretarie.

Krachtiger stakingsactiviteit kwam tot uiting te Eelde en omgeving, bij "de Drentse Punt" en vooral te Zuidlaren, waar het personeel van de gemeentesecretarie het stakingssein gaf door Vrijdagochtend de blinden van het gemeentehuis te sluiten. Toen sloten ook vele winkeliers hun winkels. Eerst Maandagmiddag 3 Mei was te Zuidlaren de rust hersteld. 
De handhaving van de door de Duitsers geëiste rust in een aantal NoordDrentse gemeenten laat geen enkele conclusie toe omtrent het individueel verzet, dat ook in deze buurt geregeld veld won en dat steeds meer overging in illegale kernvorming. Zeker is, dat ook in de "kalme" plaatsen als Assen en Hoogeveen een bereidheid tot illegale actie werd gevonden, die zich o.a. uitte in een neiging tot daden van sabotage. Zo werden op 2 en 3 Juni 1943 aanslagen op Duitse militaire treinen voorbereid in de omgeving van Assen (een betonblok op de rails, $1 \mathrm{~km}$ van het station Assen, en een lading springstof op een andere plek. Beide aanslagen werden door de railwacht ontdekt en verijdeld).

Ten Westen van de grote straatweg Assen-Groningen ligt een stuk oudDrente, waar dorpen als Roden, Peize en Norg de invloed ondergingen van het uitgebreide Friese stakingsgebied. Zo fel als aan gene zijde van de Friese grens staakte men er niet, maar men toonde zich wel solidair met de naburige Friese dorpen. In hoeverre hierbij de infiltratie van Friezen in deze streek invloed heeft uitgeoefend, valt moeilijk te bepalen.

Het signaal voor de staking in de Noord-West-hoek van Drente werd gegeven door de grote zuivelfabriek te Roden, welke voor het veehoudersbedrijf tot in wijde omtrek van het dorp van betekenis is. Nadat Vrijdag het ene gerucht na het andere de ronde deed, vond Vrijdagavond 10 uur een personeelsvergadering plaats in het schaftlokaal van de zuivelfabriek. Men besloot toen, de staking de volgende ochtend 10 uur te beginnen na verwerking van alle nog aanwezige melk. Dit werd het begin van een hardnekkige agrarische staking, waarin de middenstand niet voldoende solidariteit toonde met de stakende boeren en landarbeiders. Winkelsluiting kwam slechts bij uitzondering voor. Wel bleken enige melkrijders evenals verschillende smeden en andere ambachtslieden bereid tot staken.

De NSB-burgemeester van Roden (Bruininga) dreigde Zaterdagmorgen de $\mathrm{SD}$ te laten komen, indien het werk niet werd hervat. Intussen had de bevolking al gezien, dat de tram ook Zaterdagochtend bleef rijden, terwijl men zich afvroeg, of er nog radio-aanwijzingen uit Londen zouden komen. De afkondiging van het standrecht makte niet veel indruk, evenmin als de intimidatiepogingen van de burgemeester. Bedenkelijker was echter, dat de Duitse politie te Assen, van de toestand op de hoogte gebracht van NSB zijde, Zaterdagmiddag een overvalcommando naar Roden dirigeerde. $Z_{i j}$ begonnen de boekhouder van de Rodense zuivelfabriek te arresteren en trachtten hem te bewegen, namen van stakende arbeiders te noemen. Er vonden nog meer arrestaties plaats. Het personeel van de zuivelfabriek zwichtte voor het Duitse machtsvertoon en hervatte Maandag de werkzaamheden. De staking van boeren en landarbeiders hield echter aan, zodat de Duitsers besloten het standrecht met kracht toe te passen. $\mathrm{Nu}$ vielen er slachtoffers: de viehouder J. Postema te Roden, S. van Bergen en H. Bakker, beiden uit het gehucht Steenbergen (Alteveer). Ingewijden zijn van mening dat de Duitsers H. Bakker te Groningen tevergeefs geprest hebben, nog enige namen te noemen; hij zou 
zich daarbij bijzonder moedig gedragen hebben, maar hij moest zijn weigering met de dood bekopen.

Zwakker dan het verzet in de Noord-West-hoek was de staking in een ander Drents randgebied: de streek bij Havelte. In deze buurt was de contrôle van de Duitsers vrij sterk, o.a. in verband met de aanleg van een vliegveld bij Havelte. Vrijdagmorgen 30 April staakten de meeste boeren in de omgeving van het dorp de levering van melk; de kantoorhouder van de P.T.T., die zijn bureau sloot, zag zijn voorbeeld gevolgd door het personeel van het distributiebureau en door enkele winkeliers. Maar de arbeiders van het vliegveld, die voor het grootste gedeelte in barakkenkampen leefden, werkten door. Dit op zichzelf reeds was voldoende om het stakingsélan te breken. Des te merkwaardiger dat de Duitsers het nog nodig vonden, de gemeentesecretaris en enige anderen (op $2 \mathrm{Mei}$ ook nog vier personen te Wapserveen) te arresteren. De gevangenen werden echter weer spoedig in vrijheid gesteld.

Te Vledder en in enige naburige gemeenten kwamen de zuivelfabrieken eveneens tot stilstand. In de meeste gevallen kon niet meer worden nagegaan, of het initiatief tot de ",melkstaking" uitging van het personeel van de zuivelfabrieken, van de melkrijders of van de boeren. Dit was de betrokkenen in die verwarde dagen dikwijls zelf niet duidelijk. Daarom kan ook niet veel waarde worden gehecht aan getuigenverklaringen achteraf. De spontane reactie op het besluit van Generaal Christiansen was bijna overal de neiging om door een of andere demonstratieve houding blijk te geven van reeds lang opgekropte ontevredenheid. Het meest geprikkeld toonden zich uiteraard degenen, die als oud-militairen voor hernieuwde krijgsgevangenschap in aanmerking kwamen. Geruchten over daden van verzet in alle delen van het land gingen als een lopend vuurtje rond. De stemming was Vrijdagochtend het meest agressief; Zaterdag was bij velen de stakingslust al wat bekoeld, vooral toen wel duidelijk werd, dat niet van een nationale staking kon worden gesproken. Ook het uitblijven van duidelijke aanwijzingen uit Londen gaf een gevoel van matheid.

Wij mogen echter niet te veel generaliseren. Het merkwaardige van de April-Mei-stakingen is juist, dat $z \mathrm{ij}$ zo sterk varieerden in het moment van uitbreken, in duur en intensiteit van het verzet, zelfs in streken waar men in verband met de volksaard en sociaal-economische omstandigheden een zekere gelijkheid van reageren had mogen verwachten. - De stakingen in de oudDrentse dorpen in het driehoeks-plateau, dat het middengedeelte van de provincie beslaat (met inbegrip van de Oostelijke rand van de diluviale verhoging, de Hondsrug) geven hiervan interessante voorbeelden te zien.

In het begin van dit hoofdstuk werd reeds aandacht geschonken aan de invloed, die de Drentse volksaard - welke men vanzelfsprekend het duidelijkst waarneemt in de dorpen van het "Oude Land" - op het verzet kan hebben uitgeoefend.

Volgens Van der Kley ${ }^{1}$ ) wordt de Drent gekenmerkt door een neiging,

1) K. van der Kley, Het Drentse volkskatakter, z.j. 
zich naar groepsnormen te schikken zonder de eigen individualiteit prijs te geven. Hij is traditionalistisch, zuinig en bescheiden, wat bedachtzaam en aarzelend, uiterlijk onaandoenlijk, maar toch fijngevoelig. Daarbij komt een sterk gevoel voor recht en billijkheid. Goede kenners van het Drentse volks karakter wijzen ook nog op een lichte inslag van achterbaksheid, die tot uiting kan komen in wat geheimzinnig bedreven daden van wraakoefeningen, welke men niet moet verwarren met de hier-en-daar nog voortlevende neiging om zich door middel van een volksgericht te wreken op ieder, die de groepsnormen van de dorpsgemeenschap durft breken. Wij mogen echter niet uit het oog verliezen, dat de Drentse dorpsgemeenschappen nergens intact zijn gebleven. Het binnendringen van vreemde elementen, o.a. bouwboeren uit Friesland of uit Overijsel, de komst van vreemde arbeiders en middenstanders, verscherpte geloofstegenstellingen en een versterkt contact met de buitenwereld hebben de dorpsgemeenschappen doen afbrokkelen.

In het jongste verleden valt nog een oorzaak te noemen voor een nieuwe scheuring in de Drentse dorpsgemeenschap: de politieke tegenstellingen, die reeds in de jaren dertig ontstonden door de opkomst van de radicale agrarische beweging Landbouw en Maatschappij - in later jaren voor velen een voor portaal tot de NSB. Men hoede zich voor een voorbarig oordeel over de belangstelling, die talrijke kleine Drentse boeren voor de NSB koesterden. Gedurende de landbouwcrisis sedert 1930 bleef het inkomen van veel zwoegende boeren, onder de zware druk van de verantwoordelijkheid van het eigen bedrijfsbeheer, meestal beneden de uitkeringen die de werklozen in de steden genoten. De steunregeling voor de kleine boeren bracht slechts gedeeltelijk uitkomst; de verbittering bleef. Het program van Landbouw en Maatschappij bood vooruitzichten op een agrarische politiek met een veel sterker agrarischsociaal beleid dan de landbouw-crisispolitiek van de regering te zien gaf. En toen de NSB het agrarisch program van Landboutw en Maatschappij overnam, had zij daarmee in sommige Drentse dorpen het pleit reeds half gewonnen.

De positie van de groepjes NSB-boeren was in de Drentse dorpen zeer verschillend. Soms werden zij ontzien, soms buiten de dorpsgemeenschap geplaatst. Het kwam ook voor, dat een dorp, bijvoorbeeld Elp, a.h.w. in tweeën scheurde. Bij de stijgende verbittering in de laatste oorlogsjaren keerde zich de publieke opinie uiteraard steeds meer tegen degenen, die met de Duitsers heulden. In de stakingsdagen van April-Mei 1943 kon de haat aanleiding geven tot daden van geweld, die enigszins doen denken aan een toepassing van het oud-Drentse volksgericht. Meer dan elders in Nederland kwamen in Drente brandstichtingen voor. In de meeste agrarische stakingsgebieden was het tot stilstand komen van de zuivelfabrieken het teken voor de bevolking dat de staking was begonnen. In Drente maakte het echter nog meer indruk, dat hier en daar de nachtelijke hemel rood kleurde door het afbranden van NSB-boerderijen.

Zo werden in de nacht van 2 op 3 Mei te $E l p$ vijf boerderijen in brand gestoken; te Gieten werd dezelfde nacht eveneens de boerderij van een NSB-er 
in de as gelegd. Verder meldde men brandstichting in de turfstrooiselfabriek te Klazinaveen, een aantal heidebranden en nog andere daden van sabotage en geweld (het opendraaien van bruggen, vernieling van melkauto's enz.).

Waar de Duitse politie er in slaagde, de daders te arresteren, gebeurde dit meestal op aanwijzing van NSB-ers. Te Elp, waar de hevigste branden hadden gewoed, werd $\mathrm{H}$. Bos gefusilleerd. $\mathrm{Hij}$ was een van de vastberaden mannen, die er niet toe te bewegen was, namen van medeplichtigen te noemen. In geheel Drente arresteerden de Duitsers van Zaterdag tot Maandag 85 personen, van wie er 40 voor de bijzondere rechtbank te Groningen moesten verschijnen.

Intussen nam de stakingsbeweging in de oude Drentse dorpen Zaterdag 1 Mei snel toe. Toen men eenmaal collectief in beweging was gekomen hetgeen niet dan na enige aarzeling geschiedde - , bleek de dorpssolidariteit een factor in het volhouden van het verzet. Er is van Duitse zijde over geklaagd, dat door de gebrekkige verbindingen het standrecht in vele dorpen eerst Zaterdag in de loop van de dag kon worden afgekondigd.

Bijna overal staakte het personeel van de zuivelfabrieken, waarbij ook hier in het midden moet worden gelaten, of de zuivelfabrieken het initiatief tot staken namen dan wel tot stilstand kwamen door het ophouden van melkleveranties. De meeste bussen bleven rijden, van de winkeliers sloten slechts sommigen hun winkels. Uit de meeste plaatsen wordt gemeld, dat van kerkelijke leiding bij de stakingen geen sprake was. De boeren luisterden trouwens liever naar de adviezen van plaatselijke boerenleiders, voor zover deze niet tot de Landstand behoorden.

Te Sleen staakten de Coöp. Zuivelfabriek en de Coöp. Aardappelmeelfabriek, bij $Z$ weelo werd in de nacht van Vrijdag op Zaterdag de tramlijn opgebroken. In de meeste plaatsen kenmerkte de staking zich door de rustige solidariteit, waarmede het werk werd neergelegd en het ontbreken van iedere demonstratie (te Rolde b.v.). Het kon ook voorkomen, dat op raad van de vertrouwensman en leider van een dorpsgemeenschap van staking werd afgezien, zoals te Ruinen gebeurde (de dorpsleider was daar wel anti-Duits, maar miste iedere agressiviteit). Te Ruinen staakte zelfs de zuivelfabriek niet. Te Diever speelde zich ook weinig af, dat een vermelding waard is. Te Dwingelo waren de beide coöperatieve zuivelfabrieken enkele dagen gesloten, te Smilde twee zuivelfabrieken één dag. Uit Dinxperloo en Bovensmilde wordt gemeld, dat slechts enkele boeren geen melk afleverden en dat de landarbeiders gewoon doorwerkten. Pesse, in de buurt van Eursinge saboteerde daarentegen krachtig, voornamelijk onder invloed van een gereformeerde verzetsgroep. Systematisch, o.a. door het verspreiden van pamfletten, werd de bevolking tot staking aangemoedigd. Slachtoffers vielen hier eerst in de volgende jaren, toen het werk van de verzetsgroep zijn hoogtepunt bereikte. Een vastberaden karakter droeg de staking ook te Oosterhesselen.

Een meer bewogen beeld dan de centraal-Drentse dorpen gaven de plaatsen van het Hondsrug-gebied te zien. Te Annen (gemeente Anlo) trok men zich 
weinig aan van de vrij talrijke NSB rers, die in dit dorp woonden. Men hield er Vrijdagavond 30 April zelfs een bijeenkomst op de brink, die door ruim 100 personen werd bijgewoond. Het stakingsbesluit, dat toen werd genomen, ging gepaard met enige dreigementen aan het adres van ieder, die er zich niet aan zou houden. Hoofdzaak was natuurlijk ook hier de „melkstaking", het thuisblijven van landarbeiders en het sluiten van een aantal dorpszaken. Melkbussen, door NSB-boeren aan de kant van de weg gezet, werden Zaterdag door voorbijtrekkende stakers leeggestort.

Het Duitse politiecentrum Groningen was echter dicht bij: Zondag en Maandag vonden arrestaties plaats, waardoor de geest van verzet enigermate bekoelde. Intussen hadden de Duitsers gelegenheid gevonden, nog krachtiger in te grijpen in het naburige Eext, dat als het "Oranjedorp" bekend stond en dat door de NSB-ers zoveel mogelijk werd gemeden. Te Eext was Vrijdagmiddag een algemene staking uitgebroken, die reeds dadelijk een reactie van Duitse zijde uitlokte in de vorm van een ultimatum aan de directeur van de stakende Coöp. Zuivelfabriek „Eendracht”. Het personeel van de zuivelfabriek overwoog, Zaterdagochtend weer aan het werk te gaan, maar al gauw bleek, dat vrijwel geen enkele boer melk afleverde.

De afkondiging van het standrecht vond te Eext eerst Zaterdagavond plaats, doch scheen niet veel indruk te maken. Zondagmorgen bleef ieder zoveel mogelijk thuis. De Ned. Hervormde predikant trof in de kerk slechts een klein gehoor aan. Tijdens de dienst arriveerden Duitse politiemannen in het dorp; zij brachten een paar mitrailleurs in stelling en namen de allure aan alsof zij een zeer ernstige opstand moesten bedwingen. Het bleek, dat de Duitse autoriteiten heel verbolgen waren over het feit, dat de voorafgaande avond het brugdek van een brug in de buurt van Eext was opgebroken, kennelijk om het passeren van melkwagens te verhinderen. Stakende arbeiders en boeren waren er de vorige dag, na een opruiende rede van de bekende boer Lute Huizing, heengetrokken.

Toen de Duitsers de schuldigen niet konden vinden, richtten zij hun pressie Zondagmorgen speciaal tegen de directie van de zuivelfabriek. $Z \mathrm{ij}$ arresteerden enige bij de coöperatie aangesloten boeren en dreigden hen Maandag neer te schieten, indien de melkleveranties niet tijdig werden hervat. De volgende dag bleken de leden van de coöperatie te zwichten voor deze aandrang; $z$ ij zonden hun melk weer naar de fabriek, die de gehele dag onder zware Duitse bewaking bleef. De gearresteerden werden toen vrijgelaten. De Duitse politie bleef echter nasporingen doen naar degenen, die Zaterdag de brug tussen Eext en Eexterzandvoort hadden vernield. Ruim een week na de staking werden negen personen gearresteerd en weggevoerd. Twee van hen ( $R$. Kamping en G. Enting) zijn in een Duits concentratiekamp overleden. L. Huizing kwam zo verzwakt uit de gevangenschap terug, dat hij kort daarop overleed. De andere gearresteerden hebben enige maanden te Vught moeten doorbrengen, zonder daarvan ernstige gevolgen te ondervinden.

Te Nieuw-Buinen, waar men de 1ste Mei, evenals in het naburige Gieten, 
solidair het werk neerlegde, kwam een daad van grote individuele moed voor. Een jonge gereformeerde boer, Berend Trip, sprak Zaterdagavond, hoewel hem de afkondiging van het standrecht bekend was, de dorpelingen toe met de opwekking, passieve tegenstand te blijven bieden. Toen hij de volgende dag met enige anderen werd gearresteerd en voor het Standgericht te Gro ningen moest verschijnen, verklaarde hij, volkomen individueel te hebben gehandeld. De overige gearresteerden gingen naar zijn zeggen vrij uit. Het bleek bij het verhoor overduidelijk dat Trip had besloten, alle schuld op zich te nemen, omdat hij als ongehuwd man beter de gevolgen van zijn daad kon dragen dan zijn dorpsgenoten. In een Duits diensttelegram (zie Bijlage II 32) werd gesproken van een "fabelhafte persönliche Haltung", maar dit respect voor het slachtoffer weerhield de Duitse rechters niet, het doodvonnis uit te spreken. Hoofdzaak was, dat men weer enige vonnissen kon publiceren; het aantal schuldigen was op zichzelf bijzaak.

De overige gearresteerden uit Gieten en Nieuw-Buinen kwamen al gauw weer op vrije voeten, na betaling van een "gift" aan het Duitse Rode Kruis. Deze gebeurtenissen en een schietpartij op straat in het dorp Gieten, intimideerden de bevolking, zodat men Maandag zonder verdere tegenstand aan het werk ging.

Te Gasselte trokken directies en arbeiders van de verschillende plaatselijke bedrijven één lijn (zuivelfabriek, veevoederbedrijf en maalderij, aardappelmeel fabriek). Ook de winkels werden gesloten. Daarbij kwam een vrijwel algemene ",melkstaking". Ook hier zag men ",de jongens" van het dorp rondgaan om de boeren en de landarbeiders tot een solidaire houding op te wekken. De melkleverantie stagneerde er Maandag en Dinsdag nog. De 75 arbeiders van de aardappelmeelfabriek waren er Maandag eveneens nog niet van overtuigd dat het spel verloren was. Vooral enige groepjes gereformeerde en communistische arbeiders hadden gaarne gezien, dat nog langer tegenstand werd geboden. Na rijp beraad is men evenwel aarzelend naar de fabriek getogen.

Te Borger staakte het personeel van de zuivelfabriek des Zaterdags $1 \mathrm{Mei}$, doch zonder daarbij zoveel medewerking te ondervinden bij de bevolking als in enkele naburige gemeenten het geval was. Wij zien dit in Drente wel meer. Het lijkt me een niet al te gedurfde hypothese, wanneer men verband legt tussen de stakingsactiviteit in vele zuivelfabrieken en de bezetting van deze bedrijven door Fries personeel.

De Duitse politie beperkte zich te Borger tot enige patrouille-activiteit en het arresteren van de arts G. Oeseburg, die van anti-Duitse propaganda werd beschuldigd. Maandag werd de aanvoer van melk hervat en had het dorpsleven zijn gewone gang hernomen. In de gemeente Odoorn droeg de staking een algemener karakter dan te Borger. De veenarbeiders legden het werk neer na fluitsignalen van locomobielen, die in het veenbedrijf werden gebruikt. Dezelfde dag (1 Mei) stagneerde ook het bedrijf van de zuivelfabrieken. Hier en daar (o.a. te Valthermond) werden pamfletten verspreid. Te Exloo werden melkbussen van NSB-boeren leeggegooid. De Duitse politie verscheen toen 
met een overvalwagen, arresteerde enige personen en dreigde hen dood te schieten, indien de toevoer van melk Maandag nog te wensen zou overlaten. Dit dreigement hielp. Slechts de veenarbeiders toonden zich nog weerspannig; de meesten van hen gingen eerst Dinsdag 4 Mei naar hun werk terug. Alle gearresteerden (twee boerenzoons uit Exloo, twee veenarbeiders en een vervener uit Valthermond) werden weer daags na het eindigen van de staking vrijgelaten.

De Duitse politie meende te mogen rapporteren, dat de stakingsactie overal was mislukt. Zij zag niet, dat ook in Drente de plattelandsstakingen hun functie hadden vervuld in de voorgeschiedenis van het georganiseerd verzet. Ook in geïsoleerde dorpen was men er nu wel van overtuigd geraakt, dat niemand zich aan de Duitse greep kon onttrekken. De demonstraties van 30 April en 1 Mei droegen bij tot zuivering van de atmosfeer. Men wist, wat men te wachten had, en zag weer beter de grenzen van het bereikbare. De toenemende verbittering uitte zich in een krachtiger belangstelling voor illegale activiteit en in een verhoogde bereidwilligheid, onderduikers te herbergen. Juist het platteland, waar men in de stakingsdagen inzicht had gekregen in de mate van vastberadenheid van degenen, van wie men enige leiding verwachtte, leende zich uitstekend voor de stille en langdurige voorbereiding van het verzet, dat in de tweede helft van 1944 en in 1945 hoog zou opvlammen. 


\section{HOOFDSTUK IV}

\section{FRIESLAND}

In geen provincie is gedurende de laatste dagen van April 1943 de beroering zo sterk en zo algemeen geweest als in Friesland. Slechts hier is de staking inderdaad volkszaak geworden. Noch het massaal verzet van de Twentse of van de Zuid-Limburgse arbeiders, noch de stakingsactie in enkele Gelderse of Zuid-Hollandse steden zijn te vergelijken met de eensgezindheid, waarmede in Friesland alle standen en klassen, in de stad en op het platteland, 30 April 1943 één lijn trokken in een grootscheepse demonstratie tegen de bezettende macht.

Reeds meermalen wezen wij op het verband tussen het volks- of streekkarakter (soms de geestesgesteldheid van bepaalde beroepsgroepen) en de wijze, waarop men reageerde op de bekende proclamatie van Generaal Christiansen. Daarbij kwamen wij meestal tot de conclusie, dat een dergelijk verband in sommige gevallen wel te constateren viel, doch slechts in beperkte mate en bovendien nog met zoveel uitzonderingsverschijnselen, dat men de uitkomsten van het onderzoek slechts onder het nodige voorbehoud kan aanvaarden. Ja, men kan zelfs de vraag opwerpen, of het begrip streek- of volkskarakter in het moderne Nederland met zijn sterke sociale mobiliteit reeds niet te veel verbleekt is om nog van toepassing te zijn op streken, waar zich eeuwen lang een zekere volksaard openbaarde.

In het bijzonder voor Friesland wordt dikwijls betwijfeld, of in de beschrijving van "het Friese volkskarakter" niet te veel romantiserende tendenties zijn binnengeslopen. Vooral vanuit de Westers-rationele sfeer slaat men met wantrouwen het Friese nationalisme en de Friese taalstrijd gade en staat men afwijzend tegenover de opvatting van de Friezen, dat zij een eigen volk zouden vormen. Er hangt veel van af, wat men onder ,,volk" wil verstaan. Sociologisch beschouwd: „Onder volk verstaan wij een grote culturele groep, waarvan het traditioneel saamhorigheidsgevoel in de eerste plaats op historische lotsverbondenheid berust. In de meeste gevallen echter ook op taal en afstamming. "Volk" als groep behoort tot de levensgemeenschappen. Het vertoont alle kenmerken daarvan: duurzaamheid, normbesef en gevoel voor traditie, saamhorigheid, gevoelens van eigenwaarde - alle tezamen zich uitend in de drang, het groepsverband te handhaven" 1). De ervaring leert, dat een volk, dat een eigen staatsverband ontbeert, de neiging vertoont, een sterke nadruk

1) P. J. Bouman, Algemene Maatschappijleer, 1947, blz. 44. 
te leggen op de taalgemeenschap en zich een voorstelling te vormen van het groepskarakter, dat o.a. in die taalgemeenschap tot uiting komt.

$\mathrm{Er}$ is vooral van Friese zijde veel geschreven over het Friese volkskarakter, waarbij dan gewoonlijk onderscheid wordt gemaakt tussen Westelijk Friesland (klei- en weidegebied) en de Woudstreek. Volgens Heymans zou men de Friezen tot het emotionele, niet-actieve type (met sterk "secundaire functie") moeten rekenen. Door zijn sterke gevoeligheid en vertraagd reageren is de Friese mens een disharmonische persoonlijkheid ${ }^{1}$ ). Het is mogelijk, dat zijn bekende stijfkoppigheid gedeeltelijk als een afweerhouding tegen de innerlijke gevoeligheid moet worden beschouwd. Als verdere eigenschappen worden genoemd: eerzucht, hoogmoed en (of) fierheid, een drang tot zelfhandhaving; daarbij een neiging tot melancholie, vooral in de Westelijke bouwstreek ${ }^{2}$ ). De bewoners van de Woudstreek zijn levendiger en reageren sneller; volgens de Herenveense zenuwarts Dr Koek worden zij dan ook minder door zwaarmoedigheid geplaagd 3 ).

Vormen de talrijke beschrijvingen over het Friese volkskarakter min of meer hypothetische constructies of misschien zelfs wensdromen van een smalle bovenlaag van intellectuelen? De geschiedenis der April-Mei dagen geeft de proef op de som. Het Friese volk heeft in die critieke uren inderdaad zijn eigen aard getoond en bewezen, de grootste homogene volksgroep te zijn binnen het kader van de ruimere algemeen-Nederlandse volkseenheid. Het heeft gestaakt met een hartstocht en een onverzettelijkheid, die wij elders in het land wel op bepaalde punten aantreffen, doch nergens in een dergelijke imposante, een gehele provinciale bevolking omspannende saamhorigheid.

Het groeiend verzet had zich reeds eerder gemanifesteerd in een dikwijls brutale sabotage van allerlei Duitse maatregelen. Op veel plaatsen was de vorming van illegale kernen begonnen, eigenlijk reeds op vrij grote schaal sedert het najaar van 1941. In het Nationaal Comité tot Verzet genoten de Friese afgevaardigden de reputatie over ruimere ervaring te beschikken dan de meeste anderen. Desondanks bleef de illegale actie ook in Friesland nog beperkt tot enkelingen en werd de illegaliteit er even goed door de stakings beweging verrast als de Duitsers. Wel was het in de eerste maanden van 1943 te voorzien, dat het de een of andere dag tot een spontane uitbarsting zou kunnen komen. De spanning steeg, vooral onder de landbouwende bevolking. Men begon te begrijpen, dat Friesland, het land van de zuivel, als voedselreservoir werd ingeschakeld en steeds meer van zijn zuivelproducten aan Duitsland zou moeten afstaan. En nu wilde de bezettende macht, volgens de afkondiging, ook nog beslag leggen op de zonen van dit volk, juist bij het aanbreken van het drukke seizoen. Het vee kwam in de weide, de melk-

1) H. C. Koek, Het volkskarakter van de Friezen, 1946, blz. 13.

2) Zie o.a. J. P. Wiersma, De Friezen, in P. J. Meertens en Anne de Vries, De Nederlandse volkskarakters, 1938.

3) Dr Koek, t.a.p., blz. 14, schrijft: „In vier jaar werden door mij 99 gevallen van zwaarmoedigheid behandeld, hiervan waren 62 patiënten afkomstig van de Klei, 22 uit de Wouden, 9 uit de Stellingwerven en 6 patiënten buiten Friesland". 
productie nam toe en ook in de bouwstreek had men een drukke tijd voor de boeg. Doch zwaarder woog de principiële overweging, dat het bevel van Christiansen als een onrechtvaardig besluit werd gevoeld. Deze nieuwe Duitse maatregel sprak tot de fantasie van het volk. De broeierige stemming moest zich uiten in een betoging van verzet.

Enkele min of meer toevallige omstandigheden droegen er toe bij, dat het stakingsconsigne snel kon worden doorgegeven - vooral het neerleggen van het werk in een aantal grote bedrijven te Leeuwarden op Vrijdagmorgen 30 April, op marktdag, juist toen boeren, vrachtrijders enz., wijd en zijd uit de omgeving de stad binnenkwamen. In tal van plaatsen, ook in de provinciehoofdstad, had men Donderdagavond, dadelijk na het bekend worden van Christiansens proclamatie, al beraadslaagd. Hierbij kwamen uiteraard mannen van de illegaliteit het eerst in actie. Het staat in ieder geval wel vast dat enkelen van hen, o.a. K. Leijenaar, invloed hebben uitgeoefend op het personeel van enige grote fabrieken om de volgende ochtend thuis te blijven. Dat deed men niet. De arbeiders gingen Vrijdag wel naar hun werk, maar bleven voor de fabrieken staan om zich te beraden over hun houding. Het woord "staken" werd aan alle kanten uitgesproken; geruchten over stakingen in Twente enz. waren reeds bevestigd. Tussen acht en negen uur 's morgens begon de uittocht van fabrieksarbeiders uit een aantal centraal gelegen bedrijven: de Frico, de grote coöperatieve zuivelcentrale (personeelsbezetting 300 man), de Coöp. Condensfabriek Friesland (200 man), de Leeuwarder Papierwarenfabriek (200 man), enz.

De staking sloeg over van het ene bedrijf naar het andere; al gauw ook naar overheidsinstellingen en gemeentebedrijven, o.a. de N.V. Intercommunale Waterleiding (150 man) en het Provinciaal Electriciteitsbedrijf in Friesland (staking van 168 personen op het hoofdkantoor; het personeel van de centrale werkte door). Bij de Gemeentelijke Lichtbedrijven staakten des Vrijdags 90 personen van een personeel van $164 \mathrm{man}$. In de loop van de ochtend ging ook het personeel van de distributiedienst en van het postkantoor in staking; evenzo van de Alg. Friese Levensverzekeringsmaatschappij, van N.V. Koopmans Meelfabrieken, van de Coöp. Zuivelbank, van de N.V. Amsterdamse Bank en andere bankinstellingen.

De Duitse politie, welke onmiddellijk de hulp inriep van de resterende Nederlandse politie, kon niet meer tot effectieve maatregelen komen. Wèl werd de normale methode toegepast om pressie uit te oefenen op de directies der bedrijven, maar de staking was reeds te algemeen om de arbeiders binnen enkele uren naar de fabrieken te kunnen drijven. Slechts waar de staking aarzelend begon, bijvoorbeeld bij de Gemeentelijke Gasfabriek, vonden de Duitsers gelegenheid, de fabrieksterreinen te omsingelen.

Wij vermeldden reeds dat Vrijdag de 30ste April (Julianadag!) een marktdag was, met de gewone toevloed van veemarktbezoekers, zakenlieden, enz. Het maakte op het publiek, dat van buitenaf binnenstroomde, een diepe indruk, toen $z \mathrm{ij}$ de arbeiders van de in de nabijheid van de veemarkt gelegen fabrieken 
(Frico, Leeuwarder Papierwarenfabriek) in dichte drommen zagen langstrekken. De meeste boeren bedachten zich niet lang en haastten zich naar huis. Zo ging het bericht van de staking te Leeuwarden door alle naburige gemeenten heen. Intussen waren, onafhankelijk van de hoofdstad, ook al stakingen in andere steden begonnen. Het gerucht ging, dat de spoorwegen nu ook wel spoedig zouden staken, doch dit bericht kon door de vertegenwoordigers van het illegaal verzet, die contact zochten met de centrale leiding van het Nationaal Comité tot Verzet, niet worden bevestigd.

Nog dezelfde dag begon het de illegale groepen, die van Leeuwarden uit cellen hadden gevormd in overheidsinstellingen en bedrijven in de gehele provincie, wel duidelijk te worden, dat de staking in een chaotische verwarring zou kunnen eindigen. Radio-Oranje zweeg nog en het meestaken van de spoorwegarbeiders bleek uiterst dubieus. De illegaliteit in Friesland meende dan ook te moeten adviseren, dat men zich het beste tot een kortstondig demonstratief verzet kon beperken, vooral toen Zaterdag duidelijk was geworden, dat men niet meer op de spoorwegen behoefde te rekenen. Men slaagde er vooral te Leeuwarden in, de stakers tot een gedisciplineerd beeindigen van hun actie te bewegen. In de overheidsbedrijven werd te Leeuwarden het werk reeds Zaterdagochtend vroeg hervat; in de fabrieken in het laatste gedeelte van de ochtend (de Frico b.v. werkte van half twaalf tot twaalf uur) om tegenover de Duitsers de schijn op te houden, dat men nog vóór de Zondag in de werkplaatsen was teruggekeerd.

Buiten Leeuwarden was men minder gemakkelijk tot rede te brengen. Iedere poging om de stakingsactie ,af te remmen" stuitte reeds dadelijk op het bezwaar, dat door de ontwrichting van het telefoonverkeer de verbinding met de contactpersonen in verschillende steden en dorpen veel te wensen overliet. Maar het bleek toch ook wel heel duidelijk, dat de illegale organisatie nog niet ver genoeg was gevorderd om een volksbeweging van enkele centrale punten uit met succes te kunnen leiden. Vooral in vele dorpen dreigde de bijna ontembare lust tot staken op een bloedbad uit te lopen. De wijze waarop men hier en daar het standrecht negeerde, veroorzaakte bij degenen, die zich verantwoordelijk voelden voor het Friese verzet, een angstige spanning.

De Friese volksaard manifesteerde zich in een ongeremd oplaaien van lang opgekropte haat. In geen enkele andere provincie vond zoveel geweld tegen werkwilligen plaats. Men hield melkrijders aan, draaide bruggen open, liet melkpramen zinken en saboteerde waar dit maar mogelijk was. Bij Leeuwarden was reeds in de nacht van 29 op 30 April een waterleidingbuis op de spoorrails gelegd, waardoor een 's morgens vroeg passerende trein derailleerde. Het bevel, dat ieder 's avonds na acht uur binnen moest zijn, werd aan alle kanten overtreden. Hier en daar werden scholen gesloten. Overal zag men mannen en jongens van het ene dorp naar het andere fietsen om verslag uit te brengen over de gang van zaken. Duitse patrouilles doorkruisten de provincie. De namen van de eerste gefusilleerden werden bekend gemaakt, geruchten over wilde schietpartijen en over een toenemend aantal 
slachtoffers vonden bevestiging. Maar nog wilde men vooral in sommige afgelegen dorpen van geen wijken weten. Waar de weerstand verslapte, leefde het verzet soms weer op door toedoen van de vrouwen. Berichten over het einde van de staking te Leeuwarden, de zekerheid dat in andere delen van het land eveneens niet meer werd gestaakt en de radio-mededelingen van de regering te Londen, met het advies, dat men zich voorlopig in de Duitse overheersing moest schikken, schenen op de felst-bewogen groepen geen indruk te maken.

Ondanks alle Duitse represailles leefde hier en daar het verzet Dinsdag 4 Mei weer op. Woensdag, toen men overal elders in Nederland weer aan het werk was, kon men in Friesland nog stakende dorpen aantreffen; tot Donderdag, zelfs tot Vrijdag toe, hield de tegenstand aan. Men wilde zich niet tot rede laten brengen. Het argument, dat het spel verloren was en dat men verstandig deed, zich in het onvermijdelijke te schikken, schenen velen niet te willen horen. Enkele predikanten, die op grond van het rationeel inzicht, dat verder staken als doelloos moest worden beschouwd, de gemeenteleden trachtten te kalmeren, haalden zich daardoor de woede van de dorpsgenoten op de hals. Hun kerkdiensten werden de daarop volgende Zondagen slecht bezocht.

Merkwaardig, hoe in de solidariteit van de Friese stakingsbeweging toch nog regionale verschillen tot uitdrukking kwamen! Het heftigst en het langdurigst is gestaakt in de Westelijke en Noord-Westelijke bouwstreek, zowel door boeren als door landarbeiders, in protestants-orthodoxe èn in socialistische kring. Enige dagen korter - voor zover het mogelijk is, tot de vage schatting van een gemiddelde te komen - duurde de tegenstand in het Westelijk en Zuidelijk weidegebied. Het kortstondigst langs de Zuidrand van de provincie, in het gebied tussen Lemmer en Stavoren. In de Woudstreek werd eveneens vrij emotioneel gestaakt, echter met minder volharding dan in de Noord-Westelijke bouwstreek. Wij laten nu bijzonderheden volgen over enige regionale aspecten van het Friese verzet.

In het gehele gebied ten Westen van Leeuwarden begon de staking reeds Vrijdagmorgen. Te Franeker werd door de NSB-burgemeester zware druk uitgeoefend op de stakers (Oostwoud-Fabrieken, Meubelfabriek Fristho, de Franeker Landbouwcoöperatie en het personeel van de distributiedienst). De winkels waren slechts gedeeltelijk gesloten. Het overheidspersoneel ging ten dele Zaterdag, ten dele Maandag weer aan het werk; de arbeiders uit de genoemde bedrijven keerden druppelsgewijze terug. Het werd Woensdag, eer van een normale toestand kon worden gesproken. Ook te Harlingen hield de staking (gemeentepersoneel, scheepswerf Welgelegen, enz.) drie, vier dagen aan, zonder dat zich bijzondere gebeurtenissen afspeelden.

Taai en vastberaden was het verzet in de landbouwgemeenten in de omgeving van Harlingen en Franeker, waar akkerbouw op de zeeklei hoofdmiddel van bestaan is. Men staakte er hier en daar tot Donderdag $6 \mathrm{Mei}$, zonder onderscheid tussen de gemeenten met een sterk socialistische inslag 
(Menaldumadeel) en de gemeenten met een overwegend protestants-orthodoxe bevolking (Wonseradeel, Barradeel). Enige arrestanten werden drie maanden naar Vught gezonden; twee andere gevangenen zijn in Duitsland beland en keerden niet meer terug. Verschil in reageren tussen bouwboeren en veehouders zou men mogen afleiden uit het feit dat men in het Zuiden van de gemeente Wonseradeel (weidegebied) enige dagen korter staakte dan in de Noordelijke akkerstreek in dezelfde gemeente. Het korter staken is mis schien verklaarbaar uit het feit, dat de stakende veehouders zich voor groter moeilijkheden zagen geplaatst dan hun collega's met een akkerbouwbedrijf. Bovendien werd op de veeboeren nogal pressie uitgeoefend om de melkleveranties naar de steden niet in gevaar te brengen.

In geen geval kan het korter staken in het Friese weidegebied aan een gebrek aan temperament worden toegeschreven. De ,melkstaking" heeft overal in den lande geleid tot het stopzetten van leveranties aan melkfabrieken en tot particuliere verkoop van de melk, die men op de boerderijen over had. In het Friese weidegebied werd echter meer melk geproduceerd dan door de particuliere consumptie kon worden opgenomen. Daar was de consequentie van de melkstaking inderdaad, dat grote hoeveelheden melk moesten worden vernietigd. Een Friese boer zal niet zonder veel innerlijke weerstand melk in de sloot laten wegvloeien. Maar in de April-Meidagen deed hij het en het kon zelfs voorkomen, dat hij zijn eigen melkwagens liet kantelen om langstrekkende Duitse patrouilles er van te overtuigen, dat hij zijn melk niet kon afleveren.

Een van de merkwaardigste stakingsgebieden in de provincie Friesland was de gemeente ' $t$ Bildt. Taalkundig en wat de afstamming van een gedeelte van de bevolking betreft (nakomelingen van Noord-Hollanders, die zich in de nieuwe polders vestigden) behoort het gebied weliswaar niet in ieder opzicht bij Friesland, maar in de karaktertrekken van de zeer emotionele dorpelingen zeker wel. Men had er reeds Donderdagavond overleg gepleegd over de mogelijkheid, Vrijdagochtend te gaan staken (samenkomst van enige honderden mannen op een viersprong in St. Annaparochie). Uit getuigenverklaringen blijkt, dat mannen uit St. Annaparochie Vrijdagochtend al voor dag en dauw opstonden en naar naburige dorpen fietsten om er het uitbreken van de staking te bespoedigen. $\mathrm{Z}_{\mathrm{ij}}$ trokken zich weinig aan van de bezetting van 40 man Duitse troepen, die in St. Annaparochie was gelegerd en zich weinig om de heersende onrust scheen te bekommeren. Het kostte geen moeite, de bevolking ongeacht de berichten uit Leeuwarden in beweging te brengen. Vrijdagmorgen vroeg was alles al in rep en roer. Autobussen voor marktbezoek in Leeuwarden werden tegengehouden en gedwongen terug te keren, winkels sloten, enkele werkwilligen haalde men van het land.

Al had St. Annaparochie het initiatief genomen, spoedig bleek dat St. Jacobaparochie het centrum van verzet zou worden. De landarbeiders namen hier de leiding en het leek er op, of enkele grote boeren meestaakten uit angst voor de landarbeiders, die vanouds geneigd waren de klassestrijdgedachte als 
uitgangspunt te nemen voor ieder conflict dat zich voordeed. Juist in de omgeving van St. Jacobaparochie heeft het socialisme van vele arbeiders sterk anarchistische trekken vertoond. Hier vond Domela Nieuwenhuis zijn trouwste volgelingen en telde het N.A.S. nof vele leden, toen men in de buurt van Vrouwen- en St. Annaparochie reeds lang toenadering had gezocht tot de S.D.A.P. Voor de landarbeiders van St. Jacobaparochie met hun syndicalistische tradities had het woord "staking" nog altijd iets van zijn oude aantrekkingskracht behouden: staken was een strijdmiddel, vooral van waarde voor politiek-revolutionnaire actie.

Men kan er zich achteraf over verbazen, dat de Beauftragte te Leeuwarden, Ross, niet strenger in 't Bildt is opgetreden. Er werd eerst Dinsdag ingegrepen. J. L. Hoogland, een bekend landbouwer te St. Annaparochie, werd als gijzelaar naar Leeuwarden gevoerd. De bevolking uit St. Jacobaparochie liet zich hierdoor niet uit het veld slaan en zond zelfs Dinsdagmiddag een aantal mannen naar Oude Bildtzijl om daar tot verder staken op te wekken. De burgemeester van 't Bildt begaf zich naar Leeuwarden om te trachten. Hoogland vrij te krijgen. Een SS-officier deelde hem toen mede, dat rancunemaatregelen achterwege zouden blijven, als de bevolking Vrijdag weer aan het werk ging. Men wilde echter van geen wijken weten. Terwijl de burgemeester, G. H. Kuperus, Donderdagmorgen in St. Jacobaparochie een opstandige mensenmenigte trachtte te overtuigen van de wenselijkheid, de arbeid te hervatten, reed een overvalwagen het dorp binnen. Het gevaar dreigde, dat dit overvalcommando, onkundig van de toezegging van de SS-officier te Leeuwarden, tot scherpe represaillemaatregelen zou overgaan. Gelukkig beperkte de bevelvoerende Hauptmann zich tot enkele arrestaties. Het verzet was daarmee gebroken. Kenmerkend voor de sociale psychologie van de syndicalistische arbeidersgroepen in St. Jacobaparochie was, dat zij na de staking sterker gedeprimeerd waren dan de arbeiders uit Vrouwen- en St. Annaparochie, die meer gewend waren aan politiek gedisciplineerd optreden en in het verdere verzet hun rol bleven spelen (te St. Jacobaparochie was men b.v. zó down, dat men enige weken later vrij algemeen radiotoestellen inleverde).

Men krijgt de indruk, dat in de Friese bouwstreek de invloed van het volkskarakter in de houding van verzet meer de doorslag gaf dan de geloofsbeginselen. Onkerkelijken, vrijzinnig-hervormden, hervormden en gereformeerden trokken één lijn. De enquêtevraag, of predikanten invloed hebben uitgeoefend op het uitbreken of het volhouden van de staking, werd zeer verschillend beantwoord. Vele getuigen zijn van mening, dat de kerken door de stakingsactie werden overrompeld en er geen leiding aan konden geven. $\mathrm{Nu}$ eens hoort men de lof verkondigen van een gereformeerde predikant, dan weer van een Ned.-hervormde of doopsgezinde voorganger. Een enkele keer (o.a. te Holwerd) wordt gerept van een "stakingspreek". In de regel bleven de predikanten echter liever ,ondergronds" bezig.

Hoe het ook zij; te Dokkum en omgeving hebben de orthodoxe groepen, die in deze buurt heel invloedrijk zijn, zich krachtig geweerd. Te Dokkum 
zelf begon de staking Vrijdagochtend, volgens sommigen "spontaan", volgens anderen op initiatief van een illegale kern. Het maakte indruk, dat het personeel van het post- en telegraafkantoor de loketten sloot. Winkeliers en arbeiders van de zuivelfabriek volgden dit voorbeeld nadat verschillende boeren in de buurt van Dokkum reeds hun arbeiders naar huis hadden gezonden. De afkondiging van het standrecht werd kalm opgenomen. Wel veroorzaakte het consternatie toen Duitse patrouilles 2 en 3 Mei meenden, zich aan het consigne te moeten houden, op "samenscholingen" van meer dan vijf personen te schieten. (Bij een dergelijke schietpartij in de buurt van een der Dokkumse bruggen werden G. Ronner en J. Zijlstra gedood. De zwaar gewonde H. Adema overleed enige dagen later).

In de omgeving van Dokkum liggen de gemeenten Dantumadeel, Ferwerderadeel, Kollumerland en Nieuw-Kruisland, Oostdongeradeel en Westdongetadeel. Eigenaardig is, dat in dit gehele gebied het sein tot staken meestal door de gemeentesecretarieën werd gegeven. Vooral ten Westen van Dokkum heerste een opgewonden stemming, die licht aanleiding kon geven tot daden van geweld. Zo werd op de spoorlijn Leeuwarden-Dokkum, bij Marrum, een goederenwagen dwars over de rails getrokken. De Marrumse kruidenier Frans van Dijk hield daarop, staande op de wagen, een redevoering, die eindigde met het verzoek, het Wilhelmus te zingen. Dit alles bleef de Duitsers niet verborgen. $Z_{i j}$ arresteerden na enige dagen genoemde $F$. van $D_{i j k}$ en drie onderwijzers, maar hebben deze gevangenen om onnaspeurlijke redenen toch weer vrijgelaten. De Duitse politie kwam meermalen informeren, hoe de toestand te Marrum was, waarop de burgemeester hun verzekerde, dat de toevoer van melk naar de zuivelfabriek reeds met $200 \%$ was gestegen (zonder er bij te zeggen, dat de aanvoer van enkele liters per dag feitelijk nihil was geweest). Met dit antwoord heeft men blijkbaar genoegen genomen.

In een aantal dorpen werden de scholen gesloten. Bij Ooster-Nijkerk had men bomen omgezaagd en over de rijweg gelegd. Voorts duldde men in deze streek niet, dat men ook maar één volle melkbus langs de kant van de weg plaatste. De NSB-burgemeester van Oostdongeradeel beantwoordde de daden van sabotage met het laten arresteren van twee jonge mannen, die in het gemeentehuis van Metslawier werden opgesloten. De bevolking liet zich hierdoor niet intimideren. Publicaties van de burgemeester werden afgescheurd en overplakt met papieren met de woorden: "Weest soldaat. Duitse gemeenheid. Volkomen onwettigheid. Leve de Koningin".

De burgemeester, geprikkeld door het verzet, gaf enige melkrijders, onder bedreiging met de doodstraf als zij weigerden, bevel te rijden — óók al zouden er geen melkbussen op te halen zijn. Dit werd hun echter belet door rondfietsende groepjes jonge mannen: zij lieten een wagen in de sloot kantelen. Enige melkwagens kregen toen politiegeleide, met het gevolg, dat het Maandagmorgen tot een treffen kwam nabij Wetzens. Een agent uit Metslawier kreeg bij deze vechtpartij een snee met een dolkmes over de vingers. De schuldige, K. de Vries, smidsknecht te Niawier, werd gearresteerd en na 
veroordeling tot tien jaar gevangenisstraf naar Duitsland overgebracht, waar hij in 1945 in een kamp overleed.

Maandagmorgen 3 Mei liepen stakende boeren en arbeiders te hoop voor het gemeentehuis te Metslawier om de in vrijheid stelling te eisen van de beide mannen uit Ooster-Nijkerk, die daar gevangen zaten. Tweemaal werd gepoogd de deuren van het gemeentehuis te forceren. De NSB-burgemeester Ykema gaf de politiemannen, die zich in het gemeentehuis hadden verschanst, bevel, door de deuren heen op de betogers te schieten. Het is mogelijk, dat de burgemeester zelf eveneens heeft geschoten. Er vielen enige gewonden. Intussen vernam men, dat een patrouille Duitse politie op weg was naar het dorp. Ieder zocht een goed heenkomen. Toen de Duitsers arriveerden, vonden $z e$ het dorp verlaten. $Z_{i j}$ kregen echter op het gemeentehuis de naam van één der gewonden te horen: D. Fokkens uit Niawier. Fokkens werd na zijn arrestatie naar Leeuwarden overgebracht, standrechtelijk veroordeeld en gefusilleerd. In de dorpen Metslawier en Niawier eindigde de staking Maandagmiddag, omdat men nog in de mening verkeerde, daardoor Fokkens te kunnen redden. Eerst dagen later vernam men, dat het vonnis reeds was voltrokken.

Fel was ook de staking in de gemeenten Kollumerland en Achtkarspelen langs de Fries Groningse grens. In deze streek kwamen vrij veel daden van sabotage en geweld voor: een aanslag op de spoorlijn Leeuwarden-Groningen (tussen Buitenpost en Visvliet), vernieling van melkwagens, enz. Te Surhuisterveen brandde het voedselbureau af en werd het begin van brand ontdekt in de woning van een Rijksduitser. Dit lokte verhoogde patrouilleactiviteit van de Duitsers uit, o.a. in de gemeente Smallingerland. Te Opeinde werd daarbij op Zondagmorgen, na het uitgaan van de kerk, een tienjarig kind getroffen. Over het bloedbad in de buurt van De Wilp, juist over de Friese grens, volgen bijzonderheden in het hoofdstuk over Groningen. Bij een wilde schietpartij in de buurt van Noord-Bergum werden twee fietsers in de rug geschoten ( $F$. Polet en J. Elzinga). Voorts kwam de groenteverkoper $\mathrm{Sj}$. Stel uit Buitenpost bij een schietpartij in een naburige gemeente om het leven.

Te Stroobos arresteerde de Duitse politie een aantal stakende boeren en landarbeiders. R. Terpstra, beschuldigd van het omgooien van melkbussen, werd naar het Scholtenshuis in Groningen gevoerd en gefusilleerd. Te Suameer schoten patrouillerende Duitsers een boer (F. Weima) op eigen erf neer, omdat hij had geweigerd, de verkoop van melk aan particulieren stop te zetten.

In het algemeen reageerde de bevolking van de Woudstreek heftig en spontaan. De stakingen hebben in het Oostelijk en Zuid-Oostelijk gedeelte van Friesland gemiddeld enige dagen korter geduurd dan in de Noord-Westhoek, doch het is de vraag, of men dit mag toeschrijven aan geringere volharding. Wij merkten reeds op, dat men in de gebieden met overwegend veeteelt bij het staken der melkleveranties aan de zuivelfabrieken eerder in moeilijkheden geraakte dan in de akkerbouwgemeenten. Ook krijgt men de indruk, dat de Duitse politie in Oostelijk Friesland actiever was dan elders 
en een ruim gebruik maakte van intimidatiemethoden, waarvan het bloedbad bij De Wilp wel het meest sprekende voorbeeld is.

Te Drachten, waar ook met grote eensgezindheid werd gestaakt, vooral de 30ste April, uitte de geest van verzet zich o.a. in een voortdurend ontduiken van het bevel, dat men 's avonds om acht uur binnen moest zijn. Een en ander gaf aanleiding tot een schietpartij, waarvan Mej. J. Dijkstra het slachtoffer werd. Men heeft te Drachten de staking overigens niet op de spits gedreven, omdat men in deze plaats een illegale kern had (een der leiders daarvan was L. Bosch, inspecteur van belastingen), die reeds Zaterdag in overleg met Leeuwarden het consigne gaf, met een demonstratie van enkele dagen genoegen te nemen. In een vergadering van vertrouwensmannen van een aantal bedrijven besloot men, Maandagochtend 3 Mei weer aan het werk te gaan.

Het is niet gemakkelijk, een overzicht te krijgen van de gebeurtenissen in de Stellingwerven en in de uitgestrekte gemeente Opsterland. Hier en daar bestonden vrij sterke illegale kernen, die leiding gaven aan de stakingsbeweging (te Wolvega b.v. de rustende gereformeerde boer J. Russchen), terwijl in veel andere plaatsen geen spoor van organisatie te bekennen viel. In het algemeen was in deze streken het verzet wel het sterkst in orthodoxprotestantse kringen, vooral bij de gereformeerden, die er door hun hecht groepsverband eerder toe kwamen, verschillende vormen van illegale activiteit te aanvaarden. Men mag deze constatering echter niet te veel generaliseren. Evenmin als het juist zou zijn, in de schoolstakingen altijd de hand te zien van christelijke onderwijzers; ook idealistische socialistische onderwijzers hebben in het sluiten van scholen een werkzaam aandeel gehad. Eén slachtoffer uit de groep van het onderwijzend personeel boette als martelaar voor allen: J. Eisenga uit Gorredijk. Hij behoort tot de helden, die ook onder de zwaarste Duitse intimidatie geen enkele naam van medeplichtigen heeft willen noemen.

In de buurt van Appelscha en Wolvega werden bruggen afgedraaid met het gevolg, dat het busverkeer gedeeltelijk tot stilstand kwam. Bij een wilde schietpartij te Munnekeburen kwam J. Smid om het leven, op dezelfde wijze vielen drie slachtoffers bij Appelscha (J. Kiewiet, M. Bruinsma, A. de Boer). Naarmate de teleurstelling over het blijven rijden van de treinen groter werd, toonde men zich Maandag en Dinsdag ( 3 en $4 \mathrm{Mei}$ ) meer bereid de werkzaamheden te hervatten. De ene zuivelfabriek na de andere werd heropend. De geest van het verzet bleef echter ongebroken. Alle waarnemers zijn het er over eens, dat het in de Stellingwerven wel bijzonder goed zichtbaar was, hoe de April-Mei-stakingen de tegenstand tegen de Duitse overheersing heeft doen toenemen. Het bergen van onderduikers ging vlotter, de bereidheid tot illegaal werk werd sterker.

In het laagveengebied tussen de Stellingwerven en de Friese meren concentreerde de stakingsbeweging zich uiteraard op de zuivelfabrieken. Nog sterker kwam het karakter van de ",melkstaking" tot uitdrukking in het gehele Westelijke en Zuid-Westelijke weidegebied. Men staakte er met meer élan dan in de uitlopers van de Woudstreek (te Heerenveen duurde de staking slechts 
twee dagen, korter dan in de weidegebieden in de omgeving van deze plaats, b.v. te Boven-Knijpe en Bontebok, waar de Duitsers een tiental personen arresteerden en naar Vught zonden).

Het verloop van de melkstaking, over geheel Friesland gezien, vindt men weerspiegeld in de cijfers van melkaanvoer aan de coöperatieve zuivelfabrieken in de provincie. Deze aanvoer (voor de particuliere zuivelbedrijven ontbreken ons gegevens) bedroeg:

$\begin{array}{rl}28 & \text { April } 1943 \\ 29 & \text { April } \\ 30 & \text { April } \\ 1 & \text { Mei } \\ 2 & \text { Mei } \\ 3 & \mathrm{Mei} \\ 4 & \mathrm{Mei} \\ 5 & \mathrm{Mei}\end{array}$

1.068 .336 liter
$1.094 .684 "$ "
$719.905 ~ "$
$126.960 ~ "$
$328.113 ~ "$
$459.991 ~ "$
$798.703 ~ "$
$1.117 .308 "$

Deze statistiek spreekt een duidelijke taal. Reeds Vrijdag 30 April vertoonde zich een scherpe inzinking, hoewel in de ochtend van die dag juist in de afgelegen dorpen nog weinig stakingsactiviteit te bespeuren viel. Dat de anvoer desondanks op 30 April slechts ruim 700.000 liter bedroeg bewijst, dat de staking in het weidegebied van de provincie reeds Vrijdagmiddag vrij algemeen moet zijn verbreid geweest. De 1ste Mei stagneerde het melktransport bijna geheel en niettegenstaande de afkondiging van het standrecht op die dag bleef de aanvoer ook de volgende etmalen ver beneden het normale. Eerst 4 Mei bleek de melkstaking ten einde te lopen. De 5de Mei werkten de zuivelfabrieken overal weer op volle kracht, hetgeen wel het duidelijkste bewijs is voor de constatering, dat men in het veehoudersbedrijf korter staakte dan in enkele bouwstreken - vooral in de Noordelijke, waar in enkele gemeenten het verzet ook nog 5 en $6 \mathrm{Mei}$ aanhield.

Het zou ons verslag te eentonig maken, indien wij een opsomming zouden geven van alle stakende zuivelfabrieken en van daden van sabotage in alle dorpen, die zich bij de stakingsbeweging aansloten. In het veeteeltgebied rondom Sneek werd overal het werk neergelegd, maar wij zien wel verschillen van plaats tot plaats. Als een centrum van verzet gold Oudega in de gemeente Wymbritseradeel, waar men Vrijdag een melkboot, die de Brekken opstoomde naar de zuivelfabriek te Oudega, liet leeglopen. Eén van de felsten in deze plaats, wiens advies ook van invloed bleek op de houding van naburige dorpen, was Bouke de Vries. De Duitse politie, door verraad van deze feiten op de hoogte gebracht, omsingelde Zondagmorgen, tijdens kerkdienst, het dorp en stelde een aantal mannen in arrest. Bouke de Vries slaagde er in, tijdig te ontsnappen. De Duitsers arresteerden toen zijn vrouw en voerden haar in een overvalwagen weg in de hoop dat De Vries zich hierdoor zou laten intimideren. Inderdaad gaf hij zich Maandag aan. Donderdag 6 Mei werd hij, met J. 
Eisenga uit Gorredijk en met een boerenzoon uit de naaste omgeving (B. de Witte uit Greonterp) gefusilleerd.

Bijzonder fel was ook de staking in Oosterend (gemeente Hennaarderadeel) waar het verzet eerst verminderde na arrestatie van een aantal inwoners van het dorp. Het is mogelijk, dat in de gemeenten Baarderadeel, Doniawerstal, Hemelumer Oldephaert en Rauwerderhem nog meer dorpen zijn te noemen waar de bevolking door haar onbuigzame houding opviel. De meeste matiging werd aan de dag gelegd in de Zuid-Westhoek: in Workum, Hindelopen, Stavoren, Koudum, enz. en in het Zuidelijk randgebied langs de Zuiderzee. De bevolking, wat conservatief en bij voorkeur in kerkelijk groepsverband enigszins traag reagerend, vertoont in enkele opzichten overeenkomst met de, overigens veel minder kerkelijke, West-Friezen in Noord-Holland. Een typisch gebrek aan spontaneïteit viel vooral in Gaasterland en in het stadje Sloten waar te nemen. lets levendiger reageerde de bevolking van Lemsterland.

Een van de weinige stakingscentra in Zuid-Friesland was het plaatsje Echten ten Oosten van Lemmer: een vrij geïsoleerd dorp, aansluitend bij een oud veenderijgebied. Hier vonden voortdurend samenscholingen plaats. Het verkeer werd er gestremd door het afdraaien van een brug. Men liet zich door schietpartijen van een langstrekkende Duitse patrouille geen schrik aanjagen en staakte te Echten door tot de 6de of de 7de Mei.

Te Lemmer stuitte een Duitse overvalwagen op een geopende brug, welke op normale wijze was afgedraaid om een schip door te laten. De Duitsers, nerveus en wantrouwig als gewoonlijk, begrepen niet, dat het verkeer een ogenblik was gestremd door een passerend schip. Ze begonnen in het wilde weg te schieten, hetgeen een aan de overkant van het water wachtende visser (J. Bootsma) het leven kostte.

Enige variatie in het beeld van de melkstaking gaven de bedrijfssluitingen in kleine industrieën en winkels in enige kleine steden te zien. Te Joure staakte het personeel van de N.V. Douwe Egberts, van N.V. Zijlstra's Meubelfabriek, van de N.V. Verenigde Jouster Drukkerijen en van alle gemeentediensten. De werkzaamheden werden er Maandag 3 Mei hervat. Te Grouw begon de staking Vrijdagochtend 30 April, omstreeks 8 uur, in de machinefabriek Van der Made $\mathcal{E}$ De Vries. De stakers begaven zich daarop naar N.V. Halbertsma's Fabrieken voor houtbewerking, waar het werk eveneens werd neergelegd, evenals in de naburige zuivelfabriek. Vervolgens begaf men zich naar het gemeentehuis, waar spoedig een honderdtal stakers de hal vulden en het personeel van de gemeentesecretarie verzocht, zich bij de stakingsactie aan te sluiten. Men beperkte zich echter tot een demonstratie van één dag, althans wat het gemeentepersoneel betreft. In genoemde bedrijven werd het werk Maandag 3 Mei hervat.

Te Akkrum staakte men bij de N.V. U. Twijnstra's Oliefabrieken, bij een exportslagerij en in de kaaspakhuizen van de firma Van Woerden. De staking bereikte er Zaterdag 1 Mei haar hoogtepunt, misschien omdat in het ambtenarenreglement der gemeente is bepaald, dat op de 1 ste Mei niet behoeft te 
worden gewerkt. Te Sneek stagneerde het bedrijfsleven reeds Vrijdagochtend. In de loop van de middag legde ook het personeel van de verschillende gemeentediensten het werk neer. Door krachtig ingrijpen van de Duitse politie werden de zuivelfabrieken reeds Zaterdagavond heropend. Waarom de Grüne Polizei haar aandacht zo op Sneek concentreerde, is niet duidelijk. Er vonden arrestaties plaats en bij een schietpartij werd één persoon gedood (B. Remerij). Te Sneek, evenals te Bolsward, was het verzet eerder gebroken dan op het platteland in de omgeving van deze steden - vermoedelijk ook, omdat illegale kernen, die in contact stonden met de verzetsorganisatie te Leeuwarden, Zondag het consigne doorgaven, dat verder staken moest worden afgeraden.

Geheel buiten de emotionele episode van de April-Meidagen bleven de geisoleerd gelegen eilanden Vlieland, Terschelling, Ameland en Schiermonnikoog. Men staakte er niet, en vernam eerst met vertraging, wat zich elders heeft afgespeeld. 


\section{HOOFDSTUK V}

\section{GRONINGEN}

Er is in de provincie Groningen bijna even algemeen gestaakt als in Friesland, maar kortstondiger en wat minder fel. In de meeste Groningse gemeenten kwam vooral het demonstratief karakter van de stakingsbeweging tot uiting, niet het doorzetten tot het bittere einde. Men was goed geïnormeerd, hield telefonisch contact waar dit mogelijk was, en lette scherp op de houding van het spoorwegpersoneel. De situatie werd met een zekere nuchterheid beoordeeld.

In de stad Groningen mengde zich met de neiging, de verschillende mogelijkheden zorgvuldig af te wegen, een zekere vrees. De stad was een hoofdkwartier van de SD. Men wist, dat de Duitse politietroepen, die van het Scholtenshuis uit gedirigeerd werden, voor geen enkele daad van terreur terugdeinsden. Dit maakte de provinciale hoofdstad minder geschikt voor het geven van leiding aan verzetsacties. Op de dorpen ging men zijn eigen gang; het isolement van verschillende streken - van de Veenkoloniën bijvoorbeeld werd in de loop van de oorlogsjaren groter.

Het bevel van Christiansen, Donderdagmiddag door de plaatselijke bladen door bulletins bekend gemaakt, lokte dadelijk krachtige reacties uit. Het was te Groningen vooral op het Zuiderdiep heel druk; overal liep men te hoop om het nieuws te bespreken. In hoeverre Donderdagavond afspraken zijn gemaakt voor een staking, die Vrijdag zou beginnen, viel niet meer na te gaan. Vermoedelijk gaf overleg in de fabrieken en kantoren, Vrijdagochtend bij het begin van de werkzaamheden de doorslag. Een van de eerste stakingen begon Vrijdag tussen 9 en 10 uur v.m. op het postkantoor (ruim 100 ambtenaren verlieten het hoofdgebouw). Een uur later werd ook het werk bij de telefoondienst (telefoondistrict Groningen) neergelegd.

Intussen hoorde men van alle kanten mededelingen over het uitbreken van stakingen in grote en kleine bedrijven. Het meest massaal was de uittocht uit een viertal confectiefabrieken (elk met 200 à 300 personen personeel, meest meisjes). Tegen het einde van de morgen ging ook het grootste gedeelte van het personeel der gemeentebedrijven en van de distributiedienst naar huis. De stemming werd steeds onrustiger. Veel huisvrouwen deden haastig boodschappen, omdat zij een algemene winkelsluiting verwachtten. Er werd veel water afgetapt, met het gevolg, dat de druk op de waterleiding zó verminderde, dat men hierin op zichzelf al een aanwijzing voor staking meende te zien. 
's Middags, 30 April, begon een staking van het personeel van het Gemeentelijk Gasbedrijf; evenzo van de Stadsreinigingsdienst. Steeds meer kantoren en bureaux (o.a. van de belastingdienst, van de arbeidsinspectie en van de provinciale voedselcommissaris) sloten hun deuren.

Zaterdag $1 \mathrm{Mei}$, onder de druk van de toenemende Duitse bedreigingen - in de loop van de dag werd ook de afkondiging van het standrecht voor het gehele land bekend - eindigden enige stakingen. Maar tegelijkertijd rapporteerde de Duitse politie het uitbreken van nieuwe stakingen. Er heerste bijvoorbeeld nog stagnatie in de aanvoer van melk. Vele melkslijters en melkventers bleven thuis en gingen eerst weer aan het werk, nadat de Duitsers enigen van hen hadden gearresteerd. Zaterdagmorgen staakte ook het trampersoneel gedurende enkele uren; eveneens de rangeerders op het stationsemplacement en een gedeelte van de dienstmeisjes van het Academisch Ziekenhuis.

Uit Duitse politierapporten blijkt, dat de SD de toestand als zeer ernstig beschouwde en een verdere uitbreiding van de staking verwachtte. In werkelijkheid was de bevolking allerminst geneigd, de zaken op de spits te drijven. Men zag heel goed in, dat de staking door gebrek aan centrale leiding zeer onregelmatig verliep: velen van hen die het werk Vrijdag spontaan neerlegden, gingen Zaterdag weer aan de arbeid. Menigeen die Vrijdag werkte, bleef Zaterdag thuis. Ook maakte het indruk, dat het personeel van de meeste over heidsdiensten (P.T.T. enz.) zich Zaterdag weer in het disciplinair verband schikte - vooral omdat juist in deze groepen het consigne was uitgegeven, de gedragslijn van het spoorwegpersoneel te volgen. Voorts mag het effect van het standrecht niet worden onderschat. Men zag ook vrachtauto's vol gevangenen (uit Friesland, Drente, enz.) binnenkomen. In het Scholtenshuis heerste grote bedrijvigheid. Ooggetuigen wisten bijzonderheden te vertellen over een schietpartij op de Grote Markt, waarbij een arrestant bij een poging tot ontvluchting werd neergeschoten en een burger door een kogel dodelijk werd getroffen.

Maandagochtend was de rust weer hersteld. Slechts een aantal meisjes van de confectiefabrieken ontbrak op het appèl. Het Duitse Standgericht sprak doodvonnissen uit over een vijftal te Groningen gearresteerde melkventers. $Z_{i j}$ werden ,begenadigd"; zij zouden slechts tuchthuisstraf, d.w.z. opsluiting in een concentratiekamp, moeten ondergaan. Drie van de weggevoerden zijn te Dachau overleden (J. Zuidema, M. Woudstra en S. Frankruiter).

In het ten Zuiden van Groningen gelegen Haren begon de staking Vrijdagmorgen onder het personeel van het postkantoor. Verder sloten sommige winkeliers hun winkels. Voor het overige bleef het in de onmiddellijke omgeving van Groningen rustig.

De felste stakingen in de provincie Groningen vonden plaats in het Veenkoloniale industriegebied en in het Westerkwartier. Vooral in het Westerkwartier, in het algemeen in het gebied langs de Fries-Groningse grens, deden de reacties van de bevolking denken aan het emotionele Friese verzet. Waar 
ik mij tot taak stelde, het verband tussen de stakingsacties en de verschillende streekkarakters te onderzoeken, vond $\mathrm{ik}$ in het Fries-Groningse grensgebied een bijzonder interessant terrein van studie.

Aanvankelijk was ik geneigd, grote betekenis te hechten aan de Friese taal grens, die, zoals bekend is, enigermate afwijkt van de provinciegrens ${ }^{1}$ ). Het leek a priori niet onwaarschijnlijk, dat het onderzoek een verschillende manier van reageren zou uitwijzen aan weerszijden van de taalgrens: aan de ene kant het emotionele en verbeten Friese verzet, aan de andere zijde het meer stugge Groningse optreden, waarin verstandelijke overwegingen spoedig de hartstocht in bedwang hielden. Kenmerkend voor de Friese stakingen bijvoorbeeld was het lastig vallen van werkwilligen, die in strijd met de groepssolidariteit handel den. In Groningen was het gedrag van de bevolking veel minder solidair (behalve langs de Fries-Groningse grens).

Het typisch Gronings-rustig reageren, het staken zonder demonstratief vertoon en zonder dwang uit te oefenen op werkwilligen, kwam het duidelijkste tot uiting ten Noord-Oosten en ten Oosten van het Reitdiep. Verder Zuidwaarts, ten Oosten van de lijn Oldehove-Noordhorn-Zuidhorn, Tolbert-Leek. Men zou van een "karaktergrens" kunnen spreken.

De conclusie, die uit vrij omvangrijk enquêtemateriaal, aangevuld met een aantal interviews, valt te trekken, zou onder het nodige voorbehoud aldus kunnen worden geformuleerd, dat het Groningse streekkarakter zich op een beperkter gebied manifesteert dan met de verbreiding van het Groningse dialect overeenkomt. In het Westerkwartier en het gebied tot het Reitdiep enz. (de genoemde ,karaktergrens") vertoont de Gronings sprekende bevolking een sterk Friese inslag (d.w.z. openbaren zich karaktertrekken, die merkwaardig overeenstemmen met het „Friese volkskarakter"). De taalgrens markeert in dit geval vrijwel geen scheiding tussen de verschillende streekkarakters.

Met nadruk moet echter worden erkend, dat de verwarrende veelheid van détails ons telkens op een dwaalspoor brengt. In verschillende dorpen in het Westerkwartier vindt men een gemengde bevolking, waarvan de samenstelling niet statistisch kan worden bepaald: inwoners van Drentse herkomst, van Groningse taal en volksaard, van Friese afkomst (in een ver verleden) doch met Groningse tongval, maar ook personen die nog slechts betrekkelijk kort geleden uit Friesland kwamen en die ook op Gronings gebied voor Friezen willen doorgaan. Om het verzet in de Fries-Groningse dorpen in het grensgebied tot in bijzonderheden te kunnen nagaan, zou men voor ieder geval afzonderlijk moeten weten, hoe de reacties van de verschillende bevolkingsgroepen waren - met een differentiatie naar afkomst, taal, politieke opvatting, geloof en beroep. Tot deze detaillering - gesteld dat zij mogelijk ware geweest - kon mijn onderzoek niet afdalen.

Een voorbeeld van een weinig overzichtelijke situatie geven de stakingen in het streekdorp Zevenhuizen te zien. Het staat wel vast, dat het meest

1) Zie de kaart van J. P. Hof, Friese dialectgeographie, Den Haag 1933. 
vastberaden verzet hier uitging van Friese ingezetenen en gereformeerde groepen - het meest waarschijnlijk van Friese gereformeerden. Bij navraag waren sommigen van mening, dat de jongere generatie hier meer Gronings van aard is en ook wat onverschilliger stond tegenover de actie van de Meidagen. Nadat de Vrijdag al een onrustig verloop had gehad, ontwaakte de neiging tot verzet te Zevenhuizen Zaterdag 1 Mei in versterkte mate. $\mathrm{Er}$ was veel publiek op straat. Van enige boerenwagens, die toevallig passeerden, werden de paarden afgespannen. Men dreigde NSB-ers te molesteren, zelfs hun huizen en boerderijen in brand te steken (dit wist een der illegale leiders echter te voorkomen). Tenslotte formeerde men een stoet van enige honderden mannen om naar Roden te trekken met de bedoeling, het personeel van de zuivelfabriek in dat dorp tot meestaken te bewegen. Toen in het begin van de middag een Duitse overvalauto arriveerde, waren er in het dorp vrijwel geen mannen aanwezig. De Duitsers constateerden, dat het er rustig was, en gingen verder.

Intussen kwamen berichten binnen uit naburige dorpen. Te Haulerwijk, even over de Friese grens, werden achttien mannen gearresteerd en onder bedreiging met executie een gehele dag tegen een muur gezet. In het grensdorp de Wilp staakten de zuivelfabrieken en werden de meeste winkels gesloten. In de nacht van 2 op 3 Mei maakte men er bijna alle melkwagens en melkboten onklaar. Te Termunten, waar de Duitsers een sterke militaire post hadden gevestigd, beperkte de bevolking zich onder Duitse druk meer tot lijdelijk verzet. Te Opende kwam men niet veel verder dan een ,,melkstaking"; de bevolking toonde er zich minder fel dan te Zevenhuizen. In de gemeente Grootegast werd kalm en vastberaden gestaakt, volgens sommige waarnemers "zonder veel drukte te maken", doch zeker niet minder fel dan in Friesland. Incidenten werden uitgelokt door Friese jongemannen uit de gemeente Achtkarspelen, die door het Groningse grensgebied trokken en met rode zakdoeken om, getrokken messen in de hand, bedreigingen uitten tegen NSB-ers. Ook te Grootegast kon worden geconstateerd, dat Friezen in de stakingsactiviteit leiding gaven.

De Duitse politie, die in deze streken intensief patrouilleerde, arresteerde in de gemeente Grootegast een zestal landbouwers, die weigerden melk af te leveren. $Z_{\mathrm{ij}}$ werden naar het Scholtenshuis te Groningen gebracht, doch spoedig vrijgelaten. Er moest echter een slachtoffer vallen. Het standgerecht koos hiervoor R. Terpstra, boerenzoon uit Doezum (Ees) uit, die met enige anderen melkwagens, welke naar een zuivelfabriek reden, had tegengehouden. Hij hoorde het doodvonnis over zich uitspreken.

De meest tragische gebeurtenissen - de bloedigste uit de April-Meidagen in geheel Nederland - speelden zich in het naburige Marum af. Ook in dit dorp betekende het begrip ",melkstaking" meer dan het tijdelijk stopzetten van de melklevering aan de zuivelfabrieken. De grotendeels Gronings sprekende bevolking reageerde met Friese heftigheid. In de nacht van 2 op 3 Mei werden ook hier melkwagens en melkboten onklaar gemaakt. Er heerste een opge- 
wonden stemming, vooral onder de gereformeerden. Hoewel in de gemeente Marum de Duitste stelling Trimunt lag met een vrij sterke militaire bezetting, beging men de onvoorzichtigheid, op enige plaatsen bomen over de weg te leggen, vermoedelijk om de Maandag 3 Mei hervatte melklevering aan de zuivelfabrieken te beletten.

Uit een na de bevrijding ingesteld onderzoek is gebleken, dat uit de Duitse stelling Trimunt aan het Scholtenshuis te Groningen is gerapporteerd, dat er te Marum barricades op de weg waren opgericht. Intussen was Maandagochtend al een Feldwebel uit Trimunt (een veel agressiever type dan de commandant van de stelling Trimunt) met enige soldaten, bewapend met een machinegeweer, op weg gegaan naar Friese Palen om te controleren, waar enige arbeiders bleven, die gewoonlijk aan de Duitse verdedigingswerken arbeidden. Hij vond de weg versperd door een omgehakte boom. Dit gaf de Feldwebel aanleiding, een tiental personen op het erf van de dichtst bijzijnde boerderij te arresteren. $Z_{\text {ij }}$ werden met enige andere arrestanten, o.a. een jongen van dertien jaar, in een barak bij Trimunt opgesloten. Vermoedelijk was het niet de bedoeling, de gevangenen neer te schieten.

Omstreeks 12 uur kwam echter een overvalwagen van de SD uit Groningen aangeraasd. De Duitse politiemannen informeerden, of er arrestanten waren en toen de commandant van de stelling Trimunt dit (vermoedelijk tegen zijn zin) bevestigde, werden de gevangenen in groepjes van vier te voorschijn gehaald en neergeschoten. De dertienjarige jongen probeerde te ontsnappen; hij trok zijn klompen uit om sneller te kunnen lopen, maar viel na een Duits salvo dodelijk getroffen neer.

De slachtoffers van dit bloedbad uit de April-Meidagen waren: A. Hartholt, D. Hartholt, A. Hartholt en H. Hartholt - een vader en drie zoons uit één gezin -; E. de Jong; S. de Wal en B. Assies uit Marum (de Haar); U. van der Wier en J. van der Wier, twee zoons uit een Marums gezin, en hun neef S. van der Wier; voorts K. Doornbosch en J. Doornbosch, eveneens twee zoons uit één gezin; een onderduiker uit Amsterdam, F. L. van de Riet; J. Glas uit Dokkum, en de Marummers G. van der Vaart en G. J. Diertens. Bij een poging om aan arrestatie te ontkomen, werd te Marum nog A. Sikkinga neergeschoten. Zo kostte deze zwarte dag, de 3e Mei 1943, het dorp Marum (met de naburige gehuchten de Haar en de Wilp) achttien doden, zonder dat dit anvankelijk tot de bevolking doordrong.

's Middags werden de lijken van de te Trimunt gefusilleerden in een gesloten bestelauto in de richting Groningen vervoerd. Bij het gemeentehuis te Marum liet de Duitse militair, die met het transport was belast, even stoppen. Hij deelde kortaf mede, dat er verschillende personen waren gearresteerd. De toenmalige burgemeester, wijlen $\mathrm{D}$. van Geel, stelde alles in het werk om gewaar te worden, wat er met de arrestanten zou gebeuren of wat er zich in werkelijkheid had afgespeeld. Dezelfde dag verbreidde zich het gerucht, dat een massale moordpartij had plaats gevonden. De burgemeester van Marum, vast besloten aan de vreselijke onzekerheid een einde te maken, begaf zich 
naar het Scholtenshuis te Groningen om bevestiging te krijgen. Deze werd hem echter onthouden; de Duitsers schenen op geheimhouding prijs te stellen. Eerst enige maanden later ontving de burgemeester verschillende goederen terug, die aan de slachtoffers hadden toebehoord.

De SD zond de Beauftragte Conring een rapport over de gebeurtenissen in Marum, waarin een voorstelling van zaken werd gegeven, alsof een gevaarlijke terroristische bende daar de omgeving onveilig maakte. De bevolking zou zelfs zó blij zijn geweest over het onschadelijk maken van deze bende, dat zij de Duitse politie uit dankbaarheid bloemen aanbood. Het behoeft ons niet te verbazen dat de Beauftragte dit verhaal geloofde. Er zijn meer krasse staaltjes mede te delen van Duitse naïviteit......

Toen de noodlottige schoten in Trimunt vielen, was in het grootste gedeelte van het Westerkwartier de rust al teruggekeerd. In het algemeen werden de werkzaamheden Maandagochtend de 3e Mei hervat.

Wanneer wij het verloop van de staking in de Noordelijk gelegen dorpen langs de Fries-Groningse grens nagaan, kan ook daar veel emotioneel verzet worden geconstateerd. Doch minder dan in het Westerkwartier overwoog hier de neiging tot opstandigheid. Echte "melkstakingen" vonden plaats te Grijpskerk, Stroobos, Visvliet enz. Te Schouwerzijl bleven vooral de landarbeiders thuis.

Bij het onderzoek van de stakingsactiviteit in iets oostelijker gelegen dorper is duidelijk de "karaktergrens" zichtbaar, waarover $i k$ in het begin van dit hoofdstuk schreef. Men reageerde hier meer "Gronings"; beheerster, kalmer. Opvallend is het ongemoeid laten van werkwilligen, die in deze dorpen dan ook in grotere getale voorkwamen dan langs de Fries-Groningse grens.

Algemene stakingen werden gerapporteerd uit Kommerzijl en uit Oldehove (waar burgemeester A. Omta, een bekend illegaal leider, de gemeentesecretarie liet sluiten). Ook te Ezinge, waarvan de bevolking van ouds door een grotere solidariteit uitmunt, werd het werk zoveel mogelijk neergelegd, o.a. in de steenfabriek. Veel kalmer daarentegen bleef de stemming in Noordhorn en Zuidhorn (welvarende bevolking met vrij veel middenstanders en talrijke ,,rustende boeren"). Nog minder stakingsactiviteit viel te bespeuren te Oldekerk en Niekerk, en in Leek (met een brede groep middenstanders, die weinig voor winkelsluiting gevoelden). Voor zover men te Tolbert en te Midwolde meestaakte, gebeurde dit onder pressie van de veel fellere Zevenhuizense bevolking.

In het Noorden van de provincie droeg de staking een algemeen karakter te Zoutkamp (o.a. de "Marne"-autobusdienst) en te Leens. Uit Leens stamde het eerste slachtoffer van het te Groningen ingestelde Standgericht: J. van $Z_{\text {wol. }}$ Men krijgt echter niet de indruk, dat hier met veel enthousiasme werd gestaakt. De situatie werd realistisch beoordeeld; enig nuttig effect viel van deze staking niet te verwachten, maar men wilde uit solidariteit met de andere stakers wel meedoen. Men kon naderhand veel critiek vernemen: op de spoorwegen, op de stad Groningen (waar men zich volgens vele plattelanders veel 
te rustig had gedragen) en op de Regering te Londen, die geen aanwijzingen scheen te willen geven.

In de gemeenten Ultum, Kloosterburen en Eenrum begonnen de stakingen reeds Vrijdagmorgen. Veel landarbeiders gingen na schafttijd naar huis, dikwijls op een wenk van hun werkgevers. Toen men de volgende dag zeker wist, dat de spoorwegen niet zouden staken, werd het werk door velen hervat. Anderen staakten door tot 3 of 4 Mei en er waren zelfs (communistische) groepjes landarbeiders, die een veel langduriger staking bepleitten. In ieder geval treft ons, hoe men in deze streek wèl collectief met de staking begon, maar vrijwel individueel bepaalde, wanneer men de arbeid weer zou opvatten. Over daden van geweld tegen werkwilligen werd niets gemeld.

Verder Oostwaarts op het Hoogeland viel nog minder stakingsélan waar te nemen. In de dorpen langs de spoorlijn Groningen-Winsum-Rodeschool bestond uiteraard de neiging, het treinverkeer in het oog te houden. De staking kon nooit algemeen zijn, zolang de treinen bleven rijden. Te Baflo staakte vooral het gereformeerde deel van de bevolking, evenzo te Warffum (landarbeiders - dikwijls op een wenk van de meest principieel gezinde boeren). Maandag $3 \mathrm{Mei}$ ging in deze streek alles weer zijn gewone gang. Te Winsum vormden de steen - en zuivelfabrieken middelpunten van de stakingsbeweging. In de gemeente Kantens werd in alle lagen van de bevolking gestaakt (o.a. door het personeel van de Veilingsvereniging "Ons Belang" te Zandeweer).

In de gemeenten Uithuizen en Uithuizermeeden bleven de landarbeiders enige dagen thuis. Dit viel in dit vrij stille seizoen van de landbouw weinig op. De Duitse politie onthield zich dan ook van ingrijpen. Een wat demonstra tiever karakter droeg de staking te Spijk, in de buurt van Delfzijl. De staking duurde hier ook langer dan in de naburige gemeenten en eindigde eerst Dinsdag, nadat de Duitse politie had gedreigd, een twintigtal personen uit het dorp dood te schieten. Sommige Spijkse landarbeiders gingen echter eerst Woensdag of Donderdag naar hun werk terug.

Over de plattelandsstakingen te Bierum en Zeerijp zijn weinig bijzonderheden te vermelden. In de gemeenten Stedum en ' $t$ Zand duurde het tot Dinsdag of Woensdag, eer ieder weer aan het werk was; te Loppersum eindigde de staking Maandagochtend. Men was in deze gemeente nogal onder de indruk van de terechtstelling van enige arbeiders uit Hoogezand.

In het weidegebied in de omgeving van Groningen manifesteerde de neiging tot staken zich vooral in het stopzetten van de melkleverantie aan de zuivelfabrieken. De melk werd zoveel mogelijk aan particulieren verkocht. De uittocht van stedelingen, die in de omgeving van Groningen melk gingen halen, trok uiteraard de aandacht van de Duitse SD, die hier tot de meest actieve van het gehele land behoorde. $\mathrm{Na}$ afkondiging van het standrecht werd krachtig ingegrepen. In de gemeente Hoogkerk werd Zondagochtend een der veehouders aan de Friese Straatweg gearresteerd en ter dood veroordeeld (het vonnis werd echter nog opgeschort. De gearresteerde, A. Faber, vernam later dat hij was ",begenadigd" en zou kunnen volstaan met vijftien jaar tucht- 
huisstraf. Hij overleed 28 Februari 1945 in Dachau). Ook te Aduard, waar gedurende twee dagen vrij algemeen werd gestaakt, viel een slachtoffer (A. Harkema, die in een concentratiekamp overleed). Twee anderen werden voor een half jaar naar Vught gezonden, doch kwamen heelhuids terug. De bevolking toonde zich in deze gemeente zeer solidair en waarschijnlijk zou men de staking nog wel enige dagen langer hebben volgehouden, indien de provinciale voedselcommissaris niet de plaatselijke bureauhouder had opgebeld en had gezegd, dat onnodig bloedvergieten voorkomen moest worden en dat men verstandig deed, de melkleveranties te hervatten.

Te Bedum concentreerde de staking zich op de Coöperatieve zuivelfabriek, een van de grootste van het land. Vrijdagochtend waren reeds vele land-

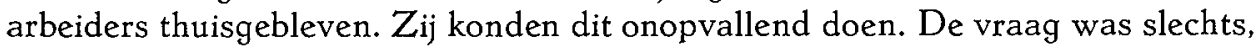
hoe het personeel van de zuivelfabriek zou handelen. Wanneer er geen rook meer opsteeg uit de hoge fabrieksschoorsteen, die wijd en zijd in de omtrek zichtbaar is, zou dit in de gehele omgeving als een stakingssignaal worden opgevat. De arbeiders van de fabriek (240 man personeel) wilden het werk echter niet neerleggen zonder overleg met de directeur P. Okkinga. Men kwam overeen, de machines Zaterdag stop te zetten. Om te voorkomen, dat sommige boeren toch nog melk zouden leveren, liet de directie aan de bij de coöperatie aangesloten boeren de sluiting van de fabriek meedelen. Dit werd voor de Duitsers een punt van aanklacht tegen de directeur, die Zaterdagmiddag als arrestant in het Scholtenshuis terecht kwam. De heer Okkinga kon evenwel aannemelijk maken, dat hij kort voor zijn arrestatie een circulaire had doen uitgaan, waarin op hervatting van melkleverantie werd aangedrongen (hij bleef een maand in gevangenschap). De Duitse politie volgde de gebeurtenissen in Bedum met de grootste aandacht. Nog enige maanden later liet zij een viertal inwoners van de gemeente arresteren, omdat deze in de stakingsdagen pamfletten zouden hebben verspreid (twee van hen, G. van der Werf en B. K. Vriezema, zijn in een Duits concentratiekamp overleden).

$\mathrm{Te}$ Middelstum, waar de bevolking een sterk gereformeerde inslag vertoont, staakte het personeel van de gemeentesecretarie en van de distributiedienst. Van hier uit werden ook secretarieën in andere dorpen opgebeld en tot staken aangemoedigd. De melkstaking in de streek ten Oosten van het Boterdiep (Thesinge, Ten Boer enz.) kenmerkte zich overigens niet door bijzondere gebeurtenissen.

Te Appingedam begon de staking spontaan op Vrijdagochtend in de Brons' Motorenfabriek $( \pm 230$ man personeel). De arbeiders waren wel de fabriek binnengegaan, maar verlieten de werkplaatsen enige minuten na het aanvangssein. Veel overleg schenen zij niet nodig te hebben. Ook de stroocartonfabriek "De Eendracht" en enige andere fabrieken en fabriekjes staakten, evenals het personeel van het D.A.M.-busbedrijf. 's Middags sloten ook enkele winkeliers hun zaken. Toen het evenwel duidelijk werd, dat de spoorwegen in vol bedrijf bleven, sloeg de stemming om. Op aandrang van de directie van Brons' Motorenfabriek ging een gedeelte der arbeiders van de grootste 
plaatselijke industrie Zaterdag weer aan het werk; de overigen begonnen Maandag.

Te Delfzijl lagen twaalf à veertien boten in de haven. De ruim 400 bootwerkers, die hier aan het werk waren, en het overige havenpersoneel lieten zich door enkele stakingsleiders zonder moeite overhalen, de arbeid neer te leggen. Vrijdagmiddag staakte ook het personeel van de distributiedienst en van enkele andere kantoren en werkplaatsen. Onder pressie van de Duitse politie was de rust echter reeds Zaterdag hersteld. Er vielen geen slachtoffers.

De landbouwgemeente Slochteren, tussen Groningen en Delfzijl, had wèl mensenlevens te betreuren. Men kan niet zeggen, dat de bevolking van deze gemeente bijzonder fel heeft gestaakt, maar het was te voorzien, dat de Duitsers na afkondiging van het standrecht, hier en daar een voorbeeld zouden stellen. In de dorpen werd Vrijdag en Zaterdag op weinig demonstratieve wijze gestaakt: landarbeiders bleven thuis, enige winkeliers sloten hun winkels, smeden en wagenmakers hun werkplaatsen. In verre omtrek kon men echter zien, dat de hoge schoorsteen van de Coöperatieve aardappelmeelfabriek „De Woudbloem" te Scharmer niet meer rookte. Het personeel van dit bedrijf, opgewonden door stakingsberichten uit Hoogezand en elders, ging Vrijdagmiddag naar huis. De arbeiders vertoonden zich ook Zaterdag niet. $\mathrm{Na}$ afkondiging van het standrecht oordeelde de directie van "De Woudbloem" het raadzaam, het personeel te waarschuwen en met klem te verzoeken, Maandagochtend weer aanwezig te zijn.

Gedurende de voorjaarscampagne, die toen aan de gang was, werkte de fabriek met drie ploegen. Van de ochtendploeg van ongeveer 30 personen, welke Maandagochtend had moeten aantreden, waren slechts 6 of 7 arbeiders aanwezig. Het is mogelijk, dat de verspreid wonende arbeiders niet alle de oproep van de directie hadden ontvangen, het kan ook zijn, dat zij zich voorgenomen hadden, een afwachtende houding aan te nemen. Hoewel de burgemeester van Slochteren aan de Duitse politie had gemeld, dat de fabriek bij Scharmer weer werkte, oefenden de Duitsers toch nog contrôle uit. In de loop van de ochtend verscheen een Duitser, vergezeld van een tolk en een Nederlandse veldwachter. $Z_{i j}$ stelden er zich eerst van op de hoogte, dat de meeste arbeiders er niet waren (vermoedelijk gaf de procuratiehouder onder Duitse pressie inzage van de personeelslijst). Daarop werden naburige arbeidershuizen doorzocht en twee arbeiders (gebroeders E. en H. Kleefman) gearresteerd. 's Middags volgde nog de arrestatie (door een der gemeenteveldwachters) van E. Thoma. De overige arbeiders haastten zich, Maandagmiddag aan hun werk te gaan, maar de Duitsers waren van plan, de intimidatie verder door te drijven. Dinsdagmiddag kwam een afdeling Duitse politiemannen in een overvalwagen, gevolgd door een luxe-auto, het fabrieksterrein van "De Woudbloem" oprijden. De Duitsers hadden de drie gevangenen bij zich. $\mathrm{Z}_{\mathrm{ij}}$ werden naast het kantoorgebouw in het bijzijn van de hoofdopzichter gefusilleerd.

In het landbouwgebied van het Oldambt, grotendeels een streek van akker- 
bouw, beperkten de stakingen zich tot het thuisblijven van landarbeiders en de sluiting van enkele winkels en kleine bedrijven in de dorpen (ook enkele zuivelbedrijven). Te Nieuwolde staakte het gemeentepersoneel één dag, sommige landarbeiders iets langer. Ook in het naburige Midwolda gebeurde niets, dat een bijzondere vermelding waard is. Te Meeden en Meedhuizen waren enige stakingsleiders, doch nadat deze door een NSB-er waren verraden (en tijdelijk de vlucht hadden genomen) ging ieder Maandag weer aan het werk. In de gemeenten Noordbroek en Zuidbroek waren onder de stakers vrij veel arbeiders, die in dienst waren van industriële bedrijven te Hoogezand. In de meeste dorpen staakten de gemeentesecretarieën, maar niet langer dan één dag.

Ook in Scheemda, Finsterwolde en Beerta bleef het vrij kalm, hetgeen wel een opmerkelijk feit is, omdat de landarbeiders vooral in Beerta en Finsterwolde om hun communistische sympathieën bekend staan. $\mathrm{Nu}$ was echter reeds in 1941 een zevental communistische arbeiders naar Duitsland gedeporteerd. Dit maande tot voorzichtigheid. Bovendien mag de eensgezindheid van de groepen communisten in dit gebied worden betwijfeld. Naast een werkelijk serieuze politieke overtuiging ziet men in deze streek ook veel anarchisme of een zuiver negatieve houding ten opzichte van ieder sociaal verband - wie in de oppositie is, om welke redenen dan ook, noemt zich hier gaarne "communist".

Vrijwel algemeen was de staking in de Veenkoloniën, waar men in bijna alle plaatsen Vrijdag in een vastberaden stemming van verzet het werk neerlegde. Er zijn redenen om aan te nemen, dat het streekkarakter van de bevolking - in combinatie met een complex van sociaal-economische factoren - zijn invloed deed gelden. De veenkoloniale bevolking is enerzijds rustig en beheerst van aard, nuchter in sommige opzichten, maar vertoont toch ook wel in vele groepen een bedwongen emotionaliteit, die soms o.a. in sectevorming een uitweg vindt. Kenmerkend zijn eveneens de energie en de pioniersgeest, die men in dit inderdaad ,koloniale" gebied (op dezelfde wijze als de Amerikaanse geschiedenis koloniale pioniersgeest vertoont) veelvuldig aantreft. Evenals in Twente vindt men in de Veenkoloniën concentraties van industrie-arbeiders, die veelvuldig op het naburige platteland wonen. $Z_{i j}$ vertonen een zekere solidariteit zonder hun individualistische neigingen te hebben prijs gegeven. Belangrijk is ook in dit geval de groepsvorming in bedrijven van middelmatige grootte, waarin de opeenhoping van mensen nog niet al te massaal is geworden. Een en ander verklaart het snelle en spontane staken na kortstondig overleg in woon- of werkplaats en het taaie doorzetten van het verzet, indien leidinggevende figuren daartoe adviseerden.

Dit alles is goed zichtbaar te Hoogezand en omgeving, waar in de fabrieken en op de talrijke scheepshellingen Vrijdagmorgen het werk zonder veel vertoon van verontwaardiging werd neergelegd. Brandpunten van stakingsactiviteit waren de scheepswerven te Foxhol, onder de rook van Hoogezand, en de grote aardappelmeelfabriek van het Scholtensconcern en MeihuizenBoon's Glucosefabriek, eveneens te Foxhol. 
Vertegenwoordigers van de verschillende bedrijven pleegden voortdurend overleg. Men was door de scholing, die de vakorganisatie had gegeven, gewend aan eensgezind en gedisciplineerd optreden (uit het ontbonden N.V.V. was een contactgroep overgebleven). Toen nu Zaterdag 1 Mei het standrecht werd afgekondigd, was het de vraag of men voor deze bedreiging zou zwichten. Vanzelfsprekend was dit voor deze bevolking allerminst. Zondag morgen moesten enige fabrieksdirecteuren uit Hoogezand in het Scholtenshuis te Groningen komen. $Z_{\mathrm{ij}}$ kregen daar te horen, dat zij aansprakelijk werden gesteld voor de hervatting van de werkzaamheden. De Duitsers dreigden, Maandag tien arbeiders te fusilleren, indien hun bevelen niet werden opgevolgd. Inderdaad ergerde het hen bijzonder, dat enige aan de grote weg Groningen-Nieuwe Schans gelegen fabrieken Vrijdag en Zaterdag hadden gestaakt.

Zondagmiddag vonden besprekingen plaats tussen fabriekskernen en directies. Daarbij bleek, dat de afgevaardigden van de arbeiders bang waren, het vertrouwen van hun collega's te verspelen, indien $z \mathrm{ij}$ een oproep tot hervatting van de werkzaamheden zouden ondertekenen. De fabrieksdirecteuren, die de toezegging hadden gekregen, dat Duitse represailles achterwege zouden blijven als de arbeiders Maandag weer aan het werk gingen, namen de verantwoordelijkheid op zich, het einde der staking te proclameren. Hun bevel werd in de fabrieken van het Scholtens-concern en de andere grote bedrijven in het algemeen gerespecteerd, zodat Maandagochtend de meeste arbeiders even disciplinair weer aan het werk gingen als ze Vrijdag eensgezind de staking waren begonnen.

In vele kleinere bedrijven, o.a. op vele scheepswerven, heerste een onverzettelijke stemming en weigerden de meeste arbeiders voor de bedreiging van het standrecht te wijken. De Duitse politie greep nu krachtig in. Overvalwagens van de SD reden Maandag 3 Mei het dorp binnen; 31 arbeiders werden gearresteerd. Ter intimidatie van de bevolking kwam 's avonds een Duitse auto met vijf gevangenen (drie uit Hoogezand en omgeving, twee onbekenden) terug. De gevangenen werden bij de fabriek van Beukema te Hoogezand tegen de muur gezet en neergeschoten (slachtoffers uit Hoogezand en omgeving: G. Imborg. W. van Rossum en P. Nieuwold). Intussen had men ook al bijzonderheden vernomen over de arrestaties bij „De Woudbloem" in het naburige Scharmer en over bloedige gewelddaden elders in de provincie. Geen wonder, dat de Hoogezandse arbeiders Dinsdagmorgen geen neiging tot staking meer vertoonden. Ook in dit geval had de Duitse terreur gezegevierd, maar ook hier meer in schijn dan in werkelijkheid. Na Mei 1943 nam in de Veenkoloniën de illegale activiteit snel toe.

Te Sappemeer staakten sedert Vrijdag de arbeiders van de scheepswerven, van de Scholtensfabriek (Sappemeer-Oost), van Koenemans' Exportbedrijf enz. Ook het gemeentepersoneel legde het werk neer. De Duitsers stelden fabrieksdirecteuren aansprakelijk en wisten door militair machtsvertoon te bereiken, dat men in het algemeen Maandag de arbeid hervatte. $Z_{i j}$ vonden 
het echter toch wel nodig, Maandag patrouilles door het dorp te laten rijden en enige malen lukraak door de straten te schieten (hierbij werd de 80 -jarige O. Leininga gedood).

Te Winschoten bestond bij het uitbreken van de staking (o.a. Chemische fabriek Gembo, de Noord-Nederlandse Machinefabriek en de Rawi-Matrassenfabrieken) weinig contact tussen de verschillende bedrijven. Wèl kwam een illegale kern in actie en werden er pamfletten verspreid om ieder tot medewerking aan te sporen. De bevolking zag in het verminderen van de druk op de waterleiding een stakingssignaal. Vrijdagmiddag 30 April sloten de meeste winkeliers hun winkels. Zaterdag toonde men zich ontmoedigd, omdat de spoorwegen niet staakten. In overleg met enige illegale voormannen werd besloten, het consigne door te geven, dat ieder Maandag weer aan het werk zou gaan. Heftiger reageerde de bevolking van Oude en Nieuwe Pekela. Reeds Vrijdag was de staking in deze dorpen vrij algemeen. Ze omvatte ook het personeel van rijks- en gemeente-instellingen. Waar nog gewerkt werd, voelde de bevolking dit als een inbreuk op de groepssolidariteit. Zaterdag kwam het tot wilde demonstraties. Enige honderden jonge mannen fietsten rond. $Z_{i j}$ dwongen bestuurders van wagens en van de weinige autobussen, die nog reden, aan de kant van de weg te gaan staan. De menigte ging de Touwfabriek "De Volharding" te Oude-Pekela binnen en verzocht het personeel, het gebouw te verlaten. Aan dit verzoek werd onmiddellijk gevolg gegeven. Ook het personeel van de gasfabriek te Oude-Pekela werd op deze wijze tot staken gedwongen. Daarna begaven de demonstranten zich naar het gemeentehuis van Nieuwe-Pekela, waar zij de NSB-burgemeester T. Heeg molesteerden. Men sloeg een portret van Mussert op zijn hoofd stuk en sleurde hem toen naar buiten. De burgemeester werd in het kanaal gedrongen, dat ter plaatse nogal ondiep was, zodat het slachtoffer slechts tot zijn middel in het water kwam te staan. Hij moest zijn NSB-speldje in het water gooien en „Oranje boven" roepen, doch slaagde er in, het vege lijf te redden. De menigte verspreidde zich. Groepjes jongelui gooiden hier en daar ruiten in bij bekende NSB-ers. Kortom, men kon hier zonder overdrijving van een volksopstand spreken.

Later op de dag verschenen Duitse politietroepen, die ongeveer twaalf personen arresteerden. Acht van hen werden ter dood veroordeeld, doch vernamen enige tijd later, dat het doodvonnis in langdurige tuchthuisstraf was veranderd. De veroordeelden, die hun straf in de kampen Vught en Amersfoort ondergingen (sommigen in Duitse kampen) zijn gelukkig behouden teruggekeerd. Alleen H. R. Ots (die gearresteerd werd, omdat de politie zijn broer niet kon vinden) is, na een langdurig verblijf te Vught, na de bevrijding tengevolge van geleden ontberingen overleden.

Te Muntendam, waar de staking wel een algemeen karakter droeg, maar zich geen bijzondere gebeurtenisen afspeelden, ging men, evenals te Oudeen Nieuwe-Pekela, Maandagochtend weer aan het werk.

In Veendam en Wildervank, twee plaatsen die economisch beschouwd één 
geheel vormen, was men reeds Donderdagmiddag op de hoogte van de staking bij Stork-Hengelo. Duintjer's Radiatorenfabriek te Wildervank die in nauwe relatie staat met de fabriek van Stork, kreeg namelijk telefonisch bericht over de gebeurtenissen in Twente. Dit verklaart, dat reeds Donderdagmiddag overleg kon worden gepleegd, met het gevolg dat de staking in Duintjer's Radiatorenfabriek Vrijdagochtend om 8 uur begon. Even later verliet ook het personeel van Duintjer, Wilkens Meihuizen \& Co N.V. te Veendam (aardappelmeel, dextrine, glucose enz.) de fabrieksgebouwen. Men ging in alle orde heen, nadat men eerst nog een kooksel van glucose volgens de regels der kunst had behandeld.

Op straat was het niet zo rustig. Evenals te Oude en Nieuwe Pekela verzamelden zich groepjes demonstranten. De weinige winkeliers, die hun winkels nog niet hadden gesloten, kregen een wenk, dit te doen. Ongeveer 300 stakers, onder leiding van de slager Pol, trokken naar het gemeentehuis en de distributiedienst om de ambtenaren aan hun verstand te brengen, dat ze beter deden heen te gaan (hetgeen dan ook gebeurde). Er vond meer plaats, dat scherpe Duitse represailles had kunnen uitlokken. De burgemeester en de plaatselijke politie waren echter betrouwbaar en waarschijnlijk heeft de com mandant van een te Veendam gevestigde luchtmachtafdeling naar Groningen getelefonerd, dat alles rustig was (de Wehrmacht saboteerde wel meer het werk van de SD).

Wel kwam een Duits bevel, dat door de fabrikanten lijsten van stakers Zaterdag vóór 1 uur moesten worden ingeleverd. Dit werd geweigerd (slechts éen fabrikant leverde een dergelijke lijst in, doch deze werd door zijn compagnon weer weggehaald). Toen de SD hierover later opbelde, antwoordden de fabrikanten, dat zij niet precies wisten, wie hadden gestaakt. Waar een deel van het personeel staakte en het bedrijf moest worden stopgezet, gingen ook werkwilligen naar huis. Zondag vond overleg tussen fabrikanten en fabriekskernen plaats, waarbij men tot de conclusie kwam, dat het raadzaam was, Maandag aan het werk te gaan. Toen de Duitse politie Maandagmorgen kwam controleren, was te Veendam de rust weergekeerd.

Te Wildervank staakte men Vrijdag - nadat het sein daartoe was gegeven door het personeel van de Radiatorenfabriek M. Duintjer \& Zn. (150 man) op de meest eendrachtige manier. Zowel het personeel van grote bedrijven (b.v. van de N.V. Tricotagefabriek A. Schmidt $\& \mathrm{Zn}-280$ personen) als de kleine winkeliers sloten zich in het verzet aaneen. Er heerste Vrijdag een opgewonden, bijna feestelijke stemming. Evenals te Veendam liepen vele arbeiders in hun beste pak te flaneren. Het kan ons verbazen, dat ook te Wildervank geen slachtoffers vielen en zelfs geen enkele arrestatie plaats vond. Vermoedelijk waren de Duitsers van mening, dat de executies te Hoogezand en te Scharmer wel voldoende angstaanjagend waren. Naar daden van sabotage in de buurt van Wildervank (het versperren van de spoorlijn ZuidbroekStadskanaal, het stopzetten van de radiodistributie) is zelfs geen ernstig onderzoek ingesteld. 
Te Stadskanaal staakte Vrijdag het gemeentepersoneel. Ook hier werd de verminderde druk op de waterleiding als een stakingssignaal opgevat. Zater dag luwde de optimistische stemming van de vorige dag. Men trachtte de situatie zo nuchter mogelijk te beoordelen; indien de spoorwegen niet staakten, was het spel verloren. Te Musselkanaal kwam het tot een wilde schietpartij bij het doortrekken van een Duitse patrouille. Mej. G. Dekker verloor hierbij het leven; zes personen werden naar concentratiekampen gezonden. Te Ter Apel staakten 150 man van de Ago-fabrieken N.V., in Sellingen concentreerde zich de staking op de Coöperatieve Zuivelfabriek. Vrijwel overal in de gemeenten Wedde, Onstwedde en Vlagtwedde zetten de boeren de melklevering stop en bleven de landarbeiders thuis, op dezelfde wijze als in het gehele veenkoloniale gebied de plattelandsstakingen gedurende enkele dagen beroering brachten in de dorpen (waar uiteraard ook vele industriearbeiders woonden, die door hun thuisblijven nog duidelijker de crisissituatie demonstreerden). Hetzelfde geldt voor de nog afgelegener gemeenten Nieuwe Schans en Bellingwolde, waar geen slachtoffers vielen, in tegenstelling met het Westelijk grensgebied van de provincie. Er had reeds genoeg bloed gevloeid.

In geen enkele andere provincie hebben de April-Mei-stakingen zoveel mensenlevens gekost als in Groningen. Vermoedelijk zal ook in weinig andere delen van het land de verbittering zó zijn toegenomen als in de Veenkoloniën en in het Groningse Westerkwartier. 


\section{HOOFDSTUK VI}

\section{LIMBURG}

De grootste concentratie van arbeiders en de organisatorisch meest kwetsbare punten vindt men in Limburg in het mijngebied. Daar is de Limburgse stakingsbeweging dan ook begonnen. Ook in het beeld van de gehele Nederlandse stakingsactie nemen de mijnsteden en -dorpen een belangrijke plaats in wat het aantal stakers in één bedrijfstak betreft zelfs de eerste plaats. Dit feit is des te opmerkelijker, omdat de Duitsers de mijnen onder strenge contrôle hielden, terwijl men verwachten kon, dat zij tegen iedere stagnatie in het bedrijf de scherpste maatregelen zouden nemen.

De gebeurtenissen in het mijngebied verduisteren enigermate de stakingen in andere delen van Limburg, van Zuid-Limburg in het bijzonder. Er is ook te Maastricht fel gestaakt. In veel mindere mate op het platteland. In de meeste Zuid-Limburgse dorpen trok alleen het thuisblijven van de mijnwerkers de aandacht. De meeste boeren werkten rustig door. Slechts de melkleveranties werden stopgezet. Men kan voor Zuid-Limburg ternauwernood spreken van een plattelandsstaking, tenzij men de in de dorpen wonende mijnwerkers als plattelanders wil beschouwen. De handeldrijvende middenstand in de dorpen heeft zich zeker niet door verzetsgeest onderscheiden.

Hoe verklaren wij het felle staken van de mijnwerkers? Wij mogen het slechts ten dele toeschrijven aan het Limburgse volkskarakter, want slechts een beperkt percentage van het ruim 40.000 man omvattende personeel van de mijnen is van Limburgse bloede. Veel vreemdelingen hebben zich hier gevestigd. De Zuid-Limburgers kenmerken zich door temperament. Hun enthousiasme is spoedig gewekt, maar bij tegenslag geeft men ook gauw de moed op. Dr W. Roukens, een der beste kenners van de Limburgse volkskarakters 1), meent bij de Zuid-Limburgers een neiging tot dwarsdrijven en politiek saboteren te kunnen opmerken. $Z_{i j}$ zijn van nature gemoedelijk, maar geprikkeld als hun iets bevolen wordt. Kenmerkend is voorts hun solidariteit en sociaal gevoel; eveneens hun gehechtheid aan de grond. Laatstgenoemde eigenschap verklaart, dat zoveel mijnwerkers hun geboortedorp trouw bleven; zij deden liever lange reizen dan in de buurt van het werk te gaan wonen. Van de ruim 40.000 mijnwerkers en ander mijnpersoneel gingen in 1943 18.500 te voet naar hun werk, 13.000 (gemiddeld $5,5 \mathrm{~km}$ van hun werk-

1) W. Roukens, De Limburgers, in P. J. Meertens en Anne de Vries, De Nederlandsche Volkskarakters, 1938. 
plaats afwonend) te fiets, 3300 met de tram, 3700 (gemiddeld $18 \mathrm{~km}$ reizend) met bussen, 5000 (gemiddelde reisafstand $20 \mathrm{~km}$ ) met de trein en 4000 (gemiddelde reisafstand $23 \mathrm{~km}$ ) met trein èn bus. 16.000 man maakten dus van moderne vervoermiddelen gebruik, een feit, dat zowel voor het uitbreken als voor de verbreiding van de staking van betekenis is geweest.

De invloed van het streekkarakter heeft zich weliswaar doen gelden, maar kan toch niet de doorslag hebben gegeven. Wij moeten op andere factoren de aandacht vestigen. Evenals elders heerste in Zuid-Limburg veel verbittering over de toenemende druk, die de bezettende macht uitoefende. Over de lonen en over de levensmiddelenvoorziening - de Duitsers zagen de mijnwerkers enigermate naar de ogen - was men niet ontevreden, maar de Duitse contrôle en de leugenachtigheid van hun krantenberichten irriteerden de massa. Bergassessor Bruch, door Seyss-Inquart aangesteld als gemachtigde van de mijnbouw hier te lande, had overal zijn spionnen. Het verzet groeide, naarmate de berichten van de oorlogsfronten gunstiger werden en de propaganda van Radio-Oranje meer indruk maakte. De verklaring van Generaal Christiansen van 29 April 1943, die stellig enkele mededelingen over vrijstellingen voor de vitale bedrijven had kunnen bevatten, werd te Heerlen Donderdag in de loop van de middag bekend (telexbericht en persbulletin). Onmiddellijk ontstond enige deining op straat. Hier en daar liep men te hoop om de zaak te bespreken; in sommige bedrijven viel het eerst het woord "staking". Illegale kernen kwamen in actie, een pamflet werd ontworpen. 's Avonds vond in het R.K. Volkshuis te Heerlen een geheime vergadering plaats, meest van reserveofficieren, die zich door de verklaring van Christiansen het meest bedreigd voelden. Er waren ook anderen aanwezig, o.a. Jan Manen, een vooraanstaande figuur in de katholieke vakbeweging. Ook in Limburg fungeerden leiders van ontbonden vakorganisaties nog steeds als vertrouwensmannen. De volgende dag verscheen, voor het eerst na langdurige onderbreking (in 1942 waren de redacteuren gearresteerd), weer een nummer van het illegale blad Het Vrije Volk.

Hoewel hier dus sporen van leiding zijn aan te wijzen, kan men toch moeilijk zover gaan, te zeggen, dat Donderdagavond de staking van de nachtploeg van de Staatsmijn Maurits op initiatief van bepaalde stakingsleiders uitbrak. Ook met de constatering, dat de staking van die groep arbeiders op dat ogenblik "spontaan" begon, komt men niet veel verder. Wil men iets verklaren, dan moet o.a. rekening worden gehouden met enige bedrijfs- en sociaal-psychologische verschijnselen.

In de eerste plaats zal het niemand, die de mijnwerkers kent, verbazen, dat juist de ondergrondse arbeiders het eerst staakten. De „ondergronders" kenmerken zich door een zeer sterk ontwikkeld solidariteitsgevoel en een krachtig zelfbewustzijn. Het zijn mannen van weinig woorden, die goed een (geheim kunnen bewaren. De ruim 1000 arbeiders van de nachtploeg van de Staatsmijn Maurits besloten na een bespreking bij de ingang van de mijn, niet naar beneden te gaan. Aan het kort overleg bij de mijn was voor een 
gedeelte van deze arbeiders reeds een langere samenspraak voorafgegaan.

De arbeiders van de Staatsmijn Maurits bij Heerlen - het grootste mijnbedrijf van Limburg, dat met ruim 10.000 man personeel bijna $1 / 4$ van de Nederlandse kolenproductie voor zijn rekening neemt - komen van heinde en ver (vgl. bovenstaande opgave van reisafstanden). Een groot aantal arbeiders van de dag- en van de nachtploegen reist met bussen. Het was in April 1943 al niet anders dan daarvóór, bij andere stakingen: lange busreizen oefenen invloed uit op de houding van de mannen. Menige staking werd in de bus geboren. Zo ook deze, naar met hoge mate van waarschijnlijkheid mag worden beweerd. Het is sociaal-psychologisch volkomen begrijpelijk, dat in een volle bus versterkte groepsgevoelens tot uiting komen. Er zijn altijd enige woordvoerders, die krasse termen gebruiken. De een wil niet voor de ander onderdoen. Al reizende wordt de stemming moediger en moediger. Arbeiders, die met hun drieën of vieren naar hun werk lopen, en wie de wijze vermaningen van hun vrouwen nog in het geheugen blijven (vrouwen zijn, voorzover het stakingsplannen van hun mannen betreft, allerminst emotioneel) komen doorgaans in kalmer gemoedstoestand aan dan degenen, die uit een bus stappen, waarin enkelen het hoogste woord hebben gevoerd.

Het is geen gewaagde veronderstelling, dat Donderdagavond 29 April de busreizigers - arbeiders van de nachtploeg - aan anderen te kennen hebben gegeven, dat zij van plan waren, na kort overleg met hun Heerlense collega's de terugreis te aanvaarden. De bussen liepen weer vol, men ging huiswaarts. Een opzienbarend feit, dat spoedig algemeen bekend werd. De stakers wisten wat hun te doen stond. De volgende ochtend, Vrijdagochtend 30 April, postten zij bij de bussen, die de arbeiders van de dagploegen van de Staatsmijn Maurits zouden vervoeren. Deze arbeiders bleven uit solidariteit nu ook thuis. Te Heerlen kwam het werk in de Staatsmijn Maurits, evenals in de cokesfabriek en in het stikstofbindingsbedrijf, volledig tot stilstand.

Bij de meeste particuliere mijnen met hun vaste, dichtbij wonende kernen van arbeiders, was het grootste gedeelte der arbeiders Vrijdagochtend wel verschenen, er heerste echter overal een opgewonden stemming. De staking bij ,de Maurits" werd druk besproken. Men kan zich voorstellen, dat men de arbeid langzaam en saboterend aanving. Wat in de mensen omging, is achteraf beschreven in brieven, in 1946 door het Rijksinstituut voor Oorlogsdocumentatie ontvangen.

Een chef van de kolenwasserij en van losvloer en zeverij van de mijn „Emma" schreef b.v.:

„Op weg naar de mijn sprak ik niemand, de afstand is kort en er is weinig verkeer. Ik ging, zoals altijd, naar binnen bij de cokesfabriek-Emma. Het was half acht. Onder in de wasserij trof ik een bankwerker, een $100 \%$ Nederlander. Hij had alleen maar een blauwe kiel over zijn kleren aangetrokken. Wij keken elkaar aan en verstonden elkaar zonder iets te zeggen. "Hoe is het boven?" vroeg ik. "Alles draait," was het antwoord, dat machteloze woede inhield. Ik ging naar boven naar mijn kantoor. Overal hing een gedrukte stemming, waarbij het tempo, dat de electromotoren onderhielden, uitdagend 
aandeed. Ik belde de losvloer op: „Hoe is het bij jullie?" „Alles draait," was het antwoord. Ik kon een lelijk woord niet onderdrukken. Een monteur stond naast mij, een oud-militair. Dat woord van mij was de druppel, die de maat vol deed zijn. "Ik ga naar huis, chef," sprak hij mij aan toen ik de haak neerlegde. "Neen," flitste het door mijn hoofd, "niet enkele slachtoffers en dan nog wel de beste en zeker niet door een woord van mij, al was het ook niet zo bedoeld." I $k$ trachtte hem te overtuigen, zijn besluit stond echter vast; verlof dan, accoord. Hij hield het toch niet meer uit tussen die draaiende machines. Even later komt een voorman binnen: „Er zijn mensen, die verlof wensen." „Nu ja, geef ze verlof." Even later komt een hulp-wasmeester: „ik heb geen mensen voor de fijnkoolverlading en voor de 0-90 vloer," deelt hij mede.

Zo deserteerde de een na de ander: bij de Staatsmijn Emma, bij de Staatsmijn Wilhelmina en Hendrik, enz. Overal kwamen Vrijdag de wielen in de schachtbokken tot stilstand, de hartslag van de mijn stagneerde."

Te Heerlen werd het druk op straat. Bij het begin van de kantoortijd bleven de ambtenaren van het hoofdgebouw der Staatsmijnen op straat staan praten (400 à 500 personen). Bijna niemand scheen er voor te voelen, naar binnen te gaan. Plotseling verscheen een kleine autobus, waaruit Duitse officieren en enige manschappen stapten, voor het hoofdgebouw. Enige ambtenaren werden onder bedreigingen het hoofdgebouw ingedreven, terwijl op straat arrestaties plaatsvonden.

Het doortastend optreden van de Duitsers kon niet meer verhinderen, dat ook op andere Heerlense bureaux en kantoren werd gestaakt. In de loop van de ochtend, 30 April, begon een staking bij gemeentewerken (ongeveer 120 personen). Ook het personeel van de distributiedienst legde het werk neer; evenzo het tractiepersoneel van het station te Heerlen. 's Middags begon een staking op het postkantoor. Voormannen van ontbonden ambtenaren- en arbeidersorganisaties gaven het stakingsparool door; met de geestelijkheid werd overleg gepleegd. Pamfletten gingen van hand tot hand. Vrijdagmiddag staakten alle mijnen, met inbegrip van de beide bruinkoolbedrijven, de Carisborg te Treebeek en de Energie te Brunssum. Van de middagploegen der gezamenlijke steenkolenmijnen bleef de 30ste April $92 \%$ van de arbeiders weg. Nog groter was het aantal stakers in de ochtenddienst van de 1ste Mei, toen namelijk van een bezetting van 16.986 ondergrondse arbeiders er 15.216 niet opkwamen 1).

De Duitse gemachtigde, Bergassessor Bruch, was bij het uitbreken van de staking afwezig. Toen hij Vrijdag terugkeerde, bleek hij in een nerveuze en driftige stemming te zijn. Hij stelde de directeuren van de Staatsmijnen aansprakelijk en verzocht Ir D. P. Ross van Lennep, hem de namen der stakende arbeiders en ambtenaren op te geven. Het antwoord luidde, dat aan dit verzoek niet kon worden voldaan.

Zaterdagochtend $1 \mathrm{Mei}$, na een nacht waarin vele arrestaties hadden plaatsgevonden, werden Ir Ross van Lennep en Mr Haex in het hoofdgebouw van de Staatsmijnen, waar zij hun werkkamers hadden naast die van Bruch, bij de Assessor ontboden. Bruch deed hun wilde verwijten en eiste opnieuw de

1) Verslag van de Inspecteur-Generaal der Mijnen over de jaren 1940-1945, blz. 7. 
inlevering van personeelslijsten. Dit werd geweigerd. Bruch kreeg toen een aanval van woede; ook de Nederlanders sloegen met de vuist op tafel. Bruch deelde mede, dat het standrecht die dag zou worden afgekondigd. Hij was van plan te Maastricht overleg te plegen met het hoofd van de Duitse politie in Limburg, Strobl. Tegen het eind van de ochtend hield Bruch een vergadering met de directeuren van alle staats- en particuliere mijnen, waarbij nogmaals de eis tot inlevering van personeelslijsten werd gesteld. Half zes moest de directie nogmaals aantreden. Wéér verlangde Bruch inlevering van lijsten van stakers, thans op grond van het standrecht.

De directies hadden intussen al biljetten laten ophangen met de raad, de werkzaamheden te hervatten. Toen Bruch met talrijke executies dreigde, verklaarden de directeuren zich bereid, aan alle bedrijfsingenieurs opdracht te geven, de arbeiders van de Zaterdag-nachtploeg te bewegen, weer aan het werk te gaan. Lijsten van stakers wilden zij echter niet inleveren. Door middel van huisbezoek, door inschakeling van burgemeesters, met aanplakbiljetten en met hulp van de radio-omroep trachtten de directeuren de bedrijfsleiders en de nachtploeg zo volledig mogelijk aan het werk te krijgen. Men wist, dat er vele slachtoffers zouden vallen, als men geen concessies deed. Een aantal gearresteerde arbeiders en ambtenaren, door de Duitsers te Maastricht gevangen gezet, diende inderdaad als gijzelaars.

Alles hing er nu van af, welke percentages van de nachtploegen Zaterdagavond op het appèl zouden verschijnen. De Duitsers oefenden strenge contrôle uit. Volgens hun politierapport verschenen van de nachtploeg 1 Mei:

Staatsmijn Maurits
Staatsmijn Emma
Staatsmijn Hendrik
Staatsmijn Wilhelmina
Mijn Oranje-Nassau I
Mijn Oranje-Nassau II
Mijn Oranje-Nassau III
Mijn Oranje Nassau IV
Mijn Willem-Sophie
Domaniale
Laura
Juliana

\begin{tabular}{|c|c|c|c|}
\hline 768 arbeiders & (norm & an & 1518) \\
\hline $595 \quad$, & $(\quad$, & , & 1050) \\
\hline 312 & , & ", & 812) \\
\hline 487 & , & " & 556) \\
\hline 260 &, & ," & $250)$ \\
\hline 213 & , & ,. & $270)$ \\
\hline 258 & , & ", & 265) \\
\hline 131 & , & , & $110)-$ \\
\hline 85 & ," & , & 201) \\
\hline " & , & , & 275) \\
\hline " & , & , & 225) \\
\hline ", & , & , & $320)$ \\
\hline
\end{tabular}

De vele arrestaties en geruchten over doodvonnissen hadden de schrik er wel in gebracht. Sommige arbeiders, die niet eens bij een nachtploeg behoorden, kwamen zich toch maar melden. Dit verklaart dat bij enkele mijnen (OranjeNasau I en IV) de nachtploegen groter werden dan zij behoorden te zijn. $B i j$ de Staatsmijnen, met hun veel meer verspreid wonende arbeiders, was het opkomstpercentage uiteraard het laagst.

Zaterdagavond werd Ir J. B. van der Drift, hoofdingenieur bij de Staatsmijn Emma, gearresteerd. De SD, die om 8 uur 's avonds bij "de Emma" kwam controleren, of er wel voldoende arbeiders aanwezig waren, beschuldigde 
Ir van der Drift er van, dat hij zich niet voldoende moeite had gegeven de nachtploeg zo volledig mogelijk bijeen te krijgen. Ir van der Drift wees er op, dat de Duitsers te vroeg begonnen waren: de ploegwisseling begon gewoonlijk immers pas om kwart over negen. Voor deze logica waren de SDmannen echter niet vatbaar. Bruch zag wèl de onbillijkheid van deze arrestatie in. Hij stelde zich rechtstreeks in verbinding met Rauter, doch deze verwees hem naar Strobl. Bruch begaf zich toen 's nachts met Ir Ross van Lennep naar Maastricht, waar hij een langdurig onderhoud had met Strobl. Strobl $z e i$, dat hij eerst een politierapport moest, afwachten.

Zoals gewoonlijk, werkten de Duitse instanties weer tegen elkaar in. Bruch was van mening, dat de situatie zich voor de Duitsers gunstig ontwikkelde. De opkomst van de nachtploegen bleek niet onbevredigend; men deed beter, voorlopig een afwachtende houding aan te nemen. De SD dacht er anders over. Tegen alle beloften in, liet Strobl in de nacht van Zaterdag op Zondag twintig arbeiders arresteren.

Zondag 2 Mei vond een onderhoud plaats tussen de directieleden Ir Ross van Lennep en Ir J. Mous. Zij waren betrekkelijk optimistisch gestemd. Om verwarring te voorkomen bij de gewone ploegwisseling (de nachtploegen krijgen dan dagdienst) op Maandagochtend, besloten zij, een circulaire te laten verspreiden met de mededeling, dat deze keer geen ploegwisseling zou plaats vinden. leder bleef in de dienst, die hij vóór de staking vervulde. Deze bekendmaking werd in het gehele mijngebied, van Roermond tot Eysden en Vaals, verspreid.

Zondagmiddag werden Mr Haex en de ingenieurs Mous en Schweitzer bij Bruch ontboden, die hun de ernstige mededeling deed, dat er executies, o.a. van twee mijnwerkers, hadden plaatsgevonden. Hij had dit tot zijn spijt niet kunnen verhinderen. Maandagochtend werden de namen van de slachtoffers gepubliceerd. Het waren de drie controleurs bij de C.C.D. M. Bouman, B. Ruyters en L. Brouwer, de chemicus J. Boogerd uit Roermond, de electromonteur R. Savelsberg uit Heerlerheide, de mijnwerkers M. Tempelaars uit Heerlerheide en S. H. Toussaint uit Amstenrade. Deze terechtstellingen maakten diepe indruk op de bevolking.

Maandagochtend 3 Mei kwamen de dagploegen evenwel minder volledig op dan men had verwacht, ten dele tit protest tegen de terechtstellingen:

Staatsmijn Maurits
Staatsmijn Emma
Staatsmijn Wilhelmina
Staatsmijn Hendrik
Mijn Oranje-Nassau I
Mijn Oranje-Nassau II
Mijn Oranje-Nassau III
Mijn Oranje-Nassau IV
Willem-Sophie
Domaniale
Laura
Juliana

Staatsmijn Maurits

Staatsmijn Wilhelmina

Staatsmijn Hendrik

Mijn Oranje-Nassau I

Mijn Oranje-Nassau III

Mijn Oranje-Nassau IV

Willem-Sophie

Laura

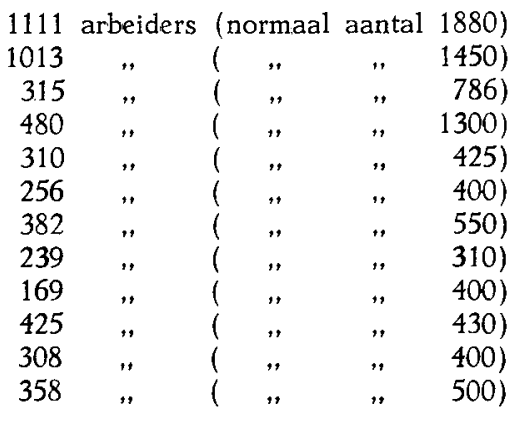


Bij deze onvoltallige bezetting bleef de productie ook die dag nog beneden de normale. Eerst de 4 de Mei vertoonde ze weer een flinke stijging, zoals uit onderstaand staatje blijkt ${ }^{1}$ ):

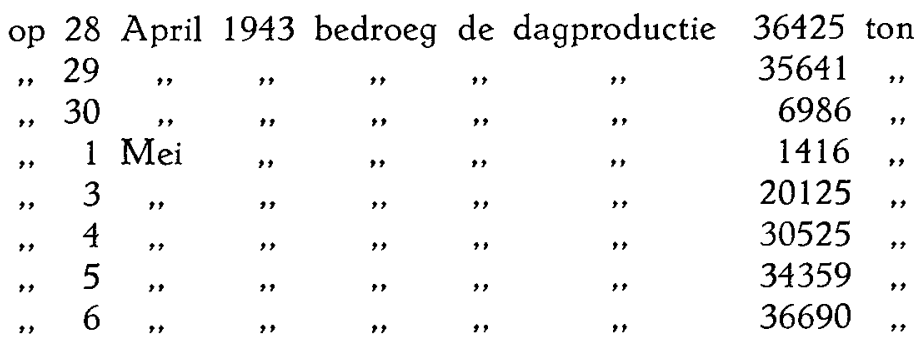

Opnieuw bleek de groepssolidariteit der ondergrondse arbeiders. Van de bovengrondse arbeiders en het kantoor - en technisch personeel verscheen een hoger percentage. Maandag vonden weer talrijke arrestaties plaats, vooral bij de Staatsmijn Emma. (Ir Paulen en vele arbeiders). In de loop van de dag werden deze arrestanten naar Maastricht vervoerd. Over tien van hen sprak het Standgericht het doodvonnis uit, doch het vonnis werd niet ineens voltrokken (wel bekend gemaakt). In de meeste Limburgse steden en dorpen was de staking Maandagochtend reeds geëindigd. De directies van de Staatsmijnen en de particuliere mijnen waren van mening dat ook de mijnwerkers in de loop van de dag wel weer aan het werk zouden gaan. De Duitsers hadden met hun intimidatiemethoden succes gehad. Maar nu plotseling maakten zij van het niet-inleveren van personeels- en stakerslijsten een prestigekwestie. Maandagochtend werden de directieleden van de Staatsmijnen en enige bedrijfsingenieurs bij Bruch ontboden 2). Bij het onderhoud dat nu plaats vond was Hauptsturmführer Strobl aanwezig. Enige Duitse politiemannen stonden stram in de houding, op tafel lag een groot plakkaat van het standrecht. Strobl sommeerde nu ieder van de directieleden individueel de stakerslijsten in te leveren. Ieder weigerde. Bruch deed alle moeite de Nederlanders tot toegeven te bewegen: "Es geht diesmal ums Leben. Denken Sie doch an Ihre Familie."

$\mathrm{Na}$ afloop van dit onderhoud begaven Ir Ross van Lennep en Ir Mous zich naar de directiekamer en stelden Mr Spitzen, Secretaris-Generaal van het Departement van Waterstaat, en Dr Hirschfeld, Secretaris-Generaal van het Departement van Handel, Nijverheid en Scheepvaart, van de gebeurtenissen op de hoogte. Onmiddellijk na dit telefoongesprek arresteerde de SD Ir Mous. Ook bij enige andere mijnen, waar men weigerde, de Duitsers lijsten van stakers te verstrekken, vonden nieuwe arrestaties plaats ${ }^{3}$ ). Bij de Staats-

1) Verslag van de Inspecteur-Generaal der Mijnen over de jaren 1940-1945, blz. 8.

2) Het waren de heren Haex, Kremer, Lieshout, Schweitzer, de Groot, Mous en Ross van Lennep.

3) Bij de Staatsmijn Maurits de ingenieurs Bakker, van Vliet en Gerards en chef-administrateur Belderok, bij de Staatsmijn Emma Ir Paulen en de wnd. bedrijfsleider Postma. 
mijnen Wilhelmina en Hendrik waar men evenmin aan de Duitse eis had toegegeven, liet de SD de directieleden echter ongemoeid.

Maandagmorgen half elf werd Ir Ross van Lennep uit Den Haag opgebeld door Dr Hirschfeld, die hem het bevel van Rauter overbracht, de lijsten af te geven. Een herhaalde weigering. Daarna zei Dr Hirschfeld: „Dan draag ik U op, de lijsten af te geven." Ir Ross van Lennep antwoordde, dat Dr Hirschfeld daartoe niet bevoegd was. De Staatsmijnen ressorteren onder Waterstaat. Dr Hirschfeld deelde toen mede, dat het voor de Duitsers louter een prestigekwestie was geworden. Rauter had gezegd: „Hoewel de lijsten in dit stadium, nu het werk hervat is, ons niet meer interesseren, moeten ze toch afgegeven worden." Hij beloofde, dat verstrekking van de lijsten geen verdere gevolgen voor de arbeiders zou hebben. Bleven Ir Ross van Lennep c.s. weigeren, dan zou dit noodlottig worden voor de gevangenen te Maastricht.

Enige tijd later belde de Secretaris-Generaal Mr Spitzen op, die de directie van de Staatsmijnen bevel gaf, de door de Duitsers gevraagde lijsten in te leveren. Er mocht terwille van een prestige-kwestie geen bloed vloeien. $\mathrm{Na}$ overleg met zijn medewerkers besloot Ir Ross van Lennep toen aan het bevel te voldoen. Ook de directies van de andere mijnen gingen hiermede accoord. Men besloot lijsten op te maken van degenen, die Maandagochtend afwezig waren en daarbij aan te tekenen, dat de afwezigheid het gevolg kon zijn van misverstand (de afgelaste ploegwisseling!) ziekte of ongeval. Voor de Duitsers was het inderdaad slechts een prestigekwestie geworden; bij de Staatsmijn Hendrik b.v. kwamen twee SD-ers controleren, maar de lijsten, die men hun overhandigde, lieten zij op tafel liggen.

Ir Ross van Lennep kreeg later nog te horen, dat hij verkeerde lijsten had gegeven. De dreiging bleef. Dinsdag $4 \mathrm{Mei}$ werd bekend gemaakt, dat nog tien arbeiders ter dood waren veroordeeld, maar dat opschorting van executie, misschien zelfs gratie mogelijk was. Ook het lot van de andere gevangenen werd afhankelijk gesteld van de gang van zaken. Verbitterd en enigszins moedeloos gingen de arbeiders weer aan het werk. De Duitsers beijverden $z$ ich toen, de gemoederen te kalmeren; de 10 ter dood veroordeelde arbeiders kregen de 26ste Mei gratie (de doodstraf werd veranderd in 15 jaar tuchthuisstraf). Tenslotte werd zelfs het loon van de stakingsdagen uitbetaald.

De directeuren en bedrijfsleiders, die te Maastricht gevangen zaten, werden na drie weken overgebracht naar St. Michielsgestel en eerst 13 Juli 1943 vrijgelaten. De ingenieurs Maus, Van der Drift en Wijffels en de heer Belderok vernamen echter dat zij ontslagen waren.

$\mathrm{Na}$ Heerlen was Maastricht een stakingscentrum in Zuid-Limburg. Meer dan elders waren te Maastricht reeds vroegtijdig illegale kernen in actie. Men had er de mogelijkheden van een staking zelfs meermalen overwogen. De beide haarden van het illegale werk lagen in ambtelijke kring: bij de Rijksbelastingsdienst en bij de C.C.D. Deze groepen zijn er inderdaad in geslaagd, enige leiding te geven bij de gebeurtenissen van 29 April en de volgende dagen. Een van de chefs van het belastingkantoor, M. Bartels, belde reeds 
Donderdagmiddag, direct na het bekend worden van het telexbericht van Christiansen's beslissing, de secretarissen van enkele grote bedrijven op om hen in bedekte termen op de hoogte te brengen van de stand van zaken. Ook met verschillende rijksdiensten werd contact onderhouden. Een Donderdagavond doorgegeven stakingsparool bleek zeer effectief: Vrijdagochtend staakten de verschillende belastingdiensten, de Raad van Arbeid, het telegraafkantoor, het Provinciehuis, het landbouwproefstation, enz. Bij uitzonde-i ring gaven ambtenaren hier dus het voorbeeld. De besten van hen beschouwden zich als de natuurlijke leiders van het volk en hebben zich ook in de volgende jaren door onverschrokken illegaal werk een groot prestige verworven.

Het voorbeeld van de ambtelijke bureaux werd Vrijdagochtend 30 April gevolgd door de banken. Het bankpersoneel was 's morgens wel verschenen, maar liep in de loop van de ochtend weg, ook de ambtenaren van de gemeentesecretarie legden na enige uren het werk neer. Op straat werd het steeds drukker. Geleidelijk begonnen arbeiders hun fabrieken te verlaten. 's Middags 30 April droeg de staking een vrijwel algemeen karakter, vooral na de sluiting van de Sphinx en andere aardewerkfabrieken (in de aardewerk-en glasindustrie vinden ruim 4000 Maastrichtenaren werk).

De opgewekte aard van de Maastrichtenaren bleek ook deze keer. Men liep met glundere gezichten buiten, men bezocht cafés en riep elkander grappen toe. Op het postkantoor, waar men niet staakte onder pressie van talrijke NSB-ambtenaren, verdrong men zich om aan de loketten telkens één postzegel van 1 cent te kopen. $\mathrm{Na}$ afkondiging van het standrecht kalmeerde de stemming, maar sommigen toonden Maastrichtse humor, door 's avonds na acht uur, als iedereen binnen moest zijn, gramofoons voor de geopende vensters te laten spelen, totdat de SD ook hier ingreep.

Zaterdag werd het werk bij de meeste overheidsdiensten en bij enkele bedrijven hervat; Maandag was de staking te Maastricht vrijwel ten einde. Ze had zich beperkt tot een krachtige demonstratie, op advies van de illegale leiders bekort nadat deze zich er van overtuigd hadden dat de spoorwegen niet zouden staken. Het voordeel van deze stakingsdagen was, dat men meer doordrongen was geraakt van het nut van organisatie. De illegaliteit kon zich sneller ontplooien. Bovendien had men nieuwe ervaringen opgedaan met de SD. Men wist voortaan beter, wie men moest vrezen en welke politiemannen betrekkelijk ongevaarlijk waren. Ook was duidelijk gebleken, dat enige NSB-ers als provocateurs hadden dienst gedaan. Maar men had voor de versterking van de illegale beweging wel een hoge prijs betaald, de dood van drie van haar beste leden: het reeds genoemde drietal van de C.C.D. (M. Bouman, B. Ruyters en L. Brouwer), beschuldigd van verspreiding van stakingsmanifesten.

Minder gedisciplineerd maar wel even enthousiast als te Maastricht is te Sittard gestaakt. Het eerst vermoedelijk door thuisblijvende of terugkerende mijnwerkers. Daarna, in de loop van Vrijdag 30 April, door het personeel van de gemeentesecretarie, van de gemeentebedrijven en van het slachthuis. 
- Ook enkele spoorwegmannen liepen van hun werk weg. Hier en daar sloten enige winkels. In overeenstemming met de luidruchtigheid van de ZuidLimburgse volksaard hielden de stakers zich bij voorkeur op straat op. Er heerste een opgewonden, in menig opzicht zelfs feestelijke stemming. Zaterdag en vooral Zondag sloeg deze stemming om in neerslachtigheid. Van enige illegale leiding viel weinig te bespeuren; wel waren enige kapelaans zeer actief.

Buiten Heerlen, Maastricht en Sittard concentreerde de stakingsbeweging zich het meest in dorpen of gemeenten in de mijnstreek - soms rechtstreeks door aanwezigheid van een mijn op het gebied van een gemeente (Brunssum Staatsmijn Hendrik; Schaesberg - Staatsmijn Wilhelmina en Oranje-Nassau Mijn II), soms indirect als woonplaats van een groot aantal stakende arbeiders (Schinveld, Schinnen, Heerlerheide, Eigelshoven, Kerkrade, Simpelveld, Klimmen, Wijlre, Born, enz.).

Het staken van de mijnwerkers veroorzaakte hier en daar een staking tegen wil en dank bijvoorbeeld van vele busdiensten. Ook het tramverkeer SittardHeerlen-Kerkrade kwam tot stilstand. De ernstigste verkeersstagnatie vond plaats in het Julianakanaal, vooral op het traject Stein-Maasbracht. Hier deserteerde een aantal sleepbootkapiteins, met het gevolg, dat talrijke sleepaken bleven liggen. Zaterdag hebben $z$ ij na afkondiging van het standrecht, hun werk onder zware bedreigingen van de Duitsers hervat.

In enkele plaatsen is door het gemeentepersoneel één dag, bij uitzondering ook wel eens anderhalve dag, gestaakt. Slechts zelden werden er winkels gesloten. Evenals in Brabant trachtten sommige boeren te profiteren van het staken van de C.C.D.-ambtenaren (een van de actiefste anti-Duitse groepen in heel Limburg). De melkaflevering aan de zuivelfabrieken stagneerde bijna overal in de provincie tot Zondag, soms een dag langer. De ,,melkstaking" verliep op dezelfde wijze als in andere provincies, met wisselende vormen van initiatief, uitgaande van boeren, van melkrijders of van de fabrieken zelf. De boeren verkochten melk aan het publiek, echter zelden tegen te hoge prijzen. Te Eysden en enige andere plaatsen staakten de groentenveilingen. De Duitse politie concentreerde alle aandacht op de stedelijke stakingshaarden, vooral op de Staatsmijnen. Invloed van de geestelijkheid was duidelijker in de steden dan op het platteland merkbaar, in Noord- en Midden - vermoedelijk meer dan in Zuid-Limburg.

Verschillende waarnemers bevestigen dat de bevolking van Midden en Noord-Limburg meer zelfbeheersing aan de dag legde dan de bevolking van Zuid-Limburg. Terwijl het bijvoorbeeld Vrijdag 30 April te Maastricht en te Sittard heel druk was op straat, bleef het te Roermond rustig. Men merkte er minder van staking, hoewel men er op ruime schaal het werk had neergelegd. Gebeurde dit misschien op advies van de geestelijkheid, die te Roermond een krachtige invloed uitoefende op deze verzetsacties? (Eén van de voormannen van het verzet was drs L. Moonen, secretaris van de bisschop van Roermond). Voor zover wij konden nagaan - concrete gegevens zijn 
voor deze vraag moeilijk statistisch te groeperen - heeft de Limburgse geestelijkheid meer risico gedragen dan de Brabantse. $Z_{i j}$ trad o.a. voor hulp aan onderduikers, juist in Limburg bijzonder sterk georganiseerd op. Waar op een gevaarlijke post een pastoor of een kapelaan gearresteerd werd, zag men hem direct door een ander vervangen - totdat deze op zijn beurt naar een Duits concentratiekamp verdween. Zo zijn er in Limburg ongeveer 70 geestelijken gearresteerd, van wie er 24 om het leven kwamen.

De staking te Roermond ging meer van ambtenaren en hoger technisch personeel dan van de arbeiders uit. Het personeel van de overheidsdiensten (P.T.T., Waterstaat, de distributiedienst, C.C.D., enz.) legde Vrijdag het eerst het werk neer, daarna kwam de riviervaart tot stilstand. Tenslotte ook de meeste particuliere bedrijven: een garage-transportbedrijf, een meelfabriek, een emballagefabriek en twee chemische fabrieken. Bij de Eci, de Electro-Chemische Industrie, hadden bij de stakingen vooral de technici de leiding. Eén van hen, de chemicus J. Boogerd, moest dit met de dood bekopen. Met grote vastberadenheid werd ook gestaakt in de naburige gemeente Herten, in de N.V. Patent en Kristalsodafabriek. De arrestatie van een aantal arbeiders en technici en het doodvonnis, dat over Boogerd werd uitgesproken, werkten deprimerend. Desondanks werd bij de chemische fabrieken ook nog de gehele Maandag gestaakt (de overheidsdiensten hadden ten dele het werk Zaterdag hervat, de meeste particuliere bedrijven Maandag ochtend).

Een illegale kern, waarvan Bob Bouman van de C.C.D. een der voormannen was, had voor de verspreiding van pamfletten gezorgd. Dit werd Bouman noodlottig. De Duitse politie, die reeds geruime tijd speciale verdenking koesterde jegens de C.C.D., arresteerde enkele ambtenaren van deze dienst, die pamfletten bij zich droegen. Nadat gedreigd werd, deze ambtenaren te fusilleren, indien Bouman zich niet meldde, gaf hij zich vrijwillig aan. Een ridderlijk man, deze oud-Indisch officier (organisator van de eerste etappedienst om buitenlandse ontvluchte krijgsgevangenen te helpen - hij bracht o.a. 25 piloten in veiligheid). Zondag 2 Mei werd hij neergeschoten.

In de plattelandsgemeenten tussen Sittard en Roermond is vrij algemeen gestaakt, evenwel met voorzichtigheid en overleg. Duitse contrôle was hier nagenoeg niet, maar het lag nu eenmaal niet in de aard van deze bevolking, zich tot het uiterste te verweren. Men mag niet uit het oog verliezen dat de Limburgse landarbeider eigenlijk niet weet, wat "staken" is. Het begrip is hem geheel vreemd. Aarzelend bleef men in vele dorpen enige dagen thuis. Nauwkeurige herinneringen aan deze voor sommige steden zo critieke dagen schijnt men er niet meer te hebben. Ten Noorden van Susteren en Echt woonden geen mijnwerkers. Het stopzetten van de vaart op het Julianakanaal en de sluiting van een aantal fabrieken te Roermond maakte op het platteland weinig indruk. Het duidelijkste stakingssignaal voor de dorpelingen was het tot stilstand komen van vrijwel alle zuivelfabrieken en het wegblijven van 
de melkrijders. In sommige gemeenten waren de gemeente-secretarieën één of meer dagen gesloten.

De Landstand bleef in Limburg volkomen passief. Waar NSB-burgemeesters aangesteld waren, kreeg de Duitse politie wel eens aanwijzingen voor arrestaties (te Neer b.v.). Van opstandige daden, zoals in de Noord-Westhoek van Noord-Brabant, was in Midden-Limburg geen sprake. De bevolking was er solidair, anti-Duits, maar niet bijzonder fel. Alle berichten uit Echt, Stevensweerd, Beegden, Maasbracht, Linne, St. Odiliënberg, Vlodrop, Horn, Heithuizen. Halen of Swalmen getuigen van het gematigd karakter van de MiddenLimburgse plattelandsstaking.

Een enigszins afzonderlijke positie neemt de industrieplaats Weert in, met haar sterk op België georiënteerde, vrij impulsieve bevolking. Hier liet zich de invloed van de concentratie van industrie-arbeiders gelden. De staking begon er Vrijdagmorgen 30 April spontaan, gelijktijdig bij boeren, landarbeiders, fabrieksarbeiders en middenstanders. Grote bedrijven, die door de staking uitgeschakeld werden, waren N.V. Smeets Drukkerijen, de N.V. Tricotagefabrieken, N.V. Halberg's Machinefabriek en Scheepswerf en de Aluminiumfabriek. Ook de zuivelfabriek werd gesloten. Ondanks Duitse dreigementen hield de staking Maandag aan, ook al werd het niet-staken van de spoorwegen opgevat als het teken dat verder verzet niet zou baten. Na enig Duits militair machtsvertoon keerde Weert Dinsdag $4 \mathrm{Mei}$ terug in het gareel van een Limburgs stadje in bezettingstijd. Er werd weer gewerkt, maar langzaam en saboterend.

Ten slotte Noord-Limburg. Deze streek is meer naar Gelderland georiënteerd. $Z_{i j}$ heeft een kalme, gemoedelijke bevolking, die minder spontane trekken vertoont dan de bewoners van Midden- en Zuid-Limburg. Als wat vuriger en emotioneler dan naburige dorpen staat Tegelen bekend. Daar is dan ook in de industrie (steen- en pannenfabrieken en ijzergieterijen) en in het agrarisch bedrijf heftiger gestaakt dan elders. Eerst Maandagmiddag, onder bedreiging van de SD, die speciale aandacht aan het weerspannige Tegelen schonk, werden de werkzaamheden door een gedeelte van de arbeiders hervat. Enkelen staakten nog door tot Woensdag.

Te Venlo begon de staking na zorgvuldig overleg. De gehele Vrijdagochtend werd er door het gemeentepersoneel en andere overheidsdiensten beraadslaagd. Het personeel van de gemeente-secretarie, van de P.T.T., van de distributiedienst en van de Raad van Arbeid kwam 's middags na het schaftuur niet meer terug. lets spontaner reageerden de arbeiders, die in de loop van de dag groepsgewijze het werk neerlegden en de fabrieken verlieten of na het schaftuur niet meer terugkeerden (Chemische fabriek L. van der Grinten, N.V. Pope's Metaaldraadlampenfabriek, N.V. Ned. Instrumentencompagnie, enz.). De haven lag stil en verlaten. De sleepboten waren door het personeel verlaten, enkele schepen vertrokken leeg en met onbekende bestemming. Ook het douanepersoneel ging naar huis. Door verspreiding van pamfletten nam de staking Zaterdag 1 Mei een nog grotere omvang aan, 
maar de stemming was toen reeds pessimistisch. Zolang de ene trein na de andere over de spoorbrug rolde, had men zekerheid, dat niet van een nationale, algemene staking kon worden gesproken. Maandag was de staking geëindigd.

Op het Noord-Limburgse platteland was de staking van de zuivelfabrieken, o.a. van de grote zuivelfabrieken te Horst, het meest opvallende verschijnsel. Blijkbaar hebben de melkrijders hierbij de actiefste rol vervuld. Dat onder hen een geest van sabotage voorkwam, blijkt uit een bericht uit Ottersum, ten Noorden van Venlo. Bij dat dorp lieten de melkrijders opgehaalde melk in het riviertje de Niers lopen.

Het busverkeer heeft Vrijdag 30 April bijna overal stilgestaan. Te Arcen staakte het personeel van de bierbrouwerij ,de Vriendenkring". Ook andere plattelandsindustrieën, o.a. enige kleine meubelfabrieken en houtzagerijen, moeten naast de stakende zuivelfabrieken worden genoemd. Als een staaltje van Limburgse humor zij nog vermeld, dat in de omgeving van Venray op 30 April een wagen van de C.C.D. rondreed, waaraan een bundel hoog boven de wagen uitstekende bonenstaken was bevestigd: het signaal "staken" werd goed begrepen! 


\section{HOOFDSTUK VII}

\section{NOORD-BRABANT}

Indien men ook voor Noord-Brabant een ,,spontaan" uitbreken van de AprilMei-stakingen heeft kunnen waarnemen, zo mogen hier toch wel enige restricties gelden. Men staakte spontaan, maar niet zonder leiding. Spontaan, omdat ook in Brabant de Duitse druk in de loop van 1942 en in de eerste maanden van 1943 zodanig verzwaard was, dat er slechts enkele druppels voor nodig waren om de emmer te doen overlopen. Betrekkelijk gedisciplineerd, omdat de bevolking gewend was, onder leiding te handelen. Een zekere mate van bedachtzaamheid en overleg kan worden afgeleid uit het feit dat in NoordBrabant meer dan in enige andere provincie vele stakingen eerst op 1 Mei en zelfs 3 Mei begonnen en na dit late begin aanhielden tot 4 of 5 Mei.

$\mathrm{Bij}$ de voorgeschiedenis van de staking moet wel in aanmerking worden genomen, dat het organisatorisch leven, dat juist in Noord-Brabant zo sterk ontwikkeld is, door Duitse maatregelen ernstig was ontwricht. Algemene verontwaardiging had ook de aantasting van het katholieke onderwijs veroor zaakt, vooral op het platteland, waar vele land- en tuinbouwscholen en het landbouwhuishoudonderwijs onder toezicht hadden gestaan van organisaties, die in 1942 hadden moeten wijken voor de Duitse drang naar politieke gelijkschakeling. De Landstand had zich meester gemaakt van de bezittingen van de R.K. Nederlandse Boeren- en Tuindersbond. Ook de wijdvertakte organisatie van de Jonge Boerenstand was opgeheven, nadat de bezettende macht reeds een jaar tevoren (zomer 1941) de liquidatie van het Ned. R.K. Werkliedenverbond had gelast. Doch van al deze organisaties bleven de bestuursleden als vertrouwensmannen van de bevolking in actie. $Z_{i j}$ hadden daarbij het organisatorisch voordeel, te kunnen steunen op de katholieke geestelijkheid.

In de centrale en Noordelijke provincies hebben de protestantse kerken hun rol in het verzet gespeeld. $Z$ ij kwamen echter eerst vrij laat tot samenwerking, zowel onderling als met buitenkerkelijke bevolkingsgroepen. In het Zuiden was de katholieke kerk van het begin af een geduchte tegenspeler van de bezettende macht. Hier kende men vrijwel geen ",neutrale" organisaties. Overal traden geestelijken op als adviseurs in het verenigingsleven. Waar organisaties ontbonden waren, bleven de contacten tussen geestelijke adviseurs en voormalige bestuursleden bestaan. Hoewel men niet kan zeggen, dat de katholieke kerk als zodanig de April-Mei-stakingen heeft aangemoedigd, kan toch worden geconstateerd, dat de geestelijkheid, die de geest van verzet in 
de bevolking wakker hield, op vele punten, voorzichtig en met beleid, de stakingsbeweging steunde. Als demonstratie had zij immers haar waarde, temeer omdat men in het begin van 1943 hier en daar tekenen van moedeloosheid had waargenomen. Het psychologisch effect van de staking was, dat zij de bevolking ervan overtuigde, dat een massale beweging voor de Duitsers gevaarlijk kon worden. Weliswaar vervielen na de onderdrukking velen in een pessimistische stemming, maar in het algemeen schijnen solidariteit en bereidheid tot illegaal werken toch aanmerkelijk te zijn toegenomen.

Zoals reeds werd opgemerkt, begonnen de meeste stakingen in NoordBrabant wat later dan in de overige provincies. Een uitstekend kenner van het Noord-Brabantse volkskarakter, C. Slootmans ${ }^{1}$ ), schrijft aan de Brabanders een zekere mate van voorzichtigheid toe. $Z_{\mathrm{ij}} z \mathrm{ijn}$ veel minder spontaan dan de Limburgers. Ook hier biedt de geschiedenis van de April-Mei-stakingen weer interessant vergelijkingsmateriaal, waarbij opnieuw kan worden geconstateerd, dat de gebeurtenissen met vroegere ervaringen in overeenstemming waren en moderne theorieën over het streekkarakter hebben bevestigd. De Brabander is niet bijzonder heldhaftig; hij is beleefd, soms op het onderdanige af, joviaal, maar in sommige opzichten berekenend, nuchter en beheerst. Hartelijk en gastvrij, jolig als er een pretje te beleven valt, weet hij toch met overleg te handelen als hij in de verdrukking raakt. En hij heeft de verdrukking gevoeld, eeuwen lang. Nog steeds zien Noord-Nederlandse historici niet voldoende in, welke gevolgen het tijdperk, waarin Noord-Brabant als generaliteitsgebied werd uitgebuit, voor land en volk van deze provincie had. De bevolking raakte er aan gewend, een stille strijd te voeren tegen de schouten en drossaards. $Z_{i j}$ raakte vertrouwd met kunstgrepen van bedrog en veinzerij om aan de al te zware belastingen te ontkomen, zij moest velerlei listen te baat nemen om haar godsdienstplichten te vervullen. Eerst later viel het dwangcomplex van deze mensen af.

De algemene trekken van het Brabantse volkskarakter worden niet overal in gelijke mate waargenomen; zij vertonen van streek tot streek nogal variatie. Maar doorgaans streed men in Noord-Brabant toch bedachtzamer, voorzichtiger en met minder open vizier dan bijvoorbeeld in Friesland. Conclusies zijn echter slechts onder voorbehoud mogelijk. Evenals elders kon de ware toedracht der gebeurtenissen niet altijd met voldoende zekerheid worden vastgesteld. Bij navraag bleek veler herinnering aan de Meidagen van 1943 vervaagd te zijn. Sommigen trachtten achteraf een geflatteerd beeld te geven van de rol, die zij speelden. Trouwens, de nauwkeurige chronologie der gebeurtenissen geeft nog geen uitsluitsel over de motieven van het handelen. Menigeen staakte tegen wil en dank mee, omdat een gedeelte van zijn collega's kantoor of werkplaats had verlaten. Bij sommige boeren nam de staking de vorm aan van een demonstratie tegen de Crisis Contrôle Dienst, soms met bij-oogmerken van winzucht. Bewaard gebleven politierapporten zijn onvolledig

1) C. J. F. Slootmans, De West-Brabanders in P. J. Meertens en Anne de Vries, De Nederlandse volkskarakters, 1938. 
of deden dienst om de Duitsers zand in de ogen te strooien. Het vermakelijkste geval van misleiding is wel, dat een politieambtenaar meldde, dat arbeiders thuis bleven van hun werk... om zich klaar te maken voor hun gevangenschap.

Als een specifiek Brabantse bijkomstigheid - voor het Westelijk gedeelte van Noord Brabant althans - vermelden wij het uitvallen van de gastoevoer, welke onder normale omstandigheden geschiedt door de grote pijpleidingen, die uit het mijngebied in Noord-Westelijke richting zijn aangelegd. Toen Vrijdag de staatsmijnen staakten, stagneerde spoedig ook de gasleverantie, met het gevolg, dat alle industrieën, die op deze gastoevoer zijn aangewezen, (bijvoorbeeld een gedeelte van de Philipsbedrijven) tot stilstand kwamen voor zover het personeel de gebouwen niet reeds had verlaten. Dit was bij Philips inderdaad het geval.

Het snelle reageren van het Philipspersoneel — ook bij deze gelegenheid weer een ietwat vreemde groep in het Brabantse land - behoeft ons niet te verbazen. Men nam er reeds Donderdagmiddag maatregelen, ongeveer op hetzelfde moment als bij Stork te Hengelo. De staking bij Philips is Vrijdagochtend het signaal geweest voor de staking te Helmond, die daar een algemener karakter aannam dan in enige andere plaats van Noord-Brabant. Eerst Zaterdag kwamen vele andere steden en dorpen in verzet. Geheel anders dan in Zuid-Holland zien wij in Noord-Brabant een vrij gelijkmatige verbreiding van de staking over de gehele provincie. Slechts de Zuidelijkste grensgemeenten bleven nagenoeg passief. De gelijkmatige verbreiding van de staking kan niet uitsluitend worden toegeschreven aan genoemde organisatorische factoren, zoals de activiteit van voormalige bestuurders van verenigingen in overleg met de geestelijkheid. Van niet minder betekenis was ook de aanwezigheid van industriekernen in alle delen der provincie. Brabant kent industriesteden, maar ook vele industriedorpen. De plattelandsindustrieën trekken arbeiders van heinde en ver aan - hierin concurrerend met de fabrieken in de steden, welke eveneens zijn aangewezen op grote aantallen arbeiders van buitenaf. De sociale mobiliteit, welke hiervan het gevolg is, heeft er toe bijgedragen dat het stakingsparool snel van mond tot mond ging. De ,,mondelinge telegraaf" maakte alle stakingsberichten spoedig in de provincie bekend. Des te opmerkelijker, dat men dikwijls zo'n vertraagde reactiesnelheid toonde.

De Duitse Beauftragte in de provincie, Thiel, was zeer verbaasd over de deining, die door het anders zo rustige Brabant ging. Zelfs de afkondiging van het standrecht scheen de bevolking niet te intimideren. Afgezien van het fusilleren van zeven personen in Eindhoven en enkele wilde schietpartijen in andere plaatsen, is de SD in Noord-Brabant niet zó bruut opgetreden als in menige andere streek het geval was. De Duitse politie schijnt hier teruggedeinsd te zijn voor de uiterste consequenties van het stakingsverbod. Er moesten slachtoffers vallen, de gewone intimidatiemiddelen vonden ook deze keer toepassing, maar men trad weinig hardhandig op in de bedrijven waar men 's Maandags nog staakte. Ook de directies van stakende bedrijven behandelde men minder streng dan bijvoorbeeld in de Zuid-Oostelijke 
industriestreek van Zuid-Holland, waar de beruchte SD-er Hoffmann de leiding van het onderzoek had.

De NSB weerde zich geducht. De staking was haar in sommige opzichten welkom. De provinciale NSB-leiders hadden er de Duitsers reeds menigmaal op gewezen, dat er nog steeds te veel anti-Duitse burgemeesters en ambtenaren in functie waren. $Z_{\mathrm{ij}}$ hadden gewaarschuwd, dat de gevolgen hiervan niet zouden uitblijven. De gebeurtenissen stelden hen in het gelijk, zodat de NSB nu de aanstelling van een groot aantal eigen functionarissen meende te mogen bepleiten. Dit is de strekking van een uitvoerig rapport, samengesteld uit gegevens verzameld door kringleiders en groepsleiders van de NSB, de plaatselijke leiders en sociale voormannen van het N.A.F. en de buurtboerenleiders. Dit rapport, dat wij als bijlage II 43 afdrukken, is een merkwaardig document. Het vormt een getuigenis van de perfide spionnage-manieren, die in NSB-kringen gebruikelijk waren geworden: een grootscheepse verklikkerij. Met naam en toenaam werden de personen genoemd, die volgens de NSB waarnemers als „ophitsers" moesten worden beschouwd. Wel merkwaardig, dat zelfs de SD van deze informaties slechts met mate gebruik heeft gemaakt. Slechts weinigen van de door de NSB aangewezen ophitsers zijn tijdens of na de staking gearresteerd. De Duitsers wisten blijkbaar heel goed, dat er heel wat persoonlijke rancune in het spel was. Het rapport is samengesteld uit gegevens, door NSB-ers uit verschillende plaatsen verstrekt. Velen van hen hadden weinig overzicht van de situatie en beperken $z$ ich tot het noemen van namen van personen, die $z$ ij wantrouwden. Lof en blaam uit dit rapport hebben slechts relatieve betekenis. Wanneer een burgemeester van een bepaalde plaats zich in NSB-ogen .,goed" hield, betekent dit nog niet, dat hij pro-Duits was. Daartegenover stond menigeen als ophitser te boek, die niet eens staakte.

Het rapport is dan ook van geringe historische waarde, ondanks de vele (en dikwijls wel juiste) plaatselijke gegevens die het bevat. Opvallend is de onvolledigheid van de berichten van het platteland. De oorzaak hiervan is, dat de Landstand zich zeer traag toonde in het verschaffen van gespecificeerde gegevens. Slechts die functionarissen van de Landstand, die lid waren van de NSB, hebben aan het rapport meegewerkt.

Tenslotte enige opmerkingen over de stakingen en de illegaliteit.

In het voorjaar van 1943 was de illegale beweging in Noord-Brabant nog niet voldoende georganiseerd om zelf voor een centrale leiding bij de stakingen te kunnen zorgen. Slechts in enkele gevallen, b.v. in Halsteren en Steenbergen, worden illegale werkers als stakingsleiders genoemd. Toch kwamen overal wel O.D.-kernen in actie, die nu voor het eerst ervoeren, dat door eensgezind optreden heel wat te bereiken viel. De teleurstelling over het niet-staken der spoorwegen en over het uitblijven van richtlijnen uit Londen was spoedig overwonnen. Het algemeen oordeel luidde, dat de stakingen in Noord-Brabant, evenals ten Noorden van de Moerdijk, de verzetsgeest hadden aangewakkerd en de belangstelling voor illegaal werk hadden doen groeien. Het aantal onder- 
duikers nam toe, de berichten van de verschillende fronten werden steeds gunstiger voor de Geallieerden. Het was niet ondenkbaar, dat een tweede stakingsactie, later, op een voor de Duitsers ongelegen ogenblik, meer resultaat zou opleveren.

Overzien wij de stakingsbeweging in de steden, dan moet in chronologische volgorde Eindhoven het eerst worden genoemd. En in Eindhoven weer speciaal Philips' Gloeilampenfabrieken.

Het enorme Philipsbedrijf, dat in 1943 te Eindhoven nog ruim 18.000 personen in dienst had, stond reeds geruime tijd onder Duitse contrôle. De Verwalter, Dr Nolte, had met zijn medewerkers Liese en Vroeg-in-de-wei (van het N.A.F, een spionnagesysteem opgebouwd. Voor het toezicht op de arbeiders diende de z.g. Werkschutz, de poortbewakers. Het wantrouwen van de Duitsers was, van hun standpunt bezien, niet ongegrond. Toen in Augustus 1941 de heer Philips Sr zijn gouden jubileum vierde, had het personeel dankbaar van de gelegenheid gebruik gemaakt om de huldiging van de eminente directeur met zóveel vertoon van vlaggen en van oranjekleuren te doen plaats vinden, dat het wel een Oranjebetoging leek. Nadien waren de Duitsers op hun hoede. Het heeft zelfs weinig gescheeld, of Hitler had zich persoonlijk met de zaak bemoeid. In ieder geval schijnt men te hebben overwogen, de Philipsfabrieken geheel naar Duitsland over te brengen.

Voor de leiders van de onderneming, die door de Duitsers wel eens ,die Englische Festung" werd genoemd, was dus in April 1943 voorzichtigheid geboden. $\mathrm{Z}_{\mathrm{ij}}$ moedigden de staking niet aan, maar werkten haar ook niet tegen. In een modern bedrijf met een uitgebreide staf van academici is men meestal goed geinformeerd. Zo kende men, vermoedelijk door een privé overgebracht kranten-telexbericht, reeds Donderdag vroeg in de middag de inhoud van Christiansen's proclamatie. Het bericht ging in alle afdelingen van mond tot mond. Wij mogen veronderstellen dat de illegale kernen, welke voortdurend in contact stonden met het hoofd van het Directiebureau Sociale Zaken, A. Voorwinde, daarbij bemiddelingsdiensten hebben verleend.

Het personeel geraakte in een geagiteerde stemming, vooral degenen die zich rechtstreeks getroffen voelden door het besluit van Christiansen. Men verliet het bedrijf niet, doch legde in vele afdelingen wel het werk neer. Met deze sit-down staking begon de 29ste het verzet. Vrijdag, geheel anders dan in Twente of in Zuid-Limburg, liepen fabrieken en kantoren weer vol. Er bestond wel een sterke drang tot staken, maar tegelijkertijd zag men toch de moderne bedrijfsdiscipline. Voorlopig luisterde men nog naar het advies van een aantal vertrouwensmannen, die Donderdagavond hadden vergaderd en die tot de conclusie waren gekomen, dat men goed deed, overleg te plegen met de spoorweg - en de P.T.T.-directies. Voor dit doel - althans voor het verkrijgen van informaties - ging de heer Voorwinde Vrijdag naar Den Haag.

Intussen groeide onder het personeel de stemming van verzet. Men hoorde van stakingen elders. Vrijdagmorgen stond men in werkplaatsen en bureaux 
in groepjes te praten, voor zover NSB - of N.A.F.-contrôle dit niet onmogelijk maakte. Het ene gerucht na het andere drong het bedrijf binnen. De spanning was op den duur niet meer te dragen, men moest door een of andere manifestatie uiting geven aan zijn gevoelens. Zo kwam men er toe, Vrijdagmiddag, na de uitbetaling van de lonen, het bedrijf te verlaten. In de loop van die middag greep de stakingsbeweging te Eindhoven snel om zich heen. Het personeel van het post- en telegraafkantoor had reeds tegen het eind van de ochtend het werk neergelegd. Aan de gemeentesecretarie begon de staking 's middags, ongeveer op het moment, dat het Philipspersoneel aanstalten maakte, de werkplaatsen te verlaten. Toen het hek eenmaal van de dam was, kwam het ene stakingsbericht na het andere binnen; het bleek dat de hele industriestad Eindhoven in rep en roer was. Op veel plaatsen werden pamfletten verspreid.

Het totale aantal stakers kan voor Vrijdagmiddag op 25.000 à 30.000 worden geschat. Behalve bij Philips, het P.T.T.-kantoor, de gemeente-secretarie en enkele andere overheidsinstellingen, werd gestaakt bij de Jasneva $\mathrm{v} / \mathrm{h}$ Jaspers Sigarenfabriek, C. Kersemakers \& Zn, Picus Houtindustrie, de Abonné Sigarenfabrieken, enz.

De volgende ochtend, Zaterdag 1 Mei, droeg de staking een nog algemener karakter. Vrijwel alle Eindhovense bedrijven, die Vrijdagmiddag niet hadden gestaakt, verklaarden zich nu solidair met de andere. Ook in de omgeving van Eindhoven, bijvoorbeeld te Valkenswaard, waren bijna geen werkwilligen meer te vinden. Naar hun woonsteden terugkerende arbeiders hadden Vrijdagmiddag het stakingsparool in een groot aantal dorpen doorgegeven.

Een neiging tot demonstreren voerde Zaterdag vele stakers uit de omgeving naar Eindhoven terug. Maakten zij gebruik van enkele Philipsbussen, die toch nog uitgezonden waren om werkwilligen op te halen? Ooggetuigen hebben meegedeeld, dat zij Zaterdagochtend enige open vrachtwagens van Philips zagen, vol arbeiders, die met rood-wit-blauwe en met rode vlaggetjes zwaaiden en liederen zongen. Van arbeiderszijde is er over geklaagd, dat een gedeelte van het hoger Philipspersoneel niet openlijker partij koos voor de stakers. Degenen, die de verantwoordelijkheid droegen, vreesden echter - niet ten onrechte de gevolgen van een al te demonstratieve houding. Wie de situatie rustig en objectief beoordeelde, kon trouwens wel voorspellen dat de staking niet consequent door te voeren was. De heer Voorwinde, Zaterdag van een verkenningstocht teruggekeerd, deelde mede, wat hij had vernomen: de spoorwegen en de centrale rijksdiensten zouden niet staken. In de grote steden was het verzet in de kiem gesmoord.

Wij constateren nogmaals, dat in de gehele stakingsactie, fel en onbeheerst als zij zich voordeed, iets school, dat illegale werkers met zorg vervulde. Reeds in het begin van 1943 waren velen van hen tot het inzicht gekomen, dat alle illegale arbeid een krachtige discipline vereiste. Zo verklaren wij, dat men in sommige illegale kringen meende te moeten afzien van het 
geven van leiding bij een staking, die te wild en chaotisch was begonnen om tot resultaten te kunnen leiden.

Het was waarlijk niet uit angst voor Duitse dreigementen of voor het afgekondigde standrecht, dat de directie van Philips besloot, de arbeiders aan te manen, Maandag weer aan het werk te gaan. Zondag na kerktijd werden hiertoe circulaires rondgedeeld. Het schijnt echter, dat communistische verzetsgroepen pamfletten verspreidden met de opwekking, de staking ook Maandag en volgende dagen vol te houden. Hierdoor ontstond verwarring. Bovendien kon de directie van Philips de buiten de stad wonende arbeiders niet meer bereiken.

Maandagochtend 3 Mei begon het werk in de meeste Eindhovense bedrijven met een zeer onvoltallige bezetting. Het is niet bekend, hoeveel arbeiders die morgen bij Philips verschenen waren (men controleerde dit liever niet nauwkeurig). De Verwalter Dr Nolte rapporteerde echter aan de SD, dat de opkomst slecht was. Voor de Duitse politie was het moment gekomen om krachtig op te treden. Overvalwagens verschenen in de straten, willekeurige personen werden gearresteerd. Het Standgericht installeerde zich in het hoofdkantoor van Philips. Uit een groot aantal arrestanten werden er zeven gekozen, die als slachtoffers moesten vallen. De zitting van het Standgericht was, wat dit betreft, maar een formaliteit. Een van de juristen van de N.V. Philips, Mr Haardt, werd door de Duitsers geprest, de beraadslagingen van het Standgericht bij te wonen, z.g. tot verdediging van de beklaagden. Als $\mathrm{Mr}$ Haardt echter iets ter verdediging van de verdachten wilde opmerken, werd hij afgesnauwd.

De executies vonden Maandagmiddag plaats op een der fabrieksbinnenplaatsen, juist toen de arbeiders hun werkplaatsen verlieten. Van degenen, die voor het vuurpeloton verschenen, waren $W$. van Beek, J. G. Eilers, J. C. W. Gielen en P. J. Verhoeven werkzaam bij Philips. P. van Kempen was in dienst bij Bata te Best, G. van Werts bij de N.V. Mignot \& de Block te Eindhoven. Verder werd nog de arbeider S. van Santvliet uit $W_{i j k}$ gefusilleerd.

Deze terechtstellingen en het bericht dat enige directeuren van de N.V. Philips gearresteerd waren - Ir F. Philips, Prof. Holst en de heren Dijksterhuis en De Vries werden naar Haaren gebracht ${ }^{1}$ ) — veroorzaakten bij de bevolking een mineurstemming. Hoewel men Maandag wel overtuigd scheen van de mislukking der stakingsbeweging, bleven ook Dinsdag nog vele arbeiders van hun werk weg. Men hoorde critiek op de spoorwegen, op RadioOranje enz., doch het was niemand duidelijk, wat men met een landelijke algemene staking had gedacht te bereiken. Voor de Duitsers was het een prestigekwestie geworden. Wij wezen er reeds op, dat zij de zaak niet verder op de spits dreven, toen Dinsdag een snel verlopen van de staking waar te nemen viel.

1) De drie laatstgenoemden werden de $10 \mathrm{de}$ Mei 1943 vrijgelaten. Ir F. Philips werd 16 Aug. 1943 van Haaren naar St. Michielsgestel overgebracht en kwam eerst 20 Sept. '43 weer op vrije voeten. 
Heftig en algemeen is de 30 ste April te Helmond gestaakt. Men had er Donderdagavond al vernomen van de sit-downstaking bij Philips. Voor zover valt na te gaan, heeft men die avond te Helmond overleg gepleegd en zoveel mogelijk een stakingsconsigne voor de volgende ochtend doorgegeven. Vrijdagmorgen verschenen de arbeiders wel in de fabrieken en begaf zich ook het administratief personeel naar kantoren en bureaux, doch blijkbaar vooral voor onderling overleg. Tussen acht en negen uur legde $95 \%$ van het fabriekspersoneel het werk neer. Op het postkantoor, bij de distributiedienst en bij de gemeentebedrijven werd eveneens gestaakt, radicaler dan waar ook in Brabant.

Van de ene fabriek na de andere zag men de arbeiders op straat verschijnen: van de Schroefboutenfabriek Helmond, van de Ververij en Blekerij "Spectrum", van de N.V. Edah, van Terwindt, Arntz \& Holtus N.V., enz. - in het geheel enige duizenden arbeiders. Bij de N.V. Cartonnagefabriek „Het Zuiden" staakten alleen de meisjes.

Voor de Duitse politionele leiding, te 's Hertogenbosch gevestigd, was de situatie te Helmond het duidelijkst. $Z_{i j}$ had ongeregeldheden te Eindhoven verwacht, maar nu bleek, dat Helmond het eerst in verzet was gekomen. Daarom begaf de SD-officier Klinkbeil uit Den Bosch zich direct naar Helmond, waar hij de burgemeester dwong, het secretariepersoneel bijeen te roepen en toe te spreken. De burgemeester hield inderdaad een toespraak, doch in geheel andere bewoordingen dan Klinkbeil had bevolen. $Z_{\mathrm{ijn}}$ houding dwong respect af. Later op de middag, de 30ste April, liet Klinkbeil alle Helmondse fabrikanten en een aantal hoofdambtenaren op het politiebureau ontbieden. Hij uitte vele bedreigingen, maar liet de heren (met uitzondering van vier personen, die in arrest bleven) weer naar huis gaan.

De fabrikanten hebben gehoor gegeven aan het bevel, hun arbeiders aan te manen tot hervatting van het werk. Zaterdag waren de meeste fabrieken weer gedeeltelijk in bedrijf. Maandag zelfs met nagenoeg voltallige bezetting. Spreekt men van een ,spontane staking", dan vormen de gebeurtenissen te Helmond daarvan een voorbeeld. Men was er Vrijdag 30 April opgewonden en recalcitrant, maar toen Zaterdag van alle kanten ongunstige berichten binnenkwamen, eindigde het verzet. Een geheel ander beeld dan te Eindhoven en Breda! Geheel anders ook dan op het platteland, dat eerst Maandag $3 \mathrm{Mei}$ in rep en roer was en waar men hier en daar met verbeten woede doorstaakte, zelfs nadat het ieder duidelijk kon zijn dat het spel verloren was.

Ook te 's Hertogenbosch braken Vrijdag 30 April stakingen uit, meest 's middags. Het verzet droeg hier, in overeenstemming met het karakter van de bevolking, een ietwat aarzelend en voorzichtig karakter. Evenals te Helmond staakte men er slechts kort. De belangrijkste bedrijven waar men de 30 ste April het werk neerlegde, waren N.V. P. de Gruyter (het gehele personeel van 970 personen), N.V. Vroom \& Dreesman (120 van de 450 personen), N.V. Grasso (175 van de 275), N.V. Lambooy Klunder (het vrijwel voltallige personeel van 220 personen), N.V. Van de Veer (35 van de 65), N.V. HEMA (30 van de 59). De cijfers wijzen op een gebrek aan solidariteit. Er 
is mij geen ander voorbeeld bekend van zoveel dicht bij elkander gelegen bedrijven, waar men zo partieel staakte. Het personeel van de distributiedienst (97 personen) ging wel bijna voltallig in staking, bij het postkantoor daarentegen slechts een 50-tal van een personeel van 192 personen (meest uniformdragend personeel van het expeditiebureel).

Zonder intimidatiemethoden van Duitse zijde te hebben ervaren (waar men het kruit liever droog hield voor Helmond en Eindhoven), keerden de meeste stakers Zaterdagochtend vanzelf weer naar het werk terug. Alleen bij De Gruyter, de Grasso Machinefabrieken (alweer de metaalbewerkers als meest actieve groep!) en bij de N.V. Van de Veer bleef het personeel Zaterdag voor het grootste gedeelte weg. Maandag was het rustig; ieder toog weer aan het werk.

Met alle voorbehoud kan uit het bovenstaande wel een en ander worden geconcludeerd omtrent de karaktertrekken van de bevolking van Eindhoven, Helmond en 's Hertogenbosch. Weer geheel andere aspecten vertoonden de stakingen in de andere grote industrieplaatsen: Tilburg, Breda, Roosendaal en Bergen op Zoom.

Te Tilburg gedroeg de bevolking zich merkwaardig kalm. Er werd niet algemeen gestaakt, feitelijk slechts in enkele grote bedrijven, b.v. in de fabriek van Thomas de Boer ( 270 man), bij de A.T.O.-van Gend \& Loos, bij de Sigarenfabriek de Huifkar en bij de Firma A. N. Mutsaers Wollen-stoffenfabriek. In het laatstgenoemde bedrijf is slechts enkele uren gestaakt onder pressie van een groepje vreemde arbeiders, die de fabriek binnendrongen. Andere incidenten van enige betekenis werden niet gerapporteerd.

De Duitse politie, blijkbaar overtuigd van de gemoedelijkheid van de Tilburgse bevolking, trad met psychologisch inzicht op (dit kwam bij uitzondering ook wel voor). Vrijdag begon een overvalwagen van de SD een inspectietocht door de stad. De wagen reed heel langzaam. De Duitse politiemannen, die een der stakende bedrijven bezochten, informeerden naar de afwezigen en gaven bevel, dat deze 's middags weer aan het werk moesten zijn. Ook dit onderzoek geschiedde in tergend langzaam tempo.. Inmiddels verbreidde zich het gerucht, dat de SD het ene bedrijf na het andere zou controleren. De meeste arbeiders wachtten dit niet af en keerden naar hun werkplaatsen terug. Hun houding getuigt niet van strijdlust, wèl van de meermalen gesignaleerde Brabantse nuchterheid en voorzichtigheid.

Te Roosendaal werd laat, aarzelend en in beperkte mate gestaakt, waarschijnlijk nog minder dan te Tilburg. Juist omdat hier en daar slechts kleine groepen arbeiders van het werk wegbleven, kon de NSB-burgemeester Daems maatregelen treffen. Hij liet Zaterdag 1 Mei door de politie een tachtigtal arbeiders ophalen. Deze werden met de nodige dreigementen toegesproken. Indien er desondanks op Maandag $3 \mathrm{Mei}$ nog een staking te Roosendaal begon - bij de Hudson Sigarenfabrieken N.V. - moet dit worden toegeschreven aan de illegale activiteit van enkele personen. In verband hiermee werd de sociale werkster mejuffrouw E. Werner gearresteerd. 
Breda, met zijn sterke inslag van vreemdelingen, geldt als een frisse en energieke stad, levendig en bedrijvig. Deze voortvarendheid kwam eind April '43 weer duidelijk tot uiting. De eerste staking begon Vrijdagmorgen bij de N.V. Hollandse Kunstzijde Industrie Breda (ongeveer 1200 man), waar men - typisch voor het moderne grootbedrijf - reeds vroeg goed geïnformeerd was over de gang van zaken in andere plaatsen. Berichten over de stakingen in Twente en bij de Staatsmijnen waren al gauw in circulatie. Het personeel stond in groepjes te praten en werkte die ochtend vrijwel niet. Toen tegen twaalf uur een arbeider ontijdig met de signaalfluit het teken ,einde van de werktijd" gaf, stroomden de gebouwen leeg. Ongeveer ter zelfder tijd begon de staking bij de N.V. Stoom Chocolade en Cacaofabriek "Kwatta" (300 personen). Deze voorbeelden werden 's middags gevolgd door gemeentewerken en gemeentebedrijven. Wilde geruchten deden de ronde. Uit vrees voor een staking bij het waterleidingbedrijf begon bijna iedereen water af te tappen. $\mathrm{Na}$ het middagschaftuur keerden vele arbeiders bij verschillende bedrijven en ambtenaren bij overheidsinstellingen (o.a. van de distributiedienst) niet meer naar hun werk terug.

Er werd druk overleg gepleegd, ook met bedrijven en overheidsinstellingen in andere plaatsen. De leiders van de Diocesane R.K. Werkliedenverbonden verleenden alle mogelijke bemiddeling. In het algemeen luidde hun advies, dat men met de nodige omzichtigheid moest optreden. Zaterdagmorgen droeg de staking een algemeen karakter. Het werk was nu ook neergelegd bij de N.V. IJzergieterijen en Emailleerfabrieken „De Etna” (600 personen), bij de N.V. Hero (600), bij de Ver. Hollandse Lucifersfabrieken (100), de N.V. Princenhage (200), de Brouwerij "De drie Hoefijzers" en bij een groot aantal kleinere bedrijven.

De Duitse politie, onder leiding van Majoor Wolk van de SD, voelde zich

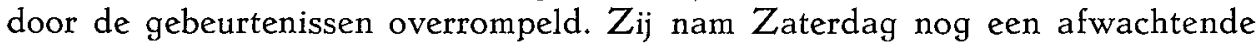
houding aan en besloot eerst Maandag door te tasten. De fabrieksdirecties kregen bevel, hun arbeiders tot hervatting van het werk op te roepen. Doch 's Maandags kwam slechts een gedeelte van de arbeiders opdagen. Het merkwaardige geval deed zich voor, dat velen die ochtend wel naar de fabrieken gingen, maar op straat bleven praten. Tegen deze weerspannigen ondernam de SD een razzia. Plotseling verscheen een overvalwagen van de SD bij de toegangspoorten van de Kwatta-fabrieken en de daartegenovergelegen „Etna". Eén arbeider werd gearresteerd en weggevoerd. De anderen vluchtten of haastten zich naar hun werkplaatsen. De algemene opkomst liet volgens de Duitsers veel te wensen over, vooral bij de N.V. Hero (waar het personeel tot verzet werd aangemoedigd door de werkman Reinierse), bij de "Etna" en bij de H.K.I. Ondanks alle Duitse dreigementen bleven zelfs Dinsdag nog vele arbeiders weg, het meest bij de Kunstzijde-fabrieken en bij de N.V. Hero.

Dinsdagmorgen werden de fabrieken van de Hollandse Kunstzijde Industrie door de SD bezet. Het hoofd van de sociale dienst van deze onderneming, 
Mr Struijcken, werd voor het Standgericht gedaagd. Het zag er naar uit, alsof er slachtoffers zouden vallen. Ook bij de directie van de Hero-fabrieken kwam de SD bedreigingen uiten. Opnieuw deden de directies een beroep op de arbeiders om het werk te hervatten. De meesten bleken daartoe wel bereid, de demonstratie had nu lang genoeg geduurd. Men wist, dat de stakingen elders reeds geëindigd waren, en had uit de woorden van Radio-Oranje begrepen, dat de regering in Londen geen hoop kon geven op een vervroegde invasie. Ook het niet-staken van de spoorwegen droeg bij tot een ietwat geslagen stemming. Toen Dinsdagmiddag vele arbeiders zich weer bij de H.K.I. kwamen melden, zagen de Duitsers af van represaille-maatregelen en stelden zij zelfs $M r$ Struijcken weer in vrijheid. $Z_{i j}$ deden nog wel nasporingen om de man te vinden, die Vrijdagochtend het fluitsignaal "einde van het werk" had gegeven. Gematigd was ook het optreden van de SD bij de Herofabrieken, waar Woensdag nog slechts de kleinste helft van het personeel op het appèl verscheen. Eerst Donderdag werd weer normaal gewerkt. Was de SD zó tevreden over de algemene gang van zaken dat zij hier van represailles afzag? Of gaf persoonlijk inzicht van SD-officieren de doorslag? Het schijnt, dat zowel bij de Duitse politie als bij Duitse troepenafdelingen in Noord-Brabant vooral katholieke Duitsers soms al het mogelijke deden, een gunstige indruk op de geestelijkheid en op de bevolking te maken.

Te Bergen op Zoom is twee dagen, Vrijdag en Zaterdag, krachtig gestaakt, zonder dat zich incidenten voordeden. Vrijdag, in de loop van de dag, verlieten de arbeiders van enige grote machinefabrieken en ijzergieterijen hun werkplaatsen. Arbeiders van kleinere bedrijven volgden hun voorbeeld: blijkens ons enquête-materiaal bij de N.V. Machinefabriek v/h Rogier, Nerincx, Richter ( 85 personen), Asselberg's IJzerindustrie Handel Mij N.V. (360) en bij de IJzerfabriek en Constructiewerkplaats „Holland" (350). In het geheel zijn er te Bergen op Zoom vermoedelijk ongeveer 2000 personen bij de staking betrokken geweest, van wie de meesten Maandag weer aan het werk gingen. Alleen bij de N.V. v/h Rogier, Nerincx, Richter ontbrak Maandag nog de helft van het personeel. Van Duitse represailles is ons niets bekend.

$\mathrm{Na}$ dit overzicht van de gebeurtenissen in de steden, delen wij nog enige bijzonderheden mee over een aantal plattelands-industrieën.

Bij de suikerfabrieken in het Noord-Westelijk kleigebied is vrij algemeen gestaakt: het eerst in de Suikerfabriek „Dinteloord" te Stampersgat. Daar bleef een gedeelte van het personeel reeds Vrijdagochtend 30 April weg, waarop de anderen ook maar heengingen, zonder met hun werk te beginnen. Vermoedelijk stonden sommigen van het personeel in verbinding met illegale kernen uit Dordrecht en omgeving. In ieder geval zijn er pamfletten verspreid. In de meeste suikerfabrieken begon de staking eerst Zaterdag, soms op aanstichten van leden van de O.D. (b.v. bij de Centrale Suiker Maatschappij te Steenbergen). Bij de Coöp. Vlasfabriek "Dinteloord" te Steenbergen nam de staking eerst Maandag een aanvang. Bij al deze fabrieken in de NoordWesthoek oefenden de directies aandrang op het personeel uit om, met het 
oog op Duitse represailles, de staking niet lang vol te houden. Dinsdag $4 \mathrm{Mei}$ werd in deze streek het werk - in de fabrieken althans - hervat.

In de Langstraat droeg de staking Vrijdag en Zaterdag een algemeen karakter. Zelfs het P.T.T.-bedrijf staakte Vrijdag gedurende enkele uren.

Het belangrijkst waren uiteraard de stakingen in de schoen- en lederfabrieken ( $\mathrm{Fa}$ Blok van Heyst, Schoenfabriek Hollandia, Fa M. Zwaan, Fa A. en J. de Kort, Lederfabriek „,de Kroon”, Handschoenenfabriek „Unique”, Schoenfabriek "Timtur", enz. - alle te Waalwijk. In het NSB-rapport over de stakingen wordt gerapporteerd, dat de fabrieksarbeiders van de Langstraat "geterroriseerd" werden door de bevolking van Kaatsheuvel en SprangCapelle. Het is waarschijnlijk, volgens wat wij van het streekkarakter van de bevolking in de omgeving van Kaatsheuvel afweten, dat daar een felle stemming heerste, met een bereidheid om tot daden van verzet over te gaan, welke men overal in de streek ten Noorden van de lijn Roosendaal-Tilburg aantrof.

Kleine industrieplaatsen, gegroepeerd om een grote fabrieksstad, ondergingen soms de invloed van het industriecentrum. Doch dit was lang niet altijd het geval. Soms werd in de randgebieden feller gestaakt dan in het centrum. Zo kwamen bijvoorbeeld Goirle en Hilvarenbeek heftiger in verzet dan Tilburg zelf. Te Goirle staakten Vrijdag en Zaterdag zes textielfabrieken en een gloeilampenfabriek (in het geheel 600 personen), benevens een aantal kleine bedrijven. Te Hilvarenbeek de zuivelfabriek en een schoenfabriek. Arbeiders bevestigden een rood-wit-blauwe vlag aan een der fabrieksschoorstenen. In Dongen legden bijna alle fabrieksarbeiders het werk neer (Stoomwasserij "De Dongen", N.V. Schoenfabriek v/h W. Lourysen \& Zn, Fa J. v. d. Assent Kanters, N.V. Gebr. A. M. Ligtenberg, J. A. Ligtenberg, Fa Snoeven \& Hooymakers). Men profiteerde er in de kleine plaatsen van, dat de Duitsers handen te kort kwamen om het verzet in de grote steden te breken.

In volkomen tegenstelling tot Tilburg was ook de heftigheid van de staking te Oisterwijk, waar alle bedrijven tot stilstand kwamen (o.a. N.V. Berkelmans Schoenfabriek, de Oisterwijkse Textielindustrie, de Nieuwe Amsterdamse Leder Mij, enz.). Te Gilze-Rijen staakten de lederfabrieken, te Schijndel de grote kousenfabriek Fa Jansen de Wit (1300 personen) en Fa H. Oerlemans Klompenfabriek. Te Oss gingen Zaterdag 500 man van de N.V. Organon in staking, te Gemert bij Helmond het personeel van N.V. J. A. Raaymakers Textielfabrieken.

Regionale invloed van Eindhoven was zichtbaar in het onstuimige karakter van de stakingen te Valkenswaard, Geldrop en Best. Waarschijnlijk heeft $V$ alkenswaard de 30ste April, wat het percentage der stakers t.o.v. de totale bevolking betreft, wel het Brabantse record bereikt. Alle bedrijven staakten, winkeliers sloten hun winkels en ook het overheidspersoneel legde het werk neer (gemeentesecretarie, gemeentewerken, distributiedienst). De grootste bedrijven te Valkenswaard gevestigd, zijn de sigarenfabrieken (Willem II Sigarenfabrieken, Hofnar Sigarenfabrieken, Haka Sigarenfabrieken enz.). 
Men was er natuurlijk goed op de hoogte van de gebeurtenissen te Eindhoven. Evenals in de naburige grote stad bleven de meeste arbeiders te Valkenswaard Maandagochtend nog van het werk weg. Eerst toen te Eindhoven slachtoffers vielen en ook uit andere plaatsen berichten van het eindigen van stakingen binnenkwamen, haalde men ook te Valkenswaard bakzeil. Dinsdag was de orde hersteld.

Te Geldrop staakten alle textielbedrijven, o.a. de Tweka-fabrieken, doch niet langer dan tot Zondag. Te Best namen de Batarschoenfabrieken een centrale plaats in de stakingsbeweging in. Men heeft er lang en verbeten gestaakt, zodat de Duitse politie, blijkens teruggevonden rapporten, steeds meer aandacht ging besteden aan deze weerspannige plaats. Vrijdagochtend half acht bleven de arbeiders van Bata voor de fabriekspoorten staan; zij weigerden, binnen te gaan. In de loop van de dag ging ook het personeel van de N.V. Tricot, van de N.V. Houtwarenfabriek Ceder en van de Klompenfabriek Gebr. van der Velden in staking - in het geheel ruim 2000 arbeiders. $\mathrm{Bij}$ de Bata staakte men Maandag nog, en men bleef staken ondanks alle terreurberichten uit Eindhoven. Toen greep een afdeling van de SD in. De Batafabrieken werden bezet. De Duitse politie constateerde, dat zich Dinsdagochtend nog slechts 600 werkwilligen hadden gemeld, zodat volgens in beslag genomen personeelslijsten nog 1000 personen ontbraken. Onder invloed van velerlei dreigementen keerden de meeste stakers Dinsdag naar hun woonplaatsen terug. Eerst Woensdag kon de fabrieksarbeid gewoon doorgang vinden.

De plattelandsstaking verliep in Noord-Brabant niet veel anders dan in andere agrarische gebieden. In wezen was de stakingsgedachte de Brabantse boer geheel vreemd. De meeste landbouwers waren echter door vee-leveranties, door de verscherpte contrôle van de crisisdiensten en door de opheffing van hun oude landbouworganisaties in een weerspannige stemming gekomen. $\mathrm{Nu}$ hadden velen ook nog hernieuwde krijgsgevangenschap in het verschiet. Zo steeg de bereidwilligheid om aan een protestdemonstratie mee te doen, al wachtte men er zich wel voor, daarmee al te vlug en al te onbezonnen te beginnen. Er werd overlegd. Men hield besprekingen onderling, men polste de dorpsgeestelijken, men luisterde naar het advies van vroegere functionarissen van de ontbonden R.K. Ned. Boeren- en Tuindersbond en van de Jonge Boerenstand. Werkelijk spontane plattelandsstakingen, die reeds Vrijdag begonnen, waren schaars.

Menigeen bedacht, dat er niet veel risico aan staken verbonden was. Wie geen melk leverde, kon de schuld werpen op de melkrijders of op de zuivelfabrieken (die zich van hun kant weer konden beroepen op gebrek aan medewerking van de boeren). Dwarskijkers van de Landstand in de dorpen zouden terugdeinzen voor verklikkersdiensten en zonder hun berichten stonden de Duitsers machteloos. Bovendien, men kon de melk wel kwijt. De C.C.D. staakte eveneens; men had nu ook in ander opzicht (graan malen, clandestien slachten) de handen vrij. 
Veel landarbeiders bleven thuis. $\mathrm{Z}_{\mathrm{ij}}$ deden dit niet op een ongelegen moment. Het vee stond in de weide, het bouwland vereiste geen dringende zorgen. Wij schrijven dit niet om de betekenis van het plattelandsverzet te verkleinen, maar men moet de realiteit willen zien. Talrijk, te talrijk, zijn de mededelingen over misbruik van de situatie. Veel melk werd te duur verkocht; andere clandestiene handelingen waren helaas geen uitzondering. Ook stedelingen misdroegen zich. Op verschillende plaatsen werd melk gestolen of zelfs melkbussen ontvreemd. Voor de stedelingen bestond geen verontschuldiging voor wangedrag, voor vele kleine boeren wel. De ellende van de langdurige landbouwcrisis na 1930 had menig keuterboertje verbitterd en a-sociaal gemaakt. Men had zoveel armoede geleden, dat het wel moeilijk was, de verleiding te weerstaan om in de oorlogsjaren extra winsten te maken.

In sommige streken, vooral in West-Brabant, kwamen op het moment van staking oude sociale spanningen tot uiting. De lage lonen uit de jaren vóór 1940, de talrijke landarbeidersstakingen, hadden veel kwaad bloed gezet. Gedurende de oorlog was de positie van de landarbeiders weinig verbeterd. Er was een loonstop ingesteld; een ontslag $\sim$ en een opzeggingsverbod volgden. Men voelde zich aan handen en voeten gebonden. Zo nam de staking van de landarbeiders soms het karakter aan van een demonstratie tegen de boeren. Dikwijls dwongen landarbeiders de melkrijders tot staking, of zij zagen er op toe, dat de boeren in de stakingsdagen geen zwarte prijzen berekenden.

In de grensgemeenten, waar de smokkelhandel welig tierde, werd, mede door het isolement van deze streken, bijna niet gestaakt. In de meeste dorpen begon de staking eerst Maandag 3 Mei. Waar de stakingsactie vroeger inzette, was zij gewoonlijk gepropageerd door uit de industrieplaatsen teruggekeerde arbeiders en arbeidsters. Stakingen op landbouwbedrijven of van zuivelfabrieken kwamen voor te Nieuw-Vosmeer, Willemsstad, Heusden, Hoge en Lage Zwaluwe, Wijk, Helvoirt, Terheijden, Rosmalen, Hilvarenbeek, Hoogeloon, Haren, Oplee, Oisterwijk, Beek, Klundert, Heeze, Boxtel, Gilze, Drunen, Bladel, Son, Breugel, enz.

In West-Brabant namen de plattelandsstakingen scherpere vormen aan dan in Oost-Brabant. Specifieke trekken van het streekkarakter kwamen het zuiverst tot uiting in de Noord-Westhoek en in de Noordelijkste streken van West-Brabant. Vooral daar droeg de staking op vele punten een principieel en heftig karakter, op menig punt zelfs met overgangsvormen naar een openlijke revolte. Opnieuw vindt men bevestigd, dat de geschiedenis van de April Mei-stakingen, voor zover deze spontaan uitbraken, uitermate illustratief is voor de streekkarakters. Wat Slootmans schreef voor de Noordelijkste streken van Brabant ${ }^{1}$ ), is geheel in overeenstemming met de feiten: "In de kleistreken boven de Langstraat tiert de geest der critiek meer, de bevolking neemt niet zo gemakkelijk iets aan, onderzoekt scherper en verzet zich eerder".

Vooral in het Land van Altena - met zijn sterk calvinistische inslag -

1) C. J. F. Slootmans, De West-Brabanders, in P. J. Meertens en Anne de Vries, De Nodorlandsche Volkskarakters, 1938, blz. 274. 
was het zeer rumoerig. Te Almkerk trachtte een opgewonden menigte arrestanten uit het gemeentehuis te bevrijden. Ook te Nieuwedijk kwam het tot botsingen met de politie. In De Werken ten Zuiden van Gorinchem trokken grote troepen stakers (200 à $300 \mathrm{man}$ ) door het dorp. Een straat werd opgebroken, aanplakborden vernield; er vonden ongeregeldheden plaats voor NSB-huizen.

In de Zuid-Oostelijke hoek van het Land van Altena vonden Maandag 3 Mei demonstraties plaats voor de zuivelfabriek te Eethen. Daarna trok een troep stakers, onder wie arbeiders van genoemde zuivelfabriek, naar het naburige $W_{i j k}$. Te Wijk groeide de betogende menigte aan tot 150 man. Men begaf zich naar het distributiekantoor en sommeerde het daar aanwezige personeel, het werk neer te leggen. Ook de kantoorhouder van de P.T.T. moest onder dwang van het publiek het loket sluiten. Vervolgens trokken de stakers naar het gemeentehuis, waar zij de burgemeester, de secretaris en de bode aantroffen. Deze bedachten zich niet lang en gingen naar huis. De stakers verbreidden zich daarna in de omgeving van het dorp om er op toe te zien, dat er geen veldarbeid meer werd verricht. Hier en daar lieten zij paarden uitspannen. Vermoedelijk hadden enige in Wijk wonende NSB-ers intussen de SD in Den Bosch gewaarschuwd. Plotseling naderde een SDcommando, dat, van de Heusdense dijk af, op de stakers begon te schieten. Ieder zocht een goed heenkomen. Nadat de SD een veertigtal weggeworpen fietsen had buitgemaakt, begon ze de omgeving van Wijk te doorzoeken en arresteerde zij daarbij vier arbeiders, die zich in een schuurtje hadden verborgen. Eén van hen, S. van Zandvliet, had een groot hakmes (zoals bij het bietenrooien wordt gebruikt) in zijn zak. Dit maakte hem tot de meest verdachte van de vier gearresteerden, die ijlings naar Eindhoven werden overgebracht om voor het Standgericht te verschijnen. Tenslotte meenden de Duitsers er mee te kunnen volstaan slechts één man van de gevangenen te offeren. Maandagmiddag vond de executie van S. van Zandvliet plaats, tezamen met een aantal Eindhovense arrestanten.

Ten Zuiden van De Biesbosch ging het ook warm toe. Te Made begonnen Maandagochtend 3 Mei demonstraties voor de zuivelfabriek. Daarna trok een troep stakers naar een naburige klompenmakerij en rolde daar bomen over de verkeersweg. Een lijnbus van de B.B.Z. werd met stenen bekogeld. Het woonhuis van een NSB-er werd omsingeld. 's Middags omstreeks vier uur verschenen twee Duitse overvalwagens in het dorp; de SD begon in het wilde weg te schieten. Tot verdere intimidatie van de bevolking nam de Duitse politie vier gijzelaars mee, o.a. burgemeester A. J. A. van Gils (zij gingen eerst naar Tilburg, daarna - gelukkig slechts voor enkele dagen — naar het concentratiekamp Vught).

Incidenten kwamen eveneens te Oosterhout voor. Daar drongen de 1ste Mei vier inwoners van de Voorhei (een berucht gedeelte van Oosterhout) de elastiekfabriek Fefap binnen om met het mes in de vuist de arbeiders te sommeren, hun werk te verlaten. De invoering van het standrecht maakte op deze 
bevolking weinig indruk. Vooral in de buurt Voorhei weigerde men 's avonds acht uur naar binnen te gaan. Sommige caféhouders stoorden zich ook niet aan het verbod om bier te tappen. Geen wonder dat de SD uit Tilburg het dorp kwam bezoeken. De Duitse politie verscheen Maandag 3 Mei met vier open auto's (op één waarvan een machinegeweer stond). Het kwam tot een wilde schietpartij, die evenwel geen slachtoffers eiste. De staking, die te Oosterhout de 1ste Mei begon, nam de volgende dagen geleidelijk een grotere omvang aan. $Z_{i j}$ droeg in menig opzicht een wanordelijk karakter, vooral in de buurt Voorhei. Het kwam voor, dat melk van de boeren gestolen werd, soms zelfs door stakers, die er op uit trokken om koeien in de omtrek van het dorp te gaan melken. Dergelijke excessen werden zoveel mogelijk door de Oosterhoutse politie tegengegaan. De 5 de Mei ontbrak op de bedrijven nog $35 \%$ van het personeel. Die dag begon echter de melkleverantie aan de zuivelfabriek weer, maar nog op de 6de Mei werden nog wel melkrijders gemolesteerd. Eerst de 8ste Mei was te Oosterhout de rust geheel hersteld.

Ongeveer even lang als te Oosterhout is in het uiterste Westen van Brabant gestaakt, o.a. te Halsteren, Steenbergen en Nieuw-Vosmeer. In het laatstgenoemde dorp zelfs acht dagen. Bij Steenderen en Nieuw-Vosmeer leek het land wel uitgestorven. Te Halsteren is het verzet aangemoedigd door enkele illegale werkers.

Misschien waren de Duitsers niet over alle dorpsstakingen volledig ingelicht. Wij merkten reeds op, dat het afdelingsbestuur van de Landstand weinig ijver betoonde in het inwinnen van informaties. De Duitse politie verscheen Maandag 3 Mei slechts in de plaatsen, waar ongeregeldheden voorvielen. De SD had trouwens een maatregel in petto, die zou kunnen leiden tot intimidatie van de tegenpartij. In de nacht van 3 op 4 Mei werden alle voormalige voorzitters en secretarissen van de afdelingen van de inmiddels ontbonden R.K. Jonge Boerenstand gearresteerd. Bovendien nog een groot aantal andere personen, die in agrarische organisaties een rol speelden: menigeen was vooraf ingelicht en slaagde er in, tijdig te ontkomen. Maar er werden toch enige honderden invloedrijke boeren en ambtenaren van hun bed gelicht. 4 Mei reed de ene vrachtauto na de andere, vol arrestanten, het concentratiekamp Vught binnen. Of het effect van deze maatregel groot is geweest? 4 Mei was de stakingsbeweging al grotendeels verlopen. Men krijgt dan ook de indruk, dat de Duitsers het niet meer nodig vonden, achteraf nog een bloedig strafgericht te houden. Er had genoeg bloed gevloeid. 5 en $6 \mathrm{Mei}$ werden de gearresteerde boeren en vele andere arrestanten uit Vught - de meesten kaalgeschoren - naar huis gezonden. 


\section{HOOFDSTUK VIII}

\section{ZEELAND}

Met Noord-Holland en Utrecht behoort Zeeland tot de provincies waar de laatste dagen van April 1943 betrekkelijk rustig verliepen. Kenners van de Zeeuwse volksaard hebben gewezen op de gemoedelijkheid en kalmte van de eilandbevolking (Zeeuws-Vlaanderen kent de Vlaamse gemoedelijkheid in nog sterkere mate) en op een gebrek aan belangstelling voor principiële vragen. Opvallend is ook het gebrek aan provinciale solidariteit. Tussen de eilanden en tussen de bevolkings- en beroepsgroepen bestaan grote verschillen. Maar in de April-Meidagen heeft men zich bijna overal in de provincie merkwaardig kalm gedragen. Alleen de bevolking van Noord-Beveland staakte krachtig en vastberaden. Mag hieruit worden afgeleid dat de Noord-Bevelanders een andere geaardheid bezitten dan de overige Zeeuwen of bewijst het verzet van Noord-Beveland dat de omstandigheden daar verschilden van de omstandigheden elders?

Inderdaad waren het de omstandigheden, die in Zeeland de doorslag gaven. De provincie, door de Duitsers tot Sperrgebiet verklaard, was niet alleen in sterke mate geïsoleerd, maar vormde ook een militair bolwerk - een onderdeel van de Duitse Atlantik Wall - waar een veel krachtiger bezettingsmacht lag dan in enige andere streek van Nederland. Overal, in de kleinste dorpen evengoed als in de steden, kende men een inkwartieringssysteem, dat ongetwijfeld een zekere druk uitoefende. Alleen op Noord-Beveland, een eiland dat door de Duitsers als strategisch onbelangrijk werd beschouwd, lagen geen Duitse regimenten.

De illegaliteit was in de eerste maanden van 1943 ook in Zeeland nog slechts in het eerste stadium van haar ontwikkeling. De contacten tussen de verschillende eilanden bleven onvoldoende en in het algemeen overheerste nog een gevoel van machteloosheid. Geen wonder, dat gedurende de stakingsdagen slechts plaatselijk enige leiding kon worden gegeven en dan nog wel speciaal op Noord-Beveland, waar de verzetsbeweging zich het rustigst had kunnen ontwikkelen.

Een enquête over de stakingen in de talrijke Zeeuwse plattelandsgemeenten leverde vrijwel negatieve resultaten op. Hier en daar bleven enige landarbeiders thuis. Waar het Vrijdag 30 April regenachtig weer was (b.v. te Oud-Vossemeer op Tholen) viel het stagneren van de werkzaamheden op de akkers weinig op. In een akkerbouwgebied is eind April trouwens niet de 
drukste tijd. Van een "melkstaking” kon slechts sprake zijn in enkele weidegebieden, doch juist daar bleven de coöperatieve zuivelfabrieken in bedrijf. Dit was b.v. het geval op Schouwen. De melkleverantie werd er niet gestaakt. De enige plaats op Schouwen-Duiveland, waar een begin van staking onder de landarbeiders voorkwam, was Zonnemaire.

Uit 's Heerenhoek op Zuid-Beveland werd gemeld, dat een aantal boeren geen melk afleverde aan de zuivelfabriek te Middelburg. Maar de Walcherse boeren - hoewel grotendeels gereformeerd en anti-Duits genoeg - zetten hun melkbussen wèl langs de kant van de weg en de melkrijders verschenen prompt op tijd.

Op Zuid-Beveland is het krachtigst gestaakt in het dorp Kapelle ten Oosten van Goes. Twee inwoners van dit dorp werden naar Vught gezonden. Vrij algemeen was de staking ook te Hoedekenskerke, doch zij duurde evenals te Kapelle niet langer dan één dag. In hetzelfde gedeelte van Zuid-Beveland begon een wilde staking te 's Gravenpolder (eerst 3 Meil). Te 's HeerArendskerke staakte het personeel van de distributiedienst. De kleinste staking uit geheel Nederland is ongetwijfeld de uit 's Heer Abtskerke nadrukkelijk gemelde staking van één man, die op Zaterdag 1 Mei niet aan het werk ging en zijn besluit zó duidelijk meedeelde, dat de waarnemend NSB-burgemeester aanstalten maakte, hem te laten arresteren.

Op Walcheren kwamen stakingen voor te Middelburg en te Vlissingen. Een te Middelburg aanwezige illegale kern meende te mogen hopen op een landelijke algemene staking, waarbij het stopzetten van het spoorwegverkeer als signaal zou dienen voor geïsoleerde streken, maar de treinen bleven rijden en eer men overleg kon plegen, waren in enkele fabrieken reeds Vrijdag 30 April spontane stakingen begonnen. Te Middelburg het eerst in The Vitrite Works (omstreeks 300 man), in de houthandel Alberts (100 man) en bij de firma Maljers. Bij deze stakingen, die slechts een dag duurden, was geen sprake van enige centrale leiding. De Duitsers dreigden met represailles en oefenden Zaterdagochtend strenge contrôle uit. Daarmee was het verzet gebroken.

Tot een korte demonstratie bleef ook de staking op de werf De Schelde te Vlissingen beperkt. Het terrein van deze oorlogsindustrie werd dagelijks door Duitse troepen bewaakt, zodat het de arbeiders niet mogelijk was, de fabrieken en de scheepshellingen te verlaten. Maar door middel van pamfletten waren de arbeiders Vrijdagmorgen 30 April op de hoogte gebracht van een plan, het werk neer te leggen. 's Morgens tegen tien uur kwamen alle werkzaamheden tot stilstand: de ratelende klinkhamers vielen één voor één uit. De Duitsers troffen uitgebreide voorzorgsmaatregelen. Met veel militair machtsvertoon (opstelling van mitrailleurs op de fabrieksterreinen) en de hevigste dreigementen probeerden zij pressie uit te oefenen. Indien men de volgende dag niet werkte, zou men alle stakingsleiders opsporen en voor de ogen van hun makkers neerschieten. Voor deze druk zwichtten de arbeiders van ,"de Schelde". Zaterdag 1 Mei vond het bedrijf weer normaal voortgang, 
al werd er nog wel wat langzamer en wat meer saboterend dan gewoonlijk gewerkt.

In Zeeuws-Vlaanderen staakte in de buurt van Terneuzen een tiental arbeiders van een aannemersbedrijf. Ze werden terstond gearresteerd. Even beperkt van omvang en betekenis waren enige stakingen te Biervliet en Vogelwaarde. Iets duidelijker geaccentueerd was het verzet te $A x e l$, waar gestaakt werd door een veertigtal arbeiders van verschillende landbouwbedrijven (eerst Maandag $3 \mathrm{Mei}$ ), evenals door enige arbeiders uit de vlasserijen. De bakkers bakten die dag wel brood, maar lieten niets bezorgen. Vele winkeliers lieten rolluiken of gordijnen neer. Zoals men ziet, geen schokkende gebeurtenissen.

Tenslotte Noord-Beveland, het enige Zeeuwse gebied waar de April-Meidagen nog als kortstondige periode van felle actie in de herinnering van de bevolking voortleven. Een rapport van de Beauftragte in de provincie Zeeland schonk dan ook speciaal aandacht aan het eiland, dat soms ,Klein-Engeland" werd genoemd. „Dieses Eiland, von aller Welt abgeschlossen, ist natürlich mit seinen sturen, konservativen Menschen den Auslassungen des Londoner Rundfunks mehr preisgegeben, zumal dort kaum Soldaten sind" - aldus de Beauftragte Münzer.

De radio heeft echter op het uitbreken van de staking op Noord-Beveland niet zoveel invloed uitgeoefend als de Duitsers menen. Er is in dit geval veeleer sprake van een geleide staking in een gebied waar de organisatie van de illegaliteit (met name van de "Orde-Dienst") reeds aanzienlijke vorderingen had gemaakt. Centrum van deze actie was het dorp Wissenkerke. De staking begon dan ook niet spontaan des Vrijdags, maar werd die dag voorbereid door het drukken van pamfletten ${ }^{1}$ ) (in de drukkerij van A. Markusse te Wissenkerke). Nadat deze in ruime mate waren verspreid en nadat ook mondeling het stakingsconsigne was doorgegeven, begon Zaterdag 1 Mei de algemene staking. Iedereen legde het werk neer. Winkels werden gesloten; zelfs het bakkersbedrijf kwam volledig tot stilstand. Van Wissenkerke sloeg de staking over naar Kortgene (waar de gemeente-secretarie sloot) en Colijnsplaat, in mindere mate naar Kamperland. Geersdijk en Kats. Ook op de tussen de dorpen gelegen boerderijen nam men aan deze demonstratie van verzet deel. Alle groepen van de bevolking toonden zich solidair: intellectuelen en landarbeiders, orthodox-protestantse kernen en on-kerkelijke kringen, enz. Wel was duidelijk zichtbaar dat de landarbeiders op afgelegen boerderijen, b.v. in de buurt van Kats zich eerst met enig tijdsverschil bij de stakers aansloten. Dit verklaart, dat de staking Maandag 3 Mei een nog algemener karakter droeg dan Zaterdag.

Münzer, de Beauftragte in de provincie, was over de staking op NoordBeveland zo onthutst, dat hij zich 3 Mei persoonlijk naar het eiland begaf om een onderzoek in te stellen. Er werd gedreigd met terechtstelling van enige stakers. Dinsdag $4 \mathrm{Mei}$ verscheen een overvalwagen en vonden

1) De tekst van het gedrukte pamflet vindt men in de brochures van N. J. Karhof, Noord-Beveland in bezettingstijd, blz. 11. 
arrestaties plaats. Enkelen, tijdig gewaarschuwd, slaagden erin, zich uit de voeten te maken. A. G. M. Markusse uit Wissenkerke, zijn zoon M. Markusse en Mulder uit Colijnsplaat werden echter naar Middelburg gevoerd en daar verhoord. $Z_{i j}$ hebben een zestal maanden in het kamp van Vught moeten doorbrengen.

Noord-Beveland onderging de collectieve straf van een verplichting tot inlevering van alle radiotoestellen, enige tijd vóór het algemene, voor geheel Nederland geldende besluit. 


\section{HOOFDSTUK IX}

\section{ZUID-HOLLAND}

Ook voor de provincie Zuid-Holland gold de ervaring dat in de stakingsbeweging de grote steden meestal niet het voorbeeld gaven. Het verschijnsel was hier nog opvallender dan elders. Te Rotterdam is heel weinig gestaakt, tot teleurstelling van naburige steden en dorpen. In Den Haag iets meer, doch niet in die mate, dat in dit geval kon worden gesproken van een voorbeeld voor de omgeving.

Voor de ambtenarenstad Den Haag, centrum ook van het Duitse bestuur, was het niet verwonderlijk, dat de verzetsgeest in toom werd gehouden door de bezettende macht. De passieve houding van Rotterdam is moeilijker te verklaren, temeer omdat de bevolking er als fel anti-Duits gold.

Rotterdam was een zwaar gehavende stad. Dit op zichzelf reeds moest de homogeniteit van de bevolking, de groepssolidariteit, hebben aangetast. Uit de verwoeste binnenstad was men weggetrokken naar de buitenwijken ${ }^{1}$ ). De contactpunten van het vroeger zo levendige centrum ontbraken. De woningtoestanden waren ongunstig, somber en zorgelijk was het leven in vele overvolle huizen. De gehele sociale structuur van de stad was trouwens veranderd. De havens lagen verlaten, talrijke bootwerkers waren weggetrokken. De bouwvakarbeiders werkten meest in Hoek van Holland tot verdere versterking van de kust. Alleen de metaalbedrijven en de scheepswerven vertoonden nog iets van het oude beeld. Maar juist bij de werven was de vrijheid van handelen tot een minimum beperkt. Duitse wachtposten aan de poorten; afweergeschut en militair machtsvertoon op de terreinen. Men legde er 30 April het werk neer, maar men durfde niet wegtrekken. En juist op industrieën als de Droogdokmaatschappij, Wilton te Schiedam of de werf Piet Smit was de aandacht van het Rotterdamse publiek gevestigd.

Het volk was onrustig en terneergeslagen, maar reageerde niet heftig. De matte stemming menen wij voornamelijk te kunnen toeschrijven aan een zekere angstpsychose na het bombardement van 14 Mei 1940. De ellende van de „totale oorlog" was daarna blijven voortduren. Tientallen Geallieerde bombardementen, geregeld luchtalarm en vele slapeloze nachten oefenden een druk uit, die de meerderheid van de bevolking het gevoel gaven, enigermate murw geworden te zijn. $\mathrm{Nu}$ en dan viel er weer een groot aantal slachtoffers

1) W. E. Boerman en G. H. L. Zeegers, Bevolkingsverschuivingen in Rotterdam tengevolge van het bombardement van 14 Mei 1940, 1946. 
(o.a. door het bombardement van 31 Maart 1943, dat ongeveer 500 slachtoffers eiste).

De volksaard van de Rotterdammers was trouwens nooit bijzonder heftig geweest, veeleer gelijkmatig, ijverig en individualistisch. Er waren uitzonderingen, óók eind April 1943. Hier en daar werd wèl gestaakt; op 30 April legde het personeel van de Verenigde Chemische Fabrieken aan de IJsseldijk ( 60 man) het werk neer. Verder werden stakingen gemeld bij de N.V. Zoutziederij v/h Kolff $\&$ Vis (40 man), bij de IJzergieterij Rademakers (250 man), bij de N.V. Van Rietschoten \& Houwens (200 man), bij de Oranjeboom brouwerij (het grootste gedeelte van het personeel) en bij de Bataafse Petroleum Mij te Pernis (500 man). Merkwaardig, dat het staken van kantoorpersoneel vooral bij de grote assurantie-maatschappijen voorkwam: de Rotterdamse Verzekering-Societeiten ( $40 \%$ van het personeel), de Nationale Levens verzekeringsbank $(80 \%)$ en de H.A.V. Bank te Schiedam.

Van de kleinere bedrijven, waar gestaakt werd, verdienen, behalve de reeds genoemde, nog vermelding: de meubelfabriek van Bouman aan de IJsselmondselaan en de Machinefabriek van Niehuis \& Van den Berg. Voorts nog de kleine drukkerij Borghouts.

Toen Zaterdag het werk bijna overal werd hervat, kon de SD alle aandacht schenken aan de weinige bedrijven, waarvan het personeel een hardnekkiger houding aannam. Het was een goede gelegenheid om toe te slaan. Bij het ontbreken van de nodige solidariteit had men immers gemakkelijk vat op enkele ondernemingen, die een eigen koers meenden te kunnen volgen. Van Bouman's Meubelfabrieken werden de directeur en zijn gehele personeel ( 60 man) gearresteerd 1). Bij de drukkerij Borghouts kwamen zes stakers (van de 7 man personeel) in arrest. Twee van hen, H. W. Bouwman en W. A. Hommel, werden gefusilleerd.

Het standrecht, dat 30 April voor de Zuidelijke en Oostelijke provincies was afgekondigd, werd 1 Mei ook voor Rotterdam van kracht verklaard. Maar was het nodig geweest, het direct in alle scherpte toe te passen op een stad, die zich uitermate rustig had gehouden? Toepassing van intimidatie-politiek lag kennelijk in de lijn der Sicherheitspolizei. De berichten uit Delft, Dordrecht en Sliedrecht enz, waren voor de Duitsers zeer ongunstig. Zij wilden dus niet het risico lopen, dat Rotterdam zijn aarzelende houding zou laten varen en een voorbeeld zou worden voor de gehele omgeving. Daarbij kwam, dat de Duitse politie steeds met groot wantrouwen tegenover de Rotterdamse bevolking stond. Het kwaad geweten na de schanddaad van 14 Mei 1940 speelde de Duitsers parten. $Z_{\mathrm{ij}}$ maken in hun politierapporten bijvoorbeeld melding van het voor hen verontrustende feit, dat tal van oud-mariniers betrekkingen hadden gekregen bij de politie enz. en nog even Oranjegezind waren als vroeger.

Een en ander verklaart dat de Duitsers eind April 1943 dadelijk politieversterkingen naar Rotterdam dirigeerden. $\mathrm{Na}$ afkondiging van het standrecht

1) De arbeiders werden 3 Mei vrijgelaten; drie van de gearresteerden gingen naar Vught. 
werd scherp gepatrouilleerd. In de avonduren werden meermalen schoten gelost naar open vensters in Crooswijk en in andere arbeidersbuurten, waar de bevolking een demonstratieve houding aannam. Slachtoffers zijn er bij deze incidenten vermoedelijk niet gevallen.

Een ander aspect vertoonde de stakingsactiviteit in het tweede stedelijk centrum van Zuid-Holland: Den Haag. Ook daar heerste een zekere mate van passiviteit, maar op een andere manier dan te Rotterdam. Men had er zich leren bedwingen. Het Duitse machtsvertoon was er zó sterk, dat de Hagenaren bij voorbaat overtuigd waren van het nutteloze van hun weerstand. $Z_{i j}$ hadden meer vertrouwen in het systeem van lijdelijk verzet, dat uitstekend kon worden aangepast aan het wat stroeve tempo van de ambtelijke sleur. Op de talrijke bureaux gaven de chefs de toon aan. Als zij de sabotagemethode van het langzaam-werken goedkeurden, accepteerde men deze gunst dankbaar. Wanneer zij de arbeidsprestaties van hun personeel wilden opvoeren, toonde men zich gewoonlijk wel bereid, enigermate aan hun wensen tegemoet te komen. De enige emotionele groep in dit spel van geven-en-nemen, vormden de kantoormeisjes. $Z_{i j}$ waren meestal nog het meest fel en principieel en geneigd, aan de impulsen van het ogenblik toe te geven.

Bij de Postcheque- en Girodienst bijvoorbeeld, toonde het vrouwelijk personeel zich eerder bereid tot staken dan de mannen. Het grote percentage meisjes in vele Haagse bureaux zal er stellig toe hebben bijgedragen, dat er de 30ste April hier en daar reeds in de voormiddag werd gestaakt. Toen op het Hoofdkantoor van de Bedrijfsschap Zuivel een der directeuren moeite deed, de stakers tot andere gedachten te brengen, omstuwden 25 meisjes van de typekamer de man, die het wagen durfde, argumenten van voorzichtigheid te uiten. De meisjes verweten hem lafheid, waarop de chef zich zenuwachtg uit de voeten maakte.

Het meest vatbaar voor nerveuze aandoeningen in die spannende dagen waren de telefonistes. Wat voor anderen geruchten waren, vernamen zij als feiten. De snelle opeenvolging van mededelingen bracht deze meisjes in een toestand van opwinding. Wij zien dan ook, dat in het gehele land bij de overheidsdiensten de telefooncentrales het eerst uitvielen. De meisjes gooiden er het werk spontaan bij neer. In Rotterdam liepen een tiental meisjes van het telefoonkantoor de straat op, hun mantels, hoeden en tasjes in het gebouw achterlatend. Anderen, die hun voorbeeld wilden volgen, werden door Duitse schildwachten tegengehouden.

Wij mogen veronderstellen, dat op 30 April de stakingsberichten vooral door telefonistes zijn verbreid. $Z_{i j}$ vernamen, hoe vooral in $T$ wente, spoedig ook in Zwolle, Arnhem en Zuid-Limburg, de staking reeds in volle gang was, vóór Den Haag en Rotterdam tot handelen waren gekomen. De telefoon heeft vanzelfsprekend ook dienst gedaan bij inter-departementaal contact. Men moest daarbij echter uiterst voorzichtig zijn, want er werden vele gesprekken afgeluisterd. 
Bij het ontbreken van leiding hing, zoals reeds werd opgemerkt, in iedere tak van dienst veel af van de houding van de chefs. De eerste stakingen begonnen 30 April in het Centrale magazijn en in de Centrale Werkplaats van de P.T.T., zij werden gevolgd door een staking van 400 meisjes van de Postcheque- en Girodienst. In de loop van de dag, vooral na het einde van de middagpauze, kwamen stakingsberichten binnen van het Rijksbureau voor Chemische Producten, het Bedrijfsschap voor Zuivel, afd. West, het Rijkskolenbureau, het Centraal Bureau v. d. Statistiek, de plaatselijke distributiediensten en van de Haagse Tramweg Maatschappij (remisepersoneel en enkele lijnen), een der bureaux van de Burgerlijke Stand, de Rijkszuivelcentrale, enz. 's Middags, de 30ste April, staakten ook 700 personen van het 1000 man sterke personeel van de Rijkstelefooncentrale.

Buiten de ambtelijke wereld werd het werk neergelegd bij Van der Heijst Radiatorenfabriek, bij Van der Heem ("Erres-radio") te Voorburg en bij de kogellagerfabriek ,Enkes", eveneens te Voorburg. Men staakte ook bij het gas en waterleidingbedrijf en bij gemeentewerken.

Vele geruchten deden de ronde. Men zag overal huisvrouwen haastig inkopen doen, iedereen probeerde zoveel mogelijk brood en groenten in voorraad te krijgen. Kenmerkend voor de nerveuze stemming was ook het aftappen van water: men liet teilen en badkuipen vollopen. Daardoor verminderde de druk op de waterleiding zó snel, dat - zoals wij reeds zo vaak zagen - de mening postvatte, dat het waterleidingbedrijf reeds staakte - hetgeen door sommigen weer werd opgevat als een signaal voor de algemene staking. In afwijking van de uiterlijke kalmte in Rotterdam, kwam het in Den Haag tot manifestaties tegen de trams, die bleven rijden. Het personeel van lijn 12 gaf toe aan de aandrang van het publiek om het werk neer te leggen. Ook arbeiders van de remise Laan van Meerdervoort-hoek Lijsterbesstraat gingen in staking. De politie arresteerde een aantal van hen, waarbij het tot een schietpartij kwam, die een samenscholing van opgewonden mensen uiteen deed stuiven. Tegen de avond reden de trams weer vrijwel normaal.

De Duitse politie patrouilleerde intensief. Uit onlangs teruggevonden rapporten blijkt duidelijk dat de Duitse autoriteiten — vermoedelijk door verraad - nauwkeurig waren ingelicht over de gang van zaken in Den Haag. $Z_{i j}$ wisten bijvoorbeeld, welke bureauchefs een sein tot staken hadden gegeven. Dat zij desondanks geen represaillemaatregelen namen en zich in Den Haag zoveel gematigder gedroegen dan te Rotterdam, meen ik te moeten toeschrijven aan het verlangen, het bestuursapparaat zo min mogelijk te ontwrichten. Bovendien wensten Seyss-Inquart, Rauter, e.a. vermoedelijk geen verbittering in hun onmiddellijke omgeving. Misschien zagen zij er ook een belang in, hun NSB-vrienden te sparen. Wanneer men in Den Haag bloed vergoot, zou daar de haat tegen de centrale NSB-figuren immers nog feller worden.

Heel wat resoluter dan Rotterdam en Den Haag gedroeg zich de nabijgelegen industriestad Delft. De staking nam daar, althans wat de industriële bedrijven betreft, een vrijwel algemeen karakter aan. $Z_{i j}$ werd een manifestatie 
van solidariteit van een grotendeels socialistische arbeidersbevolking. De omstandigheden leenden zich daar wel toe. De concentratie van bedrijven langs enkele grote wegen maakte het mogelijk, de eerste stakende groepen arbeiders te zien. Zeer duidelijk openbaarde zich een massa-psychose.

Toen Vrijdagochtend 30 April bij de Kabelfabriek reeds vrij vroeg een bericht binnen kwam over een staking bij de Kabelfabriek te Alblasserdam, ging dit nieuws spoedig als een lopend vuurtje rond. De arbeiders, die door Christiansen's proclamatie van de vorige dag in opgewonden stemming naar hun werk waren gegaan, reageerden spontaan op het bericht van stakingen elders. Toen enkelen de fabriekspoort uitliepen, volgden de anderen. In de onmiddellijke nabijheid van de Kabelfabriek liggen de Pletterij Enthoven, Spoorijzer, Braat en de Verenigde Blikfabrieken. Onmiddellijk viel het bekende verschijnsel waar te nemen, dat juist de arbeiders in de metaalnijverheid in staat zijn tot snelle beslissingen en gedisciplineerd handelen. Een meer dan middelmatige intelligentie en langdurige routine in vakverenigingszaken garanderen hier een zekere eensgezindheid. Tegen 11 uur stonden de straten vol stakende arbeiders. Alleen de arbeiders van de Verenigde Blikfabrieken verlieten op aandrang van de directie hun werkplaatsen nog niet. $Z_{i j}$ bleven eerst na het schaftuur thuis.

Aan de overkant van de Schie zagen de arbeiders van de Lijm- en gelatinefabriek, van "de Porceleyne Flesch" en van de Kistenfabriek „'t Mannetje”, een stroom van stakers stadwaarts wegtrekken. Ook zij verlieten de fabrieks terreinen. Zoals te verwachten viel, sloeg de staking kort daarop over naar het Noordelijk stadsdeel: 's middags bleven de arbeiders van Calvé, van Reineveld en van de Gist- en Spiritusfabriek van hun werk. Slechts bij Reineveld en bij de Kabelfabriek bleven een honderdtal werkwilligen achter. Vermelding verdient dat bij "De Porceleyne Flesch" de stokers de ovens niet in de steek lieten om grote bedrijfsschade te voorkomen. Ook bij de Gist- en Spiritusfabriek werd besloten, dat een aantal arbeiders op post zouden blijven tot behoud van schaarse grondstoffen.

Het totale aantal stakers in genoemde industrieën kan op 3200 worden geschat (o.a. Gist- en Spiritusfabriek 900 arbeiders, Lijm - en Gelatinefabriek 300, Calvé 400).

Grote indruk maakte ook een staking van de P.T.T., waar men reeds om 11 uur's morgens het werk neerlegde (220 man personeel). Evenals in andere kantoren van de post- en telefoondienst waren ook hier de telefonisten het eerst door stakingsberichten uit andere plaatsen in een triomfantelijke stemming van verzet gekomen. Van het personeel bleef tenslotte slechts één Duitse telefoniste over en een Hollands meisje, dat op alle aanvragen voor telefoonverbinding antwoordde: „wij staken”. Dit tweetal werd aangetroffen door de Ortskommandant, die er zich met een inspecteur van politie van kwam vergewissen of de loketten van het telefoonkantoor inderdaad gesloten waren.

Het was Vrijdagmiddag druk in de stad. „Bijna een ouderwetse Julianadag” meenden sommigen. Minder opgewekt was de stemming van de door de Duitsers 
verantwoordelijk gestelde fabrieksdirecteuren en bureauchefs. $\mathrm{Na}$ enig over leg ging het personeel van de telefoondienst tegen het eind van de middag aan het werk; het postkantoor was de volgende ochtend weer gewoon geopend.

De directies der verschillende bedrijven kregen opdracht, lijsten van de stakende arbeiders in te leveren. $Z_{i j}$ konden zich er op beroepen, niet te weten, wie de stakers waren; na de sluiting van de bedrijven waren ook de werkwilligen naar huis gegaan. Vrij meegaand toonden de meeste directies zich in het inleveren van personeelslijsten. In het algemeen was hun houding in deze dagen aarzelend en weinig principieel. $Z_{i j}$ stonden daarin niet alleen. Slechts in zeer weinig gevallen, bijvoorbeeld bij de Staatsmijnen, lieten directeuren en bedrijfsleiders zich door geen enkele intimidatie uit het veld slaan.

De Duitse politie beschikte de 1ste Mei over voldoende gegevens om handelend te kunnen optreden. $Z_{\text {ij }}$ liet van ieder groot bedrijf een aantal arbeiders arresteren, in het geheel een honderdtal. De slachtoffers werden naar Rotterdam vervoerd, doch enige dagen later weer op vrije voeten gesteld toen bleek, dat reeds Maandag 3 Mei de rust was weergekeerd. Slechts van „De Porceleyne Flesch" staakten enige arbeiders nog langer door.

De directeur van het postkantoor, Van der Valk, werd ontslagen. Verder vonden weinig represailles plaats ${ }^{1}$ ). De 3de Mei oefenden de Duitsers nog enige contrôle uit, soms met de bekende intimidatiemethoden. Bij de Machinefabriek Reineveld sloot de Grüne Polizei de directie in het kantoor op, terwijl Duitse matrozen het terrein afzetten. Nadat gebleken was, dat de arbeiders het werk hadden hervat, verdween het politiebezoek weer.

Even algemeen als te Delft, maar wat feller en onbeheerster waren de stakingen in het Zuid-Oostelijk industriegebied van de provincie Zuid-Holland. Langs de Merwede en de Noord leefde een krachtige geest van verzet, die reeds vroegtijdig de vorming van illegale kernen gestimuleerd had. Zover, dat men de staking werkelijk leiden kon, was men er nog niet. Maar men trachtte wel invloed uit te oefenen op de gang van zaken door verspreiding van pamfletten. Van grote betekenis was ook in het gebied van de benedenrivieren, dat, vooral in de scheepsbouw, traditionele relaties van vertrouwen bestonden tussen werkgevers en werknemers.

Wij zullen thans eerst een overzicht geven van de stakingen in een aantal industrieplaatsen, om vervolgens aandacht te schenken aan het stakende platteland.

Het eerste bedrijf, dat Vrijdagochtend 30 April te Dordrecht staakte, was de N.V. Dordtsche Metaalindustrie Johan de Wit, een dochteronderneming van de N.V. Philips te Eindhoven. Het personeel van de ",Johan de Wit" had zich reeds om zeven uur 's morgens in de cantine verzameld en wenste één der directeuren, die zich ijlings naar de fabriek had begeven, te spreken over de mogelijkheid van een staking. De directeur wees zijn mannen op de ernst

1) Dinsdag $4 \mathrm{Mei}$ werden gearresteerd W. A. Verkennis, bedrijfsleider van de Gist- en Spiritusfabriek en een van de portiers, Padmos. $Z_{i j}$ ondergingen een gevangenschap van 13 weken te Vught. 
van de toestand, maar eindigde zijn toespraak toch met de woorden, dat men maar moest staken als men er voor voelde. Onder een hoeraatje verliet het personeel om half acht de fabriek. Bijna even vroeg in de ochtend liepen ook de werkplaatsen van de Electro Motoren Fabriek leeg. De stakende arbeiders moedigden hun collega's van andere bedrijven aan, hun voorbeeld te volgen. Ook bij Lips, Bakovenbouw, enz. werd het werk neergelegd.

Uit het feit, dat het personeel van de N.V. Johan de Wit reeds zeven uur 's ochtends een vastberaden houding aannam, mag worden afgeleid, dat er voorafgaand contact moet zijn geweest. Het staat wel vast, dat een groot aantal arbeiders een pamflet had gelezen, dat de 30ste April in alle vroegte was verspreid. In Dordrecht bestond namelijk een verzetsorganisatie, die het illegale blaadje De Waarheid in omloop bracht. Leider van deze groep was een eenvoudig timmerman, A. Havelaar. Toen Havelaar Donderdagmiddag het bevel van Christiansen had vernomen, kwam zijn kleine organisatie direct in actie. Men stelde een manifest op, een gloedvolle opwekking tot staking, leende een stencilmachine en werkte de gehele nacht door om Vrijdag vroeg in de ochtend tienduizend manifesten in omloop te kunnen brengen.

Een andere voorbereidende actie ging uit van leerlingen van de M.T.S., die blijkbaar met collega's van andere scholen in verbinding stonden. Vermoedelijk wisten zij 's avonds de 29 ste reeds, dat Twente in rep en roer was. Uit alles blijkt, dat te Dordrecht niet alleen de arbeiders gewaarschuwd waren, maar ook een gedeelte van het hoger personeel op de hoogte was van het plan voor een demonstratieve staking. Voor het personeel van de E.M.F. en van de Dordrechtsche Asphaltfabriek staat dit wel vast, voor de overige bedrijven kan het met een voldoende mate van zekerheid worden aangenomen. Men had de 30ste ook wel ineens thuis kunnen blijven, doch ieder had heimelijk het gevoel, dat het verlaten van de fabrieken na een korte beraadslaging de staking veel meer het karakter van een indrukwekkende betoging zou geven.

Tussen 10 en 11 uur 's morgens, Vrijdag 30 April, waren grote massa's arbeiders op straat: personeel van de E.M.F. (450 man), van de Dordr. Asphaltfabriek (30), van de N.V. Biscuit- en Chocoladefabriek Victoria (omstreeks 750 stakers van 900 man personeel), van de Firma Penn \& Bauduin (270), van de Stikstofverbindingsindustrie „Nederland" (150), van de reeds genoemde N.V. Dordtsche Metaalwarenindustrie Johan de Wit (350), de N.V. Scheepswerf De Rijn (90), van de N.V. Bakovenbouw (160), de Kalkfabriek v/h Van Dijk \& Co (110), N.V. Lips Brandkasten en Slotenfabriek (340 stakers van een personeel van 430 man) en van Van Randwijk's Grafische Machine- en Materialenhandel (27). Bij deze stakers sloot zich omstreeks half elf ook het personeel van het postkantoor aan (totaal 150 personen). Wij constateren, dat ook in dit geval de telefonistes het eerst deserteerden.

Geleidelijk kwamen andere bedrijven tot stilstand, 's middags bijvoorbeeld de N.V. Scheepswerf en Machinefabriek „De Biesbosch" (745) 1). De scheep-

1) De Duitse directie van dit bedrijf had 's morgens de poorten laten sluiten. 
vaart kwam stil te liggen door het staken van het sleepbootpersoneel.

Evenals in andere steden begon het publiek haastig inkopen te doen en water te tappen.

De directeuren der stakende bedrijven kregen bevel, hun personeel te gelasten, hun werk te hervatten. De Duitse politieautoriteiten, volkomen overrompeld door de gebeurtenissen en geprikkeld door de stakingsberichten, die van alle kanten binnenkwamen, pasten hun bekende dwangmaatregelen toe. Het standrecht zou hun gelegenheid geven, alle stakers, die in hun houding bleven volharden, te fusilleren. De hevigste bedreigingen werden geuit bij de N.V. Scheepswerf en Machinefabriek De Biesbosch, die onder een Duitse directie voor de Rüstungsinspektion werkte. Toen de meeste arbeiders 's middags na het schaftuur niet terugkwamen, moesten de bazen de werklieden gaan waarschuwen, dat op verder thuisblijven de doodstraf stond. De arbeiders lieten zich intimideren en gingen tegen het eind van de middag weer aan het werk.

Minder succes hadden de Duitsers met hun pogingen, de sleepboten weer in de vaart te krijgen. Al het sleepbootpersoneel bleek onvindbaar, de Wasserschutzpolizei viste overal achter het net.

$\mathrm{Na}$ een aantal arrestaties hervatte 's middags het personeel van het postkantoor de werkzaamheden. Het enthousiasme van de morgenuren was al aanmerkelijk geluwd, vooral toen duidelijk bleek, dat de spoorwegen bleven rijden. De eerste tekenen van aarzeling onder de Nederlandse bevolking maakten het de Duitsers gemakkelijk, de uitgeoefende druk te verzwaren. Rauter c.s. vatten weer moed. Uit Den Haag en Rotterdam kwamen bevelen binnen om de Nederlandse autoriteiten aansprakelijk te stellen voor alle ongeregeldheden. Omstreeks half elf kreeg de burgemeester van Dordrecht, de heer Bleeker, bezoek van een woedende SS-officier uit Den Haag, die hem de bitterste verwijten deed. Des te onaangenamer was het voor de heer Bleeker, kort daarop te vernemen, dat ook het personeel van de gemeentesecretarie in staking was gegaan. De burgemeester verzocht de afdelingschefs, hun personeel ervan te overtuigen, dat het in ieders belang was, de staking tot een korte demonstratie te beperken.

In Den Haag overwogen Rauter en zijn staf in hoeverre Dordrecht als stakingshaard extra streng zou worden gestraft. Het was in zekere zin een geluk, dat zij het onderzoek naar de gebeurtenissen te Dordrecht in handen legden van een NSB-er, de waarnemend gewestelijke politiepresident ,,kolonel" J. J. Boelstra uit Rotterdam, die in deze zaak vrij correct optrad en genoegen nam met een verklaring van burgemeester Bleeker, dat deze zich garant verklaarde voor de hervating der werkzaamheden op Maandag 3 Mei.

Zaterdag was het verzet nog steeds algemeen. Enkele arbeiders keerden naar hun werk terug. Hier en daar kwamen bedrijven weer in beweging, doch met een minimum bezetting. De directies verkleinden in hun opgaven aan de burgemeester systematisch de aantallen stakers, de burgemeester deed op zijn beurt hetzelfde in de rapporten, die hij aan de Beauftragte voor Zuid-Holland 
moest zenden. Zodoende kregen de Duitsers de indruk, dat de staking te Dordrecht reeds Zaterdag snel verliep.

De afkondiging van het standrecht, berichten over doodvonnissen en andere daden van terreur, het niet-staken van de spoorwegen en de talrijke proclamaties van de burgemeester en van de directies der stakende bedrijven, misten hun effect niet. Zaterdagmiddag bleek men er wel van overtuigd dat het spel verloren was. De vraag, die alle stakers bezig hield, was, of men represailles had te wachten. Men had in het algemeen wel vertrouwen genoeg in een aantal directeuren om geloof te hechten aan hun verzekering, dat geen strafmaatregelen zouden worden genomen tegen de arbeiders, die Maandagochtend het werk hervatten.

Maandag was de toestand weer vrij normaal. Alleen bij Penn \& Bauduin en bij de N.V. Machinefabriek v/h H. J. Koopman waren nog niet alle arbeiders aanwezig, doch zelfs hier bleven straffen achterwege. De Duitsers toonden zich te Dordrecht veel clementer dan te Rotterdam. Wel werd de directeur van het postkantoor, H. B. Charbon, ontslagen en moest de burgemeester achteraf rekenschap en verantwoording afleggen, maar in het algemeen kwam het te Dordrecht niet tot daden van terreur. Hieruit blijkt opnieuw de betekenis van het persoonlijk element in het optreden van Duitse politie-eenheden, welke opdracht hadden gekregen, de staking te breken. Soms traden zij betrekkelijk gematigd op, menigmaal ook deinsden zij voor geen enkel middel terug.

In het belangrijke stakingsgebied langs de Merwede vormde Hardinxveld een centrum van verzet. Ook hier waren vermoedelijk reeds Vrijdagochtend vroeg pamfletten verspreid door de groep-Havelaar uit Dordrecht. Locale groepen hadden eveneens een stakingsmanifest in omloop gebracht. Donderdagavond 29 April werden uit een rijdende trein pamfletten geworpen op het perron van het station Giessendam-Neder-Hardinxveld. Het viel achteraf niet meer te controleren, in welke mate de pamflettenactie heeft bijgedragen tot het heftig karakter van de staking te Hardinxveld. Zeker is, dat de 30ste algemeen en met gevoelens van verbetenheid werd gestaakt, o.a. bij de twee grote scheepswerven "De Merwede" (400 man) en "De Hoop" (65 man), bij de N.V. Machinefabriek Holland (110 man), de IJzergieterij Versteeg (35 man) en bij een aantal kleinere bedrijven. De autobusonderneming Sliedrecht-Hardinxveld werd dadelijk stopgezet, omdat de ondernemers niet wilden riskeren, dat de ruiten zouden worden ingegooid en de banden doorgesneden.

Met voldoening constateerde de bevolking, dat ook het personeel van de gemeentesecretarie het werk had neergelegd. Slechts de waterleiding bleef in vol bedrijf.

Te Gorinchem begon de staking ongeveer 9 uur bij de N.V. Constructiewerkplaatsen De Vries Robbé \& Co (ruim 1200 man). Merkwaardigerwijze ook hier de metaalbewerkers weer het eerst! $Z_{\mathrm{ij}}$ trokken door de straten, stelden $z$ ich in verbinding met andere groepen arbeiders en hadden niet veel 
moeite, velen tot het neerleggen van het werk te bewegen. De staking was te Gorinchem al spoedig even algemeen als te Hardinxveld en te Dordrecht. $\mathrm{Z}_{\mathrm{ij}}$ omvatte zowel het personeel van overheidsdiensten (het postkantoor; op de gemeente-secretarie werd slechts gedeeltelijk gestaakt) als van particuliere bedrijven (De Vries Robbé \& Co, N.V. Staaldraadkabelfabriek v/h J. C. den Haan, N.V. Machinefabriek Baan-Hofman, Firma Joh. v. Gelderen Kruiwagenfabriek, N.V. Kalkzandsteenfabriek, Firma van Wingerden, Kopergieterij, N.V. Stoomwasserij v/h H. C. Timmers, enz.). Vele winkeliers sloten hun winkels.

Te Leerdam staakte het belangrijkste bedrijf, de Glasfabriek Leerdam, te Arkel de industrie „Betondak”. Te Sliedrecht nam men een aarzelende houding aan. Eerst nadat de onderwijzer C. Teeuw te Sliedrecht het personeel van de scheepswerf Van Rees tot staken had opgewekt, legden de arbeiders bij deze werf het bijltje er bij neer. Te Werkendam werd een straat opgebroken. De toestand was hier en daar zo gespannen, dat het scheen, alsof de staking ieder ogenblik in een opstand kon overgaan.

Zaterdag 1 Mei had zich de staking over de gehele Alblasserwaard en het Land van Altena uitgebreid. Industrie-arbeiders en plattelanders gedroegen zich hier op dezelfde wijze, zodat wij, om het overzicht over het streekkarakter te behouden, goed doen, een ogenblik af te wijken van het schema om eerst de steden en daarna het platteland te behandelen.

De typische vorm van de plattelandsstaking kwam ook in de Alblasserwaard algemeen voor: staking van melkleveranties door de boeren en staking van het personeel van zuivelfabrieken. Toen Zaterdag de melkfabriek te Giessen-Nieuwkerk nog bleek te werken, trokken arbeiders uit Hardinxveld er op de fiets heen om de zuivelarbeiders over te halen het werk neer te leggen. Een groep jonge mannen uit Hoornaar, een naburig dorp, sloot zich bij hen aan. Te Giessen-Nieuwkerk kwam het tot een treffen met de politie.

Voor de Duitsers was het een probleem, waar zij met hun betrekkelijk kleine politiemacht zouden toeslaan. $Z$ ij hadden uiteraard het gevoel, dat $z i j$ overal gelijktijdig moesten zijn. Van de verschillende Ortskommandanten had de Grïne Polizei niet veel medewerking te verwachten; het leger hield zich zoveel mogelijk buiten conflicten met de bevolking. Vanzelfsprekend konden de Duitse autoriteiten rekenen op de medewerking van een aantal NSBburgemeesters en andere functionarissen, maar zij wisten wel, dat deze zich meestal in een te moeilijke positie bevonden om ingrijpende maatregelen te treffen. Slechts waar de Duitse politie-aanvoerders ter plaatse verschenen om zelf het onderzoek te leiden, vielen er slachtoffers. Voor het Zuidelijk gedeelte van Zuid-Holland berustte de leiding bij de Dienststelle Rotterdam (Kriminalsekretär Hoffmann). Daar concentreerde men aanvankelijk alle aandacht op Rotterdam zelf, maar toen de Rotterdammers zich rustiger gedroegen dan men had verwacht, kreeg Hoffmann gelegenheid, zich naar de ZuidOosthoek van de provincie te begeven. 
Hoffmann, oud-inspecteur van politie te Duisburg, was een felle partijman. Een imposante, kundige, maar wrede figuur. $H_{i j}$ was er van overtuigd, dat de stakingsbeweging georganiseerd moest zijn. Eigen ervaringen uit Duisburg gedurende de Ruhrstaking van 1923 tegen de Fransen stonden hem voortdurend voor ogen. Hij volgde de methode om vooral daar op te treden, waar hij kon steunen op loyale NSB-burgemeesters. Bij gebrek aan voldoende Duitse politietroepen maakte hij hier en daar (meestal onder misleidende dreigementen) gebruik van de medewerking van Nederlandse politieagenten of van leden van het corps luchtbescherming. Directies van bedrijven wist hij door uiterst geraffineerde methoden van intimidatie tot allerlei concessies te dwingen. Arrestanten werden meestal pas met de nodige vertraging door de SD naar Rotterdam vervoerd.

$\mathrm{Na}$ afkondiging van het standrecht, de 1 ste Mei 1943, begaf Hoffmann zich naar $Z$ wijndrecht. Vervolgens naar Hardinxveld en nabij gelegen plaatsen. Van de jongemannen, die bij de zuivelfabriek te Giessen-Nieuwkerk in botsing met de politie waren gekomen door het omverwerpen van melkkannen en het verdelen van melk onder het publiek, werd een aantal gearresteerd. Twee van hen, L. Kootstra uit Schelluinen en A. L. Verhoef uit Hoornaar, kwamen daags daarna voor het vuurpeleton. Hoffmann beschikte over voldoende informaties om te vermoeden, dat de arbeiders te Hardinxveld Maandagochtend nog niet aan het werk zouden gaan. In de meeste plaatsen bood de bevolking, teleurgesteld door de zwakke houding van de grote steden en door het niet-staken van de spoorwegen, geen weerstand meer. Waar het verzet wel voortduurde, liep men nu groot risico. Dit bleek Maandag $3 \mathrm{Mei}$ te Hardinxveld.

De Zaterdag was zonder incidenten verlopen. Zondag werd de burgemeester van Hardinxveld, de heer De Boer, uit de kerk gehaald. Buiten stond een officier van de Grüne Polizei, een zekere Renner, die de burgemeester een pamflet liet zien, dat de Duitsers bij het viaduct aangeplakt hadden gevonden. Renner bleek een redelijk man te zijn. Hij aanvaardde de verzekering van de burgemeester, dat deze niet van de verspreiding van pamfletten op de hoogte was, maar voegde er de waarschuwing aan toe, dat er Maandag bloed zou vloeien, indien de arbeiders bleven staken. De burgemeester pleegde daarna overleg met de directeur van de Scheepswerf „De Merwede". De directies der bedrijven lieten daarna hun arbeiders weten, wat er dreigde. Velen verschenen echter Maandagochtend niet, zij kwamen eerst in de loop van de dag. Juist deze handelwijze werd hun noodlottig, want Hoffmann, die een en ander had voorzien, vond nu gelegenheid, een beperkt aantal mannen te arresteren. Een twintigtal werd gevangen genomen op het moment, dat $z \mathrm{ij}$ het terrein van de werf wilden betreden. Vier van hen stierven diezelfde avond nog door de kogel: het waren C. S. de Kok, C. van der Giessen, D. Loever en J. W. de Blaey. De overigen gingen naar Vught.

Terwijl de arrestatie van deze mannen plaats vond, was het ten Zuiden van Gorinchem te Almkerk zeer rumoerig. In dit dorp, dat hoewel in de provincie 
Noord-Brabant gelegen, toch geheel behoort tot het gebied van Gorinchem, was een menigte van 200 man te hoop gelopen. Men drong het gemeentehuis binnen en dwong het personeel van de secretarie, het werk neer te leggen. Verder werd een poging gedaan, enige arrestanten te bevrijden. Een Duits commando, dat in allerijl naar Almkerk was gedirigeerd, opende het vuur en verspreidde de menigte. Twaalf personen werden gearresteerd. Zeer opstandig toonde zich ook de bevolking van het naburige Nieutwendijk.

Een dramatische wending dreigden ook de gebeurtenissen te Werkendam te nemen. Zoals reeds werd vermeld, had men daar op de eerste stakingsdag de straatweg opgebroken. De Duitse politie meende dit feit bloedig te moeten wreken. Misschien was het ook alleen voor intimidatie dat men de burgemeester van Werkendam, J. de Bruyne, wilde dwingen, tien willekeurige namen van gijzelaars te noemen. Burgemeester de Bruyne en de predikanten Jonker, Van Wieringen en Overduin boden daarop zichzelf aan, indien de Duitsers er van wilden afzien, een tiental willekeurige slachtoffers uit de bevolking te kiezen. Hun moedige en vastberaden houding maakte indruk. De Duitse politie dreef in dit geval de zaak niet verder op de spits en volstond tenslotte met een waarschuwing.

Bewogen dagen beleefde men ook langs de Noord. Daar waren vooral de scheepswerven te Kinderdijk, Alblasserdam en Bolnes brandpunten van de stakingsbeweging. De scheepsbouwers in de randgebieden van de Alblasserwaard en van IJselmonde zijn altijd een actief slag mensen geweest. Werkgevers en arbeiders vertonen hier dezelfde karaktertrekken: democratische gezindheid, werkzaamheid en energie. $Z_{i j}$ vertrouwen elkander en zeggen elkander soms hard en duidelijk de waarheid, zonder dat dit aan de wederzijdse waardering afbreuk doet. De arbeiders in de scheepsbouw, van afkomst plattelanders uit de omgeving, waren gewend in de open lucht te werken. Een gehard slag mannen, dat de vreugde van de arbeid kende: het vervulde hen met trots, als zij de rompen op de hellingen zagen groeien, zij juichten, als er een schip te water liep. Maar de boerenafkomst verloochende zich niet. Bijna alle arbeiders langs de Noord bezaten een klein perceel grond, waarop zij aardappelen verbouwden en groenten kweekten. Versterkte dit hun gevoel van onafhankelijkheid? Het valt moeilijk te beoordelen. Er kunnen andere oorzaken zijn voor de zelfbewuste geest van deze oeverbevolking, die de 30ste April op de dijken te hoop liep en hun ergernis over het uitblijven van stakingsberichten uit Rotterdam luchtten in de woorden: „Wij van de dijk moeten het weer opknappen".

Wij mogen ook niet uit het oog verliezen, dat langs de Noord in 1943 reeds verschillende illegale kernen werkzaam waren. Daartoe droeg de aanwezigheid van vele ondergedoken studenten stellig bij. Op bijna iedere werf waren zij te vinden, deze onderduikers, die een bereidheid om ook het ruwste werk te verrichten combineerden met een vrijmoedige aanvaarding van risico, waar het om sabotage of verzet ging. In deze groep onderduikers bestond ook veel belangstelling voor vervaardiging en verspreiding van pamfletten. De 
stakingsactie van 30 April en volgende dagen werd in dit milieu dan ook als een krachtproef aanvaard.

Op de Scheepswerf en Machinefabriek van Boele te Bolnes waren eind April 1943 ongeveer 1000 man werkzaam. Reeds Donderdag was op de werf een onrustige stemming ontstaan, toen de eerste geruchten over het besluit van Christiansen daar doordrongen. Vrijdag verschenen de arbeiders wel op het werk, maar zij bleven in groepjes staan praten. Na een kalmerende toespraak van een der bedrijfsleiders schenen de werklieden wel bereid, hun instrumenten ter hand te nemen. Plotseling ging echter de fabrieksfluit, die, zoals later bleek, door een jonge arbeider in werking was gesteld. Een gedeelte van de arbeiders verliet toen het terrein. Een groot aantal achter blijvers kon hun voorbeeld niet volgen, omdat een der directeuren de werfpoort door middel van een ketting had laten afsluiten. Men forceerde de deur echter met zo'n geweld dat de ketting sprong. De werf was nu in korte tijd vrijwel geheel ontruimd. De volgende dag verschenen de arbeiders op een aanmaning van de directie wel in de fabriek, maar er werd practisch niet gewerkt. 's Avonds, $1 \mathrm{Mei}$, verscheen een overvalwagen van de SD en begon het onderzoek naar de gebeurtenissen, waarbij de Duitsers vooral belangstelling toonden voor de wijze waarop de fabrieksfluit in werking was gesteld en de werkpoort geforceerd. De bedrijfsleider D. J. Akkermans nam voor dit laatste feit alle schuld grootmoedig op zich. Hij werd daarna als gevangene naar Ridderkerk gevoerd, later met een groot aantal andere gearresteerden naar Rotterdam. Merkwaardigerwijze bleef een doodvonnis achterwege (mis schien door voorspraak van een Duitse Rijnschipper, wie hij vroeger wel eens een dienst had bewezen). In ieder geval mocht Akkermans van geluk spreken, dat zijn straf beperkt bleef tot drie maanden concentratiekamp te Vught.

Het onderzoek van de Duitse politie wees uit, dat de arbeider Willem Kersten de fabrieksfluit in werking had gesteld. Achteraf bleek echter, dat het twijfelachtig was, of Kersten in de portiersloge de fabrieksfluit had bediend, dan wel de luchtalarmsirene in beweging had gebracht. Verder onderzoek bracht vertraging. Kersten kwam er met een gevangenisstraf, gelijk aan de voorlopige hechtenis, en een ernstige waarschuwing af. Niet alleen bij de werf Boele ging ontijdig de fabrieksfluit, die het einde van de arbeidstijd aankondigde. Hetzelfde gebeurde op de werf De Groot \& Van Vliet te Slikkerveer, waar een jongen, Deurloo, aan de fluit trok. Het resultaat bleek verrassend. Eerst liep de werf van De Groot \& Van Vliet leeg (300 man), daarna twee naburige fabrieken, waar men het signaal ook gehoord had: ElectroSmit (490 man) en de Klinknagel- en Schroefboutenfabriek v/h Joh's Smit (60 man). Vervolgens de werven te Ridderkerk.

In het algemeen hebben de directies in deze streek krachtig weerstand geboden tegen de Duitse eis, dat lijsten van stakers moesten worden ingeleverd. Zeer principieel was het verzet van de directie van De Groot $\mathcal{E}$ Van Vliet. Het gevolg van haar weigering, aan het Duitse bevel te voldoen, was de arrestatie van de heer Van Vliet, van de bedrijfsleider Stekelenburg en 
van de boekhouder Van Noppen. $Z_{i j}$ werden, met enige gearresteerde arbeiders, naar Rotterdam vervoerd (later naar $V u g h t$ ).

Langs de rechteroever van de Noord concentreerden de stakingen zich te Alblasserdam en te Kinderdijk, twee plaatsen, waar reeds vóór 1943 illegale groepen de geest van verzet hadden aangewakkerd. Een illegale kern te Alblasserdam was 9 Maart 1943 gearresteerd, maar dit weerhield de anderen er niet van, hun actie voort te zetten. Tot de meest onversaagden behoorden een viertal studenten, ondergedoken bij de werf van J. \& K. Smit te Kinderdijk en een arbeider, Jan Geval, bij dezelfde werf werkzaam.

Vrijdagochtend, nog vóór 8 uur, begon de staking bij J. \& K. Smit's Scheepswerven en Machinefabriek (600 arbeiders). Deze staking werd voor de arbeiders van naburige bedrijven het signaal, eveneens het werk neer te leggen; te Kinderdijk L. Smit \& Zoon Scheeps- en Werktuigbouw (400 man), Smit $\mathcal{E}$ Co's Machinefabriek (30 man) en N.V. F. Kloos \& Zonen's Werkplaatsen (240 man). Enkele uren later volgden de arbeiders van de fabrieken en werven te Alblasserdam hun voorbeeld. Er werd gestaakt aan de Werf Jan Smit Czn (140 man), aan de Werf „De Noord” L. U. Smit (300 man), aan de Ned. Kabelfabriek (560 man) en aan de Zuurstoffabriek De Alblas (35 man).

De arbeiders namen geen demonstratieve houding aan; de meesten gingen rustig naar huis of begaven zich naar hun perceeltjes grond, waaraan zoveel vrije dagen nuttig werden besteed. Intussen hadden de Duitse politieautoriteiten zich geleidelijk enig overzicht verworven van de omvang der stakingsbeweging. Hoffmann wist Zaterdag vrij nauwkeurig, waar de stakingshaarden lagen. Nadat hij zekerheid had verkregen omtrent de handhaving van de rust te Rotterdam, begaf hij zich, zoals reeds werd medegedeeld, naar het Zuid-Oostelijk industriegebied. Daar besteedde hij bijzondere aandacht aan Alblasserdam en Kinderdijk. De directies van verschillende werven en fabrieken waren reeds Vrijdag door de SD gesommeerd om op het gemeentehuis te Ridderkerk te verschijnen. De meeste heren gaven aan deze oproep geen gehoor. Zaterdag werd hun de eis gesteld, lijsten in te leveren van de arbeiders, die deze dag niet verschenen waren, doch de directies bleken collectief van mening, dat zij dergelijke lijsten niet konden samenstellen. $Z_{i j}$ kenden elkander - velen waren door familiebanden verbonden - en wisten, dat zij door één lijn te trekken sterk genoeg tegenover de Duitsers stonden om weerstand te kunnen bieden. Ook directies en bedrijfsleiders van stakende bedrijven te Hendrik Ido-Ambacht verklaarden zich met hun collega's solidair.

De SD oefende zware pressie uit op de portiers van enkele ondernemingen. Het onderzoek, verder onder leiding van Hoffmann persoonlijk, bracht voor de Duitsers voldoende gegevens aan het licht om tot arrestaties te kunnen overgaan (van B. J. M. Lels, directeur van de firma Vroege, A. J. Prins Visser, directeur van N.V. Kloos $\mathcal{E}$ Zonen te Kinderdijk, e.a.). Deze heren werden vrijgelaten, toen Hoffmann de overtuiging had gekregen dat de stakingsleiding moest worden gezocht onder het personeel van J. \& K. Smit's Scheepswerven 
en Machinefabriek te Kinderdijk. Hij wist ook, dat daar de verspreiders van een stakingspamflet moesten worden gezocht. Maandagmorgen $3 \mathrm{Mei}$ sloeg de SD toe. In een korte, onverwachte razzia arresteerde hij een aantal personen, van wie J. de Groot en W. J. Smit nog die dag werden gefusilleerd.

De 22-jarige W. J. Smit was een student-onderduiker, die op de werf van zijn oom een werkzaam aandeel had in het verzet. Hij behoorde tot degenen, die het stakingspamflet vervaardigden en verspreidden. Toen de SD op de bewuste Maandagmorgen bij de werf verscheen, had Wim Smit nog wel kunnen vluchten. Hij bevond zich op het kantoor van zijn oom en schijnt een waarschuwing te hebben beantwoord met de woorden: „Als ze mij niet vinden, nemen ze een ander - en ik kan zwijgen." Inderdaad nam hij het geheim van het pamflettencomplot mee in zijn graf. Wij gedenken hem als een der moedigsten uit de Meidagen ' 43.

Tot de plaatsen, die de bijzondere aandacht trokken van Hoffmann, behoorde Zwijndrecht. Ook daar was de staking Vrijdag spontaan uitgebroken (Verenigde Oliefabrieken, Tomado, Schokbeton, enz.). Zij bleef echter niet beperkt tot de industriële bedrijven. Ook de tuinders in dit belangrijke tuindersgebied verklaarden zich solidair met de fabrieksarbeiders. Vrijdagochtend waren $z \mathrm{ij}$ nog met volgeladen wagens naar de veiling gereden, doch naarmate $z \mathrm{ij}$ meer berichten hoorden, kreeg ook bij hen de stemming van verzet de overhand. De keurmeester voor de groentenveiling. De Waard Sr., ontving degenen, die kwamen opdagen, met de verwijtende vraag, wat zij eigenlijk kwamen doen. Men reed toen terug en verkocht de groenten op straat.

Zaterdagmorgen kon te $Z$ wijndrecht en omgeving werkelijk van een algemene staking worden gesproken. Vermoedelijk heeft de NSB-burgemeester Aeckerlin de Duitsers op de hoogte gehouden van de stand van zaken. Hoff mann verscheen de 1ste Mei zelf ter plaatse. Hij gaf de burgemeester opdracht, de directeuren van de grote bedrijven voor een bespreking op het gemeentehuis uit te nodigen. Ook de leden van de ordedienst van de vrijwillige luchtbeschermingsdienst, die daarvoor werden uitgezocht, moesten zich naar het politiebureau begeven om instructies in ontvangst te nemen. Onder hen bevonden zich twee ambtenaren van de dienst voor sociale zaken en maatschappelijk hulpbetoon: J. van de Herik en G. S. de Waard (een zoon van de keurmeester bij de veiling, die de tuinders tot staken had aangemoedigd). Deze twee jonge ambtenaren meenden het niet met hun gereformeerde geloofsovertuiging en met hun nationale gevoelens in overeenstemming te kunnen brengen, medeburgers te arresteren. $Z_{i j}$ weigerden dus aan het bevel te voldoen, met de motivering, dat de Duitsers en de burgemeester het recht niet hadden, de mannen van de luchtbeschermingsdienst te laten optreden als agenten van de hulppolitie. In deze houding volhardden $z i j$ ook, toen $z i j$ voor de burgemeester en de SD-er Hoffmann moesten verschijnen. Zelfs het dreigement, dat zij nog dezelfde dag gefusilleerd zouden worden, bracht hen niet van hun stuk. $Z_{i j}$ werden toen naar de gevangenis te Rotterdam vervoerd. In de loop van de dag kwamen steeds meer arrestanten het raadhuis binnen. 
's Avonds, toen het aantal arrestanten tot ongeveer 130 was gestegen, gaf Hoffmann het bevel, dat alle Nederlandse politiemannen en ambtenaren het gemeentehuis zouden verlaten. Inmiddels was namelijk een groep van 30 $z$ waarbewapende SD-ers aangekomen. De arrestanten werden in de raadzaal bijeengedreven. Daarna marcheerden de SD-ers binnen, die zich aan één zijde van de zaal opstelden. Hun zware helmen en de karabijnen in de aanslag gaven deze groep Duitsers een dreigend aanzien. Roerloos stonden zij tegenover de zwijgende arrestanten, die in de veronderstelling verkeerden, dat hun laatste uur geslagen was. Een half uur duurde deze marteling, daarna mochten de oudsten gaan zitten. 's Nachts werden de gevangenen in autobussen naar Rotterdam vervoerd. $\mathrm{Na}$ een vrij oppervlakkig verhoor kwamen de meesten van hen Zondag weer op vrije voeten. Enige bedrijfsleiders moesten hun weerspannige houding boeten met een verblijf van enkele maanden in het concentratiekamp te Vught (o.a. de heren v. d. Togt, en Van Smalen).

De Duitse intimidatiemethoden hadden ook te Zwijndrecht succes. Zondag was de stemming in de plaats zeer neerslachtig. Men maakte zich zorgen over het lot van de weggevoerde arrestanten. Maandag werden de werkzaamheden in de bedrijven vrij algemeen hervat.

Zondag en Maandag kwamen geleidelijk de vrijgelaten arrestanten terug. Tot ieders verbazing Maandag ook de heren De Waard en Van der Herik. Dit verwekte zoveel enthousiasme, dat $z \mathrm{ij}$ in optocht van het station naar huis werden gebracht (volgens de burgemeester alweer een anti-Duitse demonstratie). Van der Herik werd ontslagen bij Sociale Zaken. Door relaties kwam hij terecht bij de distributiedienst, waar hij gelegenheid kreeg, illegaal werk te verrichten. De Waard kreeg daags na zijn vrijlating een oproep tot tewerkstelling in Duitsland. Hij dook onder en ging in het verzetswerk (1 Augustus 1944 werd hij gearresteerd, 30 Augustus gefusilleerd).

Zoals reeds werd beschreven, was Delft de enige industriestad buiten het Zuid-Oostelijk industriegebied, waar de staking een vrijwel algemeen karakter droeg. Opmerkelijk kalm was het gedrag der arbeiders te Schiedam, Vlaardingen en Maassluis (Hoek van Holland als vestingstad was vanzelfsprekend reeds uitgeschakeld). Te Schiedam staakte het personeel van de H.A.V.-Bank, van enige melkfabrieken en van enkele kleine bedrijven.

Noordelijker, in het industriegebied van Leiden, beperkte de staking zich eveneens tot enkele ondernemingen: A. W. Sijthoff's Uitg. Mij (120 man), de Zuivelfabriek „De Landbouw” (90), de Kon. Ned. Fabriek van Wollen Dekens v/h G. C. Zaalberg $\mathcal{E} Z \mathrm{Zn}$ en de Hollandse Constructiewerkplaatsen. Te Alphen aan de Rijn staakte het personeel van de grote drukkerij van de N.V. Samsom's Uitg. Mij, te Gouda brak een staking uit bij de P.T.T. (ook hier het eerst bij de telefoondienst).

Het is een niet al te stoutmoedige hypothese, de oorzaken van de ongelijkmatige geografische verbreiding der stakingsbeweging ten dele te zoeken in de invloed van het streekkarakter. Maar juist voor Zuid-Holland zijn wij over de streekkarakters nog minder ingelicht dan over de andere provincies. 
Bij de steden, gegroeid door vestiging van buiten af, valt een eigen aard slechts in beperkte mate te onderscheiden. Op het platteland met de daarbij aansluitende randgebieden van nieuwe industrieplaatsen, b.v. in de Alblasserwaard, zijn bepaalde karaktertrekken beter bewaard gebleven. Ook de geloofsovertuigingen zijn hier minder in de zuigkracht van de stedelijke verzwakking geraakt.

Invloed van het geloof viel stellig waar te nemen in de houding van de bevolking van de Alblasserwaard, van de Vijfherenlanden en van de Krimpenerwaard, drie overwegend Ned. Hervormde poldergebieden. Wij beschreven reeds de stakingen langs Noord en Merwede, waarbij ook het naburige platteland ter sprake kon komen ${ }^{1}$ ). In de Krimpenerwaard gedroeg de bevolking zich kalmer. Te Krimpen aan de IJsel, Krimpen aan de Lek, Lekkerkerk en Bergambacht werd echter resoluut gestaakt, vooral in een aantal kleine bedrijven.

De vraag in hoeverre dorpen met een hoog percentage gereformeerde inwoners, b.v. Giessen-Nieuwkerk (omstreeks $30 \%$ ) meer weerstand boden dan andere dorpen, valt moeilijk te beantwoorden. Het relletje bij de Coöp. Zuivelfabriek "Samenwerking" (Vrijdagmiddag 30 April 1943), dat een aantal slachtoffers heeft gekost, ontstond niet door de houding van de inwoners van het dorp zelf. Wil men een voorbeeld van een gereformeerde plattelandsgemeente waar algemeen en principiëel werd gestaakt, dan kan Barendrecht op IJselmonde worden genoemd (Velo Wasmachinefabriek, tuindersbedrijven, enz.). Eveneens enkele gemeenten in het Westland, o.a. De Lier. Wel vindt men ook in Zuid-Holland in gereformeerde kring daden van individueel verzet, die ons met eerbied vervullen voor degenen, die voor geen enkele Duitse bedreiging zwichtten (wij denken aan Zwijndrecht, waar J. v. d. Herik en G. C. de Waard door hun moedige houding opvielen). Dergelijke daden kwamen echter eveneens in het niet-gereformeerde volksdeel voor.

De beide plattelandsgebieden in Zuid-Holland waar het verband tussen het streekkarakter en de verzetshouding van de bevolking gedurende de stakingsdagen van April-Mei 1943 het duidelijkst tot uiting kwam, waren de Alblasserwaard en het Westland.

In het $W$ estland droegen tal van omstandigheden er toe bij, de staking een algemeen karakter te geven. De bevolking van tuinders en boeren, landarbeiders en kleine middenstanders is er zeer individualistisch van karakter. De aard van het tuinbouwbedrijf kweekt democratische gevoelens van onafhankelijkheid aan. Excessen hiervan worden in het Westland eveneens waargenomen: een zekere neiging tot baldadigheid en uittartende onbehouwenheid. De gang van zaken in Noord-Holland bewijst, dat een krachtig individualisme op zichzelf nog niet tot daden van verzet behoeft te leiden. $\mathrm{Er}$ is daarnaast ook enige groepssolidariteit voor nodig, die zowel in de binding van kerkgenootschappen als in economische organisaties tot uiting kan komen.

1) In de Vijfherenlanden leverden de boeren geen melk meer aan de zuivelfabrieken. Gestaakt werd te Hoornaar en Schelluinen, Noordeloos, Lexmond, Peursum, Ameide, enz. 
De Westlanders voldeden aan beide voorwaarden. In vrijwel alle Westlandse gemeenten vormden gereformeerden en katholieken een belangrijk percentage van de bevolking. De coöperatieve veilingen hadden de tuinders tot economische samenwerking opgevoed. Hetzelfde geldt voor talrijke veehouders in dit gebied, die hun melk afleverden aan coöperatieve zuivelfabrieken in de naburige steden.

Typisch voor het Westlandse streekkarakter was de bereidheid tot daden van sabotage en geweld. Nadat Vrijdagmorgen 30 April vele tuinders hun knechten naar huis hadden gestuurd - hier en daar hadden de knechten zelfs opdracht, alle bedrijven langs te gaan - trachtte men te verhinderen, dat de aanvoer naar de veilingen doorging. Op verschillende plaatsen werden vaartuigen met groenten tot zinken gebracht, bijvoorbeeld in de Lange Watering te Kwintsheul waar men een schuit liet zinken om deze belangrijke verbinding met de stad onbruikbaar te maken. Toen bij het veilingsgebouw te Poeldijk nog enige boten met groenten aankwamen - de meeste boten waren onderweg al aangehouden en teruggestuurd - sprongen een paar jonge mannen op de schuiten en voeren deze met grote snelheid door het gebouw om het veilen van de aangevoerde partijen onmogelijk te maken. Te Monster ging de veiling wel door, vermoedelijk door de intimidatie, uitgaande van het sterke Duitse garnizoen.

Vrijwel àlgemeen was de staking te De Lier, 's Gravenzande en Naaldwijk. Overal hetzelfde beeld: verlaten tuindersbedrijven, gesloten winkels en op straat drukte van stakers, die in groepjes de gebeurtenissen stonden te bespreken.

In een wijde kring om het Westland heen, vooral te Leidschendam, Pijnacker, Berkel, Rodentijs en Maasland, staakten vooral de melkbedrijven. De veehouders, die weigerden aan de zuivelfabrieken af te leveren, verkochten hun melk aan particulieren. Ook het veilingsbedrijf stagneerde. Te Berkel en Rodenrijs had men een brug vastgespijkerd om een aantal NSB-tuinders te beletten, het veilingsgebouw te bereiken. Toen de politie voor het losbreken van de brug had gezorgd en enkele schuiten de veiling bereikten, bleek daar al het personeel te zijn gedeserteerd.

Waar de schoorstenen der zuivelfabrieken niet meer rookten en melkrijders hun diensten stopzetten, was het platteland meestal het best ingelicht omtrent de verbreiding der stakingsbeweging. Juist in die streken was men door de coöperatie meestal tot solidair optreden opgevoed, zoals de stadsarbeiders in hun doen en laten de invloed van de vakverenigingen hadden ondergaan. Het is in dit verband wel interessant, een vergelijking te trekken tussen de streken met coöperatieve ervaring en andere plattelandsgebieden, bijvoorbeeld de omgeving van Gouda, het land van de zelfkazers. In de buurt van Gouda richtten de boeren zich niet naar coöperatieve zuivelfabrieken en kenden zij niet het contact met vrachtrijders die melkbussen ophaalden. $Z_{i j}$ bleven grotendeels aan het werk. Of is het te ver gezocht, hier aan de bedrijfsvorm zoveel invloed toe te kennen? Men kan ook verdedigen, dat 
het streekkarakter daar de doorslag heeft gegeven. Het is eveneens mogelijk, dat een afkeer van coöperatieve samenwerking op zichzelf reeds symptomatisch is voor een bepaald streekkarakter.

Jo IJpma wees er in haar beschrijving van de Zuid-Hollandse streekkarakters op, dat Zuid-Holland minder coöperatieve zuivelfabrieken telt dan andere provincies ${ }^{1}$ ). Een sterk individualisme, tezamen met conservatisme en gebrek aan initiatief, maakt dit verklaarbaar. Maar onze studie over de April-Meidagen bewijst alweer, hoe gedifferentieerd de streekkarakters zijn. De bevolking bijvoorbeeld van de Alblasserwaard en van het Westland ken merkte zich door een geheel andere houding dan de bewoners van de streek tussen Voorburg en Boskoop, of van de Noordelijkste sector van de provincie. De karaktertrekken die Jo IJpma en andere auteurs van ",de" bevolking van Zuid-Holland beschrijven, gelden het meest voor het Noordelijke plattelands gebied van de provincie en voor de Zuid-Hollandse eilanden: een lijdelijke houding, uiterste bedachtzaamheid, de kat-uit-de-boom-willen-kijken, gebrek aan interesse, argwaan en een neiging tot bekrompen consvervatisme. In het geloofsleven heeft persoonsvertrouwen in de predikant menigmaal meer invloed dan het beginsel. "De Zuid-Hollanders buigen moeilijk voor argumenten, wel voor gevoelens," schrijft Jo IJpma. "Als ze iemand vertrouwen, geloven ze alles wat hij zegt en gaan door dik en dun met hem mee" 2).

Voor zover er in het Noordelijk gedeelte van Zuid-Holland plattelandsstakingen voorkwamen, gebeurde dit meestal op initiatief van enkele ver trouwensmannen. In de omgeving van Alkemade en Roelofarendsveen bijvoor beeld, bleef de bevolking van boeren, tuinders en landarbeiders Vrijdag en Zaterdag volkomen passief. Nadat echter een groep onder leiding van de arts $\mathrm{A}$, van der Bijl te Oude Wetering en van de gemeente-secretaris W. A. van Harteveld te Alkemade in de nacht van Zaterdag op Zondag stakingspamfletten hadden verspreid, begon Maandag 3 Mei te Alkemade en Roelofarendsveen een algemene staking. Boeren en tuinders staakten even vastberaden als het personeel van de distributiedienst en andere ambtenaren. Men reageerde nu zeer fel. Boeren lieten als teken van verzet hun melk wegvloeien; een tuinder, die probeerde zijn groenten naar de veiling te brengen, werd gemolesteerd en in het water geduwd.

In de bollenstreek Sassenheim-Hillegom bleef het solidair verzet beperkt. Daarentegen werd te Zoeterwoude en vooral te Katwijk fel en algemeen gestaakt. De staking te Katwijk, een plaats met een sterk Duits garnizoen, verdient wel extra vermelding. Meestal bleef het in de dorpen van het kustgebied onder Duitse druk heel rustig.

Op de Zuid-Hollandse eilanden vielen van plaats tot plaats grote verschillen waar te nemen. Wij wezen reeds op de krachtige staking in de gereformeerde gemeente Barendrecht op IJselmonde. De Duitsers arresteerden er tien personen. Naburige dorpen, behalve in het industriële randgebied van

1) P. J. Meertens en Anne de Vries, De Nederlandse volkskarakters, 1938, blz, 210.

2) P. J. Meertens en Anne de Vries, t.a.p., blz. 211. 
IJselmonde langs de Noord, gedroegen zich kalmer. Men hoede zich voor voorbarige conclusies. Langs het kustgebied, achter de Atlantik Wall, oefenden de Duitse garnizoenen een zware druk uit. Het eiland Roozenburg bijvoorbeeld had een bezetting van 3000 man op een even groot inwonertal.

Op Voorne en Putten en in de Hoekse Waard kwamen hier en daar stakingen van landarbeiders voor. Op Goeree en Overflakkee werd de stakingsbeweging in de kiem gesmoord door het krachtig optreden van de Ortskommandant te Oude Tonge. Deze reed met een zwaar bewapend commando van vijftien man het hele eiland over en stelde overal de burgemeesters aansprakelijk voor wanordelijkheden. Te Oude Tonge hadden vijf kappers de 30ste April demonstratief hun zaken gesloten. Hun daad was daar het sein voor de staking. De Ortskommandant, een zekere luitenant Blütge, liet de kappers echter al gauw arresteren (door de Nederlandse politie). Daarop trok een grote menigte naar het raadhuis met het verzoek, de kappers vrij te laten op voorwaarde, dat men verder niet zou staken. Dit verzoek werd ingewilligd. Verdere stakingen op het eiland bleven beperkt tot het thuisblijven van enkele landarbeiders. Er komen op dit eiland Christelijk-gereformeerde groepen voor, die, evenals elders in den lande, steeds geneigd waren, zich aan de overheid, - al was het een Duitse overheid - te onderwerpn. Doch ook het Nederlands-Hervormde en onkerkelijke deel van de bevolking op Goeree-Overflakkee gedroeg zich opvallend passief. Het is mogelijk, dat het isolement van het eiland en het laat binnenkomen van stakingsberichten op deze houding eveneens van invloed zijn geweest. 


\section{HOOFDSTUK $\mathrm{X}$}

\section{UTRECHT}

Evenals in Zeeland en in de middengebieden van Noord- en Zuid-Holland is het in de provincie Utrecht gedurende de April-Meidagen van 1943 opvallend rustig gebleven. Zowel in de steden als op het platteland reageerde de bevolking vrij passief. In vele gemeenten bleef men aan het werk, zonder de minste neiging tot demonstratief verzet (Nigtevecht, Vinkeveen, Loenen. Loenersloot, Loosdrecht, Breukelen-Nijenrode, Kockengen, Ruwiel, Tienhoven, Achttienhoven, Eemnes, Soest, Renswoude, Leersum, Doorn, Driebergen, Wijk-bij-Duurstede, Bunnik, Odijk, Werkhoven, Vreeswijk, Jutphaas, Montfoort. Willeskop en andere gemeenten).

Waarom gedroegen boeren en arbeiders op het Utrechtse platteland zich zo geheel anders dan de bewoners van het Friese weidegebied? Hoe verklaren wij het gebrek aan spontanëiteit bij een groot gedeelte van de plattelandsbevolking in Zuid-Holland, Noord-Holland en Utrecht? Er is mij geen enkele goede beschrijving bekend van het Utrechtse plattelands-streekkarakter; ze ontbreekt zelfs in de boeken, die voor de verschillende streken van ons land uitstekende overzichten bevatten. Mag men, negatief beschouwd, zeggen, dat sommige volksgroepen worden gekenmerkt door het ontbreken van markante trekken? Vooral in de weidegebieden van het laagveen, met een verspreid wonende boerenbevolking, die weinig binding in dorpsgemeenschappen kent, is een wat mat en berustend individualisme geen uitzondering. Men is er traditioneel in het geloof, met een geringe emotionaliteit; daarbij conservatief, onvoldoende bereid tot samenwerking (beperkte belangstelling voor coöperatie) nuchter en achterdochtig.

Een geheel andere volksaard treft men aan in het Oostelijk gedeelte van de provincie, langs de Utrechts-Gelderse grens. Daar is dan ook spontaner en heftiger gestaakt dan in het midden en in het Westen van Utrecht. Hier en daar (Veenendaal) heeft men het werk zelfs uiterst demonstratief neergelegd. Verder Zuidwaarts sloten de stakingen te Amerongen en Rhenen aan bij de stakingsbeweging in het Zuid-Veluwse industriegebied.

Vóór wij aandacht schenken aan de stakingen op het platteland en in enige kleine industriecentra, dienen wij eerst vast te stellen, wat zich in de zo centraal gelegen hoofdstad van de provincie afspeelde. Dat Utrecht gedurende de April-Meidagen geen brandpunt van verzet werd, behoeft ons, gezien de sociaal-economische structuur van de stad en de kalme aard van 
haar bevolking 1 ), niet te verwonderen. Van een massaal optreden van arbei ders kon hier geen sprake zijn; ook de handeldrijvende middenstand wond zich niet op. Waar gestaakt werd, nam meestal het kantoorpersoneel de leiding en dan nog wel de jeugdigen onder hen - vooral de meisjes. In geen andere stad althans heeft het vrouwelijk element zo sterk de doorslag gegeven als te Utrecht!

De eerste staking te Utrecht begon Vrijdagochtend 30 April bij de LubroBroodfabrieken (280 man personeel, van wie vermoedelijk de helft in staking ging). Dit voorbeeld werd gevolgd door het kantoorpersoneel van de Brandstoffencommissie, die over kantoorruimte beschikte in het gebouw van het Gemeentelijk Gas-, Electriciteits- en Autobusbedrijf. Intussen hadden ook reeds enige ambtenaren van de Provinciale Utrechtse Electriciteits Maatschappij het werk neergelegd (ongeveer 100 man administratief personeel). Evenzo een aantal telefonistes van de telefooncentrale (het grootste transitokantoor in Nederland). Overal werd nu op kantoren en bureaux beraadslaagd, wat men zou doen. Daarbij kwam in het algemeen de neiging aan het licht, eerst eens af te wachten wat men bij de Ned. Spoorwegen zou doen.

De directie van de Ned. Spoorwegen confereerde met het dagelijks bestuur van de personeelraad. In deze besprekingen kwam een vrees voor riskante avonturen tot uiting. Bovendien liet men de overweging gelden, dat een mislukte staking in Mei 1943 eventuele latere stakingsactie (die zeker nodig zou zijn, als de invasie begon) in de weg zou staan. Was het niet beter, het kruit droog te houden?

Dergelijke beschouwingen zijn destijds in Nederland wel meer gehouden. Het was slechts de vraag, of $z \mathrm{ij}$ de verontwaardigde groepen arbeiders en ambtenaren konden overtuigen. In de meeste gevallen gaven sociaal-psychologische en sociologische factoren de doorslag. Dit bleek bij de Ned. Spoor wegen duidelijk. Het kantoorpersoneel te Utrecht, in enkele gebouwen verenigd, door onderling overleg in toenemende staat van opgewondenheid geraakt, toonde zich niet geneigd, het advies van directie en personeelraad te volgen. De grote verspreide massa van het overige personeel trok niet direct één lijn. Niet omdat men het dadelijk eens was met het advies van de centrale leiding, maar omdat men te weinig contact met elkander had. Zelfs plaatselijk was overleg veelal niet mogelijk: een groot gedeelte van het locomotief - en treinpersoneel kende immers geen vaste standplaats. Bovendien maakte de indeling van het personeel in dag en nachtploegen het overleg nog moeilijker.

Geheel anders was het in een groot bedrijf of in een kantoor, waar men in de gelegenheid was, de situatie te bespreken en de betekenis van alle binnenkomende geruchten (de telefoon stond niet stil) te onderzoeken.

Tegen het eind van de morgen ging het personeel van de gebouwen I en II van het hoofdbureau Ned. Spoorwegen in staking; het jeugdig vrouwelijk

1) Zie P. H. Ritter, De Utrechtenaren, in De Nederlandsche Volkskarakters door P. J. Meertens en Anne de Vries, 1938. 
personeel (dat ook het meest opgewonden was) ging het eerst de deur uit. Volgens een, afdelingschef moet het aantal stakers in deze gebouwen aanvankelijk op $50 \%$ worden geschat. 's Middags bleven er meer weg; óók het personeel van gebouw III.

Bijzondere vermelding verdient het staken van de meisjes van de telefooncentrale der directie, vooral omdat één van hen. Mejuffrouw G. Hekkert, vóor het verlaten van het bureau aan 18 hoofdstations een telexbericht zond (even voor half twee) met de mededeling, dat de staking van het spoorwegpersoneel om twee uur zou beginnen. Van enige stations werd teruggetelegrafeerd om bevestiging van dit bericht te krijgen. De directie liet het eerste bericht dadelijk herroepen. Intussen had ook de Duitse politie een en ander over de gedurfde daad van Mejuffrouw Hekkert vernomen. Er werd een arrestatiebevel tegen haar uitgevaardigd (waarop later veroordeling tot 15 jaar tuchthuisstraf volgde).

's Middags gingen de lokettisten (alweer vooral de vrouwelijke!) van het plaatskaartenbureau op het Centraal Station te Utrecht in staking. De politie trok een cordon om het stationsgebouw en oefende strenge contrôle uit. Reizigers konden zonder plaatsbewijs toegang tot de treinen krijgen. In de loop van de middag breidde de stakingsbeweging zich verder uit. Het administratief personeel van het Gemeentelijk Gas-, Electriciteits- en Autobusbedrijf legde het werk neer. Hetzelfde geschiedde bij de verkeersinspectie en bij de N.V. Sigarenfabriek Panter. Zo waren Vrijdagmiddag enige duizenden personen, meest kantoorpersoneel, in staking. In de stad ging het leven echter gewoon door. De winkels bleven geopend en het was op straat niet drukker of stiller dan gewoonlijk.

Het viel de Duitsers niet moeilijk, een sterke pressie uit te oefenen. $Z_{\text {ij }}$ stelden directeuren en bureauchefs aansprakelijk. Alle stakers kregen een oproep tot hervatting der werkzaamheden (dit geschiedde door het nietstakend personeel), waarin met zware straffen werd gedreigd. In een fluistercampagne gingen bovendien berichten van mond tot mond over het gevaar. dat het leidinggevend personeel liep, als men niet voor de Duitse aandrang $z$ wichtte. Toen het tegen de avond duidelijk werd, dat de staking zich niet verder had uitgebreid en dat de spoorwegen bleven rijden, kwam men na ampel overleg algemeen tot de conclusie, dat de staking tot een demonstratie van één dag kon beperkt blijven. Zaterdagmorgen 1 Mei was ieder aan het werk.

Met voldoening constateerde de Duitse politie ook, dat de arbeidersbevolking van de fabrieksdorpen langs de rand van het stadsgebied in haar protesthouding niet verder ging dan enige demonstraties van korte duur: Vrijdagmiddag verliet een gedeelte van het personeel van de N.V. Werkspoor te Zuilen de fabrieksterreinen. Vele arbeiders keerden spoedig terug, anderen meenden te kunnen volstaan tot een korte sit-downstaking. Bijzonder duidelijk is het beeld van deze gebeurtenissen niet. Zeker is wel, dat men er niet veel betekenis aan mag hechten. 
Ook in de Aluminium Wals- en Persbedrijven in de Utrechtse randgemeente Oudenrijn werd slechts aarzelend gedurende enkele uren gestaakt.

Te Amersfoort staakte, op grond van het genoemde telexbericht uit Utrecht, een gedeelte van het spoorwegpersoneel, doch niet veel langer dan een uur. Verder vinden wij vermeld, dat het personeel van Gerritsen's Graanhandel en Pakhuizen het werk neerlegden. Eén van de stakers, een zekere Davelaar, werd door de Duitsers gearresteerd en ,"bij een poging tot ontvluchting” doodgeschoten. Vrij kalm bleef de bevolking van Baarn, waar talrijke winkeliers hun winkels sloten, doch waar verder niets gebeurde - in tegenstelling met het naburige Bunschoten-Spakenburg, waar in de ochtend van de 30ste April een oproerige stemming heerste. De meeste Bunschotense winkeliers sloten hun winkels; bijna alle bedrijven sloten zich bij de staking aan. Voor zover viel na te gaan, geschiedde een en ander niet zonder leiding (verspreiding van stakingsmanifesten, enz.). Een contrast met de houding van het fabrieks personeel uit Amersfoort en Utrecht en omgeving vormt ook stakingsactiviteit van arbeiders en employé's te de Bilt en Bilthoven. Zaterdagochtend 1 Mei werd het werk neergelegd bij de fabriek "Inventum" te Bilthoven (250 man). Bij de Metaalwarenfabriek van Meyer en Greven (125 man) waren de arbeiders wel verschenen, doch al gauw verlieten zij en bloc de fabriek.

Dit voorbeeld werd gevolgd door het personeel van verschillende kleinere bedrijven (Instrumentenfabriek Schmitt te Bilthoven en de Apparatenfabriek Van Doorn te De Bilt). Belangrijk was ook de sluiting van de kantoren van het Bedrijfsschap voor Eieren en Pluimvee te De Bilt (120 man personeel).

Het nadeel van dergelijke geïsoleerde stakingen was, dat zij de Duitsers gelegenheid tot snel ingrijpen boden. Reeds 9 uur 's morgens, een uur na het uitbreken van de eerste staking te De Bilt, Zaterdag $1 \mathrm{Mei}$, verscheen een afdeling SS-troepen in het dorp. De Duitsers installeerden zich op het politiebureau en begonnen daarna met een systematische contrôle. $\mathrm{Z}_{\mathrm{ij}}$ gingen geducht te keer tegen de bedrijfsleiders van de fabrieken van "Inventum" en van Meyer $\mathcal{E}$ Greven en gaven zich veel moeite, op te sporen, wie de staking hadden georganiseerd. Vele arbeiders werden aangehouden (de meesten woonden niet in het dorp zelf) en verhoord na urenlange opsluiting in het bureau van politie. Een aantal bedrijfsleiders en arbeiders van de genoemde fabrieken evenals een achttal employé's van het Bedrijfsschap Eieren en Pluimvee onderging een tweede verhoor in het bureau van de SD te Utrecht. $Z_{i j}$ mochten Maandag 3 Mei naar huis gaan, nadat intussen te De Bilt en te Bilthoven het werk al volledig was hervat.

Bij het stakingsgebied De Bilt-Bilthoven sloot ook Zeist aan. De belangrijkste staking te Zeist was (Vrijdag en Zaterdag) van het personeel der N.V. Gerofabriek (omstreeks 400 man). Maar ook het personeel van de distributiedienst (omstreeks 90 personen) en van de gemeentelijke gasfabriek legde Vrijdag gedurende enkele uren het werk neer.

Een echte stakingshaard was Veenendaal, waar men even emotioneel en heftig in verzet kwam als in enkele Gelderse gemeenten (b.v. Scherpenzeel) 
aan de overzijde van de provinciegrens. Ongetwijfeld heeft zich de vrijgevochten aard van de bevolking van deze streek in de stakingen gemanifesteerd; evenzo de groepssolidariteit van de arbeiders in een aantal kleine fabrieken (meest spinnerijen). Men was te Veenendaal reeds Donderdagavond op de hoogte van het uitbreken van de stakingen in Twente. In de loop van de nacht vonden verschillende besprekingen plaats; Vrijdagochtend bleven de meeste arbeiders thuis. Behoefte aan overleg voor de fabrieksingang of in de bedrijven zelf werd niet gevoeld. Winkels werden gesloten; ook de overheidsdiensten kwamen tot stilstand.

Toen Vrijdag later in de ochtend autobussen (onder Duitse bewaking) verschenen om personeel van de „Enka" uit Ede op te halen, leverde dit weinig resultaat op. Slechts hier en daar gelukte het, enige arbeiders tot meegaan te pressen. Bestellers van de P.T.T. werden op straat door het publiek lastig gevallen, men rukte hun de brieventassen uit de handen.

's Avonds kwamen enige auto's met Duitse militairen en werden zes inwoners van het dorp gearresteerd. Ook uitten de Duitsers krasse bedreigingen tegen de fabrikanten. Deze riepen toen in hun wanhoop de hulp in van enkele predikanten om de bevolking tot kalmte aan te manen. Intussen was de woede echter al wat bekoeld. Het uitblijven van de spoorwegstaking, de arrestaties en de raad van de predikanten om de tegenstand niet op de spits te drijven, hadden tot resultaat, dat de Veenendaalse boeren, arbeiders en middenstanders Zaterdag collectief hun Vrijdag zo eensgezind begonnen staking beëindigden.

In de gemeenten Leusden en Stoutenburg beperkten de plattelandsstakingen (geen aflevering van melk aan de fabrieken, het thuisblijven van landarbeiders) zich tot enkele buurtschappen. Te Rhenen begon de staking Vrijdagochtend in enkele kleine bedrijven (Kalkzandsteenfabriek Vogelenzang, Chemische fabriek Rhenen, Meubelfabriek van de firma Koekoek en de Timmerfabriek de Stoomhamer). Ook legden ongeveer 100 personen in de dienst van de Ned. Heidemaatschappij het werk neer. Het autobusvervoer stagneerde; de meeste boeren leverden geen melk meer. Zaterdag 1 Mei keerden echter verschillende stakers naar hun werk terug en Maandag 3 Mei behoorde ook hier de staking tot het verleden, zonder dat er slachtoffers waren gevallen. In de gemeente Amerongen staakten 30 April en 1 Mei enige grote steenfabrieken, die ieder ongeveer 100 man personeel in dienst hadden.

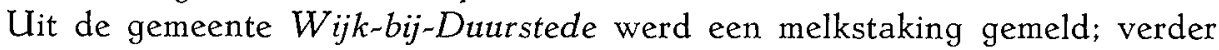
legden daar Vrijdagmiddag de gemeente-ambtenaren het werk neer (evenals te Maartensdijk). In de gemeente Lopik staakte Vrijdag het personeel van de N.V. Zuivelfabriek Amilko. In slechts één plaats in het Zuidelijk gedeelte van de provincie nam een staking een grotere omvang aan: te IJselstein. Zaterdagmorgen 1 Mei verliet daar het personeel van de N.V. Schilte E Zonen's Houthandel (omstreeks 125 man) fabriek en kantoor. Dit vond direct navolging onder het personeel van naburige bedrijven. (N.V. Stoel - en meubelfabriek v/h Gebr. van Rooijen, Fenstra's Meubelfabrieken, en nog twee of drie andere bedrijven). Het aantal stakers kan op 900 à 1000 worden geschat. $Z_{i j}$ 
beperkten zich tot een demonstratie van één dag; Maandag waren allen weer aan het werk. Ook de meubelfabriek te Polsbroek kwam een dag stil te liggen.

Van geringe betekenis waren de plattelandsstakingen in de gemeenten Wilnis, Willeskop. Hoenkoop, Benschop en Polsbroek, Zegveld, Houten, Maarssen, Mijdrecht en Abcoude. Te Abcoude werd ook gestaakt door enig personeel, dat in dienst van de Amsterdamse Ballast Maatschappij werkzaam was in de aanleg van een der rijkswegen.

Waar zich geen bijzondere gebeurtenissen voordeden, is de herinnering aan de staking al verbleekt. Enkele gevallen van sabotage werden door de Duitsers geheim gehouden, bijvoorbeeld een spoorwegaanslag bij Rhenen 7 Mei '43, enige dagen na afloop van de staking - klaarblijkelijk gepleegd om het wegvoeren van gevangenen te belemmeren. Bij deze aanslag kwam een lading springstof ontijdig tot explosie, waardoor de voornaamste dader, Ir J. W. Schouten uit Bennekom, op tragische wijze de dood vond. 


\section{HOOFDSTUK XI}

\section{NOORD-HOLLAND}

De April-Meidagen van 1943 gaven slechts in enkele streken van NoordHolland vastberaden verzet te zien: het meest in enige Zaanse industrieplaatsen (vooral Krommenie en Wormerveer), te Velsen-IJmuiden, op het platteland in vele West-Friese gemeenten (Enkhuizen, Andijk, enz.) en in de tuinbouwdorpen ten Noorden van Alkmaar.

Van beslissende betekenis was de rustige houding van de bevolking van Amsterdam, die wel enige verklaring behoeft. De Amsterdammers bewaarden nog de herinnering aan de snel-onderdrukte Februari-staking van 1941. $Z_{i j}$ hadden leren berusten. In machteloze woede had men vele transporten Joden zien afvoeren; het was wel duidelijk geworden, dat openlijk verzet tegen de Duitse terreur niet baatte. Deze overtuiging ontnam steeds meer de spontaneïteit aan de van nature zo actieve Amsterdamse bevolking.

Bij het organiseren van illegale kernen schijnen in de hoofdstad vooral de communisten een voorsprong te hebben gehad. Maar juist zij waren in de eerste maanden van 1943 door een reeks arrestaties getroffen, zodat zij zich voorzichtig moesten hergroeperen en zich dus wel twee maal moesten bedenken, eer ze een stakingsconsigne konden doorgeven.

Er heerste Donderdagavond 29 April te Amsterdam een opgewonden stemming op straat, doch georganiseerd overleg bleef vrijwel achterwege. De volgende morgen begon de eerste staking bij N.V. Werkspoor, waar een aantal arbeiders de machinefabriek verliet (v.m. acht uur). Toen het personeel van enkele werkplaatsen de poort uitging, scheen men in alle gebouwen van het bedrijf dit voorbeeld te willen volgen. Tegen half negen reden echter vijf auto's met Grüne Polizei het terrein op. De Duitse politiemannen bezetten de poort en dreven de arbeiders naar hun werkplaatsen terug. Hierdoor werd voorkomen, dat grote groepen arbeiders zich in de stad verspreidden en door een demonstratieve houding andere stakingen uitlokten. $\mathrm{Na}$ het schaftuur bleven echter vele arbeiders weg, zodat voor de middaguren het aantal stakers bij Werkspoor op 2400 kan worden geraamd (van een personeel van 3000). Op aandrang van de directie en onder Duitse pressie werden de werkzaamheden de volgende dag hervat.

Ook de stakingen bij de N.V. Nederlandsche Dok-Maatschappij (1600 man) en bij de N.V. Amsterdamsche Droogdok-Maatschappij (800 man), hadden een.rustig verloop en eindigden op de dag, waarop zij waren begonnen. 
Het is mogelijk, dat in de stad hier en daar ook nog kleinere bedrijven hebben gestaakt. Dit viel slechts vast te stellen voor de N.V. Staalmeubelfabriek Cirkel ( 55 man). De trams bleven rijden, de winkels waren geopend, het was op straat niet stiller of drukker dan gewoonlijk. Alleen 's avonds na acht uur, lagen na afkondiging van het politiestandrecht de straten eenzaam en verlaten. Uit politierapporten blijkt, dat enkele onbeduidende schietpartijen plaats vonden.

Meer variatie vertoonde het beeld in de Zaanstreek, waar men evenals te Amsterdam rekening hield met de mislukte Februari-staking. Maar in de Zaanstreek had men minder de deprimerende invloed ondergaan van de regelmatig volgehouden Jodenvervolgingen en kwam men dus wel iets gemakkelijker in beweging: hier en daar spontaan, echter ook wel op aanraden van communistische cellen in de bedrijven.

De meest dramatische wending namen de gebeurtenissen te Krommenie, waar Vrijdag 30 April 700 arbeiders van de N.V. Verenigde Blikfabrieken het werk neerlegden. De arbeiders waren 's morgens nog wel verschenen, maar nadat tijdens de arbeid stakingsgeruchten uit andere plaatsen waren besproken, zag men tegen 11 uur enige werklieden heengaan. De stemming werd steeds onrustiger. Tegen 12 uur liet de directie meedelen, dat de Rüstungsinspektion arbeiders van de Verenigde Blikfabrieken vrijstelling zou verlenen. Men was echter in een zeer recalcitrante stemming. Het ging immers niet in de eerste plaats om eigen veiligheid, doch om een principiële kwestie. Pleit het niet voor deze arbeiders, dat zij zich niet van hun stuk lieten brengen en na de middagpauze weigerden de fabrieken binnen te gaan? Waarschijnlijk - met zekerheid is het niet te bewijzen - heeft hierbij communistisch-illegale celvorming wel haar invloed doen gelden.

Enige bedrijfsleiders wezen de arbeiders er op, dat zij gevaarlijk spel speelden, maar men scheen zich daarvan rekenschap te hebben gegeven. Er werd geantwoord, dat vele andere fabrieken ook staakten (te Velzen-IJmuiden b.v.) en dat men zich solidair voelde met anderen. Zo ging men heen, rustig, zonder geschreeuw of gejoel. Arbeiders van kleinere bedrijven (b.v. van de Firma Luyt) sloten zich bij de staking aan.

Toen het in de loop van de dag en vooral 's avonds na het binnenkomen van enige treinen uit Amsterdam duidelijk werd, dat men geen hoge verwachtingen behoefde te koesteren omtrent de uitbreiding van de stakingsbeweging in naburige steden en dorpen, maakte zich een aarzeling van de massa meester. De afkondiging van het politiestandrecht, de 30ste April, gaf een somber aspect aan de toestand. Men wist nu, wat er dreigde. De aarzeling kwam Zaterdagmorgen vooral tot uiting in een behoefte aan overleg. De arbeiders schoolden samen voor de gebouwen van de Verenigde Blikfabrieken te Krommenie, zonder evenwel tot het besluit te kunnen komen, de werkzaamheden te hervatten. $Z$ ij gingen heen, vele met het bange voorgevoel, dat bloedige wraak van de Duitsers zou kunnen volgen.

Inderdaad hadden de Duitsers na afkondiging van het standrecht gemakke- 
lijk spel. Vrijdag constateerden zij reeds met voldoening, dat in Noord-Holland van een algemene staking geen sprake was en dat vooral Amsterdam rustig bleef. Dit gaf hun na afkondiging van het standrecht gelegenheid, alle aandacht te schenken aan enkele haarden van verzet. $Z_{i j}$ besloten voorbeelden te stellen, niet alleen voor de provincie, maar voor het gehele land.

Zaterdag 1 Mei, tegen het eind van de morgen, verscheen de SS met enige overvalwagens te Krommenie. Dit commando stelde zich dadelijk in verbinding met de NSB-burgemeester Jongsma en verzocht hem, namen van arbeiders te noemen, die bekend stonden als communist of die geacht werden met het communisme te sympathiseren. In de loop van de middag werden twaalf arbeiders uit hun huizen gehaald en in arrest gesteld. De volgende dag moesten de gevangenen voor het Standgericht verschijnen, dat hen, in overeenstemming met de bedreiging, dat op staken na afkondiging van het standrecht, de doodstraf was gesteld, inderdaad ter dood veroordeelde. Vier van hen werden dadelijk gefusilleerd (Joh. van Lemeren, G. Wiersma en H. Blank uit Krommenie; Th. Rijkhoff uit Assendelft). De overigen kregen te horen, dat $z$ ij een verzoek tot matiging van hun straf konden indienen. Het schijnt, dat de NSB-burgemeester, die bij de arrestatie van de arbeiders zijn medewerking had verleend, nu een clemente behandeling bepleitte. De Duitsers bleken echter zelf reeds van mening, dat er voldoende slachtoffers waren gevallen.

Met genoemde doodvonnissen was het verzet in Krommenie nu wel gebroken, vooral omdat het resultaat van het verzoek om gratie afhing van de houding, die de bevolking aannam. Maandag $3 \mathrm{Mei}$ waren alle bedrijven te Krommenie weer vrijwel volledig bezet.

Een tweede stakingshaard in de Zaanstreek vormde Wormerveer, waar de bevolking, evenals die van Krommenie, als vrij recalcitrant bekend staat. Onafhankelijk van stakingsactie elders, legden vele arbeiders te Wormerveer Vrijdagochtend het werk neer - ook hier waarschijnlijk in verschillende gevallen op instigatie van communistische groepjes in de bedrijven. Er werd de 30ste April gestaakt bij de Chocoladefabriek van Pette, de Noord-Hollandsche Machinehandel, de Meelfabriek „De Vlijt”, de Oliefabriek „De Tijd”, de Oliefabriek "De Engel" en de Veevoederfabriek „De Ster" — in totaal door 600 à 700 man. De Duitsers beperkten zich in deze gemeente tot het arresteren van vier arbeiders, die naar Amsterdam werden overgebracht, doch reeds Zondag 2 Mei hun vrijheid herkregen. Er was blijkbaar genoeg bloed gevloeid.

De sterk plaatselijke verschillen in de volksaard blijken wel duidelijk, indien men bijvoorbeeld Krommenie en Wormerveer vergelijkt met Koog aan de Zaan, waar het volkomen rustig bleef. Levendig, maar niet zo fel als te Krommenie waren de reacties te Zaandam, dat zich in het algemeen nogal sterk naar de hoofdstad oriënteert en dat evenals Amsterdam de terugslag had ondervonden van de mislukte staking in Februari 1941 (ontslag van de burgemeester en van de commissaris van politie, aanstelling van een regeringscommissaris, betaling van een boete van $f 500.000,-)$. Desondanks werd eind 
April 1943 ook te Zaandam gestaakt, in enkele gevallen niet langer dan de Vrijdagmiddag. De belangrijkste stakingen speelden zich af bij de N.V. Klinkenberg, de firma Jan Dekker en bij de Brood en Beschuitfabriek van Hille.

Te Velsen-IJmuiden begon de staking zeer vroeg. Een van de nachtploegen van de N.V. Kon. Nederlandsche Hoogovens nam reeds in de nacht van 29 op 30 April het besluit, het werk neer te leggen. In alle vertakkingen van deze onderneming bestonden goed georganiseerde illegale kernen, zodat het niet moeilijk viel, pamfletten met een stakingsoproep in alle afdelingen te verspreiden. De 30ste April waren reeds 's morgens 2000 arbeiders en employé's in staking. Niet alleen de hoogovens zelf, maar ook de staalfabriek, de cementfabriek, de plaatwalserij, enz. kwamen tot stilstand. Ook 500 man van het personeel van de N.V. Kon. Papierfabriek van Gelder $\mathcal{E}$ Zonen en de arbeiders van de N.V. de Plaatwellerij sloten zich bij de staking aan. Vrijdagmiddag werd het aantal stakers te Velsen-IJmuiden op 4000 geschat. Merkwaardig is, dat het naar huis gaan van de talrijke stakers, die in naburige dorpen woonden - geheel in afwijking van de gang van zaken in andere industriegebieden - op het Noord-Hollandse platteland weinig deining veroorzaakte. Ook is het opvallend, dat zelfs in de stakingshaarden Krommenie en Velsen-IJmuiden het overheidspersoneel weinig weerstand bood en zich aan de regels van de ambtelijke discipline hield. Passief was voorts de houding der middenstanders. Slechts in Velsen-Zuid en in Santpoort sloten vele winkeliers hun winkels (een zestal van hen uit Velsen-IJmuiden werd gearresteerd).

Te Beverwijk reageerde de bevolking onder de invloed van de fabrieksstakingen te Velsen-IJmuiden. Arbeiders van de N.V. Vruchten- en Conservenfabriek (ruim 60 man) en van de Kennemer Machinefabriek L. M. Witkamp (ruim 50 personen) verlieten Vrijdagochtend 30 April om half tien de werkplaatsen. Ook staakte het personeel van de Conservenfabriek „Bever Conserven", maar omdat dit een bedrijf van betekenis voor de voedselvoorziening was, (de Centrale keuken was er in ondergebracht), werd deze staking na enkele uren beëindigd.

$\mathrm{Na}$ afkondiging van het standrecht herhaalde zich te Velsen-IJmuiden en Beverwijk, Zaterdag $1 \mathrm{Mei}$, wat zich te Krommenie had afgespeeld. Massale arrestaties, gevolgd door executies en snelle publicatie van de vonnissen om ieder te doen weten welk risico men liep, indien men zich langer bleef verzetten. Van de ruim tachtig personen, die Zaterdag te Velsen-IJmuiden en Beverwijk gearresteerd waren, moest een tiental voor de Duitse bijzondere rechtbank verschijnen. Een van de eersten, die werd veroordeeld, was de stationschef van het station Velsen-IJmuiden: H. P. de Noo. Andere slachtoffers waren H. Strating, ingenieur bij Van Gelder's Papierfabrieken, N. van Nieuwkoop, J. Wijker, allen uit Velsen-IJmuiden; uit Beverwijk: P. Houtkoper en Th. S. Hendrikse. Acht veroordeelden kregen gratie. Zij zouden 15 jaar tuchthuisstraf moeten ondergaan.

De intimidatiemethoden van de afkondiging van het standrecht en van 
de snelle publicatie der doodvonnissen (1 en 2 Mei voltrokken) hadden het voor de Duitsers gewenste resultaat, dat in de Noord-Hollandse industrieplaatsen Zaterdagmiddag weer werd gewerkt en dat Maandagochtend $3 \mathrm{Mei}$ alle bedrijven een normale gang van zaken meldden. De neiging tot verzet was echter toegenomen; aan alle kanten openbaarde zich een grotere bereidheid tot illegale actie. In dit opzicht maakte Noord-Holland geen uitzondering op een voor het gehele land geldend verschijnsel.

Hoe verklaren wij echter, dat Noord-Holland en de provincie Utrecht zoveel zwakker reageerden op het besluit van Christiansen dan de meeste andere streken van ons land? Wij wezen reeds op de invloed van de Februaristaking 1941, die in het bijzonder te Amsterdam en in de Zaanstreek tot voorzichtigheid maande. Maar hoever reikte de invloed van enkele grote steden? In Zuid-Holland bleef het te Rotterdam en in Den Haag vrij rustig, te Delft, te Dordrecht en in het gebied van de Beneden-rivieren vlamde het verzet daarentegen hoog op.

Het stakingsonderzoek bevestigt, dat een sterk gemengde bevolking, tegenstellingen tussen stad en land en een grote regionale verscheidenheid iedere provinciale solidariteit vrijwel denkbeeldig maakt. Oorlogsomstandigheden, vooral de militaire bezetting in de kuststreek en de evacuatie van plaatsen in de gevaarlijke zône, verzwakten de toch reeds zo geringe homogeniteit van de provinciale bevolking nog verder. Te Den Helder bijvoorbeeld was de bevolking door evacuatie van 38.000 tot 18.000 gedaald.

Toch blijft het bij toepassing van de vergelijkende methode sociologisch en sociaal-psychologisch interessant, dat in Noord-Holland in enkele steden, waarvoor het argument van de ",bijzondere omstandigheden" slechts in beperkte mate gold, vrijwel niet is gestaakt. De enige staking van betekenis te Haarlem was die van het personeel van de N.V. Stork-Hijsch, dat de 30ste April het werk neerlegde uit solidariteit met N.V. Stork te Hengelo, waarmede men telefonisch in verbinding stond. Pogingen om het personeel van naburige fabrieken (Figee, Holland-Nautic, Beijnes, enz.) in het verzet te betrekken, mislukten. Moet dit worden toegeschreven aan een gebrek aan arbeiderssolidariteit of aan het ontbreken van een plaatselijke geest van verzet? Speelde groepsverbrokkeling hier een rol, o.a. door een zeer verschillende herkomst van de Haarlemse arbeidersbevolking, of overheerste de bekende NoordHollandse nuchterheid?

Ik ben geneigd, aan het Noord-Hollandse streekkarakter - in het negatieve, wat de stakingsbeweging betreft - een vrij grote invloed toe te kennen. Men zag in vele plaatsen zelfs geen rimpeling van verzet. Te Purmerend staakte Maandag 3 Mei alleen de groentenveiling. Te Alkmaar beperkte de staking zich tot de N.V. Alkmaarse IJzer- en Metaalgieterij (120 man), waarvan het personeel één middag deserteerde. Ook staakte een gedeelte van het personeel van een krantenbedrijf (15 krantenbezorgers van het Dagblad van Noord-Holland).

De spaarzame berichten over stakingen elders in Noord-Holland vormen 
geen lange reeks: in het Gooi was Weesp een stakingscentrum (N.V. Margarinefabriek „De Valk”, N.V. Gimpels Zeepfabriek, N.V. C. J. van Houten, N.V. Philips van Houten, Melkfabriek "Neerlandia”, N.V. Tricotagefabriek „De Wetri”, N.V. v/h J. Gesink \& Zn en Gebr. Hamstra). Deze stakingen duurden echter niet meer dan een halve dag, of in enkele gevallen de gehele Vrijdag. Te Muiden begonnen Vrijdagochtend stakingen bij Broshuis' Trailerfabriek, N.V. Amrok en N.V. Buvy. Te Hilversum bij de N.V. Aerodyne, de N.V. Metaalwarenfabriek G. Bredemeyer en waarschijnlijk nog enige kleine bedrijven. De N.V. Ned. Seintoestellenfabriek (ruim 2200 personen personeel) meldde een sit-downstaking van één dag, het personeel verliet de fabriek niet. Te Blaricum is enkele uren gestaakt in bedrijven van plaatselijke betekenis. Te Laren staakte het personeel van de tapijtweverij N.V. Willard, doch ook slechts kort. In het algemeen bleef de stakingsactiviteit in het Gooi beperkt tot een demonstratie van een ochtend of een middag. De Duitsers vonden hier geen termen tot streng ingrijpen aanwezig en er vielen in dit gedeelte van Noord-Holland dan ook geen slachtoffers.

Ten Zuiden en ten Zuid-Westen van Amsterdam kwamen zwakke plattelandsstakingen voor: in Aalsmeer, in de Haarlemmermeer, enz. Het bleek niet mogelijk, hierover nauwkeurige gegevens te verzamelen. Deze opmerking geldt trouwens een groot gedeelte van het Noord-Hollandse platteland. Waar weinig gebeurde, zijn de herinneringen geheel verbleekt en gevoelt men ook niet de behoefte, zich voor het geven van informatie in te spannen.

Over de kuststrook merkte ik reeds op, dat in dit militair zwaar bezette gebied weinig spontane actie te verwachten viel. Ten Noorden van het industriegebied van Velsen-IJmuiden staakte men hier en daar uit solidariteit met de industriestaking (o.a. in de gemeente Uitgeest). Uit Egmond-Binnen werd een ,melkstaking" gerapporteerd. Te Callantsoog bleven de arbeiders aan de zeewering een ochtend thuis en leverden enkele boeren geen melk af.

Merkwaardig is het verschil in reageren tussen de bevolking van WestFriesland en de plattelanders in het gebied tussen het IJ en de lijn van Egmond-Binnen over Alkmaar naar Hoorn. In geen andere streek van Nederland - met uitzondering misschien van het Utrechtse platteland - heeft men zich in de April-Meidagen van 1943 zó passief gedragen als in landelijke gemeenten in het middengebied van Noord-Holland. Vrijwel geen stakingsactiviteit viel te bespeuren in de gemeenten Broek-in-Waterland, Edam, Monnikendam, Oostzaan, Beemster, Middelie, Kwadijk, Graft, Jisp, Landsmeer, Purmerland, enz., in streken dus, die in economische en sociale structuur niet veel afwijken van het Friese weidegebied. Ik meen in de geconstateerde lijdzaamheid van de Noord-Hollanders een bevestiging te mogen zien van de verschillende beschrijvingen van het volkskarakter in dit deel van ons land: een buitengewone nuchterheid, afkeer van twist, neiging tot zelfvoldaanheid, gebrek aan principiële houding en vooral: een geringe impulsiviteit $\left.{ }^{1}\right)$. Men

1) Zie o.a. J. P. Kruyt: De Noond-Hollanders in P. J. Meertens en Anne de Vries: De Nederlandsche Volkskarakters, 1938, blz. 184 e.v. 
vroeg zich af, of men door een staking iets bereiken kon. Rustig werd voor en tegen overwogen, waarbij ook personen, die door geloofsovertuiging en vaderlandsliefde tot verzet bereid waren, gewoonlijk tot de conclusie kwamen, dat stakingsactiviteit in dit geval geen zin had. Nog één stap verder en men voelde zelfs wrevel opkomen bij het gadeslaan van de ,ondoordachte" methoden van tegenstand. Een Noord-Hollandse burgemeester schreef mij in dit verband: "Ik heb deze staking altijd gezien als een kwajongensstreek en grootdoenerij," daarmee uitsprekend wat velen indertijd hebben gedacht.

Tussen de beide uitersten van deze Noord-Hollandse nuchterheid en de Friese emotionaliteit lagen in een middenzône van spontaan verzet naast stille berusting West-Friesland en de Kop van Noord-Holland. Beschrijvingen van streekkarakters richten zich gaarne op volksgroepen, die nog een duidelijk beeld vertonen (door de verhoogde sociale mobiliteit hier te lande vervagen de grenzen steeds meer). Dit verklaart, dat in de literatuur meer aandacht aan het Friese en aan het Noord-Hollandse karakter is geschonken, dan aan het West-Friese streekkarakter.

Wie nog mocht twijfelen aan de Friese inslag in het Noordelijk gedeelte van Noord-Holland, kan uit het spontaan reageren van een aantal bevolkingsgroepen leren, dat hier in de wijze van spontaan reageren gedurende de April-Meidagen toch wel typisch Friese trekken aan het licht kwamen. Uit een nader onderzoek zou moeten blijken, in welke streken de bevolking in het bijzonder de eigenschap van .West-Friese koppigheid" vertoonde. Dit kan echter niet geschieden zonder aandacht te schenken aan de invloed van geloof en milieu. In hoeverre is de bevolking van de katholieke dorpen van Grootebroek en Bovenkarspel tot Ouddorp en Warmenhuizen inheems? Welke invloed heeft het kleine tuindersbedrijf uitgeoefend op de vorming van een individualistische houding in deze bevolking? Uit het onderzoek bleek, dat het West-Friese tuinbouwgebied even spontaan en krachtig staakte als het Westland. Dit alles maakt het wel heel moeilijk, het oorspronkelijk „,volkskarakter" in enkele trekken vast te leggen.

Daarbij komt, dat zich talrijke verschillen tussen dicht bij elkander liggende gemeenten voordoen. In het algemeen kan echter voor het Noordelijke gedeelte van Noord-Holland een veel krachtiger kerkelijke invloed op het verzet worden geconstateerd dan in het middengebied. Vooral de katholieke en de gereformeerde tuinders namen een weerspannige houding aan. Te Andijk werd de 30ste April, daags na de publicatie van het besluit van Christiansen, zelfs een bidstond in de gereformeerde kerk gehouden (nadat men voor Donderdagavond ,toevallig" de kerkeraad had bijeengeroepen). Andijk, dat reageerde als de dorpen in het Friese stakingsgebied, moet stellig als een der haarden van het verzet worden beschouwd. Jonge mannen uit dit dorp trokken naar verschillende kanten om in naburige gemeenten tot neerleggen van het werk aan te moedigen. De meeste winkeliers sloten hun winkels; er heerste een geest van grote eensgezindheid met volledige samenwerking tussen alle groepen van de bevolking (zoals men zich later juist ook in dit dorp 
enorme inspanning getroostte voor het onderbrengen van onderduikers). Van Andijk sloeg de staking over naar Enkhuizen (dat zich in de AprilMeidagen veel opstandiger toonde dan Hoorn en Medemblik). Nadat reeds Donderdagavond samenscholingen hadden plaats gevonden, hoorde men Vrijdagochtend (na aankomst van enige fietsers uit Andijk) vertellen, dat in de gehele omgeving in de tuinbouwbedrijven werd gestaakt. Vrijdagmiddag werd het werk in vrijwel alle Enkhuizense bedrijven neergelegd: bij de zaadhandelsbedrijven van Gebr. Sluis, van Adr. Sluis, van Sluis, van Sluis E Groot, en van Gebr. Vis, bij de scheepswerf Vooruit, bij de drukkerij Bijto, v/h J. W. de Graaf. Winkeliers sloten hun winkels, broodbezorgers en melkventers vertoonden $z$ ich niet meer op straat. Ook Zaterdag 1 Mei werd deze staking volgehouden.

De Duitsers hadden intussen politietroepen naar het Noorden gezonden. Te Andijk werden 17 personen gearresteerd. Dit kon evenwel niet verhinderen, dat de stakingsbeweging van de ene gemeente naar de andere oversloeg. Van Andijk naar Bovenkarspel en van Bovenkarspel naar Venhuizen. In vele gemeenten was de stemming reeds Donderdagavond 29 April zeer nerveus. Hier en daar vormden de kleine tuinders de kern van de stakingsbeweging, elders de landarbeiders. Vele boeren leverden ook geen melk meer af aan de zuivelfabrieken (waarvan er enkele de 30 ste April het bedrijf stopzetten).

Het zou ons te ver voeren, bijzonderheden mede te delen over de stakingsactiviteit in de gemeenten Opperdoes, Wervershof, Hoogkarspel, Hoogwoud, Wognum, enz. Te Wognum staakte de Coöp. Zuivelfabriek „,De Verwachting" (alleen Zaterdag gedurende de morgenuren); in de gemeente Opmeer lag het brandpunt van de staking bij de Coöp. Zuivelfabriek „Aurora” (waar het personeel van 70 personen Vrijdagavond het werk neerlegde). Te Ursem, ten Oosten van Alkmaar, staakte de N.V. Zuivelfabriek „,De Prinses”, zonder dat van de boerenbevolking in deze gemeente veel medewerking werd ondervonden. Te Stompetoren, gemeente Oterleek, kwam het bedrijf van de zuivelfabriek „Neerlandia" tot stilstand. Doch ook daar droeg de staking geen algemeen karakter. Evenmin in de gemeenten Oude Niedorp. Spanbroek, Heilo en Heer-Hugowaard.

Veel heftiger, bijna even principieel als te Enkhuizen en in de daaraan. grenzende gemeenten, ontwikkelde zich de stakingsbeweging in het gebied ten Noorden van Alkmaar, vooral in het orthodox-protestants tuinbouw-dorp Broek-op-Langedijk, waar winkeliers hun winkels sloten en samenscholingen plaats vonden. Ook te Noord- en Zuid-Scharwoude, Harenkarspel, Anna Paulowna, St. Maarten was de stemming Vrijdag en Zaterdag zeer verbitterd.

Verdeeldheid en aarzeling, met slechts hier en daar enige stakingsactiviteit, wordt gemeld uit de gemeenten Warmenhuizen, Schagen, St. Pancras, Wieringerwaard en Winkel.

Op Wieringen legden verschillende landarbeiders en arbeiders van de N.V. Grond-Mij. het werk neer. Op Texel begon de staking Zaterdag 1 Mei. op de boerderij van W. J. Jochems. Van daaruit werden arbeiders uitgezonden. 
om anderen tot meestaken te bewegen. Dit gelukte in het Noordelijk gedeelte van het eiland dadelijk; in het Zuidelijk gedeelte begon de staking eerst Maandag. In de loop van Maandag $3 \mathrm{Mei}$ werden echter overal in NoordHolland de werkzaamheden hervat. De publicatie van vele doodvonnissen, het uitblijven van de spoorwegstaking en de aarzelende houding van de regering te Londen werkten deprimerend, althans bij de beoordeling van het effect van een eventueel voort te zetten staking. De bereidwilligheid om aan illegaal verzet mee te doen, nam echter sedert de April-Meidagen in belangrijke mate toe. Wat dit betreft, waren de ervaringen in Noord-Holland niet anders dan in de overige provincies. 


\section{NABESCHOUWING}

Welke betekenis hebben de April-Meistakingen voor de geschiedenis van ons volk in de bezettingstijd gehad? Moet van een mislukking worden gesproken? Zijn de offers, die deze dagen hebben gekost, tevergeefs gebracht? Deze vragen zijn menigmaal gesteld, vooral in de soms défaitistische stemming in de eerste dagen na de stakingen.

Wij zien thans scherper. Ons onderzoek bracht duidelijk aan het licht dat de April-Meidagen een keerpunt vormden in de annalen van het verzet. Gaarna citeer ik een brief van de burgemeester van Bellingwolde, die mij schreef d.d. 9 Juni 1947: „Vele Nederlanders zijn door deze spontane staking aan de actieve zijde van het verzet terecht gekomen, hetgeen in Mei 1943 een grote winst betekende." En hij vervolgde:

„Wanneer ik mij veroorloof om een oordeel over dit gebeuren uit te spreken, dan moet mij van het hart, , ,dat het goed geweest is, dat wij met de daad hebben getoond, dat wij niet bereid waren om ons straffeloos te laten sarren tot in het oneindige" ". Aanvankelijk geschrokken zijnde, heeft de vijand zich met grotere verbetenheid geworpen op de weerstanden die hij op zijn weg aantrof. Met vrij grote zekerheid kan worden gezegd dat na dit gebeuren de bewaking van het Nederlandse Volk aan de vijand groter inspanning heeft gekost, waardoor meer personeel aan ons land werd gebonden. De onmacht van de Duitsers om de leiders van de staking uit te schakelen was mede oorzaak dat vele Nederlanders zijn gaan twijfelen aan de almacht van de Duitsers, terwijl het geloof in eigen kracht en in mogelijkheden werd herwonnen, een zelfde verschijnsel dat men veel duidelijker heeft kunnen waarnemen na het afkondigen van de spoorwegstaking in 1944.

De Meistaking in 1943 hebben wij in het totaal gebeuren niet kunnen missen."

Scherp en duidelijk formuleerde ook de burgemeester van Winschoten - het is geen toeval dat men juist in de Noordelijke provinciën de meest overwogen opinies over deze zaken verneemt - op een hem toezonden enquêteformulier:

„Mijn indruk is, dat de staking het illegaal verzet zeer heeft gesterkt. Doordat men thans in de illegale beweging een inzicht had gekregen van wat er in het binnenste van de bevolking leefde, was men niet meer aangewezen op een tot nog toe kleine kring van werkers, welke tot dusver het verzet hadden geleid, doch kon zijn vleugels breder uitslaan en meer mensen om zich vergaren. Ook had men nu het gevoel, dat niet een kleine groep van de bevolking zich inliet met het verzet, doch dat dit verzet zo nodig door de ganse natie zou worden gesteund. Door de uitgebroken staking was ook tot uiting gekomen, dat men zich niet meer zo angstvallig behoefde te gedragen als voorheen, daar nu tot uiting was gekomen, dat men een groot deel van de bevolking kon vertrouwen en er nu een kijk op had gekregen, wie dit waren." 
Inderdaad, de staking van April-Mei 1943 was een eerste demonstratie van collectief verzet, die de solidariteit in brede groepen van de bevolking versterkte. Nieuwe leiders kwamen naar voren. De belangstelling voor illegaal werk nam toe. Men had van de fouten geleerd en begon het nut van ondergrondse organisatie te begrijpen. De anti-Duitse gezindheid groeide met de dag, vooral na de nieuwe besluiten over de arbeidsinzet en over de inlevering van de radiotoestellen. Men moest voortaan in het verborgene naar buitenlandse zenders luisteren; de verspreiding van illegale blaadjes met de laatste berichten nam snel toe. Maar bovenal, het aantal onderduikers vermeerderde: studenten, die geweigerd hadden de loyaliteitsverklaring te tekenen, militairen, die zich niet hadden gemeld, arbeiders, die het arbeidsbureau links lieten liggen. Door de staking was vooral het platteland geactiveerd. Men wist nu, welke dorpen risico durfden dragen, men kon er van op aan, dat het organisatorisch netwerk der illegaliteit tot in de verste uithoeken van ons grondgebied was gesponnen. Met het toenemen van de financiële zorgen, die dit werk vergde, groeide ook de taak van het N.S.F., het Nationaal Steunfonds.

In de maanden, aan de staking voorafgaande, vorderde de organisatie van het verzet soms heel langzaam; daarna werd ze in korte tijd volkszaak.

Voor de nabestaanden van degenen, die in of tengevolge van de stakingen vielen, zijn de gebrachte offers individueel beschouwd altijd tè zwaar. Zij kunnen echter troost putten uit het feit, dat de staking, die door sommigen "een verloren en nutteloze staking" werd genoemd, in werkelijkheid een keer punt in de geschiedenis van het verzet is geworden: één van die schaarse momenten, waarin ons volk tot bezinning kon komen om zich rekenschap te geven van eigen kracht en geesteshouding. 


\section{BIJLAGEN}




\section{B IJLAGE I \\ DE APRIL-MEI-STAKINGEN IN TWENTE \\ door \\ B. A. SIJES}




\section{N HOU D}

HOOFDSTUK I

blz.

DE METHODE VAN HET ONDERZOEK . . . . . . . . 195

HOOFDSTUK II

HET VERZET IN TWENTE VOOR DE MEI-STAKING . . . 203

HOOFDSTUK III

ONTSTAAN EN UITBREIDING VAN DE STAKING . . . . 221

Het bekend worden van de Duitse maatregel . . . . . . . 221

Het uitbreken van de staking bij Stork . . . . . . . . . . 222

De uitbreiding der staking in Hengelo . . . . . . . . . 224

De uitbreiding der staking over geheel Twente . . . . . . 230

De uitbreiding der staking naar het platteland . . . . . . 235

De staking der grensgangers . . . . . . . . . . . . . 240

De uitbreiding der staking naar de verkeersdiensten . . . . . 242

HOOFDSTUK IV

BESCHRIJVING DER STAKINGSBEWEGING IN TWENTE . 245

Hengelo . . . . . . . . . . . . . . . . . . . 245

Enschede . . . . . . . . . . . . . . . . . . 254

Almelo . . . . . . . . . . . . . . . . . . 258

Borne . . . . . . . . . . . . . . . . . 262

Oldenzaal . . . . . . . . . . . . . . . . . . . 264

Haaksbergen . . . . . . . . . . . . . . . . 267

Hellendoorn . . . . . . . . . . . . . . . . . . . 269

Rijssen . . . . . . . . . . . . . . . . . . . . . 271

Vriezenveen . . . . . . . . . . . . . . . . . 273

Delden . . . . . . . . . . . . . . . . . . . 275

Denekamp. . . . . . . . . . . . . . . . . . . 276

Wierden . . . . . . . . . . . . . . . . . . 276

Weerselo . . . . . . . . . . . . . . . . . . . . 277

Goor . . . . . . . . . . . . . . . . . . . . 277

Het verloop der staking op het platteland . . . . . . . . . 278 
HOOFDSTUK V

blz.

POLITIONELE MAATREGELEN TEGEN DE STAKING . . . 281

De politionele organisatie gedurende de staking . . . . . . 281

De houding van de Twentse politie . . . . . . . . . . . 282

Chronologisch overzicht van de tegenmaatregelen . . . . . . 284

HOOFDSTUK VIII

NABESCHOUWING

N.B.: Uit dit in opdracht van het Directorium van het Rijksinstituut voor Oorlogsdocumentatie in het voorjaar van 1948 geschreven rapport zijn de hoofdstukken VI en VII resp. behandelend "De slachtoffers van de staking" en ,De financiële bestraffing der stakers," niet in deze uitgave opgenomen. Deze hoofdstukken blijven tezamen met de Bijlagen, naar welke in de tekst van het rapport herhaaldelijk verwezen wordt, op het Rijksinstituut voor Oorlogsdocumentatie (later het Algemeen Rijksarchief) gedeponeerd. 


\section{HOOFDSTUK I}

\section{DE METHODE VAN HET ONDERZOEK}

Naar aanleiding van de bekendmaking van de Wehrmachtbefehlshaber in den Niederlanden, Christiansen, op Donderdagmiddag 29 April 1943, dat de Nederlandse militairen in krijgsgevangenschap naar Duitsland zouden worden teruggevoerd, brak een staking uit bij de Machinefabriek Gebr. Stork \& Co. N.V. in Hengelo. In zeer korte tijd breidde de staking zich dezelfde middag uit naar andere fabrieken in Hengelo, Enschede, Almelo en nog enkele kleinere plaatsen, waar industrie van enige omvang gevestigd was.

De volgende morgen, Vrijdag 30 April 1943, werden de grensgangers ${ }^{1}$ ), de personelen van autobus-ondernemingen, de personelen van zuivelfabrieken en de boeren in de staking betrokken.

Zaterdagmorgen 1 Mei 1943 werd, nadat inmiddels door de Duitsers tegenmaatregelen waren aangekondigd en gedeeltelijk uitgevoerd, in Hengelo om streeks 11 uur -11.30 uur in enkele bedrijven het werk hervat. Maandagmorgen 3 Mei 1943 gingen vrijwel alle personelen in Twente op de normale aanvangstijd der fabrieken aan de arbeid.

Reeds bij de aanvang van het onderzoek bleek, dat zeer weinig materiaal uit de bezettingstijd zelf - als aanknopingspunt voor nader onderzoek aanwezig was. Veel meer dan bij het onderzoek naar de Februari-staking 1941 waren wij aangewezen op besprekingen met personen, die de gebeurtenissen eind April-begin Mei 1943 hadden meegemaakt. Deze personen kunnen naar de aard van de door hen verstrekte gegevens in vijf verschillende groepen worden verdeeld.

I. Voorzover het de actie van het staken zelf betrof, hebben wij ons in de eerste plaats gewend tot de directies der fabrieken en de vertegenwoordigers van bedrijfspersonelen. Met betrekking tot de staking op het platteland, zijn besprekingen gevoerd met directies der zuivelfabrieken en boeren.

II. Om ons in het bijzonder op de hoogte te stellen van de tegenmaatregelen der Duitsers en hun pogingen, het Nederlandse overheids- en politie-apparaat in te schakelen, hebben wij ons gericht tot burgemeesters en gemeente-personeel, alsmede tot commissarissen (resp. hoofdinspecteurs of inspecteurs) van politie en lager politie-personeel, perso-

1) Ook arbeiders, wonende in de grensstreek (bijv. Enschede, Glanerbrug, Oldenzaal, enz.), maar werkend in de Duitse fabrieken dicht bij de grens, gingen in staking. (Zie blz. 240). 
neel van de Politieke Recherche Afdeling en de Sub-Commissie $Z_{\text {wolle }}$ van het „Bureau Opsporing Oorlogsmisdrijven”.

III. Behalve met bovengenoemde personen, die ons ook bijzonderheden vertelden omtrent de stemming der bevolking tijdens de staking, meenden wij ten aanzien hiervan ons ook in verbinding te moeten stellen met personen uit de illegaliteit, geestelijken, predikanten en artsen.

IV. Daar in Twente verschillende personen naar aanleiding van deze staking het leven verloren, zijn wij bij ons onderzoek ook in contact getreden met diegenen, die daar op een of andere wijze bij betrokken waren.

V. Met betrekking tot het verzet in Twente vóór de Mei-staking, kregen wij waardevolle inlichtingen van de heer J. H. Scheps (die reeds vóór de Mei-staking in Twente vele illegale lezingen hield), de heer $\mathrm{Dr} \mathrm{H}$. Hartstra (voorzitter van de afdeling Hengelo van „Het Groene Kruis”) en van personen uit de vakbeweging.

Als gevolg van dit werk is het Rijksinstituut voor Oorlogsdocumentatie in het bezit gekomen van 260 verslagen van besprekingen. Hierbij waren 490 personen betrokken. Door met deze vijf groepen van personen het contact op te nemen, kreeg het Rijksinstituut ook de beschikking over gegevens, die tijdens of na de bezetting op schrift waren gesteld. Bij de beschouwingen, waar elk dezer vijf groepen apart wordt besproken, zal het materiaal, dat wij van elke groep ontvingen, naar inhoud en omvang nader gepreciseerd worden.

Alvorens hiertoe over te gaan, mogen enige algemene opmerkingen, de besprekingen met deze groepen betreffende, voorafgaan.

Ofschoon door ons steeds getracht werd, besprekingen met één persoon te voeren, bleek dit in vele gevallen niet mogelijk. Vaak gebeurde het, dat een bespreking, die met één persoon begon, met meerderen eindigde, doordat de mensen afzonderlijk zich slechts zeer weinig konden herinneren.

Uit de verslagen der besprekingen blijkt, dat wij ons ten opzichte van de personen, die werden gehoord, niet konden beperken tot de vraag, iets te vertellen omtrent de Meistaking, om daarna - aan het eind van de uiteenzettingen - onzerzijds nog enkele vragen te stellen. In zeer vele gevallen $z$ weeg men na de algemene bevestiging, dat de staking inderdaad had plaats gevonden. Dit geldt niet alleen voor de fabrieksdirecteur en de ambtenaar maar ook voor de boer en de arbeider. In het algemeen konden de gehoorde personen weinig bijzonderheden uit zichzelf vertellen, indien zij niet door een of andere omstandigheid - bijv. arrestatie of deportatie - bijzondere herinneringen aan de staking hadden overgehouden.

Dit falen der herinnering kan geen verwondering wekken. Zoals uit de lezing van de verslagen der besprekingen zal kunnen blijken, bleven de meeste mensen gedurende de staking in de omgeving van hun huis of gingen naar de boeren om melk te halen. Van demonstraties of vechtpartijen met de politie was - in tegenstelling tot de Amsterdamse Februari-staking - niets te 
bespeuren. Het feit echter, dat zo weinig bijzondere gebeurtenissen gedurende de stakingsdagen hadden plaats gevonden, kon slechts met zekerheid worden aangenomen, indien over de verklaringen van een zo groot mogelijk aantal personen kon worden beschikt.

Zoals uit de verslagen der besprekingen blijkt, zijn de vragen, door ons gesteld, in het algemeen in drie groepen samen te vatten.

a. De eerste groep vragen heeft betrekking op het uitbreken en de uitbreiding der staking en de ervaringen hierbij van de gehoorde personen.

b. De tweede groep houdt zich bezig met de verdere ontwikkeling en de neergang der staking, waarbij in het bijzonder naar het optreden der Duitsers werd geïnformeerd.

c. Met de derde groep trachtten wij te weten te komen, welke factoren tot het hervatten van het werk hebben geleid.

Deze drie groepen vragen werden al naarmate de omstandigheden dit eisten, aldoor in andere formuleringen en met meer details gesteld.

$\mathrm{Na}$ deze opmerkingen willen wij thans elk der vijf genoemde groepen, met betrekking tot het van deze groepen ontvangen materiaal, in het bijzonder behandelen.

Ad. I. Ten aanzien van de besprekingen met de arbeiders valt op te merken, dat wij door een zo nauwkeurig mogelijk nagaan van de stakingsbeweging in elke fabriek een inzicht konden krijgen in het mechanisme van de uitbreiding en de neergang der staking.

Vooral het onderzoek naar de wijze van uitbreiding der staking was een der moeilijkste opgaven, die moest worden opgelost. Niet alleen bestond hieromtrent geen schriftelijk materiaal, maar een dergelijk onderzoek had naar ons weten - nog nimmer plaats gevonden. De personen, die door ons werden gehoord, hadden zich er in de meeste gevallen geen rekenschap van gegeven, dat hier een probleem lag. In het bijzonder was dit onderzoek zo moeilijk, omdat in 1943 bijna alles zich afspeelde binnen twee-en-een-half uur.

Veel medewerking mochten wij bij dit deel van het onderzoek ondervinden van de directies der fabrieken, die wij om een opgave vroegen van de woonplaatsen van de in hun fabriek werkende arbeiders.

Een moeilijkheid vormden aanvankelijk de besprekingen met boeren. Bij de aanvang van ons onderzoek vroegen wij aan de directies van de zuivelfabrieken ons namen op te geven van boeren; het bezoek bij deze thuis had echter weinig succes. In het algemeen wist men zich niet veel te herinneren. Daar wij echter toch meerdere bijzonderheden wilden vernemen, gingen wij op een andere wijze de boeren in het onderzoek betrekken. Inplaats van hen thuis op te zoeken, verzochten wij de directeuren der zuivelfabrieken er vier of vijf uit verschillende buurtschappen aan de fabriek uit te nodigen. Deze methode van werken hebben wij met succes bij verschillende zuivelfabrieken kunnen toepassen.

Tevens hebben wij getracht inlichtingen te verkrijgen van die boeren, die 
in de stakingsperiode melkrijder 2) zijn geweest. Wij meenden ons tot deze personen eveneens te moeten wenden, om de omvang van de staking op het platteland te kunnen nagaan.

Ad. II. Zoals uit de verslagen der besprekingen zal blijken heeft ons onderzoek zich uitgestrekt over de gemeenten Almelo, Borne, Ambt-Delden, Stad-Delden, Denekamp, Diepenheim, Enschede (Losser), Goor, Haaksbergen, Hellendoorn, Hengelo (O), Markelo, Oldenzaal, Ootmarsum, Rijssen, Tubbergen, Vriezenveen, Weerselo en Wierden.

In verschillende van deze gemeenten waren de tegenwoordige burgemeesters tijdens de Meistaking niet aanwezig. Wij hebben, voorzover dit mogelijk was, getracht, de betreffende personen alsnog te horen of aanknopingspunten te vinden in de gemeente-dossiers betreffende de Meistaking. Hierbij zij echter opgemerkt, dat een dossier - en dan nog van zeer bescheiden omvang slechts aanwezig was in de archieven van de gemeenten Hengelo en Enschede. Deze dossiers bevatten enkele mededelingen van de hoofden der gemeentediensten en -bedrijven aan de burgemeesters, betreffende het aantal stakers bij de resp. afdelingen.

Al moge echter weinig materiaal aanwezig geweest zijn, van de wijze waarop de burgemeesters en hoofden van diensten ons vooral in den beginne bij fabrieken en boeren hebben geïntroduceerd, hebben wij zeer veel profijt getrokken.

Eveneens mocht het Rijksinstituut veel medewerking ondervinden van de Twentse politie-ambtenaren. Dagelijkse meldingsrapporten (die bij het onderzoek naar de Februari staking 1941 zo kostbaar materiaal opleverden) waren echter zo goed als niet aanwezig. Zo geeft bijv. het rapportenboek van de gemeente-politie uit Hengelo vrijwel uitsluitend een overzicht van het aantal personen, dat gedurende de staking op het politiebureau was ingesloten; nauwkeuriger bestudering toont echter aan, dat bij het wisselen van de wacht plotseling meer - of minder - arrestanten werden opgegeven dan volgens de opgaven van de daarop betrekking hebbende dag mogelijk was. Daarbij komt verder de moeilijkheid, dat slechts in een enkel geval is aangegeven, naar aanleiding van welk feit de naar het politiebureau gevoerde personen gearresteerd zijn. Desondanks vermeldden deze rapporten soms voor ons belangrijke gegevens om een bepaalde gebeurtenis te reconstrueren.

Wat in de meldings-rapporten ontbrak - de verklaring hiervan moet gezocht worden in het feit, dat men slechts zeer weinig wilde aantekenen - werd in de besprekingen met de politie-ambtenaren aangevuld.

Tevens zij vermeld, dat naar aanleiding van een bespreking met enkele Hengelose politie-ambtenaren, door ons het Directoraat-Generaal van de Politie te Arnhem is bezocht. In ruime mate hebben wij gebruik kunnen maken van het archief aldaar. Zo hebben wij de hand kunnen leggen, niet alleen op bijna alle politionele maand-overzichten, lopende van 15 April-15 Mei 1943

2) Dit zijn bceren, die meestal gedurende een bepaalde tijd, bijv. een jaar, de melk van cen aantal boeren ophalen en vervoeren naar de mclkfabriek. 
betreffende de provincies Overijssel en Gelderland, maar ook op een aantal politie-telegrammen, waarvoor in het bijzonder naar Hoofdstuk V, blz. 281 wordt verwezen.

Ad. III. De derde groep personen, waarvan wij verwachtten meerdere inlichtingen te ontvangen, waren de geestelijken, predikanten, artsen, onderwijzers en personen uit de illegaliteit.

In het algemeen kan worden vastgesteld, dat deze groep zeer weinig betreffende de staking wist mede te delen. Afgezien van het feit, dat er niet veel te vertellen was, is dit voor een belangrijk gedeelte te verklaren uit de omstandigheid, dat deze personen niet direct bij het productie-proces betrokken waren. Daar wij echter toch wilden trachten, aanknopingspunten voor eventuele nadere bijzonderheden omtrent de reacties der bevolking op de staking te verkrijgen, zijn door ons aan deze groep in totaal 312 lijsten verzonden. Bij de lijsten, verzonden aan geestelijken en artsen, sloten wij nog een aantal vragen in. Daar de staking op Donderdag 29 April 1943 begon en in het algemeen op Maandagmorgen op de normale aanvangstijd het werk werd hervat, werd de geestelijkheid gevraagd, of op Zondag 2 Mei 1943 in de preek gezinspeeld werd op een voortzetting van de staking of een hervatting van het werk. Deze laatste vraag werd in het bijzonder door ons gesteld daar medegedeeld was, dat in enkele gevallen directeuren van fabrieken zich tot de geestelijkheid gewend hadden, met het verzoek de kerkgangers mede te delen, Maandagmorgen het werk te hervatten. In het algemeen werd door predikanten en geestelijkheid geantwoord, dat men in de preek niet over de staking had gesproken.

Tot de artsen richtten wij ons met het verzoek ons mede te delen, of zij in hun huis door Duitsers aangeschoten personen hadden verbonden. Dit werd door ons gevraagd, daar meerdere malen medegedeeld werd, dat de Duitsers gedurende hun patrouilles in het wilde-weg schoten, terwijl daarentegen weinig gevallen van gewonde personen bekend waren. Uit de ingevulde lijsten blijkt, dat niemand zich naar aanleiding van een schotwond onder ,illegale" behandeling van een dokter gesteld had.

Tevens zij opgemerkt, dat lijsten verzonden werden aan kleinere bedrijven ${ }^{3}$ ) en particulieren. Aan de eerste groep werden verzonden 96 lijsten, waarvan 54 terugontvangen werden; voor de tweede groep zijn deze aantallen resp. 78 en 36.

Tenslotte moge hier een algemeen overzicht volgen van verzonden en terugontvangen lijsten. (Zie tabel op blz. 200).

Ad. IV. Daar in Twente verschillende personen naar aanleiding van deze staking het leven verloren, kwamen wij bij ons onderzoek ook in contact met personen, die hierbij op een of andere wijze betrokken waren. Meerdere malen bleek ons, dat slechts zeer vage en daardoor onbruikbare antwoorden

3) Aan de ondernemers van kleinere bedrijven werd gevraagd, in welke plaatsen de arbeiders woonden, die bij de fabriek werkzaam waren. 
werden gegeven, indien wij meer bijzonderheden wilden weten omtrent de omstandigheden, waaronder arrestatie of dood had plaatsgevonden. Wanneer desondanks in Hoofdstuk VI, getiteld „De slachtoffers van de staking”, toch een uitvoerig overzicht kon worden gegeven van de wijze, waarop verschil lende personen het leven verloren, dan is dit gevolg van het contact, dat wij opgenomen hebben met de Sub-Commissie Zwolle van het „Bureau Opsporing Oorlogsmisdrijven" 4). Van deze Commissie ontvingen wij ter foto-copiëring een aantal processen-verbaal, opgemaakt op grond van verklaringen van Nederlanders en Duitsers, die nadere opheldering konden geven omtrent de wijze, waarop verschillende personen gearresteerd of doodgeschoten waren.

\begin{tabular}{|c|c|c|}
\hline \multirow{7}{*}{$\begin{array}{l}\text { 1. Rijks- en gemeente-instellingen } \\
\text { 2. Particuliere bedrijven } \\
\text { 3. Artsen } \\
\text { 4. Geestelijken en predikanten } \\
\text { 5. Onderwijzers } \\
\text { 6. Particulieren }\end{array}$} & verzonden & terugontvangen \\
\hline & 50 & 46 \\
\hline & 96 & 54 \\
\hline & 104 & 32 \\
\hline & 82 & 30 \\
\hline & 126 & 78 \\
\hline & 78 & 36 \\
\hline Totaal & 536 & 276 \\
\hline
\end{tabular}

Van de 276 terugontvangen lijsten waren 43 niet ingevuld.

Hoe belangrijk en hoe uitvoerig het onderzoek door de Sub-Commissie Zwolle echter ook geweest moge zijn, tenslotte was haar werk slechts gericht op de - eventueel - strafbare handelingen van individuen. Onze taak was van andere aard. Wij hadden juist de handelingen van enkelingen te plaatsen in het kader van- en in zinrijk verband met de staking. Daarom is omtrent elk door de Sub-Commissie Zwolle onderzocht geval, ook door ons - voor zover het gevolgen betrof van de staking in Twente - een onderzoek ingesteld.

Ad. V. Betreffende het materiaal dat ons ten dienste stond bij het beschrijven van het verzet vóór Mei 1943 merken wij het volgende op.

Afgezien van de verslagen der besprekingen konden wij gebruik maken van enige publicaties van het Nederlands Verbond van Vakverenigingen, het Rooms-Katholiek Werklieden Verbond en het Christelijk Nationaal Vakverbond, betrekking hebbend op de bezettingstijd. Tevens stonden ons ten dienste de notulen van enkele bestuurdersvergaderingen van Twentse afdelingen van het N.V.V., gehouden in Februari 1941. Uit deze notulen blijkt duidelijk de strijd, die tegen de gelijkschakeling van de vakbeweging gevoerd is.

Eveneens hebben wij bij het schrijven van dit hoofdstuk gebruik kunnen maken van een archief van het Nederlands Arbeids Front, district Twente. Dit uitgebreide archief kwam voor een belangrijk deel ongeordend in ons bezit. Het bevatte o.a. de door de sociale voormannen opgemaakte maand-

4) In den vervolge aangeduid als "Sub-Commissie Zwolle". 
rapporten (uitgebracht aan de Provinciale Leider in Zwolle), waarin bijv. werd medegedeeld, welke houding de Gefolgschaft ten aanzien van het N.A.F. aannam. Verder vonden wij in dit archief vele meldingsrapporten betreffende de staking, samengesteld door de sociale voormannen. Eveneens was correspondentie aanwezig, gevoerd tussen het N.A.F. en de directies der bedrijven betreffende te houden bedrijfs-appèls, ontspanningsavonden, aanstelling van sociale voormannen en andere, meer organisatorisch-technische kwesties. Bij nadere contrôle der door de sociale voormannen gemaakte stakingsrapporten bleek ons, dat een belangrijk deel van dit materiaal niet betrouwbaar was. Gebleken is bijv., dat in verschillende gevallen de stakingsrapporten door de sociale voormannen opgesteld werden met medewerking van de directies der bedrijven. Daardoor waren de stakingsrapporten niet voor ons onderzoek te gebruiken. Noch de directie, noch de betrouwbare sociale voormannen hadden er belang bij, precies te vertellen, wat in het bedrijf leefde en hoe bijv. de staking was uitgebroken.

Tenslotte zij medegedeeld, dat wij ons via de pers tot de Twentse bevolking wendden, met het verzoek een aantal door ons opgestelde vragen te willen beantwoorden. Naar aanleiding hiervan ontvingen wij 17 brieven. Reeds eerder had de Chef van het Rijksinstituut voor Oorlogsdocumentatie, L. de Jong, via de radio de luisteraars verzocht, hun ervaringen uit de Mei-staking aan het Rijksinstituut mede te delen. Ongeveer 150 personen, w.o. 13 uit Twente, gaven aan de oproep gehoor.

Samenvattend is voor de vervaardiging van dit verslag betreffende de Meistaking 1943 in Twente gebruik gemaakt van:

a. 260 verslagen van besprekingen. Deze omvatten 944 bladzijden folio getypte vellen;

b. de processen-verbaal, opgemaakt door de Sub-Commissie Zwolle (92 blz.);

c. 233 ingevulde vragenlijsten;

d. politie-meldingsrapporten (in beperkte mate);

e. gemeente-dossiers (in beperkte mate);

$f$. het N.A.F, archief;

g. 30 brieven naar aanleiding van oproepen via radio en pers.

Alvorens dit hoofdstuk te besluiten, mogen nog enkele opmerkingen worden gemaakt over de wijze, waarop dit verslag is samengesteld.

$\mathrm{Na}$ een beschrijving van het verzet vóór Mei 1943 in Hoofdstuk II, wordt in Hoofdstuk III onderzocht, hoe de staking uitbrak, langs welke weg $z$ ij zich op Donderdag en Vrijdag over geheel Twente uitbreidde en welke groepen successievelijk in deze beweging getrokken werden. Wij hebben gemeend, ook de uitbreiding van de staking op Vrijdag 30 April - immers grensgangers, autobus diensten en boeren werden die dag pas in de staking betrokken in dit hoofdstuk te moeten behandelen. Hieraan is de voorkeur gegeven, omdat 
de uitbreiding, die op Vrijdag 30 April plaats vond, als het ware de natuur lijke voortzetting was van hetgeen op Donderdagmiddag 29 April was geschied. De staking had op Donderdagavond haar hoogtepunt nog niet bereikt en de tegenmaatregelen, die toen reeds door de Duitsers werden genomen, waren van zo weinig invloed, dat zij de ontplooiing van de staking niet konden remmen. Daarom meenden wij het uitbreken en de gehele uitbreiding van de staking in één hoofdstuk te moeten behandelen, zonder daar reeds de eerste tegenmaatregelen der Duitse en Nederlandse politie te vermelden.

In Hoofdstuk IV wordt een beschrijving gegeven van de stakingsbeweging in elke plaats afzonderlijk. Voor zover mogelijk was daarbij de toestand op Donderdagmiddag 29 April het uitgangspunt. Doordat reeds in Hoofdstuk III de algemene wijze van uitbreken en uitbreiding der staking behandeld is, zijn wij in de gelegenheid in Hoofdstuk IV meer bijzonderheden te beschrijven. Tegelijkertijd wordt het optreden der Duitsers gesignaleerd, zonder vooralsnog in details te vervallen.

Alvorens het optreden der Duitse en Nederlandse politie te behandelen, menen wij allereerst te moeten uiteenzetten, binnen welk organisatorisch kader dit optreden plaats vond. Daarom wordt in Hoofdstuk $\mathrm{V}$ de politionele organisatie gedurende de staking behandeld, en wordt tegelijkertijd de houding der Nederlandse politie in Twente gedurende de stakingsdagen aan verschillende voorbeelden gedemonstreerd. Daarna pas wordt een chronologisch overzicht van de tegenmaatregelen gegeven.

In Hoofdstuk VI worden de slachtoffers van deze staking behandeld. Wij houden ons daar uitvoerig bezig met de omstandigheden, waaronder deze mensen werden gearresteerd en/of doodgeschoten. Wij meenden een uitvoerige behandeling te moeten verkiezen boven het simpel vermelden van de namen der doden. Daardoor immers komen wij in de gelegenheid, aan de hand van enkele voorbeelden allerlei bijzonderheden betreffende het optreden der Duitsers te vermelden, die in het algemeen overzicht der politionele maatregelen niet voor behandeling in aanmerking komen.

Nadat in Hoofdstuk VII nagegaan is, hoe de stakers financieel gestraft werden, worden tenslotte in Hoofdstuk VIII enkele beschouwingen gewijd aan de verschillende sociale groepen, die bij de staking betrokken waren.

Aan het einde van deze inleidende woorden moge de toewijding vermeld worden, waarmede vooral de burgemeesters van Hengelo en Enschede en de heer C. van Es, directeur van de afdeling Sociale Zaken te Almelo, alsmede de directie en arbeiders van de Machinefabriek Gebr. Stork \& Co. N.V. te Hengelo, het onderzoek naar deze staking mogelijk maakten. De bereidwilligheid waarmede verder arbeiders, fabrieksdirecteuren, politie-ambtenaren, boeren en vele anderen ons hielpen, de staking te hèr-denken om haar daarna te kunnen beschrijven en begrijpen, is naar wij hopen, tot uitdrukking gekomen in de ruime mate waarmede wij van hun materiaal voor de samenstelling van dit verslag gebruik hebben gemaakt. 


\section{HOOFDSTUK II}

\section{HET VERZET IN TWENTE VOOR DE MEISTAKING}

Bij de samenstelling van dit hoofdstuk hebben wij ons hoofdzakelijk beziggehouden met die vormen van verzet, waarbij grotere groepen mensen betrokken waren. Wij meenden ons in het algemeen daartoe te moeten beperken, omdat daaruit de ontstemming tegen de Duitse maatregelen beter te reconstrueren was. Dit is de reden, waarom in dit hoofdstuk behandeld worden: de georganiseerde oppositie in het N.V.V. (beginnend in Januari 1941), het verzet tegen de gelijkschakeling van de afdeling Hengelo van „Het Groene Kruis" (in Juli 1942), de toestand op het platteland, en het verzet, dat geboden werd bij de pogingen van het N.A.F., invloed in de bedrijven te krijgen (van midden 1942 tot en met Mei 1943).

Alvorens echter tot een meer uitvoerige behandeling van deze uitingen van weerstand over te gaan, mogen enkele andere voorbeelden worden gegeven, waaraan het verzet, dat in Twente vóór het uitbreken van de staking plaats vond, gedemonstreerd kan worden.

\section{Voorbeelden van verzet}

Als eerste voorbeeld moge gewezen worden op de opheffing van de "Concertvereniging" in Hengelo, nadat in November 1941 de Kultuurkamer was ingesteld. De Hengelose "Concertvereniging" telde vóór de bezetting ca. 800 toneelleden. 550 leden voor de orkestuitvoeringen en ca. 200 voor de solistenconcerten. Vele personen waren verder lid van de plaatselijke afdeling van "Toonkunst". Behalve deze verenigingen waren er nog mannenkoren en fanfarecorpsen. Toen de gelijkschakeling van het culturele leven in 1942 steeds meer dreigde, werd in Hengelo door de heren D. W. de Monchy en $\mathrm{Mr} \mathrm{H}$. J. F, ten Cate, een vergadering belegd, waar vertegenwoordigers uit de verschillende muziekverenigingen aanwezig waren. Daar men meende in den vervolge niet meer te kunnen doen, wat men wilde, dat ,,de kunst ... niet meer vrij" 5) zou zijn, werd besloten, een ieder lid op te wekken om de werkzaamheden op cultureel gebied neer te leggen en te bedanken voor de diverse verenigingen. Aan deze opwekking werd gehoor gegeven.

Als gevolg van de opheffing van deze culturele organisaties, werden in Hengelo en Enschede reeds vóór Mei 1943 talrijke illegale concerten gegeven, waar o.a. To van der Sluis, Jo Vincent, Annie Woud, Iskar Aribo e.a.

5) Zie: Verslag No. XI, blz. 3. 
optraden ${ }^{6}$ ). De bezoekers betaalden wel entreegeld, maar dit werd - nadat de kunstenaars betaald waren - in een centrale steunkas gestort, waaruit onderduikers werden onderhouden 7 ). In het algemeen werden deze concerten voordrachtavonden door fabrikanten en intellectuelen bezocht; slechts enkele malen door middenstanders en arbeiders ${ }^{8}$ ).

Naast deze kunstbijeenkomsten werden in Twente talrijke illegale politieke vergaderingen gehouden, waar de heer $\mathrm{J}$. $\mathrm{H}$. Scheps (religieus-socialist) sprak. Onder zijn gehoor, dat naar schatting uit ,40\% socialisten en $60 \%$ nietsocialisten" bestond ${ }^{9}$ ), bevonden zich personen uit verschillende lagen der bevolking, o.a. ook directeuren van textiel - en metaalfabrieken. "Voor mij" aldus de heer Scheps - , is het morele verzet hoofdzaak gebleven en mijn actie heeft zich tot het einde toe beroepen op het Land-Oorlog Reglement" ... "Merkwaardig is wel, dat de felste actie van mijn blad „Op Korte Golf” en .Op Korte Golf" is één der oudste vormen des verzets - het eerste aansloeg in het Oosten en niet in het Westen des lands"10). Mede door de mondelinge actie, die de heer Scheps in het Oosten heeft gevoerd, werden vele zijner brochures daar gelezen 11). De lezingen door hem gehouden, noopten tot de eerste illegale bijeenkomsten van enige omvang. Aanvankelijk werden deze in lokalen gehouden, maar toen dit later te gevaarlijk werd, bij particulieren thuis. Oorspronkelijk sprak de heer Scheps overwegend voor arbeiderskringen, later werd het contact verbreed, ,zodat het alle klassen omvatte"12). Vooral voor het geestelijk verzet zijn deze vergaderingen van veel invloed geweest; ,zijn principieel standpunt heeft velen de problemen scherper doen zien en hun houding afwijzender gemaakt ten opzichte van de Duitse maatregelen" 13 ).

Ook op Donderdagavond 29 April 1943 - de dag, dat in Twente de staking uitbrak naar aanleiding van het bericht, dat de Nederlandse militairen in krijgsgevangenschap naar Duitsland zouden worden weggevoerd - hield de heer Scheps in Hengelo een inleiding. Ofschoon bekendgemaakt werd, dat een

6) Zie: a. Verslag No. XII, blz. 2.

$b$. Brief van de heer $H$. Ledeboer, directeur van Van Heek \& Co. N.V. te Enschede aan het Rijksinstituut voor Oorlogsdocumentatie. 30 October 1947.

7) Zie: $6 a)$, blz. 3 en 4

8) In totaal werden gedurende de bezettingsjaren in Hengelo ongeveer 120 culturele voordrachtavonden gegeven. Twee à drie avonden werden speciaal voor middenstanders en arbeiders georganiseerd. Zie: 6a).

9) Zie: Verslag No. I, blz. 10.

10) Zie: 9), blz. 7. (Onderstreept door de heer J. H. Scheps).

11) Het contact met Twente kwam tot stand, doordat C. v. d. Maar te Almelo (religieussocialist), J. H. Scheps om toezending vroeg van de brochure: „Ir. Mussert door De Waag gewogen". Zie: 'Verslag No. I, blz. 6.

Onafhankelijk hiervan kwam ook contact tot stand (eind 1940), doordat Dr. H. Hartstra, vcorzitter van de afdeling Hengelo (O) van. "Het Groene Kruis", zich met Scheps in verbinding stelde om een brochure, die laatstgenoemde geschreven had, op grote schaal onder doctoren te verspreiden. Zie: Verslag No. IX, blz. 1.

12) Zie: Verslag No. II, blz. 7.

13) Zie: a. Brief van Prof. Ir. J. G. Hoogland aan „Oorlogsdocumentatie”. Hengelo, 13-9 47.

b. Verslag No, IX, blz, 2. 
ieder na 20 uur niet meer op straat mocht zijn, stelden de bezoekers (een groep Hengelose fabrikanten) het op prijs, dat de heer Scheps die avond zou spreken. Omstreeks 22 uur, toen aan de gastheer, Prof. Ir J. G. Hoogland, medegedeeld werd, dat de Grüne Polizei in Hengelo was aangekomen, werd de vergadering opgeheven en gingen de aanwezigen ,langs clandestiene wegen naar hun woningen" 14 ).

De volgende avond - ondanks het bevel, dat men na 20 uur niet op straat mocht zijn - kwamen verschillende personen ten huize van de dokter G. C. Lindeboom te Goor bijeen, om naar een inleiding van de heer Scheps te luisteren. De bezoekers werden 's avonds door de heer Lindeboom als „,patiënt" naar huis gebracht 15 ).

Op Zaterdagmorgen 1 Mei 1943 was de heer Scheps aanwezig op een bijeenkomst van jongeren, die gehouden werd op een boerderij buiten Almelo $\left.{ }^{16}\right)$.

Naast deze vormen van verzet werden in Twente - evenals elders in het land - illegale bladen verspreid. Vóór Mei 1943 werden deze echter in het algemeen niet in Twente zelf gedrukt, maar uit het Westen ,ingevoerd". Dit is de reden, waarom van een verspreiding van illegale kranten op grote schaal vóór Mei 1943 in Twente niet kan worden gesproken 17).

Verder moet gewezen worden op de tegenwerking van het Gewestelijk Arbeidsbureau te Hengelo bij het uitvoeren van Duitse maatregelen. Duizenden arbeiders, die niet in Duitsland wilden werken, en talloze fabrikanten, die hun personeel niet gaarne zagen vertrekken, vonden steun in de houding van het personeel van genoemd bureau. Zo wist men bijv. voor de dreigende werkloosheid in 1941 in de textielindustrie (veroorzaakt door grondstoffen- en brandstoffenschaarste) nog telkens een oplossing te vinden. Bij uitkamming der bedrijven werden - dit alles met medewerking van de Twentse textielfabrikanten - zoveel mogelijk die arbeiders gestuurd, van wie men van te voren wist, dat zij afgekeurd zouden worden. Andere arbeiders werden geplaatst in particuliere werk-objecten voor de voedselvoorziening. Honderden arbeiders werden tewerk gesteld in de fabrieken te Gronau en Nordhorn en konden daardoor 's avonds naar huis terugkeren. Groot was het aantal ziektegevallen, ,maar met de contrôle daarop werd de hand gelicht" 18).

Ten aanzien van de metaalbewerkers, die met uitzending naar Duitsland werden bedreigd, nam het personeel van het Gewestelijk Arbeidsbureau te

14) Zie: Brief van de heer J. H. Scheps aan het Rijksinstituut voor Oorlogsdocumentatie, blz. 2. Den Dolder, 10 September 1947.

15) Zie: 14).

De heer Scheps vermeldt in zijn brief dd. 10 September 1947, dat de bijeenkomst te Borne plaats vond. Bij nader onderzoek bleek, dat dit Goor moest zijn. Zie hiervoor Verslag No. CCXXII, blz. 1.

16) Zie: 14), blz. 3 .

17) Zie: a. Verslag No. LXXXIX, blz. 3.

b. Verslag No. IV, blz. 2 en 3.

18) Zie: Verslag: "Het Gewestelijk Arbeidsbureau Hengelo (O) in Bezettingstijd 1941 1945", blz. 15 en 16 . 
Hengelo nog andere maatregelen. Zo werden bijv. aanvragen voor tewerkstelling van personeel behandeld, zonder dat de Fachvermittler daarin gekend werd. Hierdoor konden verschillende "auslandsfähige" arbeiders elders in Nederland geplaatst worden. Verder werden personen niet opgeroepen, wanneer dit moest geschieden. De voor contrôle ingerichte kaartsystemen ,werden slecht en verkeerd bijgehouden..." 19).

Ondanks de tegenwerking van het personeel van het Gewestelijk Arbeidsbureau moesten vele arbeiders naar Duitsland vertrekken. Hiertegen rees verzet, en naar aanleiding van besprekingen met fabriekskernen en -directies (o.a. van de Machinefabriek Gebr. Stork \& Co. N.V. en G. Dikkers \& Co. N.V. te Hengelo), gingen twee personen - n.l. J. B. Vlam en $T_{j}$. Roorda, beiden uit Hengelo - in April 1942 naar het Westen van het land, om na te gaan of ,nu niet het moment was om een actie als de Februari-staking ... nog eens te doen, maar dan veel breder opgezet" 20 ). De reis van beide personen strekte zich uit tot Rotterdam, Schiedam, Amsterdam, Haarlem en Velsen. In de besprekingen, die daar werden gevoerd, werd de verzekering gegeven, dat de Twentse arbeiders in staking zouden gaan ${ }^{21}$ ). De reis had echter geen succes. Blijkens de ervaringen van Vlam en Roorda, leefde men in de door hen bezochte plaatsen ,nog in de ban van de Februari-staking" 22).

De uitzending van arbeiders naar Duitsland ging inmiddels door. Op 13 Juni 1942 werden ca. vijfhonderd arbeiders uit de metaalbedrijven van o.a. de Machinefabriek Gebr. Stork \& Co. N.V., Heemaf N.V. en G. Dikkers \& Co. N.V. te Hengelo, op transport gesteld ${ }^{23}$ ). Het vertrek van deze mensen 24) - ,op het stationsplein was het zwart van de mensen, toen de trein vertrok" 25 ) - heeft op de Hengelose bevolking toentertijd een sterke indruk achtergelaten.

\section{Het verzet tegen de gelijkgeschakelde vakbeweging}

Op 16 Juli 1940 deelde Dr Hellwich, chef van de Dienststelle für Soziale Verwaltung op een vergadering een aantal bestuurders van het N.V.V. ${ }^{26}$ )

19) Zie: 18), blz. 18.

20) Zie: Verslag No. II, blz. 7.

"Voor zoiets was trouwens al contact geweest met andere delen van het land" in Augustus 1941 in Utrecht, waar enkele vakverenigingsbestuurders aanwezig waren.

21) De stakingsbereidheid, die J. B. Vlam bij de Twentse arbeiders veronderstelde, leidde hij o.a. af uit hun bedanken voor het N.V.V., toen deze organisatie in her gelijkschakelingsproces werd opgenomen. Zie: Verslag II, blz. $1 \mathrm{t} / \mathrm{m} 8$.

22) Zie: 20), blz. 8.

23) Zie: a. Verslag No. XIII, blz. 4.

b. Zie: 18 ), blz. 21 .

24) Van de 500 personen, die 13 Juni 1942 op transport werden gesteld, zijn ca. 100 man niet in Duitsland aangekomen. ,Wijl het Arbeidsbureau Hengelo in Bentheim het volle vertrouwen (der Duitsers - Noot van de auteur) genoot, werd er genoegen genomen met de verklaring van de transportleider: "Alles in Ordnung und hier angetreten". Aan het feit, dat de transportlijsten verder prompt in orde waren, gesorteerd enz., werd veel meer aandacht geschonken dan aan de Sauckel-arbeiders zelf". Zie 18), blz. 24.

25) Zie: Verslag' No. XIII, blz. 4.

26) Maandag 15 Juli 1940 werd uit Den Haag aan de secretaris van het N.V.V. telefonisch 
en daarbij aangesloten bonden mede, dat Seyss-Inquart besloten had, het bestuur van het N.V.V. uit zijn functie te ontzetten. H. J. Woudenberg werd benoemd tot Commissaris. De bij het N.V.V. aangesloten vakbonden hadden zich in den vervolge naar zijn richtlijnen te gedragen.

Over deze kwestie werd op de bijeenkomst, die niet langer dan tien minuten duurde, geen discussie toegelaten.

Dezelfde dag werd aan de voorzitter van het N.V.V., E. Kupers, die niet op deze vergadering aanwezig was, door bovengenoemde $\mathrm{Dr}$ Hellwich medegedeeld, dat de Rijkscommissaris besloten had, hem uit zijn functie te ontzetten 27). De secretaris van het N.V.V., S. de la Bella, werd eveneens ,,met verlof" gezonden 28 ).

Op 23 Juli 1940, één week, nadat Kupers en De la Bella ,waren weg gestuurd", volgde het ontslag van de andere leden van het Dagelijks Bestuur van het N.V.V.

In het begin van de maand Augustus 1940 werd door Woudenberg een vijftiental vooraanstaande bestuurders van vakbonden, aangesloten bij het N.V.V., ontslagen. Voordien was dit reeds met een aantal Joodse bestuurders gebeurd.

De ontslagen bestuurders van deze moderne vakverenigingen werden vervangen de NSB-ers of andere, door Woudenberg betrouwbaar geachte personen.

1 October 1940 - aldus het N.V.V.-verslag over de jaren 1940 - 1945 29) - werd door Mussert het nationaal-socialistische „Nederlands Arbeidsfront” ontbonden en werden de leden van deze organisatie verplicht, zich bij het N.V.V. aan te sluiten. Al deze maatregelen verwekten bij de leden van het oude N.V.V. veel onrust en duizenden bedankten voor het lidmaatschap ${ }^{30}$ ).

Doordat na de capitulatie niet direct speciale matregelen tegen de vakbeweging getroffen waren, werden ook in Twente in den beginne velen gerustgesteld en werd de organisatie-arbeid - na verkregen contact met de landelijke leiding - hervat. Voldaan was men echter niet en in besprekingen van enkele Twentse bestuurders met de N.V.V.-leiding of hoofdbesturen der aangesloten organisaties, werd dit tot uiting gebracht. Getrouw voegde men zich echter naar de adviezen der leiding ${ }^{31}$ ).

Deze houding werd gewijzigd, toen Woudenberg in Juli 1940 tot commissaris van het N.V.V. benoemd werd en de maatregelen genomen werden, die reeds

opdracht gegeven, om het Dagelijks Bestuur van deze vakcentrale, alsmede de voorzitters van de bij het N.V.V. aangesloten vakverenigingen mede te delen, ,dat zij op 16 Juli. een vergadering in hotel Parkzicht te Amsterdam hadden bij te wonen, waarin belangrijke mededelingen zouden worden gedaan." Zie: N.V.V.-verslag over de jaren 1940-1945, blz. 23.

27) Zie: 26), blz. 24 .

28) Zie: 26), blz. 25.

20) Zie uitvoeriger betreffende de gelijkschakeling van het N.V.V.: het N.V.V.-verstag ove: de jaren 1940 - 1945, blz. $23 \mathrm{t} / \mathrm{m} .33$.

30) Zie: 29), blz. 29.

31) Zie: Jaarverslag 1945 (een beknopt overzicht periode 1940-1945). Hengelose Bestuurdersbond, blz. 1. 
boven beschreven zijn. ,De lust tot onmiddellijke staking van elke activiteit moest ook toen weer bedwongen worden, want wederom kwam uit het Westen het parool „doorwerken”. Er is doorgewerkt, maar het verzet groeide" 32 ). Propaganda-materiaal werd - naarmate het een meer nationaal-socialistisch karakter begon te krijgen - teruggestuurd. De Joodse leden en bestuurders werden niet - ondanks bevel - uit de organisatie verwijderd. Sterker en - naar de mening van de Twentse leden van het N.V.V. - principiëler werd het verzet, toen $H$. J. Woudenberg een reorganisatie van het N.V.V. voorbereidde. Hierbij werd - vanuit vakbewegingsoogpunt bezien - het land in districten en districtsbureaux verdeeld, die zowel de taak van de bestuurdersbonden als een deel van de werkzaamheden der vakbonden zouden overnemen ${ }^{33}$ ). De 271 plaatselijke bestuurdersbonden in het land zouden verdeeld worden - en werden ook later verdeeld - in 72 districten, aan het hoofd waarvan een districtsleider geplaatst zou worden, die onder rechtstreekse verantwoordelijkheid aan Woudenberg zou werken. De districtsbureaux waren derhalve te beschouwen als de filiaalinstellingen van de centrale (het N.V.V.) te Amsterdam. In hun organisatorische opzet zouden zij ook een getrouwe weerspiegeling zijn van die centrale. Elke afdeling van een vakorganisatie zou ressorteren onder een district, zodat een zelfstandig bestaan der vakbondsafdelingen niet meer zou kunnen voorkomen ${ }^{34}$ ). De contributies zouden vanaf 1 April 1941 niet meer rechtstreeks worden afgedragen aan de landelijke Hoofdbesturen, maar via de inmiddels ingestelde N.V.V.-districten aan het gelijkgeschakelde N.V.V. ${ }^{35}$ ).

Duidelijk bleek de onwilligheid der Twentse vakbeweging om hieraan mede te werken op een vergadering van voorzitters en secretarissen der bestuurdersbonden uit Almelo, Hengelo en Enschede. Deze vergadering, die plaats vond op 10 Februari 1941, stond onder leiding van $\mathrm{H}$. J. Woudenberg. Bij monde van $C$. van $E_{s}$ - toentertijd voorzitter van de Enschedese Bestuurdersbond werd o.a. gezegd, dat er geen reden tot juichen was, toen Kupers en De la Bella werden afgezet en men ,een Woudenberg" 36) kreeg. Tegen deze merkte Van Es op, dat hij (Woudenberg) graag zou willen zien, dat de arbeiders hun sociaal-democratische opvattingen zouden prijsgeven voor de nationaalsocialistische, doch - zo voegde hij hieraan toe - dit zou nimmer gebeuren. $\mathrm{Hij}$ betoogde verder, dat het doorvoeren van de in uitzicht gestelde reorganisatie een afbraak werd, die tot ondergang zou leiden.

In de circulaire, die ongeveer twee weken later aan de verschillende bestuurders der aangesloten organisaties naar aanleiding van deze vergadering rondgestuurd werd, werd nogmaals gezegd, dat men de „LEIDERSGEDACHTE ...

32) Zie: 31), blz. 1 .

33) Zie: 26), blz. 30.

34) Zie: Rondschrijven van het (gelijkgeschakelde) N.V.V., Letter W. No. 90. Zie verder van deze organisatie de Rondschrijvens No, 86, 93 en 102.

35) Zie: Rondschrijven Letter W. No. 86 van het N.V.V. Amsterdam, 8 Maart 1941.

36) Zie: de rotulen van de ,Bijeenkomst van Voorzitters en Secretarissen der bestuurdersbonden uit Almelo, Hengelo (O) en Enschede onder leiding van de N.V.V.-commissaris Woudenberg op Maandag, 10 Februari 1941, 's avonds 7 uur", blz. 2. Bijlage 2. 
waarbij dan de bestuurders volkomen ondergeschikt zijn aan de LEIDER" ${ }^{37}$ ) niet wenste te aanvaarden.

Blijkbaar naar aanleiding van het krachtige verzet van $\mathrm{C}$. van Es werd deze met ingang van 18 Februari 1941 als voorzitter van de Enschedese Bestuurders Bond en als districtsleider Enschede van de Algemene Nederlandse Bond van Textielarbeiders, ontslagen. Hij diende zich vanaf die tijd van elke activiteit ten opzichte van het N.V.V. en de hierbij aangesloten vakverenigingen te onthouden, noch mocht hij invloed op deze organisaties of haar leden uitoefenen. H. J. Woudenberg zag zich ,.gedwongen" dit besluit te nemen, ,in het belang der bevordering van de eenheid in het doen en laten van de vakbeweging, ..." 38 ).

Op 23 Februari 1941 werd opnieuw een bijeenkomst te Hengelo belegd, waar aanwezig waren: de bestuursleden uit Enschede en Hengelo benevens de bestuurders van het (gelijkgeschakelde) N.V.V., Van Kampen en Hummel. Ook deze echter slaagden er niet in, de Twentse N.V.V.-bestuurders tot andere gedachten te brengen. Tijdens de vergadering werd door een der Twentse bestuurders opgemerkt, dat de woorden, door Van Es op de vergadering van 10 Februari 1941 gesproken, volkomen het inzicht der andere bestuurders vertolkten. „Ons standpunt" — aldus deze bestuurder — ,blijft hetzelfde" 39 ).

Inmiddels was reeds verschillende Twentse bestuurders het "leiderschap" opgelegd. Zo bijv. werd J. B. Vlam door H. J. Woudenberg tot secretaris van de afdeling Hengelo van de Algemene Nederlandse Bond van Handelsen Kantoorbedienden en Handelsreizigers "Mercurius" benoemd 40 ). Ditzelfde leiderschap werd J. H. Jansen voor het district Hengelo opgelegd. Zelfs werd - eveneens zonder dat men hierom had verzocht - de ,eenheidsadministratie" toegezonden 41 ).

Op 18 Maart 1941 kwamen de bestuurders van de Hengelose Bestuurders Bond bijeen. Naar aanleiding van deze vergadering werd aan de organisatiebesturen, aangesloten bij de Hengelose Bestuurders Bond, in een schrijven dd. 19 Maart 1941 medegedeeld:

,In onze gisteren gehouden bestuursbijeenkomst is na rijpelijk overwegen het besluit genomen, om per 1 April a.s. onze functies als bestuurders van de H.B.B. (Hengelose Bestuurders Bond) prijs te geven en ter beschikking te stellen van het N.V.V.

Volgens de nieuwe regelingen zult gij $U$ niet meer behoeven te belasten met het

37) „LEIDERGEDACHTE” en "LEIDER" waren groot getypt in de gecyclostyleerde circulaire.

De notulen van deze vergadering werden tegelijk met de in de tekst genoemde circulaire verzonden. Deze is gedateerd 22 Februari 1941. Zie: Bijlage 3.

38) Zie: Brief van H. J. Woudenberg aan C. van Es. Amsterdam, 18 Februari 1941. Bijlage 4.

39) Zie: Verslag van de „Besturenbijeenkomst op Zondag 23 Februari 1941 te Hengelo (O)", blz. 1. Bijlage 5.

40) Zie: Bijlage 6.

41) Zie: 31), blz. 2. 
benoemen van nieuwe functionarissen in deze vacatures, doch geschiedt dit van bovenaf door de N.V.V.-leiding" ${ }^{42}$ ).

Tegelijkertijd werd een brief verzonden aan het gelijkgeschakelde N.V.V., waarin van dit besluit kennis werd gegeven. Onmiddellijk hierop benoemde dit N.V.V. G. Visser tot districtsleider. Deze weigerde echter deze functie te aanvaarden ${ }^{43}$ ).

Het voorbeeld der bestuurders werd gevolgd door de leden 44 ). De onwil der Twentse bestuurders en leden om aan de reorganisatie van het N.V.V. mede te werken, had de arrestatie ten gevolge van $V$ an Es en $K$. Tabak (districtsbestuurders van de Textielarbeiders Bond) en G. Visser (districtsbestuurder van de Algemene Nederlandse Metaalbewerkers Bond).

Door de uitgetreden bestuurders en leden werd als antwoord daarop een ondersteunings-actie op touw gezet. Uit de binnengekomen gelden werden vóor hun arrestatie de drie, vroeger bezoldigde, vakverenigingsbestuurders ondersteund. Daarnaast werden illegale bijeenkomsten belegd, waar verschillende vraagstukken besproken werden 45 ). Hiervoor zocht men slechts de meest vertrouwde leden uit. „Omdat het georganiseerd werk was, zorgden $z \mathrm{ij}$ er dan wel weer voor, dat het in de bedrijven verder druppelde" 46 ).

Het door de Twentse moderne vakbeweging ingenomen standpunt ten aanzien van de reorganisatie van het N.V.V. werd door middel van het rondsturen van de bovengenoemde notulen der vergaderingen van 10 en 23 Februari 1941 in de rest van het land bekend gemaakt, ,met de bedoeling, elders een zelfde standpunt te laten innemen" 47 ).

Het voorbeeld, dat bestuurders en arbeiders van de moderne vakbeweging in Twente gegeven hadden, werd begin Augustus 1941 gevolgd door de besturen en leden der confessionele vakverenigings-organisaties, toen op 25 Juli 1941 bij beschikking van de Rijkscommissaris, het R.K. Werklieden Verbond evenals alle daarbij aangesloten vakbonden en diocesane bonden en het Christelijk Nationaal Vakverbond met de daarbij aangesloten organisaties, onder het commissariaat van Woudenberg gesteld werden. Op 13 Augustus 1941 hadden reeds zo goed als alle leden van het R.K. Werklieden Verbond, district Hengelo (O) bedankt 48). In het district Hengelo bestonden in Augustus 1941 vóór de gelijkschakeling 36 afdelingsorganisaties van de beide confessionele bonden. $\mathrm{Na}$ de maatregelen, door Woudenberg genomen, daalde het aantal leden tot ongeveer $1 \%$ van het oorspronkelijke aantal ${ }^{49}$ ).

42) Zie: Bijlage 7 .

43) Zie: 31), blz. 2.

44) „Bij de textiel was het zo sterk, dat de mensen hun contributieboekjes terugbrachten met het gevolg, dat zij hun $f$ 4.- steun niet meer kregen." Zie: Verslag No. II, blz. 6.

45) Het waren vooral deze illegale bijeenkomsten, waar in den beginne Scheps sprak. Zie 44), blz. 6 en 7.

46) Zie: 44), blz. 7 .

47) Zie: 31), blz. 2.

48) Zie: Bijlage 8.

49) Zie: Bijlage 9. 


\section{Verzet tegen de gelijkschakeling van „Het Groene Kruis” te Hengelo (O)}

Als voorbeeld, hoe de Hengelose bevolking zich verzette tegen de gelijkschakeling van haar zelfstandige organisaties, zij een kort overzicht gegeven van de wijze, waarop de leden van de afdeling Hengelo van „Het Groene Kruis" zelf deze vereniging liquideerden.

In het bestuur van "Het Groene Kruis", afdeling Hengelo, zaten na 10 Mei 1940 twee NSB-ers. Bij gelegenheid van de jaarvergadering van 28 April 1942 trachtten de bestuursleden in de plaats van Mevr. A. J. EkkerStork, die NSB-ster was en wier beurt het was af te treden, een tegeircandidaat te stellen, die niet tot de NSB behoorde. Om verder ,de remmen in handen te houden" 50) besloot ", het goede deel van het bestuur" 51) in plaats van de Joodse arts J. Frank (door wiens uittreden een vacature was ontstaan), Dr B. ten Haaften als candidaat te stellen. Op de jaarvergadering werden beide personen gekozen.

Op 13 Juni 1942 ontving de voorzitter van de Vereniging „Het Groene Kruis", afdeling Hengelo, Dr H. Hartstra, een schrijven van de Commissaris voor niet-commerciële Verenigingen en Stichtingen. Hierin werd hem de aanwijzing gegeven, dat de twee nieuw-benoemde bestuursleden uit het bestuur verwijderd moesten worden en vervangen door Mevr. A. J. Ekker-Stork en D. Piekhaar 52).

$\mathrm{Na}$ overleg met het bestuur schreef Dr H. Hartstra op 20 Juni 1942 aan genoemde commissaris terug, dat het niet opnieuw candidaat stellen van Mevr. Ekker-Stork voortgekomen was uit het feit, dat deze niet meer het vertrouwen van de leden genoot. Hij schreef verder, dat met zekerheid mocht worden aangenomen, dat een ingrijpen van de commissaris in interne aangelegenheden van de Vereniging "Het Groene Kruis" voor het voortbestaan van deze vereniging te Hengelo (er waren 21.066 leden) ernstige gevolgen zou kunnen hebben 53 ).

Op 4 Juli 1942 werd de heer Hartstra door de commissaris medegedeeld, dat hij de door hem gegeven aanwijzingen dd. 13 Juni 1942 zonder meer had op te volgen 54). Hierop antwoordde Dr Hartstra, dat hij met zekerheid kon voorspellen, dat nagenoeg alle leden onmiddellijk voor hun lidmaatschap zouden bedanken, indien hij aan de ,aanwijzingen" gevolg zou geven. ,Eveneens staat vast" - aldus schreef hij - „dat onze vijf wijkverpleegsters, de magazijnbewaarders en de medicus, die onze consultatie-bureaux leidt, hun ontslag zullen nemen en in ieder geval hun taak zullen neerleggen, terwijl verwacht moet worden, dat ook de Hengelose medici alle samenwerking met het Groene Kruis zullen verbreken" 55 ).

50) Zie: Verslag No. IX, blz. 4.

51) Zie: 50).

52) Zie: Bijlage 10

53) Zie: Bijlage 11.

54) Zie: Bijlage 12.

55) Zie: Bijlage 13.

Op 13 Juli 1942 werd Dr. H. Hartstra als gijzelaar naar Haaren gebracht. Zie: Verslag No. IX, blz. 5. 
Ook aan een nadere sommatie ${ }^{56}$ ) werd door het Hengelose bestuur geen gevolg gegeven. Er werd integendeel door bestuur (,,het ,goede' deel althans" 57)), zusters en concierge besloten, het werk neer te leggen. Het bestuur trad af. Dr De Vries Reilingh staakte het werk, zusters en concierge dienden hun ontslag in per 1 November 194258 ). Tevens werd een comité gevormd om de leden in te lichten en hen te bewegen als lid te bedanken. $\mathrm{Na}$ ongeveer twee maanden hadden de ,goede" leden van „Het Groene Kruis" grotendeels bedankt.

Op verschillende wijzen werd op de zusters drang uitgeoefend, het werk bij de Nederlandse Volksdienst over te nemen. Vier van de vijf zusters bleven hun ingediend ontslag per 1 November echter handhaven 59 ).

Daar de afdeling Hengelo van „Het Groene Kruis” niet meer functionneerde, maar de behoefte aan hulp bleef bestaan, gingen de leden van deze organisatie over naar het "Wit-Gele Kruis". Zodra dit echter door de Nederlandse Volksdienst geconstateerd werd, werden ook de bestuurders van het „Wit-Gele Kruis" ter verantwoording geroepen. Enige tijd daarna werd ook deze organisatie in Hengelo opgeheven ${ }^{60}$ ).

$\mathrm{Na}$ de liquidatie werd het werk van „Het Groene Kruis" en van het „WitGele Kruis" te Hengelo illegaal voortgezet. De artsen, die betrouwbaar waren, werden in deze actie betrokken ${ }^{61}$ ). Vijf particuliere verpleegsters werden in dienst genomen. Tot de bevrijding deden $z$ ij het werk van de vroegere wijkverpleegsters van "Het Groene Kruis” en van het „Wit-Gele Kruis".

\section{De toestand op het platteland}

De reacties der Twentse boeren op enkele bezettingsmaatregelen hadden voor een deel betrekking op de voedselpositie van de Nederlandse bevolking, voor een ander deel op de verplichte veeleveringen.

Zo werd bijv, de hoeveelheid ondermelk, die de boeren voor hun kalveren en varkens nodig hadden, minder, daar de Nederlandse organen der voedselvoorziening - voorzover mogelijk - de melk onder de bevolking wilde distribueren. Daar verder de invoer van granen en veevoeder werd stopgezet, kòn het niet anders, of een deel der veestapel moest worden afgeslacht.

De daling van het aantal stuks rundvee in Overijssel komt tot uitdrukking in de volgende gegevens 62 ):

56) Zie: Brief van Mevr. M. E. Rijpma te Hengelo, geen datum. Bijlage 14, blz. 2.

57) Zie: 56), blz. 2.

58) Men was aan een drie-maandelijkse opzegtermijn gebonden.

59) „De vijfde zuster is voor de drang van de Nederlandse Volksdienst ,bezweken" en heeft zich in dienst van die instantie gesteld." Zie: 56), blz. 3.

60) Zie: a. Verslag No. CCLVIII.

b. S. Stokman: Het verzet van de Nederlandse Bisschoppen enz., blz. 261.

61) Zie: 50), blz. 6.

62) Deze gegevens zijn ontleend aan de toentertijd niet voor publicatie bestemde „Uitkomsten der inventarisatie van de veestapel, December 1942".

Het aantal stuks rundvee, dat verplicht moest worden geleverd, werd niet apart vermeld. 


\begin{tabular}{|c|c|c|c|}
\hline & Dec. 1940 & Dec. 1941 & Dec. 1942 \\
\hline & & & (voorlopig) \\
\hline $\begin{array}{l}\text { Vrouwelijk jongvee beneden } 1 \text { jaar: } \\
\text { minder dan } 60 \mathrm{~kg} \text {. } \\
60 \mathrm{~kg} \text {. en meer }\end{array}$ & 56912 & 79089 & $\begin{array}{r}2450 \\
34077\end{array}$ \\
\hline $\begin{array}{c}\text { Mannelijk jongvee beneden } 1 \text { jaar: } \\
\text { minder dan } 60 \mathrm{~kg} \text {. } \\
60 \mathrm{~kg} \text {. en meer }\end{array}$ & 6318 & 10438 & $\begin{array}{r}410 \\
2386\end{array}$ \\
\hline $\begin{array}{c}\text { Jongvee } 1-2 \text { jaar: } \\
\text { drachtig } \\
\text { gust }\end{array}$ & $\begin{array}{l}30017 \\
13106\end{array}$ & $\begin{array}{l}27231 \\
12126\end{array}$ & $\begin{array}{r}20984 \\
6618\end{array}$ \\
\hline $\begin{array}{c}\text { Jongvee ouder dan } 2 \text { jaar: } \\
\text { drachtig } \\
\text { gust }\end{array}$ & $\begin{array}{r}4310 \\
452\end{array}$ & $\begin{array}{r}2123 \\
261\end{array}$ & $\begin{array}{r}2003 \\
209\end{array}$ \\
\hline $\begin{array}{l}\text { Melk- en kalfkoeien: } \\
1 \times \text { gekalfd } \\
2 \times \text { gekalfd } \\
3 \times \text { gekalfd } \\
\text { ouder }\end{array}$ & $\begin{array}{l}37485 \\
30518 \\
27959 \\
78235 \\
\end{array}$ & $\begin{array}{l}31991 \\
27738 \\
25214 \\
67901\end{array}$ & $\begin{array}{l}28202 \\
25998 \\
25692 \\
61556 \\
\end{array}$ \\
\hline $\begin{array}{l}\text { Melk- en kalfkoeien totaal } \\
\text { Stieren } 1 \text { jaar en ouder }\end{array}$ & $\begin{array}{r}174197 \\
2285\end{array}$ & $\begin{array}{r}152844 \\
2009\end{array}$ & $\begin{array}{r}141448 \\
1274\end{array}$ \\
\hline $\begin{array}{l}\text { Mestkalveren } \\
\text { Ander mestvee beneden } 1 \text { jaar (incl. ossen) }\end{array}$ & 496 & $\begin{array}{r}39 \\
123\end{array}$ & 25 \\
\hline $\begin{array}{l}\text { Mestvee en vee bestemd om vet te } \\
\text { maken (incl. ossen) I jr. en ouder }\end{array}$ & 1038 & 322 & 100 \\
\hline Totaal & 289131 & 286605 & 211984 \\
\hline
\end{tabular}

In overeenstemming met de daling van het aantal stuks rundvee valt ook de vermindering van de aanvoer van volle melk aan de zuivelfabrieken in de provincie Overijssel te constateren.

\begin{tabular}{|c|c|c|c|}
\hline n 1938 & werd & aangevoerd & $517.296 .186 \mathrm{~kg}(94 \%)$ \\
\hline 1939 &, & ," & $548.636 .021 \mathrm{~kg}(100 \%)$ \\
\hline 1940 & ,, &, & $524.693 .511 \mathrm{~kg}(95.8 \%)$ \\
\hline 1941 & , & , & $429.298 .680 \mathrm{~kg}(77.9 \%)$ \\
\hline 1942 & , & , & $303.807 .638 \mathrm{~kg}(55.3 \%)$ \\
\hline 1943 &, & , & $248.032 .702 \mathrm{~kg}(45.2 \%) 62 \mathrm{a})$ \\
\hline
\end{tabular}

De verminderde aanvoer van volle melk aan de zuivelfabrieken wordt echter mede bepaald door het feit, dat de boeren direct aan de bevolking volle melk verkochten. Ook gebeurde het wel, dat de zuivelfabrieken zelf melk ophaalden en boter karnden voor particuliere doeleinden. Tevens waren er mensen, die bij verschillende boeren melk kochten, deze karnden en de boter in de zwarte handel brachten.

62a) Deze gegevens zijn ontleend aan de staat betreffende de ,,aanvoer volle melk van veehouders in Overijssel over de jaren 1938 t/m 1943". Deze lijst is opgemaakt door de Centrale Contrôle Dienst Zwolle. 
Desondanks blijkt, dat in vergelijking met de gehele provincie Overijssel, in Twente niet veel aan zwarte handel werd gedaan. Een uitzondering moet worden gemaakt voor de gemeente Tubbergen.

Evenals melk werd in Twente ook rogge aan de bevolking verkocht en wel in kleinere hoeveelheden, variërende van $5-20 \mathrm{~kg}$. Ook gebeurde het, dat bakkers grotere hoeveelheden rogge opkochten, daarvan roggebroden bakten en deze naar andere gebieden wegstuurden $62 \mathrm{~b}$ ).

Deze verkoop van rogge aan de bevolking was uiteraard ook in strijd met de voorgeschreven verplichte graan-leveringen. Dat de boeren zich hier echter weinig aan hielden, kan blijken uit een vergelijking van de geraamde en de gedorste opbrengst $62 \mathrm{c}$ ).

OOGSTRESULTATEN OP 2 DECEMBER 1943

\begin{tabular}{l|r|r|r|r}
\hline \multirow{2}{*}{ Soort } & \multicolumn{2}{|c|}{ Raming } & \multicolumn{2}{c}{ Gedorst } \\
\cline { 2 - 5 } & per HA & Opbrengst & per HA & Opbrengst \\
\hline Rogge & 1684 & 89.611 .411 & 1806 & 45.791 .214 \\
Tarwe & 2020 & 12.446 .334 & 2222 & 6.738 .979 \\
Haver & 1680 & 20.857 .608 & 1800 & 9.590 .120 \\
Gerst & 1808 & 2.293 .692 & 2125 & 1.226 .457 \\
\hline
\end{tabular}

Uit deze cijfers blijkt, dat de gedorste opbrengst van rogge plm. $51 \%$, van tarwe plm. $55 \%$, van haver plm. $41 \%$ en van gerst plm. $53 \%$ van de raming bedroeg. Daarom werd door de Centrale Contrôle Dienst te Zwolle nagegaan, in welke plaatsen men het meest beneden de raming bleef. Naar aanleiding van dit onderzoek werd een zgn. „Bijzondere Productie-lijst" voor alle districten in Overijssel samengesteld. Deze lijst had betrekking op landbouwers en veetelers, die gedurende de bezetting niet of in onvoldoende mate medewerkten aan de levering van voedselvoorzieningsproducten van eigen bedrijf. Er blijkt uit, dat van de 419 personen in Overijssel, die te weinig hadden geleverd, 303 personen hun bedrijf in Twente uitoefenden. Geheel in overeenstemming met deze gegevens schreef de C.C.D. te Zwolle aan het Rijksinstituut voor Oorlogsdocumentatie, dat ,de levering van voedselvoorzieningsproducten door telers in Twente destijds aanzienlijk minder vlot verliep dan in het overige deel van de provincie Overijssel" 62d).

Van belang is in dit verband tenslotte, dat reeds in 1941 aan de boeren door het bestuur van de Overijsselse Landbouw Maatschappij te Zwolle een voorbeeld gegeven werd, hoe zij zich tegen de Duitse bezettingsmaatregelen te gedragen hadden.

62b) De Centrale Contröle Dienst beschouwde dit niet als zwarte handel. Zie: Verslag No. CCLIV, blz. 3.

62c) Deze hoeveelheden zijn ontleend aan een aantal lijsten, samengesteld door de Centrale Contrôle Dienst $Z$ wolle. De gegevens voor de lijsten werden verstrekt door de Plaatselijke Bureau-Houders in Overijssel.

62d) Zie: Brief van de Centrale Contrôle Dienst Zwolle, 7 Januari 1948. 
Op een vergadering, gehouden op 14 November 1941, werd door de boerenleider Roskam aan het bestuur van de Overijsselse Landbouw Maatschappij medegedeeld, dat hij aanwezig was om te proberen ,de kern der Overijsselse Landbouw Maatschappij in de Landstand over te dragen". Hij merkte verder op, ,dat, als het goed is, het zo moet lopen, dat als bijv. de regering zegt, dat 10.000 koeien geleverd moeten worden, de Landstand zorgt, dat deze 10.000 koeien er komen. Zullen hiervan ... in een zeker dorp bijv. 50 stuks geleverd moeten worden, dan moet de afdeling van de Nederlandse Landstand in dit dorp uitzoeken, hoeveel koeien elke boer leveren moet. Zo ook op elk ander gebied" $62 \mathrm{e}$ ).

Het bestuur der Overijsselse Landbouw Maatschappij was echter niet bereid om zijn werkzaamheden in de Landstand voort te zetten. De Overijsselse Landbouw Maatschappij werd „opgelost” in de Landstand 62f).

Daarvan werden de boeren automatisch lid. $Z_{\mathrm{ij}}$ moesten verplicht contributie betalen. Deze was a.h.w. een heffing, die afhankelijk van de grootte van het bedrijf, werd opgelegd. In het algemeen echter werd de Landstand door de boeren in Overijssel genegeerd. Contributie werd practisch niet betaald $62 \mathrm{~g}$ ).

\section{Verzet tegen N.A.F.-infiltratie in de bedrijven}

In het voorgaande werd uiteengezet, hoe de Twentse arbeiders in georganiseerd verband het initiatief namen in het verzet tegen de gelijkschakeling van het N.V.V.

Toen de vakbonden (N.V.V., R.K. Werklieden Verbond en Chr. Nationaal Vakverbond) gelijkgeschakeld waren, besloot de Raad van Bestuur in Arbeidszaken ${ }^{63}$ ) de gelijkgeschakelde vakverenigingen niet te erkennen. Dit parool werd aan de aangesloten werkgevers-verenigingen doorgegeven.

Op een daartoe speciaal geconvoceerde vergadering had de FabrikantenVereniging te Enschede in ondubbelzinnige bewoordingen het besluit om Woudenberg niet te erkennen, onderschreven. Kort nadat Dr Hellwich de notulen van de bewuste vergadering opgevraagd had, werd de FabrikantenVereniging te Enschede op 4 November 1941, in opdracht van de Commissaris voor niet-commerciële Verenigingen, geliquideerd ${ }^{64}$ ).

62e) Zie: „Notulen van de vergadering van het bestuur der Overijsselse Landbouw Maatschappij gehouden op Vrijdag 14 November 1941 des n.m. 13 uur in Hotel Wientjes te Zwolle".

62f) Zie: „Overijssels Landbounblad. Officiel orgaan der Overijsselse Landbouw Maat schappij. 27 e jaargang 12 Juli 1945."

629) Uit een contributieboek, dat door de administratie van de Nederlandse Landstand werd bijgehouden, blijkt, dat verreweg het grootste aantal boeren een dwangbevel werd toegezonden omdat de contributie niet werd betaald. Op welk jaar dit contributieboek betrekking heeft, is echter niet bekend. Wel werd ons door personeel van de Overijsselse Landbouw Maatschappij te Zwolle medegedeeld, dat zeker ook in 1943 door vrijwel alle boeren geen contributie werd betaald.

63) Deze werd begin 1941 opgericht. Voor de textielfabrikanten hadden hierin zitting H. B. N. Ledeboer (voorzitter van de Fabrikanten-Vereniging te Enschede), H. P. Gelderman C.Mzn. en Th. de Wit uit Hilversum.

64) Doordat de Raad van Bestuur in Arbeidszaken de gelijkgeschakelde vakbeweging niet wilde erkennen, werden de werkgevers $m$ bonden, het Centraal Overleg en de Raad van Bestuur 
In het hieronder volgende willen wij thans meer in het bijzonder nagaan, hoe fabrikanten en arbeiders gezamenlijk stelling namen tegen de infiltratie van het N.A.F. in de bedrijven. Het is van belang, dit uitvoeriger te behandelen, omdat het mede een aanwijzing kan zijn voor de sympathie van de ondernemers voor de staking, die op 29 April 1943 uitbrak.

\section{De propaganda-actie van "Vreugde en Arbeid"}

Eind Augustus 1941 richtte het N.A.F. zich tot verschillende fabrieksdirecties met het verzoek om hun medewerking te verlenen aan een feestelijke avond, die in het Concertgebouw te Hengelo gegeven zou worden onder auspiciën van de werkgemeenschap ".Vreugde en Arbeid".

Uit veertien op deze kwestie betrekking hebbende brieven blijkt, dat slechts drie firma's schreven, bereid te zijn, aan het welslagen van de plannen hun medewerking te verlenen. Elf andere firma's wezen om verschillende redenen samenwerking af.

De firma G. Dikkers \& Co. N.V. wees in haar antwoord op het sterk ontwikkelde culturele leven, dat in arbeiderskringen reeds aanwezig was en zag voor een samenwerking als door het N.A.F. bedoeld, voorlopig geen aanleiding ${ }^{65}$ ). Op dit laatste wees ook de directie van de Koninklijke Nederlandse Katoen-Spinnerij te Hengelo. $Z_{i j}$ voegde hieraan toe, dat zij $\rightarrow$ althans als ondernemer - haar medewerking niet kon geven, daar de fabriek zelf door haar fabrieksvereniging voor de culturele belangen der arbeiders zorgde en ook de zo grote materiële zorgen harer werknemers enigszins trachtte te lenigen $\left.{ }^{66}\right)$. In dezelfde geest schreef de Twentse Electrotechnische Industrie Odink $\mathcal{E}$ Koenderink, te Haaksbergen. De directie schreef verder, dat zoals haar bij nadere informatie was gebleken - bij het personeel geen belangstelling bestond ${ }^{67}$ ). In een vrij uitvoerig schrijven antwoordde de directie van Heemaf N.V., dat, om te voorzien in de door het N.A.F. gevoelde behoefte, op 11 Maart 1941 reeds een personeelsavond gegeven werd. De directie voegde daaraan toe, dat zij zich voorstelde, dit in de toekomst te herhalen en wees er op, dat ook op deze avonden het neutrale karakter bewaard bleef 68). De directie van de N.V. Katoenfabrieken v/h Arntzenius Jannink \& Co. te Goor antwoordde, dat bij informatie onder haar arbeiders gebleken was, dat het N.A.F. in Goor reeds eerder een voorstelling had gearrangeerd "voor welke bijzonder weinig belangstelling was". $Z_{i j}$ schreef verder, dat de arbeiders van haar fabriek zonder uitzondering voor het streven van het N.A.F. weinig schenen te voelen. "Onzerzijds" - aldus de directie — ,kunnen wij hun daarin niet ongelijk geven." Hierbij doelde de directie op de moeilijke levens -

in Arbeidszaken geliquideerd. „Van de aangesloten verenigingen werden de Metaalbond en de Twentse Textielfabrikanten Vereniging de eerste slachtoffers." Zie: "Jaarverslag over 1941" van de Fabrikanten-Vereniging te Enschede, blz. 1.

65) Zie: Bijlage 15.

66) Zie: Bijlage 16 .

67) Zie: Bijlage 17

68) Zie: Bijlage 18 
omstandigheden van de arbeiders en de gedeprimeerdheid door de oorlogstoestand. $Z$ ij merkte verder op, dat daardoor de arbeidersbevolking niets voor feestelijkheden gevoelde 69 ).

Tenslotte zij er op gewezen, dat ook de Duitse Verwalter van de N.V. Stoomspinnerijen en - weverijen v/h S. J. Spanjaard te Borne, van mening was, het N.A.F.-plan nog enige tijd te moeten opschuiven 70 ).

\section{De Bedrijfs-appèls}

In 1942 stelde het gelijkgeschakelde N.V.V. en later het N.A.F. zich o.a. als taak, in de fabrieken, werkplaatsen en kantoren zogenaamde bedrijfs-appèls te houden, waar de doelstellingen van genoemde organisatie nader uiteengezet zouden worden.

Uit het beperkte schriftelijke materiaal, dat ons ten dienste stond, bleek reeds, dat de directies niet - of niet gaarne - bereid waren, toestemming voor deze bedrijfs-appèls in hun fabrieken te geven 71). Daarbij werd in verschillende gevallen door hen niet verzuimd, het N.A.F. er op te wijzen, dat ook de arbeiders een dergelijk bedrijfs-appèl niet op prijs stelden. Daar, waar het het N.A.F. toch gelukte een bedrijfs-appèl te doen plaats vinden, liep dit in de meeste gevallen op een grote mislukking uit. Als voorbeeld gelde het mislukte bedrijfs-appèl bij de Machinefabriek Gebr. Stork \& Co. N.V. te Hengelo, op Woensdag 8 April 1942.

Ondanks besprekingen en uitvoerige correspondentie met de Rüstungsinspektion en de leider van het Provinciaal Bureau van het N.V.V. 72), waarin de directie van Stork bovengenoemde instanties ten sterkste het houden van een bedrijfs-appèl ontried, werd tot een dergelijke bijeenkomst besloten. Op bevel der Duitsers moest een werkplaats ontruimd worden. Deze werd door hen versierd. In de besprekingen met de directie hadden de leden van de fabriekskern er op gewezen, dat zij ,ervoor zouden zorgen" 73), dat geen arbeiders kwamen. Daar de kern echter wist, dat dit voor de directie ,een lastige zaak" 74) was, stelde zij haar voor, zelf met de betrokken instanties te spreken. Op 7 April 1942, de dag vóór het bedrijfs-appèl dus, vond een bespreking plaats tussen F. G. Stork, Ir C. Beets (secretaris van de directie), het voltallig kernbestuur, alsmede de N.V.V. functionaris Hoegen Dijkhof en de Duitser Allmann (vertegenwoordiger van de Beauftragte voor de provincie Overijssel, Schröder) ${ }^{75}$ ). In deze vergadering merkte Hoegen Dijk-

69) Zie: Bijlage 19.

70) Zie: Bijlage 20.

71) Zie hiervoor 9 rapporten van N.A.F.-functionarissen, uitgebracht aan het Provinciale Bureau N.A.F. te Zwolle. Bijlagen $21 \mathrm{t} / \mathrm{m} 29$.

72) Zie daaromtrent uitvoeriger een dossier van de Machinefabriek Gebr. Stork \& Co. N.V. te Hengelo, speciaal betrekking hebbend op het bedrijfs-appèl van 8 April 1942. Bijlagen $30 \mathrm{t} / \mathrm{m} 47$.

73) Zie: Verslag No. XXIII, blz. 7.

74) Zie: 73), blz. 8.

75) $\mathrm{Zie}$ : „Rede van de heer $\mathrm{Dijkhof}$, uitgesproken in tegenwoordigheid van een vertegenwoordiger van de Beauftragte. de heer Schröder te Zwolle". Bijlage 41. 
hof o.a. op, dat de vrijlating van de vakverenigingsbestuurders Tabak, Van Es en Visser ten zeerste bevorderd zou worden, als het bedrijfs-appèl zou slagen. Zou dit daarentegen mislukken, dan zou de volle verantwoordelijkheid op de schouders van de vertrouwenslieden vallen. Verder wees Hoegen Dijkhof er $o p$, dat in het geval het bedrijfs-appèl zou mislukken ,,minder aangename dingen konden gebeuren, bijv. werkloosheid onder het personeel of scherpe maatregelen tegen Directie of kernleden" 76 ). Zouden daarentegen de kernleden meewerken en zou het bedrijfs-appél slagen, dan zouden zij dezelfde rechten genieten als de directie en mede leiding mogen geven aan de fabriek. De kern antwoordde o.a., dat zij niet verwacht had, bedreigd te zullen worden. Haar standpunt was bepaald en daarover viel niet verder te spreken. $Z_{i j}$ deelde verder mede, dat alles wat besproken was aan het personeel zou worden verteld, opdat dit zich een eigen oordeel zou kunnen vormen. De kern merkte echter tenslotte op, dat het personeel ,toch niet" zou komen 77).

Op Woensdagmorgen, 8 April 1942, verschenen voor de poorten van de Machinefabriek Gebr. Stork \& Co. N.V. enige auto's, waarin o.a. gezeten waren: de Beauftragte voor Overijssel Dr Schröder (ook hij zou bij het bedrijfsappèl aanwezig zijn) en $\mathrm{H}$. J. Woudenberg. De bezoekers konden het fabrieksterrein niet betreden, daar de portier van de fabriek er niet in slaagde, het hek te openen. Daar de directie wist, dat het personeel niet zou verschijnen en zij niet de schijn op zich wilde laden, de arbeiders aan het werk te houden, had zij de machines stil gezet door de electrische stroom uit te schakelen. Daardoor kon het hek (dat electrisch werd bediend) niet geopend worden.

Nadat Woudenberg ,,voor het hek een vreselijk kabaal geschopt had en de portier beschuldigde, dat hij saboteerde" 78) liet Ir Beets (secretaris van de directie) een ander hek (dat niet electrisch bediend werd) openen. Op het moment echter, dat de bezoekers het terrein wilden betreden, kwam hun een stroom van arbeiders, in hun blauwe overalls nog gekleed, tegemoet en liep hetzelfde hek uit. Door de grote verwarring kwam van een officiële ontvangst niets terecht 79 ). Ir Beets verzuimde, Woudenberg en Van Kampen naar de directiekamer te geleiden. De vertegenwoordigers van het N.V.V. bleven afgezonderd staan.

Toen de Duitser en de N.A.F.-vertegenwoordigers tenslotte op het kantoor waren, deelde de directie mede, dat er in de voor het appèl gereedgemaakte hal, een tiental mensen en een paar NSB-ers aanwezig waren. Om deze reden adviseerde $z \mathrm{ij}$, de bijeenkomst niet te laten doorgaan. De Beauftragte Schröder wenste echter, dat de bijeenkomst toch zou plaats vinden 80 ). Aldus geschiedde. C. T. Stork leidde toen - naar het oordeel van een der N.A.F.vertegenwoordigers - de aanwezigen ,zeer onvoldoende" in, ",noemde niet

76) Zie: 75).

77) Zie: 75).

78) Zie: Verslag No. XX, blz. 10.

79) Zie enige aantekeningen over deze kwestie van een (onbekend gebleven) N.A.F.functionaris. Dit stuk werd gevonden in het N.A.F. archief. Bijlage 42.

80) Zie: 78), blz. 10 . 
de naam van het N.V.V. en was vrijwel onverstaanbaar" 81 ), In plaats van Woudenberg sprak Van Kampen. Tijdens de redevoering werd met grote bomen op de deuren gebonsd door jongens, die nog in de fabriek aanwezig waren 82 ).

In de Nieuwe Hengelose Courant van Zaterdag 11 April 1942 werd naar aanleiding van verschillende bedrijfs-appèls in Hengelo o.a. geschreven:

„Het fabriekshek bij de firma Stork ging Woensdag niet gemakkelijk open, toen daar een bedrijfsbijeenkomst zou worden gehouden op initiatief van het N.V.V. Deze geslotenheid openbaarde zich evenzeer bij verschillende werkers van dat bedrijf. En als een van de heren Stork de bedrijfssamenkomst met een kort woord opent, dan spreekt hij niet voor een hal gevuld met arbeiders."

Op Donderdag 9 April 1942 werd bij de Lonneker Apparatenfabriek "Nedalo", eveneens te Hengelo, een bedrijfs-appèl gehouden ${ }^{83}$ ). Deze bijeenkomst zou bovengenoemde krant gaarne als voorbeeld willen stellen. "Niet omdat de organisatie van dit bedrijfs-appèl voortreffelijk was en ook niet, omdat de werkers in dit bedrijf in wezen verschillen zouden met de arbeiders bij Stork." Volgens de schrijver van dit artikel: „Bedrijfs-appèls in Hengelo" was er echter een band tussen toehoorders en sprekers. Ook was er een oudere arbeider, die met veel aandacht zou hebben geluisterd: ,....zijn mond staat enigszins open en wanneer de rede is uitgesproken, komt uit $z^{\prime} n$ handen een klaterend applaus te voorschijn. Op datzelfde ogenblik kijkt hij links en rechts, wat heeft hij gedaan, hij heeft geapplaudisseerd..."

Ook werd nog dezelfde week een bedrijfs-appèl gehouden bij N.V. Hazemeyer's Fabriek van Signaalapparaten 84 ). Na een inleidend woord van de directeur Croll sprak Van Kampen zijn rede uit. „Buiten de fabriekshal bevinden zich vele arbeiders..." Onder de toehoorders bevonden zich personen "die met de rug naar de spreker" gekeerd stonden.

De belangstelling der arbeiders voor de bedrijfs-appèls nam niet toe. Men bleef weg. Dit blijkt o.a. hieruit, dat op 27 April 1943 - dus twee dagen voordat de staking uitbrak — op een bedrijfs-appèl van de firma Hardick $\mathcal{E}$ Seckel (textielbedrijf) te Enschede, alleen aanwezig waren de sociale voorman, één lid van het N.A.F., alsmede de heer Seckel zelf 85 ).

Op 28 April 1943 was op een bedrijfs appèl bij de N.V. Rigtersbleek v/h G. J. van Heek $\&$ Zonen te Enschede, van de 450 arbeiders „bijna niemand aanwezig" 86). Dezelfde dag waren bij de N.V. Textielfabriek "Holland" van de ongeveer 350 arbeiders slechts 18 mensen op het bedrijfs-appèl aanwezig. „De fabriekspoort was opengezet" (het was 's morgens half elf) „zodat de werkers zich buiten het terrein konden begeven" 87 ).

81) Zie: 79).

82) Zie: 78 ).

83) Zie: Nieuwe Hengelose Courant. Dagblad voor Centraal Twente. 11 April 1942.

84) Dit was een fabriek met Duitse directie.

85) Zie: Bijlage 48.

86) Zie: Bijlage 49.

87) Zie: Bijlage 50. 
Op de dag van de staking, 29 April 1943, waren op de N.V. Stoomweverij "Nijverheid" te Enschede van de 120 „werkers", ,ongeveer 40, w.o. ook het kantoorpersoneel, present" 88). Om 11.30 uur zou een bijeenkomst plaats vinden bij de N.V. Katoenspinnerij „Bamshoeve” te Enschede. Van de 280 man personeel waren er 7 aanwezig ${ }^{89}$ ).

's Middags om half vier werd een bedrijfs-appèl gehouden in de Confectiefabriek Fa. Gez. Borst te Enschede. „Inmiddels was het nieuws betreffende de krijgsgevangenen doorgekomen met het gevolg, dat de stemming onrustig werd" 90).

88) Zie: Bijlage 51.

89) Zie: Bijlage 52 .

90) Zie: Bijlage 53. 


\section{HOOFDSTUK III}

\section{ONTSTAAN EN UITBREIDING VAN DE STAKING}

\section{Het bekend worden van de Duitse maatregel}

Donderdagmorgen 29 April 1943 ongeveer 9 uur werd de Drukkerij H. L. Smit \& Zn. te Hengelo opgebeld door de N.V. Drukkerij en Uitgeverij v/h M. J. van der Loeff te Enschede. Medegedeeld werd, dat via de telex een bericht was binnengekomen, dat in de loop van de dag een persbericht zou verschijnen, betrekking hebbend op de terugvoering van Nederlandse militairen in Duitse krijgsgevangenschap.

Nadat dit telex-voorbericht bij beide drukkerijen bekend was, werden door het aldaar werkzame personeel verschillende personen op de hoogte gesteld 91), die op hun beurt weer voor verdere bekendmaking zorgden. Niet alleen in Hengelo waren versschillenden reeds vóór de aanvang van de middag-werktijd van een en ander in kennis gesteld 92 ), maar ook in Enschede was het velen bekend. Zo werd de hoofdredacteur van het Twentsch Nieuwsblad, J. J. Beunder, gedurende de middagpauze door verschillende mensen opgebeld, die informeerden, of het bericht inderdaad waar was ${ }^{93}$ ).

De berichten, die langs bovengenoemde kanalen de mensen bereikten, hadden tot op zekere hoogte nog steeds het karakter van een gerucht. Omstreeks 12 uur kwam pas uit Enschede telefonisch het officiële bericht bij de drukkerij Smit te Hengelo binnen. Direct werd daar begonnen met het opmaken van vier met grote blauwe letters geschreven bulletins. Deze werden voor de ramen van de drukkerij aangebracht. Daar men van plan was, de vier bulletins tegelijk op te hangen en daar verder het werk nog al enige tijd in beslag nam, was het intussen 7 minuten voor half twee geworden 94 ).

Vele arbeiders, die in de middagpauze naar huis waren gegaan, konden daardoor op weg naar het werk nog juist lezen, dat de leden van het voormalige Nederlandse leger terstond opnieuw in krijgsgevangenschap weggevoerd zouden worden ${ }^{55}$ ). De drukkerij H. L. Smit $\mathcal{E} \mathrm{Zn}$., die vrijwel midden in

91) Zie: a. Verslag No. CXX, blz. 1.

b. Brief van de heer A. J. P. Hengelo, 15 April 1947. Bijlage 54.

c. Brief van de heer J. H. te Hengelo aan "Oorlogsdocumentatie". 22 Augustus 1947. Bijlage 55.

92) Zie: Verslag No. XXXI, blz. 1.

93) Zie: 91 a), blz. 1 .

94) „Dat weet $\mathrm{ik}$ nog precies. Het was 7 minuten voor half twee. Ik stond er n.l. op, dat het bulletin opgehangen zou zijn, voordat de arbeiders de fabrieken in gingen". Aldus de directeur, J. J. Smit. Zie Verslag No. LIII, blz. 2.

95) Zie: Bijlage 56. 
de stad Hengelo en slechts enkele tientallen meters van de hoofdverkeersweg (de Enschedesestraat) verwijderd ligt, was in korte tijd het punt, waar een grote mensenmenigte was samengestroomd. „De commentaren, die door de omstanders geleverd werden, waren niet vleiend, doch ook niet opgewonden" 96 ). Wel hoorde men reeds uitroepen als: ,....we gooien 't spul erbij neer" 97).

Door deze samenloop van omstandigheden was reeds bij de aanvang van het werk in verschillende fabrieken in Hengelo het bericht bekend geworden. Direct werd de Duitse maatregel besproken. Voor het grootste deel der arbeiders en kantoorbedienden was het bericht nieuw. Teneinde zekerheid te hebben werden daarom uit verschillende fabrieken, arbeiders - zelfs personen van verschillende afdelingen van één fabriek - naar de drukkerij Smit gestuurd, om te controleren, in hoeverre het gerucht op waarheid berustte. Zodra deze fabrieksarbeiders (loopjongens e.a.) het bulletin gelezen hadden, liepen zij op een holletje naar de fabriek terug, ,en inderdaad, een ogenblik later hoorde men, dat "Stork" en ,Dikkers" er uit liepen" 98 ).

\section{Het uitbreken van de staking bij Stork}

Ofschoon na de schafttijd de machines in de werkplaatsen van deze fabriek weer aangezet werden, werd op verschillende afdelingen het werk niet hervat. In de grote "stelplaats" bijv. (dit is de afdeling, waar Seyss-Inquart op $20 \mathrm{Mei} 1943$ een rede zou houden naar aanleiding van deze staking) draaiden de machines, maar stonden de arbeiders met elkaar te beraadslagen. $Z_{i j}$ overwogen, wat gedaan moest worden 99). In die werkplaatsen, waar blijkbaar meerderen van de juistheid van het bericht overtuigd waren, verliet men na enige tijd de afdeling; er vormden zich groepjes van beraadslagende arbeiders in de fabrieksstraat 100 ). In andere afdelingen werd het werk eerst wel hervat, maar werden diegenen, die voor de terugvoering in Duitse krijgsgevangenschap in aanmerking kwamen, van het bericht op de hoogte gebracht en werd hun de vrijheid gelaten, te verdwijnen of vacantie te nemen ${ }^{101}$ ). Ook werden in geval men niet van de juistheid van het bericht overtuigd was, mensen naar de drukkerij Smit gezonden, om bij terugkeer mededeling te doen aan het achtergebleven personeel 102). Eén der kernleden, die zich ook op de hoogte

96) Zie: Verslag: No. XLIX, blz. 1.

97) Zie: Verslag No. XVIII, blz. 7.

88) Zie: a. Verslag No. LIII, blz. 2 .

b. „Van alle kanten kwamen er mensen aanlopen, met de jas over de arm en nog in overall; hieruit begreep $\mathrm{ik}$, dat ze zo de fabriek uitgelopen waren......" Zie brief van C. H. K., Hengelo, 25 April 1947. Bijlage 57.

99) Zie: Verslag No. XIII, bjz. 5.

100) Zie: Verslag No. XXVII, blz. 1 en 3.

101) Zie: Verslag No. XXVIII, blz. 1 en 2.

102) "Om 2 uur is van onze afdeling (Voorbereidingsbureau van de ketelmakerij) een loopjongen de stad in gestuurd om te kijken of het bericht juist was. Toen hij terugkwam en het gerucht bevestigde, zeide hij ook, dat het in de fabrieksstraat al rumoerig was." Zie: 101), blz. 2. 
was gaan stellen, keerde echter in de belangrijke afdelingen ,gieterij" en "drijfwerk" terug, die reeds verlaten waren 103 ).

Dit alles speelde zich nauwelijks drie kwartier na de schafttijd af. Het gehele personeel was in gisting. Doordat velen niet precies wisten, wat in andere fabrieken gaande was, steeg de spanning en vormden zich allerlei geruchten. Reeds voordat de staking bij de Machinefabriek Gebr. Stork \& Co. N.V. een feit was, werd verteld, dat het Spoorwegpersoneel in staking was gegaan 104).

Tussen twee uur en kwart over twee hadden reeds kleine groepjes arbeiders de fabriek verlaten 105). De honderden, die de fabriek nog bevolkten, waren - hoewel niet aan het werk - in de werkplaatsen of stonden in de fabrieks straat te praten. Het was ongeveer half drie, toen de grote groepen arbeiders het bedrijf verlieten.

Omstreeks deze tijd ging de heer $\mathrm{T} j$. Roorda - een chef, wiens functie o.a. meebracht, dat hij regelmatig verschillende afdelingen van de Machinefabriek bezocht - op de fiets van zijn afdeling naar een ander deel van de fabriek. $\mathrm{Hij}_{\mathrm{ij}}$ ontmoette iemand, die hem het bericht betreffende de terugvoering der militairen vertelde.

„Meteen" - aldus de heer Roorda 106) _ ,flitste door mijn gedachten: ,Ja, maar nù moet het gebeuren.' Ik ging naar de afdeling Engeland, waar ik baas Eertink sprak en hem het nieuws mededeelde. Daarna ging ik naar de gieterij en kwam in de fabrieksstraat de heer $\mathrm{C}$. Woerlee tegen, die ook al probeerde het zaakje aan de gang te krijgen. Ik fietste door naar de gieterij, waar ik Scholten (in 1943 lid van de fabriekskern Noot van de auteur) sprak. Ik vertelde hem, wat er stond te gebeuren en zei: ,Denk er aan, dat je het zaakje opruit'."

„Van de gieterij ging ik naar de afdeling ,drijfwerk’. Daar was Boot ook al bezig. Ik zei tegen hem: ,Goed zo, zie dat het je lukt'. En het lukte. De mensen gingen naar de wasinrichting."

„Onderweg zag ik nog mensen, die in het kantoor der gieterij stonden te praten. Ik viel ineens uit: ,Weten jullie nu nòg niet, wat jullie moeten doen?' Heeroma kwam bij mij en zei: ,Wij hebben het op de gieterij aan de gang'. Samen gingen wij naar Scholten en deze verzekerde ons, dat het op de gieterij ook in orde kwam. Ondertussen verlieten meerderen het werk. Het eerst gingen dus de arbeiders van het drijfwerk weg (die waren al buiten de poort), daarna de arbeiders van de gieterij. De ,Modelmakerij' volgde. In de grote fabriek was het gerucht intussen ook al doorgedrongen. Toen pas trokken de grote groepen de poort uit."

103) Zie: Verslag No. XXIV, blz. 1.

104) Zie: a. Verslag No. XXVI, blz. 1.

b. Zie daarentegen ook: Verslag No. XX, blz. 1.

„Dadelijk ná het uitbreken van de staking werd gezegd, dat ook de Spoorwegen staakten. Ik ben toen naar het station gegaan om er naar te informeren, maar niemand wist mij iets definitiefs te zeggen." Aldus Ir. C. Beets, secretaris van de directie van de N.V. Machinefabriek Gebr. Stork \& Co.

105) "Ik" - aldus de loonadministrateur - ,kwam om kwart over twee met de kar met geldkisten (die dag moest loon uitbetaald worden - Oorlogsdocumentatie) aan de hoofdpoort van de fabriek. Toen stonden er reeds mensen buiten." Zie: Verslag No. XXXI, blz. 1.

106) Zie: Verslag No. II, blz. 9 en 10. 
Omstreeks half drie, kwart voor drie was de staking bij Stork in volle gang. Wel waren er nog arbeiders die, voordat $z i j$ in staking gingen, hun loon haalden, maar blijkbaar was de spanning zo groot 107 ), dat velen zonder loon de fabriek verlieten. Vrijwel het gehele personeel was - zonder dat de verschillende afdelingen elkaar bewust in staking hadden meegezogen - in staking gegaan 108). Alleen de bewakingsdienst, de luchtbeschermingsdienst, het secretariaat en enkele hoofdbeambten bleven achter 109). Op het moment dat het personeel bezig was de fabriek te verlaten, kwamen nog enige chefs en bazen bij de directeur. Averès (die vanuit zijn kantoor de fabriek zag leegstromen) om orders en raad. Averès gaf de aanwijzing niets te doen en ieder volgens eigen inzicht te laten handelen 110 ).

\section{De uitbreiding der staking in Hengelo}

Het bericht betreffende de terugvoering der krijgsgevangenen naar Duitsland was in zeer korte tijd in Hengelo bekend. In de andere Hengelose bedrijven werd dan ook eveneens kort na de schafttijd over de Duitse maatregel gesproken.

Bij G. Dikkers \& Co. N.V., een metaalbedrijf, dat aan de Storkfabrieken grenst, liep men ook „van de banken weg”, toen het gerucht doordrong 111). Verschillende afdelingen zochten contact met elkaar. Het personeel verliet de werkplaatsen en stroomde op de binnenplaats bijeen. Toen de reeds in staking zijnde arbeiders van Stork voor de poort van Dikkers kwamen, liep ook het personeel van dit bedrijf er direct uit 112). Eén der personeelsleden was vóór die tijd echter reeds ",naar Stork gegaan (achterom)" 113 ). Toen hij op zijn afdeling terugkwam, was er reeds niemand meer.

Spoedig na het in staking gaan van de Stork-arbeiders, volgde het personeel van de Koninklijke Nederlandse Katoenspinnerij N.V. Dit bedrijf ligt in de onmiddellijke nabijheid van de machinefabriek Stork. Stakende arbeiders van Stork riepen naar de spinners, die voor het raam naar het ongewoon-drukkeschouwspel stonden te kijken 114). Toen men hoorde, dat er gestaakt werd, legde men het werk neer en verliet de fabriek vrijwel zonder dat de verschillende afdelingen elkaar waarschuwden. Eigenlijk liepen de afdelingen op het gerucht, dat Stork staakte, direct weg. Wel gebeurde het, dat arbeiders

107) Zie: a. Verslag No. XVII, blz. 3 en 4.

b. Tekenend is ook, dat er arbeiders waren, die gereedschap wilden meenemen om spoorrails op te breken. Zie eveneens Verslag No. XVII, blz. 3.

108) „Op weg naar huis...... kwam ik mensen tegen, die in andere delen van de fabriek van Stork werkten. Ook deze waren dus al in staking gegaan. Het lijkt mij, dat de verschillende afdelingen onafhankelijk van elkaar in staking zijn gegaan." Zie: Verslag No. XXVI, blz. 1 .

109) Zie: Verslag No. XX, blz. 3.

110) Zie: 109), blz. 2.

111) Zie: Verslag No. XXXV, blz. 2.

112) De arbeiders van Stork vertelden, dat zij in staking waren gegaan ,en dat ook de spoorwegen gingen staken". Zie: Brief van A. W., Hengelo. 25-4-'46.

113) Zie 111), blz. 2.

114) Zie: Verslag No. LI, blz. 3. 
en arbeidsters door verschillende afdelingen moesten om uitgang of kleedkamers te bereiken, maar een voorafgaand onderling contact van het gehele bedrijfspersoneel over de vraag of men wel of niet gezamenlijk in staking zou gaan, vond niet plaats.

Diezelfde middag brak de staking uit bij de Kant- en kousenfabriek De Jong \& Van Dam N.V. Ook in deze fabriek ging reeds bij het wisselen der ploegen (ca. 2 uur) het gerucht, dat de krijgsgevangenen weggevoerd zouden worden 115). Het bericht, dat de arbeiders van Stork in staking waren gegaan, was de druppel die de emmer deed overlopen. Een vrouwelijk personeelslid ging naar de verschillende lokalen en vertelde, dat een staking uitgebroken was 116). Er werd door het personeel over gepraat en ,zo gauw een bepaalde afdeling het nieuws hoorde, liepen de mensen eruit" 117).

Aan de fabrieken van de Koninklijke Nederlandse Zoutindustrie (die buiten het bebouwde gedeelte van de stad Hengelo gelegen zijn) brak de staking iets later uit dan in de bovengenoemde fabrieken. Op zeker moment - ongeveer half vier - stonden wat mensen ,die heel zenuwachtig deden"118) op het fabrieksterrein. Toen de directie informeerde, bleek, dat opgeroepen werd om in staking te gaan. Volgens verklaringen van arbeiders uit deze fabriek schijnt het bericht, dat bij Stork gestaakt werd. de fabriek te zijn binnengebracht door iemand, die werkzaam was bij Van Gend \& Loos. In tegenstelling tot andere bedrijven kon een deel van het personeel van de Kon. Nederl. Zoutindustrie de fabriek pas verlaten, nadat voorzorgsmaatregelen genomen waren. Zo kon b.v. de stroom niet direct afgezet worden, maar alleen langzamerhand geminderd. Ook gassen, o.a. chloorgas, moesten, voordat men vertrekken zou, afgevoerd worden naar compressors 119). Zodoende waren er nog afdelingen aan het werk, toen de meeste mensen al weg waren 120 ). Diegenen, die zonder nadeel voor het bedrijf direct konden vertrekken, gingen ogenblikkelijk in staking ${ }^{121}$ ).

Van een poging der reeds in staking zijnde arbeiders, het kantoor - en bedrijfspersoneel van het Twents Centraal Station voor Electrische Stroomlevering N.V. in de staking te betrekken, is niets gebleken. Zo kwamen bijv.

115) Zie: Verslag No. XLVI, blz. 2.

116) Zie: Verslag No. XLVII, blz. 1.

117) Zie: 116), blz. 3.

118) Zie: Verslag No. XLIX, blz. 1.

119) „Alle bedrijfsafdelingen hangen hier nauw samen en de mensen hebben zelf overleg gepleegd en keurig volgens de regels alles stil gelegd en voorzorgen genomen, om later weer in bedrijf te kunnen gaan." Aldus Prof. Ir. J. G. Hoogland. Zie: 118), blz. 2.

120) Zie: 118), blz. 7.

121) "Op zeker moment kwam er iemand bij ons, di e he el ve r w on de r d (spatiëring van de auteur) vroeg, of wij nog werkten. Toen wij gingen kijken, zagen wij, dat de mensen bij elkaar stonden, ofschoon het werk nog niet was stilgelegd. Wij hebben het hele zaakje zo laten staan." Aldus de heer L. van Lier, voorman magnesium-afdeling. Zie: Verslag No. XLIX, blz. 8. Hieruit blijkt dus, dat men in deze afdeling, waar het personeel zonder enig nadeel voor het bedrijf direct vertrekken kon, het werk neerlegde. Ditzelfde verschijnsel vindt men, behoudens enkele uitzonderingen, terug in de metaal- en textielfabrieken. 
aan het kantoor van het Twents Centraal Station berichten binnen van publiek, dat daar voor een of andere aangelegenheid moest zijn. Toen de personeelchef, die op zijn fiets stapte om te zien wat er van de geruchten waar was, in de stad was gekomen ,kwam al volk uit de fabriek van Stork" 122). Na overleg van de personeelchef met de directie werd het besluit genomen, dat in staking kon worden gegaan, mits het personeel, direct bij de stroomopwekking betrokken, aan het werk zou blijven ${ }^{123}$ ). Aan de mensen van de buitendienst kon dit besluit niet meer worden medegedeeld, maar deze waren reeds in staking gegaan. Het personeel van de electrische centrale hoorde van de staking via het electriciteitskantoor. De bankwerkers en sjouwers legden het werk neer ${ }^{124}$ ).

Dezelfde middag gingen de arbeiders van de N.V. Heemaf eveneens in staking. Toen het bericht betreffende de terugvoering der krijgsgevangenen in deze fabriek bekend werd, ,, is er wel een beetje ,geslabakt" 125). Er werd pas niet meer gewerkt, toen bekend werd, dat het personeel van Stork in staking was gegaan. Vele arbeiders gingen naar een der kernleden 126) en vroegen, wat gedaan moest worden. Intussen stelde de werkmeester met enige andere kernleden de directeur van deze fabriek, Ir H. I. Keus, ervan op de hoogte, ,dat men in de fabriek opgewonden was naar aanleiding van de bekendmaking ... en nu het werk wilde neerleggen" 127 ). De directie deelde deze personen mede, dat zij reeds van de Duitse bekendmaking had ge hoord en de Rüstungsinspektion in Baarn had opgebeld om nadere inlichtingen te verkrijgen 128). Uit dit gesprek was echter gebleken, dat men in Baarn geen nadere inlichtingen kon geven; men zou — zo werd gezegd - informeren en de Heemaf nader berichten. De directie gaf de werkmeester en de kernleden daarom in overweging op deze berichten te wachten. Toen echter geen andere mededelingen van de Rüstungsinspektion kwamen en de directie er niet in slaagde, met deze Duitse instantie nogmaals telefonisch contact te krijgen, besloot Ir Keus zich met een toespraak tot het personeel te wenden. Daartoe werden alle arbeiders in de hal bijeengeroepen. Geluidversterkers werden aangebracht.

In zijn rede zette Ir Keus uiteen, dat hij pogingen in het werk had gesteld, zich met de betreffende instanties in verbinding te stellen, doch dat de telefoon, blijkbaar doordat ook anderen op inlichtingen aandrongen, bij herhaling gestoord werd. Hij zeide verder, dat hij zijn pogingen zou voortzetten, „wanneer $\mathrm{U}$ ons daarin steunt door normaal aan het werk te blijven." Tijdens

122) Zie: Verslag No. LVII, blz. 1.

123) Zie: 122), blz. 2.

124) Zie: Verslag No. LVIII, blz. 1 en 2.

125) Zie: Verslag No. XLIII, blz. 1.

126) "Ik geloof, dat ik wel 100 mensen om mij heen had staan." Aldus het kernlid, J. C. Geers. Zie: 125), blz. 2.

127) Zie: Verslag No. XLII, blz. 1.

128) Enige weken tevoren was aan de directie van de N.V. Heemaf toegezegd, dat van dit bedrijf geen personeel naar Duitsland gezonden zou worden. 
het overleg leek het Ir Keus aller belang te zijn, ,de werkzaamheden niet te onderbreken, ook niet, omdat de consequenties, waarover $U$ nog niet hebt nagedacht, hier voor allen zoveel ernstiger kunnen zijn dan gij wellicht nu nog vermoedt" ... ,Wij geven toe" — aldus Ir Keus — ,dat het gemakkelijker is, anderen na te volgen dan er een eigen houding op na te houden, maar wij menen $U$ dit advies uit onze volle en eerlijke overtuiging niet te mogen onthouden." Nadat het personeel medegedeeld was, dat de directie gaarne bereid was, eventueel binnenkomende berichten via de kern te verspreiden, besloot Ir Keus zijn toespraak met de woorden: „Ik verzoek $U$ nu, aan het werk te gaan, want de toestand, zoals die thans is, kunnen wij al niet verantwoorden" 129 ).

Ondanks het advies van Ir Keus besloot het personeel, het werk niet te hervatten en zich bij de andere stakers aan te sluiten.

Voor zover het de grote bedrijven in Hengelo betreft, was er slechts één fabriek, waar op Donderdagmiddag niet werd gestaakt.

N.V. Hazemeyer's Fabriek van Signaal-apparaten had een Duitse directie, terwijl van het 1179 man sterke personeel, 129 Duitsers, 59 NSB-ers en 11 personen van andere dan Nederlandse nationaliteit waren. Toen Donderdag om plm. 14 uur mensen in deze fabriek kwamen met de mededeling, dat de militairen naar Duitsland teruggevoerd zouden worden, maakte dit op allen een grote indruk. Sommige oud-militairen gingen direct naar hun baas en vroegen een verlof-briefje, teneinde de fabriek te mogen verlaten. Toen ca. 20 mensen buiten de poort stonden, werd er echter een "Wachtsmann" voor geplaatst. Een chef van de "Abnahmeraum" zeide in een toespraak, dat de Duitse maatregel niet voor het personeel van Hazemeyer's Fabriek van Signaal apparaten gold. Niemand mocht de fabriek verlaten. Gewerkt werd er vanaf dit moment echter niet meer ${ }^{130}$ ).

Bovengenoemde Duitse fabriek is wel te onderscheiden van de N.V. Fabriek voor Electrische Apparaten v/h F. Hazemeyer \& Co. Dit bedrijf had enkele gebouwen aan de Duitse Signaal-apparatenfabriek verhuurd. Beide fabrieken stonden wel op één terrein, maar waren zowel technisch als commercieel gescheiden. Het personeel van de Nederlandse fabriek legde Donderdagmiddag het werk neer naar aanleiding van een bericht, dat Stork in staking was gegaan 131 ).

In de kleinere Duitse fabriek "Nedalo" 132) werd door enkelen van het Nederlandse personeel reeds op Donderdagmiddag gestaakt.

129) Zie: a. „Mededeling aan het personeel in de grote hal op Donderdag, 29 April 1943. om half vier." Bijlage 58.

b. "Ik" — aldus Ir Keus — "had geen verwachting, dat men na de toespraak weer aan de gang zou willen gaan, maar voelde mij toch verplicht, de mensen op het gewicht van hun besluit te wijzen." Zie: Verslag No. XLII, blz. 2.

130) Zie: Verslag No. XLI, blz. 10.

131) Zie: Verslag No, XXXVI, blz. 1.

132) De N.V. Nederlandse Apparatenfabriek „Lonneker" (bekend als "Nedalo") behoorde tot het Siemens-Concern en stond als zodanig geheel onder Duitse leiding. Directie en hoger technisch personeel waren Duits of Duits georiënteerd. Zie: Vragenlijst No. 158. 
Verder breidde de staking zich nog uit over een aantal kleinere bedrijven, die hier buiten bespreking worden gelaten ${ }^{133}$ ).

Deze Donderdagmiddag ging ook vrijwel het gehele Gemeente personeel in staking. Zo bijv. het personeel van de Gemeente-secretarie 134), de Distributiedienst 135), de Gemeentewerken en -bedrijven 136), de Gemeentelijke Dienst voor Sociale Zaken 137) enz. Zelfs de schoolarts met de schoolverpleegster legden die middag het bijltje erbij neer ${ }^{138}$ ).

Een belangrijke rol in de uitbreiding van de staking speelde het personeel van het Telefoondistrict Hengelo. Gesprekken voor Stork werden aanvankelijk doorgegeven, totdat door de telefoniste van Stork gezegd werd, dat zij de gesprekken niet meer kon aannemen, daar het personeel wegliep 139). Dit bericht werd dan weer door de telefoniste van het Hoofdkantoor aan de abonné doorgegeven. Verder werden door het personeel van het telefoonkantoor Hengelo andere telefoonkantoren in het land van de staking bij Stork op de hoogte gesteld ${ }^{440}$ ). Ook werden door de telefonisten, die aan ,,inlichtingen" zaten, geen gesprekken meer aangenomen. Men ,hiet alle lampen vallen"141). De staking aan dit telefoonkantoor kon echter niet tot ontplooiing komen, daar het personeel zich door de directeur, Verwey de Winter, liet bewegen aan het werk te blijven ${ }^{142}$ ).

Het uitbreken van de staking bij Stork had - zoals uit het voorgaande reeds blijkt - een volkomen spontaan karakter. Hiermede wordt in dit verband bedoeld, dat deze fabrieksarbeiders in zeer korte tijd zonder enige aansporing van een buiten de werkgemeenschap staande organisatie of niet-georganiseerde groep van personen, noch door middel van pamfletten, noch mondeling daartoe opgewekt, op de aangekondigde maatregel vrijwel gelijkelijk reageerden door het stilleggen van de arbeid. Deze wijze van uitbreken der staking bepaalde tegelijkertijd de wijze van uitbreiding. Doordat van een strijd - bijv, met de directie - voor het doorzetten der staking geen sprake was, had zich in het bedrijf geen a.h.w. tot één lichaam georganiseerde stakingsmacht gevormd. De arbeiders en kantoorbedienden gingen naar huis, zonder dat de verschil

133) Zie: Vragenlijsten Nos. 156, 157, 159, 161, 162, 163.

134) Zie: Vragenlijst No. 143.

135) Zie: Vragenlijst No. 146.

136) Zie: Vragenlijst No. 144.

137) Zie: Vragenlijst No. 147.

138) Zie: Vragenlijst No. 149.

139) Zie: Verslag No. LVI, biz. 1.

140) ,De post waaraan je zat, daar gaf je het aan door. Zo kwam het bericht in Amsterdam. Leeuwarden en Den Bosch." Zie: 139), blz. 2.

141) "Ik zat die middag aan ",inlichtingen". Op ons bord brandden bijv. 12 lampen; dit betekent, dat 12 abonné's wilden spreken, maar wij ,lieten al die lampen vallen' en hebben geen gesprekken meer aangenomen." .......,Een meisje, dat tegenover mij zat en nogal ,fel' was, liet ook alle lampen wegvallen'." Zie: 139), blz. 2.

142) Zie: Brief van de directeur, Verwey de Winter, aan de Directeur-Generaal der P.T.T. Den Haag. Hengelo, 30 April 1943. Bijlage 59. 
lende afdelingen van deze éne fabriek afdelingsgewijs met elkaar in contact waren getreden. Ook van een systematische uitbreiding der staking, van een bewust opgezette poging der Stork-arbeiders zelf om andere bedrijven in deze beweging te betrekken, is weinig terug te vinden. Dit sluit niet uit, dat er getracht is, andere arbeiders in de staking te betrekken. Maar dat had meer een individueel karakter of werd gedaan door een kleine groep personen ${ }^{143}$ ). Zo ging men o.a. naar het personeel van de locomotievenloods in Hengelo. Wel waren er machinisten, die bereid waren, zich met de daad solidair te verklaren, maar zij wensten eerst inlichtingen uit andere plaatsen ${ }^{144}$ ).

Ondanks het ontbreken van een bewust, dus georganiseerd opgezette poging, de staking over andere bedrijven uit te breiden, is uit het voorgaande gebleken, dat in een zeer korte tijd bijna alle bedrijfspersonelen in Hengelo het werk verlaten hadden. De oorzaak is te zoeken in het feit, dat tussen de fabrieken zeer druk getelefoneerd werd - waarbij de functie van het telefoonkantoor niet onderschat mag worden - en in de omstandigheid, dat de belangrijkste fabrieken, zoals de Koninklijke Nederlandse Katoenspinnerij, G. Dikkers \& Co. N.V. en de - na de staking door bombardementen bijna geheel verdwenen - Koninklijke Weefgoederenfabriek, in de onmiddellijke nabijheid van de Machinefabriek Gebr. Stork \& Co. N.V. gelegen waren.

Toen de arbeiders van Stork de werkplaatsen om ca. half drie-kwart voor drie verlieten, was het ten enenmale onvermijdelijk, dat de personelen der aangrenzende bedrijven de in staking zijnde Stork-arbeiders zagen. Zo trokken bijv. arbeiders van Stork langs de poort bij Dikkers. Vanuit de werkzalen der Koninklijke Nederlandse Katoenspinnerij zag het personeel, dat de fabrieken van Stork werden verlaten. Gezien de grote spanning, die er heerste, behoefden blijkbaar de personelen der aangrenzende bedrijven slechts het voorbeeld te zien, om ook het werk neer te leggen. En toen ook déze massa van fabrieksarbeiders eenmaal op straat was, kon reeds voor Hengelo vrijwel van een algemene staking gesproken worden. Onder die omstandigheden waren ook de arbeiders van de N.V. Heemaf niet meer te houden.

Zo werd zonder enige bijzondere actie der arbeiders in vrijwel één tot anderhalf uur de staking in Hengelo een feit.

Belangrijk en in het bijzonder te vermelden is wel, dat $\mathrm{Tj}$. Roorda, werkzaam bij de N.V. Stork, na overleg met één zijner directeuren, Averès, dezelffe

143) a. Deze (onze) ervaring geldt voor vrijwel geheel. Twente. Dit is dus geheel in tegenstelling tot de tactiek der Amsterdamse Februaristakers, die in grote colonnes demonstratief door de stad trokken en nog werkende arbeiders, door hun enthousiasme en gezamenlijk optrekken, a.h.w. de werkplaatsen uit-trokken.

b. "Op weg naar huis kwam ik langs de Heemaf en zag enige mensen fabrieksafval laden. I $k$ stapte van mijn fiets af en vroeg: "Hebben jullie nog niets gehoord?'." Aldus J. Roesink, werkzaam bij de N.V. Stork. Zie: Verslag No. XXIX, blz. 1.

c. Naar aanleiding van een vraag aan Mr. H. J. F. ten Cate, of hij bij het uitbreken der staking colonnes stakers zag, die van de ene fabriek naar de andere trokken, antwoordde deze: "Niets daarvan, helemaal niets. Het was de simpelheid zelf." Zie: Verslag No. XI, blz. 1.

144) Zie: Verslag No. XXIV, blz. 2. 
avond nog naar Amsterdam ging. Hij wilde trachten, de staking naar het Westen van het land te doen overslaan ${ }^{145}$ ).

\section{De uitbreiding der staking over geheel Twente}

In het algemeen zijn twee belangrijke factoren aan te wijzen, die de snelle wijze bepaalden waarop de staking zich vanuit Hengelo over andere plaatsen in Twente uitbreidde.

In de eerste plaats was de telefoon ook voor deze gelegenheid een machtig communicatie-middel. Zo werd bijv. de telefooncentrale van $V$ an Heek \& Co. $N . V$. te Enschede opgebeld door het telefoonkantoor te Hengelo ${ }^{146}$ ). Het bericht luidde: „Hengelo staakt, staakt U ook?" Direct daarop werd de verbinding verbroken.

„Een stakingspsychose" 147 ) werd a.h.w. veroorzaakt door personeel van de Drukkerij en Litgeverij v/h M. J. van der Loeff te Enschede, dat - toen om half drie geruchten gingen, dat in Hengelo werd gestaakt - „zeker dertig zaken" opbelde 148).

Naarmate meer bekend werd, dat een staking in Hengelo en ook in Enschede uitgebroken was, belden de bedrijven elkaar voortdurend op ${ }^{149}$ ).

In Almelo werd de telefoniste van Palthe's Textielveredelingsbedriven N.V. door de hoofdtelefoniste van Stork uit Hengelo opgebeld, dat een staking was uitgebroken. Palthe's telefoniste gaf dit weer door aan de personeelsafdeling ${ }^{150}$ ) en aan de telefoniste van Bendien's Confectiefabrieken N.V.151). De Katoenmaatschappij v/h Gebr. Scholten \& Co. te Almelo werd opgebeld door Palthe en - waarschijnlijk - door Stork 152).

Ook werden nog andere grote textielfabrieken van de staking in Hengelo en elders telefonisch op de hoogte gesteld ${ }^{153}$ ).

Dat de telefonische berichtgeving zich niet tot Enschede en Almelo beperkte, blijkt ook uit het feit, dat Donderdagmiddag omstreeks vier uur - half vijf, de Koninklijke Stoomweverij te Nijverdal N.V. vanuit Hengelo op de hoogte gesteld werd van de staking bij Stork 154). Het bericht betreffende de

145) Zie: a. Verslag No, II, blz. 10.

b. Tj. Roorda is dezelfde persoon, die reeds in April 1942 met J. B. Vlam naar het Westen was gegaan, om een staking voor te bereiden n.a.v. de dreigende

146) Zie: Verslag No. CII, blz. 2.

147) Zie: Verslag No. CXX, blz. 4.

148) „Wij vroegen alleen: ,Wordt er bij jullie al gestaakt?' Dan kregen wij ten antwoord: ,Neen, meneer.' Waarop wij weer zeiden: 'In Hengelo staakt alles en in Enschede trouwens ook.' Zij vroegen dan wel eens met wie zij spraken, maar dan legden wij de hoorn op de haak en belden het volgende bedrijf." Zie: 147), blz. 4.

149) Zie: Verslag No. CXXXVIII, blz. 1.

150) Zie: Verslag No. LXXV, blz. 1.

151) Zie: Verslag No. LXVI, blz. 1.

152) Zie: Verslag No. LXXXI, blz. 1.

153) Zie: a. Verslag No. LXXIX, blz. 1.

b. Verslag No. LXIX, blz. 2.

154) Zie: a. Verslag No. CLXVII, blz. 1.

$b$. Brief van enige personeelsleden van de Kon. Stoomweverij te Nijverdal N.V. Nijverdal, 28 Maart 1947. Bijlage 60. 
Hengelose staking werd bij de Koninklijke Oldenzaalse Stoomweverij $v / h$ J. Molkenboer Jr. in Oldenzaal bekend, doordat een personeelslid, werkzaam bij de N.V. Fabriek van Electrische Apparaten v/h F. Hazemeyer \& Co. te Hengelo, opbelde 155). Tenslotte kan er op gewezen worden, dat ook in de plattelandsgemeente Weerselo Donderdagmiddag reeds het bericht van de staking in Hengelo langs telefonische weg bekend werd 156).

Behalve door telefonische mededelingen, werd de Hengelose staking op geheel andere wijze bekend. Vele arbeiders, die in Hengelo werkten, woonden in andere plaatsen 157). Toen de staking eenmaal uitgebroken was en deze arbeiders naar hun woonplaatsen terugkeerden en aldaar het lijfelijk overtuigend bewijs gaven van de uitgebroken staking, was dit in menig geval de stoot, die ook in die plaatsen tot een staking leidde.

Zo trokken Hengelose arbeiders voorbij de fabriek van $J . F$. Scholten $\mathcal{E} Z n$. $N . V$. te Enschede en schreeuwden de arbeiders toe eveneens het werk te staken ${ }^{158}$ ). Bij de portier van $V$ an Heek \& Co. N.V. kwamen eveneens Hengelose arbeiders vertellen, waarom zij het werk hadden neergelegd 159).

In Almelo kwamen arbeiders, die in Hengelo werkten voorbij het telefoonkantoortje (dat aan de ingang van de fabriek gelegen is) van Bendien's Confectiefabrieken N.V. en riepen de telefoniste toe, dat men ,er ook uit moest gaan" 160).

Arbeiders, die in Hengelo in staking waren gegaan, doch in Goor woonden, kwamen daar om ca. 15 uur aan. Deze mensen waren het, die de staking uit Hengelo overbrachten 161 ).

Voor Markelo geldt, dat men van de staking pas iets merkte, toen arbeiders, die in Goor werkten, naar hun woonplaats in Markelo terugkeerden. Niet uitgesloten is, dat men vóór die tijd reeds telefonisch op de hoogte gesteld was 162 ).

De burgemeester van Delden vertelt, dat hij Donderdagmiddag 29 April 1943, tussen 15 en 16 uur in het gemeentehuis was en zag, dat arbeiders die in Hengelo werkten, doch in Delden woonden, met autobussen langs kwamen, roepende, dat in Hengelo een staking uitgebroken was ${ }^{163}$ ).

De gemeente-secretaris van Oldenzaal schreef in zijn dagboek op 29 April 1943: „Waar in Hengelo op enkele fabrieken het werk werd neergelegd .... komen in de namiddag groepen arbeiders in hun werkpakken, van Hengelo

155) Zie: Verslag No. CLXXXIX, blz. 1.

156) Zie: Verslag No. CCV, blz. 1.

157) Hier zij nog opgemerkt, dat ook de bureaux der dagbladen in Enschede (Zie: Verslag No. CXIX, blz. 3), Almelo (Zie: Verslag No. LXXXIII, blz. 1) en Goor (Zie: Verslag No. CLVI, blz. 1), het bericht betreffende de krijgsgevangenen bekend maakten.

158) Zie: Verslag No. CXXXIX, blz. 1.

159) Zie: Verslag No. CV, blz. 1.

160) Zie: Verslag No. LXVI, blz. 2. In deze fabriek ging men op Vrijdagmorgen in staking.

161) Zie: Verslag No. CLVI, blz. 1.

162) Zie: Verslag No. CLXXII, blz. 1.

163) "Voor mij" - aldus de burgemeester — "was het toen nog niet duidelijk, dat deze staking samenhing met de terugvoering der krijgsgevangenen." Zie: Verslag No. CLI, blz. 1. 
lopend, de stad binnen" ${ }^{164}$ ). Een afdelingsbaas van de N.V. H. P. Gelderman $\mathcal{E} \mathrm{Zn}$, eveneens te Oldenzaal, bevestigt het dagboekbericht met de woorden: „,Mijn zoon kwam terug vanuit Hengelo (hij werkte bij Stork) en vertelde, dat zij het werk hadden neergelegd. Hij was terug komen lopen" ${ }^{165}$ ).

Hoe ver de staking zich op Donderdagmiddag 29 April 1943 in Twente reeds uitgebreid had, blijkt uit de hierna volgende opgave. Deze heeft alleen betrekking op bedrijven, door het Rijksinstituut voor Oorlogsdocumentatie bezocht, d.w.z. bedrijven, waar vóór of gedurende de bezetting 250 arbeiders of meer werkten ${ }^{166}$ ).

SCHEMA I

\begin{tabular}{|c|c|c|c|c|c|}
\hline Gemeente & No. & Naam van de Fabriek & $\begin{array}{l}\text { aan- } \\
\text { tal } \\
\text { ar- } \\
\text { bei- } \\
\text { ders }\end{array}$ & $\begin{array}{c}\text { In stak } \\
\text { gegaan } \\
\begin{array}{c}\text { Donder- } \\
\text { dag }\end{array}\end{array}$ & $\mid \begin{array}{l}\text { Vrij- } \\
\text { dag }\end{array}$ \\
\hline Hengelo & $\begin{array}{l}1 . \\
2 . \\
3 . \\
4 . \\
\\
5 . \\
6 . \\
7 . \\
8 . \\
9 . \\
10 .\end{array}$ & $\begin{array}{l}\text { Machinefabriek Gebr. Stork \& Co. N.V. } \\
\text { N.V. Heemaf } \\
\text { N.V. Hazemeyer's Fabriek van Signaal- } \\
\text { apparaten } \\
\text { N.V. Fabriek van Electr. Apparaten v/h } \\
\text { F. Hazemeyer \& Co. } \\
\text { G. Dikkers \& Co. N.V. } \\
\text { De Jong \& Van Dam N.V. } \\
\text { Kon. Nederl. Katoenspinnerij N.V. } \\
\text { Kon. Weefgoederenfabriek C. T. Stork \& } \\
\text { Co. N.V. } \\
\text { Kon. Nederl. Zoutindustrie } \\
\text { Twents Centraal Station voor Electrische } \\
\text { Stroomlevering N.V. }\end{array}$ & $\begin{array}{r}3006 \\
1078 \\
1065 \\
884 \\
721 \\
312 \\
427 \\
550 \\
480 \\
150\end{array}$ & $\begin{array}{r}29 / 4 \\
29 / 4 \\
- \\
29 / 4 \\
29 / 4 \\
29 / 4 \\
29 / 4 \\
29 / 4 \\
29 / 4 \\
29 / 4\end{array}$ & $\begin{array}{l}- \\
30 / 4 \\
- \\
- \\
- \\
-\end{array}$ \\
\hline Enschede & $\begin{array}{l}11 . \\
12 . \\
13 . \\
14 . \\
15 . \\
16 . \\
17 . \\
18 . \\
19 .\end{array}$ & $\begin{array}{l}\text { Ramie-Union N.V. } \\
\text { N.V. Spinnerij "Tubantia" v/h B. W. \& } \\
\text { H. ter Kuile } \\
\text { Nico ter Kuile \& Zn. N.V. } \\
\text { Gerhard Jannink \& Zn. N.V. } \\
\text { Van Heek \& Co. N.V. } \\
\text { Gebr. van Heek } \\
\text { N.V. Boekelose Stoomblekerij } \\
\text { J. F. Scholten \& Zn. N.V. } \\
\text { N. J. Menko N.V. }\end{array}$ & $\begin{array}{r}308 \\
\\
311 \\
700 \\
500 \\
1146 \\
800 \\
167 \\
539 \\
1023\end{array}$ & $\begin{array}{l}- \\
\overline{29 / 4} \\
29 / 4 \\
29 / 4 \\
29 / 4 \\
\overline{29 / 4} \\
29 / 4{ }^{167}\end{array}$ & $\begin{array}{l}30 / 4 \\
30 / 4 \\
- \\
\overline{-} \\
\overline{30 / 4} \\
-\end{array}$ \\
\hline
\end{tabular}

164) Zie: a. Dagboek van de Gemeente-secretaris Oldenzaal. Bijlage 61.

b. „Op Donderdag, 29 April 1943 omstreeks 3 uur kwamen in Oldenzaal de arbeiders, die bij Stork in Hengelo werkten, terug. $\mathrm{Er}$ ontstonden kleine oploopjes." Aldus de agent van de gemeentepolitie te Oldenzaal, J. L. Wildeboer. Zie: Verslag No. CLXXVI, blz. 1.

165) Zie: Verslag No. CLXXX, blz. 1.

166) Hierbij hebben wij ons gebaseerd op gegevens, verstrekt door de Kamer van Koophandel te Hengelo (O).

167) De staking bij N. J. Menko N.V. brak uit op Donderdag 29 April om 18 uur bij het wisselen der ploegen. Zie: Verslag No. CXXIII, blz. 1. 
(Vervolg Schema I)

\begin{tabular}{|c|c|c|c|c|c|}
\hline Gemeente & No. & Naam van de Fabriek & $\begin{array}{l}\text { aan- } \\
\text { tal } \\
\text { ar- } \\
\text { bei- } \\
\text { ders }\end{array}$ & $\begin{array}{l}\text { In stak } \\
\text { gegaan } \\
\text { Donder- } \\
\text { dag }\end{array}$ & $\begin{array}{l}\text { ng } \\
\text { Vrij- } \\
\text { dag }\end{array}$ \\
\hline \multirow[b]{2}{*}{ Almelo } & $\begin{array}{l}20 . \\
21 . \\
22 . \\
23 . \\
24 .\end{array}$ & $\begin{array}{l}\text { Blijdenstein \& Co. N.V. } \\
\text { N.V. Katoenspinnerij ,"Bamshoeve" } \\
\text { Twentse Electrische Tramweg Mij. } \\
\text { N.V. Gebr. Jannink } \\
\text { N.V. Rigtersbleek v/h G. J. v. Heek \& Zn. }\end{array}$ & $\begin{array}{r}250 \\
365 \\
53 \\
75 \\
567\end{array}$ & $\frac{29 / 4}{2}$ & $\begin{array}{l}-\overline{30 / 4} \\
30 / 4 \\
30 / 4 \\
-\end{array}$ \\
\hline & $\begin{array}{l}25 . \\
\\
26 . \\
27 . \\
28 . \\
29 . \\
30 . \\
31 . \\
32 . \\
33 .\end{array}$ & $\begin{array}{l}\text { Tricot-, Kapok- en Verenfabriek v/h } \\
\text { Scholl, Engberts \& Scholten N.V. } \\
\text { N.V. Katoen Mij. v/h Gebr. Scholten \& Co+ } \\
\text { N.V. Leeuwarder Textiel Mij. } \\
\text { H. ten Cate Hzn. \& Co. N.V. } \\
\text { J. ten Bos } \\
\text { Bendien's Confectiefabrieken N.V. } \\
\text { N.V. Stoomspinnerij , Twenthe". } \\
\text { Palthe's Textielveredelingsbedrijven N.V. } \\
\text { N.V. Almelose Confectiefabriek v/h H. } \\
\text { Smits \& Co. }\end{array}$ & $\begin{array}{r}90 \\
266 \\
353 \\
696 \\
50 \\
1055 \\
213 \\
1019 \\
\\
455\end{array}$ & $\begin{array}{c}29 / 4 \\
29 / 4 \\
29 / 4 \\
- \\
-\overline{29 / 4} \\
-\end{array}$ & $\begin{array}{l}\overline{-} \\
30 / 4 \\
\overline{30 / 4} \\
30 / 4 \\
30 / 4 \\
- \\
30 / 4\end{array}$ \\
\hline Borne & 34. & $\begin{array}{l}\text { N.V. Stoomspinnerijen en -weverijen } \mathrm{v} / \mathrm{h} \\
\text { S. J. Spanjaard }\end{array}$ & 900 & $29 / 4$ & - \\
\hline Oldenzaal & $\begin{array}{l}35 . \\
36 .\end{array}$ & $\begin{array}{l}\text { H. P. Gelderman \& Zn. N.V. } \\
\text { N.V. Kon. Oldenzaalse Stoomweverij v/h } \\
\text { J. Molkenboer Jr. }\end{array}$ & $\begin{array}{r}803 \\
174\end{array}$ & $29 / 4$ & $\begin{array}{l}- \\
30 / 4\end{array}$ \\
\hline Rijssen & 37. & Ter Horst \& Co. N.V. & 1313 & $29 / 4$ & 一 \\
\hline Haaksbergen & 38 & N.V. D. Jordaan \& Zn. & 945 & $29 / 4$ & - \\
\hline Vriezenveen & 39 & Jansen \& Tilanus N.V. & 564 & $29 / 4$ & 一 \\
\hline Nijverdal & 40. & Kon. Stoomweverij te Nijverdal N.V. & 1150 & $29 / 4$ & - \\
\hline \multirow[t]{2}{*}{ Goor } & 41. & N.V. Eternit & 68 & $29 / 4$ & 一 \\
\hline & & Totaal aantal arbeiders & 25591 & & \\
\hline
\end{tabular}

Van de 41 grootste bedrijven in Twente, waar in totaal 25.591 personen werkzaam waren, waren op Donderdagmiddag 28 fabrieken met een personeel van 20.947 mannen en vrouwen in staking. Ofschoon dus niet in alle bedrijven werd gestaakt, werd wèl in alle plaatsen waar industrie gevestigd was afgezien van de zuivelfabrieken - het werk neergelegd 168). Indien men aanneemt, dat de werktijd der fabrieken omstreeks half zes eindigt, kan hieruit afgeleid worden, dat de staking zich in geheel Twente in ongeveer $21 / 2$ uur tijd uitgebreid heeft.

168) In Losser lag de grote fabriek van N.V. Textiel Mij L. van Heek $\mathcal{E}$ Zn. omstreeks Mei 1943 wegens grondstoffenschaarste vrijwel geheel stil. Zie: Verslag No. CLXXI, blz. 1. 
Zoals reeds opgemerkt, werkten in Hengelo vele arbeiders, die in andere plaatsen woonden. Aan de hand van enkele voorbeelden werd aangetoond, hoe deze arbeiders de staking in andere plaatsen bekend maakten, waardoor zij mede een factor vormden in het doen uitbreken der staking elders. Uit een nader onderzoek bleek echter, dat niet alleen in Hengelo, maar ook in Almelo - en in mindere mate in Enschede en Oldenzaal - deze spreiding bestond. Dit blijkt uit onderstaand schema 169). Het heeft betrekking op 8 bedrijven in Hengelo, 8 in Enschede, 7 in Almelo en 2 in Oldenzaal.

SCHEMA II

\begin{tabular}{|c|c|c|c|c|}
\hline \multicolumn{5}{|c|}{ Arbeiders } \\
\hline \multirow[b]{2}{*}{ Wonende in: } & \multicolumn{4}{|c|}{ Werkzaam te } \\
\hline & Hengelo & Enschede & Almelo & Oldenzaal \\
\hline Almelo & 239 & 4 & 2868 & - \\
\hline Borne & 434 & - & 51 & 一 \\
\hline Delden & 200 & 1 & - & - \\
\hline Denekamp & 3 & 1 & 一 & 6 \\
\hline Enschede & 896 & 4242 & 2 & 18 \\
\hline Goor & 108 & - & - & - \\
\hline Haaksbergen & 101 & 36 & - & - \\
\hline Hengelo (O.) & 4906 & 14 & - & 2 \\
\hline Hellendoorn & 5 & - & 128 & - \\
\hline Losser & 23 & 416 & - & 326 \\
\hline Markelo & 3 & - & 一 & - \\
\hline Oldenzaal & 321 & 17 & - & 588 \\
\hline Rijssen & 5 & - & 196 & 一 \\
\hline Tubbergen & - & - & 139 & - \\
\hline Vriezenveen & 4 & 18 & 216 & - \\
\hline Weerselo & 97 & 2 & $\overline{-1}$ & 35 \\
\hline Wierden & 10 & - & 228 & 一 \\
\hline
\end{tabular}

Het feit, dat zovele arbeiders uit Hengelo, Almelo en Enschede reeds vóór het einde der werktijd naar huis toe gingen, had tot gevolg, dat het in de kleinste gehuchten van Twente reeds op Donderdagmiddag bekend was, dat in de steden werd gestaakt. In de kleinere fabrieksplaatsen, zoals Vriezenveen waar het personeel van Jansen \& Tilanus N.V. ook reeds op Donderdagmiddag in staking was gegaan, had men daardoor de zekerheid, niet alleen te staan. De arbeiders, werkzaam bij Jansen $\mathcal{E}$ Tilanus N.V. konden van arbeiders, werkend in Hengelo, Enschede en Almelo vernemen, dat daar een vrijwel algemene staking uitgebroken was 170 ).

169) Bovenstaand schema is een uittreksel van een meer uitvoerig overzicht. Zie: Bijlage 62.

Aan de 36 grootste bedrijven in Twente werd gevraagd, een gedetailleerde opgave te verstrekken van de woonplaatsen van het personeel, omstreeks Mei 1943. Van 27 bedrijven werd een bruikbaar overzicht ontvangen. De andere 9 bedrijven konden de gegevens niet verstrekken, daar o.a. door zware bombardementen de administratie vernietigd was.

170) Uit schema II blijkt, dat 4 arbeiders werkzaam te Hengelo, 18 in Enschede en 216 in Almelo, in Vriezenveen woonden. 


\section{De uitbreiding der staking naar het platteland}

In het voorgaande werd aangegeven, langs welke weg de staking zich in Twente tot vrijwel alle plaatsen, waar enige industrie gevestigd was 171) (zuivelfabrieken uitgezonderd) uitbreidde. Tevens werd aangetoond, langs welke wegen de stads-, zowel als de dorpsbevolking om 17.30-18 uur van de staking op de hoogte was. Dat dit bericht toen nog niet tot de gehele plattelandsbevolking was doorgedrongen, kan - gezien de uitgestrektheid der plattelandsgemeenten - geen verwondering wekken. Verschillende boeren hadden echter reeds op Donderdagavond van het uitbreken der staking gehoord. Hierop werd door hen verschillend gereageerd.

Gebleken is bijv., dat reeds op Donderdagavond - zij het op bescheiden schaal - enig overleg tussen boeren is geweest om zich bij de staking aan te sluiten. Een landbouwer, wonende in Twekkelo, maar zijn melk afleverend aan een zuivelfabriek in Enschede 172) vertelt, dat hij op Donderdagavond met verschillende boerenjongens afgesproken had, de volgende morgen (Vrijdag 30 April) melk, die naar de fabrieken zou worden gevoerd, van de wagens te halen. In ieder geval zou men zorgen, dat de melk niet in de fabriek kwam. Zo heeft in Rijssen het personeel van de Fabriek van Melkproducten D. Eerdmans Jzn. 's avonds de melkrijders (ook boeren) gewaarschuwd, de volgende morgen geen melk aan de fabriek te leveren 173 ).

Een landbouwer, wonend in Enter, maar melk leverend aan de Rijssense zuivelfabriek, bevestigt, dat de melkrijder bij hem kwam vragen, wat de boeren zouden doen. ,Daarop werd gezegd, dat de melkrijder niet behoefde terug te komen" 174 ). Ook in Wierden hebben verschillende melkrijders van te voren afgesproken, geen melk bij de boeren op te halen. Een melkrijder uit deze omgeving vertelde, dat de melkrijders op Donderdagavond afspraken, geen melk te vervoeren 175 ).

Ook uit andere verklaringen, die echter een meer afwachtende houding der boeren typeren, blijkt, dat de melkleveranciers op Donderdagavond bekend waren met de uitgebroken staking.

Zo bijv. de boeren, wonende in de grensstreek van Vriezenveen, Almelo en Tubbergen, aan wie het bericht medegedeeld werd door ,vaste melkklanten". Vrijdagmorgen zette men de melk echter gewoon voor de melkrijder klaar 176). Ook in het buurtschap Harbrinkshoek (onder de gemeente Tubbergen) had men wel reeds op Donderdagavond van de staking gehoord, maar zette men de melk klaar ${ }^{177}$ ). In de Zuid-Westhoek van de gemeente Borne was op

171) Uit den aard der zaak zijn plaatsen als Almelo, Enschede en Hengelo niet zonder meer te vergelijken met bijv. Vriezenveen, Rijssen, Losser enz. De eerste zijn industrieplaatsen, de andere meer plattelandsgemeenten, waar enige industrie (soms één grote fabriek) gevestigd is.

172) Zie: Verslag No. CCXXI, blz. 2.

173) Zie: Verslag No. CCXXXIX, blz. 1.

174) Zie: Verslag No. CCXL, blz. 1.

175) Zie: Verslag No. CCL, blz. 1.

176) Zie: Verslag No. CCXI, blz. 4.

177) Zie: 176), blz. 5. 
Donderdagavond - zo deelt een landbouwer mede - de eerste reactie: „Dan staken wij ook." De melk werd echter Vrijdagmorgen wel aan de weg gezet ${ }^{178}$ ).

Eveneens zette een ander, wonend in Zenderen, Vrijdagmorgen de melk klaar, terwijl hij Donderdagmiddag reeds van de staking gehoord had 179). Verder drongen die avond ook stakingsgeruchten door in de buurt van Zuna. Men ,wilde ook wel wat doen", maar nam ,,een afwachtende houding" aan. "We waren benieuwd" — aldus één der boeren — ,of de melkrijder zou komen" 180 ).

Nog op andere wijze reageerden de boeren op Donderdagavond op het stakingsbericht. Zo vertelde een landbouwer, wonend te Haaksbergen, dat men op Donderdagavond van de staking gehoord had, maar geen overleg had gepleegd om ook gezamenlijk - als boeren dus - in staking te gaan. „Iedereen maakte voor zichzelf uit, wat gebeuren moest. Ik en - zoals ik merkte vele andere boeren, hebben Vrijdagmorgen geen melk aan de weg gezet" ${ }^{181}$ ).

Uit bovenstaande voorbeelden blijkt, dat verschillende boeren, die melk leverden aan de zuivelfabrieken, op Vrijdagmorgen niet geheel onkundig waren van de uitgebroken staking. Andere boeren daarentegen hadden niets of alleen bij gerucht iets vernomen. De wijze waarop zij in de staking betrokken werden, werd door oorzaken bepaald, die in het hieronder volgende toegelicht worden.

Er werd reeds uiteengezet, hoe in Twente op Donderdagmiddag in alle plaatsen, waar industrie van enige omvang gevestigd was, de staking uitbrak. Hierop vormden de zuivelfabrieken vrijwel de enige uitzondering. Men bleef tot het einde van de werktijd doorwerken. Op Vrijdagmorgen pas legden de personelen van verschillende zuivelfabrieken het werk neer.

De omvang der staking aan de 24 zuivelfabrieken - voorzover ons bekend, zijn dit alle zuivelfabrieken in Twente - blijkt uit het volgende overzicht.

1. Aan 4 zuivelfabrieken kwam het personeel in het geheel niet op, n.l. te Boekelo, Rijssen, Vriezenveen en Hengelo (Melkinrichting „De Volharding" N.V.). De $10 \mathrm{~kg}$ melk, die Vrijdagmorgen aan de laatstgenoemde zuivelfabriek werd aangevoerd, werd in ontvangst genomen door de directeur 182 ).

2. Aan 4 zuivelfabrieken kwam het personeel wel op, maar ging bij de aanvang van de werktijd niet aan de arbeid (n.l. te Borne 183). Enschede, Goor en Oldenzaal).

178) Zie: 176), blz. 6 .

179) Zie: 176), blz. 2.

180) Zie: Verslag No. CCXXXIV, blz. 1.

181) Zie: Verslag No.CCXXV, blz. 1.

182) Zie: Verslag No. CCXXVIII.

183) Het personeel van deze fabriek is naar huis gegaan, nadat de melkrijders op aandringen der Bornse fabrieksbevolking met de melk naar de boeren terugkeerden. Zie: Verslag No. CCXIII, blz. 1. 
3. Aan 2 zuivelfabrieken ging het personeel in de loop van de morgen in staking (n.l. te Almelo en Denekamp).

4. Aan 3 zuivelfabrieken ging het personeel naar huis, omdat slechts een deel der melkrijders melk had aangevoerd (n.l. te Haaksbergen, Wierden en Ambt-Delden).

5. Aan 11 zuivelfabrieken bleef op Vrijdag het personeel in de fabriek en ging dus niet in staking (n.l. te Bornerbroek, Delden, Hellendoorn, Hengelo (Hengelose Coöp. Melkinrichting), Losser 184), Markelo, Ootmarsum, Rossum, Saasveld, Tubbergen en Weerselo).

Hieruit blijkt dus, dat op Vrijdag 30 April, 13 van de 24 personelen niet of slechts gedurende kortere tijd in de zuivelfabriek aanwezig waren. Van deze 13 zijn slechts 4 personelen in het geheel niet verschenen.

Indien bovenstaande indeling - die gebaseerd is op het wèl of niet in staking gaan van de personelen der zuivelfabrieken - tevens als basis wordt genomen om na te gaan, in hoeverre melkrijders op Vrijdagmorgen aan de zuivelfabrieken kwamen, dan blijkt het volgende:

1. Aan de 4 zuivelfabrieken in resp. Boekelo 185), Rijssen 186), Hengelo (Melkinrichting "De Volharding” N.V.) 187) en Vriezenveen 188), waar het personeel niet verscheen, kwamen ook geen melkrijders.

2. Aan de 4 zuivelfabrieken te Borne, Enschede, Goor en Oldenzaal, waar het personeel bij de aanvang van de werktijd niet aan het werk ging, kwamen wel melkrijders. Hierbij dient echter te worden opgemerkt:

a. In Borne, aan de Coöp. Stoomzuivelfabriek en Melkinrichting „Borne", kwam slechts een gedeelte der melkrijders. „Vooral echter op aandrang van het publiek is het ... niet tot werken gekomen. Arbeiders uit Borne hebben de melkrijders er op gewezen, terug te keren" 189).

b. In Enschede kwam het personeel aan de Lonneker Coöp. Melkinrichting en Zuivelfabriek G.A. wel aan de fabriek, maar ging na enige weifeling niet aan het werk 190). De melkrijders, die opgekomen waren, moesten met de melk terugkeren.

c. In Goor ging het personeel van de Coöp. Zuivelfabriek „Weddehoen" op Vrijdagmorgen niet aan het werk. De melkrijders, die reeds

184) Het personeel van deze zuivelfabriek ging op Vrijdagmorgen in staking, maar kwam s middags weer terug. Zie: Verslag No. CCXXX, blz. 1.

185) Zie: Verslag No. CCXII.

186) Zie: Verslag No. CCXXXIX, blz. 1

187) Zie: Verslag No. CCXXVIII.

188) Zie: Verslag No. CCXIII, blz. 2.

189) Zie: Verslag No. CCXIII, blz. 1.

190) Zie: Verslag No. CCXX, blz. 2. 
opgekomen waren, werden aangespoord terug te keren. Op weg naar de boeren hebben deze rijders anderen weer gewaarschuwd 191).

$d$. In Oldenzaal ging het personeel, dat wel opgekomen was aan de Coöp. Stoomzuivelfabriek en Melkinrichting "Ons Belang”, niet aan het werk. De melkrijders moesten met de melk terug naar de boeren 192 ).

3. Aan de 2 zuivelfabrieken in Almelo en Denekamp - waar het personeel in de loop van de morgen pas in staking ging - was reeds een gedeelte der melkrijders gekomen.

a. Aan de Almelose Coöp. Melkinrichting te Almelo was het personeel van de zuivelfabriek opgekomen. Spoedig na de aanvang van het werk ging het grootste deel echter in staking. Van de 37 melkrijders (het normale aantal) kwamen die morgen 6 à 8 man. De melkbussen van deze rijders ,werden leeggegooid in de tanks en de arbeiders en melkrijders gingen naar huis" 193 ).

b. Op Vrijdagmorgen was men in Denekamp aan de Coöp. Stoomzuivel fabriek "Volharding" bezig, de melk in ontvangst te nemen, toen uit Oldenzaal opgebeld werd, dat aan de zuivelfabriek aldaar een staking uitgebroken was. "Eerst hebben wij” — aldus B. de Boer, directeur van de zuivelfabriek te Denekamp - ,geprobeerd, de boeren, die melk kwamen brengen, terug te sturen, maar dat lukte niet. Als de zaak eenmaal draait, is het niet zo gemakkelijk te onderbreken. De boeren bleven hier, laadden de melk af enz., tot het ons op een gegeven moment begon te vervelen. $W_{i j}$ zeiden toen: , $W_{i j}$ doen het niet meer' en wij deden de deuren dicht" ${ }^{194}$ ). De boeren, die nog komen moesten, werden aan het begin van het dorp opgevangen en aangespoord terug te keren. Het personeel van de zuivelfabriek ging daarna naar huis.

4. Aan 3 zuivelfabrieken, n.1. te Haaksbergen 195), Wierden 196) en AmbtDelden 197) ging het personeel naar huis, omdat door melkrijders slechts weinig melk werd aangevoerd.

5. Ten aanzien van de resterende 11 zuivelfabrieken - waar het personeel dus niet in staking ging - valt betreffende de melkrijders het volgende aan te tekenen:

191) Zie: Verslag No. CCXXII, blz. 1.

192) Zie: Verslag No. CCXXXV, blz. 1.

193) Zie: Verslag No. CCX, blz. 2.

194) Zie: Verslag No. CCXVIII, blz. 1.

195) Zie: Verslag No. CCXXIII, blz. 1.

196) Zie: Verslag No. CCXLVII, blz. 1.

197) Zie: Verslag No. CCXVI, blz. 1. 
a. Aan de zuivelfabrieken te Ootmarsum 198) en Rossum 199) kwamen alle melkrijders en werd de normale hoeveelheid melk geleverd.

b. Aan de zuivelfabriek te Hengelo (Hengelose Coöp. Melkinrichting) werd op Vrijdag $3389 \mathrm{~kg}$ afgeleverd, terwijl de leverantie op Donderdag 29 April, $7729 \mathrm{~kg}$ bedroeg 200). In Delden werd aanmerkelijk minder dan de normale hoeveelheid door de melkrijders aan de fabriek gebracht 201).

c. Aan de zuivelfabrieken te Bornerbroek 202) en Saasveld 203) kwamen geen melkrijders aan de fabriek.

d. In Hellendoorn 204), Markelo 205), Tubbergen 206) en Weerselo 207) kwamen de melkrijders wel aan de fabriek, maar leverden niets af en keerden met de melk naar de boeren terug.

e. Aan de zuivelfabriek te Losser waren Vrijdagmorgen de melkrijders wel opgekomen. Toen men aan het werk was, werd bekend, dat in Hengelo een staking was uitgebroken. De fabriek werd daarop gesloten en de melkrijders keerden terug. 's Middags kwam het personeel van de zuivelfabriek echter weer terug 208 ).

Indien de bovenstaande opmerkingen betreffende de melkrijders worden samengevat, dan blijkt:

1. dat aan 6 zuivelfabrieken de melkrijders niet verschenen en dus niets afgeleverd is, n.l. te Boekelo, Rijssen, Hengelo (Melkinrichting „De Volharding" N.V.), Vriezenveen, Bornerbroek en Saasveld;

2. dat aan 2 zuivelfabrieken door alle melkrijders de normale hoeveelheid melk afgeleverd is, n.l. te Ootmarsum en Rossum;

3. dat aan 8 zuivelfabrieken wel melkrijders geweest zijn, maar met alle melk teruggekeerd zijn, n.l. te Borne, Enschede, Goor, Hellendoorn, Markelo, Oldenzaal, Tubbergen en Weerselo;

4. dat aan 8 zuivelfabrieken een aantal melkrijders geweest is, dat melk afleverde, n.l. te Almelo, Denekamp, Haaksbergen, Wierden, AmbtDelden, Hengelo (Hengelose Coöp. Melkinrichting), Delden en Losser.

198) Zie: Schema III.

199) Zie: Schema III.

200) Zie: Schema III.

201) Zie: Verslag No. CCXVII, blz. 2.

202) Zie: Verslag No. CCXIV, blz. 1.

203) Zie: Verslag No. CCXLVI, blz. 1.

204) Aan de zuivelfabriek te Hellendoorn werd, ondanks dat niet gestaakt werd, slechts $33 \mathrm{~kg}$, oftewel nog geen half procent van de normale hoeveelheid aangevoerd. Om deze redenen hebben wij gemeend, deze fabriek te moeten indelen in die groep van zuivelfabrieken. waaraan op Vrijdag 30 April geen melk werd aangevoerd. Zie: Schema III.

205) Zie: Verslag No. CCXXXI, blz. 1.

208) Zie: Verslag No. CCXLI, blz. 1.

207) Zie: Verslag No. CCXLIII, blz. 1.

208) Zie: Verslag No. CCXXX, blz. 1. Daar het personeel van deze fabriek slechts kort 
$\mathrm{Al}$ mogen dus - zoals uit de punten $1 \mathrm{t} / \mathrm{m} 4$ blijkt - aan 18 van de 24 zuivelfabrieken wel melkrijders geweest zijn, het totaal van de afgeleverde hoeveelheid melk was gering. Op Vrijdagmorgen 30 April werd slechts $22.862 \mathrm{~kg}$ melk afgeleverd, terwijl dit getal op Donderdag 29 April voor hetzelfde aantal fabrieken nog $132.016 \mathrm{~kg}$ had bedragen. Dit blijkt uit nevenstaand schema 209 ).

Van de resterende 5 zuivelfabrieken is wel bekend, dat aan één, te AmbtDelden, op Vrijdag in totaal geleverd is plm. $1000 \mathrm{~kg}{ }^{210}$ ). In Bornerbroek 211), Borne 212) en Rijssen ${ }^{213}$ ) werd verder - volgens opgave van de directies op Vrijdag niets geleverd en in Delden ${ }^{214}$ ) slechts een deel der melk.

Uit dit alles blijkt, dat de hoeveelheid van $22.862 \mathrm{~kg}$ melk met slechts enkele duizenden $\mathrm{kg}$ melk verhoogd moet worden om het totaalcijfer te krijgen.

In het begin van de beschouwing betreffende de staking op het platteland werd vermeld, dat een deel der boeren reeds Donderdagavond van de uitgebroken staking gehoord had. In hoeverre dit gerucht tot in alle buurtschappen doorgedrongen was, was uit den aard der zaak niet na te gaan. Uit het feit echter, dat - zoals thans gebleken is - Vrijdagmorgen aan 6 zuivelfabrieken in het geheel geen melkrijders kwamen en aan andere, bijv. te Haaksbergen, Wierden, Ambt-Delden, Hengelo (Hengelose Coöp. Melkinrichting) en Delden, weinig melk aangevoerd werd, blijkt wel, dat het bericht betreffende de staking reeds onder een groot aantal boeren en melkrijders bekend moet zijn geweest.

Verder kon nog een groot aantal boeren in de staking betrokken worden, doordat ook de personelen van de zuivelfabrieken op Vrijdag het werk neerlegden. Het gevolg hiervan was, dat niet alleen vele melkrijders gedwongen werden met de melk terug te keren (zoals bijv. te Borne, Enschede, Oldenzaal en Denekamp), maar ook, dat die boeren, die reeds geen melk geleverd hadden, in hun verzet gesterkt werden.

\section{De staking der grensgangers}

Op Donderdagavond kwamen de Nederlandse arbeiders, die in de fabrieken in Nordhorn werkten, naar huis. Aan de grens reeds werd hun door de Duitse grensbewakers verteld, dat er in Nederland iets gaande was 215). $\mathrm{Na}$

in staking was, hebben we haar gemakshalve ingedeeld in de groep van zuivelfabrieken, waar door personeel niet werd gestaakt. Uit het bovenstaande blijkt echter, dat de kortstondige staking zijn invloed heeft gehad.

209) Door 19 van de 24 zuivelfabrieken werden de volledige dagcijfers, betrekking hebbend op de periode 26 April-4 Mei 1943, verstrekt.

210) In Ambt-Delden werd plm. $1000 \mathrm{~kg}$, zijnde ongeveer $1 / 3$ van de normale hoeveelheid, aangevoerd. Zie: Verslag No. CCXVI, blz. 1.

211) Zie: Verslag No. CCXIV, blz. 1.

212) Zie: Verslag No. CCXIII, blz. 1.

213) Zie: Verslag No. CCXXXIX, blz. 1.

$214)$ Zie: Verslag No. CCXVII, blz. 2.

215) Zie: Verslag No. CIXXXVI, blz. 1. 
SCHEMA III. AAN ZUIVELFABRIEKEN GELEVERDE HOEVEELHEDEN MELK (in kg.) GEDURENDE DE PERIODE 26/4 $1943 \mathrm{t} / \mathrm{m} \quad 4 / 5 \quad 1943$

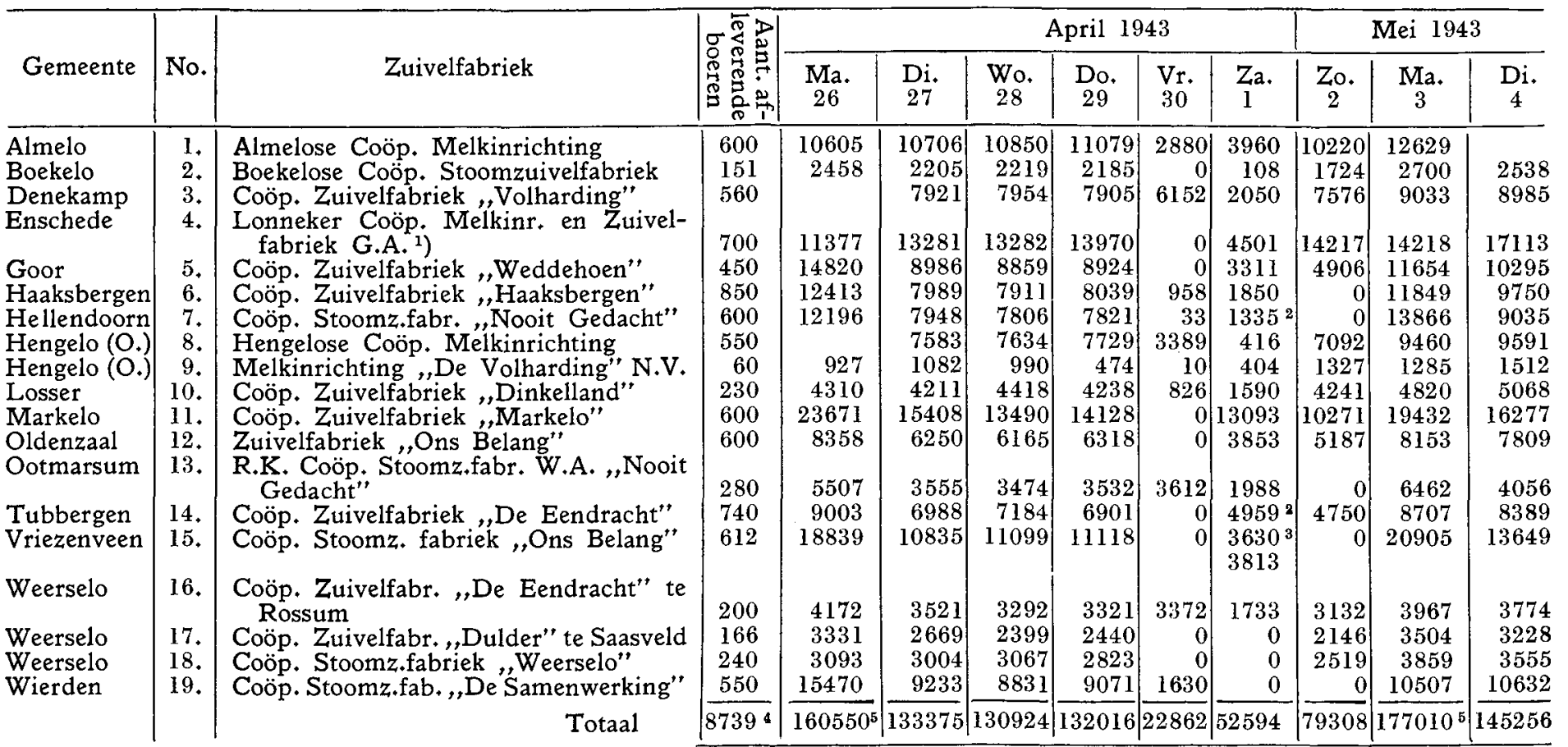

1) 25 en 26 April 1943 werd in totaal afgeleverd $22.754 \mathrm{Kg}$; 27 en $28,1943, ", ", 26.563$ " 2 en 3 M̈ei 1943 " " " " " " 4 en $5 " 1943$ " " " " 34.227 ", In het schema werd per" dag" het "gemiddelde van de aanvoer over 2 dagen opgenomen.

2) Deze hoeveelheid melk werd 's avonds aangevoerd.

3) $3630 \mathrm{Kg}$. melk werd 's morgens en $3813 \mathrm{Kg}$. melk 's avonds aangevoerd.
4) In totaal leverden 10.369 boeren aan 24 zuivelfabrieken.

5) De zuivelfabrieken te Haaksbergen, Hellendoorn, Vriezenveen en Wierden ontvingen op Maandag $3 \mathrm{Mei} 1943$ een tweedaagse hoeveelheid melk, daar deze fabrieken op Zondag gesloten waren. 
de douane te zijn gepasseerd, zagen de terugkerende arbeiders langs de spoorlijn mensen staan, die hun toeriepen, de volgende dag, Vrijdag, het werk niet te hervatten 216). Doordat deze grensgangers nauwelijks wisten, wat er gaande was en doordat in de trein arbeiders zaten, die naar verschillende plaatsen moesten, kon er van een gezamenlijk overleg geen sprake zijn. Vandaar, dat afspraken om op Vrijdag in staking te gaan, op Donderdagavond niet gemaakt werden.

De volgende morgen zijn wel grensgangers uit Hengelo, Borne, Almelo, Oldenzaal en Enschede naar Duitsland vertrokken. Het waren er echter weinig. Toen de derde trein naar Gronau vertrekken zou, werd het station Enschede gewaarschuwd, dat de tweede trein, die reeds vertrokken was, bij de eerstvolgende post, buiten het station, stil stond. Arbeiders hadden aan de noodrem getrokken, teneinde de trein te verlaten om alsnog in staking te gaan. Een ander middel om weg te komen was er niet, daar - zoals de commies J. de Kiewit verklaarde - de Groene Politie voor het station stond en zou kunnen verhinderen, dat arbeiders het station verlieten 217 ).

Dit oponthoud was de Duitsers niet onbekend gebleven. Vandaar dan ook, dat Duitse politie de bewaking van de, de reis naar Duitsland vervolgende, trein overnam 218 ).

Op Vrijdag werd dus slechts door een deel der grensgangers gestaakt; op Zaterdag werd door hen het werk op normale wijze hervat.

\section{De uitbreiding der staking naar de verkeersdiensten}

De staking van het personeel bij de autobusdiensten in Twente heeft zich beperkt tot drie ondernemingen, n.l. de $T$ (wentse) $E$ (lectrische) $T$ (ramweg Maatschappij) te Enschede, het Reisbureau ".Twenthe" te Enschede en de N.V. "Wato" te Wierden. Van deze drie ondernemingen is de eerste verreweg het belangrijkste, daar zij de enige maatschappij is, die het lijnvervoer verzorgt 219). Tevens waren er nog enkele autobusdiensten, die arbeiders naar Nordhorn vervoerden.

De staking aan de Twentse Electrische Tramwegmaatschappij was op Vrijdagmorgen 30 April 1943 omstreeks half acht volledig. Niemand - behalve de sociale voorman - ging toen meer aan het werk. 's Morgens vroeg, om half zes, was wel een chauffeur van de garage met zijn autobus naar het vertrekpunt vertrokken, maar na twintig minuten was hij terug, daar de mensen zeiden, dat hij niet moest rijden 220 ).

Reeds vóór die tijd echter waren al autobussen vertrokken. Ter toelichting hiervan diene het volgende.

Donderdagavond om half elf gingen vanuit Enschede lege wagens naar

216) Zie: 215), blz. 1 en 2.

217) Zie: Verslag No. CXXVIII, blz. 1 en 2.

218) Zie: 217), blz. 2.

219) Zie: Verslag No. CXLI, blz. 2.

220) Zie: Verslag No. CXLII, blz. 6. 
Nordhorn, om arbeiders op te halen, die in de fabrieken aldaar in de late ploeg werkten. Om half twaalf 's avonds werd dit herhaald. Deze bussen moesten resp. om 24 uur en 1 uur 's nachts in Enschede binnen komen. $Z$ ij moesten echter weer Vrijdagmorgen om resp. 4 en 5 uur arbeiders, die in de vroege ploeg werkten, vanuit Enschede naar Nordhorn vervoeren. Nadat de arbeiders dan ter plaatse afgezet waren 221), moesten deze autobussen weer naar Enschede terugkeren, nadat eerst in Oldenzaal arbeiders, bestemd voor de Enschedese fabrieken, opgenomen waren.

Deze bussen nu, waren in Enschede niet op tijd aangekomen. In Oldenzaal n.1. waren de plm. 200 arbeiders niet bereid te vertrekken. De autobussen bleven wachten. Toen deze in Enschede niet op tijd aankwamen, gingen een controleur van de binnendienst en de bedrijfsleider van Enschede naar Oldenzaal en gaven de chauffeurs opdracht, met lege wagens naar Enschede terug te rijden. Slechts een zes-tal NSB-ers gingen als passagier mede.

Toen deze wagens binnengereden waren, was het autobus-lijnvervoer in Twente stopgezet. Daardoor werden geen passagiers meer vervoerd op de trajecten:

Enschede - Oldenzaal - Ootmarsum
Enschede - Oldenzaal - Denekamp
Enschede - Hengelo - Glanerbrug
Hengelo - Haaksbergen
Enschede - Oldenzaal - Denekamp - Nordhorn
Ootmarsum - Tubbergen - Almelo
Ootmarsum - Denekamp - Nordhorn 222)

Op al deze diensten is één dag gestaakt.

Twee dagen werd gestaakt aan het Reisbureau "Twenthe". Hoewel op Donderdagavond het personeel $(20$ man) reeds in staking ging, werden die dag de Nederlandse arbeiders, die in Duitsland werkten, nog wel opgehaald. Door de staking aan dit bedrijf konden plm. 300 arbeiders, werkzaam in de textielfabrieken in Nordhorn en 50 arbeiders, voor de "Katastrophen Einsatz" aan de "Reichsbahn" niet vervoerd worden 223 ).

In tegenstelling tot bovengenoemde verkeersdiensten is het spoorwegpersoneel in Twente niet tot staking gekomen. Slechts in enkele plaatsen is wat overleg geweest. Zo werden vanuit Enschede voelhorens uitgestoken naar Almelo, Hengelo en Oldenzaal. In Hengelo en Almelo wist het spoorwegpersoneel, ondanks dat men graag wilde meedoen, geen uitweg uit de moeilijkheden 224). Bij nadere informatie van het Enschedese stationspersoneel in

221) Opgemerkt dient dus te worden, dat de gehele vroeg-dienst wel werkte.

222) Zie: 220 ), blz. 8 .

223) Zie: Lijst No. 100

224) Zie: Verslag No. CXXVII, blz. 1. 
Hilversum bleek, dat daar alles normaal functionneerde 225). Ook het contact met Oldenzaal bracht geen resultaat 226 ).

Ook vanuit Almelo werd contact gezocht. Zo werden andere spoorwegstations opgebeld, o.a. Amsterdam, Amersfoort, Hengelo, Enschede en Oldenzaal. Herhaalde malen trachtte men het Hoofdkantoor in Utrecht op te bellen. Toen men eindelijk verbinding kreeg (Vrijdag plm. 12 uur) werd aan het personeel medegedeeld, dat niet gestaakt zou worden 227).

Ofschoon op zeer beperkte schaal is van overleg sprake geweest. Dat het in Twente nergens tot staking kwam, komt doordat de personelen van deze kleinere stations en locomotievendepôts niet overtuigd waren, dat de grotere stations zouden volgen. Men wachtte op elkaar, maar vóór alles op het sein van boven af. Aan elke onzekerheid voor het spoorwegpersoneel en zeker voor de stakende arbeiders werd echter een einde gemaakt, toen bekend werd, dat de spoorwegdirectie het personeel ten sterkste ontried, het werk neer te leggen.

Het niet-staken van het spoorwegpersoneel heeft in Twente een diepe indruk achtergelaten. Men voelde zich verlaten en geïsoleerd. Het is wel de belangrijkste factor, waardoor de gehele staking in Twente voor Hengelo slechts anderhalve dag en voor andere plaatsen in Twente hoogstens twee dagen geduurd heeft.

225) Zie: 224), blz. 1.

226) Zie: Verslag No. CXXVI, blz. 1.

227) Zie: Verslag No. LXXIV, blz.1 en 2. 


\section{HOOFDSTUK IV}

\section{BESCHRIJVING DER STAKINGSBEWEGING IN TWENTE}

Zoals gebleken is, brak de staking in Twente in bijna alle plaatsen, waar industrie gevestigd was, op Donderdagmiddag uit tussen 14.30 uur en 17.30 uur 228). Voor Hengelo eindigde de staking eigenlijk op Zaterdagmorgen plm. 10.30 uur -11 uur; in de andere plaatsen hervatten de personelen op Maandagmorgen $3 \mathrm{Mei}$, de arbeid bij het begin van de werktijd. Zoals echter uit het volgende zal blijken, was de bereidheid om verder te staken op Zaterdag reeds in geheel Twente verdwenen. Uit een beschouwing over het verloop der stakingsbeweging in de belangrijkste plaatsen in Twente, zullen de oorzaken hiervan naar voren springen.

\section{HENGELO}

D o n d e r d a g. - De verbittering, die reeds lang onder de bevolking leefde, kwam tot uiting in de snelle wijze, waarop zij in staking ging. Niet alleen legde het personeel van de gemeente-bedrijven de arbeid neer, maar ook bouwvakarbeiders, schilders en glazenwassers volgden het voorbeeld der fabrieksarbeiders en kantoorbedienden. Daar er geruchten gingen, dat ook het personeel van de Gemeente-Waterleiding in staking was gegaan (hetgeen echter niet het geval was), begon vrijwel een ieder water te tappen. Zo leek het voor velen, alsof het gerucht inderdaad op waarheid berustte. Brandkranen en brandputten werden opengezet en men vulde emmers, teilen en pannen 229). De staking had een ieder zo overvallen en het watertappen had zo'n omvang aangenomen, dat rijen bij de brandkranen werden gevormd 230 ). Doordat er plotseling een zeer grote afname plaats vond, kwam op den duur zeer weinig water uit de kraan, hetgeen het gerucht van de staking bij de Waterleiding opnieuw versterkte.

Tekenend voor de vijandige stemming der bevolking op het moment, dat zij in beweging was, is het feit, dat ,een nazi-sympathiserende" Donderdag-

228) Hieronder zijn dus ook begrepen de plattelands-gemeenten, zoals bijv. Rijssen en Vriezenveen, die slechts één grote fabriek hebben.

229) Zie: a. Verslag No. XVIII, blz. 11 en 12.

b. "Ik" - aldus Mr H. J. F. ten Cate - ,ben naar huis gegaan en heb daar geprobeerd, het bad vol te laten lopen......" Zie: Verslag No. XI, blz. 2.

230) „Alles had, ondanks de opwinding, waarin allen verkeerden, een zeer ordelijk verloop......" Zie: Brief van G. Zw. Hengelo, 21 Maart 1947. Bijlage 63. 
middag ijlings zijn ,technische noodhulp"-propagandabiljetten verwijderde 231).

Overal zag men verder mensen, die brood kochten 232 ). Leraren van een U.L.O.-school, die op de hoogte werden gesteld van de uitgebroken staking, legden zonder zich te bedenken het werk neer. De school liep in korte tijd leeg 233). Sommige winkeliers timmerden planken voor de ruiten en sloten de winkels 234). Ook werden de meeste garage-bedrijven gesloten 235 ).

Vanaf het moment, dat de staking in de fabrieken uitbrak en de rest der Hengelose bevolking daarin werd opgenomen, was het druk op straat. De mensen stonden in groepen bij elkaar en bespraken de toestand. Na half vijf echter, toen de stakers naar huis gingen, werd het rustiger.

Een schets van de stakingsbeweging in Hengelo - en hetzelfde geldt vrijwel voor alle andere plaatsen in Twente - is tevens een geschiedenis van de Duitse tegenmaatregelen, al waren deze laatste in de eerste uren van de staking niet duidelijk merkbaar. Alvorens echter over te gaan tot een beschrijving van de snelle wijze, waarop de Duitsers op de staking reageerden, moge eerst het volgende worden opgemerkt.

Kort nadat de arbeiders van de Machinefabriek Gebr. Stork \& Co. N.V. de fabriek hadden verlaten, vond een bespreking plaats tussen Kapitän-Leutnant Mayer - iemand die bij de Machinefabriek in opdracht van de Rïstungsinspektion regelmatig contrôle-bezoeken aflegde - , de bedrijfsleider F. G. Stork en de heer Sprössig, een Duits ingenieur van Stork, die als verbindingsman met Duitse instanties fungeerde. Deze Mayer deelde mede, dat het niet de bedoeling was, dat het gehele vroegere Nederlandse leger in krijgsgevangenschap moest terugkeren, doch slechts het kader. Verder was hij van mening, dat diegenen, die in een Rüstungsbetrieb werkten, vrijgesteld zouden worden en daarmee dus ook de oud-militairen van het Stork-personeel. Daar Mayer meende, dat de arbeiders weer aan het werk zouden gaan (indien zij dit wisten), werd het onderstaande bericht ter kennis van de arbeiders gebracht:

„In opdracht van de Rüstungs-inspectie delen wij mede, dat van de opkomst in krijgsgevangenschap zijn vrijgesteld alle mannen, die werkzaam zijn in de Rüstungs-bedrijven, dus ook in ons bedrijf en die geboren zijn in de jaren 1898 tot en met 1925 .

Hgl. 29.4.43.

De Directie." 236)

Dit bericht werd echter in een lege fabriek opgehangen 237 ).

Korte tijd nadat de staking was uitgebroken, belde de loco-burgemeester van Hengelo, G. J. Steggink, de griffie op van het Commissariaat van de Provincie Overijssel te $Z$ wolle en deed mededeling van de bijzondere toestand in Hengelo. Doordat Seyss-Inquart's Beauftragte Weidlich op dat moment niet

231) Zie: 230 ).

232) Zie: Verslag No. XI, blz. 2.

233) Zie: Brief van P. A. M., Almen, geen datum. Bijlage 64 .

234) Zie: Lijst No. 171.

235) Zie: Lijst No. 191.

236) Zie: Bijlage 65.

237) Zie: Verslag No. XX, blz. 3. 
aanwezig was, werd Steggink daarop uit $Z$ wolle opgebeld en werd hem bericht, dat Weidlich nog dezelfde avond naar Hengelo zou komen.

Voordat deze bespreking plaats had, was echter eerst nog een vergadering op het politiebureau gehouden, waar aanwezig waren: een Majoor van de SS (uit Arnhem), de leider van de SD uit Enschede, de Ortskommandant van Hengelo, de NSB-commissaris van politie Wuyster, de inspecteur van politie Waldkötter 238) en de loco-burgemeester van Hengelo, Steggink. Gedurende deze bespreking werd besloten, dat door middel van luidspreker-wagens de bevolking zou worden aangezegd, 's avonds om 20 uur binnenshuis te zijn. Dit laatste is geschied 239 ).

Daarna vond de bespreking plaats op het Gemeentehuis tussen de locoburgemeester van Hengelo en Beauftragte Weidlich. Ook de toenmalige gemeente-secretaris, J. Bottinga, was aanwezig.

Toen Steggink naar het Gemeentehuis ging, het was ongeveer half acht, kwamen juist Duitsers, in overvalwagens gezeten, Hengelo binnenrijden. Dit was nauwelijks 5 uur nadat de eerste arbeiders uit de Machinefabriek Stork waren weggelopen.

De bespreking tussen Steggink en Weidlich - de laatste was in gezelschap van een geuniformeerde NSDAP-er - was, volgens eerstgenoemde, onbelangrijk 240). Weidlich gaf geen algemene richtlijnen, volgens welke de locoburgemeester had te handelen. Wel werd verlangd, dat Steggink de namen zou noteren van die leden van het gemeente-personeel, die in staking gegaan waren. Dit werd door de loco-burgemeester geweigerd. Tevens werd hem opgedragen, een verslag samen te stellen. Daarmee was deze bespreking ten einde.

Donderdagavond zijn geen verdere bijzonderheden voorgevallen. De bevolking, aan welke medegedeeld was, vanaf 20 uur binnen te blijven, hield zich rustig. G. J. Steggink verklaart, dat na 20 uur die avond geen mensen meer op straat zijn geweest.

In de nacht van Donderdag op Vrijdag kwamen nog plm. 200 Duitsers in Hengelo aan 241 ).

238) „Waldkötter had me, alvorens de spreking begon, verteld, dat hij bij de politie ,de hele zaak in orde had'. Als zij (het politiepersoneel - Noot van de auteut), opdrachten zouden krijgen, die zij niet zouden kunnen uitvoeren, dan zou, het hele zaakje het kanaal ingaan." Aldus G. J. Steggink. Zie: Verslag No. XVI, blz. 5.

239) a. Zie 233).

b. Zie: Telexbericht No. 14134. Bijlage 103.

c. Zie: Telexbericht No. 1362. Bijlage 105.

d. Daarentegen verklaart Steggink, dat - naar hij meent — de bevolking door middel van aanplakbiljetten gewaarschuwd is, om 20 uur binnenshuis te zijn. Zie: 238).

Dit lijkt ons echter - gezien de korte spanne tijds - onwaarschijnlijk. Waarschijnlijk hebben de aanplakbiljetten, waarop Steggink doelt, betrekking op de afkondiging van het Politie-Standrecht op Vrijdagavond 30 April 1943.

De politie te Hengelo kon ten aanzien van de wijze, waarop de bevolking op Donderdagavond werd gewaarschuwd, geen precieze gegevens verstrekken.

240) Zie: 238), blz. 6.

241) Zie: Verslag No. XVIII, blz. 8. 
V rij dag. - Vrijdag 30 April 1943 ging Hazemeyer's Fabriek voor Signaal-apparaten N.V. - vrijwel de enige fabriek in Hengelo, die op Donderdag niet in staking was gegaan - niet aan het werk. Het personeel van het Telefoonkantoor werd die dag door de directeur, Verwey de Winter, en enige leidende ambtenaren ,op de ernst van hun daad ... gewezen" 242), toen om half tien de aanwezige telefonisten in staking gingen. Het personeel, dat naar de telefoonzaal terugkeerde, belde echter andere plaatsen op en gaf door, dat men weer aanwezig was, maar niet verder zou werken 243). 's Middags ongeveer 16 uur werd het personeel opnieuw aangemaand, aan het werk te gaan. Besloten werd toen, langzamer te werken. Per kwartier werd toen ongeveer één telefoongesprek ",gemaakt" 244).

Ofschoon die dag wel wat arbeiders in de omgeving van de Machinefabriek Stork en G. Dikkers \& Co. N.V. stonden 245), kwam het nergens tot een hervatting van het werk. Wel stond men in de stad in groepjes de toestand te bepraten, maar van grote drommen stakers, die, zoals in de Amsterdamse Februari-staking, demonstratief door de stad trokken, was in Hengelo niets terug te vinden. Het was er, gezien de omstandigheden, betrekkelijk stil 246).

Die dag, dus Vrijdag 30 April, patrouilleerden de Duitsers druk door de straten. Om 13.30 uur werd door een „Duits politieman" 247) opdracht gegeven, voor de grote bedrijven twee agenten van politie te plaatsen.

Intussen hadden verschillende directies zich met de bedrijfskernen in verbinding gesteld. Zo bijv. had Ir H. I. Keus, directeur van de N.V. Heemaf, een vergadering met de gehele kern van ongeveer dertig man. Ook de beambtenkern was aanwezig. Ir Keus trachtte - aldus een der kernleden „op alle mogelijke manieren te laten zien, dat het nu niet bepaald verkeerd was, wat we deden, maar dat we de gevolgen goed onder ogen moesten zien. Wij moesten de gevolgen dan ook voor onze verantwoording nemen" 248 ).

Ook de bedrijfsleider, F. G. Stork, trad Vrijdagmorgen met de bedrijfskern in overleg 249). Er werd op deze bijeenkomst opgemerkt, dat men moest oppassen, niet op een eiland te komen. Bij deze gelegenheid wees F. G. Stork op berichten uit verschillende delen van het land, volgens welke wel in diverse streken gewerkt werd. De kern daarentegen wees weer op plaatsen, waar

242) Zie: Brief van de directeur van het Telefoondistrict Hengelo, Verwey de Winter, aan de Directeur-Generaal der P.T.T. te Den Haag. Bijlage 59.

243) „Wij hebben de telefonisten van verschillende kantoren opgebeld en gezegd: ,Wij staken, wij werken niet meer'." Zie: Verslag No. LVI, blz. 2.

244) Zie: Brief van Mej. E. G. Vennink (telefoniste). Enschede, 25 Februari 1946. Bijlage 66.

245) Zie: a. Verslag No. XXVII, blz. 2.

b. Verslag No. XVI, blz. 7.

246) Zie: a.. 245), a, blz. 4.

b. Lijst No. 186.

247) Zie: Rapport No. 120 van 30/4 '43-1/5'43. 13.30 uur. Politie te Hengelo.

248) Zie: Verslag No. XLIII, blz. 4.

249) ."Het was echter lastig" - aldus G. H. Erdtsieck - ,om daarheen te gaan, want er joegen overvalwagens door de straten." Zie: Verslag No. XXIV, blz. 4. 
werd gestaakt. In elk geval kwam in deze bespreking tot uitdrukking, dat - gezien de toestand - de staking niet langer dan tot Maandagmorgen zou kunnen duren.

De directie van de Machinefabriek Stork overwoog verder, toen men zag, dat de staking niet algemeen was: "Hoe maken wij er het beste van?" 250). Men besloot, dat de directie en chefs elke dag zouden moeten komen en althans bij het begin van de werktijd aanwezig resp. te bereiken zijn om - bij een eventuele komst der Duitsers - het beste voor de arbeiders te kunnen doen 251).

Diezelfde middag moest de directie van de N.V. Stork de volgende mededeling ter kennis van het personeel brengen:

„Leden van de vroegere Nederlandse Weermacht, die werkzaam zijn in bedrijven, die onder toezicht staan van de Rüstungsinspektion zijn van de door de Wehrmachtbefehlshaber der Niederlande aangekondigde maatregelen uitgesloten.

Indien deze leden der vroegere Nederl. Weermacht deelnemen aan een staking of op enige wijze tegen de voorschriften van de Wehrmachtbefehlshaber der Niederlande in verzet komen, worden $z \mathrm{ij}$ onmiddellijk in gevangenschap weggevoerd.

In ontwerp getekend

LAMPRECHT

Rüstings-inspektie Baarn." 252)

Of dit bericht, dat waarschijnlijk pas na 17 uur werd aangeplakt, nog ter kennis kwam van het personeel van de Machinefabriek Stork, is te betwijfelen ${ }^{253}$ ). In elk geval werden door het ,Decreet betreffende de afkondiging van het politie-standrecht voor de Provincie Overijssel" niet alleen zij, maar alle arbeiders gelast het werk te hervatten.

Wat echter, nog voordat het politie-standrecht werd afgekondigd, bepalend was voor de stemming en houding van directies en arbeiders was het feit, dat het Spoorwegpersoneel niet in staking was gegaan 254). Dit was ook daarom van groot belang, omdat de politiemannen op een staking van het Spoorwegpersoneel wachtten 255 ). Doordat de Twentse bevolking ook niet voldoende wist, wat elders gebeurde, kreeg men de indruk, op een eiland te

250) Zie: Verslag No. XX, blz. 3.

251) Zie: 250).

252) In de oorspronkelijke Duitse tekst werd aan het einde van de eerste alinea een beperking gemaakt door de woorden: "sofetn die Betriebe ihre Unabkömmlichkeit nachweisen". $O p$ verzoek van de directie werd door Kap.-Leutn. Mayer toestemming verleend, deze woorden in de officiële tekst weg te laten. Zie: Bijlage 65 .

253) Zie: 250), blz. 4 .

254) a. Prof. Ir J. G. Hoogland had de overtuiging, dat, nu de Spoorwegen niet meededen, "het dwaasheid was, de staking voort te zetten." Zie: Verslag No. XLVIII, blz. 2.

b. ,'s Avonds zijn wij er nog op uit gegaan, om te kijken of de Spoorwegen staakten. Wij kwamen toen tot de ontdekking, dat het Spoor werkte en toen wisten wij al, dat het een verloren zaak was." Aldus een arbeider, werkzaam bij het Twents Centraal Station voor Electrische Stroomlevering N.V. Zie: Verslag No. LVIII, blz. 4.

255) Zie: Verslag No. XVIII, blz. 5. 
zitten. Onder dergelijke omstandigheden kon het niet anders, of de wil om de staking voort te zetten moest afnemen.

Op Vrijdagmiddag heerste reeds in Twente een neerslachtige stemming. Toen reeds voelde men, dat verder staken in zeker opzicht zinloos was. En dit werd versterkt door het feit, dat omstreeks deze tijd aan de bevolking ondubbelzinnig bleek, dat de Duitsers deze staking - hoe dan ook — zouden proberen neer te slaan. De decreten betreffende de afkondiging van het politiestandrecht spraken duidelijke taal.

In de loop van de Vrijdagmiddag werden de burgemeesters van de verschillende Twentse plaatsen opgeroepen, naar Hengelo te komen en zich te melden in het "Bataafse Kamp” bij Weidlich en Hauptmann Ney. Daar werd hun opgedragen, er voor te zorgen, dat het gemeente-personeel Zaterdag weer aan het werk moest zijn. Diegene, die niet op het werk zou verschijnen, „zou ... met kogel of strop gestraft worden" 256). Ook de arbeiders moesten zo snel mogelijk weer beginnen. Weidlich eiste van de burgemeesters, dat zij in het belang van de bevolking zouden medewerken tot de opheffing van de staking. Zou dit laatste niet gebeuren, dan moest op een ernstig bloedvergieten gerekend worden 257 ).

Bij deze gelegenheid werden aan de burgemeesters de decreten ,betreffende de afkondiging van het politie-standrecht voor de provincie Overijssel" overhandigd. Hierbij werd - met onmiddellijke inwerkingtreding - diegene standrechtelijk veroordeeld en ingevolge art. 66 der ,Verordening Openbare Orde $1943^{\prime \prime}$ in het algemeen met de dood gestraft:

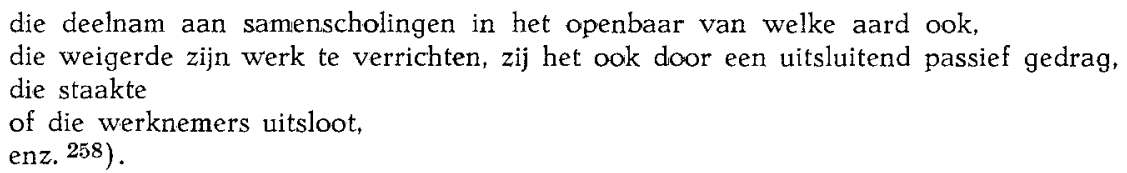

Verschillende burgemeesters, o.a. van Delden, Hellendoorn en Markelo, merkten op, dat het onmogelijk was, deze decreten vóór 20 uur 's avonds ter kennis van de gehele bevolking te brengen. Naar aanleiding hiervan belde Weidlich - naar hij zeide - Rauter op, maar zou ten antwoord gekregen hebben, dat deze maatregel voor het gehele land gold, zodat uitzonderingen niet konden worden toegestaan 259). Enkele burgemeesters kregen echter de toezegging, dat de Duitse troepen pas Maandag 3 Mei zouden komen en dat zij daardoor het bevel over hun gemeente tot Maandag zelf in handen zouden kunnen houden 260 ).

In Hengelo werden intussen deze plakkaten aangeplakt. De bevolking werd tegelijkertijd op de hoogte gesteld, weer om 20 uur binnen te zijn.

256) Zie: Verslag No. XVI, blz. 8.

257) Zie: Verslag No. CLXXII, blz. 3.

258) Zie: Bijlage II 2. Het politie-standrecht is ingegaan op Vrijdag, 30 April 1943 om 20 uur.

259) Zie: Verslag No. CLXV, blz. 2.

260) Zie: 259), blz. 2. 
Vrijdagmiddag werden de Hengelose fabrikanten opgeroepen om die avond op het Gemeentehuis te Hengelo te verschijnen. Wel werd eerst onder de fabrikanten onderling getelefoneerd of men wel of niet zou komen, maar tenslotte werd besloten, wel te gaan.

Het feit, dat de staking zich niet tot het spoorwegpersoneel had uitgebreid, dat niet in het gehele land werd gestaakt en ook, dat het politie-standrecht was afgekondigd, speelde bij de overweging om wel te gaan een belangrijke rol. Om ca. 19 uur was men dan ook present.

Nadat men een uur op de komst van Weidlich had gewacht, kwam deze eindelijk aan. Hij was zeer nerveus 261 ) en hield een toespraak, vol met bedekte bedreigingen. Hij zeide, dat er bedrijfsleiders waren, die deze staking aanmoedigden, maar daarvoor ter verantwoording zouden worden geroepen 262). Verder zou Zaterdag de Grüne Polizei in de stad komen met een Lleberfallkommando en zouden mensen worden opgehaald en doodgeschoten, als deze niet in de fabriek waren 263). De arbeiders hadden te zorgen, om half acht 264) (volgens andere verklaringen om 8 of 9 uur 265) in de fabriek te zijn. De directies zouden - teneinde dit mogelijk te maken - hun bazen hiervan op de hoogte moeten stellen, die op hun beurt dan weer de arbeiders moesten waarschuwen. Daar het inmiddels 20 uur was geworden en niemand meer op straat mocht zijn, zouden de bazen briefjes aan het politie-bureau kunnen halen, teneinde zonder gevaar hun opdracht te kunnen uitvoeren.

Doordat het echter inmiddels al laat geworden was, was het onmogelijk aan deze eis van Weidlich te voldoen. Ir H. I. Keus bracht dit volgens Prof. Ir J. G. Hoogland tot uitdrukking in de volgende woorden:

,Ik wil U eerst duidelijk maken, waarom de staking is geweest. De mensen zijn zeer nerveus door de bombardementen. Er was hun beloofd, dat zij niet weg hoefden en toch komt de zeer ontactische mededeling van Christiansen. U moet begrijpen, dat de mensen, die hier in een val leven, dergelijke mededelingen niet kunnen verdragen. $Z_{i j}$ werken hier voor $U$ en het is begrijpelijk, dat zij reageren. $U$ wrilt de staking morgenochtend om half acht beëindigen. Dat kan niet. Wij kunnen vanavond niets meer doen. Wij zijn wel genegen, ons er voor te spannen, maar $U$ moet ons de tijd geven. Geeft $U$ de tijd tot 10 uur, dan zullen wij er voor zorgen" 266 ).

Weidlich was niet bereid aan de voorwaarde, die Ir Keus stelde, te voldoen. Hij was van mening, dat de staking georganiseerd was en dat de organisatie, die het gelukt was, het bedrijfsleven in één uur stil te leggen, dit ook weer in één uur aan de gang kon krijgen. Ir Keus opponeerde opnieuw door te zeggen, dat de staking ,een spontane actie" was. Hij betoogde, dat juist de snelle uitbreiding van de staking uitdrukte, dat deze niet georganiseerd was. „Als $U$ aan Uw eis vasthoudt" - aldus Ir Keus — ,zult U de mensen ten

261) Zie: Verslag No. XLVIII, blz. 1.

262) Zie: Verslag No. XLV, blz. 2.

263) Zie: Verslag No. XX, blz. 4.

264) Zie: 261), biz. 2.

265) Zie: 262), blz. 2.

266) Zie: 261), blz. 2 . 
alle tijd tegen $U$ krijgen en er zullen veel doden vallen, waarvoor $U$ dan verantwoordelijk bent" 267).

Tenslotte zwichtte Weidlich voor de argumenten en werd besloten, dat met het optreden der Grüne Polizei gewacht zou worden tot Zaterdagmorgen 10 uur 268). Arbeiders, die dan nog op straat zouden zijn, zouden door de Duitsers worden neergeschoten.

Ondanks het late uur werden Vrijdagavond verschillende arbeiders gewaarschuwd 269). Van andere fabrieken, zoals bijv. bij Stork 270) en Heemaf 271), werden personeelsleden of kernleden Zaterdagmorgen vroeg ingeschakeld om de rest van het personeel te waarschuwen, vóór 10 uur het werk te hervatten. Diegenen, die bij Stork werkten en buiten Hengelo woonden, werden Zaterdag en Zondag, hetzij mondeling, hetzij telefonisch gewaarschuwd, Maandag te komen 272 ).

$Z$ at e r d a g. - Zaterdagmorgen waren in Hengelo vele arbeiders op weg naar de fabriek. In tegenstelling tot de afspraak, dat de Duitsers de arbeiders gelegenheid zouden geven, om 10 uur in de fabriek aanwezig te zijn, rukten $z$ ij eerder uit en begonnen om half tien op de bevolking te schieten. Hierbij werden 3 personen geraakt. Eén persoon, G. J. Weyenborg, die met zijn baas bij een wagon moest $z$ ijn op het stationsemplacement, werd door een schot in de hartstreek gewond en stierf. H. W. Varvik, fietsende op het rijwielpad Hengelo-Borne, werd door een schot in het hoofd getroffen en overleed eveneens. H. Hartekamp, als loopjongen werkzaam bij een apotheek, werd in de Spoorstraat, vlak bij de Machinefabriek Stork, op het moment, dat de arbeiders juist de fabriek ingingen, door een schot in het linkerbeen geraakt; de man heeft een been moeten missen 273 ).

Ook werden verschillende personen door Duitsers opgepakt en op overvalwagens weggevoerd. Het was toen - aldus Ir C. Beets - ,een ware terreur en wij voorzagen wel, dat het een vreselijk bloedbad zou worden; tot onze redding ging gelukkig de sirene voor luchtalarm" 274). De Duitsers vlogen weg en de arbeiders vluchtten uit de fabriek. De meisjes, die in het "Verenigingsgebouw" de lonen uitbetaalden aan diegenen, die dit Donderdag nog niet hadden ontvangen, lieten de kistjes met geld in de steek en verdwenen eveneens.

$\mathrm{Na}$ het luchtalarm kwamen de arbeiders en de Duitsers terug. De laatsten

267) Zie: 261), blz. 2 en 3

268) Ir C. Beets verklaart daarentegen, dat de Duitsers tot half elf zouden wachten. Zie: Verslag No. XX, blz. 4.

269) Zie: a. Verslag No. LVII, blz. 3.

b. Verslag No. XLIX, blz. 9.

270) Zie: 268), blz. 5 .

271) Zie: Verslag No. XLIII, blz. 4.

272) Zie: a. Bijlage 67.

b. Verslag No. XXXII, blz. 1.

273) Zie: a. Bijlage 68 .

b. Verslag No. CCLIX.

c. Hoofdstuk VI.

274) Zie: 263), blz. 5 . 
liepen de fabriek door en ,,dreigden de mensen, die geen overall aan hadden of niet werkten, dat zij aan het werk moesten gaan" 275).

Dezelfde morgen werd van alle middel- en groot-bedrijven, alsmede blijkens een aantekening in het politie-dossier Hengelo 276) — van ,de voor het leven noodzakelijke bedrijven" gevorderd, dat vóór half één ${ }^{277}$ ) lijsten ingeleverd werden met de namen van arbeiders en beambten, die niet op het werk verschenen waren. Uitgezonderd waren de bedrijven, waarvoor aan het personeel in verband met de viering van de eerste Mei „vrij was verleend" en waar de tegenorder, dat wèl gewerkt moest worden, niet tijdig bekend was. De lijsten moesten ondertekend zijn door de directies, en "door terzake deskundige personen" op kamer 7 van het politie-bureau te Hengelo worden ingeleverd 278 ).

In hoeverre dit bevel door de directies werd uitgevoerd, is niet met zekerheid na te gaan. (Wel werd door de Machinefabriek Stork een lijst opgemaakt, waarop vermeld stonden de namen van die personen, wier aanwezig- heid door contrôle-klokken niet vastgesteld kon worden 279)).

Dat de Duitsers al direct voor de Machinefabriek Stork een bijzondere belangstelling hadden, blijkt uit het feit, dat daar Zaterdagmiddag enige Duitse officieren kwamen - waaronder Hauptmann Ney - die weten wilden, wie de aanstichters van de staking waren geweest. $Z_{\mathrm{ij}}$ vroegen, of de directie er niet van op de hoogte was, dat één der ingenieurs tot de hoofd-aanstichters behoorde. De Duitsers bedoelden F. M. Loep. Ofschoon de directie betoogde, dat deze ingenieur absoluut geen schuld kon hebben, werd deze man later toch door de Duitsers gefusilleerd 280).

In de nacht van Zaterdag op Zondag werden vele personen door de Duitsers van hun bed gelicht. Naast enkele directeuren van grote fabrieken, zoals C. T. Stork, werden vele andere personen gearresteerd, die vroeger een of andere functie hadden uitgeoefend in vakverenigingen en politieke partijen. Men werd gebracht naar café Haverkate in Hengelo en moest daar tot Zondagavond blijven. De gehele Zaterdagnacht en Zondag werden gearresteerden uit verschillende plaatsen uit Twente in dit café binnengebracht. Op Zondagavond werd aan deze mensen door de Duitsers gezegd, dat het gevaarlijk was in de buurt van zo veel grote fabrieken onder een glazen dak te verblijven. $Z_{i j}$ werden daarop in overvalwagens niet - zoals gezegd werd naar een school gebracht, maar naar Vught 281). Enkele N.A.F.-leden als mede o.a. C. T. Stork werden vrijgelaten.

275) Zie: Verslag No. XXII, blz. 4.

276) Zie: Bijlage 69.

2i7) Krachtens een aantekening in een dossier der Machinefabriek Gebr. Stork $\mathcal{E}$ Co. N.V. betreffende de Meistaking ( $\mathrm{Zie}$ : Bijlage 70 ) moesten vóór 12 uur lijsten met namen worden ingeleverd.

278) Zie: 276).

279) Zie: Bijlage 71.

280) Voor bijzonderheden zie: Hoofdstuk VI.

281) Zie: a. Verslag No. CL, blz. 6.

b. Verder Hoofdstuk VI. 
M a a n d a g. - De volgende morgen (Maandag 3 Mei 1943) werd door alle personelen van de Hengelose fabrieken het werk volledig hervat.

Dezelfde morgen moest de leider van elk bedrijf ,,als eerste op de arbeidsplaats aanwezig zijn" 282). Ongeveer een uur na de gebruikelijke aanvangstijd moest een schriftelijk verslag worden uitgebracht aan de Dienststelle van de Sicherheitspolizei. Medegedeeld moest worden, welke arbeidskrachten eventueel niet op het werk waren verschenen. Zo heeft bijv. de Machinefabriek Stork lijsten ingeleverd. Achter de naam van iedere persoon, die afwezig was, werd echter een of andere reden opgegeven. Iedereen was verantwoord afwezig (ziekte, ongeval, karwei enz.) 283).

In het voorgaande werd reeds vermeld, dat de Duitsers met bijzondere belangstelling informeerden naar - volgens hen - een der hoofdaanstichters van de staking. Het was hun niet onbekend gebleven, dat bij de Machinefabriek Stork de staking het eerst uitgebroken was. Vandaar, dat zij in deze fabriek een nader onderzoek instelden 284). Maandagavond werden nog de kernleden van de Machinefabriek Stork van huis gehaald en naar het politiebureau te Hengelo gebracht. Dezelfde avond echter werden allen weer losgelaten 285). Dinsdagmorgen werden met een auto veertien bedrijfschefs en afdelingshoofden van de Machinefabriek Stork 286) door de Duitsers naar het politiebureau gebracht, doch ook - met uitzondering van F. M. Loep - weer vrijgelaten .s Middags werd F. G. Stork naar het politiebureau gehaald en werden hem verschillende vragen gesteld betreffende F. M. Loep 287).

Deze laatste werd door de Duitsers standrechtelijk veroordeeld 288).

\section{ENSCHEDE}

D onderdag. - Toen bekend werd, dat in Hengelo gestaakt werd, legden verschillende Enschedese bedrijfspersonelen eveneens het werk neer. Dat in Enschede niet gesproken kon worden van een centraal punt, van waaruit de staking zich uitbreidde, blijkt wel hieruit, dat arbeiders van verschillende fabrieken direct na het verlaten der bedrijven elkaar op straat troffen.

Zo ontmoetten bijv. arbeiders, werkzaam bij J. F. Scholten $\&$ Zn. N.V. personeel van Blijdenstein $\mathcal{E}$ Co. N.V. 289). Arbeiders van Van Heek \& Co.

282) Zie: Bijlage 72.

283) Zie: Verslag No. XX, blz. 7.

284) Eveneens werd een onderzoek ingesteld bij de N.V. Fabriek van Electrische Apparaten v/h F. Hazemeyer $\mathcal{E}$ Co. en N.V. Hazemeyer's Fabriek van Signaalapparaten. Het verhoor, door de Ulntersturmführer Lorentz afgenomen, had voor het personeel geen nadelige gevolgen. Zie: a. Verslag No. XXXVI, blz. 3.

b. Verslag No. XXXVII, blz. 1 .

c. Verslag No. XL, blz. $2 \mathrm{t} / \mathrm{m} 4$.

285) Zie: Verslag No. XXIV, blz. 9 t/m 13.

Een der kernleden, die Maandagavond niet thuis bleef, ging zich de volgende dag - nadat hij gehoord had, dat de kernleden vrijgelaten waren - bij de Duitsers melden. Ook hij kon spoedig vertrekken.

286) Zie: Bijlage 73 .

287) Zie: Verslag No. XXII, blz. 5 en 6.

288) Voor bijzonderheden aangaande het proces tegen F. M. Loep wordt verwezen naar Hoofdstuk VI.

289) Zie: Verslag No. CXXXIX, blz. 4. 
N.V. troffen personen, werkzaam bij Blijdenstein $\mathcal{E}$ Co. N.V. en andere be drijven 290). Op het moment, dat zij elkaar tegen kwamen, beduidden zij elkaar „volhouden" 291). Sterk werd de uitbreiding der staking bevorderd, doordat de fabrieken elkaar onderling opbelden 292 ).

Kort nadat de geruchten omtrent de staking de ronde hadden gedaan, gingen ook verschillende gemeente-bureaux en -bedrijven in staking. Evenals in Hengelo werd het gerucht verspreid, dat het personeel van de "Waterleiding" in staking zou gaan of was gegaan. Een ieder ging daarop water tappen. Bij bakkers en kruideniers was kort na het uitbreken der staking een oploop van mensen om brood en andere eetwaren in te slaan. ,Allen kregen" - zo gold voor het publiek bij één winkel 293) — ..... voor één of twee dagen brood, al was het veel roggebrood."

Die avond mocht het publiek - in tegenstelling tot Hengelo - wel op straat. In verschillende woonwijken stonden overal groepjes mensen met elkaar te praten. Daar werd reeds ,zo half en half" 294) gezegd, dat Vrijdag het - werk niet hervat zou worden. Daar er in verschillende arbeidersbuurten nog geen zekerheid bestond, wat de volgende dag zou gebeuren, gingen de volgende morgen (Vrijdag) om 6 uur enkele arbeiders de stad in om te zien, wat er zou gebeuren. Omstreeks deze tijd schijnen de meeste vroege ploegen aan het werk te zijn gegaan. Later pas kreeg dit groepje arbeiders de indruk, dat de staking meer algemeen begon te worden 295). Bedrijven, zoals RamieUnion N.V., Spinnerij ,"Tubantia" v/h B. W. \& H. ter Kuile en N.V. Katoenspinnerij „Bamshoeve", die op Donderdag nog hadden doorgewerkt, gingen Vrijdagmorgen in staking.

V rij d a g. - 's Morgens om 7-8 uur waren de Duitsers al op pad. $Z_{\text {ij }}$ meenden door schieten de arbeiders de fabriek in te krijgen. Zo openden zij het vuur op personeel van de Spinnerij ,Tubantia" 296). Het resultaat was echter, dat meisjes, bij deze fabriek werkzaam, in de garage van de $\mathrm{T}$ (wentse) $\mathrm{E}$ (lectrische) $\mathrm{T}$ (ramweg Maatschappij) vluchtten. Een ooggetuige vertelt:

\footnotetext{
,Wij zijn de straat, die langs de fabriek loopt, in gevlucht, maar wij hadden het ongeluk, dat wij nu vóór de overvalwagen uit liepen. Als wij langzamer liepen om hem te laten passeren, dan ging de wagen ook weer langzamer rijden. Wij zijn tenslotte maar een woning in gevlucht, maar de overvalwagen bleef hier steeds rijden. Als wij verder wilden, moesten we steeds kleine stukjes lopen en weer een tuin of woning in vluchten, omdat de wagen langs kwam" 297).
}

290) Zie: Verslag No. CIII, blz. 1.

291.) Zie: 290).

292) Zie: a. Verslag No. CXL, blz. 2.

b. Verslag No. CXXXVIII, blz. 1

293) Zie: Brief van mevrouw J. L. J. $-N$. Enschede, geen datum, bijlage 74.

294) Zie: Verslag No. CXL, blz. 4.

295) Zie: 294), blz. 4.

296) Zie: 294), blz. 3.

297) Zie: 294), blz. 5. 
Evenals in Hengelo vonden ook in Enschede deze dag geen bijzonderheden plaats. Het was in de stad niet bijzonder druk. De meeste mensen bleven thuis of gingen naar de boeren melk halen.

In de loop van de dag onderhielden de fabrikanten onderling contact. Er waren bij hen mededelingen binnengekomen, dat lijsten van stakers ingeleverd moesten worden. Teneinde gezamenlijk een houding te bepalen, werd in de directie-spreekkamer van Van Heek $\mathcal{E}$ Co. N.V. (de directeur van deze fabriek was tevens voorzitter van de ontbonden „Fabrikanten-Vereniging") een vergadering van 15 à 20 fabrieksdirecteuren belegd. Daar werd besloten, ,,dat met behulp van alle ten dienste staande middelen voorkomen zou worden, dat lijsten zouden worden gemaakt, teneinde de Duitsers geen gelegenheid te geven, slachtoffers te maken" 298). Daar tevens, zowel door de politie 299) als door de burgemeester en de gemeente-secretaris 300) nog in de loop van de avond aan de directies medegedeeld werd, dat diegene, die niet op Zaterdagmorgen aan het werk zou zijn, zou worden doodgeschoten, besloten de verschillende fabrikanten al het mogelijke aan te wenden om de arbeiders alsnog te waarschuwen, op tijd in de fabriek te zijn 301).

Een aansporing - maar dan van geheel andere aard - om het werk te hervatten, lag in het optreden der Duitsers op Vrijdagavond. Evenals in Hengelo werden Vrijdagavond in Enschede de decreten betreffende de afkondiging van het politie-standrecht aangeplakt. Om 20 uur moest de bevolking binnen zijn, op straffe van te worden doodgeschoten. Vóór die tijd echter raasden de Duitsers al met hun wagens door de straten en schoten links en rechts. Zo werd $H$. Slotboom, die om ongeveer 19.20 uur op straat was, door de Duitsers zodanig aangeschoten, dat hij de volgende morgen vroeg reeds was overleden 302). De 19-jarige J. B. J. Steinmeyer, die bij het vliegveld juist bezig was zijn paarden in te spannen om naar het station te gaan, werd om 19.55 uur getroffen. Ook hij overleed aan zijn verwondingen 303 ). Omstreeks 20 uur werd iemand, die schoten hoorde en uit nieuwsgierigheid ging kijken, eveneens doodgeschoten. De man had de straat echter nog niet betreden, maar bleef "binnen de poort in een steeg tussen de huizen" 304 ).

Op een ieder, die de Duitsers zagen lopen, ook wanneer hij in zijn tuin was, werd geschoten 305 ).

Om plm. 20 uur bleef de bevolking in die delen van de stad, waar de Duitsers nog niet verschenen waren, voor de deur op straat staan. „De mensen beseften de ernst van de toestand niet" ${ }^{306}$ ). Tot deze conclusie kwam de

298) Zie: Verslag No. CII, blz. 3.

299) Zie: a. Verslag No. CII, blz. 4.

b. Verslag No. CVI, blz. 1 en 2 .

300) Zie: Brief van Mr J. W. A. v. H., Johannesburg, 20 Mei 1947, Bijlage 75.

301) Zie: Bijlage 76.

302) Zie: Verslag No. CXLIV, blz. 1.

303) Zie: Verslag No. CXLV, blz. 1.

304) Zie: Verslag No. CXLVI, blz. 1.

305) Zie: Verslag No. LXXXVIII, blz. 4.

306) Zie: 305, blz. 3. 
Enschedese Hoofdinspecteur van Politie, A. T. Bruyning, toen hij met de Commissaris van Politie, de NSB-er A. Berends, een rondrit maakte door de buurten de Stevenvennen, Braker en Pathmos, waar de bevolking op straat stond te praten. Op de Braker ging Bruyning een huis binnen, waarvoor hij mensen had zien staan en zeide: ,Jullie beschouwen het als een grapje, maar er zijn al doden gevallen, want de Duitsers schieten maar raak. Dit is de reden, waarom ik zo optreed. Straks komen de Duitsers en schieten, en dan vallen er werkelijk slachtoffers" 307 ).

Naar aanleiding van de afkondiging van het politie-standrecht, het niet in staking gaan van het spoorwegpersoneel en de boven omschreven gebeurtenissen gingen verschillende fabrikanten er toe over, hun personelen te waarschuwen, het werk te hervatten.

$Z$ a $t$ e $r$ d a g. - Zo begonnen reeds de bazen, werkzaam bij J. F. Scholten $\& \mathrm{Zn}$. N.V., Vrijdagnacht om 4 uur het personeel te waarschuwen. $Z_{\text {ij }}$ deelden de arbeiders mede, dat in opdracht van de Duitse politie alle bedrijven op - Zaterdagmorgen half negen op het politie-bureau lijsten moesten inleveren met de namen en adressen van alle arbeiders, die die morgen niet aan het werk waren gegaan. Tevens werd hun gezegd, dat diegenen, die niet verschenen, zouden worden doodgeschoten ${ }^{308}$ ). Een rondschrijven met dezelfde strekking om Maandagmorgen het werk te hervatten werd verstuurd door Nico ter Kuile \& Zn. N.V. ${ }^{309}$ ).

Verreweg de meeste fabrikanten gingen er echter pas hetzij Zaterdagmorgen hetzij, zoals bij de N.V. Rigtersbleek v/h G. J. van Heek \& Zn., Zaterdagmiddag toe over, bazen of ander personeel bijeen te roepen. De instructies, bestemd voor de arbeiders, luidden om op Maandagmorgen het werk te hervatten 310 ). Uit een overzicht, betrekking hebbend op de werkhervatting in de twaalf grootste textielfabrieken in Enschede, blijkt, dat Maandagmorgen overal het werk hervat werd. Het personeel van J. F. Scholten \& Zn. N.V. en van N. J. Menko N.V. was reeds Zaterdagmorgen gedeeltelijk opgekomen. Het personeel van Blijdenstein $\mathcal{E}$ Co. N.V. was die dag ook in de fabriek aanwezig, doch werkte niet 310 a).

Om nog meer druk op de bevolking uit te oefenen gingen de Duitsers er ook Zaterdagmorgen toe over in-het-wilde-weg op de bevolking te schieten. Een jongen van 19 jaar, die op straat was, werd omstreeks 12 uur getroffen. Dezelfde dag overleed hij aan zijn verwondingen 311 ).

Verder werden - evenals in Hengelo - velen gearresteerd 312). Zo werden 307) Zie: 305 , blz. 4 .

308) Zie: a. Bijlage 76.

b. Verslag No. CXXXVIII, blz. 2. Een derde van het personeel van J. F. Scholten $\mathcal{E} \mathrm{Zn}$. N.V. hervatte op Zaterdag het werk.

309) Zie: Bijlage 77. Dit personeel hervatte op Maandag 3 Mei de arbeid.

310) Zie: a. Verslag No. CVII, blz. 3.

b. Verslag No. XC, blz. 3 .

c. Verslag No. CXXXV, blz. 2.

310a) Zie: Schema IV.

311) Zie: Verslag No. CXLIII, blz. 1.

312) Zie: a. Verslag No.LXXXVIII, blz. 4. 
alleen al van de Meubelfabriek "Glanerbrug” N.V. negen arbeiders van huis gehaald en naar Vught vervoerd 313 ).

Mede onder de druk van deze arrestaties hervatten de personelen op Maandagmorgen het werk. In bijna alle fabrieken kwamen de Duitsers controleren. Hierbij hebben zich verder geen bijzonderheden voorgedaan.

SCHEMA IV

\begin{tabular}{|c|c|c|}
\hline \multirow[b]{2}{*}{ Naam van de Fabriek } & \multicolumn{2}{|c|}{ werk hervat op } \\
\hline & $\begin{array}{l}\text { Zaterdag } \\
1 \text { Mei } 1943\end{array}$ & $\begin{array}{c}\text { Maandag } \\
3 \text { Mei } 1943\end{array}$ \\
\hline $\begin{array}{l}\text { N.V. Katoenspinnerij ,BBamshoeve" } \\
\text { Blijdenstein \& Co. N.V. } \\
\text { N.V. Boekelose Stoomblekerij } \\
\text { Van Heek \& Co. N.V. } \\
\text { Gebr. van Heek \& } \\
\text { Gerhard Jannink \& Zn. N.V. } \\
\text { Nico ter Kuile \& Zn. N.V. } \\
\text { N. J. Menko N.V. } \\
\text { N.V. Ramie-Union } \\
\text { N.V. Rigtersbleek v/h G. J. van Heek \& Zn. } \\
\text { J. F. Scholten \& Zn. N.V. } \\
\text { N.V. Spinnerij ,Tubantia" v/h B. W. \& } \\
\text { H. ter Kuile }\end{array}$ & $\begin{array}{l}1 \text { Mei } 1943 \\
\text { gedeeltelijk } \\
\text { 1/3 van pers. } \\
\text { aanwezig }\end{array}$ & $\begin{array}{rll}3 & \text { Mei } & 1943 \\
3 & \text { Mei } & 1943 \\
3 & \text { Mei } 1943 \\
3 & \text { Mei } 1943 \\
3 & \text { Mei } 1943 \\
3 & \text { Mei } 1943 \\
3 \text { Mei } 1943 \\
\text { alg. hervat } \\
3 \text { Mei } 1943 \\
3 \text { Mei } 1943 \\
3 \text { Mei } 1943 \\
\text { volledig hervat } \\
3 \text { Mei } 1943\end{array}$ \\
\hline
\end{tabular}

\section{ALMELO}

D o n d e r d a g. - In Hoofdstuk III werd reeds vermeld, dat de telefoniste van Stork Palthe's Textielveredelingsbedrijven N.V. in Almelo opbelde en zei, dat een staking uitgebroken was. Vanuit Palthe werd dit bericht telefonisch aan andere bedrijven doorgegeven. In korte tijd was zo ook in Almelo op Donderdagmiddag de staking een feit. Deze had echter - vergeleken met de staking op Donderdagmiddag in Hengelo en Enschede - niet zo'n algemene omvang. Van de negen door ons bezochte grote fabrieken, gingen er slechts vier in staking. Belangrijk is in dit verband echter, dat van de plm. 4200 arbeiders, die bij deze negen fabrieken werkzaam waren, die dag reeds bijna 2100 arbeiders het werk hadden neergelegd. Door dit feit was een verdere uitbreiding verzekerd. Op Vrijdag volgden dan ook prompt alle andere bedrijven, alsmede verschillende gemeente-kantoren en -bedrijven.

Evenmin als in Hengelo en Enschede was in Almelo van een uiterlijke opwinding sprake. „Het was net, alsof de fabriek gewoon uitliep", verklaarde

b. Voor een beschrijving van de belevenissen van H. J. Blijdenstein B.Jzn., directeur van Blijdenstein \& Co. N.V., die tien dagen gearresteerd is geweest in Hengelo en Enschede, zie: Verslag No. XCIV.

313) Zie: Lijst No. 92. 
een kantoorbediende, werkzaam bij Palthe ${ }^{314}$ ). Demonstraties van de fabriek verlatende arbeiders kwamen niet voor.

Ook in Almelo gingen de winkeliers er toe over, de winkels te sluiten. Dit gebeurde reeds, terwijl de arbeiders de fabrieken verlieten ${ }^{315}$ ). Eveneens gingen geruchten, dat de Spoorwegen in staking waren gegaan. Waarschijnlijk is de oorsprong hiervan o.a. te zoeken in de wens der bevolking, dat het spoorwegpersoneel aan deze actie zou deelnemen. Zo werd door personeel van Palthe op het moment, dat het de fabriek uitliep, gezegd: „Als de Spoorwegen nu ook maar meestaken" 316 ).

Geruchten gingen, dat het personeel van de Gemeente-Waterleiding in staking was gegaan. Vandaar dat bij de Almelose Coöp. Melkinrichting velen in de remise kwamen om water te halen. De mensen (sommigen sloegen wel 100 à 200 liter water in) waren zo zenuwachtig, dat ze bijna begonnen te vechten 317 ).

Dat de arbeiders en arbeidsters na het verlaten der fabriek niet meer op straat bleven, is ook in Almelo te constateren. Toen Dr C. G. Recter - chef van de sociale afdeling van $\mathrm{H}$. ten Cate $\mathrm{Hzn}$. \& Co. N.V. - Donderdagmiddag met de trein om ca. 18 uur in Almelo aankwam ,was het stil" 318).

Donderdagavond, ca. 23 uur, kwamen in Almelo de Duitsers in twee grote vrachtwagens aan. Daar hun komst van te voren was aangekondigd, kreeg een agent van politie opdracht, de Duitsers (zij behoorden tot de Ordnungs polizei) aan de grens der gemeente op te wachten. Eerst gingen zij naar het Gemeentehuis, daarna naar de Ortskommandant en vervolgens naar een school in de Bornerbroeksestraat, waar zij hun kwartier vestigden. Die nacht rukten de Duitsers niet meer uit.

Diezelfde avond en nacht werd het Almelose politiepersoneel ervan in kennis gesteld, om Vrijdagmorgen ca. 5 uur aanwezig te zijn.

$\mathrm{Vr}$ ij d a g. - Die morgen kregen 24 man van het politiepersoneel opdracht, naar de school te gaan, waar de Duitsers gelegerd waren. Daardoor was van een normale straatdienst ( 5 man moesten op het politiebureau blijven) geen sprake. Voorzover er agenten straatdienst moesten verrichten, waren zij in gezelschap - en daarmee in feite onder toezicht - der Duitsers. Andere agenten moesten met de Duitsers naar de fabrieken om deze te ,beschermen" 319).

314) Zie: Verslag No. LXXVII. blz. 1.

315) J. B. ter Brugge, economisch-technisch adviseur bif $H$. Smits $\mathcal{E}$ Co. verklaart o.a., dat het sluiten van de winkels en het in staking gaan der arbeiders "een gemengd proces" was. Zie: Verslag No. LXII, blz. 1.

316) Zie: Verslag No. LXXVIII, blz. 1.

317) Zie: Verslag No. CCX, blz. 1 en 2.

318) Zie: Verslag No. LXIX, blz. 2.

319) Zie: a. „Politioneel Maandrapport over het tijdvak 15 April t/m 14 Mei 1943. Gemeente Almelo." Behalve de 56 officieren en minderen der Ordnungspolizei, die Donderdagavond aankwamen, arriveerden in de loop van de stakings dagen te Almelo alsnog 30 man Orónungspolizei.

b. Verslag No. LIX, blz. 3. 
Vele bijzonderheden zijn van deze Vrijdag 30 April niet te vermelden. Wel gingen, zoals reeds vermeld, de andere fabrieken in staking. Hun voorbeeld werd gevolgd door onderwijzend personeel 320 ). Hoe algemeen de staking in Almelo was, moge o.a. blijken uit het feit, dat ook een tandtechniker het werk neerlegde 321 ).

Ondanks het feit, dat de staking zich op Vrijdag uitbreidde, is gebleken, dat arbeiders wel aan enkele fabrieken waren verschenen. Zo waren er enkelen, werkzaam bij $\mathrm{H}$. ten Cate $\mathrm{Hzn}$. \& Co. N.V., ,die hun brood en kannetje koffie meegebracht hadden" 322 ).

Personeel van de Hollands-Zwitserse Borduurfabriek Fa. Egger \& Cie. vluchtte alle kanten op, toen de Duitsers een mitrailleur bij deze fabriek opstelden ${ }^{323}$ ). Het personeel van de N.V. Leeuwarder Textiel Mij durfde niet nader te komen, doordat gewapende Duitsers voor de fabriek bleven staan ${ }^{324}$ ). In het algemeen echter - zo luiden de politie-verklaringen waren voor de fabrieken niet veel arbeiders verschenen.

Behalve voor de bedrijven waren ook in de stad op bepaalde punten mitrailleurs opgesteld. Dit is de reden waarom slechts weinig mensen op straat waren 325 ). Wel stonden kleinere groepjes wat met elkaar te praten, maar deze werden door de Duitsers direct uiteen gejaagd. In de namiddag werd ook te Almelo het politie-standrecht afgekondigd.

Vrijdagnacht werden verschillende fabrikanten door de politie opgebeld en werd hun medegedeeld, dat een gevaarlijke toestand ontstaan was 326 ). Tevens werd gezegd, dat de directie - die aansprakelijk gesteld werd voor de staking - er voor moest zorgen, dat het bedrijf weer op gang kwam 327 ).

$\mathrm{Z}$ aterdag. - Van een algemene werkhervatting op Zaterdag was in Almelo geen sprake. In sommige fabrieken was een deel der arbeiders aanwezig; in andere weer niemand.

Blijkbaar naar aanleiding van deze toestand riep de Beauftragte Weidlich de Almelose fabrikanten op Zaterdagmiddag 1 Mei op het Gemeentehuis bijeen. Aanwezig waren verder: de burgemeester (Mr M. Sichterman), de Hoofd-Inspecteur van Politie (P. Brasser) en een wachtmeester van de Grüne

320) „, "Vaandag hebben jullie geen school, want de Duitsers hebben hun woord gebroken", werd aan een paar kinderen, die gekomen waren, uitgelegd. Met ons drieën bezochten we andere scholen en bereikten, dat verscheiden collega's naar huis gingen. 's Middags (Vrijdagmiddag - Noot van de auteut) was de staking der onderwijzers vrijwel algemeen." Zie: "Verslag April-Meistaking 1943" van H. Kieft, onderwijzer te Almelo.

321) „Ook mijn techniker legde het bijltje erbij neer, zodat ik gedurende een week geen prothetisch werk kon afleveren." Zie: Brief van G. A. G., tandarts, Almelo.

322) Zie: Verslag No. LXIX, blz. 3.

323) Zie: Verslag No. LIX, blz. 3.

324) Zie: a. Verslag No. LXXII, blz. 1.

b. "Ik stond" - aldus een bandleidster van deze fabriek - ,een eind (van de fabriek) af en zag toen Duitsers lopen met het geweer in de aanslag. Wij hadden het hart niet om bij de fabriek van de fiets te stappen." Zie; Verslag No. LXXIII, blz. 3.

325) Zie: 323), blz. 3.

326) Zie: Verslag No. LXXII, blz. 1.

327) Zie: Verslag No. LXXXI, blz. 1. 
Polizei. De Beauftragte begon zijn uiteenzettingen - aldus is in een dagboek van $\mathrm{Tj}$. Bendien aangetekend 328 ) - met op te merken, ,dat volgens het Standrecht een ieder, die niet werkt, doodgeschoten kan worden en dat dit ... door de Hollandse Klompentelegraaf reeds voldoende bekend” zou zijn. „De Hollanders dachten zeker, dat de Duitsers geen 30.000 mensen zouden doodschieten, maar zij zullen dit gerust doen, desnoods 50.000." Weidlich wenste van elke fabrikant te weten, wanneer de staking begonnen was, en hoeveel leden van het personeel Zaterdagmorgen aanwezig waren geweest. Uit de aantallen, die hem bij deze gelegenheid werden opgegeven, blijkt, dat slechts een klein deel van de Almelose fabrieksbevolking het werk had hervat.

Reeds 's morgens had H. Smits, directeur van de N.V. Almelose Confectiefabriek v/h H. Smits \& Co., een bezoek van Weidlich en de burgemeester gehad. Bij deze gelegenheid werd de eis gesteld, dat het werk in zijn fabriek onmiddellijk zou worden hervat. Doordat toen via de Radiodistributie-Centrale een oproep tot het personeel werd gedaan om alsnog te verschijnen, kon Smits op de bijeenkomst op het Gemeentehuis opgeven, dat 150 man aanwezig waren 329 ).

De vergadering op het Gemeentehuis eindigde met de eis van Weidlich, dat lijsten moesten worden ingeleverd van het personeel, dat op Zaterdag het werk niet had hervat.

$\mathrm{Na}$ deze bespreking was het oordeel der fabrikanten, dat het gezien de veranderde toestand het beste was, de personelen op de hoogte te stellen. Zo werden bij verschillende fabrieken briefjes opgehangen, waarin een resumé werd gegeven van de bespreking op het Stadhuis. De personelen werd aangeraden Maandag het werk te hervatten ${ }^{330}$ ).

Arbeiders, die buiten Almelo woonden, werden gewaarschuwd door tussenkomst van politie-instanties ${ }^{331}$ ) en spoorwegstations ${ }^{332}$ ).

Diezelfde dag werden door de Duitsers enkele personen gearresteerd. De Almelose politie slaagde er echter in, verschillenden van hen weer vrij te krijgen ${ }^{333}$ ). 's Avonds werd door een Duitse patrouille een vrouw doodgeschoten en haar man zwaar gewond ${ }^{334}$ ).

$\mathrm{M}$ a a n d a g. - Maandagmorgen werd de arbeid in Almelo vrijwel algemeen hervat. $\mathrm{Bij}$ Palthe daarentegen kwamen te weinig mensen om het bedrijf te laten functionneren ${ }^{335}$ ). Ook bij Bendien waren verschillende meisjes Maandagmorgen niet opgekomen ${ }^{336}$ ).

328) Zie: Bijlage 78 .

329) Zie: 328).

330) Zie: a. Verslag No. LXXIX, blz. 3.

b. Verslag No. LXXXI, blz. 2.

c. Verslag No. LXVIII, blz. 2.

d. Bijlage 79 .

331) Zie: Verslag No. LXXXIV, blz. 2.

332) Zie: Verslag No. LXXV, blz. 3.

333) Zie: Verslag No. LIX, blz. 4.

334) Zie hiervoor uitvoeriger: Hoofdstuk VI.

335) Zie: Verslag No. LXXV, blz. 2.

336) Zie: Verslag No. LXVI, blz. 3. 
De Duitsers waren die dag op de fabrieken om te controleren of de personelen aanwezig waren. Bijzonderheden hebben zich hierbij niet verder voorgedaan.

\section{BORNE}

D o n d e rd a g. - Donderdagmiddag, 29 April 1943, omstreeks 13 uur13.30 uur was het het personeel van de N.V. Stoomspinnerijen en -weverijen v/h S. J. Spanjaard ter ore gekomen, dat de Nederlandse militairen zich voor Duitse krijgsgevangenschap moesten melden. Er ontstond onrust in de fabriek en verschillende personen spraken er over om het werk neer te leggen. „Van de staking bij Stork ... was toen nog niets bekend" 337 ).

Enige tijd later, omstreeks 15 uur, kwamen stakende arbeiders van Stork aan de poort en wekten het personeel van Spanjaard op, het Hengelose voorbeeld te volgen 338$)$. Om ongeveer 16 uur was in deze grootste fabriek van Borne het personeel vertrokken, ondanks de pogingen van directie-zijde om de arbeiders en arbeidsters binnen te houden 339 ).

Ook de draadvlechterij Jonge Poerink $\&$ Co. ${ }^{340}$ ) ging in staking. Dat deden ook de gemeentelijke instellingen van Sociale Zaken en de Gemeentebedrijven ${ }^{341}$ ).

$\mathrm{Na}$ het uitbreken van de staking trachtte ook hier een ieder zoveel mogelijk levensmiddelen in huis te krijgen. Ook werden emmers en teilen vol water getapt, tot men uiteindelijk ,vvil inplaats van goed drinkwater kreeg" 342 ). 's Avonds werden nog de arbeiders, die bewakingsdiensten (zoals bijv. voor luchtalarm, brand enz.) bij Spanjaard te verrichten hadden, bijeen geroepen. Aan J. A. Brasser (die naar aanleiding van deze staking enkele dagen later gefusilleerd werd) zeiden zij, dat er een algemene staking was en dat men dus onmogelijk kon werken ${ }^{343}$ ).

V r ij d a g. - Donderdagavond plm. 23 uur werd de directeur van Spanjaard, Ir Ch. Gielen, verzocht, op de fabriek te komen. Daar werd hem door een commandant van de Grüne Polizei gezegd, dat diegenen, die Vrijdag 7 uur niet aan het werk zouden zijn, doodgeschoten zouden worden ${ }^{344}$ ). Vrijdagmorgen kwam echter niemand van het personeel opdagen. Melkrijders, die toen nog niets van de staking wisten, werden door stakende arbeiders

337) Zie: Verslag No. CL, blz. 1.

338) Zie: 337), blz. 1.

339) "In verband met het feit, dat wij sedert 1942 een Verwalter hadden en dus uit den aard der zaak voorzichtig moesten zijn..." Al.dus de directeur van Spanjaard, Ir. Ch. G. Zie: Verslag No. CXLIX, blz. 1.

340) Zie: Lijst No. 50.

341) Zie: Lijsten No. 43 en 44.

342) Zie: a. 337), blz. 1.

b. Brief van H. G. Br. Borne, geen datum. Bijlage 80 .

343) „Als er immers een staking is en je gaat werken, ben je een onderkruiper en in de regel ben je dan niet gelukkig. Dat was zo het motief van de mensen, die niet wilden bewaken. De nachtwakers daarentegen hebben gezegd, dat zij wel wilden bewaken." Zie: 337), blz. 2.

344) Zie: 339, blz. 1. 
uit Borne aangespoord met hun melk naar de boeren terug te keren ${ }^{345}$ ).

Veel bijzonderheden vonden die dag verder niet plaats ${ }^{346}$ ). Wel waren wat mensen opgepakt, die naar het hotel "De Keizerskroon" (waar de Duitsers waren gevestigd) werden gebracht om aardappelen te schillen 347 ).

Vrijdagavond werd het politiestandrecht afgekondigd. Even na 20 uur trok de Grüne Polizei er reeds op uit en "haalde" de eerste personen uit Borne "op" 348). Ook werd op de bevolking, die zich niet al te nauwkeurig aan de voorschriften hield om na 20 uur binnen te blijven, geschoten.

$Z$ at erdag. - Zaterdagmorgen kwam een deel der arbeiders - naar schatting 200 personen — in het bedrijf van Spanjaard terug. Gewerkt werd er niet 349 ).

Ongeveer om 11 uur ,,begon de eerste mensenjacht in het groot in ons dorp" schrijft H. G. Brink in Spinspan (fabrieksorgaan van de N.V. Spanjaard). „Overvalwagens met gewapende groenen grepen de mannen van de straat en haalden hen uit de huizen. Velen vluchtten de bossen in, maar ook velen werden eerst naar "De Keizerskroon" gebracht en daarna naar Hengelo" 350 ). Later in de middag werden allen echter weer vrijgelaten, alsmede diegenen, die Vrijdagavond gearresteerd waren 351 ).

In de loop van de dag werd aan het personeel van de N.V. Spanjaard door middel van een "Bekendmaking" van deze fabriek medegedeeld, dat op Maandag 3 Mei weer volgens de normale werktijdregeling zou gewerkt worden 352 ).

Zaterdagnacht werden verschillende mensen uit huis gehaald en naar het hotel „De Keizerskroon” gebracht. In de loop van de volgende dag (Zondag) werd nog een aantal boeren (12 à 14 man) gearresteerd. Deze laatsten mochten in Borne blijven in tegenstelling tot de twaalf Zaterdagnacht gearresteerde personen. Deze werden Zondagmiddag om plm. 16 uur naar Hengelo vervoerd. $\mathrm{Bij}$ het café „Haverkate" in Hengelo werden zij afgezet, waar toen reeds een groot aantal personen, waaronder vele bekenden uit politiek en vakbeweging, gevangen zat. Vanuit dit café werden de Bornse gearresteerden met de anderen naar $V$ ught vervoerd ${ }^{353}$ ).

345) Zie: Verslag No. CCXIII, blz. 1.

346) Zie: 342) b.

347) Zie: 337), blz. 2 en 3.

348) a. ,Er werden 12 arbeiders van huis gehaald en die zouden direct doodgeschoten worden, indien de andere arbeiders zich Zaterdag, 1 Mei 1943 vóór 11 uur niet aan de fabriek gemeld hadden." Zie: Lijst No. 50.

b. Zie: 337, blz. 3 .

349) Zie: 337), blz. 3 .

350) "Spinspan" van en voor het personeel der N.V. Stoomspinnerijen en -weverijen v/ h S.J. Spanjaard te Borne. Juli 1947. Jaargang 2, Nummer 3, blz. 23 en 24.

351) Zie: a. 337), blz. 4 en 5.

b. 350 ), blz. 24 .

c. Tot de gearresteerden behoorde ook de directeur van de Coöp. Stoomzuivelfabriek en Melkinrichting "Borne". Zie hiervoor uitvoeriger: Verslag

352) Zie: Bijlage 81 . No. CCXIII.

353) Zie: 337$)$, blz. 5 en 6. 
Op Maandag werd in Borne het werk hervat. Maandagavond werden twee chefs, werkzaam bij de N.V. Spanjaard, gearresteerd en „op de vlucht" dood geschoten. Over deze gefusilleerden zal in Hoofdstuk VI, „De slachtoffers van de staking", uitvoeriger worden geschreven.

\section{OLDENZAAL}

Donderdag. - Donderdagmiddag gingen de stakende arbeiders, die in Hengelo werkten, maar in Oldenzaal woonden, naar hun woonplaats terug. Het feit, dat $z$ ij in staking waren gegaan, was in deze gemeente spoedig bekend.

Een deel der arbeiders, werkzaam bij H. P. Gelderman $\mathcal{E}$ Zonen N.V., legde die middag het werk neer. Bij deze fabriek werd eind April 1943 in ploegen gewerkt van 5 uur -13.30 uur en van 13.30 uur -22 uur. Even vóór de schafttijd van 18 uur werden reeds door $80 \%$ van het personeel, werkzaam in de kunstzijde-weverij, de getouwen afgezet ${ }^{354}$ ). Deze arbeiders, alsmede de rest van het in de late ploeg werkende personeel, verlieten in de schafttijd de fabriek 355 ). De in de gewone dagploeg werkende arbeiders gingen vóór het einde der werktijd (18 uur) naar huis ${ }^{356}$ ).

Daar geruchten in omloop waren, dat het personeel van de Waterleidingdienst ook in staking zou gaan, begon men - evenals in andere plaatsen water te tappen ${ }^{357}$ ). Verschillende personen probeerden zo snel mogelijk iets op hun distributiebescheiden te krijgen 358 ).

$\mathrm{Vrijdag.} \mathrm{-} \mathrm{Vrijdag} \mathrm{om} 5$ uur kwam de morgenploeg van de N.V. Koninklijke Oldenzaalse Stoomweverij v/h J. Molkenboer Jr. wel op, maar zij ging om half acht, tegelijk met het opkomen van de dagploeg, in staking ${ }^{359}$ ). Enkele kleinere bedrijfjes legden die dag ook het werk neer ${ }^{360}$ ). Eveneens werd die dag aan de douane-dienst gestaakt 361 ). Van de Gemeente-diensten werkten 's morgens de Reinigingsdienst en de Dienst van Openbare Werken niet. In de middag werd het werk echter weer hervat. De diensten van Gas, Waterleiding en Electriciteit hebben niet gestaakt 362 ).

Vrijdagmorgen 7 uur kreeg het politiepersoneel van de SS-er opperluitenant B. Halm, opdracht om groepjes van meer dan 4 personen uiteen te drijven. Bij winkels, waarvoor veel publiek stond om inkopen te doen, werd die morgen door de politie geassisteerd 363 ). Op het postkantoor vond een kleine run plaats, daar verschillenden hun spaargelden opvroegen. Rond de autobussen,

354) Zie: Verslag No. CLXXVIII, blz. 5.

355) Zie: 354, blz. 2.

356) Zie: Zie Verslag No. CLXXX, blz. 1.

357) Zie: Dagboek van B. H. Hommen, gemeente-secretaris van Oldenzaal. Bijlage 61.

358) Zie: Dagboek van G. Haandrikman, hooff-conducteur bij de Nederlandse Spoorwegen.

359) Zie: Verslag No. CLXXXIX, blz. 1. Aan deze fabriek was het personeel op Donderdag niet in staking gegaan.

360) Zie: a. Lijst No. 247.

b. Lijst No. 248 .

361) Zie: Verslag No. CXC, blz. 3.

362) Zie: 357).

363) Zie: Verslag No. CLXXVI, blz. 2. 
die om 2 uur in de namiddag naar Duitsland moesten vertrekken, groepten op de Markt nogal wat mensen tezamen teneinde de wegrijdende bussen, die leeg waren, te zien. $\mathrm{Na}$ een half uur was echter alles weer rustig ${ }^{364}$ ). Ook kwamen die dag ongeveer tien Duitsers in de stad. Op de Markt werd in de lucht geschoten. Veel bijzonderheden zijn van deze dag verder niet te vermelden 365 ).

Omstreeks 17.30 uur werd ook in Oldenzaal het politie-standrecht voor de provincie Overijssel afgekondigd. 's Avonds na 20 uur mocht niemand meer op straat. Vrijdagavond laat werd E. Trachsler, bedrijfsleider van H. P. Gelderman $\mathcal{E}$ Zn. N.V., door de politie opgebeld, waarbij hem gezegd werd dat hij in opdracht van de burgemeester Zaterdagmorgen om 5 uur aan de fabriek moest zijn ${ }^{366}$ ).

$Z$ a terdag. - Die morgen werd echter noch bij de N.V. v/h J. Molkenboer Jr. noch bij H. P. Gelderman $\mathcal{E} Z \mathrm{Zn}$. N.V. het werk hervat. Wel kreeg de directeur van eerstgenoemde fabriek van de politie bericht, dat de arbeiders bij elkaar geroepen moesten worden, daar anders slachtoffers zouden vallen. Om half elf werden toen de motoren aangezet en leek het, alsof de fabriek liep. Tevens werden enkele bazen rondgestuurd om de arbeiders weer naar de fabriek te halen. Op deze wijze gelukte het, wat personeel naar de fabriek te krijgen; gewerkt werd echter practisch niet 367 ). Ook kwam nog bericht, dat uiterlijk om 12.30 uur bij de Sicherheitspolizei in Enschede lijsten moesten worden ingediend van diegenen, die ,zonder geldige reden" Zaterdag het werk niet hadden hervat 368 ).

Bij H. P. Gelderman \& Zn. N.V. waren - in tegenstelling tot de N.V. v/h J. Molkenboer Jr. - op Zaterdagmorgen wel Duitsers aan de fabriek verschenen. De directeur, H. Gelderman, en de chef de bureau, H. Schouwenburg, die op het kantoor aanwezig waren, werden met het geweer in de rug gedwongen, namen op te geven van kantoorpersoneel. Met deze lijst wilden de Duitsers verschillende personen ophalen 369 ). Een hoofdtouwbaas werd meegenomen en moest als gids op de wagen der Duitsers plaats nemen. Doordat echter niemand van de op de lijst geplaatsen thuis was 370 ), werden verschillende personeelsleden, die intussen naar de fabriek waren gegaan, meegenomen en naar Hengelo vervoerd. Diezelfde middag werden zij door de Duitsers vrijgelaten. $Z_{i j}$ kregen opdracht, de fabrikanten te zeggen, dat Maandag de fabrieken weer moesten draaien en dat de geestelijken dit bericht

364) Zie: 357).

365) Zie: 363), blz. 3.

366) Zie: Verslag No. CLXXVIII, blz. 3.

367) Zie: Verslag No. CLXXXIII, blz. 3.

368) Zie: a. 357).

b. Verslag No. CLXXVIII, blz. 6.

c. Verslag No. CLXXXIX, blz. 2.

d. 367), blz. 3 .

369) Zie: Verslag No. CLXXVII, blz. 3.

370) Zie: Verslag No. CLXXIX, blz. 1 en 2. 
van de kansels moesten afroepen. Deze opdrachten zijn door de vrijgelaten arrestanten niet uitgevoerd $\mathbf{3 7 1}$ ).

In de loop van de dag werd bekendgemaakt, dat bij niet onmiddellijke herlatting van het werk stakers, die in het openbaar of in woningen en andere gebouwen met daarbij behorende terreinen werden aangetroffen, onmiddellijk voor het Standgericht zouden worden gebracht. Na het aanplakken van deze publicatie verdween het zich op de straten bevindende publiek ${ }^{372}$ ).

Zaterdagavond werden verschillende personen uit huis gehaald en naar het politiebureau gebracht. Daar kregen zij van de aanwezige politiemannen gelegenheid, eventueel bezwarende papieren te verbranden 373 ).

Z o n d a g. - Ook op Zondag werden - blijkens een aantekening in het dagboek van de Gemeente-secretaris, B. H. Hommen, te Oldenzaal - nog verschillende personen gearresteerd. In totaal waren toen in het politie-bureau één-en-twintig personen aanwezig, die allen dezelfde dag (om 14 uur) via Enschede naar Hengelo werden vervoerd. Negen werden naar Vught getransporteerd 374 ).

In de namiddag werd per publicatie bekend gemaakt, dat degenen, die in het buitenland werkten en vóór 6 uur 's morgens moesten vertrekken, zich voor een vergunning om vroeg op straat te mogen zijn, moesten wenden tot de Duitse politie in Hengelo 375 ). Dit gold eveneens voor de arbeiders, die in Oldenzaal in de vroege ploegendienst werkten. Zo kreeg bijv. een wever, die Maandagmorgen in de vroege ploeg moest werken bij H. P. Gelderman $\&$ Zn. N.V., Zondagavond bericht, dat hij een Ausweis kon halen om 's morgens vroeg op straat te kunnen zijn ${ }^{376}$ ). Later in de avond werd deze publicatie teniet gedaan door de bepaling, dat men reeds om 4 uur op straat mocht zijn ${ }^{377}$ ).

Zondagavond en Zondagnacht werd aan alle hoofden van bedrijven en kantoren enz., die met personeel werkten, een aanzegging namens de Sicherheitspolizei uitgereikt, inhoudende, dat het bedrijfshoofd vóór de komst van het personeel op 3 Mei aanwezig moest zijn. De arbeiders, die een uur na de vastgestelde aanvangstijd niet aanwezig zouden zijn, moesten aan de Sicherheitsdienst te Hengelo worden opgegeven 378 ).

Maandag, $3 \mathrm{Mei}$, werd het werk in Oldenzaal overal hervat.

H. P. Gelderman \& Zn. N.V. leverde lijsten in, waarop alle afwezigen werden vermeld, doch met de aantekening ,,ziek" of ",met verlof" 379).

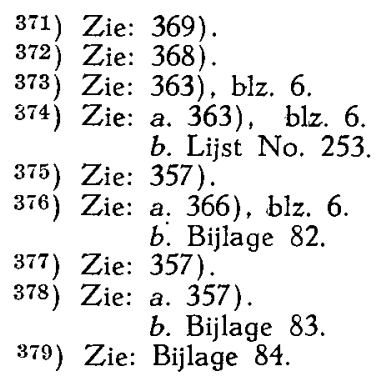




\section{HAAKSBERGEN}

Donderdag. - De staking in Haaksbergen brak spoedig uit, nadat bekend was geworden, dat in Hengelo de arbeiders het werk hadden neergelegd.

De arbeiders en arbeidsters, werkzaam bij de N.V. D. Jordaan $\mathcal{E} Z_{\text {nn.'s }}$ Textielfabriek gaven het voorbeeld. Personeel van de Gemeente-secretarie ${ }^{380}$ ), alsmede van J. P. Odink $\mathcal{E}$ Koenderink N.V. (60 arbeiders) volgde diezelfde middag 381).

V r ij d a g. - Vrijdagmorgen ging de N.V. Twentse Kabelfabriek (79 arbei ders) en in de middag de firma D. J. ten Hoopen $\mathcal{E} \mathrm{Zn}$. (103 arbeiders) in staking 382). De gemeente-secretarie bleef de gehele dag gesloten.

Bijzonderheden hebben zich op Vrijdag. Zaterdag en Zondag niet voorgedaan. Wel belde Vrijdagmorgen de Grüne Polizei de Commissaris van Politie te Haaksbergen op. Er werd geïformeerd naar de stand van de staking. Het antwoord was, dat men niets van een staking had gemerkt.

$Z$ aterdag. - Op Zaterdagmorgen, ongeveer 9 uur, kwamen Duitsers aan het Gemeentehuis. $Z_{\mathrm{ij}}$ gingen ,vreselijk ... te keer" 383 ), daar naar hun mening de plakkaten betreffende de afkondiging van het politie-standrecht op Vrijdagavond niet goed aangeplakt waren. Nadat de waarnemend burgemeester met de Duitsers op de overvalwagen gedwongen was te tonen, waar de decreten aangeplakt waren, vertrokken de Duitsers en lieten de waarnemend burgemeester weer vrij.

Dezelfde dag ging ook nog J. G. H. Jordaan, directeur van de N.V. D. Jordaan $\mathcal{E} Z \mathrm{Zn}$ 's Textielfabriek, naar de pastoor en vroeg of naar zijn mening de mensen - gezien de afkondiging van het politiestandrecht en het niet meestaken der spoorwegarbeiders - weer aan het werk moesten gaan. Volgens de heer Jordaan antwoordde de pastoor het advies gegeven te hebben, Maandag weer te beginnen ${ }^{384}$ ).

Zondagmiddag riep de bedrijfsleider van de N.V. Jordaan de bazen bijeen. Hun werd verzocht zoveel mogelijk mensen te waarschuwen om Maandag het werk te hervaten, daar anders moeilijkheden verwacht werden.

$\mathrm{M}$ a a n d a g. - Maandagmorgen ging slechts een deel van de dagploeg aan de arbeid. Soms liepen arbeiders, die eerst de fabriek waren binnengegaan, er later weer uit. Ondanks de pogingen, die de heer Jordaan in het werk stelde om de arbeiders het werk te doen hervatten, was het zeer moeilijk, voordat hij iemand aan het weven kon krijgen; ,,de arbeiders vertikten het" — aldus de directeur 385 ).

Op 3 Mei 1943 kreeg Haaksbergen een nieuwe burgemeester. Een uur

380) Zie: Verslag No. CLVII, blz. 1.

381) Zie: Lijst No. 216.

382) Zie: a. Lijst No. 217.

b. Lijst No. 218.

383) Zie: 380 ), blz. 2 .

384) Zie: Verslag No. CLX, blz. 2.

385) Zie: 384$)$, blz. 3. 
nadat deze zijn ambt had aanvaard, kwam bij hem een luitenant van de Ordnungspolizei en vroeg, of het de burgemeester bekend was, dat in Haaksbergen de fabrieken in belangrijke mate nog staakten en welke maatregelen daartegen genomen waren. De burgemeester antwoordde, dat hij juist van de Brigade-commandant van de marechaussee mondelinge mededelingen had ontvangen ${ }^{386}$ ). Daarop vertrok de Duitse luitenant en begaf zich naar de Brigade-commandant. Deze moest met de Duitsers op een overvalwagen (waarin 6 of 7 Duitsers zaten) mee om de weg naar de fabrieken te wijzen 387 ). Zo kwamen zij omstreeks 10 uur bij de N.V. Jordaan, waar één der Duitsers, de luitenant Schatz, J. G. H. Jordaan opdracht gaf, een lijst samen te stellen van diegenen, die om 12 uur het werk nog niet zouden hebben hervat. Ongeveer 13 uur-13.30 uur zijn deze lijsten door Jordaan bij de Duitsers ingeleverd 388 ).

's Middags ongeveer 16 uur kwamen de Duitsers opnieuw bij de N.V. Jordaan. Op last van de luitenant Schatz moest het personeel, dat de arbeid pas na 12 uur had hervat, op een plaats in de fabriek bijeen komen om te worden toegesproken. In een garenloods werd de aanwezige arbeiders echter persoonlijk door de Duitser gevraagd, waarom men gestaakt had. Sommigen moesten, na te hebben geantwoord, apart gaan staan. Deze werden aan het einde van de bijeenkomst (het waren vier-en-twintig personen, onder wie negen meisjes) gearresteerd en naar "Dolphia" in Enschede vervoerd. 's Avonds om 22 uur konden veertien personen - na eerst verhoord te zijn - naar Haaksbergen terugkeren. De andere negen werden op een auto geladen en weggereden in de richting Hengelo. Ter hoogte van "Den Broeierd" werd gestopt en werd de inzittenden gelast, de wagen te verlaten. Toen de negen arbeiders uit de wagen gesprongen waren en op de weg stonden, werd plotseling het vuur op hen geopend. Zeven man werden "op de vlucht" doodgeschoten. Twee wisten die avond nog te ontkomen ${ }^{389}$ ). Eén van hen A. B. Wijlens - werd echter de volgende dag op de fabriek gearresteerd en daarna gefusilleerd. De andere - Herman Goering geheten - dook onder. Hij heeft precies kunnen navertellen, hoe deze mensen op Maandagavond doodgeschoten werden.

Dinsdag kwamen ook Duitsers bij J. P. Odink \& Koenderink N.V. en werden acht arbeiders uit de fabriek weggehaald. Na te zijn verhoord, werden zij 's avonds weer vrijgelaten $\left.{ }^{390}\right)$. Bij D. J. ten Hoopen $\mathcal{E} \mathrm{Zn}$. werd die dag de directie door de Duitsers gesommeerd, de arbeiders bijeen te roepen. Aan vele personen werd o.a. gevraagd, waarom zij niet gewerkt hadden. Zes arbeiders werden in arrest genomen; Woensdag werden zij door de Duitsers weer in vrijheid gesteld 391 ).

386) Zie: Bijlage 85.

387) Zie: Verslag No. CLVIII, blz. 2.

388) Zie: 384), blz. 4

389) Zie: a. Verslag No. CLXI, blz. 4.

390) Zie: Lijst No. 216.

b. uitvoeriger: Hoofdstuk VI.

391) Zie: Lijst No. 218. 


\section{HELLENDOORN}

Donderdag. - Donderdagmiddag, 29 April 1943, werd de Koninklijke Stoomweverij te Nijverdal N.V. vanuit Hengelo opgebeld. Medegedeeld werd, dat bij de N.V. Machinefabriek Gebr. Stork \& Co. het werk neergelegd was. Vanuit de "Stoomweverij" werden andere bedrijven, zoals de Stoomspinnerij te Nijverdal N.V. en de Koninklijke Stoomblekerij te Nijverdal, Ter Horst \& Co. N.V. te Rijssen en het personeel van het gemeentehuis te Hellendoorn van de staking in Hengelo op de hoogte gesteld. Omstreeks 16.30 uur legde het personeel van de Koninklijke Stoomweverij te Nijverdal N.V. het werk neer 392$)$.

V r ij d a g. - De volgende dag werd het werk eveneens neergelegd bij de Gemeente-secretarie ${ }^{393}$ ) en het bijkantoor van het Gewestelijk Arbeidsbureau 394 ). Alleen gedurende de morgenuren werd gestaakt door het personeel van de distributie-dienst ${ }^{395}$ ).

Bij de Koninklijke Stoomweverij waren arbeiders werkzaam, die door de oorlogsomstandigheden niet in de fabriek, maar in de zgn. Cultuur-Technische Dienst werkten. Deze dienst werd als een soort wachtgeldregeling beschouwd. Reeds bij geruchte hadden de arbeiders op deze ontginningswerken vernomen, dat een staking uitgebroken was. Bij aankomst in Nijverdal hoorden zij precies, wat er was gebeurd. Vrijdagmorgen gingen deze arbeiders naar het station; onder hen waren echter enkelen, die niet alleen van plan waren, het werk niet te hervatten, maar ook, zulks anderen te verhinderen. Toen de trein, die hen naar de werk-objecten moest vervoeren - en waarin reeds arbeiders uit Raalte zaten - binnenkwam, werden allerlei pogingen gedaan, ook deze arbeiders in de actie te betrekken. De arbeiders van Raalte stapten uit, echter nog niet direct met de bedoeling om te staken. Toen de trein zich in beweging zette en zij weer snel wilden instappen, werd hun dit verhinderd, doordat de arbeiders uit Hellendoorn de portieren dicht gooiden. Ook probeerde men nog het spoorwegpersoneel in de staking te betrekken, doch zonder resultaat 396 ).

Vrijdag was het verder vrij rustig in deze gemeente. Wel werden die dag vrijwel alle winkels gesloten 397 ). Aan de zuivelfabriek, die geopend was, waren 's morgens de melkrijders verschenen. Door ,hardhandig" ingrijpen ${ }^{398}$ ) van de onderwijzer-hoefsmid G. J. Broeze, keerden de melkrijders echter met de melk naar de boeren terug.

In de loop van de namiddag moest de burgemeester naar Hengelo komen om de aanplakbiljetten betreffende de afkondiging van het politie-standrecht

392) Zie: Brief van personeel van de Koninklijke Stoomweverij te Nijverdal N.V. Nijverdal, 28 Maart 1947. Bijlage 60.

393) Zie: Lijst No. 237.

394) Zie: Uittreksel uit het Politierapport No. 499 van 9 Mei 1943. Bijlage 86.

$395)$ Zie: Lijst No. 238.

396) Zie: Verslag No. CLXVII, blz. 7.

397) Zie: 394).

398) Zie: Brief van G. J. Br. Hulzen, 23 April 1946. Bijlage 87. 
in ontvangst te nemen. Daar hij in deze vergadering opmerkte, dat het hem niet mogelijk was, vóór 20 uur 's avonds de decreten ter kennis van de bevolking te brengen, werd hem door Weidlich gezegd, dat de Duitse politietroepen in Hellendoorn pas op $3 \mathrm{Mei} z o u d e n$ komen. Verder zou de burgemeester ,de politie over de gemeente tot Maandag zelf in de hand ... kunnen houden" 399). Toen de burgemeester van Hellendoorn die avond in zijn gemeente aankwam, zag hij dat er al Duitsers aanwezig waren. De afdeling Duitse politie bestond uit één luitenant en zes minderen. $Z_{i j}$ namen hun intrek in een hotel te Nijverdal 400 ).

$Z$ aterdag. - Zaterdagmorgen half zeven verscheen de Grüne Polizei aan de Koninklijke Stoomweverij en werd de bedrijfsleider, J. A. Borghuis gesommeerd, ervoor te zorgen, dat een ieder om half acht weer aan het werk zou zijn. Om half acht kwamen de Duitsers terug, maar arbeiders waren niet aanwezig. Daarop werd de heer Borghuis bevolen, maatregelen te nemen, dat 's middags een ieder in de fabriek aanwezig zou zijn. Aan de Duitsers werd geantwoord, dat Zaterdagmiddag een vrije middag was voor het personeel. $\mathrm{Om}$ 10 uur kwamen de Duitsers opnieuw terug en vroegen naar de directie. Geantwoord werd, dat deze in Almelo haar kantoren had en daar te vinden was.

Kort daarop werden de gezamenlijke bedrijfsleiders van de Kon. Stoomweverij gelast in de Marechausseekazerne te verschijnen. Door de luitenant Waltz, Commandant van de Grüne Polizei te Nijverdal werd geëist, dat de arbeiders Maandagmorgen het werk moesten hervatten.

De bedrijfsleiders werden ,op de gevaren gewezen, die een verdere weigering met zich zou brengen. Uitdrukkelijk verklaarde hij, dat de arbeiders, die het werk a.s. Maandag niet op de gewone tijd hervat zouden hebben, opgehaald zouden worden en naar Hengelo vervoerd om aldaar terechtgesteld te worden." "U zult toch wel begrijpen" - zo zeide de luitenant Waltz "dat das Reich, dat een bewapend Holland in vier dagen tot wapenstilstand dwong, thans een niet-bewapend land in kortere tijd klein krijgen kan" 401).

Intussen waren de Duitsers in Nijverdal die morgen reeds aan het patrouilleren geweest. Hierbij was de Hellendoornse politie ingeschakeld. Op zeker moment werd deze surveillance-dienst gestaakt en moesten de politiemannen naar de kazerne. Daar kregen zij van de Duitsers opdracht, 10 à 20 mensen op te pakken. De politie sprak onderling af, dit te weigeren. Door ingrijpen van de burgemeester gingen deze arrestaties niet door 402 ).

Onder de bovengenoemde omstandigheden besloot de directie van de Koninklijke Stoomweverij, die intussen van een-en-ander op de hoogte gesteld was, 's avonds een bespreking te houden met de fabriekscommissie en een paar bovenbazen. Daar werd besloten - al waren er uiteenlopende opvat-

399) Zie: Verslag No. CLXV, blz. 2.

400) Zie: 394).

401) Zie: 392).

402) Zie: 399), blz. 3 en 7. 
tingen -, dat iedereen in zijn eigen kring zoveel mogelijk bekendheid zou geven aan de wens om Maandag het werk weer te hervatten 403).

Intussen waren die dag de winkels weer geopend en waren de werkzaamheden op het Gemeentehuis, de distributiedienst en het bijkantoor van het Gewestelijk Arbeidsbureau hervat 404). In de loop van de dag werd Broeze, de persoon die aan de zuivelfabriek nogal ", hardhandig had ingegrepen", door de luitenant Eckhard (kampleider van Ommen) en de K.K.-man Diepgrond gearresteerd; dit gebeurde zonder medeweten van de Duitse groep in Nijverdal 405).

Zaterdagavond werd door de Duitse politie op verschillende personen, die na 20 uur op straat liepen, zonder waarschuwing geschoten 406). Hierbij werd iemand gewond, die, voordat hij hersteld was, wekenlang in het ziekenhuis moest verblijven 407 ).

Maandag werd in Hellendoorn weer overal het werk hervat.

\section{- RIJSSEN}

Donderdag. - Zoals reeds opgemerkt, werd op Donderdagmiddag om 16 uur-16.30 uur het bericht, dat in Hengelo gestaakt werd, door de Koninklijke Stoomweverij te Nijverdal N.V. telefonisch aan Ter Horst \& Co. N.V. te Rijssen medegedeeld ${ }^{408}$ ). Omstreeks 17 uur was de staking in de gehele fabriek een feit ${ }^{409}$ ). Daar het werk ongeveer een half uur vóor het wisselen der ploegen werd neergelegd, kwam ook de volgende ploeg niet meer op ${ }^{410}$ ).

Evenals elders ging men ook hier over tot het tappen van veel water. Een poging om het personeel der Spoorwegen te Rijssen in de staking te betrekken, had geen succes $\mathbf{4 1 1}$ ).

$\mathrm{V} r$ ijd a g. - De volgende dag breidde de staking zich over de boeren-

403) Zie: a. Verslag No. CLXVI, blz. 2.

404) Zie: 394$)$.

b. 396), blz. 6 .

405) Zie: a. 399), blz. 3 en 4 .

b. G. J. Broeze werd door het Standgericht te Hengelo tot twee jaar gevangenisstraf veroordeeld. Weliswaar was eerst de doodstraf geëist, maar daar het optreden van Broeze had plaatsgevonden vóór de afkondiging van het Standrecht, werd deze straf veranderd. $\mathrm{Na}$ in Vught gezeten te hebben, werd hij overgeplaatst naar St. Michielsgestel, waar hij op 20 April 1944 werd 406) Zie: a. 394). ontslagen. Zie: 398).

407) Zie: a. Lijst No. 245 .

b. Politioneel maandrapport van het Gemeentebestuur van Hellendoorn aan de Gewestelijke Politie-president te Arnhem. Hellendoorn, 17 Mei 1943.

b. Telexbericht van Ney an de Höhere SS - und Polizeiführer, Den Haag. Nr. 14576. 2 Mei 1943.

"Eine mänliche Person auf der Flucht angeschossen und lebensgefährlich

408) Zie: 392). verletzt."

409) Zie: Brief van G. H. Hofstede. Rijssen, 30 Maart 1947. Bijlage 88.

410) Zie: Verslag No. CXCIV, blz. 2.

411) Zie: 409). 
bevolking van Rijssen en omgeving uit. Arbeiders van de zuivelfabriek hadden reeds Donderdagavond de melkrijders gewaarschuwd, de volgende dag geen melk te brengen. Op Vrijdagmorgen werd dan ook geen melk afgeleverd 412).

Bijzonderheden zijn uit dit landelijke Rijssen betreffende Vrijdag 30 April niet te vermelden. Alleen werd 's avonds door middel der plakkaten bekend gemaakt, dat het politiestandrecht afgekondigd was ${ }^{413}$ ).

$\mathrm{Z}$ at e rdag. - Ook Zaterdag $1 \mathrm{Mei}$ was het rustig. Het personeel hervatte die dag niet het werk.

In Rijssen was het aan de directie van Ter Horst $\mathcal{E}$ Co. N.V. bekend, dat in andere plaatsen van Twente de staking reeds verliep. Vandaar dat $z \mathrm{ij}$ overlegde, welke maatregelen genomen moesten worden. Door middel van de geestelijkheid en de predikanten en door inschakeling van het bazenpersoneel, werd de arbeiders gewezen op de gevolgen van een eventueel verder staken ${ }^{414}$ ).

M a a n d a g. - Maandagmorgen, 3 Mei 1943, omstreeks 6 uur, waren er al wat arbeiders voor de fabriek van Ter Horst $\mathcal{E}$ Co. N.V. Enkele personen gingen naar binnen, ,maar het merendeel werd tegengehouden door personen, die niet aan deze fabriek werkten" 415 ). Om half zeven, de directie was toen aanwezig, kwam de marechaussee mededelen, dat aan de commandant in Goor een bericht over de stand van zaken moest worden doorgegeven.

Daar om half acht de dagploeg moest opkomen, wachtte de marechaussee met het doorgeven van het rapport. Omstreeks deze tijd waren nog slechts weinigen de fabriek ingegaan. Dit werd aan de Commandant in Goor doorgegeven. Waarschijnlijk naar aanleiding hiervan kwamen om half tien de Duitsers in twee overvalwagens Rijssen binnenrijden. Zij holden - bij de fabriek aangekomen - het fabrieksterrein op en ,schoten als gekken in het wilde weg" 416). De Duitsers liepen de fabriek in en diegenen, die binnen waren, o.a. ook de sociale voorman en een paar NSB-ers, werden op een overvalwagen geladen. Daar echter de Duitsers niet veel mensen in de fabriek konden vinden, begonnen zij op straat mensen gevangen te nemen 417).

Die morgen hadden de Duitsers uit Enschede telefonisch aan de burgemeester van Rijssen gevraagd, of er in zijn gemeente nog werd gestaakt. Hij antwoordde, dat slechts $25 \%$ van de arbeiders, werkzaam bij Ter Horst \& Co. N.V., afwezig was. In werkelijkheid echter was slechts $25 \%$ aanwezig. Daar de burgemeester de juiste toestand wilde opnemen, ging hij naar de fabriek. Door de toen juist het dorp binnenrijdende Duitsers werd hij aangehouden en als eerste gearresteerde op een wagen gezet. De Duitsers reden het dorp verder rond en pakten nog enkele mensen van de straat. Tenslotte ging de

412) Zie: Verslag No. CCXXXIX, blz. 1.

413) Zie: Verslag No. CXCIII, blz. 1.

Ook de burgemeester, W. Zeeuw, moest die dag naar Hengelo om de decreten te halen: Toen hij echter 's avonds in Rijssen aankwam, waren zij reeds aangeplakt.

414) Zie: 410), blz. 3.

415) Zie: 410), blz. 4.

416) Zie: 410), blz, 4 .

417) Zie: 410), blz. 4 . 
overvalwagen naar Ter Horst $\mathcal{E}$ Co. N.V., waar personen op een andere wagen werden geladen. Op dat moment kwam een auto aan, waarin Weidlich zat. Deze herkende de burgemeester en liet hem van de wagen halen. Op het kantoor van Ter Horst \& Co. N.V. werd hij verhoord, maar daarna vrijgelaten.

Het was intussen 11 uur geworden. De Duitsers hadden de gemeente afgezet; niemand kon er in of uit ${ }^{418}$ ). Verschillende personen werden ook toen nog gearresteerd, onder wie opnieuw (omstreeks 13 uur) de burgemeester. In totaal zijn - naar opgaven van de burgemeester - ongeveer dertig man gearresteerd, onder wie enkele directeuren en de procuratie-houder van Ter Horst $\&$ Co. N.V., drie predikanten, en arbeiders en arbeidsters. Allen werden eerst naar Almelo en daarna naar Hengelo (het „Bataafse Kamp”) vervoerd. Daar werden de predikanten vrijgelaten. Op een andere stopplaats werden de meisjes van de wagen gezet; zij konden naar de fabriek terugkeren. De anderen werden naar het politiebureau in Hengelo gebracht, waar zij Woensdag, $5 \mathrm{Mei}$ 1943, allen vrijgelaten werden 419 ).

Maandagmiddag 13.30 uur was de staking bij Ter Horst $\mathcal{E}$ Co. N.V. beeindigd ${ }^{420}$ ).

\section{VRIEZENVEEN}

Dond e r d a g. - Het bericht betreffende de terugvoering der Nederlandse militairen in Duitse krijgsgevangenschap verspreidde zich snel langs de zes kilometer lange dorpsweg van Vriezenveen. Geruchten gingen, dat het personeel van de interlocale waterleidingdienst en het provinciaal electrisch bedrijf in staking was gegaan. Verwacht werd, dat het spoorwegpersoneel zich daarbij zou aansluiten. Op grond van deze geruchten ging men water tappen. Men schafte zich kaarsen en carbid-lampen aan 421 ).

Omstreeks 15.30 uur belde de telefoniste van Palthe's Textielveredelingsbedrijven N.V. (Almelo), Jansen \& Tilanus N.V. te Vriezenveen op. Medegedeeld werd, dat de arbeiders van Palthe de fabriek verlieten. Nadat dit in de fabriek van Jansen $\mathcal{E}$ Tilanus bekend werd, ging men ook daar diezelfde middag in staking 422 ).

's Avonds om 20 uur werd het Gemeentehuis te Vriezenveen er telefonisch van in kennis gesteld dat om 21.30 uur leden van de Sicherheitspolizei uit Arnhem zouden komen. Omstreeks 22 uur kwamen zij inderdaad. De burgemeester ontving de Duitsers in de Raadszaal. Ook J. ter Steeg, directeur van de Coöp. Stoomzuivelfabriek "Ons Belang”, moest aanwezig zijn 423).

418) Zie: 413), blz. 2 en 3.

419) Zie: a. 413), blz. 4 en 5 .

420) Zie: 409).

b. 410), blz. 4 en 5 .

421) Zie: Verslag van J. Krol Jzn., in Mei 1943 burgemeester van Vriezenveen, blz. 1.

422) Zie: Brief van W. C. Tilanus, directeur van Jansen $\mathcal{E}$ Tilanus N.V. aan J. C. M. Kruisinga. Geen plaatsnaam, 14 April 1947, Bijlage 89.

423) Zie: Verslag No. CCXLII, blz. 1. 
De Duitse woordvoerder vroeg, wanneer en hoe de staking der fabrieksarbeiders de burgemeester bekend was geworden en welke maatregelen hij tegen de staking had getroffen. De burgemeester werd gelast ervoor te zorgen, dat de fabriek van Jansen $\&$ Tilanus N.V. Vrijdag met volledig personeel tijdig op gang werd gebracht. Aan Ter Steeg vroeg de Duitser, of hem iets bekend was van een putsch. Ook wilde hij van hem weten, of zijn personeel de volgende morgen weer op het werk zou verschijnen. Ter Steeg antwoordde bevestigend.

Daar de burgemeester tijdens het gesprek had opgemerkt, dat de Duitsers zich - in verband met het hervatten van het werk door het fabrieks-personeel - beter met de directie van Jansen $\mathcal{E}$ Tilanus N.V. in verbinding konden stellen, gingen enkele Duitsers naar het woonhuis van $C$. B. Tilanus. De burgemeester en de directeur der zuivelfabriek moesten op de terugkomst der Duitsers wachten. Aan C. B. Tilanus, die de Duitsers ontving, werd eveneens gevraagd langs welke weg de directie ter ore was gekomen, dat in andere plaatsen gestaakt werd. Ook drongen de Duitsers er op aan, dat de arbeiders van de tricot-fabriek de volgende morgen het werk zouden hervatten 424 ). Nadat de Duitsers op het Gemeentehuis teruggekeerd waren, konden de burgemeester en Ter Steeg vertrekken.

V rijdag. - Vrijdag breidde de staking zich over geheel Vriezenveen uit. Aan de zuivelfabriek kwamen geen melkrijders en geen personeel 425 ). Winkels waren gesloten, brood was in het dorp niet te krijgen ${ }^{426}$ ). Ruim 1000 veenarbeiders legden die dag het werk neer ${ }^{427}$ ). Dienstmeisjes liepen - evenals vele anderen, die het werk hadden neergelegd - op straat te wandelen 428 ).

Vrijdagmorgen reeds kwamen de Duitsers om 8 uur -8.30 uur aan de fabriek van Jansen $\mathcal{E}$ Tilanus N.V. Slechts enkele mensen, onder wie NSB-ers en kantoorpersoneel, waren aanwezig. Wel stonden meerdere arbeiders buiten de fabriek, maar zij gingen niet naar binnen ${ }^{429}$ ).

Verdere bijzonderheden vonden die dag niet plaats. In de loop van de namiddag werd het politiestandrecht afgekondigd.

Vrijdagavond omstreeks 20.30 uur patrouilleerde de staatspolitie. Deze lukte het niet, de bevolking binnen de huizen te krijgen. Daarop kwamen de Duitsers, die wel schoten, maar niemand verwondden. Uit angst dat dit alles toch ernstige gevolgen zou hebben, joeg toen J. F. Jansen, wachtmeester, met de gummiknuppel een drietal opgeschoten jongens binnen de huizen 430 ).

$Z$ a t e rd a g. - Zaterdagmorgen werd door iemand een melkbus van een wagen getrokken. Twee bewoners, voor wier huis dit plaats vond, werden

424) Zie: Verslag No. CXCVIII, blz. 3.

425) Zie: 423), b.lz. 2.

426) Zie: Dagboek van de Notaris J. C. M. Kruisinga te Vriezenveen. (Deel IV, blz. 170).

427) Zie: 421), blz. 4.

$428)$ Zie: Verslag No. CCII, blz. 1.

429) Zie: 424), blz. 3.

430) Zie: Verslag No. CCIII, blz. 1. 
gearresteerd. Ook een ander - het hoofd van een winkel-grootbedrijf - werd, doordat het personeel in staking was gegaan, door de Duitsers eerst afgeranseld en daarna naar het politie-bureau gebracht ${ }^{431}$ ).

Die morgen om 8.30 uur werd door Jansen \& Tilanus N.V. aan bazen en kantoorpersoneel een oproep gezonden, om om 10 uur aanwezig te zijn. Deze hebben daarna de arbeiders gewaarschuwd, om 11 uur het werk te hervatten 432 ). Omstreeks die tijd ging men ook inderdaad aan de arbeid. Onder contrôle der Duitsers werd Zaterdagmiddag tot 16 uur gewerkt ${ }^{433}$ ).

Aan de zuivelfabriek was op Zaterdag ongeveer een derde deel van de normale hoeveelheid melk aangevoerd. Verschillende melkrijders kwamen met lege wagens, omdat een aantal boeren die dag geen melk had klaargezet. Daar ernstige repressailles van de Duitsers werden verwacht, werden door de directeur van de zuivelfabriek de melkrijders verzocht, alsnog melk te brengen. 's Avonds werd door de zuivelfabriek nog een derde deel van de normale hoeveelheid melk ontvangen ${ }^{434}$ ).

\section{DELDEN}

In de kleine bedrijfjes, de N.V. Chemische Fabriek "Servo" (138 arbeiders) ${ }^{435}$ ) en Ficker $\&$ Wap N.V. (62 arbeiders) ${ }^{436}$ ) werd op Donderdagmiddag het werk neergelegd. „Een groep Deldense mensen, die in Hengelo werkten, kwamen uit protest lopend in gesloten colonne, vaderlandse en andere liederen zingend, naar Delden terug" 437). Op het gerucht, dat ook het personeel van de "Waterleiding" in staking was gegaan, begon een ieder water te tappen.

Van het gemeentepersoneel heeft op Vrijdag een deel, n.l. de distributiedienst, gestaakt. Dezelfde avond werd het politie-standrecht afgekondigd in de Stad-Delden.

Zaterdag, 1 Mei, werd de burgemeester door de Duitsers opgebeld en gevraagd, of het personeel van de distributie-dienst staakte. Aan de Duitsers werd geantwoord, dat er niet gestaakt was 438 ). Eveneens werd de Chemische Fabriek "Servo" opgebeld; de politie moest namens de Duitsers informeren, hoe de situatie was. Er werd geantwoord, dat het invoeren van de spertijd, alsmede het feit, dat op $1 \mathrm{Mei}$ een balans-inventaris werd gemaakt, redenen waren, dat slechts door een gedeelte van het personeel werd gewerkt. Op dezelfde gronden werd aan de eis der Duitsers om lijsten te maken van stakers en niet-stakers niet voldaan 439 ).

431) Zie: a. Brief van B. C., Vriezenveen, 22 April 1946, Bijlage 90.

b. Verslag No. CC, blz. 2.

c. 421$)$, blz. 5 .

432) Zie: 424), blz. 3 .

433) Zie: 431) a.

434) Zie: 423), blz. 3.

435) Zie: Lijst No. 37.

436) Zie: Lijst No. 38.

437) Zie: Brief van C. J. M. G., Delden, 28 April 1946, Bijlage 91.

438) Zie: Verslag No. CLI, blz. 2.

439) Zie: Brief van de N.V. Chemische Fabriek "Servo”. Delden, 18 Juli 1947. Bijlage 92. 
Maandag, 3 Mei ging het grootste deel van het personeel van laatstgenoemde fabriek weer aan het werk. De Duitsers, die diezelfde dag kwamen informeren, werd er op gewezen, dat door het invoeren van de spertijd de gehele ploegendienst in de war was gekomen en slechts weer in orde zou zijn, wanneer Ausweise zouden worden verstrekt. Verschillende leden van het personeel wilden echter niet graag in spertijd werken, daar er voor hen - zo meenden $z \mathrm{ij}$ - gevaren aan verbonden waren ${ }^{440}$ ).

\section{DENEKAMP}

De staking in de landelijke gemeente Denekamp beperkte zich tot de Coöp. Stoomzuivelfabriek "Volharding", de landbouwvereniging "A.B.T.B." en het plaatselijk Bureau der Voedselvoorziening 441).

Vrijdagmorgen, 30 April, brachten de melkrijders hun melk aan de zuivel fabriek. Om ongeveer half tien werd door een personeelslid van de zuivelfabriek te Oldenzaal telefonisch medegedeeld, dat daar een staking uitgebroken was. Gevraagd werd, of men in Denekamp het voorbeeld zou willen volgen. Aan dit verzoek werd voldaan. De melkrijders werd gevraagd, de melk terug te brengen. Daar deze niet wilden, werden de deuren van de zuivelfabriek gesloten. De boeren, die nog moesten komen, werden aan het begin van het dorp gewaarschuwd, terug te keren ${ }^{442}$ ). Op deze wijze werd Denekamp in de staking betrokken.

Vrijdagmiddag om 17 uur werden de directeuren van de "Volharding" en de "A.B.T.B." samen met de Plaatselijke Bureau-Houder op last van de NSB-burgemeester gearresteerd. Tot Zaterdagmorgen verbleven zij op een kamer op het Gemeentehuis. Omstreeks half twaalf werden zij door de burgemeester verhoord, maar spoedig vrijgelaten ${ }^{443}$ ).

's Middags vond een vergadering plaats van de directeur en de bestuurders van de zuivelfabriek. Besloten werd, de boeren door middel van briefjes mede te delen, dat de melk weer geleverd moest worden.

Zaterdagnacht werden in Denekamp ongeveer 15 personen gearresteerd. $Z_{i j}$ werden naar het Verenigingsgebouw van de Hervormde Kerk gebracht en bleven daar tot Zondagmorgen. Die dag werden zij naar Hengelo vervoerd. en Zondagavond naar Vught ${ }^{444}$ ).

\section{WIERDEN}

In Wierden begon op Vrijdagmorgen om plm. 7 uur de staking. Een groep arbeiders van de Wierdense Exportslachterij trok naar de Ververij Höfkens,

440) Zie: 439).

441) Zie: Verslag No. CLIII.

442) Zie: Verslag No. CCXVIII, blz. 1.

443) G. I. Karreman, in 1943 groepscommandant der Marechaussee te Denekamp, had de drie arrestanten niet in de cel, maar in een kamer op het Gemeentehuis laten ovemachten. Naar aanleiding hiervan werd hij op last van de burgemeester, Eekhof, gearresteerd en naar Vught getransporteerd. 7 Mei 1943 werd hij weer in vrijheid gesteld. Zie: Verslag No. CCLVII.

444) Zie: Verslag No. CCXVIII, blz. $2 \mathrm{t} / \mathrm{m} 4$. 
de Confectiefabriek Wassink en de Zuivelfabriek en riep het personeel op, eveneens in staking te gaan ${ }^{445}$ ). Het personeel van het Gemeentehuis was wel aanwezig, maar werkte niet 446 ).

Vrijdagmiddag kwam Weidlich bij de burgemeester en vertelde hem, dat het politie-standrecht afgekondigd zou worden. Ongeveer 18 uur -18.30 uur werden de plakkaten in deze gemeente gebracht ${ }^{447}$ ).

Een der arbeiders van de Exportslachterij, zou Zondag door de Duitsers worden opgehaald. $Z_{i j n}$ arrestatie kon verhinderd worden, doordat men de Duitsers op hun vraag, waar deze man woonde, een verkeerd adres opgaf. Daardoor kreeg men tevens de gelegenheid, hem te waarschuwen en voor een "spoed-operatie" in het ziekenhuis op te laten nemen. Op deze wijze heeft men hem uit de handen der Duitsers weten te houden 448).

Enkele dagen later weigerden twee personen de biljetten, waarop de doodvonnissen bekend werden gemaakt, op te hangen. Ze werden gearresteerd, maar weer vrijgelaten ${ }^{449}$ ).

\section{WEERSELO}

In deze gemeente, waar geen industrie is, werd op Vrijdag door het personeel van het gemeentehuis gestaakt 450). Melkrijders keerden met hun melk naar de boeren terug, doordat de deuren van de zuivelfabriek niet werden geopend. Het personeel daarentegen bleef in de fabriek ${ }^{451}$ ).

Op Zaterdag, $1 \mathrm{Mei}$, werd het werk door het gemeentepersoneel weer hervat ${ }^{452}$ ). Het personeel van de zuivelfabriek en de melkrijders hervatten echter niet de arbeid. Om ca. 12 uur kwamen toen de Duitsers en arresteerden de burgemeester, de voorzitter van het bestuur van de zuivelfabriek, alsmede de directeur ${ }^{453}$ ). Later op de dag, plm. 15 uur, werd een melkrijder van huis opgehaald. $Z_{i j}$ allen werden voor het politie-standgericht te Hengelo gebracht. Met uitzondering van de directeur der zuivelfabriek - die voor een maand naar Scheveningen werd gebracht - werden allen die dag weer vrijgelaten ${ }^{454}$ ).

\section{GOOR}

In April/Mei 1943 werd aan de fabriek N.V. Eternit v/h Martinit nog slechts in beperkte mate gewerkt. Op de dag van het uitbreken der staking

445) Zie: Lijst No. 270.

446) Zie: Verslag No. CCVIII, blz. 1.

447) Zie: Verslag No. CCVI, blz. 1 en 2.

448) Zie: a. 445).

449) Zie: 445)

b. Lijst No. 273.

450) Zie: Verslag No. CCV, blz. 1.

451) Zie: Verslag No. CCXLIII, blz. 1.

452) Zie: 450), blz. 2.

453) Zie: a. 450), blz. 2 en 3.

b. Lijst No. 267.

454) Zie: a. 450), blz. 4.

b. Verslag No. CCXLIV, blz. 2. 
werkten aan dit bedrijf slechts 68 personen. Een der opzichters van deze fabriek, die in de stad was geweest, kwam met de mededeling terug, dat de Nederlandse militairen opnieuw in krijgsgevangenschap naar Duitsland zouden worden teruggevoerd. Het personeel verliet toen echter nog niet de fabriek. Dit gebeurde pas, toen een personeelslid van het Expeditiebedrijf Wibbelink (dit bedrijf is naast de N.V. Eternit gevestigd) kwam melden, dat men in Hengelo in staking was gegaan. Zonder de machines schoon te maken verliet het personeel de fabriek. Platen, die in een pers waren en onder een druk stonden van 400 atmosferen, moesten door het toezichthoudend personeel zelf geborgen worden 455 ).

Zonder dat enig overleg was gepleegd ging de volgende dag niemand van het personeel van deze fabriek aan het werk. In de stad stonden wat groepjes mensen te praten, vooral bij het station ${ }^{456}$ ). Die dag ging ook het personeel van de N.V. Katoenfabriek v/h Arntz. Jannink \& Co. in staking (60 arbeiders) ${ }^{457}$ ). De morgenploeg van het personeel van de gasfabriek legde die dag eveneens het werk neer. De middagploeg is om 14 uur echter weer aan het werk gegaan. De aflevering van gas heeft niet gestagneerd, daar twee ketels in reserve waren ${ }^{458}$ ).

Vrijdagavond werd in Goor het politie-standrecht afgekondigd.

Zaterdagavond kwam Duitse politie uit Hengelo of Almelo. Er werd wel gesurveilleerd, maar de Duitsers vertrokken spoedig 459).

Verdere bijzonderheden uit Goor zijn niet te vermelden.

\section{HET PLATTELAND}

Het verloop van de staking op het platteland blijkt uit de hoeveelheden afgeleverde melk aan de zuivelfabrieken gedurende de stakingsdagen.

Aan de zuivelfabrieken werd afgeleverd op:

Donderdag, 29 April 1943

Vrijdag, 30 April 1943

Zaterdag, 1 Mei 1943 ('s morgens)

$$
, \quad, \quad, \quad, \quad \text { ('s avonds) }
$$

Zondag, 2 Mei 1943

Maandag, 3 Mei 1943
$132.016 \mathrm{~kg}$

22.862 ,

$41.887 \mathrm{~kg}$

10.707 ,

455) Zie: Brief van B. W., Goor, April 1946, Bijlage 93.

456) Zie: 455).

457) Zie: Lijst No. 210.

458) Zie: Verslag No. CLVI, blz. 2.

459) Zie: 458), blz. 6.

460) Zie: Schema III. Deze totalen hebben betrekking op 19 van de 24 zuivelfabrieken.

De andere 5 zuivelfabrieken bezaten dergelijke gegevens niet meer. Tevens dient er hier op te worden gewezen, dat op Zaterdag, 1 Mei de koeien weer in de weide kwamen. Hieruit is mede het feit te verklaren, dat op Maandag 3 Mei meer melk werd geleverd dan op Donderdag 29 April. 
Zaterdagmorgen 1 Mei 1943 werd $41.887 \mathrm{~kg}$ melk - $19.025 \mathrm{~kg}$ melk méér dan de vorige dag - door de melkrijders naar de fabrieken vervoerd. Dit betekent echter, dat die morgen nog steeds ongeveer $70 \%$ van de Donderdag aangevoerde hoeveelheid niet geleverd werd.

Op Zaterdag waren de personelen van de zuivelfabrieken te Boekelo, Rijssen, Weerselo en Wierden nog steeds in staking. Bovendien werd geen melk verwerkt in de zuivelfabrieken te Borne en Saasveld. Slechts ten dele werd melk door melkrijders aangevoerd o.a. in Denekamp, Enschede, Goor, Haaksbergen, Hengelo (Hengelose Coöp. Melkinrichting), Hellendoorn, Oldenzaal, Ootmarsum, Rossum, Tubbergen en Vriezenveen.

Het feit, dat op Zaterdagmorgen $19.025 \mathrm{~kg}$ melk méér werd aangevoerd dan op Vrijdagmorgen is te verklaren uit de druk, door de Duitsers reeds op Vrijdagavond op de directies der zuivelfabrieken uitgeoefend. Dit moge aan de hand van enkele voorbeelden toegelicht worden.

Markelo. In de loop van Vrijdag kwam de onderluitenant van de marechaussee, O. Taai, bij de directie van de zuivelfabriek "Markelo" en vroeg de adressen van de melkboeren, die die dag niet geleverd hadden. Daar men bevreesd was, dat iets zou gebeuren, waarschuwde de directie de melkrijders, zo snel mogelijk weer te leveren ${ }^{461}$ ). Dit is dan ook de reden, dat - terwijl op Vrijdagmorgen niets geleverd werd - op Zaterdagmorgen reeds $13.093 \mathrm{~kg}$ melk aangevoerd werd.

Goor. In deze plaats werden door de politie aan de directeur der zuivelfabriek de adressen van de melkrijders opgevraagd. De melkrijders werd door de politie en marechaussee aangezegd, weer te leveren. Inderdaad werd Zaterdagmorgen $3311 \mathrm{~kg}$ melk geleverd, terwijl op Vrijdagmorgen niets aangevoerd was 462 ).

Aan vier zuivelfabrieken, n.l. te Denekamp. Ootmarsum, Hengelo (Hengelose Coöp. Melkinrichting) en Rossum werden daarentegen op Zaterdagmorgen in totaal $10.338 \mathrm{~kg}$ melk minder geleverd dan op Vrijdag 30 April. Voor Hengelo is dit waarschijnlijk te verklaren uit het patrouilleren der Duitsers op Zaterdagmorgen. De directeur der Hengelose Coöp. Melkinrichting verklaart n.1.: „Die Zaterdag was er echter nog maar een kleine hoeveelheid melk, daar de meeste boeren niet met hun paarden op de weg durfden te komen" 463 ).

Ten aanzien van Rossum geldt, dat dit dorp zeer afgelegen ligt. Dit is de reden, waardoor de staking daar „pas eigenlijk op Zaterdag goed bekend werd" 464).

In totaal werd - gelijk reeds opgemerkt - ongeveer $30 \% 465$ ) van de hoeveelheid van Donderdag op Zaterdagmorgen door de melkrijders aange-

461) Zie: Verslag No. CCXXXI, blz. 1.

462) Zie: Verslag No. CCXXII, blz. 1 en 2.

463) Zie: Verslag No. CCXXVII, blz. 1.

464) Zie: Verslag No. CCXLV, blz. 1.

465) Dit heeft dus betrekking op 19 van de 24 zuivelfabrieken. 
voerd. Die morgen waren aan twintig zuivelfabrieken de personelen weer aanwezig. Vier waren nog in staking.

In de loop van de dag werd de druk der Duitsers op de directies der zuivelfabrieken groter. Zo kwamen de Duitsers aan de Coöp. Stoomzuivelfabriek "Nooit Gedacht" te Hellendoorn. Zij eisten, dat binnen 24 uur alles weer normaal zou functionneren 466). Zaterdagavond werd aan deze fabriek reeds $1335 \mathrm{~kg}$ melk geleverd, d.w.z. $1302 \mathrm{~kg}$ méér dan de vorige dag.

Naar aanleiding van een bevel der Duitsers aan de assistent-directeur der Coöp. Stoomzuivelfabriek "De Eendracht" te Tubbergen, werden Zaterdagmiddag omstreeks 18 uur de boeren (aan deze fabriek leverende) gewaarschuwd, weer melk te leveren 467). Aangevoerd werd nog dezelfde avond $4959 \mathrm{~kg}$ melk (de vorige dag niets).

Niet alleen bij deze twee, maar bij nog andere zuivelfabrieken kwamen de Duitsers. $Z_{i j}$ bevalen, dat het werk zou worden hervat, en joegen de bevolking angst aan door arrestaties. Zo werd de directeur der zuivelfabriek te Denekamp Vrijdagavond gearresteerd, maar weer Zaterdag (om ca. 12 uur) vrijgelaten ${ }^{468}$ ). In de gemeente Weerselo werd de directeur der Coöp. Stoomzuivelfabriek "Weerselo" gearresteerd en met hem de voorzitter der zuivelfabriek, alsmede een melkrijder ${ }^{469}$ ). In Borne werd de directeur der zuivelfabriek Zaterdag om ca. 12 uur gearresteerd. Na vrijgelaten te zijn werd door hem - in overleg met anderen - besloten, de boeren te waarschuwen Zondag weer melk te leveren ${ }^{470}$ ).

Niet alleen direct op bevel der Duitsers, maar ook naar aanleiding van de veranderde toestand zelf namen weer andere directeuren van zuivelfabrieken het initiatief, de boeren c.q. de melkrijders te waarschuwen. Zaterdagmiddag werden bijv. door de directeur der zuivelfabriek te Bornerbroek verschillende melkrijders gewaarschuwd, op Zondag de melklevering te hervatten ${ }^{471}$ ). De melkrijders van de Coöp. Stoomzuivelfabriek ,De Samenwerking" te Wierden werden op Zaterdag gewaarschuwd, op Maandag weer melk te leveren 472).

Het algemeen verloop der stakingsbeweging op het platteland blijkt uit het feit, dat op Zondag 2 Mei 1943 reeds $79.308 \mathrm{~kg}$ melk werd aangevoerd. Dit was echter nog steeds $40 \%$ minder dan de hoeveelheid, die op Donderdag, 29 April 1943 verwerkt werd.

Maandag 3 Mei was de melkleverantie weer normaal ${ }^{473}$ ).

466) Zie: Verslag No. CCXXVI, blz. 2.

467) Zie: Verslag No. CCXLI, blz. 2.

468) Zie: Verslag No. CCXVIII, blz. 2. Zaterdagnacht werd hij (met vele anderen) opnieuw gearresteerd.

469) Zie: Verslag No. CCXLIII, blz. 1.

470) Zie: Verslag' No. CCXIII, blz. 4.

471) Zie: Verslag No. CCXIV, blz. 1.

472) Zie: a. Verslag No. CCL, blz. 1.

473) Zie: 460).

$$
\text { b. Verslag No. CCXLVIII, blz. } 1 .
$$




\section{HOOFDSTUK V}

\section{POLITIONELE MAATREGELEN TEGEN DE STAKING}

\section{De politionele organisatie gedurende de staking}

$\mathrm{Bij}$ het nemen der tegenmaatregelen in Twente waren zowel de Duitse als de Nederlandse politie-instanties betrokken. Ten aanzien van de Duitse instanties valt op te merken, dat reeds op Donderdag 29 April 1943 vanuit de Aussenstelle der Sicherheitspolizei te Arnhem de eerste Duitse politietroepen, "mit scharfen Weisungen versehen" 474) naar Hengelo gedirigeerd

- werden.

Daar „eine zentrale Leitung aller Durchführungsmassnahmen zur Niederringung des Streiks" door de Duitsers niet doelmatig werd geacht, werden op 30 April 1943 zgn. "Sicherungsbereiche" ingesteld; o.a. het Sicherungsbereich Overijssel 475). De commandant hiervan werd de Hauptmann Ney. Zijn standplaats was Hengelo.

Deze Hauptmann Ney was belast met het commando over de verschillende afdelingen van de Ordnungspolizei, welke tijdens de staking in verschillende steden van Overijssel gedetacheerd waren ${ }^{476}$ ). In hoofdzaak was de taak van deze Ordnungspolizei: het handhaven van de bepalingen betreffende de speruren, het verrichten van arrestaties en het in opdracht van de Sicherheitspolizei transporteren van gevangenen ${ }^{477}$ ).

In de voornaamste steden van Overijssel werd een Duits officier gestationneerd met een Zug. Deze bestond uit een aantal manschappen van de Ordnungspolizei en was belast met het handhaven van de orde ter plaatse. Zo was bijv. in Hengelo de luitenant Schatz Zugführer van de aldaar ingezette Ordnungspolizei 478). Dat deze zijn activiteit ook uitbreidde tot andere plaatsen dan Hengelo, blijkt o.a. uit het feit, dat hij bij de arrestatie van negen arbeiders uit Haaksbergen (van wie acht doodgeschoten werden) betrokken is geweest ${ }^{479}$ ). Naast deze Züge van de Ordnungspolizei waren, bijv. in Hengelo, ook nog afdelingen van de Sicherheitspolizei ingezet.

474) Zie: "Blitz"-telex van Rauter aan Himmler dd. 29 April 1943. Bijlage $\$ 4$.

475) Zie: Rondschrijuen (F. S.-Blitz) van Dr. Harster aan alle Aussenstellen. 30 April 1943. Bijlage 95.

476) Zie: Proces-Verbaal, opgemaakt door de Sub-Commissie Zwolle van het Bureau Opsporing Oorlogsmisdrijven, naar aanleiding van verklaringen van Fr. Kohrmeyer. 23 Maart 1947. Bijlage 173, blz. 2.

477) Zie: Proces-Verbaal, opgemaakt door de Sub-Commissie Zwolle naar aanleiding van verklaringen van Fr. Kohrmeyer. 28 Juni 1947. Bijlage 168, blz. 3.

478) Zie: 477), biz. 3.

479) Zie hiervoor uitvoeriger: Hoofdstuk VI. 
Krachtens een besluit van de Höhere SS - und Polizeifühter werd de Nederlandse politie "onder de voor hun ambtsgebied bevoegde commandant van het SS - en politie-ambtsgebied gesteld". De instructies van deze commandanten dienden in elk geval ,in hun volle omvang te worden opgevolgd" 480 ). Zo deelde te Hengelo - in opdracht van de Sicherheitspolizei - de NSBcommisaris van Politie, J. A. Wuyster, de leiders der bedrijven mede, dat zij zich een uur na de gebruikelijke aanvangstijd op Maandag 3 Mei naar de Dienststelle van de Sicherheitspolizei te Hengelo moesten begeven, teneinde aldaar schriftelijk verslag uit te brengen, welke arbeidskrachten eventueel niet op het werk verschenen waren $\mathbf{4 8 1}^{4}$ ).

In Enschede moest de gemeente-politie de Duitsers vergezellen bij het ophalen van burgers uit huis 482 ).

In Almelo moest de gemeente-politie met de Duitsers samen patrouille lopen 483 ).

Deze voorbeelden hebben betrekking op aanwijzingen, die de gemeentepolitie ter plaatse van de Duitse politie-instanties direct kreeg. Het algemeen organisatorisch contact tussen de Duitse en Nederlandse politie-organen was op andere wijze opgebouwd. Uit de, in de volgende bladzijden te citeren, telex berichten en circulaires blijkt, dat het Directoraat-Generaal van Politie te Hoogsoeren de bevelen ontving van de Höhere SS- und Polizeiführer. Deze bevelen werden door het Directoraat-Generaal van Politie doorgegeven aan de Gewestelijke Politiepresident te Arnhem, die op zijn beurt de Commandant van het Gewest Marechaussee Arnhem (waaronder Twente ressorteerde) en de gemeentelijke politie-autoriteiten in Twente door middel van telex berichten en circulaires op de hoogte stelde. Via de commissarissen van politie of andere aanwezige politie-commandanten werden deze berichten aan het lager politie-personeel ter kennis gebracht.

\section{De houding van de Twentse politie}

Uit het feit, dat de Nederlandse politie in Twente ingeschakeld werd, kan natuurlijk niet haar eventuele bereidheid afgeleid worden om tezamen met de Duitsers de staking te breken. Dit blijkt o.a. hieruit, dat na het bekend worden van de staking door het politie-personeel overleg werd gepleegd om ook de arbeid neer te leggen. G. A. Waldkötter, wnd-commissaris van Politie te Hengelo verklaarde: „Een aantal mensen van de politie kwam ook nog bij mij om te overleggen of wij, dus de politie, moesten staken. Ik heb toen gezegd, dat naar mijn mening de politie pas moest gaan staken, als de Spoorwegen het ook deden. Zo hebben wij toen besloten" ${ }^{484}$ ). J. W. ter Avest,

480) Zie: a. Telex-bericht No. 585 van de wnd. Gewestelijk Politiepresident aan de Commandant van het Marechausseegewest Arnhem. 1 Mei 1943. Bijlage 96.

b. Telex-bericht No. 961 van de wnd. Directeur-Generaal van Politie aan de

481) Zie: Bijlage 98 gewestelijke Politiepresidenten. 1 Mei 1943. Bijlage 97.

482) Zie: Verslag No. LXXXVIII, blz. 4.

$483)$ Zie: Verslag No. LIX, blz. 4.

484) Zie: Verslag No. XVIII, blz. 5. 
opper-wachtmeester van de gemeente-politie Hengelo (afdeling recherche), deelde mede: „...ik herinner mij, dat ik de heer Waldkötter verteld heb, dat er op straat een aantal agenten stond te beraadslagen, wat te doen. In opdracht van de heer Waldkötter ben ik toen naar hen toe gegaan en heb gezegd, dat volgens hem de politie moest afwachten" 485 ).

En tenslotte zij er op gewezen, dat - vóórdat de bespreking op het politiebureau op Donderdagmiddag 29 April 1943 plm. 18 uur begon (zie blz. 247) Waldkötter tegen de loco-burgemeester G. J. Steggink zeide: ,....dat hij bij de politie , de hele zaak in orde had'. Als de politie opdrachten zou krijgen, die zij niet zou kunnen uitvoeren, dan zou ,het hele zaakje het kanaal' ingaan" 486 ).

De Hoofdinspecteur van Politie te Enschede, A. T. Bruyning, werd Donderdagavond door zijn collega uit Deventer, de inspecteur van Politie H. Richy, opgebeld; hem werd gevraagd: „Wat doen jullie, gooien jullie de boel erbij neer?" Bruyning antwoordde, dat zij ,de zaak eerst eens rustig aan moesten zien" 487). Later belde Bruyning verschillende collega's op; allen deelden de mening, die hij aan Richy had uiteengezet. De volgende morgen ging hij naar het bureau. „Ook daar was weer die feeststemming. Er was weer het gevoel van: wij krijgen de Moffen er wel onder" 488 ).

In Almelo was het politiepersoneel

,het liefst... direct weggelopen. $\mathrm{Na}$ enig gepraat kwam men echter tot de conclusie, dat het beter was, niet in staking te gaan zonder overleg met politie-personelen van andere plaatsen. Zo heeft men contact gezocht met de politie van Hengelo, Enschede, Deventer en Zwolle. Dit werd reeds op Donderdag gedaan. Ook keek men bij het politiepersoneel reeds de eerste dag naar de Spoorwegen. Maar ook van deze kant werd het initiatief niet genomen. Eigenlijk zat iedereen op 'het' sein te wachten. Het kwam echter niet en daarmee ook niet de staking bij het politie-personeel" 489 ).

De opperwachtmeester bij de Staatspolitie, H. Lucas werd Dinsdagmorgen door de Duitse politie opgebeld; hem werd medegedeeld, dat twee personen, die deel uitmaakten van de negen gearresteerde arbeiders uit Haaksbergen, ontvlucht waren en opnieuw gearresteerd moesten worden. Door zijn bemiddeling (Lucas liet deze beide personen via anderen waarschuwen) wist één persoon zich nog te redden 490 ).

In Denekamp moesten enkele personen op last van de burgemeester gearresteerd worden. De politiemannen, die hen moesten ophalen, lieten hen de keus, alsnog te verdwijnen ${ }^{491}$ ).

In Markelo wist een wachtmeester bij de Rijkspolitie de (NSB)-groeps-

485) Zie: 484), blz. 7.

486) Zie: Verslag No. XVI, blz. 5

487) Zie: Verslag No. LXXXVIII, blz. 1.

488) Zie: 487), blz. 2.

489) Zie: Verslag No. LIX, blz. 2.

490) Zie: Verslag No. CLVIII, blz. 2.

491) Zie: Verslag No. CLIV, blz. 2. 
commandant $\mathrm{O}$. Taai ervan te weerhouden enige arrestanten aan het Standgericht te Hengelo uit te leveren ${ }^{492}$ ).

In Oldenzaal werd de burgemeester in de nacht van 1 op 2 Mei 1943 door de politie aldaar opgebeld en gewaarschuwd, dat de Duitsers op weg waren, hem te arresteren ${ }^{493}$ ).

Gezien de sympathie, die het politie-personeel voor de staking had, is het begrijpelijk, dat de Beauftragte Weidlich in zijn Erfahrungsbericht über die Streikbewegung in der Provinz Overijssel het volgende oordeel geeft:

.Ihr (de Nederlandse politie - Noot van de auteur) Auftreten der Bevölkerung gegenüber. war aber meistens ziemlich schlapp. Es ist anzunehmen, dass ein Teil von thnen Sympathie für die Streikenden hatte, wenn sie es auch nicht offen zeigten.

In den letzten Tagen (bet Erfahrungsbericht is gedateerd 15 Mei 1943 - Noot van de auteur) konnte wiederholt festgestellt werden, dass Niederländische Polizei bei Feststellung von Ulebertretung der Spertstunde vor allem gegen deutschfreundliche Niederländer vorging" 494 ).

Op blz. 282 werd aangegeven, op welke wijze de Twentse politie betrokken werd bij de uitvoering der Duitse maatregelen. Waarschijnlijk slaat hierop de opmerking van Weidlich: ,Die Niederländische Polizei tat wohl im grossen und ganzen ihre Pflicht" 495 ).

Datgene wat $z$ ij deed, werd echter door haar sympathie voor de staking ,ziemlich schlapp" gedaan.

\section{Chronologisch overzicht van de tegenmaatregelen}

In een geheime circulaire dd. 26 April 1943, uitgaande van de Wehrmachtbefehlshaber in den Niederlanden, schreef deze aan verschillende Wehrmachtonderdelen: "Der Führer hat durch Fernschreiben ...v. 24.4 .43 entschieden, dass der $W$. Befh. Ndl. die ehemaligen Angehörigen der niederländischen Wehrmacht in die Kriegsgefangenschaft nach Deutschland zurückzuführen hat" 496). In deze circulaire, die 28 April 1943 eveneens door de Höhere SSund Polizeiführer Nordwest ontvangen werd, kon deze verder lezen:

„Nicht ausgeschlossen ist es, dass durch diese einschneidende Massnahme die Bevölkerung der Niederlande erheblich beunruhigt wird. Aufflackerende Untuhe im Keime zu ersticken, ist Angelegenheit der Deutschen Ordnungspolizei."

.Sonstige polizeiliche Massnahmen werden durch den Höheren SS- und Polizeiführet West durchgeführt" 497 ).

Dezelfde dag werd per schrijven aan de Aussenstellen van de Sicherheitspolizei und des $S D$ het bericht betreffende de terugvoering der krijgsge-

492) Zie: Verslag No. CLXXIII, blz, 2.

493) Zie: Verslag No. CLXXIV, blz. 2.

494) Zie: Bijlage 99, blz. 5 en 6.

495) Zie: 494), blz. 5.

496) Zie: Rondschrijven van de Wehrm. Befehlsh. in den Niederlanden aan verschillende Wehrmachtsonderdelen. H. Qu., den 26.4.43. Ia. Nr. $3408 / 43$ geh. Bijlage 100 .

497) Zie: 496). 
vangenen medegedeeld 498). Ofschoon de Aussenstellen en dus ook de Aussenstelle Arnhem (waaronder Twente ressorteerde), voorzover bekend, geen bijzondere bevelen hadden om eventuele ,aufflackerende Unruhe im Keime $z u$ ersticken", waren $z$ ij in elk geval van de aanstaande terugvoering der krijgsgevangenen op de hoogte gesteld.

Do nderdag. - Donderdagmiddag 29 April 1943, 16.15 uur, seinde de SS-Hauptsturmführer Thomsen ,,an den BdS", dat hem zoëven bekend werd, dat in Hengelo kort voor half vier, arbeiders van de firma Stork, Hazemeyer's Electrische Apparaten en Dikkers op grond van de bekendmaking betreffende krijgsgevangenschap de arbeid hadden neergelegd. "Von anderen Orten der Provinz" - aldus eindigt het telegram - „sind derartige Meldungen bislang nicht eingegangen" 499 ).

Het bericht betreffende de uitgebroken staking werd door de SS-Obersturmbannführer Knolle aan alle Aussenstellen per Blitz-telex doorgeseind 500).

Om 17.55 seinde Thomsen opnieuw, dat de staking zich over andere plaatsen uitgebreid had. Hij deelde o.a. mede, dat de Ortskommandant in Hengelo voor Donderdagavond de bioscoopvoorstelling verboden had 501).

Dezelfde middag om 18.25 uur ontving de wnd politie-president te Arnhem, Walraven, via de telex het eerste bericht, dat in Enschede een staking was uitgebroken ,,in verband met het krantenbericht betr. het melden van oudmilitairen..." De wnd commissaris van Politie te Enschede, A. Berends, verzocht de wnd politiepresident, het uitbreken der staking ter kennis te brengen van de "Major der Sicherheitzpolizei" te Arnhem, Nitsche 502).

Het bericht van het uitbreken der staking te Hengelo ontving de commandant van het Marechausseegewest Arnhem, J. E. Feenstra, om 18.00 uur. Door de Commissaris van Politie te Hengelo werd medegedeeld, dat voorlopig maatregelen waren getroffen in overleg met Sicherheitspolizei en Ortskommandant. Dit bericht werd door de Commandant van het Marechausseegewest Arnhem per telex om 18.30 uur doorgeseind aan de wnd politiepresident te Arnhem 503). Soortgelijke stakingsberichten uit Nijverdal 504) en Almelo 505) werden door de wnd politiepresident te Arnhem ontvangen.

Daarna werd de Directeur-Generaal van Politie, zetelende te Hoogsoeren, door de wnd politiepresident te Arnhem van de staking op de hoogte gesteld 506).

498) Het afschrift van dit schrijven is niet compleet. Aanwezig zijn slechts de eerste twee pagina's. Aan het hoofd van het afschrift van dit schrijven staat echter aangetekend, dat het op 28 April 1943 door SS-Scharführer Hermjohannes is „abgesandt”.

499) Zie: Bijlage 101.

500) Zie: Bijlage 102.

501) Zie: Bijlage 103.

502) Zie: Bijlage 104.

503) Zie: Bijlage 105.

504) Zie: Bijlage 106.

505) Zie: Bijlage 107.

506) Zie: Bijlage 108 . 
Donderdagavond om 20.20 uur deelde Thomsen aan Harster, de Befehlshaber der Sicherheitspolizei in Den Haag, mede: .Jedenfalls unterscheidet sich das Strassenbild in den vom Streik betroffenen Städten im Augenblick nicht von dem Bild in den anderen Städten der Provinzen Gelderland und Overijssel." Het telex-bericht vervolgt dan:

„Mit dem gesamten zur Verfügung stehenden VM (Vertrauensmännet - Noot van de auteur) Apparat, einem Kommando von 12 Angehörigen der Dienststelle Arnheim und den Angrehörigen des Postens Enschede, werden die als Rädelsführer zu betrachtenden Personen festgestellt und im Laufe der Nacht festgenommen. Die Abwehrbeauttragten der Rüstungsbetriebe haben sich aut dem Standpunkt gestellt, dass in diesem Falle von wirklichen Rädelsführern nicht gesprochen werden könne, weil das Verlassen der Werke spontan nach dem Bekanntwerden des WBN-Befehls erfolgt sei" 507 ).

Reeds om 18.15 uur werd Himmler per telex door Rauter op de hoogte gesteld van de staking in Hengelo. "Das Polizei-Bataillon Arnheim” — aldus Rauter aan Himmler - ,twurde von mir sofort nach Hengelo in Marsch gesetzt und wird gegen 20 Uhr dort eintreffen. Für 20 Uhr ist Sperrstunde angeordnet worden. Die Polizei ist mit scharfen Weisungen versehen" 508).

V rij d a g. - Naar aanleiding van een telefonisch onderhoud tussen het Directoraat-Generaal van Politie en de wnd politiepresident te Arnhem, ontving de laatste een telex-bericht waarin werd vermeld, dat afdelingen van het Duitse politiebataljon te Arnhem gedetacheerd waren naar de steden Almelo, Hengelo en Enschede. De Nederlandse politie was - zo werd verder bericht - onderworpen aan de bevelen van de Commandant van het Duitse bataljon. De wnd politiepresident diende - teneinde hieromtrent nadere gegevens te verkrijgen — zich met de Commandant van het bataljon ,te verstaan" 509 ).

Dezelfde dag verzocht de wnd politiepresident in een telex-bericht de commandant van het Marechausseegewest Arnhem, aan het „onderhebbend politiepersoneel" o.a. mede te delen, dat onvoorwaardelijk uitvoering van alle bevelen geëist werd. "Degenen, die zich aan weigering schuldig maken" aldus het telex-bericht - ,zullen als saboteurs worden behandeld" 510 ).

Vrijdagavond, 30 April werd het decreet betreffende het politiestandrecht voor de Provincie Overijssel afgekondigd. Een ieder had zich ,te onthouden van iedere beroering, welke de openbare orde en de veiligheid van het openbare leven zou kunnen verstoren." Bij de uitvoering van zijn taak - aldus het decreet - kon de Höhere SS- und Polizeiführer van het geldende recht afwijken 51!).

507) Zie: Bijlage 109.

508) Zie: 474). Zoals reeds vermeld kwamen de eerste Duitse politietroepen in Hengelo om plm. 7.30 uur aan. Zie: blz. 247.

509) Zie: Bijlage 110.

510) Zie: Bijlage 111.

511) Zie: Decreet betreffende de afkondiging van het Politie-Standrecht te Overijssel. Bijlage 112. 
Dezelfde dag was reeds per FS-Blitz alle Aussenstellen medegedeeld, dat Standgerichte ingesteld zouden worden 512). De zetels der Standgerichte bevonden zich in de gebouwen, waar de resp. Aussenstellen gevestigd waren. Alleen Hengelo vormde hierop een uitzondering. De zittingen van het Stand gericht te Hengelo vonden plaats in het Hoofdbureau van Politie, kamer 9513 ).

Kort na het uitbreken van de staking kreeg de voormalige Sturmbannführer, ChetRichter bij het SS- und Polizeigericht te Den Haag, Ernst Härtl, bevel, de in de Verordening Openbare Orde 1943 voorgeschreven Polizeistandgerichte in te stellen. Bepaald werd, dat een dergelijk Standgericht o.a. zou worden ingesteld in Hengelo, waarvoor als voorzitter werd aangewezen Dr Boulanger, een Richter van het SS- und Polizeigericht te Den Haag ${ }^{514}$ ).

Al spoedig ontstonden tussen de SS-Obersturmfühnet und SS-Richter, Dr Boulanger, en de SS-Hauptsturmführer, Thomsen, meningsverschillen, die voor een deel voortkwamen uit de opvatting van Dr Boulanger, dat ,er eigenlijk niets bijzonders aan de hand was..." 515). Kort na het instellen van het Standgericht had Rauter n.l. Thomsen opgebeld en gevraagd, waarom uit Hengelo geen doodvonnissen kwamen ${ }^{516}$ ). Hierop zou - volgens verklaringen van Dr Härtl - Thomsen geantwoord hebben, dat Boulanger niet actief genoeg was 517). Daar samenwerking tussen beiden niet meer mogelijk was, werd Dr Boulanger vervangen door de SS-Sturmbannführer, Dr Arno Arlt, een Untersuchungstichter bij het SS- und Polizeigericht te Den Haag.

Zijn Gericht te Hengelo, dat juist de zaak tegen Loep, ingenieur bij de Storkfabrieken, moest behandelen, bestond verder uit de SS-Sturmbannführer en Universitätsprofessor, Dr Nelis en één officier van de Ordnungspolizei van een in Den Haag gelegerde eenheid (naam onbekend). Als griffier fungeerde een Hauptwachtmeister der Schutzpolizei. Als vertegenwoordiger van de openbare aanklager trad op de SS-Hauptsturmführer Thomsen 518 ). Als verdediger werd toegevoegd een SS-Offizier ${ }^{519}$ ). De vonnissen werden ,mit der Urteilbegründung und dem wesentichen Ermittlungsergebnis durch Fernschreiber oder Kurier dem Höheren SS- und Polizeiführer in Den Haag übermittelt..., der über die Bestätigung zu entscheiden hatte" 520 ).

512) Zie: 475).

513) Zie: Proces-Verbaal. Gemeentepolitie te Hengelo, afdeling Politieke Opsporingsdienst. No. 2398. R 48. Bijlage 113 .

514) Zie: Proces-Verbaal, opgemaakt door de Sub-Commissie Zwolle, naar aanleiding van verhoren van Ernst Härtl, blz. 12. Bijlage 168.

515) Zie: 514), blz. 12.

516) Zie: 513), blz. 3.

517) Zie: a. 514), blz. 12.

b. De SS-Obersturmführer der Sicherheitspolizei, L. Heinemann verklaart, dat de SS-Richter Dr. Boulanger drie personen ter dood veroordeelde (deze vonnissen zijn door de kogel op 2 Mei 1943 voltrokken) en één persoon tot 10 jaar tuchthuisstraf. Overigens heeft deze Richter meerdere personen tot gevangenisstraf veroordeeld. Zie: Proces-Verbaal opgemaakt door de SubCommissie $Z$ wolle naar aanleiding van een verhoor van $L$. Heinemann, blz. 3/5, Bijlage 168 .

518) Zie: Proces-Verbaal, opgemaakt door de Sub-Commissie Zwolle van het verhoor van Dr. Arno Arlt, blz. 9. Bijlage 168.

519) Zie: Proces-Verbaal, opgemaakt door de Sub-Commissie Rotterdam van het Bureau Opsporing Oorlogsmisdrijven, naar aanleiding van een verhoor van Dr. Arno Arlt. 10 Juni 1946. Bijlage 114, blz. 2.

520) Zie: Bericht van Kriegsgefangener Dr. A. Arlt. Rotterdam, 15 Augustus 1946, blz. 2. Bijlage 115. 
Door het Standgericht te Hengelo werden in totaal zes doodvonnissen uitgesproken en daarna door de kogel voltrokken 521 ).

$Z$ aterdag. - Naar aanleiding van het afkondigen van het politiestandrecht werd door het Directoraat-Generaal van Politie - dat deze instructies weer ontving van de Höhere SS - und Polizeiführer - aan de gewestelijke politiepresidenten te Amsterdam, Rotterdam, Groningen (te Leeuwarden), Eindhoven en Arnhem medegedeeld, dat:
a. voor de uitvoering van alle maatregelen, voortvloeiende uit de afkondiging van het politie-standrecht, de commandanten van de SS en de politie-ambtsgebieden bevoegd waren;
b. ingesteld was:
SS en politie-ambtsgebied Overijssel. Commandant was de Hauptmann der Schutz- polizei Ney te Hengelo;
c. de Nederlandse politie, onder de voor hun ambtsgebied bevoegde commandant van het SS - en politie-ambtsgebied werd gesteld. Instructies van deze commandanten dienden in hun volle omvang te worden opgevolgd;
$d$. de bevoegdheid van de B.d.O.-verbindingsofficieren bij de gewestelijke politie-presi- denten tot het geven van instructies bleef bestaan;
e. alle verloven voor het Nederlandse politiepersoneel werden ingetrokken en de dienst- tijd op 12 uur werd gebracht 522 ).

Bovenstaande berichten werden door de wnd politiepresident doorgeseind aan de lagere Nederlandse politie-organen 523 ).

Zaterdag, 15.58 uur, seinde het Directoraat-Generaal van Politie te Hoogsoeren (naar aanleiding van een door hem ontvangen bericht van de Commissaris-Generaal voor de Openbare Veiligheid, Rauter) o.a. aan de wnd politiepresident te Arnhem, ,dat het, in verband met de uitvaardiging van het politie-standrecht, aan leden van de Nederlandse politie ten strengste verboden is, bij politioneel optreden waarschuwingsschoten te lossen. Bij eventuele incidenten, waarbij van de vuurwapenen gebruik moet worden gemaakt, dient dus onmiddellijk zonder pardon raak te worden geschoten" 524 ). Een instructie in deze zin is door de wnd politiepresident aan de Nederlandse politieautoriteiten doorgegeven 525 ).

Zondag. - Deze dag deelde het Directoraat-Generaal van Politie te Hoogsoeren - naar aanleiding van een door hem ontvangen bericht van de Höhere SS - und Polizeiführer, Befehlshaber der Sicherheitspolizei — o.a. aan de wnd gewestelijk politiepresident te Arnhem mede, dat de Nederlandse politie gedurende de uitvaardiging van het politie-standrecht het daarin vastgestelde uitgaansverbod met de meeste gestrengheid diende te handhaven.

521) Zie uitvoeriger: Hoofdstuk VI.

522) Zie: 480) b.

523) Zie: 480) a en Bijlage 116.

524) Zie: Bijlage 117.

525) Zie: Bijlage 118, 119 en 120. 
Voorts werd medegedeeld, dat ondanks het door de Befehlshaber der Sicherheitspolizei uitdrukkelijk gegeven bevel om geen waarschuwingsschoten te lossen, het nog herhaalde malen voorkwam, dat dit wel gedaan was 526). Een instructie in deze zin werd doorgegeven aan de Nederlandse politieautoriteiten 527 ), die het weer ter kennis brachten van het politie-personeel 528).

Dezelfde dag werd door de wnd gewestelijk politiepresident de politiegezagsdragers in het gewest Arnhem er op gewezen:

a. dat sportwedstrijden, dus ook alle sportbeoefening, waarbij enig publiek aanwezig was, verboden was. Persoonlijke sportbeofening was toegelaten;

b. dat het verbod, zich na 20 uur in de openlucht op te houden, met grote gestrengheid diende te worden gehandhaafd. Arbeiders in continubedrijven, die in de spertijd op straat moesten komen, mochten dit wel, mits zij voorzien waren van een legitimatiebewijs, afgegeven door de directie van het bedrijf en afgestempeld door de Duitse Polizei-Offizier beim Beauftragten in Arnhem of Zwolle ${ }^{529}$ ).

Een circulaire van deze inhoud werd ter kennisneming gezonden o.a. aan de Directeur-Generaal van Politie, de Sicherheitspolizei te Arnhem en de Verbindungsoffizier des B.d.O. zum Landespolizeipräsidenten. Herrn Major Nitsche, te Arnhem 530).

$\mathrm{M}$ a a n d a g. - Uit binnengekomen meldingen was, - zo deelde het Directoraat-Generaal van Politie aan de gewestelijke politiepresidenten o.a. te Arnhem mede - herhaaldelijk gebleken, dat gedurende de afkondiging van het politie-standrecht de Nederlandse politie niet scherp genoeg optrad tegen ,,eventuele molestaties van de zijde van het publiek". De politie zou ,,door ordeverstoorders herhaaldelijk lastig gevallen" zijn, waarbij ", het publiek een dreigende houding" zou hebben aangenomen.

In verband hiermede - zo seinde het Directoraat-Generaal van Politie verder - had de Höhere SS - und Polizeiführer bepaald, dat in dergelijke gevallen onmiddellijk en onverbiddelijk van de vuurwapenen gebruik moest worden gemaakt, waarbij ,teneinde met alle kracht het politie-gezag te handhaven" ..., ,in geen geval waarschuwingsschoten" gelost mochten worden.

Eveneens werd geconstateerd, dat in verschillende gemeenten vooral des nachts aanplakbiljetten betreffende de afkondiging van het politie-standrecht afgescheurd waren. Op last van de Höhere SS und Polizeiführer moest tegen "dit euvel eveneens op de scherpste wijze worden opgetreden". Mochten zich dergelijke feiten wederom voordoen - aldus het telex-bericht — dan zouden de burgemeesters (politie-gezagsdragers) alsmede de plaatselijke politie hier-

526) Zie: Bijlage 121.

527) Zie: Bijlage 122.

528) Zie: Bijlage 123 .

529) Zie: Bijlage 124.

530) Zie: 529). 
voor aansprakelijk gesteld worden 531 ). Ook dit bericht werd aan het lagere politie-personeel doorgegeven 532 ).

Deze zelfde dag bepaalde de Höhere SS - und Polizeiführer:

..Ich ersuche den Kommandeuren der Sicherungsbereiche mitzuteilen, dass die Leichen der aut den Strassen erschossenen niederländischen Staatsangehörigen nur bedingt freizugeben sind, d.h. dass die Beerdigung dieser Erschossenen zwar auf Friedhöfen stattfinden könne, aber nur unter Beteiligung des allerengsten Familienkreises und unte: Kontrolle durch niederländische Polizei" ${ }^{533}$ ).

Via het Directoraat-Generaal van Politie en de wnd gewestelijk politiepresident te Arnhem werd dit bericht - dat ook door Rauter aan alle Aussenstellenleiter der Sicherheitspolizei medegedeeld werd - aan de Nederlandse politie-organen doorgegeven 534).

Din s d a g. - Op deze dag werd door de wnd gewestelijk politiepresident Walraven o.a. aan de politie-gezagsdragers Gewest Arnhem medegedeeld, dat personen, die terzake overtreding van het uitgaansverbod werden aangehouden, ingesloten moesten worden. Processen-verbaal moesten niet worden opgemaakt, doch namen met woonadres moesten aan de Sicherheitspolizei te Arnhem doorgegeven worden. In afwachting van een beslissing van de SD moesten deze personen worden ingesloten 535 ).

Een circulaire, o.a. het bovenstaande bevattend, werd aan de DirecteurGeneraal van Politie toegezonden, alsmede aan de Sicherheitspolizei Arnhem 536).

S a me n v a t t ing. - Op 15 Mei 1943 werd het politie-standrecht opgeheven. De diensten van de politie konden weer worden verricht op de wijze, zoals vóór de invoering van het politie-standrecht het geval was 537).

In de periode van 4 Mei 1943 tot 15 Mei 1943 werden via het Directoraat. Generaal van Politie en de wnd politiepresident te Arnhem nog verschillende telegrammen aan de politie-gezagsdragers in het gewest Arnhem verzonden. Daar deze op de staking zelf van geen invloed meer waren, wordt hiervoor alleen naar de bijlagen verwezen ${ }^{538}$ ).

531) Zie: Bijlage 125 .

532) Zie: Bijlage 126

533) Zie: Bijlage 127.

534) Zie: Bijlage 128 .

535) Zie: Bijlage 129.

536) Zie: 535).

537) Zie: Bijlagen 130 en 161.

538) De bijlagen $131 \mathrm{t} / \mathrm{m} 135$ hebben nog betrekking op de periode vóór $4 \mathrm{Mei}$ 1943. De bijlagen $136 \mathrm{t} / \mathrm{m} 164$ hebben betrekking op de periode 4 Mei 1943 t/m 28 Juli 1943. 


\section{HOOFDSTUK VIII}

\section{NABESCHOUWING}

In het voorgaande werd uiteengezet, op welke wijze de Twentse bevolking zich reeds vóór de staking tegen de Duitsers verzette. Bij de arbeiders en ondernemers kwam dit vooral tot uitdrukking in het verzet tegen de gelijkschakeling van hun vakorganisaties en tegen de inschakeling van het Betrieb in de acties van het N.A.F. en "Vreugde en Arbeid”. De boeren saboteerden reeds de verplichte vee- en graanleveringen, terwijl leden en leiders van de culturele organisaties hun werk liever voortzetten langs illegale weg, dan op een of andere wijze met de Duitsers te collaboreren.

Al moge de staking op 29 April 1943 voor velen - ook zelfs voor de stakers in Twente - plotseling zijn ontstaan, gebleken is, dat de belangrijkste voorwaarde voor een dergelijk optreden zich gedurende geruime tijd had ontwikkeld. Deze bestond hierin, dat de bestaande sociale tegenstellingen tot op zekere hoogte - zij het voorlopig - ondergeschikt werden gesteld aan het algemeen gevoeld verlangen om op een of andere wijze actief en massaal uiting te geven aan de ontevredenheid, die bij allen heerste.

Een dergelijke, zich ontplooiende massa-situatie kon echter slechts tot stand komen in het levend contact tussen de mensen. Oude tegenstellingen moesten door daden worden overbrugd, nieuwe banden door gesprek en door gemeenschappelijke, op partiële doelen gerichte acties worden aangeknoopt.

Dat alles heeft zijn tijd nodig gehad. Maar dit elkaar-willen-begrijpen en naar-elkaar-willen-luisteren kwam in Twente toch al vrij spoedig tot stand. We vonden het terug in de vergaderingen, waar Scheps sprak en zowel ondernemers en arbeiders als intellectuelen aanwezig waren. Hetzelfde zagen wij in de succesvolle gemeenschappelijke weerstand, die arbeiders en ondernemers boden aan de pogingen van het N.A.F., de fabriekspersonelen met zijn ideologie te infiltreren. Boeren en stedelijke bevolking - een tegenstelling, die in Twente overigens niet bestaat - kwamen nog meer met elkaar in contact, doordat stedelingen voor prijzen die men nauwelijks zwart kon noemen, boter, melk en graan konden kopen. En tenslotte bleek, dat ook een poging werd ondernomen om met behulp van de directies van Stork en Dikkers een staking over het gehele land - naar het voorbeeld van de Februaristaking - te organiseren, teneinde de toenemende uitzending van arbeiders naar Duitsland te keren.

Dat alles zegt niet, dat de sociale groeperingen in Twente, ieder door hun 
eigen overwegingen geleid, zich in één rechte lijn naar de gemeenschappelijke actie tegen de Duitsers bewogen. Het in lange tijd ontstane wantrouwen - in het bijzonder van de textielarbeiders tegen de fabrikanten - was niet in drie jaren verdwenen. De - zij het gedwongen - aanvankelijke medewerking van de ondernemers aan de uitzending van arbeiders naar Duitsland wekte ook onder de arbeiders in Twente veel ontstemming. De bombardementen maakten allen, maar in het bijzonder de arbeiders, die de voor de Duitsers werkende fabrieken bevolkten, prikkelbaar. Toen b.v. in October 1942 de fabrieken van Stork werden gebombardeerd - twee personen werden gedood $\rightarrow$, weigerden de arbeiders die dag het werk opnieuw te hervatten, daar zij van mening waren, dat dit ongeluk het gevolg was van "onvoldoende luchtbescherming" 703 ).

De toenemende druk van de Duitsers op elk der sociale lagen, — zoals dit geschetst werd in hoofdstuk II - bracht op den duur echter onderling meer begrip, omdat allen dezelfde vijand hadden. In het zich ontplooiend verzet ontstond het besef van een gemeenschappelijke tegenstander.

Door de bijzondere sociale gelaagdheid van deze zich ontwikkelende collectiviteit was het karakter van het verzet van elke groep niet hetzelfde. Zo saboteerden de ondernemers b.v. de uitzending van arbeiders naar Duitsland door middel van vrijwel uitsluitend administratieve maatregelen en door de voor de Duitsers uit te voeren werken zo slecht mogelijk te organiseren. De arbeiders werkten langzaam en de boeren ontdoken - in den beginne niet al te opvallend - de verplichte leveringen.

Bepaalde dus het karakter der sociale lagen de wijze, waarop de verschillende groepen van de bevolking zich verzetten, eveneens werd daardoor de wijze bepaald, waarop zij in de staking werden betrokken.

De wijze, waarop de arbeiders de fabrieken verlieten, hebben wij uitvoerig beschreven. In het algemeen zochten de arbeiders met de directies geen contact. In die fabrieken echter, waar om raad werd gevraagd, lieten de ondernemers de arbeiders zelf de keus, wat zij wilden doen. Tegenover de actieve functie, die de arbeiders - door hun maatschappelijke positie bepaald - in dit conflict hadden, kon de ondernemer meestal niet anders dan lijdelijk toezien. $Z_{i j n}$ rol werd bepaald door het feit, dat hij geen arbeid had neer te leggen, waaruit zijn demonstratieve gezindheid kon blijken. Het enige, wat hij deed, was of de poorten laten sluiten of op kantoor blijven. Zowel het een als het ander is gedurende de staking in Twente dan ook gebeurd.

Toen de arbeiders op Donderdagmiddag 29 April 1943 de fabrieken verlieten, geschiedde dit met honderden tegelijk. Het personeel van elke fabriek had door het doen van de daad als het ware één besluit genomen. Doordat echter in de grote plaatsen zoals Hengelo, Enschede en Almelo meerdere fabrieken vrijwel tegelijk in staking gingen, vormden al deze fabrieksperso-

703) Zie: a. Verslag No. XXIII, blz. 13/14.

b. Van October 1942 tot midden April 1943 vielen 29 bommen op de fabrieken. Herhaaldelijk werd grote schade aangericht. 
nelen op het moment van het uitbreken van de staking één grote collectiviteit, waarin elke arbeider als het ware was ondergedoken.

Geheel anders daarentegen was het geval met de ondernemers. $Z_{\mathrm{ij}}$ konden niet "onderduiken" in de anonymiteit van hun groep. $Z_{i j}$ waren de personen - juist door hun geringe aantal —, tot wie de Duitsers zich gemakkelijk en individueel konden wenden. $Z_{i j}$ waren veel eerder dan de arbeiders te bereiken en konden daardoor ook direct door de Duitsers aansprakelijk worden gesteld, niet alleen voor het feit, dat de arbeiders de fabriek hadden verlaten, maar ook voor hun eventueel weer verschijnen. Wel hadden de ondernemers hun woonplaats kunnen verlaten, maar raadzaam was dit niet ${ }^{704}$ ). Wilden $z$ ij dus aan hun kwetsbare positie ontkomen, dan konden zij niet anders doen dan - zoals b.v. verschillenden in Almelo en Enschede - hun huis verlaten, onderduiken en pas te voorschijn komen, toen duidelijk bleek, dat de staking geen uitbreidingsmogelijkheid meer bezat en het niet-hervatten van het werk zeer veel slachtoffers zou kosten.

Ook blijkt het passieve verzet van de ondernemers uit het feit, dat niet $z$ ij het initiatief namen, de arbeiders te waarschuwen om het werk te hervatten. $Z_{\text {ij }}$ deden dit niet, hoewel reeds Vrijdagmiddag duidelijk bleek, dat de staking afgebroken moest worden, doordat het spoorwegpersoneel bleef rijden en de staking dus niet algemeen zou worden. Het standpunt der directies werd feitelijk pas bepaald, toen hun Vrijdagavond door Weidlich op het Stadhuis te Hengelo onder dreigementen werd gelast, de arbeiders te waarschuwen, het werk te hervatten. De Enschedese fabrikanten gingen daar pas toe over, toen hun Vrijdagavond werd medegedeeld, dat zij lijsten met namen van de stakers moesten inleveren.

Al mogen de ondernemers dus geen actieve functie bij het uitbreken der staking hebben gehad, hun gezindheid ten aanzien van de Duitsers was bekend en dat speelde bij het in actie komen der arbeiders een rol.

Geen ogenblik kan vergeten worden, dat deze staking tenslotte uitbrak onder een bezettende macht, waarvan bekend was, dat zij niet alleen reeds één staking bloedig had onderdrukt, maar voor nog veel ingrijpender represailles niet zou terugdeinzen.

Wij willen hiermede niet de indruk wekken, dat de personelen bij het verlaten van de fabriek daaraan bewust hebben gedacht. Op het moment van het bekend worden van de Duitse aankondiging wilde men slechts één ding: ,er uit!" Dat hierover zo weinig discussie behoefde te zijn, werd voor een deel in de hand gewerkt door het feit, dat men zich bij het verlaten der fabriek in de rug gedekt voelde.

Vanaf het moment echter, dat de arbeiders de fabrieken hadden verlaten,

i04) Ir T. M. Loep, werkzaam bij Stork, had na het uitbreken van de staking Hengelo verlaten. Na zijn terugkeer werd hij op $4 \mathrm{Mei} 1943$ gearresteerd en door het Standgericht te Hengelo ter dood veroordeeld. Volgens dit Standgericht had Ir Loep zich zich met opzet van iedere invloed op de arbeider onthouden om de staking niet te belemmeren. Het vonnis tegen Ir Loep werd voltrokken.

Zie uitvoeriger: Hoofdstuk VI. 
was ook bij hen een passieve houding waar te nemen. $Z_{\mathrm{ij}}$ gingen naar huis en bleven de volgende dag thuis of gingen naar de boeren om melk te halen. Op straat was het Donderdagmiddag druk, maar op Vrijdag overal rustig. Samenscholingen op grote schaal en van demonstratieve aard vonden nergens plaats. Uit de besprekingen met de vele arbeiders is verder niet gebleken, dat men zich op de hoogte ging stellen van de toestand elders, b.v. in Arnhem en Zwolle. Slechts een enkeling - zoals de heer Roorda - ging naar het Westen van het land om te pogen, de staking verder te dragen. Hieruit blijkt wel, dat de Twentse arbeidersbevolking in deze staking geheel anders reageerde dan de Amsterdamse Februari-stakers, die - toen op de tweede stakingsdag de Duitse terreur in hevige mate woedde - ook toen in hoge mate van hun anti-Duitse gezindheid blijk gaven.

Verschillende personen in Twente waren van oordeel, dat dit kalme verloop der Meistaking in Twente verklaard diende te worden uit de Twentse volksaard. De juistheid hiervan kan echter slechts worden beoordeeld, indien deze Meistaking vergeleken wordt met voor-oorlogse stakingen. De moeilijkheid daarbij is, dat bij de voor-oorlogse conflicten de belangen-tegenstelingen van geheel andere aard waren: door de arbeiders werd toen veel emotioneler gereageerd. Zo vonden in de grote textiel-staking van 1931/1932 wèl grote samenscholingen plaats, werd wèl gevochten met politie of marechaussee en werden ruiten ingegooid bij onderkruipers. Hevig was toen het tumult op een vergadering waar vakbondsbestuurders het advies gaven, het werk te hervatten.

Een dergelijk emotioneel optreden van de Twentse arbeidersbevolking was in Mei 1943 uiteraard ondenkbaar. Een ieder, ook bazen en leidinggevend personeel, staakte, en vrijwel de gehele arbeidersbevolking begreep het advies van de ondernemers om aan het werk te gaan. Zeer goed wist men, toen het vaststond, dat een algemene staking niet zou plaats vinden, dat het nietopvolgen van het bevel der Duitsers, om het werk te hervatten, een terreur tengevolge zou hebben, zoals nooit in Nederland, ook niet in de Februaristaking, had plaats gevonden.

In de hoofdstukken over ontstaan en uitbreiding der staking is komen vast te staan, dat van een bewust elkaar wederzijds in de staking betrekken niet veel sprake was. Voor een belangrijk deel kan dit hieruit worden verklaard, dat de maatregel van de Duitsers plotseling vrijwel alle gezinnen tegelijkertijd trof. Hier werd iets essentieels geraakt, iets dat direct met het naakte leven van zoon of broer, verloofde of echtgenoot te maken had. "Terugvoering in Duitse krijgsgevangenschap" werd door een ieder gevoeld en begrepen als "wegvoering naar een concentratie-kamp". Verzet hiertegen behoefde, juist doordat het allen als een fatale slag trof, niet te worden voorbereid. Daarvoor was men reeds in te grote massa's in de bedrijven aanwezig; daarvoor was het onderling contact te innig. De eerste weifeling bij Stork werd reeds omgezet in een massaal verlaten van de fabriekshallen, toen het gerucht zekerheid werd. Nadat eenmaal door de best geschoolde arbeiders van Twente het voorbeeld gegeven was, golfde de staking verder, van stad tot stad, van dorp 
tot dorp; en zij kwam pas tot stilstand aan de peripherie van dit uitgestrekte industrie-gebied.

Het spontaan uitbreken van deze staking - evenals trouwens van alle spontaan uitbrekende massa-bewegingen - vond dus zijn oorzaak in verschillende tegelijk werkende factoren. In de eerste plaats waren haat en bereidheid tot verzet reeds vroeger door het optreden der Duitsers gewekt. Tot gesloten, actief en massaal verzet kon het echter pas komen op het moment, toen allen tegelijk en in dezelfde mate werden bedreigd en diegenen, die de stoot tot het openlijk verzet moesten geven, in gesloten en sedert langere tijd op de proef gestelde gemeenschappen aanwezig waren. En het waren de "technische" omstandigheden, in hoofdstuk III beschreven, die het mogelijk maakten, dat deze staking zich in nauwelijks $21 / 2$ uur over geheel Twente kon uitbreiden. Er werd toen met betrekking tot Hengelo opgemerkt, dat de uitbreiding van de staking "vanzelf" ging, doordat enige belangrijke fabrieken vlak bij elkaar lagen. Verder wezen we op het belangrijke feit, dat een deel van de arbeiders niet in hun woonplaats werkte. Ook de betekenis van het onderling contact door middel van de telefoon werd uitvoerig toegelicht.

Eén der factoren, die het ontstaan en de uitbreiding van de staking op Donderdagmiddag nog versnelden, was het gerucht, dat de Spoorwegen in staking waren gegaan.

Niet alleen de Stork-arbeiders maar allen, die zich met goede gevoelens met de staking verbonden voelden, begrepen de belangrijkheid van dit gerucht. Indien de machinisten de locomotieven zouden verlaten, zouden zij - het klinkt paradoxaal - door het niet-rijden de stakingscentra juist verbinden. Dat dit niet is geschied, heeft een zeer grote teleurstelling veroorzaakt en bij de Twentse arbeiders het besef gewekt dat verder staken onmogelijk was.

Daar in Twente de staking algemeen was, kan wel gezegd worden, dat het hoogtepunt was bereikt, toen bekend werd, dat de Spoorwegen zouden blijven rijden. Op dat moment was er voor de politie geen reden meer om het werk neer te leggen en was er evenmin voor de ambtenaren aanleiding om nodeloos risico te nemen. Voor de arbeiders was er geen andere mogelijkhid dan de waarschuwing van de fabrikanten goed ter harte te nemen.

Wel werd het besluit van de arbeiders om het werk te hervatten mede bepaald door het dreigen en het optreden der Duitsers.

In Hengelo togen de arbeiders op Zaterdagmorgen echter naar het werk, toen in deze stad nog geen personen waren doodgeschoten. Wel hadden de Duitsers reeds enkele malen geschoten, maar schietpartijen vingen eerst aan, en de eerste doden vielen pas, toen de arbeidersmassa's op weg waren naar de fabriek om de arbeid te hervatten. Voor Hengelo kan dus niet worden gezegd, dat de arbeid pas na zware terreur der Duitsers werd hervat. Veeleer waren de metaalarbeiders van mening, dat staken zonder uitzicht op verdere uitbreiding zinloos was.

Zoals Hengelo het sein tot de staking had gegeven, zo vormde deze stad ook het uitgangspunt tot het hervatten van het werk. 
Twee andere in de stakingsbeweging opgenomen groepen waren de boeren en de personelen van de zuivelfabrieken. Vooral de laatste hebben voor de uitbreiding van de staking op het platteland een belangrijke rol kunnen spelen, doordat zij het werk neerlegden. Een zuivelfabriek is, krachtens de functie, die zij in de verzorgingsindustrie op het platteland heeft, een middelpunt. Alle boeren, die tot haar werkgebied behoren, hebben daar hun dagelijks contact. Alle individuele verzetswil, die bij de boeren bestond, kon zich echter in de staking pas gelijkelijk richten, indien voor het gehele werkgebied van de zuivelfabriek één gebod gold. Dit werd gegeven, toen ook de personelen van zuivelfabrieken in staking gingen. Door deze actie kwam een groot deel van de boeren in een gelijke positie te verkeren en uitte zich de individuele verzetswil tegenover de Duitsers in een demonstratie van eensgezind optreden.

Doordat vele zuivelfabrieken niet werkten, kon geen melk aan de bevolking worden verstrekt. Daar deze echter toch de melk nodig had, ging zij het zelf halen, hetgeen - gezien de ligging der steden - geen moeilijkheden opleverde. Het gevolg hiervan was echter, dat arbeiders en boeren hun stakingsgezindheid aan elkaar overdroegen. Daardoor werd een eenheid gevormd, die ver uitging boven de oorspronkelijke stakingseenheid der stedelijke bevolking. In deze zin had de gesloten zuivelfabriek de bemiddelende rol, land en stad in één actie te betrekken. Vandaar ook, dat de poging der Duitsers om de staking op het platteland in Twente breken, niet zozeer gericht was tegen de boeren als wel tegen de directies van de zuivelfabrieken. Op hen werd een zware druk uitgeoefend om de boeren weer tot het leveren van melk aan te zetten.

Tot slot het volgende.

Een van de moeilijkste taken, waarvoor de historicus zich voortdurend gesteld ziet, is het zinvol plaatsen van een bepaalde gebeurtenis in het geheel van de maatschappelijke en culturele relaties van een bepaalde tijd. De Twentse staking van 1943 heeft, wij zagen het, een historische achtergrond gehad; zij had echter ook diep-ingrijpende gevolgen. Deze te onderzoeken en te beschrijven viel buiten het kader van onze opdracht. De latere historicus zal echter, naar wij vertrouwen, met alle kennis die hem ten dienste staat, op dit aspect van de betekenis van deze grootste verzetsmanifestatie het volle licht kunnen werpen. 
B IJ L A GE II

DOCUMENTEN OVER DE APRIL-MEI-STAKINGEN

VAN 1943 


\section{LIJST VAN DOCUMENTEN OVER DE APRIL-MEI-STAKINGEN VAN 1943}

pag.

1. Brief van de Befehlshaber der Sicherheitspolizei und des SD, III C 5 aan het Reichssicherheitshauptamt, d.d. 1-1-1943

2. Telexbericht van de Reichsführer-SS, H. Himmler, aan SS-Gruppen-

3. Brief van de Rijkscommissaris, Dr A. Seyss-Inquart, aan de Reichsführer-SS, H. Himmler, d.d. 15-2-1943

4. Notitie d.d. 22-2-1943 van een bespreking in de Rijkskanselarij te Berlijn op 22-2-1943

305

5. Notitie d.d. 22-2-1943 van een bespreking in de Rijkskanselarij te

Berlijn op 22-2-1943 (uitgebreidere versie) . . . . . . . . 308

6. Notitie van de Befehlshaber der Sicherheitspolizei und des SD, III D 5, d.d. 26-2-1943 . . . . . . . . . . . .. . .

7. Notitie van een ambtenaar van de Rijkskanselarij te Berlijn d.d. 1-3-1943 over de uitvoering van het Führererlass van 13-1-1943 .

8. Bericht in de Deutsche Allgemeine Zeitung, d.d. 5-3-1943 . . .

9. Twee telexberichten van commissaris-generaal F. Schmidt aan alle Beauftragten des Reichskommissars, d.d. 5-3-1943

306

310

10. Telexbericht van commissaris-generaal F. Schmidt aan de Generalbevollmächtigte für den Arbeitseinsatz, Gauleiter F. Sauckel, d.d. 22-3-1943

11. Telexbericht van commissaris-generaal F. Schmidt aan de Generalbevollmächtigte für den Arbeitseinsatz, Gauleiter F. Sauckel, d.d. 12-4-1943

12. Telexbericht van commissaris-generaal F. Schmidt aan de Generalbevollmächtigte für den Arbeitseinsatz, Gauleiter F. Sauckel, d.d. 16-4-1943

13. Notitie van het Auswärtige Amt d.d. 17-4-1943

14. Telexbericht van de Rijkscommissaris, Dr A. Seyss-Inquart, aan de Chef der Rijkskanselarij, Dr H. H. Lammers, d.d. 19-4-1943 . .

15. Telexbericht van de Rijkscommissaris, Dr A. Seyss-Inquart, aan de Chef der Rijkskanselarij, Dr H. H. Lammers, d.d. 22-4-1943 . .

16. Telexbericht van Botschafter $K$. Ritter aan het Auswärtige Amt, Berlijn, d.d. 24-4-1943. 
17. Telegram van Botschafter K. Ritter aan het Auswärtige Amt, Berlijn, d.d. 24-4-1943

18. Rondschrijven van de Wehrmachtbefehlshaber in den Niederlanden, d.d. 26-4-1943

19. Bekendmaking van de Wehrmachtbefehlshaber in den Niederlanden, General der Flieger F. Christiansen, d.d. 29-4-1943

20. Telexbericht van de SS-Gruppenführer H. A. Rauter aan de Reichsführer-SS H. Himmler, d.d. 29-4-1943

21. Telexbericht van $\mathrm{Dr} R$. Brandt, persönlicher Referent van de Reichsführer-SS H. Himmler, aan SS-Gruppenführer H. A. Rauter, d.d. 30-4-1943

22. Notitie van het Bureau van de Befehlshaber der Sicherheitspolizei und des Sicherheitsdienstes, Den Haag, d.d. 30-4-1943

23. Telexbericht van de Befehlshaber der Sicherheitspolizei und des SD, Den Haag, Dr W. Harster, aan alle Aussenstellen, d.d. 30-4-1943

24. Stabsbefehl van SS-Gruppenführer und Generalleutnant der Waffen-SS K. M. Demelhuber, commandant van de Waffen-SS in Nederland, d.d. 30-4-1943

25. Telexbericht van W. W. Dittmar, perschef van de Rijkscommissaris, aan alle Pressereferenten bij de Beauftragten, d.d. 30-4-1943

26. Telexbericht van de Befehlshaber der Sicherheitspolizei und des SD, Den Haag, Dr W. Harster, aan het Reichssicherheitshauptamt, d.d. 30-4-1943

27. Bekendmaking van de Wehrmachtbefehlshaber in den Niederlanden, General der Flieger F. Christiansen, d.d. 30-4-1943

28. Bekendmaking van de Rijkscommissaris, Dr A. Seyss-Inquart, d.d. 1-5-1943

29. Proces-verbaal, afkomstig van de Aussenstelle Amsterdam van de Befehlshaber der Sicherheitspolizei, d.d. 1-5-1943

30. Telexbericht van Regierungsrat E. Deppner aan alle Aussenstellen van de Befehlshaber der Sicherheitspolizei, d.d. 1-5-1943

31. Telexbericht van SS-Sturmbannführer, W. Lages, Aussendienststellenleiter van de Sipo en SD, Amsterdam, aan de Befehlshaber der Sicherheitspolizei und des Sicherheitsdienstes, Den Haag, d.d. 2-5-1943

32. Telexbericht van SS-Richter Dr Wendt aan H. A. Rauter, d.d. $2-5-1943$

33. Telexbericht van H. Wölk, hoofd van de Aussendienststelle Rotterdam van de Sicherheitspolizei en de SD, aan de Befehlshaber der Sicherheitspolizei und des SD, Den Haag, d.d. 3-5-1943

34. Telexbericht van Dr W. Harster, Befehlshaber der Sicherheitspolizei und des SD, Den Haag, aan het Reichssicherheitshauptamt, d.d. 3-5-1943 
35. Telexbericht van Dr W. Harster, Befehlshaber der Sicherheitspolizei und des SD, Den Haag, aan het Reichssicherheitshauptamt, d.d. 3-5-1943.

36. Telexbericht van commissaris-generaal F. Schmidt aan alle Beauftragten des Reichskommissars d.d. 3-5-1943

37. Brief van de leider van het plaatselijk kantoor Apeldoorn van het Nederlandse Arbeidsfront aan de Provinciale Frontleider Gelderland van Het Nederlandse Arbeidsfront, d.d. 3-5-1943

38. Brief van $\mathrm{H}$. Wölk, hoofd van de Aussendienststelle Rotterdam van de Sicherheitspolizei und des SD, aan Dr W. Harster, Befehlshaber der Sicherheitspolizei und des SD, Den Haag, d.d. 4-5-1943

39. Telexbericht van Dr W. Harster, Befehlshaber der Sicherheitspolizei und des SD, Den Haag, aan het Reichssicherheitshauptamt en andere Duitse instanties, d.d. 4-5-1943

40. Rapport van W. Lages, hoofd van de Aussendienststelle Amsterdam van de Sicherheitspolizei en de Sicherheitsdienst . . . . .

41. Telexbericht van de Befehlshaber der Sicherheitspolizei und des SD, Den Haag, aan het Reichssicherheitshauptamt, d.d. 7-5-1943

42. Telexbericht van commissaris-generaal F. Schmidt aan alle Beauftragten des Reichskommissars d.d. 12-5-1943

43. Rapport van A. A. M. Stoetzer, districtleider van de NSB in Noord-Brabant

44. Telexbericht van de Reichsführer-SS, H. Himmler aan H. A. Rauter, d.d. 9 5-1943

45. Rapport van de Befehlshaber der Sicherheitspolizei und des SD, Den Haag, III B, d.d. 12-5-1943

46. Rapport van de Befehlshaber der Sicherheitspolizei und des SD, Den Haag, III D 5, aan het Reichssicherheitshauptamt d.d. 13-5-1934

47. Telexbericht van de Rijkscommissaris, Dr A. Seyss-Inquart, aan alle Beauftragten d.d. 10-5-1943

48. Rapport van de Beauftragte voor de provincie Zeeland, d.d. 11-5-1943

49. Rapport van de Beauftragte voor de provincie Drente, d.d. 13-5-1943

50. Rapport van de Beauftragte voor de provincie Friesland, d.d. 14-5-1943

51. Rapport van de Beauftragte voor de provincie Groningen, d.d. 14-5-1943

52. Rapport van de Beauftragte voor de provincie Limburg, d.d. 14-5-1943

53. Rapport van de Beauftragte voor de provincie Noord-Brabant, d.d. 14-5-1943 
pag.

54. Rapport van de Beauftragte voor de provincie Overijssel, d.d.

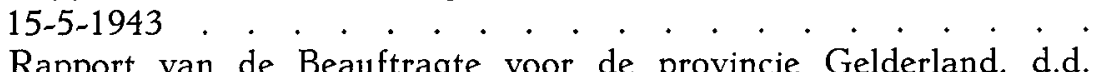

55. Rapport van de Beauftragte voor de provincie Gelderland, d.d. 15-5-1943 . . . . . . . . . . . . . . . . . . . .

56. Rapport van de Beauftragte voor de provincie Utrecht, d.d. 15-5-1943 . . . . . . . . . . . . . . . . . . . . 409

57. Rapport van de Beauftragte voor Amsterdam (Noord-Holland),

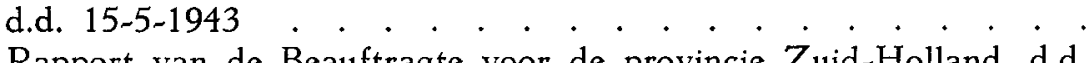

58. Rapport van de Beauftragte voor de provincie Zuid-Holland, d.d. 17-5-1943 . . . . . . . . . . . . . . . . . . . . 416

59. Stimmungsbericht aus den Niederlanden d.d. 10-5-1943 . . . . 423

60. Stimmungsbericht aus den Niederlanden d.d. 20-5-1943 . . . . 429

N.B.: De hier afgedrukte documenten zijn grotendeels afkomstig uit de collecties van het Rijksinstituut voor Oorlogsdocumentatie. De resterende werden in fotocopie verworven van het 7771 US Document Center. Berlijn, het Office of Chief of Counsel for War Crimes, Berlin Branch, en het Bureau Coördinatie van de Politieke Recherche-Afdeling, 's-Gravenhage. De bij de documenten geplaatste voetnoten zijn alle afkomstig van het Rijksinstituut voor Oorlogsdocumentatie. 


\section{Brief van de Befehlshaber der Sicherheitspolizei und des SD, III C 5 aan het Reichssicherheitshauptamt, d.d. 1-1-1943}

III C $5-6482 / 42$

1) An das

Reichssicherheitshauptamt

- III D - (Westgebiete)

An das

Reichssicherheitshauptamt

- III D 5 -
Dezember 1942

am 1.1.'43 abgesandt

Berlin.

Betrifft: Vermittlung niederländischer Arbeiter nach Deutschland.

Vorgang: Bericht BdS. Den Haag vom 16.11.1942 - III C 5 - 6482/42.

Im Bericht vom 16.11.1942 wurde mitgeteilt, dass der Generalbevollmächtigte für den Arbeitseinsatz den Niederlanden auferlegt habe, in der Zeit vom 1.9.1942 bis 30.4.1943 insgesamt 100.000 Arbeiter dem Reich zur Verfügung zu stellen. Dieses Kontingent ist inzwischen erneut erhöht worden. Danach sollen im November und Dezember je 25.000 und in der Zeit vom 1.1. -30.4.43 insgesamt 100.000 niederländische Arbeiter nach Deutschland vermittelt werden.

Für die Bereitstellung der 25.000 Arbeiter im Dezember wurde von dem Leiter der Hauptabteilung Soziale Verwaltung folgende Planung aufgestellt:

10.000 Arbeitskräfte aus den zur Entlassung kommenden Angehörigen des Niederl. Arbeitsdienstes und aus Studenten von den Hochschulen,

10.000 Arbeitskräfte aus der Gewerblichen Wirtschaft einschl. der Rüstungsindustrie,

10.000 Arbeiter und Angestellte aus den staatlichen und kommunalen Behörden.

Der Beauftragte des GBA 1 ), Generalkommissar z.b.V. Schmidt, hat den geschlossenen Einsatz von 5.000 Männern des Niederl. Arbeitsdienstes die jetzt zur Entlassung kommen, aus politischen Gründen sofort abgelehnt. Mit dem Einsatz von ca. 5.000 Studenten hat er sich zunächst einverstanden erklärt, später - nachdem der Generalsekretär des Departements für Volksaufklärung und Künste, van $\operatorname{Dam}^{2}$ ), bei $\mathrm{ihm}$ vorgesprochen hatte - brachte er dem Leiter der Hauptabteilung Soziale Verwaltung gegenüber jedoch zum Ausdruck, dass er sich keineswegs in dieser Frage bereits festgelegt habe.

Die Bereitstellung der Arbeitskräfte aus der Gewerblichen Wirtschaft und der Rüstungsindustrie geschieht im Einvernehmen mit der Rüstungs-Inspektion. Lediglich die Abteilung Marine hat von vorne herein erklärt, infolge des "Hansa-Programms" keine Arbeiter von den Werften und den angeschlossenen Betrieben abgeben zu können. Bei der Durchführung des Abzuges von Arbeitskräften wurden dann aber von den betreuenden Dienststellen in verschiedenen Fällen der Arbeitseinsatzbehörde Schwierigkeiten gemacht.

$\left.{ }^{1}\right)$ GBA is de afkorting voor "General-Bevollmächtigte für den Arbeitseinsatz" (Gauleiter F. Sauckel).

2) Prof. dr J. van Dam was secretaris-generaal voor opvoeding, wetenschap en kultuurbescherming. 
Die Erfassung von Arbeitern und Angestellten aus den staatlichen und kommunalen Behörden läuft bereits seit längerer Zeit. Die Behörden sind heute stark mit Arbeitskräften übersetzt und arbeiten z.T. nur 36 bis 40 Stunden in der Woche. Von dem ehemaligen Leiter der Hauptabteilung Soziale Verwaltung, Präsident Boening, war den Behörden aufgetragen worden, von sich aus eine Liste über die Arbeiter und Angestellten aufzustellen, die abgegeben werden könnten. Diese Aktion ist jedoch restlos gescheitert, von verschiedenen Behörden ist überhaupt keine Stellungsnahme erfolgt. Jetzt sollen aus allen Behörden zunächst einmal $10 \%$ der Belegschaften abgezogen werden.

Insgesamt ergibt sich daraus, dass mit der Erfüllung der für Dezember gestellten Auftrage schon aus dem Grunde nicht gerechnet werden kann, weil die Erfassung nach der vorgesehenen Planung nur z.T. erfolgen kann. Wenn das Gesamtergebnis der Vermittlungstätigkeit im Dezember trotzdem einigermassen befriedigend sein wird, so liegt dies daran, dass durch die Bombardierung der Philips-Werke in Eindhoven einige Tausend Arbeiter für den Deutschland-Einsatz frei wurden. Von der Hauptabteilung Soziale Verwaltung war vorgesehen, diese Arbeiter so schnell wie möglich nach Deutschland in Marsch zu setzen. Auf Anordnung des Generalkommissars z.b.V. durfte der Einsatz jedoch erst nach einer gewissen Zeit vorgenommen werden, da eine erneute Beunruhigung der Bevölkerung von Eindhoven vermieden werden sollte. Nach hiesiger Ansicht wäre es auch aus politischen Gründen richtiger gewesen, die Arbeiter umgehend in Deutschland einzusetzen. Vielleicht wäre dadurch endlich einmal eine Stimmung gegen England erzielt worden, die durch die Bombardierung nicht hervorgerufen wurde.

Um die Bereitstellung von Arbeitskräften auf breiterer Basis $z u$ ermöglichen, ist von dem Leiter der Hauptabteilung Soziale Verwaltung die Einführung eines Arbeitsbuches geplant, und zwar sollen jahrgangweise alle Niederländer zu den Bürgermeistern vorgeladen werden, die dann die Ausfüllung vornehmen. Es ist selbstverständlich zunächst an die Jahrgänge gedacht, die für den Deutschland-Einsatz in Frage kommen. Bisher ist in dieser Frage jedoch von der politischen Seite noch keine Entscheidung gefallen.

Wie aus dem Vorhergesagten hervorgeht, bestehen zwischen den Auffassungen des Beauftragten des GBA. und dem Leiter der Hauptabteilung Soziale Verwaltung in Bezug auf Arbeitseinsatzfragen erhebliche Unterschiede. Der Leiter der Hauptabteilung Soziale Verwaltung, Dr. Apitz, hat in einem Schreiben an den GBA diese Schwierigkeiten in seiner Arbeit aufgezeigt, und einmal betont, dass er für die Durchführung seiner Aufgaben keine genügenden Vollmachten besitze und z.a. der Beauftragte des GBA., Generalkommissar z.b.V. Schmidt, die politischen Momente zu stark berücksichtige. Ausserdem hat der Stellvertreter des Generalkommissar z.b.V. in seiner politischen Stellung - Oberbereichsleiter Eftger - dem Leiter der Hauptabteilung Soziale Verwaltung gegenüber zum Ausdruck gebracht, dass er auch in der Stellung als Beauftragter des GBA. der Stellvertreter des Generalkommissars z.b.V. sei. Dr. Apitz hat in seinem Schreiben an den GBA, auf diesen Umstand hingewiesen und um Bestätigung durch den GBA. gebeten.

Dieses Schreiben des Leiters der Hauptabteilung Soziale Verwaltung wurde dem Generalkommissar z.b.V, nach Ausgang zur Kenntnis gegeben. Dieser hat daraufhin Dr. Apitz zu sich kommen lassen und ihm erhebliche Vorwürfe gemacht, u.a. dass er illoyal gehandelt habe. Dr. Apitz hat demgegenüber erwidert, dass er alle Fragen nur rein sachlich aufgezeigt habe. Der Generalkommissar z.b.V. hat nun ebenfalls in einem Schreiben an den GBA. seine Auffassung zum Ausdruck gebracht und sich vorbehalten, weitere Massnahmen gegen Dr. Apitz zu ergreifen.

2) I C zum Austragen

3) zurück an III C 5 


\section{Telexbericht van de Reichsführer-SS, H. Himmler, aan SS-Gruppenführer H. A. Rauter, d.d. 10-2-1943}

An

SS-Gruppenführer $\mathrm{R}$ a u te $\mathrm{r}$

Den Haag

Lieber Rauter!

Habe Ihre drei FS. $\left.{ }^{1}\right)$ vom 9. und 10.2. bezüglich Mord an Dr. R e y d on und Frau erhalten. Seien wir uns darüber klar, dass damit mit den Aktionen der letzten Tage die bewusste Obstruktion und Sabotage der Gegner in den Niederlanden begonnen hat.

1. Ich gebe Ihnen den Befehl, in der schärfsten Form ohne jede Rücksicht durchzugreifen. Es sind die Plutokratensöhne, und zwar nicht 2000, sondern tunlichst alle zu verhaften. In den meisten Fällen mit den Vätern.

2. Beamte, denen man nachweisen kann, dass sie falsche Adressen hergegeben haben, kommen ebenfalls ins $\mathrm{KL}^{2}$ ). Diese aber in den Steinbruch.

3. Die Wiedereinziehung der Unteroffiziere in Kriegsgefangenenlager halte ich für unbedingt notwendig.

4. Rückzieher dürfen in keiner Form gemacht werden. Die Ausquartierung der Juden hat unentwegt weiterzulaufen.

5. Melden Sie dem Reichskommissar jeden von diesen NSB Grössen der so kläglich versagt. Der Reichskommissar muss ein klares und eindeutiges Bild bekommen, wie es um Herrn Mussert und seine Mitarbeiter wirklich steht.

Geben Sie mir weiter laufend über die Entwicklung Bericht.

Heil Hitler!

Ihr H. Himmler

10.2.1943.

3. Brief van de Rijkscommissaris, Dr A. Seyss-Inquart, aan de Reichsführer-SS, H. Himmler, d.d. 15-2-1943

RK 294/43 geh. S-P

Den Haag, 15 Febr. '43

Bezug: Tgb. Nr. 44/23/43 g.

Geheim

1) FS betekent: „Fernschreiben" (telexbericht).

-) Konzentrationslager. 
Reichsführer!

Rauter teilte mir auch mit, dass der Führer die Einziehung der demobilisierten Niederländer begrüsst, und ich will in dieser Richtung mein Möglichstes tun. Allerdings müssen wir diese Angelegenheit mit einiger Vorsicht vorbereiten, denn einerseits kann ein solcher Entzug zu einer schweren Störung unserer Rüstungswirtschaft usw. führen, andererseits könnte die Nichtbefolgung einer solchen Einberufung durch die Betroffenen zu einer schweren Schädigung unserer Autorität führen, da wir ja $z u$ wenig deutsche Kräfte haben, um die Leute einzelweise herauszufangen, und die niederländische Polizei in diesen Dingen kaum voll einsatzfähig ist Aber wir werden schon alles machen, was möglich ist, zu einem guten Ende zu kommen.

Ich begrüsse Sie mit

Heil Hitler

als Ihr stets ergebener

Seys s-Inquart

An den Reichsführer-SS

Reichsleiter $\mathrm{He}$ in $\mathrm{rich} \mathrm{Himmler}$

Berlin SW 11

Prinz-Albrecht-Str. 8

\section{Notitie d.d. 22-2-1943 van een bespreking in de Rijkskanselarij te Berlijn op 22-2-1943}

\section{Vermerk:}

Berlin, den 22. Februar 1943

Heute fand um 11 Uhr vormittags unter Vorsitz von StS. 1) Kritzinger eine Besprechung über die Frage statt, ob und in welcher Weise dem Führererlass vom 13. Januar 1943 entsprechend Massnahmen in den Niederlanden zur Durchführung gelangen können. Die Teilnehmer sind aus der anliegenden Liste (Anlage 1) 2) ersichtlich.

StS. Dr. Fischböck ${ }^{3}$ ) führte aus, dass voraussichtlich ein Bedarf an Arbeitskräften dadurch entstehen werde, dass die Wehrmacht beabsichtige, aus Gründen der militärischen Sicherheit die früheren Angehörigen der holländischen Wehrmacht aus den westlichen Gebieten zu entfernen, auch soweit sie in kriegswichtigen Betrieben und in der Landwirtschaft beschäftigt

\footnotetext{
1) Staatssekretär.

2) Deze bijlage is hier niet afgedrukt.

3) Staatssekretär Fischböck was in Nederland commissaris-generaal voor financiën en economie.
} 
sind. Dazu käme noch der zusätzliche Bedarf, der durch den laufenden Abzug von Fachkräften in das Reich durch den Generalbevollmächtigten für den Arbeitseinsatz entstehe. Es sei beabsichtigt, diesen Bedarf durch die Kräfte $z u$ decken, die durch Stilllegung von Betrieben und Geschäften freigesetzt würden.

Als Grundlage für die in dieser Richtung zu treffenden Massnahmen diene eine Verordnung zur Sicherheit der Erzeugung und des Arbeitseinsatzes, die am erlassen und im Verordnungsblatt für die besetzten niederländischen Gebiete veröffentlicht sei (Anlage 2) 1). Von Seiten des Reichskommissars bestehe kein Hemmnis dagegen, Luxuseinrichtungen, wie Luxusgaststätten, Bars, Hunderennen u.ä. stillzulegen.

Diese Massnahmen hätten nur optische Bedeutung. Eine Freisetzung von Arbeitskräften sei hierbei höchstens im Umfange von etwa 700-1000 Personen zu rechnen.

Des weiteren sei alsdann die Schliessung entbehrlicher Einzelgeschäfte beabsichtigt, wie Briefmarkengeschäfte, Ausstellungsräume für Automobile, Warenhäuser und Konfektionsgeschäfte. Dabei bestehe die Absicht, im Durchschnitt in jeder Stadt ein Warenhaus zu belassen. Auch hier sei das Ergebnis nicht erheblich. Er rechne aus diesem Komplex mit einem Freiwerden von etwa 17000 Arbeitskräften.

Im übrigen sollten nach dem gleichen Schema wie im Reich weitere Betriebe in Handel, Gewerbe und Verkehr stillgelegt werden. Allgemein sei hierzu zu bemerken, dass die Stillegung jeweils nur in dem Umfange vorgenommen werden soll, in dem sofort auch eine Unterbringung der freigesetzten Arbeitskräfte gesichert sei, da sich sonst diese Kräfte alsbald "verkrümeln" würden. Es habe daher kéinen Sinn, mit der Schliessung von Betrieben in erheblichem Umfange voranzugehen.

Vor einer Meldepflichtverordnung nach Muster des Reichs verspreche er sich kaum einen Erfolg. Eine solche Verordnung würde wegen des $z u$ erwartenden Widerstandes auf so grosse Schwierigkeiten stossen, dass es besser sei, sie nicht erst in Erwägung zu ziehen. Auf Biegen oder Brechen sollte man eine derartige Massnahme nicht versuchen. Er, StS. Fischböck, wolle sie zwar nicht ausschliessen, er sei aber der Ueberzeugung, dass man auf dem Wege der Stilllegung leichter und besser zum Ziele kommen werde.

Von der Möglichkeit einer Erfassung der in den stillgelegten Betrieben vorhandenen Waren zum Zwecke der Ablieferung an das Reich verspreche sich StS. Fischböck keinen Erfolg. Er habe erhebliche Zweifel, ob diese Frage organisatorisch überhaupt zu lösen sei. So wie eine solche Massnahme bekannt werde, sei damit zu rechnen, dass die Warenbestände verschwänden. Er sei zwar bereit, für zweckmässig gehaltene Massnahmen zu treffen, wenn es für erforderlich gehalten werde; wegen des Ergebnisses solle man sich aber übertriebenen Erwartungen nicht hingeben. Min. Dir. Gramsch regte an, doch auf dem Wege über die Grosshandelsunternehmungen $z u$ einer Erfassung der Warenbestände zu kommen und die Bestände in den Einzelgeschäften den Holländern zu überlassen. Auch von einem solchen Wege verspreche sich StS. Fischböck keinen besonderen Erfolg, da Grosshandelsunternehmungen (Sortimenter) in Holland nur eine ganz geringe Rolle spielten und die Warenverteilung, anders als im Reich, unmittelbar vom Produzenten zum Einzelhändler gehen.

Das Ergebnis der Aussprache war:

1. Es wird für erwünscht gehalten, wenn die ehemaligen holländischen Soldaten in Deutschland in kriegswichtige Betriebe zur Arbeit eingesetzt werden. Die Entscheidung darüber liegt bei Generalfeldmarschall Keitel.

1) Deze Bijlage is hier niet afgedrukt. De betrokken Verordening (VO 16/1943) werd op 19 Februari 1943 gepubliceerd. 
2. Zum Ersatz der dadurch aus Holland abgezogenen Arbeitskräfte Schliessung der Geschäfte nach Bedarf.

3. Ob Massnahmen nur der Optik wegen (Schliessung von Luxusgeschäften) getroiffen werden sollen, wird unter politischen Gesichtspunkten vom Ausschuss bezw. vom Reichsmarschall entschieden werden müssen.

4. Es wird entschieden werden sollen, ob der Versuch gemacht werden soll, die Warenbestände der zur Schliessung gelangenden holländischen Geschäfte für das Reich sicherzustellen.

\section{Notitie d.d. 22-2-1943 van een bespreking in de Rijkskanselarij te Berlijn op 22-2-1943 (uitgebreide versie)}

Berlin, den 22. Februar 1943

Vermerk:

Unter Vorsitz von Staatssekretär Kritzinger wurde in Anwesenheit von Vertretern von OKW, Rüstungsministerium, Reichswirtschaftsministerium und Reichsernährungsministerium mit den Vertretern der besetzten Gebiete die Frage besprochen, in welcher Weise sie die im Reich getroffenen Massnahmen zur Intensivierung der Kriegführung in ihren Ländern durchzuführen beabsichtigen.

1. Norwegen......1)

2. Holland.

Generalkommissar Fischböck betonte einleitend die von dem Reichskommissar befolgte Politik der grundsätzlichen Angleichung an die Verhältnisse im Reich. Aufhebung der Zollund Devisengrenze; Einbau der gesamten Warenbewirtschaftung in die reichsdeutsche Organisation der Reichsstellen; Gleichschaltung der Organisation der gewerblichen Wirtschaft mit der im Reich, usw.

Der Reichskommissar beabsichtigt

a) den Luxus-Sektor (Gaststätten, Bars, Vergnügungslokale usw) zu schliessen. Ergebnis: 700 - 1000 Menschen;

b) Die Schliessung einer gewissen Art von Einzelhandelsgeschäften wie im Reich (Damensalons, Herrenmassschneiderei, Briefmarkenhandlungen, Goldschmiede usw.).

Etgebnis: etwa 16.000 Menschen.

c) Von den insgesamt 3,6 Mill. Berufstätigen werden nur 214.000 in Betrieben beschäftigt, die von der Rüstungsinspektion besonders betreut werden, also speziell im deutschen Interesse arbeiten. In nicht betreuten Industriebetrieben rd. 600.000. Diese und Handel und Verkehr werden in erster Linie für die Auskämmung in Frage kcmmen. Der Reichskommissar will zwar grundsätzlich nach dem Reichsvorbild vorgehen, aber nicht mit schlagartigen Betriebsstililegungen beginnen, weil es sehr schwer sein würde, die einmal aus der Arbeit gebrachten Menschen hinterher wieder zu erfassen. Deshalb sollen nur jeweils soviel Betriebe stillgelegt werden, wie man Arbeitskräfte sinngemäss unterbringen kann. Sehr viel Fachkräfte crwartet der Generalkommissar allerdings nicht, weil hier schon viel für Deutschland aussortiert wurde. Im Endergebnis soll aber das gleiche Ergebnis wie in Deutschland erzielt werden.

1) Het gedeelte over Noorwegen is hier weggelaten. 
Eine Meldepflichtverordnung hält der Reichskommissar nicht für durchführbar, weil hierfür nur holländische Behörden zur Verfügung stehen, die nicht mitziehen würden. Im Laufe der Debatte wurde der Plan mitgeteilt, aus der Küstenzone, d.h. ungefähr der Hälfte des ganzen besetzten Gebietes, wehrfähige Holländer abzuschieben, also sozusagen die ehemaligen Angehörigen der holländischen Armee wieder einem geschlossenen Arbeitseinsatz an anderen Stellen zuzuführen. Es zeigt sich, dass unter den 300.000 Mann, die theoretisch in Frage kommen, sicherlich die besten auch in Deutschland verwendbaren Arbeitskräfte stecken. Und selbst wenn man annimmt, dass ein Teil von Ihnen in der holländischen Rüstungsindustrie, in der holländischen Landwirtschaft oder in der deutschen Rüstungsindustrie schon arbeiten und deshalb sozusagen uk. ${ }^{1}$ ) gestellt werden müssten, würde ein Schub von etwa 100.000 jüngerer Kräfte das beste sein, was man in erster Linie aus Holland erhalten könnte. Hierüber waren sich alle einig. OKW versprach, in wenigen Tagen die Entscheidung des Generalfeldmarschalls Keitel zu diesem von dem Wehrmachtbefehlshaber gemachten Vorschlage; dann würde zwar der $Z$ wang in Holland auch gross sein, aber für militärische Massnahmen besteht mehr Verständnis als für zivile. Man würde es dann den Holländern überlassen können, durch Meldepflichtverordnung und Geschäftsschliessungen nach deutschem Muster innerhalb Hollands eine Auffüllung der durch den Abzug der wehrfähigen Mannschaften gerissenen Lücken zu erzielen.

Das Ergebnis war, dass zunächst die Verhandlung mit den Militärbefehlshabern in Paris und Brüssel abgewartet werden soll, um prüfen zu können, ob die drei westlichen besetzten Gebiete nicht gleichmässig $z \mathfrak{u}$ behandeln sind, und dass Generalkommissar Fischböck gebeten wird, mit seinen Massnahmen noch nicht $z u$ beginnen, bevor nicht die Entscheidung über die Militäraktion gefallen ist, die ihm im übrigen die Arbeit erleichtern würde.

Offen geblieben ist auch noch die Frage, ob es richtig ist, lediglich zur Herstellung der Optik die gegen "Luxus" usw. gerichteten Massnahmen Deutschlands auf Holland zu übertragen.

Was die Erfassung der Waren anlangt, so verwies Generalkommissar Fischböck auf den Mangel an deutschen Exekutiv-Organen und die Unzuverlässigkeit der holländischen Polizei. Durch eine Beschlagnahme und Inventarisierungspflicht würden die Holländer sofort auf den Gedanken gebracht werden, dass die Waren nach Deutschland gehen sollen, und würden dann ihre Vorräte verstecken und verheimlichen. Es sei deshalb nicht anzunehmen, dass man unter diesen Umständen erhebliche Warenbestände erhalte. Auch der Vorschlag, die Vorräte der Einzelhandelsgeschäfte einem geregelten Verbrauch zur Versorgung der Holländer selbst vorzubehalten und für Deutschland nur die Grosshandelsläger vorzusehen, wurde von Generalkommissar Fischböck nicht für durchführbar gehalten, weil Grosshandel in dem in Deutschland üblichen Sinne nicht existiert, die Einzelhandelsgeschäfte vielmehr weitestgehend unmittelbar vom Erzeuger kaufen. Wohl aber werde durch die immer weitere Verschärfung der Fertigungsverbote usw. der Nachschub an uninteressanten Waren abgebremst werden.

\section{Ergebris:}

In erster Linie sollte der Abtransport der Wehrfähigen nach Deutschland unter irgend einem Vorwand gefördert werden. Er bringt schnell ordentliche Arbeitskräfte in grossen Mengen.

Die sonstigen Massnahmen müssen vielleicht Zug um Zug durchgeführt, aber jedenfalls mit einem Schlage in allen Einzelheiten gesetzlich verankert werden, damit nicht der Schleichhandel zu sehr gestärkt wird.

Das Vorgehen gegen "Luxus" muss mit den beiden anderen westlichen Gebieten abgestimmt werden.

3. Protektorat...... ${ }^{2}$ )

1) unabkömmlich, onmisbaar.

2) Het gedeelte over het Protectoraat (Bohemen-Moravië) is hier weggelaten. 


\section{Notitie van de Befehlshaber der Sicherheitspolizei und des SD, III D 5, d.d. 26-2-1943}

III D $5-1141 / 43$

Den Haag, den 26. Februar

1943

Betrifft: Vermittlung von niederländischen Arbeitern nach Deutschland.

Vorgang: Besprechung beim Chefintendanten des WBN. 1) in Hilversum am 24.2.1943.

\section{1) Vermerk}

Die obige Besprechung, $z u$ der alle Wehrmachtsdienststellen in den Niederlanden eingeladen waren, hatte den $Z$ weck, für alle Betriebe, an deren Weiterbestand die einzelnen Wehrmachtsdienststellen interessiert sind, ein einheitliches Verfahren hinsichtlich der Sicherung der notwendigen Arbeitskräfte festzulegen. Es handelte sich also nicht um die Dienststellen selbst und die dort Angestellten, sondern um Fertigungsbetriebe (auch keine Einzelhandelsund Handwerksbetriebe), die entweder der Wehrmacht selbst gehören oder von ihr in starkem Masse mit Aufträgen belegt sind.

Major Nitz von der Rüstungs-Inspektion gab in seinen Ausführungen zunächst einen kurzen Ueberblick über die derzeitige Arbeitseinsatzlage und erwähnte speziell die augenblicklich laufende S.E.-Aktion (Sondereinsatzaktion). Im Rahmen dieser Aktion mussten aus den Rüstungsbetrieben des Reiches 250.000 Fach- und Schlüsselkräfte des Metallsektors für die technischen Einheiten der Wehrmacht abgegeben werden. Die Auflage, diese Fachkräfte möglichst bis zum 1.3.1943 durch annähernd gleichwertige Arbeiter zu ersetzen, wurde ausschliesslich den besetzten Westgebieten erteilt. Auf die Niederlande entfallen von dieser Aktion 22.000 Arbeitskräfte.

Es kommt daher immer mehr darauf an, wie Major Nitz weiter ausführte, sich arbeitseinsatzmässig in den Niederlanden dem Reich anzupassen, d.h. die Facharbeiter nur an den unbedingt erforderlichen Arbeitsplätzen anzusetzen und alle anderen Arbeiten durch Hilfskräfte und auch Frauen ausführen $z u$ lassen.

Die Arbeitseinsatzbehörde ist z.Zt. dabei, jahrgangweise die gesamte männliche Bevölkerung von 18 bis 45 Jahre zu erfassen, um sie restlos dem Arbeitseinsatz zuzuführen. Diese Erfassung soll neuerdings wie folgt durchgeführt werden:

Jeder Niederländer in diesen Altersgrenzen erhält bei der Ausgabe der Distributiekarten einen Fragebogen, der von der Hauptabteilung Soziale Verwaltung aufgestellt wurde. Diesen Fragebogen hat der Betreffende selbst auszufüllen und seine Angaben über den Arbeitsplatz durch den Betrieb bestätigen zu lassen. Durch öffentliche Aufrufe werden die einzelnen Jahrgänge aufgefordert, diese Fragebogen bei dem zuständigen Arbeitsamt abzugeben. Ueber die Abgabe wird auf der Stammkarte durch das Arbeitsamt ein Quittungsvermerk angebracht. Bei der Ausgabe der nächsten Distributiekarten erhält dann nur derjenige Angehörige der aufgerufenen Jahrgänge seine Marken, wenn er auf seiner Stammkarte die Quittung des Arbeitsamtes hat. Falls die Praxis ergeben sollte, dass in grösserem Rahmen die aufgerufenen Jahrgänge der Aufforderung keine Folge leisten, sondern einfach auf die Lebensmittelkarten verzichten und von den Rationen der anderen Familienmitglieder mit verpflegt werden, ist vorgesehen, ggf. durch Rückgriff auf die Karten der ganzen Familie einen weiteren Druck auszuüben.

1) Wehrmachtbefehlshaber in den Niederlanden (Generaal F. C. Christiansen). 
Um bei dieser jahrgangweisen Erfassung die Arbeiter der Rüstungsbetriebe gesondert zu halten und sie entsprechend vom Arbeitseinsatz nach Deutschland freizustellen, ist von der Rüstungsinspektion nach Absprache mit der Hauptabteilung Soziale Verwaltung festgelegt worden dass alle Rüstungsbetriebe ihre Angehörigen der Jahrgänge 1920 bis 1924 (diese Jahrgänge sollen zunächst aufgerufen werden) listenmässig melden und für jeden einen vorgeschriebenen Ausweis vorbereiten, der den Arbeiter als Angehörigen des bestimmten Rüstungsbetriebes kennzeichnet. Diese Ausweise werden von der Rüstungs-Inspektion überprüft und abgestempelt und dann von dem Arbeiter beim Arbeitsamt zusammen mit dem Fragebogen abgegeben. Diese Arbeiter sollen von den Arbeitsämtern zunächts nicht angetastet werden. Ein Arbeitsplatzwechsel ist diesen Arbeitern untersagt, anderenfalls wird die Freistellung widerrufen. Es ist für die nächste Zeit sowieso eine Verordnung vorgesehen, die allgemein jeden Arbeitsplatzwechsel unter Genehmigungspflicht durch die Arbeitsämter stellt.

Major Nitz stellte anheim, ein gleiches oder ähnliches Verfahren für die wehrmachtseigenen Fertigungsbetriebe zur Anwendung zu bringen, wobei er jedoch darauf hinwies, dass für die Freistellung ein scharfer Massstab anzulegen sei, da sonst mit besonderen Massnahmen des Generalbevollmächtigten für den Arbeitseinsatz $z u$ rechnen sei, zu denen dieser auf Grund des Führerbefehls ermächtigt sei.

Nach verschiedenen Debatten wurden folgende Grundsätze herausgestellt:

1.) Es wird grundsätzlich zwischen wehrmachtseigerten Betrieben und solchen Betrieben, die nur Aufträge von Wehrmachtsdienststellen haben, unterschieden.

2.) In den wehrmachtseigenen Fertigungsbetrieben wird untersucht, welche Arbeiter der Jahrgänge 1920 bis 1924 unersätzlich sind. Diese werden listenmässig zusammengestellt und die Listen dann zusammen mit den Fragebogen über die höheren Kommandostellen dem Chefintendanten zugeleitet. Von dort erfolgt eine Ueberprüfung und ein Vermerk auf den Fragebogen, dass der Arbeiter in dem bestimmten Wehrmachtsbetrieb tätig und unersätzlich ist. Die abgestempelten Fragebogen erhalten die Arbeiter dann zurück.

3.) Für die Betriebe, die lediglich Aufträge von den Wehrmachtsdienststellen haben, erfolgt keine Einschaltung der Wehrmacht. Alle diese Betriebe sollen listenmässig in dreifacher Ausfertigung unter Angabe der Höhe der verlagerten Aufträge dem Chef-intendanten nahmhaft gemacht werden, der je eine Ausfertigung der Rüstungs-Inspektion und der Zentralauftragstelle übermittelt. Durch diese Stellen soll dann, wenn es erforderlich erscheint, die Freistellung der notwendigen Arbeiter dieser Jahrgänge erfolgen.

M(üller) (?)

SS-Hauptsturmführer.

2.) SS-Brigadeführer Dr. Harster über SS-Obersturmbannführer Knolle und SSHauptsturmführer $\mathrm{Fahr}$ enholt $z$ mit der Bitte um Kenntnisnahme.

3.) Zurück an III D 5 . 


\section{Notitie van een ambtenaar van de Rijkskanselarij te Berlijn d.d. 1-3-1943 over de uitvoering van het Führererlass van 13-1-1943}

Berlin, den 1. März 1943.

Betrifft: Durchführung des Führererlasses vom 13. Januar 1943 in den Niederlanden.

Generalkommissar Schmidt rief mich heute an, um mir folgendes mitzuteilen:

Staatssekretär Fischböck habe in der Besprechung am 22. Februar erklärt, dass eine Meldepflicht in den Niederlanden nicht durchführbar sei. Herr Fischböck sei bei der Abgabe dieser Erklärung offenbar nicht vollständig informiert gewesen. Es sei richtig, dass eine allgemeine Meldepflicht wie im Reich unzweckmässig sei; weil die zur Meldung Aufgeforderten sich in grösserem Umfange nicht melden würden; man gehe daher in den Niederlanden so vor, dass man auf Grund der Unterlagen, die die Lebensmittelregelung liefere, unmittelbar die in Frage kommenden Personen zur Arbeit dienstverpflichte.

Herr Schmidt teilte mir weiter mit, dass die von der Wehrmacht beabsichtigte Internierung der ehemaligen Soldaten der holländischen Armee durchgeführt werden solle. Die Mitteilung des OKW., dass der Reichskommissar die Entscheidung hierüber zunächst noch zurückgestellt wissen wolle, beruhe auf einem Irrtum.

was geparafeerd: onleesbaar.

\section{Bericht in de Deutsche Allgemeine Zeitung, d.d. 5-3-1943}

\section{TOTALER KRIEGSEINSATZ AUCH IN DER HOLLANDISCHEN WIRTSCHAFT}

Die Heranziehung der Niederlande zum totalen Kriegseinsatz, die soeben durch weitgreifende Anordnungen des Reichskommissars Seyss-Inquart sichergestellt wurde, wird das Bild der Niederländischen Wirtschaft von Grund auf verändern. Trotzdem die Niederlande seit fast drei Jahren in den Krieg einbezogen sind wimmelte es bisher in den prunkvollen Bankgebäuden von Amsterdam und in den Verwaltungspalästen der grossen Reedereien und Ueberseehandelsgesellschaften in den Hafenstädten noch von Angestellten, die im Grunde nichts zu tun hatten und lediglich auf die Zeit warteten, wo das Ueberseegeschäft wieder in Gang kommen wird. Alle diese Angestellten werden bei Kriegswichtigen Arbeiten eingesetzt werden, wobei es dahingestellt bleibt, ob sie in Holland selbst oder im Reich oder den andern besetzten Gebiete beschäftigt werden. Die Schliessung der beschäftigungslosen Firmen wird von dem Bevollmächtigten für die Einschaltung der NSB in die Verwaltung, A. Mussert, gemeinsam mit den deutschen Instanzen vorbereitet. Obwohl bereits etwa 300000 Niederländer in Deutschland arbeiten, ist man überzeugt, dass die Arbeitskraftreserven für die totale Mobilisierung in den Niederlanden noch unverhältnismässig höher sind als im Reich. 
$\mathrm{Zu}$ den Scharen beschäftigungsloser Angestellter tritt die kaum weniger grosse Schicht derjenigen Niederländer, die auf der Grundlage mehr oder weniger grosser Kapitalien bisher überhaupt nicht oder nur gelegentlich gearbeitet haben. Auch sie werden von der Mobilisierungsverordnung restlos erfasst. Weitere Arbeitskräfte werden durch die Schliessung aller nichtkriegswichtigen Fabrikbetriebe freigesetzt. Der weibliche Arbeitseinsatz wird dagegen zurücktreten, da die jetzt aufgerufenen Frauen nur in den Niederlanden selbst beschäftigt werden sollen. Mangels hinreichender Einsatzmöglichkeiten in der Industrie werden die Niederländerinnen vorwiegend $z \mathrm{u}$ landwirtschaftlichen Arbeiten herangezogen werden. Der Aufruf zur totalen Mobilisierung hat in den Niederlanden keineswegs überrascht, nachdem sich gezeigt hat, dass dort nur die gleichen Massstaben angewendet werden wie im Reich.

\section{Twee telexberichten van commissaris generaal F. Schmidt aan alle Beauf- tragten des Reichskommissar, d.d. 5-3-1943}

reichskommissar den haag, fs 5415 den 5. 3. $43 / 16.551$ )

an a $11 e$

beauftragten des reichskommissars

betrifft: arbeitseinsatz

vertraulich!

wie ich bereits mit meinem fernschreiben ueber die schliessung von geschaeften mitgeteilt habe, wird nunmehr in kuerze die durchfuehrung anlaufen. das entscheidungsrecht musste aus technischen gruenden den zustaendigen niederlaendischen general-sekretaeren als beschwerdeinstanz und den buergermeistern als entscheidungsinstanz uebertragen werden.

die verordnung wird aber einen passus enthalten, der besagt, dass die beauftragten vorher von den buergermeistern von deren entscheidung $z u$ verstaendigen sind.

ich schlage daher der einheitlichkeit halber folgenden weg vor:

1. der buergermeister hat mit seinen zustaendigen stellen unter einschaltung der organisation der niederlaendischen gewerblichen wirtschaft $\mathbf{z u}$ klaeren, welche geschaefte unter das verbot fallen. der beauftragte stellt mit dem distriktsleiter, dem wirtschaftsleiter der nsb und den groepsleidern einerseits und unter einschaltung des arbeitsbereichs: kreisleiter, wirtschafts berater und ortsgruppenleiter andererseits, das einvernehmen ueber die zu treffenden mass nahmen her. diese so erarbeiteten vorschlaege muss der beauftragte bei dem zustaendigen buergermeister vertreten, sollte keine uebereinstimmung erzielt werden, ist der buergermeister von dem niederlaendischen sektor angewiesen sich wegen entscheidung an den zustaendigen generalsekretär $z u$ wenden. in diesem fall geben mir die beauftragten ueber fernschreiber ihre meinung durch, damit ich meinerseits die entscheidung beeinflussen kann.

1) In deze Bijlage en in andere geeft de cijfercombinatie, die op de datum volgt, het uur van verzenden van het betrokken telexbericht of telegram aan. 
2. aus grundsaetzlichen erwaegungen hat der reichskommissar das anweisungsrecht den beauftragten nicht gegeben, was m.e. auch nicht unbedingt erforderlich ist, wenn der beauftragte seine ganze person selbst in die waagschale wirft und in allen gemeinden eine kurze besprechung mit dem buergermeister unter jeweiliger einschaltung des kommissars durchfuehrt. ob das notwendig ist, entzieht sich meiner kenntnis. in der verordnung selbst ist es nicht vorgesehen, dass der kommissar eingeschaltet wird. der starke persoenliche einsatz des beauftragten is bei dieser massnahme erforderlich. es ist auch nichts dagegen einzuwenden, wenn er seine referenten fuer die kleineren gemeinden einschaltet.

3. die zweite massnahme ist die anwerbung von arbeitern ins reich. ich habe mir in den letzten tagen in einer stadt selbst das buero fuer buitenlandsche arbeit angesehen. diese bueros leisten eine hervorragende arbeit und sind, wie bekannt, den niederlaendischen gewestelijken arbeitsbueros lose angehaengt.

ich bitte die beauftragten, sich diese einrichtungen anzusehen und einmal persoenlich augenschein von der arbeit zu nehmen. je mehr druck von oben fuer den arbeitseinsatz erfolgt, umsomehr muessen wir dem arbeitsuchenden menschen die moeglichkeit seines freiwilligen arbeitseinsatzes geben. das kann nur in diesen einrichtungen geschehen. dadurch, dass in naechster zeit geschaefte geschlossen werden, ist es moeglich, an verkehrsreichen gutliegenden stellen ueberall solche werbebueros einzurichten, wenn auch nur fuer eine bestimmte uebergangszeit.

es ist $z u$ beachten: leiter dieser bueros muessen niederlaender sein, die bereits in der arbeitsvermittlung gearbeitet haben. hierfuer kommen die leute aus den gewestelijken arbeitsbueros infrage. diese maenner koennen in einem 24-stunden kursus in rotterdam eingeschult werden.

mit der durchfuehrung dieser massnahme habe ich oberregierungsrat pg. dr. ju etting, rotterdam, tel. 27165 , beauftragt. fuer die werbung in der presse, vielleicht auch durch maueranschlag werden die mittel zur verfuegung gestellt und koennen direkt bei dr. piesbergen angefordert werden. ich darf bitten, auf diese aufgabe ihr besonderes augenmerk zu richten.

wie mir mitgeteilt wird, sind bereits auf grund der anordnung des generalsekretärs frederiks von den gemeinden, die insgesamt eine einwohnerzahl von 5 millionen menschen enthalten, die listen der beamten eingereicht. hier ist jetzt mit dem verschaerften arbeitseinsatz vorzugehen.

\section{4. organisation der arbeitsaemter.}

nach reiflicher ueberlegung habe ich entschieden, dass auf die dauer gesehen die aussenstellen der sozialen verwaltung eingezogen werden muessen. ich beabsichtige daher, nur deutsche fachwerber in die hollaendischen arbeitsbueros zu setzen, wie es bereits jetzt schor der fall ist, diese werber werden dem beauftragten personell angegliedert mit der anweisung der unterrichtung der beauftragten. sonst stehen sie unter der zentralen lenkung und befehlsgewalt der hauptabteilung soziale verwaltung, da mir nur der direkte weg die gewaehr fuer die durchfuehrung der mir auferlegten auftraege gibt. diese massnahme wird zug um zug duchgefuehrt.

geheim.

fuer alle wehrmachtangelegenheiten, die damit zusammenhaengende und inmarschsetzung verschiedener jahrgaenge, teile ich ihnen mit, dass es notwendig ist, dass sie sofort die listen aller derjenigen niederlaendischen reserveoffiziere und aktiven unteroffiziere der hollaendischen wehrmacht zusammenstellen, die heute in der nsb oder in ihren gliederungen taetig sind. fuer die behoerden, fuer die ruestungsindustrie und lebenswichtigen betriebe ist nicht beabsichtigt dass fuer diese gruppe weit gehende uk-stellungen vorgenommen werden, vielmehr vertritt der wehrmachtbefehlshaber hier die meinung, dass hier eine restlose einziehung 
verfolgen muss. mit dieser sonderaktion habe ich den kreisleiter $\mathrm{schuemann}$ in meinem stab beauftragt. listen die sie ueber die distriktsleider anfordern, muessen spaetestens am donnerstag, den 11. maerz 1943, in meinem besitz sein.

die zentralstellen der nsb werden durch kam. van geelkerken direkt bearbeitet.

heil hitler!

$\mathrm{sch} \mathrm{mid} t$

generalkommissar

reichskommissar den haag, fs 5418 den 5. 3. $43 / 19.30$

an a $11 \mathrm{e}$

beauftragten des reichskommissars

betrifft: arbeitseinsatz

geheim.

- - - mein heutiges fernschreiben

nachsatz zum letzten absatz (geheim.)

ich schlage vor, bei den distriktsleidern die anforderungen der listen mit folgender begruendung anzufordern. wie bereits bekannt, wird anfang naechster woche eine verordnung ueber die gruendung der niederlaendischen landwacht erfolgen.

hierfuer sind die listen aller reserveoffiziere und aktiven unteroffiziere, die heute der nsb angehoeren, notwendig. unter diesem motto kann mit dem distriktsleider gesprochen und ohne aufsehens von ihm die liste angefordert werden. ueber die obigen massnahmen ist grundsaetzlich mit keiner weiteren stelle $z u$ sprechen und muss persoenlich von dem beauftragten oder seinem vertreter durchgefuehrt werden.

heil hitler!

$\mathrm{schm}$ id t

generalkommissar

\section{Telexbericht van commissaris-generaal F. Schmidt aan de General- bevollmächtigte für den Arbeitseinsatz, Gauleiter F. Sauckel, d.d. 22-3-1943}

reichskommissar den haag, fs 5518 den 22. 3. $43 / 11.15$

an den

generalbevollmaechtigten fuer den arbeitseinsatz

gauleiter s a u c k e l

betrifft: anwerbung niederlaendischer arbeitskraefte

ich bestaetige ihr fernschreiben vom 18. d.mts. und habe bereits schon in meinem sonderbericht mitgeteilt, dass ich zuerst die dienststellen mit der durchkaemmung der kleinen betriebe 
befassen musste. diese arbeit war zeitraubend. trotzdem wurden 35.907 arbeiter vermittelt, davon die von mir bis zum 15. 3. 43 geforderten 22.000 metallwerker bereits am 12. maerz in marsch gesetzt.

ich bin davon ueberzeugt, dass die vermittlungen ende maerz und anfang april die gewuenschten erfolge haben werden und dass weiter darueberhinaus die wehrmachtsaktion laeuft, sodass ich die geforderten 100.000 bis zum 30. april stellen werde. ich habe bereits in einem telefongespraech mit gauleiter sauckel berichtet, dass die saeuberung und auskaemmung der kleinbetriebe nach metallwerkern die fachwerber sehr stark in anspruch genommen hat und dass jetzt selbstverstaendlich durch die schliessung der geschaefte und die anderen massnahmen, die eingeleitet wurden, mit einer erhoehten vermittlung begonnen wird. allein dadurch, dass der wehrmachtbefehlshaber seit 14 tagen auf eine anweisung des oberkommandos der wehrmacht wartet, ist die jahrgangweise erfassung, die zuerst die kriegsgefangenen betreffen wollte, verschleppt worden. ich habe mich daraufhin heute mit einem fernschreiben erneut an reichsleiter bormann gewandt mit der bitte, mit dem generalfeldmarschall von keitel hierueber $z \mathrm{u}$ sprechen. die massnahmen sind durchgearbeitet und koennen sofort anlaufen.

heil hitler! $\mathrm{sch} \mathrm{midt}$

\section{Telexbericht van commissaris-generaal F. Schmidt aan de General- bevollmächtigte für den Arbeitseinsatz, Gauleiter F. Sauckel, d.d. 12-4-1943}

reichskommissar den haag, fs 5605 den 12. 4. $43 / 9.35$

an den

generalbevollmaechtigten fuer den arbeitseinsatz

gauleiter $\mathrm{s}$ a u c kel

zur sofortigen persoenlichen vorlage oder evtl. tel. uebermittlung

an den gauleiter

betrifft: arbeitseinsatz der niederlande

am sonnabendmittag, den 10. april 1943, wurde ich von dem chef des stabes des wehrmachtbefehlshabers, general von wuehlisch, angerufen, der mir mitteilte, dass das oberkommando der wehrmacht den aufruf des wbn in der bekannten angelegenheit noch nicht freigegeben haette, es schiene ihm so, als wenn ueberhaupt im augenblick vom okw kurz getreten wuerde. ich habe daraufhin dem general mitgeteilt, dass ich von ihnen strenge anweisungen haette. falls der wbn bis mittwoch die massnahme nicht verkuendete, muesste ich mit der jahrgangweisen ertassung beginnen. der general aeusserte gegen diese meine in aussicht genommene massnahme allergroesste bedenken und gab zum ausdruck, dass die augenblickliche situation wehrpolitisch meine massnahme nicht befuerworten koenne. ich waere ihnen nun $z u$ dank verpflichtet, wenn sie diese frage nochmals mit dem okw klaeren koennten.

heil hitler! ihr schmidt 


\section{Telexbericht van commissaris-generaal F. Schmidt aan de General- bevollmächtigte für den Arbeitseinsatz, Gauleiter F. Sauckel, d.d. 16 -4-1943}

reichskommissar den haag, fs 5626 den 16. $4.43 / 15.20$

an den

generalbevollmaechtigten fuer den arbeitseinsatz

gauleiter s a c ckel

eilt sehr!

sehr geehrter gauleiter!

in verfolg meines fernschreibens vom 12. april 1943 muss ich ihnen leider mitteilen, dass der wehrmachtbefehlshaber in den niederlanden bis jetzt noch keine genehmigung vom oberkommando der wehrmacht fuer seinen aufruf, erfassung der ehemaligen niederlaendischen soldaten, erhalten hat. heute habe ich eine laengere aussprache mit dem reichskommissar dr. seyss-inquart gehabt, der damit einverstanden ist, dass ich in meiner eigenschaft (arbeitseinsatz) mit der verordnung ueber die meldepflicht herauskomme, er macht aber darauf aufmerksam, dass diese von mir durchgefuehrte aktion sehr stark darunter leiden wuerde, wenn dann in der naechsten woche der aufruf des wehrmachtbefehlshabers fuer die soldaten erschiene. es ist nicht zu verkennen, dass damit unsere aktion gefaehrdet wuerde, da sofort die oeffentlichkeit meine aktion als gescheitert und daher die wehrmachtsmassnahme als strafsonderaktion ansehen wuerde. der reichskommissar bittet sie daher, doch nochmals beim oberkommando der wehrmacht vorstellig $z u$ werden, damit moeglichst schnell die aktion des wehrmachtbefehlshabers in den besetzten niederlanden freigegeben wird. da der reichsfuehrer damals die zuruckfuehrung der niederlaendischen soldaten dem fuehrer vorgetragen hat, erkundigte sich der reichsfuehrer erneut bei dem hoeheren ss- und polizeifuehrer nach dem stand dieser massnahme. der hoehere ss- und polizeifuehrer wird daher ebenfalls sich heute mit einem fernschreiben an den reichsfuehrer ss ueber den stand der aktion wenden und in unserem sinne fuer die durchfuehrung eintreten. sowohl bei den zivilen wie bei den wehrmachtstellen besteht volle klarheit darueber, dass diese obenbezeichneten kraefte moeglichst schnell aus dem raum abgezogen werden muessen. technische schwierigkeiten sind nicht vorhanden. es handelt sich lediglich, wie uns vom okw vertraulich mitgeteilt wird, um fragen, die zwischen dem auswaertigen amt und dem okw noch nicht abgestimmt sind. sollten sie trotzdem die sofortige durchfuehrung meiner aktion fuer erforderlich halten, bitte ich um drahtnachricht, da es nicht moeglich ist, mit der jetzigen erfassungsmassnahme groessere erfolge $z \mathfrak{u}$ erreichen, da sich die zahl der in marsch gesetzten zwischen 4 bis 5.000 in diesem monat bewegt.

heil hitler! $\mathrm{schmidt}$ 


\section{Notitie van het Auswärtige Amt, d.d. 17-4-1943}

Geheime Reichssache

\section{Aufzeichnung}

Betr.: Ueberführung ehemaliger niederländischer

Wehrmachtsangehöriger nach Deutschland.

Mit Befehl vom 23.3.43 hat der Chef des OKW den Wehrmachtbefehlshaber Niederlande angewiesen, entsprechend seinem Vorschlag die Angehörigen der ehemaligen niederländischen Wehrmacht erfassen, festnehmen und abschieben zu lassen. Die Unterbringung der Angehörigen der ehemaligen niederländischen Wehrmacht habe zunächst in Kriegsgefangenenlagern $z u$ erfolgen.

Die Behandlung der festzunehmenden Niederländer sei der von Kriegsgefangenen anzupassen. Eine Schutzmacht werde nicht beteiligt.

Das Auswärtige Amt ist vor Erlass dieses Befehls vom OKW nicht um Stellungnahme gebeten, sondern nachträglich erst um Aeusserung ersucht worden, ob

1) die festzunehmenden Personen (ungefähr 300.000 Mann, wobei 100.000-120.000 Mann für Zwecke der Küstenverteidigung, Rüstungsindustrie in den Niederlanden verbleiben sollen, die für den Arbeitseinsatz nach Deutschland verbracht werden sollen, als Kriegsgefangene oder als Internierte $z \mathfrak{u}$ behandeln seien.

2) gegen einen Entwurf einer Bekanntmachung der Massnahmen Bedenken bestehen.

Das Auswärtige Amt kann hierzu nur insofern sich als zuständig erachten, als aussenpolitische Belange durch die Massnahmen berührt werden. Es ist also zu prüfen, ob dies der Fall ist.

Auszugehen ist hierbei zunächst von der Frage, ob die Wiederfestnahme der Angehörigen der ehemaligen niederländischen Wehrmacht und ihre Rückführung

1) in die Kriegsgefangenschaft oder

2) in ein Interniertenlager und

3) ihr Arbeitseinsatz

völkerrechtlich $z \mathrm{u}$ rechtfertigen ist.

Zu 1) Bei der Kapitulation der niederländischen Wehrmacht im Mai 1940 sind deren sämtliche Angehörige durch das mit dem holländischen General Winkelmann geschlossene Abkommen $z \mathrm{u}$ Kriegsgefangenen erklärt worden. Durch Führerbefehl sind diese Kriegs* gefangenen einige Zeit später mit Rücksicht auf das Wohlverhalten der niederländischen Bevölkerung aus der Kriegsgefangenschaft entlassen worden. Nachdem in den letzten Monaten die Haltung der niederländischen Bevölkerung sich entschieden geändert hat, und es zu zahlreichen Sabotagehandlungen und vielen Fällen der Spionnage und Feindsbegünstigung gekommen ist, kann die Voraussetzung für die seinerzeitige Entlassung der Angehörigen der ehemaligen niederländischen Wehrmacht aus der Kriegsgefangenschaft als hinfällig betrachtet werden. Ihre Wiederfestnahme und Rückführung in die Kriegsgefangenschaft ist daher zu rechtfertigen. Völkerrechtlich ist kein Rechtsatz bekannt, der es dem Nehmestaat verbietet, bei Obwalten neuer militärischer Umstände die einmal entlassenen Kriegsgefangenen, die sich inzwischen $z u$ einer militärischen Gefahr entwickelt haben, wieder in Kriegsgefangenschaft zurückzuführen. 
$\mathrm{Zu}$ 2) Die Ueberführung des genannten Personenkreises in Interniertenlager und dessen Evakuierung lässt sich in dieser Form nicht begründen und muss völkerrechtlich als nicht ohne weiteres vertretbar angesprochen werden.

$\mathrm{Zu}$ 3) Gegen eine etwaige Heranziehung der von der Massnahme betroffenen niederländischen Personen zu Arbeitszwecken bestehen, falls diese Personen als Kriegsgefangene wieder festgenommen werden, und falls ihr Arbeitseinsatz nach den allgemein für Kriegsgefangene geltenden Regeln erfolgt, keine Bedenken. Anders steht es jedoch mit der Heranziehung Internierter, die völkerrechtlich nicht begründet ist.

Sofern die Angehörigen der ehemaligen niederländischen Wehrmacht wieder in die Kriegs gefangenschaft zurückgeführt werden sollen, werden vom Auswärtigen Amt gegen die Massnahme, über deren sachliche Begründung das OKW im Einvernehmen mit dem Reichskommissar für die besetzten niederländischen Gebiete allein entscheiden kann, aussenpolitische Bedenken nicht erhoben. Dagegen erscheint die Ueberführung der genannten Personen in Interniertenlager und ihre Evakuierung nach Deutschland zum Zwecke des Arbeitseinsatzes vom aussenpolitischen Standpunkt nicht unbedenklich. Die zwangsweise Verbringung einer so grossen Anzahl von Niederländern in das Reich würde zweifellos im Auslande grösstes - Aufsehen erregen und der sehr aktiven Feindpropaganda neue Nahrung geben. Diese feindliche Propaganda könnte höchst unerwünschte Wirkungen auch in den sonstigen Westgebieten haben.

Abgesehen hiervon muss auf eine mögliche Einschaltung der Schutzmacht hingewiesen werden. Es ist seit langem Bestreben des Auswärtigen Amtes, die Tätigkeit der Schutzmächte der von uns besetzten Gebiete und der Staatsangehörigen dieser Gebiete möglichst einzuschränken. Auch in dem obenangeführten Befehl des Chefs des OKW vom 23.3.43 ist zum Ausdruck gebracht, dass eine Schutzmacht nicht beteiligt werden soll. Nach Ansicht des AA 1) wird der Schutzmacht gegebenenfalls schwer verweigert werden können, sich sei es um die Kriegsgefangenen, sei es um die internierten und nach Deutschland evakuierten Niederländer zu kümmern. Nach Erfahrungen des Auswärtigen Amtes ist anzunehmen, dass sich der Geschäftsverkehr mit der Schutzmacht wegen der wieder in die Kriegsgefangenschaft zurückgeführten Niederländer wesentlich reibungsloser abspielen dürfte, als hinsichtlich der internierten und nach Deutschland evakuierten. Auch unter diesem Gesichtspunkt wäre es wünschenswerter, von der Internierung und Evakuierung abzusehen und sich für die Rückführung in die Kriegsgefangenschaft $z u$ entscheiden.

Sollte die Entscheidung in diesem Sinne ergehen, so wäre die beabsichtigte Bekanntmachung entsprechend $z u$ formulieren. Das $A A$ würde sich eine Stellungnahme $z u$ einer solchen Bekanntmachung bis nach Vorliegen eines entsprechenden neuen Entwurfs vorbehalten müssen.

Berlin, den 17. April 1943.

1) Auswärtiges Amt. 


\section{Telexbericht van de Rijkscommissaris, Dr A. Seyss-Inquart, aan de Chef der Rijkskanselarij, Dr H. H. Lammers, d.d. 19-4-1943}

reichskommissar den haag, fs 5636 den 19.4. $43 / 16.20$

an den

reichsminister und chef der reichskanzlei

berlin

sehr geehrter herr doktor la m mers!

im einvernehmen mit dem wehrmachtbefehlshaber beabsichtigen wir in den niederlanden zwei massnahmen durchzufuehren, die einerseits die herausnahme der wehrfaehigen nieder. laender, soweit wir sie hier nicht brauchen, aus dem lande bezweckt, andererseits im wege einer anmeldung die einziehung von jahrgaengen zwecks arbeitseinsatz im reich vorbereiten soll. die letztere, die nach meiner genehmigung durch den generalkommissar zur besonderen verwendung in seiner eigenschaft als beauftragter des generalbevollmaechtigten fuer den arbeitseinsatz durchzufuehrende massregel, würde die erste in ihrer wirkung beeintraechtigen, wenn sie vorausginge; wie ich hoere, wird die frage, ob die wehrpflichtigen niederlander aus dem lande herausgenommen werden sollen, in dieser woche dem fuehrer vorgetragen. die dringende notwendigkeit, den arbeitseinsatz in die wege zu leiten, macht es erforderlich, dass wir hier baldigst $z \mathfrak{u}$ einer entscheidung kommen und ich halte nach wie vor beide massnahmen fuer das wirksamste. sollte die entscheidung nicht in der richtung fallen, dass die wehrfaehigen niederlaender herausgenommen werden, muesste ich wohl umgehend die erfassung leiten, wenngleich es dann schwer sein wird, auf militaerischem wege noch nachzukommen. ich erlaube mir ihnen hiervon mitteilung zu geben mit der bitte, nach moeglichkeit in diese sache einzugreifen.

se y s s-inquart

\section{Telexbericht van de Rijkscommissaris, Dr A. Seyss-Inquart, aan de Chef der Rijkskanselarij, Dr H. H. Lammers, d.d. 22-4-1943}

reichskommissar den haag, fs 5654 den $22.4 .43 / 16.40$

an den

herrn reichsminister und chef der reichskanzlei

be $\mathrm{r} 1$ in w8

vossstrasse 6

da die aufgaben des arbeitseinsatzes draengen, sehe ich mich vor die notwendigkeit gestellt, mit der bereits in meinem frueheren schreiben erwaehnten meldepflichtverordnung und der einziehung einiger jahrgaenge vorzugehen, falls sich die entscheidung ueber die einziehung der gedienten jahrgaenge durch die wehrmacht noch verzoegern oder negativ ausfallen sollte. im hinblick auf mir berichtete ruecksichtnahmen auf die internationale lage bitte ich sie 
mir mitzuteilen, ob bedenken bestehen, dass ich nach den osterfeiertagen eine meldepflicktverordnung erlasse und im anschluss daran die in den niederlanden noch nicht gedienten aber inzwischen wehrfaehig gewordenen jahrgaenge einziehe. in hinblick auf die dringlichkeit dieser entscheidung fuer den arbeitseinsatz bitte ich um eine moeglichst umgehende nachricht. ich zeichne mit

heil hitler! ihr stets ergebener seys $\mathrm{s}$ - in quart

\section{Telexbericht van Botschafter K. Ritter aan het Auswärtige Amt, Berlijn, d.d. 24-4-1943}

Fuschl Nr. $536 \quad$ 24. April $1943 \quad 12.00$

Geheime Reichssache

Auswärtiges Amt für

die Abteilung Pol

\section{G - Fernschreiben}

Im Anschluss an meine Notiz vom 20. April Nr. 193 wegen der Evakuierung der früheren holländischen Kriegsgefangenen usw.

Am 23. April vormittags rief mich General Warlimont vom Oberkommando der Wehrmacht an teilte mir mit, dasz Gauleiter Sauckel dem OKW gegenüber beschwert habe, dasz er wegen Evakuierung der Holländer vom $\mathrm{OKW}$ und vom Auswärtigen Amt keine Antwort bekomme. Er schiebe dem OKW und dem Auswärtigen Amt die Schuld dafür zu. dasz infolge des Ausbleibens der Holländer das Rüstungsprogram nicht eingehalten werden könne. Das OKW hat mich gebeten, dafür zu sorgen, dasz das OKW vom Auswärtigen Amt nunmehr eine Antwort auf die gestellte Frage bekomme.

Ich habe daher die Angelegenheit am 23.4. dem Herrn RAM 1) vorgetragen und auf Grund dieses Vortrages dem General Warlimont am 23.4. nachmittags folgendes mitgeteilt:

der Herr RAM ist

1) mit der Aktion im ganzen einverstanden,

2) ebenso damit einverstanden, dasz die Aktion damit begonnen wird, dasz die Angehörigen der ehemaligen niederländischen Wehrmacht erfaszt werden,

3) damit einverstanden, dasz die Angehörigen der ehemaligen niederländischen Wehrmacht wieder in den Status der Kriegsgefangenschaft zurückgeführt werden.

4) Der Herr RAM hält gleichfalls den Tenor des Entwurfes für eine Bekanntmachung in Holland nicht für angebracht. Es ist nicht Sache des Auswärtigen Amts, eine solche Bekannt-

1) Reichsaussenminister (J. von Ribbentrop) 
machung abzufassen. Der Herr RAM legt aber Wert darauf, die von militärischer Seite $z u$ entwerfende Bekanntmachung vor der Veröffentlichung zu sehen. General Warlimont hat zugesagt, dasz die Bekanntmachung dem Auswärtigen Amt vor der Veröffentlichung mitgeteilt wird. Ich habe ihm dabei empfohlen, zu prüfen, ob nicht der Wortlaut des seinerzeitigen Führerbefehls über die Entlassung der holländischen Kriegsgefangenen einen geeigneten Inhalt für die Motivierung der jetztigen Masznahme gibt.

Ritter

\section{Telegram van Botschafter $K$. Ritter aan het Auswärtige Amt, Berlijn, d.d. 24-4 1943}

Sonderzug, den 24. April 1943 / 19.10 Uhr

Salzburg, den 24. April 1943

Geheime Reichssache!

Nr. 541 vom 24.4. Sofort!

Auswärtiges Amt, Abteilung Pol

Im Anschluss an mein Fernschreiben von heute morgen wegen der Erfassung niederländischer Staatsangehöriger für den deutschen Arbeitsmarkt teile ich nachstehend den vom Führer bereits genehmigten Wortlaut einer Bekanntmachung über Hie Rückführung der Angehörigen der ehemaligen niederländischen Wehrmacht in die Kriegsgefangenschaft mit. Der Herr Reichsaussenminister ist unterrichtet. Ich stelle anheim, in Berlin sofort auch die Presseabteilung über die Angelegenheit zu unterrichten. Wegen der Veröffentlichung hat die Presseabteilung nichts zu veranlassen. Die Veröffentlichung erfolgt durch Militärbefehlshaber Niederlande. Es folgt der Wortlaut der Bekanntmachung:

Nach der Kapitulation der niederländischen Wehrmacht im Mai 1940 hat der Führer und Oberste Befehlshaber der deutschen Wehrmacht alsbald die Entlassung der niederländischen Soldaten aus der Kriegsgefangenschaft angeordnet. Diese Massnahme wurde unter der selbstverständlichen Voraussetzung getroffen, dass die niederländischen Wehrmachtsangehörigen diese grosszügige Handlungsweise durch eine entsprechende Einstellung zur deutschen Besatzungsmacht beantworten würden. Während ein grosser Teil von ihnen auch dieser Erwartung entsprochen hat, ist in vielen Fällen unter der Einwirkung unverantwortlicher Hetzer eine entgegengesetzte Entwicklung eingetreten. Es mussten deshalb bereits im Mai 1942 die ehemaligen Berufsoffiziere in die Kriegsgefangenschaft zurückgeführt werden. Die deutsche Wehrmacht hat seitdem fast ein volles Jahr in der Erwartung verstreichen lassen, dass diese deutliche Warnung verstanden werden würde. Tatsächlich haben jedoch einzelne Angehörige der ehemaligen niederländischen Wehrmacht immer wieder durch ihr feindseliges Verhalten das in sie bei der Entlassung gesetzte Vertrauen getäuscht. Dieser Missbrauch einer aus freien Stücken zurückgegebenen Freiheit wird nunmehr nicht länger geduldet.

Der Wehrmachtbefehlshaber in den Niederlanden ordnet deshalb die sofortige Rückkehr der Angehörigen der ehemaligen niederländischen Wehrmacht in die Kriegsgefangenschatt an. 
Er wird die Betroffenen zur Meldung in der Tagespresse auffordern. Wer der Aufforderung des Wehrmachtbefehlshabers nicht Folge leistet oder sich auf andere Weise der Rückführung in die Kriegsgefangenschaft $z u$ entziehen versucht, hat mit schärfsten Massnahmen zu rechnen. Dies gilt auch für Personen, die die Betroffenen bei derartigen Versuchen unterstützen.

Alle diejenigen, die nunmehr in die Kriegsgefangenschaft zurückkehren müssen, mögen dies allein den Hetzern zuschreiben, die durch ihr verbrecherisches Verhalten diese Massnahme erzwungen haben.

Schluss der Bekanntmachung.

Rit ter.

\section{Rondschrijven van de Wehrmachtbefehlshaber in den Niederlanden, d.d. 26-4-1943}

Ia Nr. $3408 / 43$ geh.

H. Qu., den 26.4 .43

\section{Geheim!}

Betr.: Evakuierung ehemaliger holl. Soldaten

Der Führer hat durch Fernschreiben OKW /WFST/Qu. (Verw.) Nr. 001983/43 g. Kdos. v. 24.4.43 entschieden, dass der W. Befh. Ndl. die ehemaligen Angehörigen der niederländischen Wehrmacht in die Kriegsgefangenschaft nach Deutschland zurückzuführen hat.

Am 28.4. wird in der Presse eine diesbezügliche Bekanntmachung erfolgen.

Ausgenommen von der Rückführung sind alle diejenigen Personen, die bei der Wehrmacht, den Dienststellen des Reichskommissars, den Dienststellen des Höheren SS- und Polizeiführers Nordwest, bei den Arbeiten der Küstenverteidigung, in der Rüstungsindustrie, in lebenswichtigen Betrieben usw. beschäftigt sind.

Voraussichtlich anschliessend an diese Rückführung werden durch die Dienststellen des Reichskommissars für die besetzten niederländischen Gebiete die ungedienten Jahrgänge erfasst und, soweit ihre Anwesenheit auf Arbeitsplätzen in den Niederlanden nicht erforderlich ist, nach Deutschland zum Arbeitseinsatz überführt.

Da damit zu rechnen ist, dass ein erheblicher Teil, besonders der jungen Jahrgänge, versuchen wird, sich dem Arbeitseinsatz zu entziehen, ist die Truppe anzuhalten, ihre besondere Aufmerksamkeit auf Fluchtversuche nach England oder über die belgisch-niederländische Grenze $z u$ richten.

Nicht ausgeschlossen ist es, dass durch diese einschneidende Massnahme die Bevölkerung der Niederlandse erheblich beunruhigt wird. Aufflackernde Unruhe im Keime zu ersticken, ist Angelegenheit der deutschen Ordnungspolizei. 
Von Seiten der Wehrmacht sind jedoch die Auswirkungen der Anordnungen zu beobachten und - falls Gefahr im Verzuge - sind gemachte Beobachtungen rechtzeitig dem W.Befh. Ndl. zu melden.

Die Soldaten haben alles zu unterlassen, was die Beunruhigung der Bevölkerung noch steigern kann.

Die Rüstungsinspektion wird gebeten, auf Fluchtversuche (Flugzeugfabriken, Werften) besonders $z \mathrm{u}$ achten.

Sonstige polizeiliche Massnahmen werden durch den Höheren SS- und Polizeiführer West durchgeführt.

Für den Wehrmachtbefehlshaber in den Niederlanden

Der Chef des Generalstabes

I.V.

$\mathrm{M} \ddot{\mathrm{u} l l}$ e r

\section{Bekendmaking van de Wehrmachtbefehlshaber in den Niederlanden, General der Flieger F. Christiansen, d.d. 29-4 1943}

$\mathrm{Na}$ de capitulatie van het Nederlandsche Leger in Mei 1940 heeft de Führer en Opperbevelhebber van de Duitsche Weermacht bevel gegeven tot onmiddellijke invrijheidstelling van de Nederlandsche soldaten uit de krijgsgevangenschap. Deze maatregel werd vanzelfsprekend genomen op voorwaarde, dat de Nederlandsche officieren en manschappen deze grootmoedige handelwijze met een dienovereenkomstige houding ten aanzien van de Duitsche bezettende macht zouden beantwoorden. Een groot gedeelte van hen heeft aan deze verwachting voldaan; in vele gevallen is echter onder invloed van onverantwoordelijke ophitsers een tegenovergestelde ontwikkeling gevolgd. Reeds in Mei 1942 moesten derhalve de voormalige beroepsofficieren opnieuw in krijgsgevangenschap worden weggevoerd. De Duitsche Weermacht heeft sindsdien bijna een vol jaar laten verstrijken in de verwachting, dat deze duidelijke waarschuwing zou worden verstaan. In feite hebben echter afzonderlijke leden van het voormalige Nederlandsche Leger door hun vijandig gedrag telkens opnieuw het vertrouwen, dat bij hun vrijlating in hen werd gesteld, geschonden. Dit misbruik van een volkomen vrijwillig teruggeschonken vrijheid wordt thans niet langer meer geduld.

De Wehrmachtbefehlshaber in den Niederlanden beveelt derhalve, dat de leden van het voormalige Nederlandsche Leger terstond opnieuw in krijgsgevangenschap worden teruggevoerd. $\mathrm{Hij}$ zal de betrokken personen in de dagbladpers tot persoonlijke aanmelding oproepen. Wie aan den oproep van den Wehrmachtbefehlshaber geen gevolg geeft of tracht, zich op andere wijze aan de krijgsgevangenschap te onttrekken, moet op de strengste maatregelen rekenen. Dit geldt eveneens voor personen, die de betrokkenen bij dergelijke pogingen ondersteunen. Allen, die thans in krijgsgevangenschap moeten terugkeeren, hebben dit uitsluitend aan de ophitsers te danken, die door hun misdadig gedrag dezen maatregel noodzakelijk maakten. 


\section{Telexbericht van SS-Gruppenführer H. A. Rauter aan de Reichs- führer-SS H. Himmler, d.d. 29-4-1943}

B lit $z$ vermerk den haag $61529 / 4 \quad(18.15)$

an den

Reichsfuehrer-SS

heinrich hi m m le r,

feldkommandostelle

dringend, sofort vorlegen

reichsfuehrer,

in den heutigen mittagszeitungen ist der aufruf des wehrmachtbefehlshabers erschienen, wonach alle niederlaender, die im mai 1940 in der niederlaendischen wehrmacht gedient haben, der kriegsgefangenschaft zugefuehrt werden sollen. in hengelo sind um $15.30 \mathrm{uhr}$ die arbeiter mehrerer firmen daraufhin sofort in streik getreten und haben die arbeit niedergelegt. in amsterdam hat der aufruf groesstes aufsehen erregt, in saemtlichen strassen haben sich menschengruppen gebildet, die diese massnahme diskutierten. man glaubt nicht recht an diese massnahme und versucht die hintergruende zu entraetseln. man nimmt an, dass die kriegsgefangenen in den deutschen ruestungsbetrieben eingesetzt oder aus sicherheitsgruenden wegen einer moeglichen invasion nach deutschland abgeschoben werden sollen. in arbeiterkreisen wird laut, dass man zuerst die juden weggeschaft habe, nun kaemen die soldaten an die reihe. den reichskommissar, der in berchtesgaden weilt, konnte ich noch nicht erreichen, da er mit begleitung nicht im hotel ist. ich habe die absicht, das polizeistandrecht in den streikgebieten sofort zu proklamieren. blankounterschriften des reichskommissars die der reichskommissar fuer diese zwecke immer bei mir deponiert hat, liegen bei mir vor, nur benoetige ich die grundsaetzliche genehmigung des $\mathrm{rk}^{1}$ ), da ja er das standrecht verfassungsmaessig proklamiert. das polizei-bataillon arnheim wurde von mir sofort nach hengelo in marsch gesetzt und wird gegen $20 \mathrm{uhr}$ dort eintreffen. fuer $20 \mathrm{uhr}$ ist sperrstunde angeordnet worden.

die polizei ist mit scharfen weisungen versehen. in Amsterdam wird streife von der polizei gefahren, um daempfend auf die massen einzuwirken. der wehrmachtbefehlshaber und der chef des generalstabes sind mit der ausrufung des polizeistandrechts auch einverstanden. -

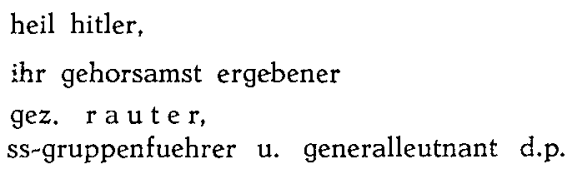

\footnotetext{
1) Reichskommissar.
} 


\section{Telexbericht van Dr R. Brandt, persönlicher Referent van de Reichs- führer-SS H. Himmler, aan SS-Gruppenführer H. A. Rauter, d.d. $30-4-1943$}

\section{SS-Gruppenführer R a u t e r}

Den Haag

Ihr Fernschreiben vom 29.4.1943 hat den Reichsführer-SS in der Feld-Kommandostelle nicht erreicht. Ich habe es ihm nachgeschickt.

Der Reichskommissar ist nicht mehr in Berchtesgaden. Soviel ich erfahren konnte, wollte er in Strassburg an einer Kundgebung teilnehmen. Ich nehme an, dass Sie hierüber Auskunft von seinem Büro erhalten können.

B r a n $\mathrm{d} t$

SS-Obersturmbannführer.

\begin{tabular}{ccc}
\multicolumn{3}{c}{ Befördert durch F.S. } \\
Tag & Monat & Uhrzeit \\
30. & 4 & 18.33
\end{tabular}

\section{Notitie van het Bureau van de Befehlshaber der Sicherheitspolizei und des Sicherheitsdienstes, Den Haag, d.d. 30-4-1943}

Betrifft: Streikbewegung

6,50 Uhr. Landgerichtsrat Schlüter teilt mit, dass Plakate bis 7 Uhr nicht fertiggestellt sein können.

Anschliessend Bericht an Brigadeführer.

7,30 Uhr. Landgerichtsrat Schlüter teilt mit, dass die Plakate um 10 Uhr fertiggestellt sind. Bürstenabzug ist von $\mathrm{ihm}$ durchgesehen. Er hat mit Ordonnanz des BdO, vereinbart, dass Abholung um 9,45 Uhr erfolgt.

9,00 Uhr. Regierungsdirektor Herrmann wird über Ultimatum bezügl. Limburger Kohlengruben unterrichtet und gebeten, eine zweite Staffel für die Verteilung der Plakate in diesem Gebiet vorzubereiten. Mit der Verteilung wird erst nach Abruf begonnen (das gilt auch für Overijssel).

9,02 Uhr. Landgerichtsrat Schlüter wird die Drucklegung der Plakate für das Limburger Gebiet veranlassen und wegen Bestellung der Sonderbeauftragten mit Staatssekretär Wimmer Fühlung nehmen.

9,15 Uhr. Regierungsdirektor Herrmann wird benachrichtigt, dass für die Plakattransporte der Fieseler-Storch zur Verfügung steht. Dieser ist in Schipol startbereit. 
9,16 Uhr. Gruppenführer $\mathrm{R}$ a uter teilt mit, dass für Limburg der Vizepräsident Stühler als Sonderbeauftragter eingesetzt werden soll. Es sollen 6000 Plakate angefertigt werden.

Anschliessend telefonische Weitergabe an Landgerichtsrat Schlüt e r.

9,35 Uhr. Oberstltnt. Mülle r teilt mit, dass Fieseler wegen Nebel ausfällt.

9,38 Uhr. Gruppenführer Rauter gibt bekannt, dass anstelle des Vizepräs. Stühler Pg. $\mathrm{Hi} \mathrm{m}$ erich als Sonderbeauftragter bestellt wird.

9,39 Uhr. Regierungsdirektor Herrmann wird über den Ausfall des Fieseler unterrichtet. Er teilt mit, dass die Verteilung der Plakate in anderer Weise gewährleistet ist.

9,42 Uhr. Schlüter wird unterrichtet, dass Beauftragter $\mathrm{Himmerich}$ sein soll.

9,43 Uhr. Gruppenführer Rauter befiehlt die Herstellung der Plakate auch für Nordholland. Sonderbeauftragter soll S chröder sein.

9,45 Uhr. Spanner wird gebeten, Plakate für Nordholland mit Sonderbeauftragten Schröder sofort vorzubereiten. Bestellt werden 10000 Stück.

9,49 Uhr. Sturmbannführer $\mathrm{H}$ a e r te l, SS - und Polizeigericht, nach Weisung des Höheren SS- und Pol. Führers werden die Polizeistandgerichte in den Provinzen Overijssel und Limburg sofort eingerichtet. Overijssel übernimmt SS-Obersturmführer Dr. B o ula nger, während für Maastricht der SS und Polizeirichter aus Düsseldorf herangezogen wird. Das Polizeistandgericht für Nordholland übernimmt Stubaf. Dr. H a e r t e 1 persönlich.

10.00 Uhr. Gruppenführer Rauter teilt mit, dass er bei der heute stattfindenden Pressekonferenz über das Polizeistandrecht sprechen will. Es ist folgendes $z \mathfrak{u}$ veranlassen:

1. Benachrichtigung des Leiters der Pressekonferenz und des Oberregierungsrat St a m pe von der Absicht des Gruppenführers.

2. Mitteilung an Gruppenführer über genauen Zeitpunkt und Ort der Pressekonferenz.

3. Besorgung einer grösseren Anzahl der vorgesehenen Plakate.

4. Besorgung einer ausreichenden Anzahl des Ordnungsschutzgesetzes, da von der Presse eine eingehende Erörterung verlangt wird.

10,10 Uhr. Stelle fest, dass Oberregierungsrat Stampe verreist ist. Stellvertreter ist $\mathrm{H}$ a g e n. Dieser veranlasst örtliche Verlegung der heutigen Pressekonferenz vom Departement in den Pressesaal im Kneuterdijk. Deshalb zeitliche Verlegung von 1/2 12 auf 12 Uhr.

10,15 Uhr. Amsterdam, Reichsrichter Dr. S ch w e b e 1, Sonderbeauftragter für Nordholland.

10,20 Uhr. Schlüter verständigt .

10,22 Uhr. Plakatanforderung bei Regierungsdirektor Herrmann. Dieser teilt mit, dass bisher lediglich die Plakate mit dem Aufruf des Reichskommissars, nicht aber die des Höheren SS - und Polizeiführers vorliegen. 50 Stück kommen ins Vorzimmer SSBrig. Führer Dr. Harster.

Anschliessend wurde Schlüter von mir gebeten, in der Druckerei für beschleunigte Arbeit $z u$ sorgen.

10,35 Uhr. Anruf Gruppenführer Rauter, Sonderbeauftragten für Nordholland ist Sch r öder, in dessen Vertretung Schwebel.

11,00 Uhr. Gruppenführer Rauter ist einverstanden, dass die Plakate an Dr. Hagen gehen zur Vorbereitung des Satzes bei der niederl. Presse. Plakate wurden um 11,03 mit Ordonnanz zu Dr. Hagen (Verschlussumschlag) gesandt. Die Pressekonferenz soll um 12 Uhr im Juliana-Palais stattfinden.

11,25 Uhr werden Reg. Dir. Herrmann und Stubaf. Ha e rtel verständigt, dass das Polizeistandrecht verhängt wird für Nordholland, Gelderland, Overijssel und Limburg. 
11,30 Uhr. Anruf Hauptstuf. S a me 1, Hertogenbosch. In Hertogenbosch Generalstreik (Wasser, Telefoon, Gas), ausserdem streiken einige grössere Firmen. Bei Philips sind die Arbeiter erschienen, arbeiten aber nicht (wie in Flugblättern empfohlen war).

11,30 Uhr. Verständigung des Gruppenführers vom Zustand in Hertogenbosch. Er ist gleich mit der Auffassung, dass zunächst einmal die Wirkung des Polizeistandrechts in den 4 Provinzen abgewartet werden soll.

12,00 Uhr. Pressekonferenz mit Erläuterungen von Gruppenführer Rauter zum Polizeistandrecht, insbesondere über die Zusammensetzung und die Tätigkeit der Polizeistandrechte.

12,40 Uhr. Gruppenführer Rauter ordnet an, dass die Plakate für die 4 Provinzen ausgeteilt werden können, sobald sie aus der Druckerei kommen. Weiterer Abruf ist nicht abzuwarten.

12,48 Uhr. Regierungsdirektor Herrmann, teilt mit, dass der erste Transport nach Overijssel bereits abgegangen ist.

12,55 Uhr. In der Druckerei stellte ich fest, dass 2 Posten vor der Tür standen, die niemanden aus dem Gebäude liessen. Im Beisein von Landgerichtsrat Schlüter und Unterstuf. Vogel habe ich veranlasst, dass ein dritter Satz vorbereitet wird und zwar für die gesamten niederl. Gebiete. Dieser Satz wird vorläufig nicht verwendet, sondern steht in Reserve. In Kürze werden 8 Maschinen arbeiten. Der Direktor glaubte mit der Fertigstellung der Plakate für alle Provinzen um 18 Uhr rechnen zu dürfen. Nach Rücksprache mit Gruppenführer Rauter wurde die Wegnahme der Posten in Aussicht gestellt. Im Betrieb bleiben nur die Druckerei- und Setzarbeiter, die im übrigen je 20 Zigaretten erhalten. Der Direktor hat darauf hingewiesen, dass durch rasches Arbeiten grösseres Blutvergiessen verhindert wird. Die übrigen Angestellten können zur normalen Zeit das Gebäude verlassen.

13,15 Uhr. Oberleutnant Mantey teilt mit, dass die Staffel nach Hengelo zum Kommandeur des Bataillons mit je 3000 Plakaten um 12,45 Uhr abgegangen ist und voraussichtlich $z$ wischen 15,00 und 15,30 Uhr in Hengelo eintrifft. Er wird entsprechende Meldungen an den BdS. gelangen lassen, sobald die nächsten Staffeln abgehen.

Ich habe Oberltn. Mantey mitgeteilt, dass die Plakate für die vier Provinzen sofort ausgeteilt werden können und kein weiterer Abruf abzuwarten ist.

13,30 Uhr. Deutsche Zeitung teilt mit, dass mangels Telefonverbindung Gefahr besteht, die Presseveröffentlichung über das Polizeistandrecht erst in der zweiten Auflage erscheinen lassen zu können. Der Text wird mit Kurier nach Amsterdam geschafft. 


\section{Telexbericht van de Befehlshaber der Sicherheitspolizei und des SD, Den Haag, Dr W. Harster, aan alle Aussenstellen, d.d. 30-4 1943}

FS. Nr. 14329

Den Haag, den 30.4.43.

An alle Aussenstellen

Beförd. 30 Apr. 1943 / 19.15

Betr. Streikbewegung.

Die eben stattgefundene Besprechung beim Höheren SS- und Polizeiführer, an der die Befehlshaber der Waffen-SS, der $\mathrm{OP}^{1}$ ) und der $\mathrm{SP}^{2}$ ) sowie die beteiligten Sachbearbeiter teilgenommen haben, hatte folgende Ergebnisse:

Am 1.5. wird voraussichtlich zwischen 6 und 7 Uhr morgens im ganzen Lande das Standrecht durch Anbringung von Plakaten proklamiert werden können. Gruf. Rauter wünscht, dass die besonderen von ihm angeordneten Massnahmen, wie Schiessen gegen Ansammlungen usw. erst eine Stunde nach erfolgter Plakatierung (das ist also örtlich verschieden) einsetzen sollen. Da eine zentrale Leitung aller Durchführungsmassnahmen zur Niederringung des Streiks usw. nicht zweckmässig ist, wird das gesamte Gebiet in folgende Sicherungsbereiche, die je einem Kommandeur unterstehen, eingeteilt.

Sicherungsbereich Gelderland - Kommandeur SS-O'Stubaf. Fortenbacher, Dienstsitz Arnheim. Sicherungsbericht Overijssel - Kommandeur Hauptmann Ney, Hengelo.

Sicherungsbereich der 3 nördlichen Provinzen (Groningen, Friesland u. Drenthe) - Kommandeur Major Mechels, Dienstsitz Groningen.

Sicherungsbereich Limburg - Kommandeur Hauptmann Bernickel, Dienstsitz Maastricht, Sicherungsbereich Süd-Holland - Kommandeur Oberst Böhmer, Dienstsitz Den Haag, nach Rotterdam wird ein Bataillon der Ordnungspolizei mit Major Hälwes verlegt.

Sicherungsbereich Nord-Brabant und Zeeland - Kommandeur Furck, Tilburg.

Sicherungsbereich Utrecht - Kommandeur SS-O'Stubaf. Beiersdorf, Dienstsitz Utrecht.

Sicherungsbereich Nord-Holland - Kommandeur Major Kärgel, Dienstsitz Amsterdam.

Die Kommandeure der Sicherungsbereiche sind die Vertreter des Höheren SS- und Polizeiführers und ihm dafür verantwortlich, dass rasch und energisch zugegriffen wird. Ihnen sind alle Kräfte der SS und Polizei in Ihrem Bereich unterstellt. Die Kommandeure haben dafür zu sorgen, dass die ihnen am 1.5. um etwa 5 Uhr zugehenden Plakate verbreitet werden. Die niederländische Polizei untersteht den Kommandeuren der Sicherungsbereiche. Die Ordnungspolizei soll Streifen fahren. Es darf nicht angerufen, nicht in die Luft geschossen werden. Es muss sofort scharf geschossen werden. Frauen sind zu schonen. Die Kommandeure haben dem Höheren SS- und Polizeiführer laufend alle 3 Stunden durch FS zu berichten.

Standgerichte werden errichtet in

Groningen mit dem SS-Richter Dr. Wendt aus Hamburg als Vorsitzenden

für Gelderland und Overijssel mit dem Sitz in Hengelo mit dem SS-Richter Dr. Boulanger als Vorsitzenden

für Nordholland und Utrecht mit dem Sitz in Amsterdam und SS-Stubaf. Dr. Arlt als Vorsitzenden

für Limburg mit dem Sitz in Maastricht und dem SS-Richter Dr. Hansen aus Düsseldorf als Vorsitzenden

für Südholland und Zeeland mit dem Sitz in Den Haag mit SS-Stubaf. Dr. Haertl als Vorsitzenden.

1) Ordnungspolizei.

2) Sicherheitspolizei. 
Mit Ausnahme von Hengelo haben die Standgerichte ihren Sitz bei den Aussenstellen zu nehmen. Die Abteilung III beim Befehlshaber der Waffen-SS stellt die Schreiber zur Verfügung. Die Urteile der Standgerichte sollen rasch, aber nur in der örtlichen Presse bekanntgemacht werden. Hierbei ist mit dem Pressebearbeiter beim Beauftragten des RK Fühlung zu nehmen.

SS-Gruf. Rauter wünscht, dass die Kommandeure mit den Sonderbeauftragten, den Standgerichten und den Aussenstellen der Sicherheitspolizei eng zusammenzuarbeiten und nach Möglichkeit in einer gemeinsamen Dienststelle amtieren.

Der Gruppenführer hat schliesslich noch darauf verwiesen, dass grundsätzliche Massnahmen der Sonderbeauftragten nur mit seiner Zustimmung getroffen werden können ( $\$ 65$ II Ordnungsschutz - V.O.).

Ich mache darauf aufmerksam, dass der 1. Mai nur von den hier ansässigen Reichsdeutschen arbeitsfrei verbracht wird, während er für die Niederländer als normaler Werktag gilt. Wenn jedoch einzelne niederländische sympathisierende Betriebe sich dem deutschen Feiertag anschliessen sollten, so ergeht hierüber nähere Mitteilung durch den Generalkommissar z.b.V. an die Kommandeure der Sicherungsbereiche.

Ich weise hiermit sämtliche Aussenstellen an, die Polizeistandgerichte auf den Dienststellen aufzunehmen und mit ihnen engstens zusammenzuarbeiten.

Den Inhalt dieses FS bitte ich sofort mit den Beauftragten zu besprechen.

Dr. Harster

\section{Stabsbefehl van SS-Gruppenführer und Generalleutnant der Waffen-SS K. M. Demelhuber, commandant van de Waffen-SS in Nederland, d.d. 30 -4 -1943}

Abt. Ia Tgb. Nr. $229 / 43$ g. Kdos

St. Qu., den 30.4.1943

Betr.: Streikbewegungen und innere Unruhen.

1.) Anlässlich der Zurückführung der Niederländischen Soldaten in die Gefangenschaft ist es in einzelnen Provinzen zu Aufstandsbewegungen gekommen, die auf andere Provinzen übergreifen können.

2.) Der Höhere SS- und Polizeiführer ,Nordwest" hat für die besetzten niederländischen Gebiete das

Polizeistandrecht

verhängt.

Das Polizeistandrecht tritt eine Stunde nach Plakatanschlag in Kraft.

3.) Zur Durchführung des Polizeistandrechtes werden die Niederlande in

SS- und Polizei-Sicherungsbereiche

eingeteilt, die mit Ausnahme der Sicherungsbereiche Utrecht und Nordholland territorial mit den Provinzen übereinstimmen. Der Sicherungsbereich Utrecht umfasst die Provinz Utrecht zuzüglich dem Wehrmacht-Kommandantur-Bereich Hilversum. 
4.) Die W affen-SS übernimmt die Sicherungsbereiche Ut recht und Gelderland.

5.) Es werden eingesetzt

a) als Führer des Sicherungsbereiches Utrecht:

SS-Ostubaf. B e ye rsdorf f mit Sitz in Utrecht in der Dienststelle des PolizeiOffiziers beim Beauftragten des Reichskommissars,

b) als Führer des Sicherungsbereiches Gelderland:

SS-Ostubaf. Fortenbacher mit Sitz in Arnheim, Stabsquartier SS-Panz.Gren. Ausb. u. Ers. Btl. 12.

6.) Die Führer der Sicherungsbereiche sind verantwortlich für die Durchführung der vom Höheren SS und Polizeiführer auf Grund des $\S 64$ der „Ordnungsschutzverordnung 1943" gegebenen Anordnungen.

Sie veranlassen die Bekanntmachung der Anordnungen des Höheren SS- und Polizeiführers durch Plakatanschlag.

Sie schlagen in ihren Bereichen alle Aufstandsbewegungen und Unruhen mit rücksichtsloser Härte nieder. Auf Zusammenrottungen jeder Art ist unverzüglich und ohne $W$ ar nung das Feuer zu eröffnen.

7.) Den Führern der Sicherungsbereiche stehen zur Verfügung:

a) im Sicherungsbereich Utrecht:

die SS-Pol.Art.Ers.Abt.,

die SS-Panz.Jäg.Ausb.Abt.2 mit Ausnahme der an den Sicherungsbereich Nordholland abzugebenden Teile und

die im Sicherungsbereich vorhandenen holländischen Polizeikräfte.

b) im Sicherungsbereich Gelderland;

das SS-Gren.Ausb.u.Ers.Bt1.4

das SS-Panz.Gren.Ausb.u.Ers.Btl.12 und

die im Sicherungsbereich vorhandenen holländischen Polizeikräfte.

8.) Die Führer der Sicherungsbereiche geben 3-stündlich einen fernschriftlichen Lagebericht an den Höheren SS- und Polizeiführer "Nordwest" und an den B.d.W.SS Ndl.

9.) Die Führer der Sicherungsbereiche sind angewiesen, mit den Sonderbeauftragten des Reichskommissars, dem SD und den Polizei-Standgerichten zusammenzuarbeiten.

Das Polizei-Standgericht für den Sicherungsbereich Utrecht befindet sich in A ms t e r d a m,

das Polizei-Standgericht für den Sicherungsbereich Gelderland in He ngelo.

10.) Es werden abgestellt:

SS-Obersturmführer Grie s e n b e ck, Stab B.d.W.SS zum Polizei-Standgericht Hengelo,

SS-Obersturmführer Gra n, SS-Gren.Ausb.u.Ers.Btl.4 zum Polizei-Standgericht Maastricht

SS-Untersturmführer Ka u e r, SS-Panz.Gren.Ausb.u.Ers.Bt1.12 zum Polizei-Standgericht Groningen.

Meldung am 1.5.43 bei der jeweiligen Dienststelle der Sicherheitspolizei,

11.) SS-Panz.Jäg.Ausb.Abt.2 bildet 2 mot.Schtz.Kp. und unterstellt sie dem Führer des Sicherungsbereiches Nordholland. Wegen Abruf der Kompanien tritt SS-Panz.Jäg.Ausb. Abt.2 mit dem Kdr. II/Pol.-Rgt.3 in Amsterdam, Kolonial-Institut in Verbindung.

Zuführung nach Amsterdam im Kfz.-Marsch.

12.) Die 6.(Gen.)/SS-Gren. Ausb.u.Ers.Btl.4 bildet eine mot. Schtz.Kp. und unterstellt diese dem Führer des Sicherungsbereiches Nord-Brabant.

Die Kompanie hält sich in ihren Unterkünften abrufbereit.

13.) Wenn die Verlegung von Einheiten in andere Orte notwendig wird, ist wegen Unterbringung usw. mit der zuständigen Ortskommandantur Verbindung aufzunehmen. 
14.) Betriebsstoff-Anforderungen sind an Befehlshaber der Ordnungspolizei, Den Haag, zu richten.

Im Entwurf

gez. Demelhuber

SS-Gruppenführer und Generalleutnant der Waffen-SS

Verteiler:

SS-Gren.Ausb.u.Ers.Btl.4,

SS-Panz.Gren.Ausb.u.Ers.Bt1.12

- 1. Ausf. und 2. Ausf.

SS-J.G.Ausb.Btl.2,

- 3. Ausf.

SS-Panz.Jäg.Ausb.Abt.2,

SS-Pol.Art.Ers.Abt.

SS-Wachbtl. „Nordwest",

SS-Kraftfahrschule I,

SS-Stabskp. „Nordwest",

Kdt.St.Qu.,

K.T.B.

Vorrat

nachrichtlich

Wbfh.Ndl. Ia,

Höh.SS u. Pol.Fhr.,

SS-FHA, Ia,

Feldkr. 674 u. 724

Befh.d.Ordn.Pol.

Befh.d. S.u. SS-u.Pol.Gericht X
- 4. Ausf.

- 5. Ausf.

- 6. Ausf.

- 7. Ausf.

- 8. Ausf.

- 9. Ausf.

- 10. Ausf.

- 19., 20., 21. Ausf.

- 22., 23., 24., 25., 26. Ausf.

- 11. Ausf.

- 12. Ausf.

- 14. Ausf.

- 16. Ausf. und 17. Ausf.

- 18. Ausf.

- 13. Ausf. und 15. Ausf.

\section{Telexbericht van $W+W$. Dittmar, perschef van de Rijkscommissaris, aan alle Pressereferenten bij de Beauftragten, d.d. 30-4-1943}

reichskommissar den haag, fs 5685 den 30. 4. $43 / 17.25$

an a $11 \mathrm{e}$ pressereferenten bei den beauftragten

im auftrage von generalkommissar schmidt bitte ich sie sicherzustellen, dass in jeder provinz mindestens eine tageszeitung normal wiedererscheint, die gesammte gefolgschaft ist vor verlassen des arbeitsplatzes durch revers $z u$ verpflichten, dass sie am folgenden tage zur arbeit antritt unter hinweis auf die bestimmungen des polizeistandrechts.

von faeller, in denen zeitungen (aus auch technischen gruenden wie fehlen des gas) nicht erscheinen oder erscheinen koennen, erbitte ich fernschriftliche meldung. 


\section{Telexbericht van de Befehlshaber der Sicherheitspolizei und des SD, Den Haag, Dr W. Harster, aan het Reichssicherheitshauptamt, d.d. 30-4-1943}

Den Haag, den 30. April 1943.

An den

Chef der Sicherheitspolizei und des SD

An das

RSHA, Amt III und IV

Berlin

Betr.: Abführung der Angehörigen der ehemaligen niederländischen Wehrmacht in die Kriegsgefangenschaft.

- Vorg.: Hies. Blitz-FS vom 29.4.1943 und 30.4.1943.

In den Abendblättern wurde nachstehende Bekanntmachung des WBN veröffentlicht:

,Im Verfolg der am 29. April 1943 in der Tagespresse veröffentlichten Bekanntmachung wird hiermit zur Meldung und Rückführung in die Kriegsgefangenschaft aufgerufen:

Das Berufspersonal der ehemaligen niederländischen Wehrmacht unter dem Range des Offiziers mit Geburtsdatum nach dem 31. März 1898, soweit es im Mai 1940 im wirklichen Wehrmachtsdienst stand.

Es haben sich zu melden im Wehrmachtlager Amersfoort, Zonnebloemstraat, jeweils zwischen 8 und 11 Uhr, die Angehörigen der

I. Infanterie, Artillerie, Kavallerie, des technischen Personals, der Polizeitruppen am 7. Mai 1943.

II. Marine mit Anfangsbuchstaben $\mathrm{A}-\mathrm{H}$, Pioniere, Luftwaffe, Sanitätsdienst am 10. Mai 1943.

III. Marine mit Anfangsbuchstaben I- $Z$ und Angehörige aller oben nicht genannten Waf. fengattungen und Einheiten am 13. Mai 1943.

Bei der Meldung sind die Kennkarten, und, soweit noch vorhanden, militärische Ausweispapiere vorzulegen.

Anzug: Soweit wie möglich Uniform, sonst Zivilkleidung. Es wird dringend empfholen, Werktags- und Sonntagskleidung, Wolldecken, Leibwäsche und Extra-Schuhwerk mitzubringen. Das Gesamtgepäck darf den Umfang von zwei Handkoffern nicht überschreiten.

Von der Meldung und Rückführung in die Kriegsgefangenschaft sind befreit:

1.) Alle Angehörigen der niederländischen Polizei und ihrer Nebenorganișationen, weil sie augenblicklich Dienst tun bei

a) der staatlichen Ordnungspolizei,

b) der Gemeindeordnungspolizei,

c) der Marechaussee,

d) der Wasserschutzpolizei,

e) dem staatlichen Fahndungsdienst (Fahndungszentrale, Fahndungshauptabteilungen, Fahndungsabteilungen),

f) dem Gemeindefahndungsdienst,

g) der staatlichen Feuerwehr, 
h) den Gemeindefeuerwehren,

i) den freiwilligen Feuerwehren als hauptamtliche Kräfte oder Leiter,

k) der Grundorganisation des Luftschutzdienstes (staatlich besoldet).

2.) Unteroffiziere, die während ihrer aktiven Dienstzeit Verwaltungsbeamte (administrateurs) waren.

3.) Personen, die hauptamtlich beim Niederländischen Arbeitsdienst angestellt sind.

4.) In Deutschland arbeitende Personen.

Die unter 1) genannten Personen haben bis 15. Mai 1943 eine Bestätigung ihrer vorgesetzten niederländischen Dienststelle über ihre gegenwärtige Anstellung (actief dienstverband) an den Kommissar für die Belange der ehemaligen niederländischen Wehrmacht, Den Haag, Lange Voorhout 7, einzusenden.

Wer der Aufforderung des Wehrmachtbefehlshabers nicht Folge leistet oder sich auf andere Weise der Rückführung in die Kriegsgefangenschaft $z u$ entziehen versucht, hat mit schärfsten Massnahmen $z \mathfrak{u}$ rechnen. Dies gilt auch für Personen, die die Betroffenen bei derartigen Versuchen unterstützen.

Weitere Aufrufe erfolgen."

Am 1.5.1943 wird zwischen 6 und 7 Uhr morgens auf Anordnung des Reichskommissars nunmehr im ganzen Lande das Standrecht durch Anbringung von Plakaten proklamiert. Die Ordnungspolizei und die Waffen-SS haben vom Höheren SS- und Polizeiführer die Anweisung, eine Stunde nach erfolgter Plakatierung schärfstens gegen die Streikenden vorzugehen. Da eine zentrale Leitung aller Durchführungsmassnahmen zur Niederlegung des Streikes usw nicht zweckmässig erscheint, wird der niederländische Raum in fünf Sicherungsbereiche, die je einem Kommandeur unterstehen, eingeteilt. Die niederländische Polizei ist den Kommandeuren der Sicherungsbereiche unterstellt. Standgerichte werden errichtet in Groningen für die nördlichen Provinzen, in Hengelo für die Provinzen Overijssel und Gelderland, in Amsterdam für die Provinzen Nordholland und Utrecht, in Maastricht für Limburg und Nordbrabant, in Den Haag für Südholland und Zeeland. Die Standgerichte nehmen ihren Sitz bei den Aussendienststellen der Sicherheitspolizei und des SD. - Um Schwierigkeiten zu vermeiden, hat der Reichskommissar angeordnet, dass morgen am 1.5.1943 ebenfalls alle reichsdeutschen Dienststellen sowie NSB-Betriebe zu arbeiten haben.

\section{B. Stimmung innethalb der NSB.}

Im grossen und ganzen lehnt das Hauptquartier der NSB die neue Massnahme ab unter besonderem Hinweis darauf, dass es sich hierbei um eine reine deutsche Massnahme handelt. Man befürchtet, dass das Ansehen der NSB bei der niederländischen Bevölkerung weiter abnehmen wird. Für die Entwicklung macht man weitgehendst die Niederländ.-SS und vor allem den Voorman Feldmeije $r$ verantwortlich. Der Leider der NSB hat den Auftrag gegeben, dem WBN sofort Listen aller infrage kommenden NSBer zu erstellen, damit diese nicht in die Kriegsgefangenschaft abgeführt werden.

\section{Allgemeine Stimmung.}

Die heute nachmittag erfolgte Bekanntmachung der Ausführungsbestimmungen $z u$ der gestrigen Bekanntmachung des WBN wird in der niederländischen Bevölkerung allgemein als erster Rückzug angesehen, da die gestrige Veröffentlichung sämtliche ehemaligen Angehörigen der niederländischen Wehrmacht zur Rückführung vorsah währen nach den Ausführungsbestimmungen 'nur die aktiven Wehrmachtsangehörigen überführt werden sollen. Selbstverständlich sahen diese Kreise diesen angeblichen Rückzug bereits als einen Erfolg ihren Streikbewegungen an.

Zusammenfassend kann als allgemeine Stimmung der Bevölkerung festgestellt werden, dass die Bekanntmachung des WBN innerhalb weniger Stunden hellste Empörung und Panik- 
stimmung ausgelöst hat. Hierzu hat besonders die Tatsache, dass in den ersten Veröffentlichungen keine Einzelheiten mitgeteilt wurden, welche der ehemaligen Angehörigen der niederländischen Wehrmacht erfasst werden sollten, sowie das Fehlen eines genauen Termins über die Rückführung $z u$ diesem Stimmungsabfall beigetragen. Durchschnittlich haben $70-80 \%$ der Betriebe und davon ca. $90 \%$ der Belegschaft die Arbeit niedergelegt. In mehreren Orten geriet die Versorgung der Gas-, Wasser- und Elektrizitätswerke vorübergehend ins Stocken. Grundsätzlich kann dabei aber festgestellt werden, dass die breite Masse der Arbeiterschaft an sich fast durchweg gar nicht daran gedacht hat zu streiken und dass es lediglich einzelnen aktiven Hetzern gelungen ist, ohne grössere Schwierigkeiten die durch die Flugblattpropaganda der letzten Wochen und durch die ausländischen Hetzsender geistig auf derartige Ereignisse vorbereitete Bevölkerung von der Notwendigkeit eines allgemeinen Streiks zu überzeugen. Ueberall da, wo einsichtige Betriebsleiter in geschickter Form die Arbeiter beeinflussten, konnte eine Betriebsaufnahme im Laufe des heutigen Tages erreicht werden. In den meisten Fällen haben jedoch die Betriebsführer ihren Betrieb verlassen und konnten auch in ihren Wohnungen nicht erreicht werden. In der deutschfeindlichen Bevölkerung werden als Grund für die Massnahme des WBN die folgenden Gerüchte laut:

1.) Besonders in intellektuellen Kreisen verlautet, dass die ergriffenen Massnahmen eine Antwort des Wehrmachtbefehlshaber auf die Osterrede der ehemaligen niederländischen Königin darstelle. In dieser Rede soll die Königin vor allem der wehrhaften niederländischen Jugend mit Bewunderung gedacht haben und mit dem Hinweis auf die baldige militärische Niederringung des Reiches der Erwartung Ausdruck gegeben haben, dass die Befreiung des niederländischen Volkes bevorstehe.

2.) Im Zusammenhang hiermit werden Hoffnungen auf die bevorstehende Invasion erneut laut. Die Besatzungsmacht sei sich ihrer Stärke nicht voll bewusst und befürchtet, dass für den Fall einer Invasion die Angehörigen der niederländischen Wehrmacht zu den Trägern eines militärischen Aufstandes hinter der Front würden. Dies sei umso wahrscheinlicher, weil nach den im Umlauf befindlichen Gerüchten bereits jetzt von englischen Flugzeugen Waffen für die Aufständischen abgeworfen würden. Vor allem auch intellektuelle Kreise versuchen die Meinung zu verbreiten, dass es sich bei der Aktion in diesem Sinne um eine vorbeugende Massnahme handele und dass die Niederländer diese Repressalie mit Gelassenheit auf sich nehmen müssten, da sie gleichzeitig die Rückkehr der Köningin und die Wiedereinführung früherer Zustände in den Niederlanden in Aussicht stelle. Unter diesem Gesichtspunkt müsse die Rückführung in die Kriegsgefangenschaft als ein notwendiges Uebel angesehen werden.

3.) Weit verbreitet ist die Ansicht, dass das Reich angesichts des grossen Mangels an Arbeitskräften auf diese Weise versuche, zusätzliche niederländische Arbeiter ins Reich $z$ u schaffen. Nachdem die Sabotage des Arbeitseinsatzes vor allem unter der Beamtenschaft und den Meldebehörden mit grossem Erfolg durchgeführt worden sei und sich die Bevölkerung auch sonst auf alle erdenkliche Weise der Dienstverpflichtung zu entziehen verstehe, habe die Besatzungsmacht einen neuen. Weg zum Arbeiterfang ergriffen. Vor allem seien die Versuche, die niederländische Jugend mit dem Ziele eines Arbeitseinsatzes zu erfassen, völlig gescheitert. Andererseits werden hierzu in Arbeiterkreisen vereinzelt Stimmen laut, die bedauern, dass sie sich bisher nicht freiwillig zum Arbeitseinsetz gemeldet haben oder sich der Verpflichtung entzogen haben. Sie stellen fest, dass sie dann wenigstens in Zukunft mit einem regelmässigen Heimaturlaub und mit einer durchweg guten Bezahlung hätten rechnen können.

Bei den Gemeindeverwaltungen im Osten der Niederlande hat die Streikbewegung bereits abgenommen gegenüber einer Zunahme in den nord- und südholländischen Provinzen. Die Streikbewegung hat sich auch auf die öffentlichen Verkehrsmittel ausgedehnt. Im Südosten der Niederlande wurde auch bereits der Eisenbahnverkehr zum Teil mitbetroffen. Durch Panikkäufe bei den Lebensmittelgeschäften kam es in den Nachmittagstunden bereits zu 
erheblichen Störungen in der Lebensmittelversorgung. In grösseren Städten haben die Warenhäuser sowie die kleineren Betriebe weitgehend geschlossen. Durch den Streik bei den Gruben in Limburg ist eine erhebliche Störung in der Gasversorgung der südlichen Provinzen eingetreten.

Der heutige Geburtstag der Prinzessin Juliana trat auf Grund der Streikbewegung nicht näher in Erscheinung.

Nachsatz zu B. (Stimmung innerhalb der NSB). Bemerkenswert ist, dass durchweg bei allen Streikenden auch NSBer mitbeteiligt waren.

\author{
BdS, Den Haag, \\ Dr. Harster
}

SS-Brigadeführer und Generalmajor der Polizei.

\title{
27. Bekendmaking van de Wehrmachtbefehlshaber in den Niederlanden, General der Flieger F. Christiansen, d.d. 30-4-1943
}

In vervolg op de op 29 April 1943 in de dagbladpers gepubliceerde bekendmaking wordt hiermede ter aanmelding en terugvoering in de krijgsgevangenschap opgeroepen:

Het beroepspersonee 1 van de voormalige Nederlandsche weermacht be neden den rang van officie $r$ met geboortedatum n a 31 Maart 1898, voor zoover dit personeel in Mei 1940 in werkelijken dienst van de Nederlandsche weermacht stond.

In het weermachtskamp te Amersfoort, Zonnebloemstraat, moeten zich telkens tusschen 8 en 11 uur de volgende personen aanmelden:

de leden:

1. Van het wapen der infanterie, cavalerie, artillerie, technisch personeel, politietroepen, op 7 Mei 1943.

2. Van de zeemacht met beginletter $\mathrm{A}-\mathrm{H}$ en de leden van het wapen der genie, pontonniers en torpedisten, militaire luchtvaart, mil. geneeskundigen dienst op 10 Mei 1943,

3. Van de zeemacht met beginletter $\mathbf{I}-\mathbf{Z}$ en de leden van alle, boven niet genoemde wapens en onderdeelen op 13 Mei 1943.

Bij de aanmelding moeten het persoonsbewijs en voor zoover nog aanwezig de militaire identiteitspapieren worden vertoond.

K lee ding: Zooveel mogelijk uniform, anders burgerkleeding. Dringend wordt aanbevolen daagsche en Zondagsche kleeren, wollen dekens, lijfgoed en extra-schoeisel mede te brengen. De gezamenlijke bagage mag den omvang van twee handkoffers niet overschrijden.

Van de aanmelding en terugvoering in de krijgsgevangenschap zijn uitgezonderd: 
1. alle leden der Nederlandsche politie en haar nevenorganisaties in zooverre deze personer momenteel in actieven dienst staan bij:

a. de staatsordepolitie;

b. de gemeentelijke ordepolitie;

c. de marechaussee (gendarmerie):

d. de politie te water;

e. de staatsrecherche (recherchecentrale, recherchehoofdafdeelingen, rechercheafdeelingen);

f. de gemeentelijke recherche;

g. de staatsbrandweer;

h. de gemeentelijke brandweren;

i. de vrijwillige brandweren, voor zoover deze personen daar als hoofdberoep een functie uitoefenen of leiders zijn;

k. de vaste kern van den Luchtbeschermingsdienst (bezoldigd door den Staat);

2. onderofficieren, die tijdens hun actieven diensttijd bestuursambtenaren (administrateurs) waren,

3. personen, die als hoofdberoep een functie bij den Nederlandschen Arbeidsdienst uitoefenen,

4. in Duitschland werkende personen.

De onder 1. genoemde personen moeten vóór 15 Mei 1943 een bevestiging van de boven hen staande Nederlandsche dienstinstantie betreffende hun tegenwoordige aanstelling (actief dienstverband) inzenden aan den commissaris voor de belangen van de voormalige Nederlandsche weermacht te Den Haag, Lange Voorhout 7.

Wie geen gevolg geeft aan den oproep van den Wehrmachtbefehlshaber of zich op andere wijze aan de terugvoering in de krijgsgevangenschap probeert te onttrekken, moet op de scherpste maatregelen rekenen. Dit geldt ook voor personen, die de betrokkenen bij dergelijke pogingen ondersteunen.

Verdere oproepingen zullen volgen.

\section{Bekendmaking van de Rijkscommissaris, Dr A. Seyss-Inquart, d.d. 1-5-1943}

Het Rijkscommissariaat maakt bekend:

De Reichskommissar für die besetzten Niederländischen Gebiete heeft op grond van de artikelen 62 en volgende der verordening openbare orde 1943 met onmiddellijke werking voor het bezette Nederlandsche gebied in zijn geheel het politiestandrecht afgekondigd en in verband hiermede beschikt: 
„Ik beveel, dat een ieder zich heeft te onthouden van iedere handeling, welke de openbare orde en de veiligheid van het openbare leven zou kunnen verstoren of in gevaar zou kunnen brengen, en zich heeft te schikken naar de bijzondere maatregelen, welke ik, daarbij uitdrukkelijk de aandacht vestigende op de scherpte van het politiestandrecht, zal uitvaardigen.

$\mathrm{Hij}$, die in strijd handelt met dit bevel, wordt standrechtelijk veroordeeld.

De höhere SS- und Polizeiführer treft alle maatregelen, welke hij voor de handhaving of het herstel van de openbare orde of van de veiligheid van het openbare leven noodig acht.

Bij de uitvoering van zijn taak kan de höhere SS- und Polizeiführer van het geldende recht afwijken.

Tot mijn bijzonderen gemachtigde in den zin van artikel 65 der verordening openbare orde 1943 voor het bezette Nederiandsche gebied in zijn geheel benoem ik den commissarisgeneraal voor bestuur en justitie dr. Wimmer. Aan hem is ondergeschikt het geheele openbare bestuur, met uitzondering van de politie en onverminderd de aan den höheren SS- und Polizeiführer opgedragen' taak.

Aan den bijzonderen gemachtigde voor het bezette Nederlandsche gebied in $z$ ijn geheel zijn de bijzondere gemachtigden voor de afzonderlijke provincies ondergeschikt. Ik benoem tot bijzonderen gemachtigde voor de provincie:

Noord-Brabant: den Oberbereichsleiter Himmerich;

Gelderland: den plaatsvervangenden gevolmachtigde Brandes;

Zuid-Holland: den gevolmachtigde Reichsleiter Schwebel, en tot diens vertegenwoordiger den gevolmachtigde voor de stad Rotterdam, Präsident dr. Völckers;

Noord-Holland: den gevolmachtigde dr. Schröder en tot diens vertegenwoordiger den Reichsrichter Schwebel;

Zeeland: den gevolmachtigde Oberbereichsleiter Münzer;

Utrecht: den gevolmachtigde Oberbereichsleiter Müller-Reinert;

Friesland: den gevolmachtigde Ministerialrat Ross;

Overijssel: den gevolmachtigde Weidlich;

Groningen: den gevolmachtigde Landrat dr. Conring;

Drenthe: den gevolmachtigde Oberbereichsleiter Sellmer;

Limburg: den Oberbereichsleiter Himmerich."

Bovendien heeft de Rijkscommissaris op grond van artikel 62, lid 3, der verordening openbare orde 1943 met uitdrukkelijke verwijzing naar de gestrengheid van het politiestandrecht voor het bezette Nederlandsche gebied in zijn geheel het volgende beschikt:

„1) Hij die deelneemt aan samenscholingen in het openbaar van welken aard ook,

2) hij die weigert zijn werk te verrichten, zij het ook door een uitsluitend passief gedrag, die staakt of die werknemers uitsluit,

3) hij die zonder daartoe gerechtigd te zijn, schiet-, slag- of stootwapenen bij zich draagt of in zijn bezit heeft,

4) hij die pamfletten vervaardigt, verspreidt, of in zijn bezit heeft, welke de openbare orde zouden kunnen verstoren,

5) hij die zich tegen de openbare macht verzet, wordt standrechtelijk veroordeeld en wordt derhalve ingevolge artikel 66 der verordening openbare orde 1943 in het algemeen gestraft met den dood.

Poging, uitlokking of deelneming zijn op gelijke wijze strafbaar als het voltooide strafbare feit."

De höhere SS- und Polizeiführer beim Reichskommissar für die besetzten Niederländischen Gebiete heeft op grond van artikel 64 der verordening openbare orde 1943 in verband met het door den Reichskommissar für die besetzten Niederländischen Gebiete afgekondigde politie standrecht voor het bezette Nederlandsche gebied in zijn geheel beschikt: 
„1) De aan mij ondergeschikte SS- en Politie-eenheden schieten onverwijld zonder waarschuwing, wanneer samenscholingen van welken aard ook plaats vinden of wanneer meer dan vijf personen op openbare wegen of pleinen zich verzamelen. Door de Duitse politie toegestane bedrijfsvergaderingen zijn daarvan uitgezonderd.

2) het is verboden zich tusschen 20 en 6 uur in de open lucht op te houden. Uitzonderingen worden door de Duitsche politie toegestaan.

3) Verboden is het schenken en het gebruiken van brandewijn en andere alcoholhoudende dranken in openbare localiteiten, alsmede het afleveren en het verkopen van zoodanige dranken.

4) Aan werkgevers is het verboden, loonen en salarissen uit te betalen aan stakers voor dagen, waarop geheel of gedeeltelijk werd gestaakt.

5) De Duitsche veiligheidspolitie neemt alle winkels in beslag, welke gedurende den tijd dat het politiestandrecht van kracht is, niet geopend $z$ ijn op de voorgeschreven of op de ter plaatse gebruikelijke tijden.

Hij die in strijd handelt met een der verboden, genoemd onder 2) tot en met 4) wordt gestraft met gevangenisstraf van ten hoogste vijf jaren en met geldboete tot een onbeperkt bedrag of met een dezer straffen, voor zoover niet op grond van andere bepalingen een zwaardere straf is verbeurd.

Het nemen van maatregelen op het gebied der veiligheidspolitie blijft onaangetast."

\section{Proces-verbaal, afkomstig van de Aussenstelle Amsterdam van de Befehlshaber der Sicherheitspolizei, d.d. 1 5-1943}

III B $10662 / 43$

Amsterdam, den 1. Mai 1943.

Im Auftrage von Major Kärgel, Ordnungspolizei Amsterdam, sollten sämtliche Streikenden der Vereinigten Blechwarenfabriken in Krommenie festgenommen werden. Den festnehmenden Beamten der Ordnungspolizei (1-20) wurden die Kriminalsekretäre Kaune und Haveneth zugeteilt. Wie festgestellt wurde, haben zirka 700 Arbeiter der Vereinigten Blechfabriken die Arbeit bis heute nicht aufgenommen. Es handelt sich um Leute, die in Krommenie, Amsterdam, Beverwijk und noch verschiedenen anderen Orten wohnhaft sind, sodass eine Festnahme sämtlicher Streikenden im Augenblick nicht möglich war. Nach Rücksprache mit dem Bürgermeister von Krommenie J on g m a, wurden nur die Rädelsführer festgenommen. Diese sind dem Bürgermeister als ehemalige Kommunisten, bezw. mit der komm. Partei sympathisierende Mitglieder bekannt. Es handelt sich um folgende Personen, die hiermit dem Standgericht vorgeführt werden:

1. Klaas van V e e $\mathrm{n}$, wohnhaft in Krommenie, Schoolstr. 22,

2. Frans Offe $\mathrm{nberg}$, wohnhaft in Krommenie, Militaireweg 124, 
3. Gerard Wiersma, wohnhaft in Krommenie, Emmastr. 19.

4. Jacob Kramer, wohnhaft in Krommenie, Militaireweg 93,

5. Hendrikus $\mathrm{He}$ ij, wohnhaft in Krommenie, Klaas Katerstr. 13,

6. Johannes van L e mme re n, wohnhaft in Krommenie, Militaireweg 81.

7. Theodorus $\mathrm{R}$ ij $\mathrm{kh}$ of $\mathrm{f}$, wohnhaft in Assendelft, Dorpstr. 707.

8. Gerke Mastenbroek, wohnhaft in Krommenie, Heiligeweg 116 ,

9. Willem van 't Ve e r, wohnhaft in Krommenie. Blok 30.

10. Pieter van L o o n, wohnhaft in Krommenie, Militaireweg 10,

11. Willem Vredenburg, wohnhaft in Krommenie, Klaas Katerstraat 17.

12. Hendrik Bla nk, wohnhaft in Krommenie, Zuider Hoofdstr. 73.

Diese sämtliche aufgeführten Personen sind bei den Vereinigten Blechfabriken beschäftigt und haben die Arbeit seit gestern verweigert und trotz wiederholter Aufforderung von Seiten des Betriebsleiters $\mathrm{Stu}$ urma n bis heute nicht wieder aufgenommen.

Die namentliche Liste sämtlicher in Streik befindlichen Arbeiter der Vereinigten Blechfabriken wird durch den Bürgermeister am 3.5.1943 morgens nachgereicht.

(w.g.) Kaune

Kriminalsekretär (w.g.) Haveneth

Kriminalsekretär (w.g.) Möllers (?)

Zugw. d. SchP.

\section{Telexbericht van Regierungsrat E. Deppner aan alle Aussenstellen van de Befehlshaber der Sicherheitspolizei, d.d. 1-5-1943}

den haag nr 14518 1. 5. $43 / 17.05$

an alle a us enstelle $\mathrm{n}$ - dringend sofort vorlegen

betr.: ueberwachung der gottesdienste

vorg: ohne

soweit moeglich, bitte ich die morgigen gottesdienste in den kirchen ueberwachen zu lassen und mit fs nach hier $z$ berichten, falls irgendwelche aeusserungen im hinblick auf die augenblickliche lage gemacht werden - 
31. Telexbericht van SS-Sturmbannführer, W. Lages, Aussendienststellenleiter van de Sipo en SD, Amsterdam, aan de Befehlshaber der Sicherheitspolizei und des Sicherheitsdienstes, Den Haag, d.d. 2-5-1943

amsterdam fs $\mathrm{nr} 5161$ 2. 5. 43. / 14.20

an den b.d.s. den ha a g -

dringend - sofort vorlegen -

betr.: ueberwachung der gottesdienste. -

vorgang: verfg. vom 1.5 .43 - leiter. IV

fs nr 14518. -

bei der heutigen kirchenueberwachung wurde festgestellt, dass in den kath. kirchen kein - hirtenbrief verlesen worden ist und in allen prot. kirchen keine kanzelabkuendigung stattgefunden hat. es ist nicht ein einziger fall bekannt geworden, wo ein geistlicher $z \mathfrak{u}$ der augenblicklichen lage waehrend der predigt stellung genommen hat. - die kirchen waren waehrend des gottesdienstes sehr stark besucht einige kirchen mussten wegen ueberfuellung geschlossen werden. bei den kirchenbesuchen herrschte im allgemeinen eine gedrueckte stimmung. -

aussendienststelle amsterdam - IV B 3136/43. der aussendienststellenleiter

1 a ge s ss-stubaf.

\section{Telexbericht van SS-Richer Dr Wendt aan H. A. Rauter, d.d. 2-5-1943}

groningen fs. nr. 979 2. $5.43 / 18.35-\mathrm{gl}-$

an den hoeheren ss- und polizeifuehrer -

gruppenfuehrer ra u t e $\mathrm{r}$

den haag -

betrifft: standgericht groningen. -

der niederlaendische st. a. berend $t \mathrm{r}$ i p, geb. 2.11.1917 in gieten, landbauer, ledig, keine kinder, frueher christliche historische unie, religion niederl. ref., verwaltet den hof im eigentum der mutter, vater heute 7 jahre tot, zum to de verurteilt, trip hat am $1.5 .1943,19.20 \mathrm{uhr}$, in kenntnis aller gesetzlichen bestimmungen vor 400 bis 500 personen gesprochen, aufgefordert 
zum passiven verhalten, also kein blutbad, keine fensterscheiben. gibt sachverhalt voellig zu. hat gesprochen, weil er die verantwortung als unverheirateter ohne kinder gegenueber den uebrigen bewusst uebernehmen wollte. fabelhafte persoenliche haltung.

erbitte bestaetigung und vollstreckungsanordnung. -

standgericht groningen - gez. dr. we n d t ss-richter

aussendienststelle groningen $-\mathrm{h}$ a a s e ss-stubaf

\section{Telexbericht van H. Wölk, hoofd van de Aussendienststelle Rotterdam van de Sicherheitspolizei en de SD, aan de Befehlshaber der Sicherheits polizei und des SD, Den Haag, d.d. 3-5-1943}

rotterdam no: 1918 3. $5.43 / 13.35$ re. -

dringend sofort vorlegen. -

an den bds. $-3 \mathrm{~b}-$ in den haag. -

betrifft: lagebericht - allgemeine stimmung und lage. -

die stimmung und lage innerhalb der niederlaendischen bevoelkerung wurde in der berichtswoche ausschliesslich durch die verordnungen des wehrmachtbefehlshabers in den niederlanden betreffend rueckfuehrung der ehemaligen wehrmachtsangehoerigen in die kriegsgefangenschaft, durch den daraufhin in den ganzen niederlanden ausgebrochenen streik und schliesslich durch die verhaengung des polizeistandrechts beherrscht. alle anderen ereignisse sind dem gegenueber weit in den hintergrund getreten - bei der stimmungsbilder kann man 3 gruppen feststellen:

1.) stimmung in deutschfeindlichen arbeiterkreisen.

2.) stimmung in deutschfeindlichen intelligenzkreisen.

3.) stimmung in deutschfreundlichen und nsb-kreisen.

waehrend man in arbeiterkreisen insbesondere in rotterdam keinesfalls eine einheitliche auffassung dahingehend hatte, dass der streik zu begruessen sei und man stattdessen lediglich nachteile, vor allem ernaehrungsmaessig, befuerchtete, herrschte in den deutschfeindlichen intelligenzkreisen die meinung vor, dass mit einer derartigen massnahme eigentlich schon laengere zeit haette gerechnet werden muessen und man brachte dabei zum ausdruck, dass derartige verordnungen doch nur ein zeichen von deutscher schwaeche waren. gerade in diesen kreisen, in denen der engl. rundfunk in letzter zeit mehr denn je abgehoert wird, haben die verordnungen nicht die ueberraschende wirkung gehabt, wie in arbeiterkreisen und unter der landbevoelkerung, so wertet man in diesen kreisen die anordnungen lediglich als letzte kraftanspannung des zusammenbrechenden deutschlands, selbst hatte man allerdings nicht den mut, sich dem streik der arbeiter und bauern anzuschliessen. so blieb man praktisch 
ausserhalb dieser streikaktion und betaetigte sich nur als hetzer im hintergrunde. die mitwirkung der oranjetreuen, sogenannten besseren niederlaendischen kreise an dieser streikaktion ist dadurch erwiesen, dass der streik ausgerechnet am geburtstag der prinzessin juliana begonnen wurde. hinzu kommt, dass die rueckkehr der ehemaligen niederlaendischen koenigin nach dem befreiten holland noch nie so stark propagiert wurde, wie in den letzten tagen. auffallend ist, dass sich die angriffe und hetze der gegner diesesmal ausschliesslich gegen deutschland richten und man die beteiligung des nsb. an den neuesten massnahmen abstreitet. allerdings ist man in diesen kreisen sehr gespannt, welche haltung mussert $z u$ den massnahmen offiziell einnehmen wird.

die anfaengliche freudige stimmung wurde jedoch bereits schon nach den ersten festnahmen durch die sicherheitspolizei wesentlich gedaempft. nach bekanntgabe der erschiessung von 17 raedelsfuehrern ist ueberall eine grosse ernuechterung und angststimmung festzustellen. nirgends ist noch ein wille zum streik verspuerbar. man geht wieder geregelt seiner arbeit nach und verhaelt sich im uebrigen so, dass der polizei kein anlass zum einschreiten geboten wird. auch sind alle jetzt restlos davon veberzeugt, dass die besatzungsmacht diesesmal tatsaechlich ernstlich gewillt ist, jeden widerstand mit der waffe zu brechen. man ist schon jetzt der einheitlichen meinung, dass der streik voellig in sich zusammen gebrochen ist und

- statt vorteile nur nachteile und schaeden, vor allem fuer die arbeiterbevoelkerung, gebracht hat. -

freudig begruesst wurden die deutschen massnahmen in grossgermanisch gesinnten kreisen. man freut sich, dass endlich einmal scharf durchgegriffen wird und aeussert befriedigung darueber, das die nsb-politik endlich einmal in den niederlanden in den hintergrund trete und stattdessen die deutsche besatzungsmacht klare und eindeutige folgerungen aus den bisherigen erfahrungen gezogen hat.

die zeit der versoenlichen haltung gegen die niederlaendische bevoelkerung muesse ein fuer alle mal vorbei sein. man ist der meinung, dass die lage in den niederlanden heute gaenzlich anders waere, wenn schon 1940 solch klare entscheidungen deutscherseits getroffen worden waeren.

ein weiterer ausfuehrlicher fs bericht ueber die auswirkungen des streikes wird im laufe des morgigen tages dort gegeben.

aussenstelle rotterdam wo el k ss-sturmbannfuehrer 


\section{Telexbericht van Dr W. Harster, Befehlshaber der Sicherheitspolizei und des SD, Den Haag, aan het Reichssicherheitshauptamt, d.d. 3-5-1943}

An

den 3. Mai 1943.

den Chef der Sicherheitspolizei, Berlin, das RSHA - Amt III und Amt IV -, Berlin, den Beauftragten des Chefs der Sicherheitspolizei beim Militärbefehlshaber in Brüssel,

den Inspekteur Düsseldorf,

den Inspekteur Hamburg.

nachtichtlich an alle Aussenstellen des BdS

Betr., Streikbewegungen in den Niederlanden.

Vorg.: Zuletzt mein FS vom 2.5.43, Nr. 14693.

Die Lage stellt sich nach den zwischen 9.00 und 10.00 Uhr hier eingegangenen Meldungen folgendermassen dar:

1.) In den besonders rüstungswirtschaftlich bedeutsamen Provinzen des Westens mit den Hauptorten Amsterdam, Rotterdam und Den Haag ist der Streik völlig zusammengebrochen. Es wird in allen Betrieben, Behörden und Werken voll gearbeitet.

2.) In den Provinzen Gelderland und Overijssel, von denen der Streik ausgegangen war, wird in fast allen Betrieben voll gearbeitet. In 3 mittleren Betrieben, die weiterstreiken, ist zurzeit Waffen-SS und Ordnungspolizei je in Kompaniestärke eingesetzt. Es ist beabsichtigt, das Polizeistandgericht jeweils gleich in dem umstellten Betrieb tagen zu lassen. In Arnheim ist das Justizgebäude vor einer Stunde in Brand gesteckt worden.

3.) Im Limburger Kohlengebiet sind in den grösseren Gruben etwa $70 \%$, in den kleineren bis zu $90 \%$ zur Morgenschicht eingefahren. Schwierigkeiten machen einzelne Direktoren, die sich weigern, die Listen über die nichterschienenen Arbeiter an die Sicherheitspolizei einzuliefern. 2 Direktoren wurden festgenommen und sehen ihrer standgerichtlichen Aburteilung entgegen.

4.) In der Provinz Nordbrabant streiken die Philips-Werke mit etwa 20000 Mann Belegschaft. Schärfste Massnahmen sind eingeleitet. Im ostwärtigen Teil der Provinz (gegen das Limburger Kohlengebiet $z u$ ) wird weiter in einzelnen Betrieben gestreikt.

5.) In den 3 Nordprovinzen, die der rassischen Eigenart der friesischen Bauern entsprechend erst 2 Tage später $z u$ streiken begonnen hatten, arbeiten zwar die öffentlichen Betriebe und Verkehrsmittel, dagegen wird in den Privatbetrieben zum Teil weiter gestreikt. In der Provinz Drenthe sind heute Nacht 7 Bauernhöfe und eine Torfstreufabriek in Flammen aufgegangen.

6.) Ausser in den westlichen Provinzen wurde im ganzen Land von Polizei- und Waffen-SSStreifen gegen Ansammlungen, die allerdings in keinem Fall drohende Haltung eingenommen hatten, von der Schusswaffe Gebrauch gemacht. Dabei gab es eine geringe Anzahl Tote.

7.) Der Plakatanschlag über die inzwischen vollstreckten 26 Standgerichtsurteile hat zu einer erheblichen Ernüchterung beigetragen. Die Bevölkerung hatte nicht gedacht, dass die Besatzungsmacht mit ihren Drohungen im derartigen Umfange Ernst machen würde.

8.) Die Züge mit den Grenzgängern nach Deutschland sind nach den bisherigen Meldungen voll besetzt und ohne $Z$ wischenfälle abgefahren. 
9.) In einzelnen Gegenden werden wild hergestellte Flugblätter, die zum Streik bis zur Widerrufung der Kriegsgefangenschaft auffordern, verbreitet.

Dr. Harster.

\section{Telexbericht van Dr W. Harster, Befehlshaber der Sicherheitspolizei und des SD, Den Haag, aan het Reichssicherheitshauptamt, d.d. 3-5-1943}

den Haag, den 3.5.1943.

An

den Chef der Sicherheitspolizei, Berlin

- das RSHA - Amt III und Amt IV -, Berlin

den Beauftragten des Chefs der Sicherheitspol.

beim Militärbefehlshaber in Brüssel,

den Inspekteur Dïsseldorf,

den Inspekteur Hamburg

Nachrichtlich

an alle Aussenstellen des BdS

Betr.: Streikbewegungen in den Niederlanden.

Vorg.: zul. mein FS vom 3.5.43 Nr. 14734.

Die Lage hat sich in allen Provinzen beruhigt. Allerdings war hierzu ein ausserordentlich scharfes Zugreifen der Polizei und eine ausgedehnte Tätigkeit der Polizeistandgerichte erforderlich. Im Limburger Kohlengebiet sind in der Mittagsschicht durchschnittlich etwa $70 \%$ der Arbeiter erschienen. Bei Philips in Eindhoven hat sich durch sehr scharfe Massnahmen der Stand der Arbeiter bis in den Spätnachmittag auf $75 \%$ erhöht. Ausserordentlich bewährt hat sich hier und in der Provinz Gelderland, dass bei Streiks in grösseren Betrieben das Gelände der Firma umstellt wurde und die Sicherheitspolizei mit dem Polizeistandgericht gleich auf dem Gelände Untersuchung und Verhandlung durchgeführt hat. Im Laufe des Tages sind noch etwa 30 Todesurteile gefällt worden, die zum Teil bereits bestätigt und von denen auch einige vollstreckt sind. Weitere etwa 30 Todesurteile sind im Laufe des Abends noch $z \mathrm{u}$ erwarten. In der Provinz Groningen, in der sonst Ruhe herrscht, wurden etwa 20 Personen beim Bau einer Strassensperre durch eine Ordnungspolizeistreife überrascht, die sofort das Feuer eröffnete. Das Ergebnis waren 16 Tote. Ausserdem sind in den übrigen Provinzen 22 Personen durch Streifen erschossen und 53 verletzt worden. In sämtlichen Provinzen, mit Ausnahme der Provinz Friesland, wo auf dem Lande noch weitere Unruhe herrscht, kann der Streik als annähernd zusammengebrochen bezeichnet werden. Dies ist in erster Linie auf die durch die Standgerichte gefällten Todesurteile und das rücksichtslose Eingreifen der Streifen der Ordnungspolizei und der Sicherheitspolizei zurückzuführen. Einen besonders ernüchternden Eindruck hinterliessen bei der Bevölkerung die öffentlichen Anschläge über die Vollstreckung der Todesurteile. Dies führte in Einzelfällen dazu, dass die Leute sich geradezu wieder in die Betriebe drängten, um ihre Arbeit wieder aufzunehmen. Auffallend häufig wurden heute Angriffe gegen Milchlieferungen gemeldet.

Dr. Harster. 


\title{
36. Telexbericht van commissaris-generaal F. Schmidt aan alle Beauftragten des Reichskommissars d.d. 3-5-1943
}

reichskommissar den haag, fs 5695 den 3. 5. $43 / 10.25$

an a $11 \mathrm{e}$

beauftragten des reichskommissars

in diesen beiden letzten tagen haben sich auch verschiedene leute, die sich sonst uns nicht $z u$ erkennen gaben, entblaettert und sich in ihrer wirklichen haltung und auffassung gezeigt. so sind dem reichskommissar bis jetzt einige hotels bekannt geworden, deren inhaber sich in diesen tagen deutschen gegenueber herausfordernd und beleidigend benommen haben. diese art faelle muessten aufgegriffen und einer radikalen loesung zugefuehrt werden, d.h. konfizierung des vermoegens, bestrafung der inhaber usw. es kommt hier nicht auf viele sondern auf einzelne praegnante faelle an, die dann wunder wirken werden. ich darf sie im auftrage des reichskommissars bitten, ihr augenmerk auf diesen sehr wichtigen politischen punkt zu richten und mir bericht $z u$ erstatten.

des weiteren weise ich daraufhin, dass meiner meinung nach gemeinden, die sich auffallend an der streikbewegung beteiligt haben, nunmehr dadurch bestraft werden, dass man ihnen durch politische massnahme die gesamten rundfunkgeraete nimmt.

deutsche und nsber sowie der buergermeister selbst sind hiervon auszunehmen. auch diese massnahme soll nur in ganz besonderen faellen angewandt werden.

heil hitler!

$\mathrm{sch} \mathrm{midt}$

generalkommissar

\section{Brief van de leider van het plaatselijk kantoor Apeldoorn van Het Neder- landse Arbeidsfront aan de Provinciale Frontleider Gelderland van Het Nederlandse Arbeidsfront, d.d. 3-5-1943}

\author{
Vertrouwelijk. \\ Het Nederlandse Arbeidsfront, \\ Provinciaal Bureau Gelderland, \\ Prov. Frontleider Gelderland, \\ Jansbuitensingel 17. \\ Arnhem.
}

Kameraad,

Apeldoorn, 3 Mei 1943.

Zoals wij U j.1. Vrijdag reeds telefonisch mededeelden, hebben de arbeiders in verschillende bedrijven reeds direct des morgens het werk neergelegd, welke staking zich langzamerhand over het gehele arbeidsgebied van Apeldoorn uitbreidde, in de middaguren 
gevolgd door de sluiting van diverse winkels ter plaatse (o.a. de levensmiddelenwinkels).

$\mathrm{Om}$ een overzicht te geven van de bedrijven die in het geheel niet gewerkt hebben, is, gezien het groot aantal bedrijven ter plaatse niet doenlijk. Wel kunnen wij zeggen, dat het werk in de volgende bedrijven vrijwel onmiddelijk werd neergelegd:

Papierfabriek van Gelder Zonen

Rocarto's Cartonnagefabriek

Buiscar

Apeldoornsche Machinefabriek

Industrie $\{$ te Vaassen

Apeld. Coöp. fabr. van Melkproducten

J. Klein Bussink \& Zoon, Duivenlaan

Nieuwe Apeldoornsche Courant en drukkerij

Diverse witwasserijen

terwijl b.v. de werkplaatsen en fabrieken van:

v. Houtum \& Palm, Apeldoorn ) door het voorbeeld van Van Gelder daartoe idem Ugchelen $\{$ aangemoedigd.

Plaatijzer Industrie

later op de morgen volgden.

In de middaguren staakten de werknemers o.a. van:

Nova autobussen

N.V. Hiweg

Nettenfabriek Von Zeppelin

Ned. Cocosfabriek

Apeldoornse Cartonnagefabriek (des morgens werkten er 30 van de 120 , des middags niemand meer).

de bedrijven, die bleven werken waren o.m.

Apeldoornse Messenfabriek

Slotenfabriek Nemef

Tech. Bureau Van Reekum

Borstelfabriek De Ster

Chemische fabriek Bohnhoff

Centrale Schoenmakerij

Staalwarenfabriek Elesva

Broodbakkerij Jolink, Zwolscheweg

Wij wijzen er op, dat bovenstaande opsomming van bedrijven geenszins als volledig beschouwd kan worden.

Wij hebben ons des morgens telefonisch met de diverse bedrijven in verbinding gesteld, toen ons echter bleek, dat de stakingsneiging zich als een olievlek uitbreidde, hebben wij verdere pogingen in die richting gestaakt, en ons uitsluitend bezig gehouden met het observeren der plaatselijke toestand en verbindingen tot stand te brengen met onze sociale voormannen.

Aan dit laatste voegen wij direct toe, dat onze voormannen, met uitzondering van die van Van Gelder, zich eigener beweging tot ons wendden, teneinde te vernemen welke houding $z$ ij hadden aan te nemen, resp. wat door hen gedaan diende te worden.

Zoals vanzelf spreekt hebben wij er met nadruk op gewezen, dat de obstructie niet ongestraft zou blijven, dat er ongetwijfeld slachtoffers zouden vallen, en dat het hun plicht was als socialen voorman de arbeiders met klem te adviseren de arbeid te hervatten. Verder gaven wij hen opdracht de fabriek, resp. werkplaats, niet te verlaten zonder toestemming van de Betriebsführer. 
Wij kunnen direct hieraan toevoegen, dat in die bedrijven waar wij sociale voormannen hebben en waar het werk was neergelegd, dit direct des Zaterdagsmorgens werd hervat.

In de hiervoren genoemde bedrijven, die door bleven werken zijn eveneens sociale voormannen door ons aangesteld.

De redenen waarom het werk werd neergelegd zijn uitsluitend toe te schrijven aan het wederom in krijgsgevangenschap stellen van de vroegere leden der Nederlandse weermacht.

Wij hebben de indruk, dat de stakingsbeweging uitgegaan is van Epe/Vaassen en wel voornamelijk door de arbeiders van "Industrie” en „Vulcanus" te Vaassen (totaal \pm 1000 man). Telefonisch werden wij er 's morgens mede in kennis gesteld, dat te Epe b.v. de winkels niet geopend zijn geworden.

E.e.a. behoort echter niet tot onze Gemeente, zodat de Plaatselijk leider van Epe U hieromtrent wel nader zal hebben ingelicht.

Voor zover wij hebben kunnen nagaan hebben de Betriebsführer wel pogingen in het werk gesteld om de bedrijven gaande te houden, echter zou het wel interessant wezen te vernemen in welke bewoordingen deze pogingen waren gesteld.

Bij de Gemeente staakten geheel of gedeeltelijk:

de Distributiedienst $(57 \mathrm{man})$

Gemeente Waterleiding ( \pm 40 man).

Onnodig te zeggen, dat door de Burgemeester onmiddellijk maatregelen werden getroffen.

Bij het Postkantoor hebben de beambten even geaarzeld, hebben echter de wijste partij gekozen en direct doorgewerkt; van staking is hier dus geen sprake.

Tenslotte nog de mededeling, dat de boeren, die contractueel melk moesten leveren aan de fabriek „Mariëndaal" niet kwamen opdagen; ook des Zaterdags slechts een gering aantal, zodat de Directie zich genoodzaakt zag j.1. Zaterdag een advertentie in de Nieuwe Apeldoornse Courant te plaatsen, teneinde de leveranciers op hun plicht te wijzen. Heden, Maandag, hebben nog niet alle boeren aan deze oproep gehoor gegeven.

Met Kameraadschappelijke groet,

HET NEDERLANDSE ARBEIDSFRONT.

Leider Plaatselijk Kantoor Apeldoorn.

J. L i m b u r g. 


\title{
38. Brief van $H$. Wölk, hoofd van de Aussendienststelle Rotterdam van de Sicherheitspolizei und des SD, aan Dr W. Harster, Befehlshaber der Sicherheitspolizei und des SD, Den Haag, d.d. 4-5-1943
}

\author{
Rotterdam, den 4. Mai 1943.
}

An den

Befehlshaber der Sicherheitspolizei und des SD

für die besetzten niederländischen Gebiete -

SS-Brigadeführer Dr. Harster

$\mathrm{D}$ en $\mathrm{Ha}$ a g.

Betrifft: Streikbewegung in den Niederlanden -

Lageberichterstattung.

Vorgang: Dort. FS Nr. 14692 vom 2.5.1943 -

hies. laufende Berichterstattung.

Die allgemeine stimmungsmässige Lage der letzten Tage wurde völlig durch die Anordnung der Rückführung der ehemaligen Angehörigen der niederländischen Wehrmacht in die Kriegsgefangenschaft und durch die Streikbewegung mit der Verhängung des Standrechts über das gesamte niederländische Gebiet beherrscht. Auf die Presseveröffentlichungen vom Donnerstag, den 29.4.1943 waren am Freitag, den 30.4.1943 einige Arbeiter aus Protest der Arbeit ferngeblieben. Andere legten ihre Arbeit im Laufe des Vormittags nieder und forderten die übrigen Betriebsangehörigen ebenfalls zum Streik auf. Von diesen Rädelsführern ausgehend, breitete sich der Streik schnell aus, sodass bereits am Sonnabend der Streik der Niederländer alle anderen stimmungsbildenden Ereignisse weit überschattete. Ueberall, sei es in Fabriken, Kantoren und anderen Betrieben oder auf der Strasse oder in Geschäften, verbreiteten sich die Nachrichten und Gerüchte über die Streikbewegung wie ein Lauffeuer. Stand man anfangs den Nachrichten etwas skeptisch gegenüber, weil man in diesen anfänglichen Einzelaktionen lediglich kleine unorganisierte Widerstandsherde erblickte, denen Streikerfolge versagt bleiben würden, so änderte sich diese Meinung schlagartig, als das Polizeistandrecht auch über die Provinz Süd-Holland ausgedehnt wurde. Sofort war man davon überzeugt, dass die Streikbewegung auch in der Provinz Süd-Holland mittlerweile grösseren Umfang angenommen haben musste, obwohl man wusste, dass es in Rotterdam selbst lediglich erst in einem Fabrikatbetrieb zum Streik gekommen war. In deutschfeindlichen Kreisen machte sich eine freudige, hoffnungsfrohe Stimmung bemerkbar.

Insbesondere in deutschfeindichen Intelligenz- und Mittelstandskreisen, von denen man annehmen kann, dass sie in letzter Zeit die englischen Rundfunksendungen regelmässig abgehört haben, glaubte man, dass mit diesen Streiks der Auftakt zum Generalstreik gegeben sei. Aeusserungen wie "So geht es gut", „Der Anfang is gemacht" usw. kennzeichneten die siegesfreudige Stimmung in diesen Kreisen. Im Zusammenhang damit wurden Gerüchte über eine angeblich in den nächsten Tagen zu erwartende, von der Exkönigin Wilhelmina in einer Rundfunkrede am Vorabend des Geburtstages der Prinzessin Juliana angekündigten englisch-amerikanischen Invasion in den Niederlanden eifrig weitererzählt, und auch von vielen Niederländern geglaubt. Dass es sich tatsächlich um den Anfang eines geplanten allgemeinen Befreiungskampfes der Niederlande handeln würde, glaubten viele Gegner daraus entnehmen zu können, dass der Streik am Geburtstag der Prinzessin Juliana begann. In diesen deutschfeindlichen Intelligenz-Kreisen hatte deshalb die Bekanntgabe der Verhängung des Polizeistandrechts über Gesamtniederland keinesfalls die einschüchternde Wirkung, wie z.B. in Arbeiter und Handwerkerkreisen. Sie glaubten vielmehr in diesen scharfen Anordnungen Anzeichen für eine Schwäche und Kopflosigkeit der deutschen Besatzungsmacht, ähnlich wie 
bei den kürzlichen Verordnungen zur Neuordnung des niederländischen Hochschulwesens, erkennen zu können und waren einheitlich der Ansicht, dass es nur bei Drohungen bleiben würde. Demgegenüber war die Reaktion auf den Streikbeginn innerhalb der deutschfeindlichen Arbeiterschaft lange nicht so hoffnungsvoll und siegesgewiss. Von Anfang an stand die Mehrzahl dieser Kreise dem Streik skeptisch gegenüber, weil man wenig Hoffnung auf ein Gelingen setzte. Man fand es im Anfang zwar erfreulich, dass einige Aktivisten den Mut zum offenen Widerstand hatten, versprach sich jedoch andererseits von dem Widerstand, der noch nicht einmal von allen Angehörigen der niederen Bevölkerungsklasse getragen wurde, keinen beachtenswerten Erfolg. Dass die Anordnung des Wehrmachtbefehlshaber in den Niederlanden betr. die Rückführung der Angehörigen der ehemaligen niederländischen Wehrmacht durch den Streik rückgängig gemacht würde, glaubten innerhalb der Arbeiterbevölkerung nur wenige. Vielmehr waren aus diesen Kreisen Aeusserungen vernehmbar, aus denen doch eine gewisse Angst vor den angekündigten scharfen Massnahmen sprach.

Stark zum Streik geneigt war die bäuerliche Bevölkerung besonders in der Umgebung der Orte, in denen Fabriken streikten. Dort haben sich viele der Bauern dem Streik angeschlossen. Auf die dadurch verursachten Versorgungsschwierigkeiten und deren stimmungsmässige Auswirkungen wird am Schluss dieses Berichtes noch besonders eingegangen.

Begrüsst wurde die Verhängung des Standrechtes in deutschfreundlichen Kreisen, die schon längst scharfe Massnahmen gegen die verbohrten und unverbesserlichen „Holländer" erwartet hatten. Die zuversichtliche und freudige Stimmung in diesen Kreisen wurde allerdings dadurch erheblich getrübt, dass aus den Veröffentlichungen über die Rückführung der Angehörigen der ehemaligen niederländischen Wehrmacht in die Kriegsgefangenschaft nichts darüber hervorging, ob NSB-Angehörige und deutschfreundliche Niederländer von der Rückführung in die Kriegsgefangenschaft befreit seien oder nicht. Man findet es bedauerlich, dass bis heute noch keine Klarheit über diesen Punkt herrscht. Man hält es wohl für völlig ausgeschlossen, dass man von deutschfreundlichen nationalsozialistischen Niederländern, die sich gewissermassen verdient gemacht hätten, verlangen könnte, in deutsche Kriegsgefangenschaft zu gehen, ist andererseits infolge völliger Ungewissheit sehr verängstigt und stellt bei allen möglichen Dienststellen Rückfragen, ohne eine überzeugende und bindende Auskunft zu erhalten. Ehemalige NSNAP-er erwarten ebenfalls, dass sie, wie auch die NSB-er, nicht in Kriegsgefangenschaft zurückgeführt werden, auch wenn sie heute nicht Mitglied der Bewegung sind. Sie weisen daraufhin, dass sie ihre deutschfreundliche Einstellung schon zu einer Zeit bewiesen hätten, als ein grosser Teil der heutigen NSB-Anhängerschaft seine deutschfeindliche Einstellung noch offen bekundete.

Nach Verkündung det ersten Todesursteile gegen 17 Rädelsführer in den Provinzen NordHolland und Limburg hat überall, insbesondere jedoch innerhalb der streikenden Arbeiterschaft selbst, eine Ernüchterung und grosse Niedergeschlagenheit Platz gegriffen. Hass- und wuterfüllt erkennt man, dass alles erfolglos gewesen sei. Nichts sei erreicht, stattdessen hätten einige treue Niederländer ihr Leben ,unschuldig” hingeben müssen. Man spricht von NaziTerror, GPU-Methoden, Grausamkeit und Menschenabschlachtungen. Man glaubt jetzt, Deutschlands wahre Absichten klar erkannt zu haben, die auf eine Terrorisierung der Bevölkerung in den besetzten Gebieten und Weltherrschaft hinauslaufen würden. Alle bisher gezeigten Bestrebungen der deutschen Besatzungsbehörden in den Niederlanden seien in Wirklichkeit Heuchelei gewesen, mit dem Ziele, die wahren Absichten zu verschleiern. Wenn man bisher in deutschfeindlichen niederländischen Kreisen unter besonders günstigen Umständen zu einer Aenderung der politischen Gesinnung im positiven Sinne vielleicht geneigt gewesen wäre, so kann dieses jetzt unter keinen Umständen mehr angenommen werden. Man hat jetzt einen unabänderlich fanatisch deutschfeindlichen Standpunkt eingenommen und ist davon überzeugt, dass es nie mehr eine Brücke zwischen dem deutschen und niederländischen Volke geben kann. Das Andenken an diese „unschuldig" ermordeten „Holländer" würde im Herzen des gesamten holländischen Volkes wachgehalten. 
Wie nicht anders zu erwarten, wurde der Streik der Arbeiter und Bauern auch von den im Staats- und Gemeindedienst tätigen niederländischen deutschfeindlichen Beamten und Angestellten begrüsst. Allerdings trauten sich diese Kreise aus Angst vor den angekündigten scharfen Strafmassnahmen kaum, sich offen an dem Streik zu beteiligen. Man besprach meist heimlich die neuesten, Ereignisse, knüpfte Hoffnungen auf eine baldige Befreiung vom Nazi-Regime daran und vermied ängstlich alle Handlungen, durch die man als streikverdächtig hätte erscheinen können. Aeusserlich völlig ruhig verhielten sich die deutschfeindlichen Bürgermeister des hiesigen Bereiches. Einige dieser Bürgermeister haben jedoch durch ihr passives Verhalten offensichtlich den Streik gefördert, zumindest jedoch gezeigt, dass sie nicht gewillt waren, gegen die Streikenden mit der erforderlichen Härte vorzugehen. Vielfach haben sie sich überhaupt erst um den Streik gekümmert, als sie durch die Sicherheitspolizei dazu aufgefordert wurden. Es ist auffallend, dass ausgerechnet in Gemeinden mit deutschfeindlichen Bürgermeistern und entsprechender Polizei die Verhängung des Standrechts später bekannt gegeben wurde, wie z.B. in Gemeinden mit politisch zuverlässigen und deutschfreundlichen Bürgermeistern. (Alblasserdam, Hardinxveld, Dordrecht usw.) Das verspätete Anbringen der Plakate entschuldigten diese deutschfeindlichen Bürgermeister $z$.B. damit, dass sie erst Leim zum Ankleben hätten beischaffen müssen, was einige Zeit in Anspruch genommen hätte. Dass der Streik am Sonnabend, den 1.5.1943 zum Teil in grösserem Umfang fort- gesetzt wurde, ist ebenfalls auf das Verhalten einzelner deutschfeindlicher Bürgermeister zurückzuführen, die jede Initiative vermissen liessen und nicht daran dachten, von sich aus als Leiter der örtlichen Polizeibehörde den anfänglich nur durch einige Personen getragenen Streik zu unterdrücken. Die schlaffe Haltung solcher Bürgermeister zeigt sich jedoch auch bei der Durchführung der angeordneten polizeilichen Massnahmen. So waren einige diesez deutschfeindlichen Bürgermeister bis heute nicht in der Lage, dafür $z \mathfrak{u}$ sorgen, dass das Aufenthaltsverbot im Freien zwischen 20,00 und 6.00 (anfangs) und 20,00 und 4,00 Uhr in ihrer Gemeinde streng befolgt wurde. Vielfach liegt dieses allerdings auch an der beharrlich gegnerischen Haltung der örtlichen niederländischen Polizei, die ihre Streifen bisweilen gleichgültig und ohne Interesse durchführte.

Erfreulich ist die Tatsache, dass sich die Lage in Städten und Gemeinden mit deutschfreundlichen nationalsozialistischen Bürgermeistern durch Ruhe und Disziplin kennzeichnete. Aus solchen Gemeinden wurden entweder keine oder nur sehr wenige Streikversuche bekannt, die durch das tatkräftige Eingreifen des Bürgermeisters und der ihm unterstellten örtlichen Polizei im Keime erstickt wurden.

So ist es z.B. in Gouda zu keinem nennenswerten Streik gekommen. Lediglich einige Telefonistinnen des Postamtes legten auf einen Telefonanruf vom Postamt in Utrecht die Arbeit nieder, um sie nach Androhung von Polizeistrafen durch den Bürgermeister einige Stunden später wieder aufzunehmen. Dass es dort trotz des zweifellos vorhandenen Willens zum Streik nicht $z u$ einem solchen gekommen ist, ist in erster Linie auf das aktive Eingreifen des örtlichen Bürgermeisters und des nationalsozialistischen Polizeikommissars Schadee zurückzuführen.

In der Gemeinde Leerdam war es ebenfalls der erst vor kurzem ernannte nationalsozialistische Bürgermeister van L e e $r$, der den am Freitagvormittag in einer Glasfabrik ausgebrochenen Streik beilegen konnte. Von besonders gutem Erfolg waren die Massnahmen zur Verhinderung des Streikes auf der Insel Overflakkee, wo nach Absprache zwischen dem nationalsozialistischen Bürgermeister in Oude Tonge, B e k k e r, und dem Ortskommandanten, Oberleutnant Blüt ge, letzterer mit einem 15 Mann starken Kommando schwerbewaffnet von Ort zu Ort gefahren ist und die fast ausschliesslich fanatisch deutschfeindlichen Bürgermeister dahingehend informiert hat, dass er jeden Streik mit Waffengewalt brechen und ausserdem die Bürgermeister verantwortlich machen werde. Zweifellos wäre es sonst auch dort zu umfangreichen Streiks gekommen, zumal in Oude Tonge 5 Friseure ihre Geschäfte geschlossen und den Streik begonnen hatten. Nach Festnahme des Rädelsführers durch die 
Polizei zog eine grössere Volksmenge zum Rathaus, um durch die Zusicherung, dass sie dafür sorgen wollte, dass es nicht zu einem Streik käme, die Freilassung des Friseurs zt: erbitten. Auch in den Gemeinden auf der Insel Overflakkee mit deutschfeindlichen Bürgermeistern und deutschfeindlicher Polizei wurde festgestellt, dass diese durch ihr mehr oder weniger schlaffes Vorgehen zeigten, dass sie sich bis zu einem gewissen Grad mit der Haltung der Streikenden einverstanden erklärten. Einsichtige Niederländer erklärten, dass gerade die überaus laue Haltung der niederländischen Polizei zu einem erheblichen Teil den Widerstand begünstigte.

Schwerer fiel es dem NSB-Bürgermeister van $\mathrm{Houten}$ in Gorinchem, sich gegen die Streikenden in Gorinchem durchzusetzen. Dort hatte der Streik bereits am Freitagvormittag in grösserem Umfange begonnen und wurde trotz der Strafandrohungen des Bürgermeisters fortgesetzt. Die Tatsache, dass Bürgermeister van Houten durch den deutschfeindlichen Polizeikommissar, der das Vertrauen des vor einigen Wochen von der hiesigen Dienststelle festgenommenen und beurlaubten deutschfeindlichen ehemaligen Bürgermeister Ridder van Rappard, genoss schlecht unterstützt wurde, wirkte sich hier hinderlich aus.

In Rotterdam selbst blieb es verhältnismässig ruhig, sodass Bürgermeister Müller und der Polizeipräsident wenig Gelegenheit zum Eingreifen hatten. Bei Bekanntwerden des einzig vorgekommenen Streiks in einer Möbelfabrik griff die hiesige Dienststelle unter Hinzuziehung des Leiters und mehrerer Beamte der Gruppe 10, die sich übrigens auch bei dieser Aktion jederzeit für die Interessen der hiesigen Dienststelle restlos einsetzte, sofort streng durch und nahmen alle streikenden Personen fest. In Rotterdam und Schiedam sind allerdings Klagen darüber bekannt geworden, dass Streifen zur Kontrolle der Einhaltung des Aufenthaltsverbots auf den Strassen nach 20,00 Uhr durch die niederländische Polizei gleichgültig und lässig durchgeführt würden, sodass in den ersten Tagen Personen noch um 22,00 Uhr in vielen Fällen ungehindert die Strassen passieren konnten.

In deutschfeindlichen Professoren und Studenten-Kneisen, die ohnehin im Laufe der jüngsten Entwicklung im niederländischen Hochschulwesen eine bestimmte fanatisch-deutschfeindliche Stellung bezogen haben, herrschte selbstverständlich ebenfalls eine freudige Stimmung über den Streik. Das gleiche gilt auch für die Erzieherschaft an den höheren Schulen und Volksschulen. Dass nur einige Schulen an dem Streik teilnahmen, lag daran, dass die Hochschulen z.Zt. geschlossen sind und an den höheren Schulen die Osterferien zur Zeit noch andauern. $Z$ weifellos hätten sich auch diese deutschfeindlichen Kreise innerhalb der niederländischen Professoren-, Erzieher- und Studentenschaft sonst an dem Streik beteiligt, zumal die deutschfeindliche Hetze in diesen Kreisen in letzter Zeit stärker ist als je zuvor. Unter den am 3.5.1943 durch das Polizeistandgericht Rotterdam zum Tode verurteilten Rädelsführern befindet sich auch ein Volksschullehrer.

Die stimmungsmässige Reaktion der NSB auf die jüngsten Ereignisse ist nicht einheitlich. Man kann feststellen, dass nur in grossgermanischen NSB-Kreisen und selbst dort noch nicht einmal überall, ehrlich Freude über die scharfen Massnahmen herrscht. Sofort bei Veröffentlichung der Verordnung des Wehrmachtbefehlshabers betr. die Rückführung der Angehörigen der ehemaligen niederländischen Wehrmacht konnte man eine passive verstockte Haltung in grossdietschen NSB-Kreisen beobachten. Aus Unterhaltungen mit diesen NSBMitgliedern konnte man feststellen, dass diese die Notwendigkeit dieser Massnahmen nicht einsahen und sich stattdessen teilweise als Verteidiger der "armen" betroffenen Niederländer betätigten. Hinzu kommt auch hier wieder, dass bis heute noch nichts endgültiges darüber bekannt ist, ob die NSB-Mitglieder von der Rückführung in die Kriegsgefangenschaft ausgenommen sind oder nicht. Diese Tatsache hat die Stimmung in den NSB-Kreisen wesentlich beeinflusst. Noch grösser wurde die Niedergeschlagenheit und Passivität in den grossdietsch gesinnten NSB-Kreisen nach Verhängung des Standrechts und vor allem nach Bekanntgabe der Vollstreckung der ersten Todesurteile. Weniger in der Oeffentlichkeit, jedoch mehr 
in Unterhaltungen mit Gleichgesinnten, erklärt man, dass die Urteile insbesondere unter Berücksichtigung der Tatsache der deutsch-niederländischen Blutsverwandtschaft $z u$ hart seien. Aber nicht nur mit den Urteilen sondern auch mit der Rückführung der ehemaligen Angehörigen der niederländischen Wehrmacht in die Kriegsgefangenschaft und der Verhängung des Standrechts sind diese Kreise nicht einverstanden. Am besten beweisen dies die Aeusserungen des Distriktsleiters der NSB, Bürgermeister $M \ddot{u} 11 \mathrm{e} \mathrm{r}$, der in einer Unterhaltung mit dem Distriktssekretär äusserte, die NSB könnte jetzt aufhören mit ihren Versuchen, das niederländische Volk für den Nationalsozialismus $z \mathrm{u}$ gewinnen, denn die Deutschen hätten đan letzten Weg zum Herzen des gutwollenden Teiles der niederländischen Bevölkerung versperrt; er könne wohl die deutschen Massnahmen vom militärischen Standpunkt aus verstehen, die Tatsache aber, dass die NSB und ihre Arbeit sehr schwer darunter zu leiden hätten, bleibe aber bestehen. Er sei in diesen Tagen von vielen führenden NSB-Mitgliedern angesprochen und angerufen worden, die alle zum Ausdruck gebracht hätten, dass die Arbeit des Leiders umsonst gewesen sei. Dieser Schlag habe die NSB schwer und endgültig getroffen. Hoffentlich könnte Mussert wenigstens noch etwas zur Linderung der angeordneten Massnahmen tun. Diese Aeusserungen hat Bürgermeister Müller bereits am 1. Mai gemacht, als die inzwischen ausgesprochenen Todesurteile noch nicht bekannt waren. Die anfänglich grosse Hoffnung dieser Kreise, dass sich die deutsche Führung durch Vermittlung Musserts zu einer teilweisen Rückgängigmachung der angeordneten Massnahmen entschliessen könnte, ist jetzt, nachdem man deutsche Härte kennengelernt hat, überall verschwunden. In diesen Kreisen ist man sich ausserdem darüber klar, dass Mussert bei dem Militärbefehlshaber, General der Flieger Christiansen, und bei dem Höheren SS- und Polizeiführer, SS-Gruppenführer Rauter, lange nicht einen so grossen Einfluss habe, wie bei dem Reichskommissar. Bei vielen grossgermanisch gesinnten NSB-Mitgliedern herrscht neben der Freude über das längst erwartete harte deutsche Durchgreifen aber auch Bedauern darïber, dass sich die Lage so entwickelt hat. Man glaubt, dass die entscheidende Stunde für die NSB gekommen sei. Es böten sich Mussert drei Möglichkeiten, von denen er eine wählen könnte, nämlich:

1. könnte er die Seite der Deutschen wählen, dann würde er aber das niederländische Volk nie (auch nach dem Kriege) mehr für sich gewinnen können;

2. könnte er die Seite der deutschfeindlichen Niederländer wählen, dann würde jedoch die NSB von deutscher Seite ausgeschaltet, oder aber er könnte;

3. sich sozusagen ",neutral" verhalten, wodurch er jedoch ebenfalls nur verlieren und nichts gewinnen könnte.

Lange könnte er seine Bewegung jedoch trotzdem nicht mehr halten. Aus grossgermanischen Kreisen kommen im Zusammenhang mit diesen Ereignissen Stimmen der Freude über die Ausschaltung der NSB und Aeusserungen, dass endlich eine klare und offene wenn auch harte Linie, verfolgt würde. Wie führende NSB-Mitglieder in Rotterdam die Anordnung betr. die Rückführung der Angehörigen der ehemaligen niederländischen Wehrmacht in die Kriegsgefangenschaft gleich in den ersten Tagen für ihre NSB-Zwecke ausgenutzt hatten, beweist die Tatsache, dass verschiedenen NSB-ern mitgeteilt wurde, dass sie jetzt, falls sie nicht "Volk en Vaderland" auf der Strasse kolportieren würden, als Mitglieder der NSB gestrichen und in deutsche Kriegsgefangenschaft wandern müssten.

In deutschfreundlichen NSB-Kreisen wird bedauert, dass die wahren Hetzer insbesondere in Intelligenzkreisen von den angekündigten harten Massnahmen so gut wie gar nicht betroffen würden. Diese Personen sässen vorwiegend in solchen Berufen, die laut Presseveröffentlichung von der Rückführung in die Kriegsgefangenschaft befreit seien. So wird dieses z.B. von den Angehörigen des früheren niederländischen Marinekorps behauptet. Die Angehörigen dieses auschliesslich oranjetreuen "Marinierskorps", dass sich bei den Kämpfen um die Maasbrücke in Rotterdam in den Maikämpfen 1940 durch besonders hartnäckigen Widerstand ausgezeichnet haben soll, sollen nach Mai 1940 von den damals noch demokratischen niederländischen Behörden vorwiegend in der Polizei, Hilfspolizei, Feuerwehr, Luftschutz 
usw. untergebracht worden sein und inzwischen teilweise führende Funktionen einnehmen. Heute sollen diese Personen genau so oranjetreu sein wie früher und nach Ansicht deutschfreundlicher Kreise bei einer evtl. englisch-amerikanischen Invasion in den Niederlanden sehr gefährlich sein. Ausgerechnet diese gefährlichsten und deutschfeindlichsten Personen seien nunmehr von der Rückführung in die Kriegsgefangenschaft befreit. Man glaubt deshalb, dass es Deutschland bei der Rückführung in die Kriegsgefangenschaft wahrscheinlich gar nicht so sehr auf die Entfernung der im Falle einer Invasion gefährlichen Personen ankommt, wie man zuerst angenommen habe. Vielmehr glaubt man jetzt noch mehr, dass Deutschland lediglich Arbeitskräfte brauchte, die man auf dem Wege der freiwilligen Dienstverpflichtung in den Niederlanden bisher nicht in der gewünschten Anzahl habe bekommen können und aus dem Grunde daher jetzt auf diese Art zwangsweise holen würde. Auffallend ist die bereits im vorigen Bericht mitgeteilte Tatsache, dass aus deutschfeindlichen Kreisen bisher nur wenig Stimmen dahingehend vernommen wurden, dass die NSB an diesen Verordnungen der letzten Tage mitschuldig sei.

Die Aerzte des hiesigen Dienstbereiches haben sich völlig ruhig verhalten und dem Streik nicht angeschlossen. Diese Haltung hat im Hinblick auf die fanatisch deutschfeindliche Einstellung und auf den erst kürzlich durchgeführten Aerztestreik überrascht. Selbstverständlich hat man in diesen Kreisen den Streik begrüsst, war sich jedoch von vornherein klar, dass der Streik erfolglos verlaufen würde. Bis jetzt ist noch kein Fall bekannt, dass von Aerzten, Gesundheitsämtern oder Krankenpersonal gestreikt wurde bezw. wird.

Viel kritisiert wurden die Veröffentlichungen der Anordnungen in der niederländischen Presse. Besonders in den Presse-Veröffentlichungen betr. die Rückführung der Angehörigen der ehemaligen niederländischen Wehrmacht in deutsche Kriegsgefangenschaft waren soviel Unklarheiten enthalten, dass die Bevölkerung durch diese Berichte nur noch mehr in Unruhe und Ungewissheit versetzt wurde. Die erste Presseveröffentlichung, in der lediglich die Tatsache und keine Einzelheiten der Rückführung in die Kriegsgefangenschaft bekanntgegeben wurde, hat in den betroffenen Familien panikartigen Schrecken ausgelöst und ausserdem den Eindruck entstehen lassen, dass alle Angehörigen der ehemaligen niederländischen Wehrmacht sich zusammen und sofort, d.h. in den nächsten Tagen, melden müssten. Es konnte deshalb auch nicht ausbleiben, dass die betroffenen Niederländer nach Bekanntwerden dieser Anordnung sofort panikartig ihre Arbeit niederlegten, um wenigstens noch ein paar Stunden bezw. Tage bei ihrer Familie sein zu können. Es kann angenommen werden, dass diese Formulierung der Presseveröffentlichung $z u$ dem Streik erheblich beigetragen hat.

Wie nicht anders $z u$ erwarten, hat die Mehrzahl der niederländischen Zeitungen die Anordnungen der Besatzungsmacht der letzten Tage kommentarlos veröffentlicht. Kleinere, jedoch mehr beschwichtigende als appellierende und verurteilende Kommentare wurden lediglich von wenigen nationalsozialistischen Zeitungen gebracht.

Durch den Streik vieler Bauern und Gärtnereibesitzer, insbesondere in rein ländlichen Gebieten, war die Lebensmittelversorgung in den ersten Tagen ernstlich gefährdet. Hinzu kommt, dass auch einige Lebensmittelgeschäfte auf dem flachen Lande sich dem Streik durch Geschäftsschliessung angeschlossen hatten. Besondere Schwierigkeiten sind in der Milch- und Gemüseversorgung aufgetreten. Mehrere Molkereien haben am 30.4 und 1.5.1943 die Milch der Bauern nicht angenommen, sodass dort Stockungen eintraten. Besonders aufgefallen sind hierbei der frühere englische Milchkonzern "Amelko" in Schoonhoven, deren deutschfeindlicher Direktor die Annahme der Milch verweigerte, woraufhin die Fahrer der Transportfirma die Milch in Schoonhoven auf eigene Rechnung ohne Marken verkauften. Dort, wie auch an anderen Orten setzte eine regelmässige Plünderung der Milch $\sim$ und Butterwagen ein, wobei es zu regelrechten Prügeleien der Bevölkerung untereinander kam. Dass es in Schoon- 
hoven überhaupt zu solchen Plünderungen kommen konnte, lag allein an der unentschlossenen, wenn nicht sogar streikfreundlichen Haltung des fanatisch-deutschfeindlichen Bürgermeisters Ni e uwe nhuisen und seines Polizeikorps. In Gorinchem hat die Firma "Amelko" ebenfalls die Milch nicht angenommen. In Gouda war es die "Goudsche Melkinrichting" (Direktor ist der deutschfeindliche ehemalige Rotarier Wim van $W$ ij $n$ e $n)$, die bis zum Sonnabend die Annahme der Milch verweigerte. In grösserem Umfange ist es jedoch unter den Bauern selbst zum Streik gekommen. Viele Bauern lehnten gegenüber den Milchabholern die Milchabgabe $a b$ und verkauften die Milch stattdessen frei an die einheimische Bevölkerung. In einigen Orten, wie Leerdam, Naaldwijk, usw. wurde die Milch unter Polizeiaufsicht direkt an die Bevölkerung abgegeben. In Hardinxveld, wo sich die Bauern besonders widerspenstig benahmen, wurden 13 Personen festgenommen. In Schiebroek bei Rotterdam wurde ein Bauer, der die durch die Polizei sichergestellte Milch wieder an sich nehmen wollte, wegen Widerstands und tätlichen Angriffs mit einer Milchflasche von einem Polizeibeamten angeschossen und dann festgenommen. Er liegt zur Zeit im Krankenhaus. Auch in der Gemüseabfuhr und Gemüseversorgung sind durch den Streik der Bauern und Gärtnereibesitzer in den ersten Tagen Stockungen eingetreten. Im Westland befanden sich z.B. am 30.4 und 1.5.1943 fast alle Gärtnereibetriebe im Streik.

- Aus allen Bezirken des hiesigen Dienstbereiches gingen allerdings auch Meldungen ein, dass die Bauern durch die auferlegten Sperrstunden ihre üblichen Melkzeiten nicht mehr einhalten könnten, sodass die Milchabholer unverrichteter Dinge zu den Molkereien zurückfuhren und dort vielfach der Eindruck entstand, die Bauern seien in den Streik getreten. In diesen Fällen haben die Bauern die Milch zu Käse verarbeitet, sodass kein Verlust eingetreten ist.

Dass der Streik in manchen Fabriken grösseren Umfang einnehmen konnte, war in den meisten Fällen auf die deutschfeindliche, mit den Streikenden sympatisierende Haltung der Betriebstührer und Direktoren zurückzuführen, die nichts oder sehr wenig zur Beilegung des Streiks unternahmen. In diesen Fällen wurden die verantwortlichen Personen festgenommen und teilweise bereits dem Standgericht vorgeführt.

Geschäftsschliessungen sind im hiesigen Dienstbereich lediglich in kleineren ländlichen Gemeinden vorgekommen. Durch polizeiliches Einschreiten wurden die Geschäfte jedoch meistens am gleichen Tage wieder geöffnet, sodass die Lebensmittelversorgung von dieser Seite weniger gefährdet wurde. Aus einigen Landgemeinden wurde gemeldet, dass Betriebsführer entgegen der Anordnung, ihrer Gefolgschaft, die einige Stunden bezw, einen Tag gestreikt hatten, am 30.4 bezw. 1.5.1943 den vollen Lohn ausbezahlt haben. Bei einigen Betriebsführern ist jedoch anzunehmen, dass sie die entsprechenden Lohnabzüge erst bei der nächsten Löhnung vornehmen werden.

Sehr hemmend für die sicherheitspolizeiliche Arbeit hat sich die Tatsache ausgewirkt, dass die Nachricht, nach der am 1. Mai in diesem Jahre gearbeitet werden musste, manchem Arbeiter oder Angestellten tatsächlich zu spät bekannt wurde, so dass die Feststellung, wer nun eigentlich streikte und wer nicht, dadurch erheblich erschwert wurde. Auch der Zeitpunkt der Veröffentlichung über die Rückführung in die Kriegsgefangenschaft hätte, wenn an zentraler Stelle die Möglichkeit eines Streiks hätte in Rechnung gestellt werden können, zweckmässigerweise zu Beginn einer Woche und nicht an einem Freitag erfolgen müssen.

Der Aussenstellenleiter H. W ö $1 \mathrm{k}$ 


\section{Telexbericht van Dr W. Harster, Befehlshaber der Sicherheitspolizei und des SD, Den Haag, aan het Reichssicherheitshauptamt en andere Duitse instanties, d.d. 4-5-1943}

An

den Chef der Sicherheitspolizei, Berlin

das RSHA -- Amt III und Amt IV -, Berlin

den Beauftragten des Chefs der Sicherheitspolizei

beim Militärbefehlshaber in Brüssel

den Inspekteur Düisseldorf,

den Inspekteur Hamburg,

nachrichtlich

an alle Aussenstellen des BdS

Betr.: Streikbewegung in den Niederlanden

Vorg.: FS vom 4.5.43, Nr. 14912.

Mit Ausnahme der Provinz Friesland ist der Streik überall im Laufe des Tages endgültig bereinigt worden. Die Limburger Kohlengruben wurden in der Mittagsschicht mit einer weit über $100 \%$ liegenden Belegschaft befahren, auch aus Südholland wird gemeldet, dass die Arbeiter sich heute zeitiger und in grösseren Scharen zur Arbeit einfanden. Die marxistischen Kreise haben ebenfalls die Parole ausgegeben, den Streik abzubrechen. Die Arbeiterschaft habe bewiesen, dass sie die deutschen Willkürmassnahmen nicht unberechtigt hinnehme und dass sie durchaus in der Lage sei, auch der Waffengewalt der deutschen Polizei zu trotzen. In diesen Parolen wird weiter gesagt, dieser Streik sei eine durchaus gelungene Generalprobe gewresen.

Im Limburger Kohlenrevier wurde staatlichen. Dienststellen heute Nachmittag durch die Post ein anonymes Schreiben zugesandt mit folgendem Inhalt:

„Bereitet den Generalstreik zum 7.5.43 vor. Die Ernährungsämter, PT'T, Banken und Börsen werden sich an diesem Tage dem Streik anschliessen und eine Verhinderung der Anmeldung der Berufssoldaten herbeiführen. Alle Mittel zur Durchführung des Streiks sind erlaubt. Widersetzt Euch gegen jede Anordnung der deutschen Behörden. Haltet aus, wir kommen. Lehrer und Schüler, besucht am Freitag, den 7.5.43, keine Schulen, sondern haltet Euch in den Wohnhäusern auf. Die deutsche Besatzung beträgt zurzeit weniger als 30000 Mann. Niederländische Frauen, sorgt für die kommenden Tage für genügend Lebensmittelvorrat und helft Euch untereinander. Bleibt am Donnerstag im Hause. Schickt Eure Kinder nicht auf die Strasse, es besteht Gefahr, kocht im voraus, füllt Eure Wasserbehälter und haltet Eure Lebensmittelmarken bereit."

Der 7. Mai ist der Tag, an dem die ersten Kriegsgefangenen einzurücken haben.

Auch aus der Provinz Overijssel kommen Gerüchte über einen am 7. ausbrechenden Generalstreik, dem sich diesmal auch die niederländische Eisenbahn anschliessen wird.

Die im FS vom 3.5. Nr. 14734 unter Nr. 5 gemeldeten Brandstiftungen sind geklärt. Es handelt sich um 2 Täter, die ihrer standgerichtlichen Verurteilung entgegensehen. 
Wegen der allgemeinen Beruhigung haben die Standgerichte mit Ausnahme des zurzeit in Leeuwarden (Provinz Friesland) tagenden ihre Tätigkeit eingestellt.

In der Provinz Friesland herrscht weiter grosse Unruhe. Die Milchtransporte werden von organisierten Banden halbwüchsiger Burschen überfallen. Die Bekämpfung durch die Streifen der Polizei ist ausserordentlich schwierig, da einerseits das Gebiet sehr gross ist, die Siedlungen weit auseinander liegen und die Streifenfahrten offensichtlich von Sympathisierenden fernmündlich vorausgemeldet werden.

Dr. Harster.

\section{Rapport van W. Lages, hoofd van de Aussendienststelle Amsterdam van de Sicherheitspolizei en de Sicherheitsdienst}

\section{DER „MAI-STREIK” 1943 IN AMSTERDAM, NORDHOLLAND UND UTRECHT}

\section{Vorgeschichte.}

Es erscheint mir auf Grund einer Reihe von amtlichen Ausführungen und offiziellen Presseveröffentlichungen nicht zwingend $z u$ sein, nochmal im einzelnen über die Ursache dieses Mai-Streiks in diesem Kreise ${ }^{1}$ ) Ausführungen zu machen. Es ist ja allen Anwesenden hier bekannt, dass die vom WBN. ergangene Bekanntmachung über die Rückführung der früheren niederländischen Wehrmachtsangehörigen in die Kriegsgefangenschaft innerhalb der Bevölkerung dieses Gebietes eine Erregung auslöste. - Die Störung der öffentlichen Ruhe, Ordnung und Sicherheit in dem Bereich der Aussendienststelle Amsterdam trat zu diesem Zeitpunkt noch nicht ein.

Während in den Nachmittagsstunden des 29.4.1943 die ersten Gerüchte über Streikansätze in anderen Teilen des Landes in der Stadt auftauchten, verhielt sich die arbeitende Bevölkerung im Bereich der Aussendienststelle Amsterdam zunächst ruhig.

\section{Lage.}

Die Entwicklung der Streikbewegung vollzog sich in diesem Bereich in 3 Stadien, die wie folgt $z u$ umreissen sind:

a) Industriestreik in IJmuiden, Amsterdam und Zaanstrecke (Wormerveer, Krommenie) am 30.4.1943,

b) Gewaltstreik nach Verhängung des Polizeistandrechts in IJmuiden und Zaanstrecke am 1.5.1943,

c) Bauernstreik.

Die Entwicklung des Streiks in der Provinz Utrecht ist mit der in der Provinz Nordholland und Amsterdam nicht $z u$ vergleichen. Die Provinz Utrecht streikte nicht nur äusserlich anders, sondern auch in den Streikansätzen zeigte sie andere Formen, d.h. es waren mehr Sympathiekundgebungen, die die Bevölkerung als solche und die Provinz ganz allgemein auch nicht annähernd $z u$ erschüttern vermocht hätten, wie es in anderen Teilen der Aussendienststelle Amsterdam hätte eintreten können.

1) Lages heeft dit rapport voorgelezen op een in Mei 1943 gehouden bijeenkomst van de Aussenstellenleiter der Sicherheitspolizei und des SD. 


\section{Massnahmen:}

Diese Entwicklung, die in einigen anderen Provinzen des Landes sprunghafter vorwärts getrieben und zum Teil besorgniserregende Streikansätze zeigte, veranlasste den Reichskommissar unter Uebertragung seiner Befugnisse an den Höheren SS- und Polizeiführer die Verhängung des Polizeistandrechts erst in einer Provinz und später auf alle Provinzen zu erstrecken. Auf Grund der bekannten Ordnungsschutzverordnung wurde das Polizeistandrecht näher umrissen und einschneidende Massnahmen getroffen. Zur Niederringung dieser Streikbewegung wurde sodann die Abgrenzung bestimmter Sicherungsbereiche unter Führung eines Kommandeurs vorgenommen. Sie wurden als Vertreter des Höheren SS- und Polizeiführers bestimmt, ihnen alle Kräfte des SS und Polizei im Bereich unterstellt. Im gleichen Zuge wurden bestimmte Polizeistandgerichte in einzelnen Bezirken errichtet. Erwähnenswert erscheint noch die auf Grund der Ordnungsschutzverordnung vorgenommene Einsetzung von Sonderbeauftragten des Reichskommissars.

Dem Kommandeur des Sicherungsbereiches Nordholland und Amsterdam, einem Major der Ordnungspolizei, standen in der Streikzeit zur Verfügung: 9 Offziere und 100 Mann.

Dem Kommandeur des Sicherungsbereiches Utrecht, einem höheren Waffen-SS-Führer, standen insgesamt 14 Führer, 77 Unterführer und 570 Mann, insgesamt 661 Kräfte, ausgenommen Sicherheitspolizei und niederländische Polizei, zur Verfügung.

\section{B. Ablauf.}

\section{Stadium: 30.4 .1943}

Die ersten Streikfälle waren am 30.4.1943 um 7.30 Uhr in IJmuiden-Velsen zu verzeichnen, wo der grösste Teil der Belegschaft der Hochofenwerke und anschliessend die Gefolgschaft der Papierfabrik van Gelder u. Zonen in den Streik trat, so dass nach kurzer Zeit etwa 3.500 Arbeiter in diesem Bezirk ihre Arbeit niedergelegt hatten. Von IJmuiden griff die Streikwelle zunächst nach der Zaanstrecke und um 9 Uhr auf Amsterdam über, wo die Werkspoor-Fabrik in den Teilstreik trat. Im Laufe des Vormittags schlossen sich in Amsterdam noch einzelne Grossbetriebe, wie die Amsterdamsche Droogdok-Maatschappij, die Fa. Ducro u. Brauns und andere der Streikwelle an. Insgesamt haben ca. 12.000 Arbeiter und Angestellte sich an der Streikbewegung in Nordholland am 30.4.1943 beteiligt. Für Amsterdam ergibt die Beteilung ca. $3 \%$ der arbeitenden Bevölkerung .

\section{Stadium 1.5.1943}

Nach der Bekanntgabe des Polizeistandrechtes war die Streikbewegung in Amsterdam beendet. In sämtlichen Amsterdamer Betrieben war am 1.5.1943 wieder ein normaler Arbeitsgang zu verzeichnen. Dagegen dauerte der Streik in den Hochofenwerken und der Papierfabrik in IJmuiden, sowie in der Blechfabrik in Krommenie trotz Verkündung des Polizeistandrechtes in unvermindertem Umfang fort. Nach Einsatz von Kommandos des Sicherheitspolizei in Verbindung mit der Ordnungspolizei und Waffen-SS, über den ich noch später im einzelnen sprechen werde, wurde eine Anzahl Personen festgenommen und dem Polizeistandgericht Nordholland zugeführt.

Als Schwerpunkt des Industriestreiks war die Gemeinde IJmuiden-Velsen anzusehen. Da die Belegschaft den Aufforderungen zur Wiederaufnahme der Arbeit nicht nachkam, wurden einzelne Arbeiter-Wohnviertel von Verbänden der Waffen-SS und Ordnungspolizei umstellt und streikende Arbeiter aus den Wohnungen geholt.

\section{Stadium:}

Während der Industriestreik sich aus dem Gebiet Overijssel nach Nordholland übertragen hatte, kam die Welle des Bauernstreikes aus der Provinz Friesland und griff vor allem in Poldergebiet Wieringermeer um sich. Dieser Streik kam erst nach der Verkündung des Polizeistandrechtes zu seiner richtigen Entfaltung, was aber auf die Ausdehnung des Streikes keinen Einfluss gehabt hat. Der Streik erreichte seinen Höhepunkt am 3. Mai und wurde 
durch eine Reihe von Einzelfestnahmen gebrochen, so dass am 4. Mai die ganze Streikaktion im Aussendienststellenbereich Nordholland beendet war.

Der ganze Streik verlief in passiver Form, ohne dass es zu ernsteren $Z$ wischenfällen gekommen war.

\section{Provinz Utrecht:}

Wie ich schon eingangs kurz erwähnte, kann zu der Geschichte des Streiks in der Provinz Utrecht gesagt werden, dass diese Bewegung bei weitem nicht so einschneidend und klar zum Ausdruck gekommen ist, wie in anderen Provinzen des Landes. In den Nachmittagsstunden des 30.4.1943 machte sich zunächst in Utrecht in der Eisenbahnerschaft eine Streikunruhe bemerkbar. Einzelne Eisenbahner verliessen ihren Dienstplatz. Am 1.5.43 war auch dieser Teil bereits wieder an der Arbeit. Eine gleiche Erscheinung war am Nachmittag des 30.4 .1943 beim Fernsprechamt der niederländischen Post in Utrecht zu verzeichnen. Sonst war im grossen und ganzen vom Streik nichts bemerkbar. Ueber die eigentlichen Streikausfälle und Auswirkungen berichte ich später unter dem Wirtschaftsteil.

\section{Erfahrungen und Erkenntnisse.}

\section{A. Nachrichtendienst}

\section{1.) Stimmung und Lage nach dem Streik}

Der Maistreik 1943, dessen unmittelbare Ursache in der bekannten Veröffentlichung des WBN. lag, ist als eine überparteiliche Entladung des Volksunwillens gegenüber der Besatzung anzusehen.

Die Verhängung des Polizeistandrechts sowie die damit verbundenen scharfen Massnahmen und Erschiessungen stellten die Ruhe wieder her. Die während des Polizeistandrechts erlassenen Verordnungen über den Arbeitseinsatz der Studenten, die Meldepflicht sämtlicher Männer im Alter von 18-35 Jahren, die Herabsetzung der Butter- und Fleischrationen, sowie die Ablieferungspflicht sämtlicher Rundfunkempfangsgeräte führten eine allgemeine Stimmungsverschlechterung herbei, die umso krasser in Erscheinung trat, da die Kriegslage für die Achsenmächte in Tunis einen ungünstigen Verlauf genommen hatte.

Als die Ursache der Streikunruhen weist man nunmehr darauf hin, dass es taktisch falsch gewesen sei, kurz vor dem 30. April und 1. Mai einen solchen Erlass $z u$ veröffentlichen, da beide Tage vor dem Kriege im niederländischen Volk feierlich begangen worden seien. In deutschfreundlichen Kreisen erklärte man, dass neben dem Erlass des WBN eine Berichterstattung über die Versorgung der hinterbliebenen Familieangehörigen sowie die Behandlung der Kriegsgefangenen in Deutschland in der Presse hätte eher erfolgen müssen. Zumindest hätte man aber deutscherseits einige Zeit vorher vorbereitend auf den Erlass des WBN hinweisen können.

Gegnerkreise haben darauf hingewiesen, dass der WBN erklärt habe, die zur Entlassung gekommenen niederländischen Kriegsgefangenen hätten sich gut geführt. Gewisse Elemente jedoch hätten die damals gezeichnete Loyalitätserklärung gebrochen. Man stellte die Frage, $\mathrm{ob}$ es gerecht sei, hunderttausend Niederländer für die Taten einzelner büssen zu lassen. Ausserdem habe es den Anschein, als ob die Deutschen den Kopf verloren hätten, was u.a. daraus hervorgehe, dass sie den gesamten ihnen zur Verfügung stehenden Verwaltungsapparat zerschlügen. Wenn man ohne Rücksicht etwa vierhunderttausend Niederländer in die Kriegsgefangenschaft führe, so bedeute dieses einen gewaltigen Rückschlag auf das gesamte öffentliche Leben. Der Erlass des WBN hat deshalb die weitverbreitete Auffassung hervorgerufen, dass man deutscherseits wiederum die Mentalität des niederländischen Volkes nicht verstanden habe. Im übrigen könne der WBN einen Führer-Erlass nicht aufheben. 
Man weist ausserdem daraufhin, dass man deutscherseits den Streik einzelner Betriebe viel zu ernst aufgefasst habe. Es sei für hunderttausende Arbeiter in den Niederlanden unmöglich gewesen, bis zum Sonnabend morgen über den Erlass des Reichskommissars vom 30.4.1943 informiert $z \mathfrak{u}$ sein, da vor allem in den kleineren Gemeinden die Pressebekanntmachungen, sowie die Plakatanschläge erst im Laufe der Mittagsstunden eine Wirkung gezeigt hätten, während die Drahtfunkmitteilungen in den meisten Fällen nicht abgehört werden konnten. Zudem sei es seit mehreren Tagen bekannt gewesen, dass man in Deutschland den 1. Mai nicht als Feiertag, wohl aber als einen arbeitsfreien Tag bezeichnet habe. Aus diesem Grunde sei am 1. Mai die Mehrzahl der Arbeiter in den Randgemeinden der Grossstädte und auf dem Lande zu Hause geblieben. In den Grossstädten dagegen wie Amsterdam, Rotterdam und Den Haag, habe man am 1.5. nicht gestreikt. Hier seien die Städter von dem Erlass des RK in jedem Fall rechtzeitig in Kenntnis gesetzt worden. Dies sei vor allem der Fall gewesen bei Gemeindebetrieben und staatlichen Einrichtungen, für die in keinem Fall der 1. Mai ein freier Tag gewesen sei. Im Gegensatz hierzu sei in den verschiedenen Wehrmachtsbetrieben Amsterdams am 1. Mai nicht gearbeitet worden.

Man findet es unverständlich, dass der Streik wiederum vielen Arbeitern das Leben gekostet hat, während der Widerstand auf dem Lande ohne grössere Nachteile für die Bauern und Landarbeiter beseitigt worden sei.

In Kreisen ehemaliger linksgerichteter Parteifunktionnäre wurde erklärt, dass man keinesfalls von einem Streik sprechen könne, der mit den Streikunruhen des Februar 1941 zu vergleichen sei. Amsterdam habe kaum gestreikt, obwohl es das politische Zentrum der Niederlande sei. Wenn Amsterdam streike, bedeute das ein Fanal für die restlichen Provinzen. Man könne deshalb nicht von einer revolutionnären Haltung der Arbeiterschaft sprechen, sondern müsse die Haltung der Werktätigen, vor allem am 30.4.43, als eine spontane Aeusserung bezeichnen, für die man in erster Linie die herrschende Ernährungslage verantwortlich machen müsse. Es sei natürlich nicht von der Hand zu weisen, dass kommunistische Elemente und ausgesprochene Gegnerkreise versucht hätten, den Erlass des WBN sowie die herrschenden Sorgen der Arbeiterschaft für eigene Zwecke nutzbar zu machen.

Die Herausgabe zahlreicher Flugblätter seitens illegaler Widerstandsorganisationen, vor allem der CPN, beweist, dass sich diese Gruppen die Lage zunutze machten, um die Arbeiterschaft aufzuwiegeln. Bemerkenswert ist, dass die ersten Flugblätter erst erschienen, nachdem der Streik bereits im Gange war, so dass anzunehmen ist, dass die illegalen Organisationen in diesem Falle nicht als direkte Urheber dieser Aktion zu betrachten sind, obwohl die Ausweitung und der Gewaltstreik nach Veröffentlichung des Polizeistandrechtes $z$ weifellos auf die rege Agitation der einzelnen illegalen Funktionäre verschiedenster Richtung zurückzuführen ist.

Die Tatsache, dass der Streik gerade im Industriezentrum Amsterdam, wo von jeher derartige Bewegungen ihren Ausgang nahmen, nur eine passive Form und einen derartig geringen Umfang annahm, ist das Ergebnis der Zerschlagung der illegalen Widerstandsorganisationen, insbesondere der CPN, sowie des seit 2 Jahren aufgebauten Nachrichtenapparates unter den Grossbetrieben.

Wenn der Streik in IJmuiden, Wieringen und der Zaanstrecke einen ernsteren Charakter aufwies, so handelt es sich hier um politische Schwerpunkte in der Provinz Nordholland mit denen auf Grund der bestehenden Entfernung kein so enger Kontakt wie mit Amsterdamer Betrieben möglich war, nunmehr aber mit allen Mitteln angestrebt und durchgeführt wird.

In NSB-Kreisen ist man über den Erlass des WBN sowie über die Verordnungen und Bekanntmachungen, die während des Polizeistandrechts veröffentlicht wurden, ebenfalls nicht gut zu sprechen. Die Durchführung der erlassenen Massnahmen lasse $z u$ wünschen übrig, 
da die gesamte Bevölkerung die klare Linie vermisse und letzten Endes SS-Gruppenführer Rauter die Schuld gebe. Ausserdem seien die Verordnungen einander so schnell gefolgt. dass die Durchführung derselben in keiner Weise gewährleistet sei. Man macht in den eigenen Reihen Mussert den Vorwurf, dass er $z \mathfrak{u}$ dem Erlass des WBN nicht eindeutiger Stellung genommen habe. Wenn er schon auf den Führer vereidigt worden sei, müsse er sich restlos hinter die deutsche Besatzungsmacht stellen. Man übt auch starke Kritik an der Niederschlagung des Streiks und erklärt, dass man vor allem auf dem Lande die NSB hätte einsetzen können, um eine Wiederaufnahme der Arbeit herbeizuführen. Im Vechtgebiet sei es einigen Kameraden und dem Leiter des Landstandes gelungen, indem man die Arbeiter durch Zureden auf die Folgen eines Streiks hingewiesen habe. Man wirft Mussert und vor allem seiner Umgebung vor, dass er als Leider des niederländischen Volkes weder zu dem Erlass des WBN noch in seiner Rede am 1. Mai zu den Ereignissen Stellung genommen habe. Man ist deshalb allgemein der Auffassung, dass die NSB durch ihre passive Haltung sämtliche noch vorhandenen Sympathien in der Bevölkerung verloren habe.

$\mathrm{Zu}$ den Ereignissen der letzten Wochen werden innerhalb der Bevölkerung, vor allem in positiv eingestellten Kreisen, folgende grundsätzliche Erwägungen angestellt:

1.) Man hätte im Zusammenhang mit dem Erlass des WBN Presseveröffentlichungen bringen sollen, die sich mit dem Schicksal der Kriegsgefangenen, mit der Unterbringung derselben und mit der Unterstützung der Familienangehörigen befasst hätten. Auf diese Weise bätte sich die Auswirkung dieses Erlasses neutralisiert.

2.) Auf dem Lande sei ein sofortiges Eingreifen der Marechaussee, der Ortspolizei und nicht zuletzt der Bürgermeister notwendig gewesen. Man könne es doch nur auf die Haltung niederländischer Autoritäten zurückführen, wenn auf dem Lande die Milch nicht abgeliefert, sondern öffentlich an Passanten verkauft worden sei.

3.) Die Plakatanschläge sowie die sonstigen Bekanntmachungen über den Erlass des RK hätten in sämtlichen Gemeinden so rechtzeitig erfolgen sollen, dass jeder von dem Inhalt Kenntnis genommen hätte. Ausserdem sei es angebracht, vollzogene standrechtliche Erschiessungen, in einer anderen Aufmachung zu bringen, als die Erlasse und Verordnungen des RK.

4.) Wenn man die Sperrstundenübertreter mit einem Abtransport nach Vught bestrafe, so sei es angebracht, diese Strafandrohungen in der Presse bekannt zu geben. Durch das bei anderen Gelegenheiten schlappe Auftreten der niederländischen und deutschen Polizeiorgane sei es vor allen Dingen in den Städten zur Gewohnheit geworden, die angesetzte Sperrstunde nach eigenem Ermessen zu verlängern. Auch das Verbot des Aufenthaltes im Freien sei in der ersten Veröffentlichung so undeutlich gebracht worden, dass in einem späteren Hinweis darauf hingewiesen werden musste, der Aufenthalt im Freien sei in jeder Form verboten.

5.) Obwohl man in der Presse die Streikbewegung auf dem Lande nicht erwähnt habe, sei man dazu übergegangen, die Verkürzung der Butter und Fleischrationen damit zu begründen, dass die Haltung der Landbevölkerung diese Kürzung notwendig gemacht habe. Es sei angebracht gewesen, dem Niederländer die Butter- und Fleischknappheit in einer Form darzustellen, die ihm die gegebenen Schwierigkeiten der gesamten Ernährungslage vor Augen führe. Unerklärlich sei es, dass nach diesem Streik der Bauer und Landarbeiter eine höhere Butterzuweisung erhalte, wie dies in den Städten der Fall sei.

6.) Der Arbeitseinsatz der Studenten sei ebenfalls merkwürdig. Die gesamten Massnahmen auf diesem Gebiet liessen jede klare Linie vermissen. Von einem Arbeitseinsatz als eine Folge der Nichtunterzeichnung der Loyalitätserklärung könne kaum die Rede sein, da man die Studenten in Berlin bestens empfangen und sie in Damengesellschaft durch die Stadt gefahren habe. In den Niederlanden werde den positiv eingestellten Studenten 
nunmehr das Studium erschwert, während den niederländischen Studenten in Deutschland noch im Arbeitseinsatz die Möglichkeit gegeben werde, das Studium fortzusetzen.

7.) Die Reihenfolge der Verordnungen und die Schwere derselben müsse man als taktisch falsch bezeichnen. Eine Durchführung derselben sei nicht gut möglich, da weder die Kriegsgefangenen noch die Meldepflichtigen in Bezug auf den Arbeitseinsatz den Anordnungen Folge leisten würden. Dasselbe gelte für die Ablieferungspflicht der Rundfunkempfangsgeräte. Der Niederländer fühle sich in seiner eigenen Person ungerecht behandelt und stelle sich auf den Standpunkt: „Wer etwas von mir will, soll es holen".

Man vertritt allgemein die Ansicht, dass die deutsche Besatzungsmacht vor der restlosen Durchführung der erlassenen Verordnungen zurückschrecke und erklärt in Gegnerkreisen hierzu, dass der geschlossene Widerstandswille des niederländischen Volkes hierzu massgeblich beigetragen habe. In deutschfreundlichen Kreisen hegt man die Befürchtung, dass die Nichtdurchführung der verschiedenen Verordnungen die Gegnerkreise in ihrer vertretenen Ansicht bestärke. Bisher sei festzustellen, dass alle bisher getroffenen Massnahmen entweder ungenügend durchdacht, zumindest aber nicht konsequent durchgeführt worden seien. Zur Rückführung ehemaliger niederländischer Wehrmachtsangehöriger in die deutsche Kriegsgefangenschaft sei schon jetzt festzustellen, dass dieser Erlass des WBN nur zu einem geringen Teil durchgeführt werde. Vonseiten des RK verlautet hierzu, dass die Zahl der Kriegsgefangenen, die in Deutschland interniert würden, nur etwa 35.000 Mann betrage.

Der Streik, das Polizeistandrecht, die Verordnungen, sowie die allgemeine Kriegslage haben im hiesigen Bereich die Gegnerkreise in ihrer Haltung bestärkt, den abwartenden Teil der Bevölkerung nachteilig beeinflusst und die deutschfreundlichen Kreise zu einer Kritik veranlasst, die sich in diesem Falle eingehend mit den Massnahmen der Besatzungsmacht, deren Gründe und Durchführung befasst.

\section{2.) V-Mann-Apparat}

Dieser Maistreik 1943 hat neben seinen politischen und wirtschaftlichen nachteiligen Auswirkungen zumindest aber sicherheitspolizeilich und sicherheitsdienstlich den Vorteil, dass eine Reihe von Einzelfragen weit mehr als in allen Besprechungen in kurzen Hinweisen wieder entscheidend in das Blickfeld der Verantwortlichen gerückt ist. Hierzu gehört mit an erster Stelle die nachrichtendienstliche aber auch sicherheitspolizeiliche V-Mannarbeit. Wie ich schon früher verschiedentlich angeregt habe, ist es eine zwingende Notwendigkeit geworden, unverzüglich einen zuverlässigen, ehrenamtlichen Mitarbeiterapparat nicht nur in den Städten, sondern gerade in den bäuerlichen Provinzen aufzubauen. Die Erfahrungen in meinem Bereich haben gezeigt, dass im grossen und ganzen die Industriezentren einigermassen mit solchen Mitarbeitern durchsetzt sind, mit denen wir im Falle von Unruhen zumindest Verbindung halten können. Es wird allen Aussendienststellen klar geworden sein, dass gerade die ersten Ansätze von solchen Ausnahmezuständen die schwersten sind, dass die Gerüchtebildung eine sehr grosse ist, Weisungen und Berichterstattungen kurzfristig gegeben worden und die wirklichen Verhältnisse nur in kürzesten Zeitabschnitten durch persönliche oder fernmündliche Erfragung klar erkannt werden können. Die im normalen Dienstbetrieb zur Verfügung stehenden V-Personen sind in der Hauptsache arbeitsgebietsmässig einseitig tätig, und das ist nur gut.

In Notzęiten ist meiner Auffassung nach die Spezialberichterstattung eine zweitrangige. Viel wichtiger ist beispielweise im Wieringermeerpolder, oder aber im industriellen Zaangebiet, in der Holzbranche, in der Metallindustrie, in der Lebensmittelversorgung und darüber hinaus in den öffentlichen Betrieben Auskunftspersonen $z u$ haben, die einfach und klar ganz bestimmte allgemeine Rückfragen beantworten können. Es erscheint mir ungemein 
wichtig, nicht nur in der Grossindustrie, sondern in allen Gruppen des Handels, der Wirtschaft, der öffentlichen Betriebe ein solches Mitarbeiternetz zu wissen, das uns in die Lage versetzt, klar und richtig, vor allem aber schnellstens der Stabsarbeit leistenden Dienststelle richtige Nachrichten zukommen zu lassen. Ich rege daher bei dieser Berichterstattung an, dass die Zentralisierung in der Führung dieser Mitarbeiter in jedem Aussenstellenbereich vorgenommen werden muss. Das kostet praktisch einen Mann, der allerdings nicht nur sicherheitsdienstlich, sondern auch sicherheitspolizeilich ein gewisses Wissen vereinigt und praktisch nicht nur karteimässig, sondern auch persönlich jederzeit die Mängel in einzelnen Gebieten beseitigt, die zurzeit noch herrschen. Der Ausbau dieses Apparates erscheint mir, wie ich bereits erwähnte, als eine der vordringlichsten Aufgaben der kommenden Wochen und Monate. In etwa kommenden Notzeiten des besetzten niederländischen Gebietes, wo die öffentlichen Verkehrsmittel und Einrichtungen still liegen, wo gegebenenfalls offener Aufruhr herrschen kann, ist auf diesen Apparat nicht zu verzichten.

\section{3.) Wittschaft}

Die sich am 29.4.1943 in den anderen Teilen des Landes entwickelnde Streikbewegung griff am 30.4.1943 zunächst nur in mässigen Grenzen auf die Arbeiter und späterhin auch auf die Landbevölkerung über, um, mit Ausnahme der sich inzwischen in IJmuiden. Krommenie und Amsterdam gebildeten Schwerpunkte, im Laufe des 30.4. bezw, 1.5. wieder abzuklingen, so dass am 2.5. unter dem Eindruck der scharfen Massnahmen, die im Rahmen des Polizeistandrechtes ergriffen wurden, im allgemeinen auf dem Wirtschaftssektor von Amsterdam, Nordholland und Utrecht wieder geregelte Verhältnisse eingetreten waren.

Die Streikbewegung innerhalb des ländlichen Teiles der Bevölkerung schien eine Gefährdung der gesamten Nahrungsmittel und Milchversorgung mit sich zu bringen. Es gelang jedoch, dank der Einsicht ländlicher Kreise, die Schwierigkeiten $z \mathfrak{u}$ bereinigen, so dass lediglich die gesamten Massnahmen auf die Milchversorgung beschränkt werden konnten. So sind nach den bisherigen Feststellungen und Schätzungen von Fachkreisen am 1. und 2.5.1943 insgesamt 50.000 Liter Milch nicht angeliefert, bezw. kleinere Mengen durch Umkippen der Milchkannen vernichtet worden. Es war so, dass sich ein Teil der ländischen Bevölkerung weigerte, der üblichen Milchablieferungspflicht nachzukommen.

Die Erörterung der Gründe, die die Bauern veranlassten, sich in einer solchen Menge am Streik zu beteiligen, hat $z u$ keinem positiven Ergebnis geführt. Seitens der Niederländer wird mehrfach die Ansicht vertreten, die Landbevölkerung sei der allgemeinen Streikpsychose erlegen und ausserdem seien diese Umstände u.a. hetzerischen Elementen, denen die Fälle der Vernichtung von Milch und Beschädigung von Transportmitteln ein Mittel zum Zweck war, zuzuschreiben. Die ländliche Bevölkerung sei sozusagen in einen Angstzustand versetzt worden, der zur Zurückhaltung der Milch geführt habe.

Im Wieringermeerpolder streikten ebenfalls Teile der Landarbeiterschaft, die von den Bauern noch insoweit unterstützt wurden, dass man ihnen versprach, für die Streiktage den vollen Lohn auszuzahlen. Auch in diesem Gebiet wurde in einigen Fällen die zur täglichen Abholung an den Wegen bereitgestellte Kannenmilch umgeworfen, so dass der gesamte Inhalt verloren ging. Die Streikbewegung brach auch hier schnell zusammen.

Im übrigen wurde sofort nach Erscheinen der deutschen Kommandos die Lage stets stabilisiert.

Wie schon erwähnt, bildeten sich auf dem industriellen Sektor 3 Schwerpunkte und zwar in Amsterdam, IJmuiden und Krommenie heraus. In Amsterdam streikte am 30.4 die Firma Werkspoor mit 408 Angestellten und 1294 Arbeitern, während des ganzen Tages. Die Firma, die fast ausschliesslich für die deutsche Marine arbeitet, hatte einen Arbeits- 
stundenausfall von rund 15.000 Stunden zu beklagen. Die Nederlandsche Dokmij. streikte mit 770 Mann und hatte einen Ausfall von 4.815 Arbeitsstunden. Die Amsterdamsche Droogdokmij. streikte mit 800 Mann, hatte aber nur einen Ausfall von 400 Arbeitsstunden zu verzeichnen. In verschiedenen anderen Firmen zeigten sich kleinere Streikansätze, die aber rechtzeitig erkannt und jeweils von der zuverlässigen Betriebsführung eingedämmt werden konnten, auf der anderen Seite steht fest, dass die Betriebsführung der Firmen, in denen gestreikt wurde, kaum etwas getan habe, die Lage von vornherein positiv zu beeinflussen. Die Streiks in den vorgenannten Fabriken waren auf Grund der eingetretenen Ernüchterung am 30. zusammengebrochen. Am 1.5. wurde mit Ausnahme einiger weniger Arbeiter die Arbeit wieder voll aufgenommen.

Ein wesentlich anderes Bild zeigte sich in IJmuiden-Velsen. Dort traten am 30.4. im Hochofenwerk 300 Arbeiter in den Streik, die sich bis zum Abend desselben Tages auf 2.000 Mann vermehrten und am 1.5. die Zahl von 2.800 Mann erreichten. Das Werk hatte einen Gesamtarbeitslohnstundenausfall von 28.000 Stunden, einen Produktionsausfall von 385 t Roheisen, 670 t Normalkoks, 480 t Rohstahl, 250 t Bleche, 80 t Gussröhren, 98 t Stickstoff und $427 \mathrm{t}$ Zement.

Die am gleichen Ort bestehende Papierfabrik hatte an beiden Tagen bei 865 Streikenden einen Arbeitsstundenausfall von 6.318 Stunden. Auch bei dieser Firmai steigerte sich der Ausfall am zweiten Tage. In dem dritten Schwerpunktort Krommenie streikten bei den Vereenigden Blikwarenfabrieken ca. 700 Mann, bei einem Arbeitsstundenausfall von 6.000 Stunden.

Auch bei diesen drei vorgenannten Firmen trat neben dem Versagen der Werkleitungen die politische Verhetzung klar zu Tage. Nur die getroffenen scharfen Massnahmen mit ihren unbestreitbar weitstrahlenden Auswirkungen haben eine Eindämmung bezw. Einstellung des Streikes veranlassen können.

Zusammenfassend kann, unter Berücksichtigung der beiliegenden Aufstellung, gesagt werden, dass, ausser den 3 aufgezeigten Schwerpunkten, die Streiklage im Verhältnis zu den anderen Landesteilen nicht sehr gross war und dass dort, wo tatsächlich gestreikt wurde, mit Hilfe der eingesetzten Kommandos, der Bürgermeister und der Betriebsführer, die Ruhe noch an demselben Tage (in den weitaus meisten Fällen) wieder hergestellt wurde. In mehreren Betrieben wurden sogar seitens der Arbeiter Ueberstunden gemacht, um die ausgefallene Produktion möglichst rasch einzuholen. Wenn es trotz des Wissens um Gefährlichkeit und Sinnlosigkeit jedes Versuches, sich den Anordnungen $z \mathfrak{u}$ widersetzen, in einzelnen Teilen des Dienststellenbereiches zu unorganisierter Arbeitsverweigerung kam, die Landwirtschaft ihre Ablieferungspflicht nicht erfüllte, so bestätigen diese Vorgänge nur die Verpflichtung der verantwortlichen Stellen zum schärfsten Durchgreifen. Die ergriffenen Massnahmen haben, soweit die Lage überprüft werden kann, innerhalb 48 Stunden die Ruhe und Ordnung wieder hergestellt. Sie fanden in breiten Kreisen der Bevölkerung die sich über die schweren Folgen weiterer Unbesonnenheiten klar waren, durchaus volles Verständnis, wie die Auslassungen vieler Niederländer bewiesen haben.

Betrifft: Streikbewegung 30.4 bis 1.5 .1943

A m s terd a m

1. Werkspoor

$1.700 \mathrm{Mann}$

Stundenausfall 14.864

die Firma arbeitet in der Hauptsache für die Marine. Die Streikenden haben in der Nacht zum 1.5, vollzählig die Arbeit wieder aufgenommen.

2. Fa. Ducros u. Brauns 200 Mann

Stundenausfall

600

die Arbeit wurde am 1.5. vollzählig wieder aufgenommen. 
3. Nederlandsche Dokmij 770 Mann

Stundenausiall

4.812

die Arbeit wurde am 1.5. vollzählig wieder aufgenommen.

4. Amsterdamsche Droogdokmij.

800 Mann

Stundenausfall

400 die Arbeit wurde am 1.5. vollzählig wieder aufgenommen.

5. Staalmeubelfabrik „De Cirkel”

55 Mann

Stundenausfall

330 die Arbeit wurde am 1.5. vollzählig wieder aufgenommen.

IJ muiden - Velsen

1. Hochofenwerk

In diesem Werk wurde am 30.4. und am 1.5. gestreikt.

Es trat ein Erzeugungsausfall ein von 385 to Roheisen, 670 to Normalkoks, 480 to Rohstahl, 250 to Bleche, 80 to Gussröhren, 98 to Stickstoff und 427 to Zement.

2. Papierfabrik van Gelder $u$. $Z$ n.

865 Mann

Stundenausfall 6.318

In diesem Werk wurde am 30.4. und am 1.5. gestreikt.

3. N.V. de Plaatwelletij

15 Mann

Stundenausfall

45

die Arbeit wurde am 1.5. vollzählig wieder aufgenommen.

Krommenie

1. Blechwatenfabrik

750 Mann

Stundenausfall

6.000

in diesem Werk wurde am 30.4. und am 1.5. gestreikt.

2. Weberei van Leijden

60 Mann

Stundenaustall

240

die Arbeit wurde am 1.5. vollzählig wieder aufgenommen.

$\mathrm{H}$ a a r $1 \mathrm{e} \mathrm{m}$

1. N.V. Stork, Hebezeuge

350 Mann

Stundenausfall 3.230

die Arbeit wurde am 1.5. vollzählig wieder aufgenommen. Es liegen Wehrmachtsaufträge vor.

A $1 \mathrm{~km}$ a a r

1. Metall- und Eisengiesserei

120 Mann

Stundenausfall

600

die Arbeit wurde am 1.5. vollzählig wieder aufgenommen... ${ }^{1}$ )

4.) Unterrichtung der Aussendienststellen

Die vom BdS. den Aussendienststellen in den letzten Tagen des Maistreiks 1943 zugegangene Abschrift der Lageberichterstattung an das RSHA ist in künftigen Fällen nur erwünscht. Daneben bitte ich zu erwägen, in solchen Notzeiten anzuordnen, dass die benachbarten Aussendienststellen sich gegenseitig täglich ganz kurz durch FS über die Lage in ihrem, besonders aber in den Grensgebieten unterrichten.

\section{B. Polizeilicher Einsatz}

1.) Der Sicherungsbereich und seine Einheiten

Den Zuständigkeitsbereich der Kommandeure der einzelnen Sicherungsbereiche auf die Provinzen bezw. mehrere Provinzen zu erstrecken, hat sich nur günstig ausgewirkt. Die Zusammenarbeit mit den beiden Kommandeuren in meinem Aussendienststellenbereich war gut. Sachlich habe ich folgende Feststellungen getroffen:

a) Sicherungsbereich Nordholland

Der Kommandeur war der Bataillonskommandeur der Ordnungspolizei. Ihm standen

1) Hier ontbreken 3 pagina's in het exemplaar van Lages' rapport, dat het Rijksinstituut bereikte. 
neben seinen und niederländischen Hilfspolizeikräften auch Einheiten der Waffen-SS zur Verfügung. Praktisch habe ich zu dem Kommandeur einen Führer und eine Reihe bewährter Männer abgestellt, die bei Einsatz von Polizeikommandos mit die sicherheitspolizeilichen Belange usw. vertraten. Hier hat es geklappt.

\section{b) Sicherungsbereich Utrecht}

Der Kommandeur war ein Führer des Waffen-SS. Ihm standen ausschliesslich Kräfte der Waffen-SS zur Verfügung. Er hat mit dem Postenführer in Utrecht enge Verbindung gehalten.

Die aufgetretenen Mängel waren jedoch in beiden Fällen mehr oder weniger folgende:

1.) Bei der Bekämpfung von Streikbewegungen, insbesonders bei schlagartigem Zugreifen in Werken usw. kann auf keinen Fall auf die Auffassung der Sicherheitspolizei und des SD verzichtet werden. Die sehr eifrig tätig gewordenen Einsatzkräfte der Ordnungspolizei und Waffen-SS kennen nicht die politischen Hintergründe, die Erkenntnisse der Sicherheitspolizei und des SD und arbeiten daher mehr kriegseinsatzmässig. Es ist nicht von der Hand zu weisen, dass die Ergebnisse über die Festnahme von Rädelsführern beim Streik nicht so waren, wie wir sie bei unseren sicherheitspolizeilichen Aktionen kennen. Diese Erfahrungen haben die Polizeistandgerichte, auf die ich später noch zu sprechen komme, ebenfalls gewonnen. Wenn nun aber noch reine SS-Führer der Waffen-SS in den Sicherungsbereichen ihre Truppen einsetzen, so geschieht das nach den Gesichtspunkten des gegebenen klaren wörtlichen Befehls, bezw. den Anordnungen des Höheren SS- und Polizeiführers. Auf die Erfassung der Stellen in den Unruhegebieten, die hetzerisch tätig geworden sind, kommt es ihnen letzten Endes nicht an. Sie können auch diese Kreise nicht erfassen, da sie die Entwicklung und die Verhältnisse gar nicht kennen.

Es erscheint mir von Wichtigkeit in Wiederholungsfällen neben dem Kommandeur des Sicherungsbereiches, und zwar im Wege der Anordnung, einen verantwortlichen SS-Führer der Sicherheitspolizei und des SD des betreffenden Bereiches mit einzubauen, der alle Sachgebiete unserer Arbeit und die gewonnenen Erfahrungen des Gebietes beherrscht. Seine Aufgabe wird in der Hauptsache sein, die Offiziere bezw. Führer der eingesetzten Polizei und Waffen-SS Verbände unauffällig dahin auszurichten, wie sie neben dem Einsatz mit der Waffe unsere Belange mit zu erfüllen haben. Daneben schlage ich weiter vor, dass grundsätzlich alle eingesetzten Kommandos des Sicherungsbereiches mit Angehörigen der Sicherheitspolizei durchsetzt sein müssen.

Technisch $z \mathbf{u}$ beanstanden war in Utrecht die mangelhafte Meldung eingesetzter Waffen-SSVerbände über Zusammenstösse usw.

Die Befehlsübermittlung dürfte in künftigen Fällen auch auf der Stabsdienststelle zentral $z$ u steuern sein. Es gab eine Reihe von Befehlen und Anordnungen die einmal die Sicherheitspolizei betrafen und die entweder an den Kommandeur des Sicherungsbereiches oder aber an den Sonderbeauftragten des RK, auf den ich noch zu sprechen komme, gerichtet waren, zum anderen gingen Befehle hier ein, die ausschliesslich die Ordnungspolizei bezw. die Kommandeure betraf. In diesen Fällen schlage ich vor, dass alle beteiligten Stellen gleichmässig und gleichzeitig von allen sie mittelbar oder unmittelbar interessierenden Erlassen Kenntnis bekommen.

\section{2.) Einsatz Sicherheitspolizei und $S D$}

Einen Teil hierzu habe ich eben bereits geschildert. Neben der Schaffung einer eigenen Reserve sind möglichst viel Kräfte von uns den Kommandeuren beizugeben. Nicht unzweckmässig erscheint mir ferner dass bei einer Schaffung von Kommandeuren von Sicherungsbereichen offiziell jedenfalls der Aussendienststellenleiter oder sein Vertreter zu dem Stabe tritt. Es hat sich nur zweckmässig erwiesen, dass die Kommandeure möglichst täglich noch 
vom Leiter oder Vertreter im Amt über eine Reihe von Auffassungen und auch Ereignissen mündlich aufgeklärt und quasi ausgerichtet werden. Erstrebenswert erscheint mir der Umstand, dass es in Zukunft die Aufgabe der Kommandeure mit ihren Ordnungs- und Waffenpolizeilichen Kräften sei für die Aufrechterhaltung der öffentlichen Sicherheit und Ordnung auf der Strasse und die Brechung des offenen Streiks zu sorgen. Mit dem Augenblick des Einschreitens solcher Verbände in den Betrieben bleibt die Befehlsgewalt bei der Ordnungspolizei bezw. Waffen-SS-Führer, Träger solcher Aktionen ist aber der Führer der Sicherheitspolizei.

\section{3.) Holländische Polizei}

In einigen Gemeinden der Provinz Utrecht, besonders in der Stadt Utrecht, aber auch in Nordholland, in IJmuiden und Krommenie, hat die Zusammenarbeit mit der holländischen Polizei ausgezeichnet geklappt. In anderen kleineren und kleinsten Gemeinden, insbesondere im Wieringermeer, hat die Polizei restlos versagt. Hier erscheint mir die Frage der Umorganisation oder die Schaffung grösserer Landgemeinden mit einem stärkeren Polizeikorps und konsequenten Führern das allein beste Mittel zur Beseitigung solcher Mängel zu sein.

\section{4.) Landespolizeipräsidenten}

Die Stellung des Landespolizeipräsidenten ist in diesem Maistreik 1943 nicht gestärkt worden. Er hatte kaum Aufgaben zu erfüllen, und meldete mal hin und wieder irgendwelche Einzelereignisse. Es erscheint zweckmässig ihm in solchen Fällen mehr Verantwortung zu übertragen.

5.) Verschiedene Einzelfragen

a) Vor Eintritt solcher Unruhezeiten ist es zweckmässig, sich nach Nothaftunterkünften umzusehen, die jederzeit, wenn auch primitiv in der Ausstattung, greifbar sind.

b) Zwingend ist sodann die sofortige Ueberprüfung des Waffen - und Munitionsbestandes der Aussendienststelle. Im Ernstfall bei klarem Waffeneinsatz der Aussendienststelle ist die vorhandene Munition nach kürzester Zeit verbraucht. Reserven stehen nicht zur Verfügung. Bei weitem sind nicht alle Männer mit Karabinern ausgerüstet. Handgranaten fehlen völlig. Diese Frage verdient auch im Zusammenhang mit dem A-Fall grösstes Interesse.

\section{c) Verbindungsführer zur Wehrmacht}

Es erscheint zweckmässig in solchen Unruhezeiten vom BdS, aus die Einrichtung eines Verbindungsführers der Sicherheitspolizei und des SD aus den einzelnen Aussendienststellenbereichen zur zuständigen höchsten Wehrmachtsdienststelle zu erwägen, um die Wehrmacht als solche über die Entwicklung auf dem Laufenden zu halten. Sonst wird nur der Dienstbetrieb durch fernmündliche Rückfragen usw. gestört.

\section{d) Spenrstundiensünder}

Massnahmen gegen Sperrstundenübertreter sind schnellstens $z \mathfrak{u}$ publizieren. Es ist auch die Inhaftierung zeitlich $z \mathfrak{u}$ begrenzen. Die Erfassung, Unterbringung und Transportierung solcher Unzahl von Sperrstundensündern erschwert täglich den gesamten Einsatz der Polizei.

\section{e) Schussuaffengebrauch}

Es erscheint ebenfalls zweckmässig, hinsichtlich der Frage des Schusswaffengebrauches und der Berichterstattung neue Anordnungen zu treffen, die gleichzeitig mit Beginn der Verhängung des Polizeistandrechis als klare Befehle gegeben werden. In diesem Zusammenhang kurz zu der Frage der Behandlung von Leichen. Es erscheint mir nicht überspitzt zu sein, auch in Zeiten des Polizeistandrechtes an Leichensachen, verursacht durch Waffengebrauch der eingesetzten Verbände, zumindest soweit tätig zu werden, bis man weiss, wie die Auffassung höheren Orts ist. Erst als einige Leichen eine geraume 
Zeit irgendwo lagen und niemand eine Entscheidung treffen wollte, habe ich in einigen Fällen mich dienstlich eingeschaltet und eine Entscheidung erbeten. Ich bitte, diese Frage bei künftigen General-Anordnungen schon von Anfang an klar zu stellen. Es werden sehr viele Rückfragen und Unannehmlichkeiten vermieden.

\section{E) Rüstungsinspektion}

Die Rüstungsinspektionen dürfte gelegentlich durch den BdS dahin auszurichten sein, dass sie schneller als beim Maistreik 1943 uns über Ansätze von Streik oder Unruhe in den Betrieben Kenntnis gibt. In meinem Bereich hat sie es zum Teil deshalb unterlassen, weil sie später davon erfuhr als wir. Es könnte nicht schaden, wenn wir diesen Teil der deutschen Rüstung in unseren Meldeapparat unmerklich mit einbauen. In diesem Zusammenhang will ich nicht unerwähnt lassen, dass in all den Betrieben, die eine straffe und klare Betriebsführung haben, ich denke an die Fokker und Fordwerke, keine Streikansätze festzustellen waren. Vielleicht dient diese Feststellung dazu, die Rüstungsinspektion entsprechend $z u$ verständigen.

g) Tätigkeit der Kirche

Es interessiert noch, dass die katholische Kirche in Krommenie durch einen katholischen Geistlichen versucht hat, bei dem Direktor der Werke die Bitte vorzutragen, für die Hinterbliebenen der Erschossenen einen Betrag zu zeichnen.

\section{h) Soziale Betreuung der Hinterbliebenen von standgerichtlich Erschossenen}

In dem gleichen Werk in Krommenie wurde kurze Zeit nach dem Erschiessen der Verurteilten durch die Arbeiterschaft der Betriebsführung die Bitte vorgetragen, zuzulassen, dass die Belegschaft für die Hinterbliebenen laufend eine Unterstützung zahlt. Die Betriebsführung lehnte dieses ab. Hier dürfte der Hebel anzusetzen sein, dass schnellstens die soziale Betreuungsstelle von Partei und Staat sich einschaltet.

\section{Polizeilicher Einsatz. (Verwaltung und Recht)}

\section{1.) Stellung des Sonderbeauftragten}

In dem Erlass des RK hat dieser entsprechend Par. 65 der Ordnungsschutzverordnung Sonderbeauftragte eingesetzt. Ihnen untersteht nach einem Fernschreiben des BdS. lediglich die öffentliche Verwaltung nicht polizeilicher Art, soweit der Höhere SS- und Polizeiführer in diese nicht eingreift. Daraus ergibt sich, wie der BdS. mitteilt, dass die Sonderbeauftragten keinerlei Einfluss auf die Bekämpfung von Streik, Widerstands- und Aufstandsbewegungen haben.

Es ist eine bekannte Tatsache, dass alle jene, die kraft ihrer Berufsausbildung mit dem polizeilichen Dienst oder ähnlichen nichts zu tun haben, sich nunmehr berufen fühlen, auch einmal polizeilich tätig zu werden. Hier bilden die Beauftragten, soweit ich sie bislang kennen gelernt habe, nur in den wenigsten Fällen eine Ausnahme. Beim Maistreik 1943 hat der Sonderbeauftragte für Amsterdam und Nordholland naturgemäss eine Reihe von Meldungen aus den Provinzen erhalten, die er zum Teil an mich gegeben hat oder an den Kommandeur des Sicherungsbereiches. Er hat aber auch in mehreren Fällen ein bestimmtes polizeiliches Einschreiten unter Festnahme bestimmter Personen gewünscht. Daḱs ist dann im Sinne unserer Auffassung erledigt worden. Es sind also praktisch keine Schwierigkeiten entstanden. Befremdend hat allerdings gewirkt, dass der Höhere SS- und Polizeiführer sich täglich und auch verschiedentlich des Nachts laufend über rein polizeiliche Ereignisse und Entwicklungen fernmündlich von ihm berichten liess. In einem oder zwei Fällen kam diese Rückfrage an den Aussendienststellenleiter. Es ist natürlich verständlich, dass eine solche Sonderbehandlung durch den Höheren SS- und Polizeiführer den rein verwaltungsdienstlich tätigen Beauftragten dahin beeinflusst, dass er selbst glauben kann, nun auch etwa polizeiliche Auffassungen auf 
Grund der Berichterstattung usw. durch den Höheren SS- und Polizeiführer durchzuführen. Diese Angelegenheit hat sich keinesfalls schwierig in der Zusammenarbeit ausgewirkt, da der Beauftragte ja die Auffassung der Aussendienststelle nicht erst seit heute genauestens kennt.

\section{2.) Die Anordnungen des Höheren SS- und Polizeiführers}

Wie schon eingangs einmal berichtet, kostet die Veröffentlichung der Anordnungen und Bekanntmachungen des Höheren SS- und Polizeiführers unter solchen Verhältnissen noch zu viel Zeit. So ist es praktisch nicht möglich gewesen, dass eine durch FS am Nachmittag des 30.4.43 gegebene Entscheidung, wonach am 1. Mai in sämtlichen, auch deutschen Betrieben gearbeitet wird, praktisch in grossen Industriebetrieben den nicht tätigen Arbeitern rechtzeitig zur Kenntnis zu bringen. Darunter fallen sogar eine Reihe deutscher Wehrmachtsbetriebe. Eine schnellere Uebermittlung der ergangenen Anordnungen und Bekanntmachungen ist auf jeden Fall anzustreben.

\section{3.) Polizeistandgerichte}

Die Urteilsfindung der Polizeistandgerichte richtet sich — und das ist ja für alle Fälle eine Selbstverständlichkeit — nach der Erheblichkeit des zusammengetragenen belastenden Materials des Angeklagten. Somit steht und fällt auch die Qualität der Fälle, die das Polizeistandgericht abzuurteilen hat. Es ist wohl allen Angehörigen der Sicherheitspolizei und des SD in diesen Streiktagen zum Bewusstsein gekommen, dass leider in der Hauptsache nicht die Fälle vor das Standgericht gekommen sind, die eigentlich dahin gehörten. Darïber habe ich bereits kurz gesprochen. Hier ist der Fehler zu suchen in dem einseitigen Einsatz bestimmter Waffen- oder Ordnungspolizeiverbände, oder aber wo sicherheitspolizeiliche Kräfte zu spät, wie beispielsweise in IJmuiden-Velsen, zum Einsatz kamen. Sodann sind einige dicke Fälle leider erst nach Aufhebung des Polizeistandrechtes zu uns gekommen.

Ich glaube, dass die Ausführungen des Reichskommissars über die Polizeistandgerichte alles das gebracht haben, was die Aussendienststellen selbst in den Zeiten des Streiks festgestellt haben.

\section{Schlussbetrachtung}

Abschliessend können folgende Punkte herausgestellt werden.

1.) Die eingesetzten polizeilichen Organe einschliesslich der Waffen-SS waren jederzeit Herr der Lage. Eine Verschlimmerung der Streikverhältnisse hätte mit grösster Wahr. scheinlichkeit kein Versagen der Ordnungsorgane im Gefolge gehabt.

2.) Die Gegenüberstellung der Erkenntnisse aus dem Generalstreik 1941 mit denen des Maistreiks 1943 zeigen bedeutsame Unterschiede, die den Fortschritt im dienstlichen Einsatz der Sicherheitspolizei und des SD ganz allgemein deutlich vor Augen führen. Seinerzeit mangelnde nachrichtendienstlich - man kann sagen zu späte - Arbeit, uneinheitliche Führung der Verbände, eine ausserordentlich gut geführte illegale CPN; heute - d.h. im Maistreik 1943 - klare Befehlsführung der Ordnungsorgane, zum Teil vorbildliche nachrichtendienstliche Arbeit und nicht zuletzt die Folge der zweijährigen systematischen Zerschlagung der CPN. durch die Organe der Sicherheitspolizei und des SD.

3.) Ich schliesse diese Ausführungen mit der gewonnenen Erkenntnis, dass wir im 4. Kriegsjahr in den besetzten niederländischen Gebieten in jeder Phase dieser Streikbewegung voll und ganz Herr der Lage waren.

Lages 


\section{Telexbericht van de Befehlshaber der Sicherheitspolizei und des SD, Den Haag, aan het Reichssicherheitshauptamt, d.d. 7-5-1943}

Beförd. den 7. Mai 1943. 11/37

An den

Chef der Sicherheitspolizei, Berlin, das RSHA - Amt III - Amt IV -, Berlin,

den Beauftragten des Chefs der Sicherheitspolizei

beim Militärbefehlshaber in Brüssel,

den Inspekteur Düsseldorf,

den Inspekteur Hamburg,

nachrichtlich

an alle Aussenstellen des BdS

Betr: Streikbewegung in den Niederlanden.

Vorg.: zul. mein FS vom 5.5.1943 Nr. 15228.

Die Streikbewegung in den Niederlanden ist vollständig abgeklungen. Allgemein wurden jedoch Streikparolen, illegale Hetzschriften usw. mit Aufrufen, am heutigen Tage den Generalstreik zu proklamieren, verbreitet. Während gestern, 6.5., der Meldetermin für die Studenten war, hat sich heute, am 7.5., der erste Teil der ehemaligen niederländischen Wehrmacht zu melden. Das Ergebnis der Studentenmeldung ist 3167. Die Sollstärke ca. 6-7000. Der Abtransport erfolgte ohne Störung. Die niederländische Eisenbahn arbeitete reibungslos. Vorsorglich hatte die Deutsche Bahnverwaltung genügend Lokomotiven mit Deutschem Personal bereitgestellt. Weiterer Bericht erfolgt im Laufe des Nachmittags.

BdS Den Haag

i.V. gez. Knolle

SS Obersturmbannführer

\section{Telexbericht van commissaris $\sim$ generaal F. Schmidt aan alle Beauftragten des Reichskommissars d.d. 12-5-1943}

reichskommissar den haag, fs 5752 den 12. 5. $43 / 16.40$

vertraulich!

generalkommissar z.b.v., den haag

an a 11 e beauftragten des reichskommissars.

betrifft: massnahme des wehrmachtbefehlshabers in den niederlanden ueber die rueckfuehrung der soldaten der ehemaligen niederlaendischen wehrmacht in die kriegsgefangenschaft.

aufgrund verschiedener rueckfragen mit dem wehrmachtbefehlshaber in den niederlanden hat sich das oberkommando der wehrmacht entschlossen, die ehemaligen niederlaendischen 
soldaten in die kriegsgefangenschaft wieder zurueckzufuehren. dieser vorgang ist den beauftragten bekannt. wesentlich ist, dass der fuehrer eine genehmigung nicht $z u$ der evakuierung, sondern zur abfuehrung in die kriegsgefangenschaft gegeben hat. die zurueckgefuehrten werden daher auch nicht im arbeitseinsatz sauckel verwandt, sondern bleiben kriegsgefangene und werden im kriegsgefangeneneinsatz verwendet, die bestimmungen, die fuer die englischen kriegsgefangenen bestehen, gelten auch fuer die niederlaendischen kriegsgefangenen. gerade aus verschiedenen ueberlegungen heraus hat das okw. daher das international korrekteste verfahren angeordnet.

der reichskommissar wie der wehrmachtbefehlshaber legen groessten wert darauf, dass nach moeglichkeit - alle - ehemaligen soldaten zurueckgefuehrt werden sollen. freistellungen werden mit deutschen dienststellen besprochen. ich gebe ihnen daher fuer ihre unterrichtung folgende anhaltspunkte:

1. das okw. will grundsaetzlich den raum frei haben von ehemaligen gedienten niederlaendischen soldaten.

2. ehemalige niederlaendische soldaten, die den jahrgaengen 1912 bis 1918 angehoeren und angehoerige der jahrgaenge 1907 bis 1911 soweit sie ledig sind, sind von jeder freistellung ausgenommen. die gleiche regelung gilt fuer reserveoffiziere.

3. fuer die freistellung kommen lediglich schluessel- und fachkraefte in frage, die in der nach hier verlagerten kriegsproduktion unbedingt notwendig sind.

4. sollten trotzdem schon jahrgaenge, die in punkt 2 genannt sind, freigestellt worden sein, so findet eine ueberpruefung durch die zustaendigen verantwortlichen dienststellen statt (z.b. ruestungbetriebe, durch die der ruestungs- und beschaffungskommission, ernaehrung und landwirtschaft durch deren organe).

5. von der rueckfuehrung sind ausgenommen:

mitglieder der $\mathrm{nsb}$, funktionaere der naf und des niederlaendischen volksdienstes und die mitglieder der niederlaendisch-deutschen kulturgemeinschaft.

6. fragen, die im oertlichen raum nicht geklaert werden koennen, sind $\mathrm{pg}$. $\mathrm{s} \mathrm{chue} \mathrm{mann}$ telefonisch unter den haaig 183410 , apparat 2770 mitzuteilen, bezw. schlage ich vor, sich mit pg. schuemann direkt in verbindung $z \mathfrak{u}$ setzen.

7. fuer die freizustellenden werden ausweise ausgegeben und zwar:

a) ein allgemeiner ausweis, den die wehrmacht herausgegeben hat,

b) ein ausweis der ruestungsinspektion,

c) drei ausweise der hauptabteilung ernaehrung und landwirtschaft (gelb fuer die landwirtschaft, gruen fuer die landwirtschaftliche industrie und rot fuer deren verwaltung),

d) nach genehmigung des wehrmachtbefehlshabers und meiner dienststelle hat die nsb. einen eigenen ausweis herausgebracht.

e) die ausweise der wehrmacht und der ernaehrung und landwirtschaft muessen darueberhinaus mit der kennkartennummer gezeichnet sein. bei dem ausweis der wehrmacht ist diese nummer rechts oben einzusetzen, waehrend die nsb-ausweise nur in verbindung mit dem mitgliedsbuch gueltig sind.

8. jeder freigestellte hat dem aufruf des wehrmachtbefehlshabers folge $z u$ leisten und hat an den zu bestimmenden platz zu stellen. an ort und stelle wird er aufgefordert, seinen ausweis bezw. die kennkartennummer, stammbuch der nsb. usw, vorzuzeigen. nach aufnahme seiner genauen personalien und pruefung seines ausweises kommt er anschliessend wieder zur entlassung. 
9. alle studenten, die vor dem 5. mai 1943 die loyalitaetserklaerung abgegeben haben und im besitze des bestaetigungsvermerkes der zustaendigen universitaet oder hochschule sind, sind ebenfalls von der ueberstellung in die kriegsgefangenschaft ausgenommen.

10. alle die, die zur gestellung aufgefordert sind, haben ihre kenn- und stammkarten bei sich $z u$ fuehren.

11. die zurueckfuehrung der kriegsgefangenen wird einige wochen in anspruch nehmen.

12. niederlaender, die

a) die deutsche staatsangehoerigkeit erworben haben und darueber hinaus noch die niederlaendische besitzen,

b) den antrag auf erwerb der deutschen staatsangehoerigkeit gestellt haben,

sind ebenfalls von der rueckfuehrung ausgenommen und muessen hierueber eine bescheinigung der dienststelle des generalkommissars fuer verwaltung und justiz (abtlg. fuer angelegenheiten deutscher staatsangehoeriger) vorlegen.

ich bitte, hierueber die amtlichen beratungsstellen $z \mathfrak{u}$ unterrichten.

13. bezueglich des oeffentlichen dienstes wird auf das fernschreiben des sonderbeauftragten fuer die gesamten besetzten niederlaendischen gebiete vom 9. 5.1943 bezug genommen.

14. nach ruecksprache mit dem chef des stabes beim wehrmachtbefehlshaber, general von w uelisch, sind ebenfalls von der ueberstellung in die kriegsgefangenschaft alle grensgaenger die am 23. 4. $1943 \mathrm{im}$ reich einen festen arbeitsplatz inne hatten. freizustellen.

heil hitler!

$\mathrm{sch}$ m id t

generalkommissar

\section{Rapport van A. A. M. Stoetzer, districtleider van de NSB in Noord- Brabant}

\section{RAPPORT OVER DE GEBEURTENISSEN IN DE PROVINCIE NOORD-BRABANT TUSSEN DONDERDAG 29 APRIL, EN WOENSDAG 5 MEI}

Dit rapport is samengesteld uit gegevens, verstrekt door de kringleiders en groepsleiders van de NSB., de plaatselijk leiders en sociale voormannen van het N.A.F. en de buurtboerenleiders van de Nederlandse Landstand.

Over verschillende plaatsen konden nog geen gegevens verzameld worden, daarom zal nog een aanvullend rapport worden samengesteld, waarin tevens nog binnengekomen gegevens over de plaatsen, waarover in dit verslag wel gesproken wordt, verwerkt zullen worden.

\section{ALGEMEEN}

De onrust op 29 en 30 April brak uit naar aanleiding van de publicatie van den Wehrmachtbefehlshaber. Dit was echter niet meer dan een aanleiding om het volk zijm lang opgekropte 
opstandigheid te doen uiten. Men heeft verzuimd deze opstandigheid te keeren door doeltreffende straffen enerzijds en door maatregelen o.a. op sociaal gebied anderzijds. Bovendien heeft men verzuimd overheidsdiensten, die volkomen onbetrouwbaar waren, uit te zuiveren of om te zetten.

De slappe houding van de artsenkwestie heeft het volk in de waan gebracht, dat met een massale actie iets te bereiken was. Typerend hiervoor is een pamflet, waarvan afschrift bij dit rapport wordt gevoegd. ${ }^{1}$ ) (Zie bijlage 1) ${ }^{2}$ ).

De vorm van de publicatie van den Wehrmachtbefehlshaber was ook gedeeltelijk schuld aan de uitbrekende onrust. Verschillende kleinere en grotere bijkomstige omstandigheden makkte het moment van publicatie bovendien zeer ongunstig. Ik wil b.v. wijzen op het feit, dat de menschen in het voorjaar altijd meer moed hebben en meer op avontuur belust zijn. Bovendien was in de meeste plaatsen de voedselvoorziening (boter en groenten) al wekenlang volkomen vastgelopen. Ook de stand van de oorlog gaf de mensen hoop op een succesvolle actie.

Het eigenaardige verschijnsel, dat het platteland speciaal in de katholieke provincies, meer in bewreging kwam dan in de grotere steden is op de eerste plaats terug te voeren op de agitatie van de R.K. geestelijkheid. Wel kan in het algemeen niet van een georganiseerde actie gesproken worden, maar er is toch reeds sinds geruime tijd een systematische actie, vooral door de jongere geestelijkheid, voor sabotage en opstand gevoerd. Deze actie kon in verschillende steden vastknopen aan hele- of halve-communistische kernen in diverse bedrijven.

Vooral op het platteland heeft bovendien de ondermijning van elke gezag en elke overheidsinstelling door burgemeesters en andere wereldlijke en geestelijke autoriteiten funeste gevolgen gehad. De boer is zodanig illegaal geworden, dat alleen de angst voor harde straffen hem terughoudt van a-sociale handelingen. Dat overigens de opstandigheid van den boer niet voortkwam uit vaderlandsliefde, blijkt wel uit het feit, dat hij terstond van de gelegenheid profiteerde om extra winsten te maken door boter te karnen van de achtergehouden melk en door graan te laten malen voor de zwarte handel. Op verschillende plaatsen stalen de boeren bovendien elkanders melkbussen.

Het is begrijpelijk dat het publiek in de stad op verschillende plaatsen melkwagens bestormden, daar zij zagen, dat de normale voorziening in de war liep. Hier was meer sprake van zelfbediening dan van opstand.

Vastgesteld moet worden dat op Donderdag en Vrijdag vele burgemeesters en Betriebsführers door hun passieve houding of zwijgende goedkeuring er toe hebben bijgedragen, dat de staking doorzette. Toen $z \mathrm{ij}$ later begrepen, wat $z \mathrm{ij}$ eigenlijk riskeerden, traden $z \mathrm{ij}$ in het algemeen wel op, maar toen was de eenmaal in beroering gekomen massa niet gemakkelijk te stuiten.

Het feit, dat terstond het gehele apparaat van den voedselcommissaris uitviel, bevorderde natuurlijk de ongebondenheid op het platteland. Practisch alle plaatselijke bureauhouders verzaakten hun plicht, evenals de ambtenaar van de C.C.D.

Daar, waar door direct ingrijpen en door het spreken van duidelijke woorden goedwillende burgemeesters en Betriebsführers trachten de onlusten te voorkomen, is in het algemeen de opstandige beweging beperkt gebleven. Daar op vele andere plaatsen de onruststokers vrij spel hadden, sloeg de onrust gemakkelijk over op hun gemeenten of bedrijven.

Bij het ontstaan van de onlusten kunnen we een merkwaardige wisselwerking constateren van zenuwachtigheid en opstandigheid, van geruchten en feiten. Vele lieden waren op

1) Volgens mijn mening heeft men ook verzuimd om het volk tot nu toe de toestand waarin het verkeerde, duidelijk genoeg voor ogen te stellen. Ook de zeer verwarde gezagsverhoudingen in ons land, de vele door elkaar heen werkende instanties en gezagsdragers, droeg er toe bij, dat het volk op een dergelijke onverantwoordelijke en uitgezichtsloze manier in verzet kwam. (Noot van de auteut).

2) De Bijlage is hier niet afgedrukt. 
Donderdag 29 April in de veronderstelling dat zij reeds zeer spoedig (de volgende dag), in krijgsgevangenschap teruggevoerd zouden worden. $Z_{i j}$ wilden daarom naar huis om een en ander te regelen, en liepen uit hun bedrijven en werkplaatsen weg. Zo ontstond het praatje van de staking, dat nog gestimuleerd werd door illegale pamfletten, aanplakbiljetten enz. Het ene bedrijf vertelde van het andere dat het staakte. De ene stad vertelde van de andere dat er formeel oproer was. Toen b.v. in een plaats de waterleiding een ogenblik uitviel, was dit terstond door de gehele provincie bekend, met het gevolg dat de mensen overal water gingen aftappen. De waterleiding kon dit niet bijhouden, het water liep een ogenblik niet meer en nieuwe geruchten over nieuwe stakingen deden de ronde.

Ik ben er van overtuigd dat slechts zeer weinigen een werkelijk opstandige actie wilden voeren. Allen waren echter blij eindelijk eens iets te kunnen doen. Natuurlijk waren terstond ook weer de geruchten present over een grote invasie, het afwerpen van wapens door Engelse vliegtuigen, enz.

Zeer merkwaardig is verder, dat de stakers zelf Utrecht als het centrale punt beschouwden. Zo staakte b.v. het P.T.T.-personeel te Eindhoven zgn. op een sein uit Utrecht; in dezelfde geest lieten zich stakers in enkele dorpen uit. Te Mierlo werd gezegd, dat er telefonische seinen uit Amsterdam en Zaandam ontvangen waren.

De stakingen zijn in die plaatsen het meest langdurig en algemeen geweest, waar geen Wehrmacht of N.S.B. aanwezig was en waar uit de bevolking nog nooit mensen als gijzelaar of politiek misdadiger opgepakt zijn.

Tot Zondag $2 \mathrm{Mei}$ werden practisch geen tegenmaatregelen genomen. Ik veronderstel dat de betrokken autoriteiten nog geen overzicht over de actie hadden. Op Zondag 2 Mei werd door den Gewestelijken politie-president, kameraad Kooymans, aan de burgemeesters opdracht gegeven om de voorzitters en secretarissen van de coöperatieve fabrieken en/of de bestuursleden van de R.K. jonge Boerenstand te arresteren om deze te gebruiken als een soort gijzelaars voor het herstel van de melklevering. Deze maatregel bleek effectief te zijn, want Maandag was er reeds een aanzienlijke verbetering te bespeuren, terwijl Dinsdags practisch alles weer normaal was.

Bovendien werden in de loop van Zondag en Maandag verschillende andere personen door de S.D. of door enkele burgemeesters, op eigen initiatief vastgezet. Toen bovendien tot de bevolking doordrong welke scherpe maatregelen (doodvonnissen) elders in het land en in Eindhoven genomen waren, was de rust snel hersteld.

Met weinige uitzonderingen was de stemming onder het volk tijdens de onlusten niet kwaadaardig. Men kon rustig in N.S.B.-uniform onder de stakers gaan en op enkele plaatsen gelukte het zelfs geuniformeerde N.S.B.-kameraden om de stakers tot rede te brengen. Het overvalcommando van de S.D. boezemde bovendien een heilzame schrik in.

(Een stemmingsbericht van den boerenleider der provincie is als bijlage 2 bij dit verslag gevoegd) 1).

De stemming van het volk na het gebeurde is moeilijk te bepalen. In het algemeen wordt er alleen maar gesproken over het gemis aan boter en vlees. Bovendien voelt het volk zich bedrogen, omdat deze actie wederom tot niets heeft geleid. Ze hebben weer eens gezien, dat de ophitsers achter de schermen zich gedekt houden. Op sommige plaatsen is de stemming zelfs meer anti-Engels geworden, omdat de bevolking in het naieve vertrouwen geleefd had, dat men van de overkant hulp zou krijgen.

Wel is men in het algemeen verontwaardigd over het feit dat van de Philipsfabrieken te Eindhoven alleen vier gewone arbeiders en een kleine kantoorbediende doodgeschoten zijn. Het volk weet daar en elders grotere schuldigen aan te wijzen.

Hoewel de stemming door een en ander niet meer anti-N.S.B. geworden is dan die reeds was, zal de propaganda toch veel moeilijker worden. Nodig schijnt mij in ieder geval, dat vele min of meer hooggeplaatste personen, die zich bij deze gebeurtenissen bloot gegeven hebben, alsnog aangepakt worden.

1) Hier niet afgedrukt. 
Nodig is ook dat het Nationaal Socialisme meer directe invloed op het volk krijgt, o.a. door het bezetten van die posten, die midden in het volk gelegen zijn. Op het platteland is in dit opzicht de werkkring van de plaatselijke bureauhouders van den voedselcommissaris belangrijk. Het gehele apparaat van Louwes heeft zich in onze provincie wel zo onbetrouwbaar getoond, dat hier straf moet worden ingegrepen. Ook bij de politie dient nog veel verbeterd te worden.

De vervanging van enkele burgemeesters moet noodzakelijk volgen, terwijl ook enige Betriebsführers uit hun bedrijven gezet dienen te worden ${ }^{1}$ ).

\section{Telexbericht van de Reichsführer-SS, H. Himmler aan H, A. Rauter, d.d. 9,5 1943}

SS-Gruppenführer $\mathrm{R}$ a u te $\mathrm{r}$

Den Haag / Holland

\section{Lieber Rauter!}

Ich spreche Ihnen und Ihren Männern für das umsichtige und tatkräftige Durchgreifen bei dem von einer verbrecherischen Emigranten Regierung angezettelten Generalstreik und die rasche Niederschlagung desselben meine volle Anerkennung aus.

Ich trete mit grösstem Nachdruck für die Einziehung der Radio-geräte ein. Seien sie sich darüber klar, dass eine Unterlassungssünde, die jetzt in diesem psychologisch günstigen Zeitpunkt nach Niederschlagung des Generalstreiks begangen würde, so leicht nicht wieder gutzumachen wäre.

Heil Hitler

Ihr

Berlin, den 9. Mai 1943.

H. Him m le r

\section{Rapport van de Befehlshaber der Sicherheitspolizei und des SD, Den Haag, III B, d.d. 12-5-1943}

Den Haag, den 12. Mai 1943.

Betrifft: Vorgeschichte der Streikbewegungen in den Niederlanden.

Die Ürsachen zu den Streikbewegungen, die durch die Bekanntmachung des WBN vom 29.4.43 über die Rückführung des niederländischen Heeres in die Kriegsgefangenschaft aus-

1) De rest van dit rapport, handelend over plaatselijke toestanden, is hier niet afgedrukt. 
gelöst wurden, liegen tiefer und weit zurück. Nachdem in den Maitagen 1942 die aktiven Offiziere und Kadetten der ehemaligen niederländischen Wehrmacht in ein Kriegsgefangenlager überführt worden waren, wollten die Gerüchte nicht verstummen, dass dieses gleiche Los zu gegebener Zeit auch die Reserve-Offiziere und Unteroffiziere treffen würde. Diese Gerüchte riefen in der Bevölkerung naturgemäss immer wieder Aufsehen hervor. Dazu kam die sich immer stärker bemerkbar machende Arbeitsverpflichtung nach Deutschland, die die Widerstandskreise dazu bewegte, scharf gegen diese deutschen Massnahmen Stellung zu nehmen. Hier war es besonders die katholische Kirche, die in eifriger Arbeit bei ihren Anhängern versuchte, diese davon abzubringen, sich nach Deutschland vermitteln zu lassen. Selbst die Bischöfe nahmen in einem Hirtenbrief zu dieser Frage Stellung und trugen so das ihre dazu bei, die gesamte Stimmung und Lage zu trüben, wobei diese Hetze ihren Höhepunkt in dem Hirtenbrief vom Februar 1943 erreichte. Dieser Hirtenbrief veranlasste z.B. Verwaltungs- und Polizeibeamte, gegen die Verschickung niederländischer Arbeiter ins Reich zu protestieren und ihre Mitarbeit zu verweigern. Die Besatzungsmacht sah sich gezwungen, gegen eine Reihe von Beamten disziplinärisch vorzugehen. Auch die calvinistische Kirche liess es sich nicht nehmen, in vielleicht noch schärferer Form gegen die Arbeitsverschickung nach Deutschland zu hetzen. Aus diesen Gründen entstand eine ungewöhnlich feindselige Stimmung in der Bevölkerung, die sich nun nicht mehr - wie bislang - gegen die niederländischen Nationalsozialisten und die NSB, sondern nun in erster Linie auch gegen das Reich und die Besatzungsmacht richtete. Diese Haltung der Bevölkerung wurde noch genährt durch die dauernden Sendungen der englischen Sender und Radio Oranjes. Der überwiegend grössere Teil der Bevölkerung hörte regelmässig diese Sendungen ab und tat das seine, um sie in Gerüchtsform weiterzuverbreiten. Insbesondere wurden auch die Reden der Königin und der Regierungsmitglieder immer wieder abgehört.

In diesem Zusammenhang muss auf einen weiteren Faktor hingewiesen werden, der dazu angetan war, das Verhältnis von der Besatzungsmacht zur Bevölkerung zu stören, nämlich die Gerüchte von einer bevorstehenden alliierten Invasion grossen Stils in die besetzten Westgebiete. Widerstands- und nationale Organisationen nahmen diese Gerüchte immer wieder zum Anlass, Bewregungen aufzuziehen, mit dem Ziele, bei einer eventuellen Invasion aktiv in den Kampf einzugreifen. Es erübrigt sich wohl, darauf hinzuweisen, dass derartige Organisationen ihre Mitglieder meistens aus Kreisen der ehemaligen Offiziere der Wehrmacht rekrutierten. Dass zwischen diesen Organisationen und der CPN Bindungen bestanden, zeigt ihre Gefährlichkeit. In diesem. Zusammenhang muss auch auf den Streik vom Februar 1941 in Amsterdam hingewiesen werden, der von der CPN als eine Art Probe für einen zukünftigen Generalstreik inszeniert wurde und der nur durch rücksichtsloses Eingreifen der Deutschen Polizei im Keime erstickt werden konnte.

Diese Faktoren veranlassten den Reichskommissar und seine Generalkommissare, die Frage zu erörtern, ob es zweckmässig sei, in einem Küstengebiet, das so dicht bevölkert ist und auf welches mit einem Angriff der Alliierten gerechnet werden muss, die wehrhaften Jahrgänge der ehemaligen niederländischen Armee weiter unbekümmert in Freiheit zu belassen. Zweifellos ist anzunehmen, dass im Falle einer Invasion die Alliierten sich dieser voll ausgebildeten Jahrgänge bedienen werden, gegen Deutschland zu kämpfen.

In der niederländischen Armee waren 320.000 Mann mobilisiert, wozu noch drei weitere noch nicht mobilisierte Jahrgänge mitsammen 240.000 Mann kommen. Es ist anzunehmen, dass von diesen 560.000 Männern sich bereits 100.000 Mann in Arbeitseinsatz im Reich befinden, sodass zirka 400.000 Mann übrig bleiben. Wenn man ausserdem noch berücksichtigt, dass ein grossẹr Teil dieser Jahrgänge in kriegswichtigen Industrien arbeitet, wie Bahn, Post, Gasund Elektrizitätswerke, so werden zirka noch 320.000 Mann übrig bleiben, die für eine Ueberführung ins Reich infrage kommen.

Bei der Betrachtung der Art und Weise, wie man diese Männer ins Reich überführen 
müsse, war man allgemein der Auffassung, dass eine Abschiebung im Wege des Arbeitseinsatzes auf grösste Widerstände stossen würde, während man sich einer militärischen Massnahme ohne weiteres unterwerfen würde. Man glaubte, dass sowohl die niederländischen Verwaltungsbehörden als auch die Kirchen dieser militärischen Auflage keinerlei Widerstand entgegensetzen würden. Nach Abschiebung ins Reich sollte dann unter allen Umständen versucht werden, den grössten Teil dieser Niederländer in Deutschland in der. Arbeitsprozess einzuschalten, was, wie allgemein angenommen wurde, ohne weiteres zu erreichen sei.

Aus den oben angeführten Gründen wandte sich der Höhere SS- und Polizeiführer Nordwest an den WBN mit der Anregung, die ehemaligen Angehörigen der niederländischen Wehrmacht in die Kriegsgefangenschaft zu überführen. Der Reichsführer-SS hat diesen Vorschlag des Höheren SS- und Polizeiführers Nordwest dem Führer vorgetragen und befürwortet. Der Führer war sofort einverstanden und hat die sofortige Durchführung genehmigt. Dies veranlasste den Wehrmachtbefehlshaber, am 29.4.43 seine Bekanntmachung herauszugeben, die dann zu den Unruhen führte.

\section{Rapport van de Befehlshaber der Sicherheitspolizei und des SD, Den Haag, III D 5, aan het Reichssicherheitshauptamt d.d. 13-5-1943}

III D $5-1832 / 43 \mathrm{~g}$

Gefertigt 13.5.43

1) An das

Geheim!

Reichssicherheitshauptamt

- III D 5 -

Berlir:

Betrifft: 1.) Bekanntmachungen des Wehrmachtbefehlhabers in den Niederlanden vom 29. und 30.4.1943 über die Rückführung des Berufspersonals der ehemaligen niederländischen Wehrmacht in die Kriegsgefangenschaft.

2.) Anordnung des Höheren SS- und Polizeiführers beim Reichskommissar für die besetzten niederländischen Gebiete vom 4.5.1943 über die Meldung von ehemaligen niederländischen Studierenden.

3.) Anordnung des Reichskommissars für die besetzten niederländischen Gebiete (Generalkommissar z.b.V.) vom 6.5.1943 über die Meldepflicht zum Zwecke des Arbeitseinsatzes.

4.) Tätigkeitsbericht der Hauptabteilung Soziale Verwaltung. 
Vorgang: Bericht B.d.S. Den Haag vom 19.4.1943 - III D 5 - 1832 / 43 g.

Anlagen: - 5 -

Bereits im hiesigen Bericht vom 19.4.1943 war darauf verwiesen worden, dass die Wehrmacht sich gegenüber dem Generalkommissar z.b.V. bereit erklärt hatte, eine Aktion unter dem Motto „Evakuierung der wehrfähigen Männer" zu starten. Der Wehrmachtbefehlshaber in den Niederlanden erliess dann auch am 29. und 30.4 .1943 die in Abschrift beigefügten Bekanntmachungen über die Rückführung des Berufspersonals der ehemaligen niederländischen Wehrmacht in die Kriegsgefangenschaft (Anlage 1 und 2). Als Auswirkung hiervon war eine Streikbewegung in den Niederlanden zu verbuchen, die im Lagebericht Nr. 142 vom 4.5.1943 näher behandelt ist. Im Verfolg energischer polizeilicher Massnahmen wie Standrecht u.ä., war es möglich, schnellstens überall die Arbeitsaufnahme wieder herbeizuführen.

Die innere Streikbereitschaft steht insbesondere im limburgischen Kohlengebiet im ursächlichen Zusammenhang mit den Ernährungsschwierigkeiten. Die Kumpels fahren in Ermangelung anderen Aufstrichs oder Wurst vielfach mit Marmeladebroten oder - wie in einem Falle mitgeteilt wurde - mit gekochten Kartoffeln belegten Broten zur Schicht ein.

Wie die Hauptabteilung Soziale Verwaltung mitteilt, ist vorgesehen, sämtliche ReserveOffiziere aus den Niederlanden zu entfernen und von den Jahrgängen 1905 bis 1911 unter dem Range eines Offiziers nur die Verheirateten hier zu belassen. Den unter diese Verordnung fallenden Männern, die in den Niederlanden belassen werden, werden seiten der Wehrmacht besondere Kriegsgefangenen-Ausweise ausgestellt. Die Hauptabteilung Soziale Verwaltung rechnet damit, dass auf Grund dieser Verordnung ca. 40.000 Männer dem Arbeitseinsatz im Reich zugeführt werden können.

Am 4.5.1943 erliess der Höhere SS- und Polizeiführer beim Reichskommissar für die besetzten niederländischen Gebiete eine Anordnung über die Meldung ehemaliger niederländischer Studierender (Anlage 3). Von den rund $6.000 \mathrm{zu}$ erfassenden Studenten haben sich bisher ca. 3.700 gemeldet. Obgleich die Meldefrist an sich vorüber ist, erhöht sich diese Zahl noch ständig, was nicht zuletzt auf die loyale Behandlung und gute Verpflegung im Lager Ommen zurückzuführen sein dürfte. Wie aus Briefen dieser Studenten an ihre Verwandten $z u$ entnehmen ist, ist die Stimmung im Lager gut und sie betonen befriedigt, dass sie nicht "gedrillt" werden.

Wenn diese Studenten einen ihrem Studium venwandten Arbeitsplatz im Reich erhalten, z.B.Mediziner in Krankenhäusern oder Apotheken, dürtten sie sich in ihtem neuen Atbeitskreis zweifellos schnell einleben und damit im Reich eine Ausrichtung für die Zukunft erhalten, die sich auch nach ihrer Rückkehr in die Niederlande nur positiv auswirken kann. Jedoch verlautet, die OT. will - entgegen den Vereinbarungen des Generalkommissars z.b.V. mit Gauleiter Sauckel - diese Studenten in Finnland zum Strassenbau einsetzen. Wegen der politischen Rückwirkungen müsste hiergegen nach hiesigem Erachten umgehend vorgebeugt werden.

Der Reichskommissar für die besetzten niederländischen Gebiete (Generalkommissar z.b.V.) erliess schliesslich am 6.5.1943 noch eine Anordnung über die Meldepflicht zum Zwecke des Arbeitseinsatzes aller Männer vom vollendeten 18. bis zum vollendeten 35. Lebensjahr (Anlage 4). Hierzu wurde zunächst der Jahrgang 1921 am 12. Mai aufgerufen. Die Hauptabteilung Soziale Verwaltung glaubt, alle 11/2 Wochen einen Jahrgang bearbeiten zu können, und sie hofft, von jedem Jahrgang mit ca. 80 . bis 85.000 Männern rund 10.000 zum Einsatz 
in Deutschland zu erfassen. Nach einer Geheim-Auweisung muss die Hauptabteilung Soziale Verwaltung die NSB-Angehörigen, WA-Leute u.ä. von einem Einsatz im Reich ausnehmen. Wohl können diese in den Niederlanden umgesetzt werden, soweit es sich nicht um Amtswalter u.ä. handelt.

Während dieser grossen Arbeitsbelastung der Hauptabteilung Soziale Verwaltung wurde deren bisheriger Leiter, SS-Untersturmführer $D r$. Apitz plötzlich abberufen und an seine Stelle trat ein Regierungsrat Dr. Jütting, der bisher bei der Arbeitseinsatzbehörde in Rotterdam tätig war. Auf der Hauptabteilung Soziale Verwaltung wird der Standpunkt vertreten, dass Dr. Apitz dem Generalkommissar z.b.V. „zu unbequem" war, da Dr. Apitz wiederholt auf Grund seiner ausgezeichneten Kenntnisse auf dem Arbeitseinsatzsektor Stellung gegen den Generalkommissar z.b.V. habe nehmen müssen. Tatsache ist, dass Dr. Apitz die jahrgangweise Erfassung bzw. Arbeitsbuchpflicht seit langem gefordert hat, da dies die einzige erschöpfende Möglichkeit sei, die Arbeitskräfte zu erfassen und deren Einsatz zu lenken, während sich der Generalkommissar z.b.V. hiergegen bisher stets "mit Rücksicht auf die politischen Auswirkungen" gewehrt hat. Nach dem Vorschlag des Dr. Apitz wären zweifellos die jetzigen Auswirkungen vermieden worden.

Der Tätigkeitsbericht der Hauptabteilung Soziale Verwaltung für den Monat April 1943 wird als Anlage 5 zur Kenntnisnahme übersandt.

2.) I C zum Austragen

3.) zurück an III D 5

\section{Telexbericht van de Rijkscommissaris, Dr A. Seyss-Inquart, aan alle Beauftragten d.d. 10-5-1943}

reichskommissar den haag, fs 5739 den 10. 5. $43 / 16.00$

an

a $11 \mathrm{e}$ beauftragten in den provinzen

amsterdam und rotterdari

ich bitte mir einen erfahrungsbericht ueber die streiktage einzusenden. derselbe soll in einer moeglichst kurzen form den ablauf der ereignisse darstellen, wobei nur die nach ihrer meinung wichtigsten einzelheiten festzuhalten sind. besonderes gewicht lege ich auf ihre meinung ueber die ursachen dieses streikes und folgerungen, die daraus zu ziehen sind. ich bitte daher fuer ihren taetigkeitsbereich insbesondere folgende fragen $z \mathfrak{u}$ pruefen:

1.) welches sind die hintergruende des streikes.

2.) was war die unmittelbare veranlassung, von wo ist er ausgegangen und in welcher weise hat er sich verbreitet. 
3.) welche ueberlegung veranlasste die streikenden $\mathrm{zu}$ ihrer handlung und welche ziele verfolgten sie.

4.) welchen umfang nahm der streik im verhaeltnis $z u$ den uebrigen betrieben und dienststellen ihres taetigkeitsbereiches ein.

5.) welchen einfluss hat die fuehrung der betriebe und dienststellen genommen beziehungsweise welche bedeutung hatte die unterlassung einer einflussnahme,

6.) welche moeglichkeiten bestanden fuer sie selbst, auf den lauf der ereignisse einfluss zu nehmen.

7.) wie funktionierte die zusammenarbeit im deutschen bereich und in welcher weise funktionierten die nachrichtenmittel fuer sie zu den zentralen beziehungsweise welche moeglichkeit bestand, nachrichten an die bevoelkerung weiterzugeben.

8.) wie war der einsatz und das verhalten der hier in frage kommenden staatlichen stellen und obrigkeitlichen dienststellen auf niederlaendischer seite.

9.) wie war das verhalten beziehungsweise der allfaellige einsatz der politischen parteien und ihrer mitglieder und formationen.

10.) unter welchem eindruck steht nunmehr die niederlaendische bevoelkerung ruecksichtlich des streikes und im hinblick auf die wiederholung einer solchen aktion.

11.) welche schlussfolgerungen ziehen sie aus diesen ereignissen fuer den fall einer feindlichen landung.

ich bitte sie auch ihre meinung ueber entsprechende vorkehrungen fuer wiederholungsfaelle besonders im falle einer landung anzuschliessen und insbesondere ein besonders unsinniges verhalten der streikenden, das letzten endes nur die niederlaendische bevoelkerung trifft, kurz zu erwaehnen. ich waere ihnen verbunden, wenn ich ihre mitteilung bis montag den 17. mai erhalten koennte.

im uebrigen haben der streik und die mit diesem zusammenhaengenden ereignisse gegenstand eingehender pruefungen $z \mathbf{u}$ sein und bitte ich sie in einem der wichtigkeit dieser fragen entsprechenden zeitraum mir ihre vorschlaege zu erstatten, welche aenderungen in personeller beziehung in der verwaltung und wirtschaft bezw. perlustrierung in den in frage kommenden bevoelkerungsschichten von ihnen fuer notwendig erachtet werden. bezueglich der letzteren fragen bitte ich sie das einvernehmen mit den uebrigen zustaendigen deutschen stellen vor berichterstattung herzustellen.

heil hitler!

se ys s-inquart 


\section{Rapport van de Beauftragte voor de provincie Zeeland, d.d. 11-5-1943}

1. Utsache der Streiks Ende April/Anfang Mai ist die wiederholte Aufforderung des Londoner Rundfunks, den Massnahmen der Deutschen Besatzung passiven Widerstand entgegenzusetzen.

Weil die Bevölkerung Zeelands im allgemeinen von einem solchen Widerstand nichts wissen wollte, bildeten sich einzelne Widerstandsorganisationen, besonders in der intellektuellen Schicht. Eine solche ist von mir bei den Bürgermeistern vor einiger Zeit ausgehoben worden (Bürgermeister von Gorinchem und 4 seeländische Bürgermeister). Betont muss hierbei werden, dass die Initiative fast nie innerhalb der Provinz ergriffen wurde, sondern meistens von Männern der holländischen Provinzen ausging, von wo auch immerfort Flugblätter kamen, die zum Widerstand aufforderten. Im vorigen Jahr war schon mal in Middelburg eine Widerstandsorganisation vom S.D. zerschlagen worden. Ich bin aber überzeugt, dass noch weitere derartige Organisationen bestehen, vielleicht in Zierikzee, Goes, Terneuzen und Hulst.

Dadurch, dass immer wieder die gefährlichsten Persönlichkeiten — die mir in dieser kleinen Provinz zumeist bekannt sind - als Geiseln festgenommen werden, wird die Festigung dieser Widerstandsorganisation verhindert. Ein grosser Fehler wird jedoch bei der Freilassung von Geiseln gemacht, indem man Krankheiten oder hohes Alter als Gründe zulässt. Diese Geiseln richten nach ihrer Freilassung sofort wieder Unheil an. Man soll vor jeder Freilassung den zuständigen Beauftragten fragen, denn er kennt die Männer meistens besser als der S.D. in Den Haag. (Der S.D. in der Provinz wird dabei auch nicht befragt!) Dagegen soll man auf Vorschlag der Beauftragten dann und wann einen weniger gefährlichen Geise] freilassen und dafür einen anderen an seine Stelle setzen. Bei vielen wirkt allein die Haft Wunder! Also:

1. Die gefährlichen Elemente in Haft halten, auch wenn krank oder zu alt.

2. Die weniger gefährlichen dagegen häufiger austauschen.

2. Veranlassung zum Streik gab die Bekanntmachung des W.B.N. über die Wiedereinziehung der Kriegsgefangenen.

Auffallend ist nun, dass die ersten Streiks am 30.4. alle in Betrieben mit unzuverlässigen Betriebsführen stattfanden, die schon längst als Geiseln hätten fort müssen, aber von der Rüstungsinspektion gehalten werden. Ich bin der Ansicht, dass die Leistungskapazität auch dann nicht leiden würde. Es sind dies Betriebsführer, die erst recht dann wieder streiken lassen werden, wenn irgendwo eine feindliche Landung erfolgt, wodurch dann unsere Truppen gebunden sind. Von einem organisierten Streik kann in der Provinz keine Rede sein. Weil dies nicht der Fall war und die Firmen für sich alleine standen, nahmen sie schon am gleichen oder nächsten Tage die Arbeit wieder auf. Das gleiche war der Fall bei dem Verwaltungspersonal des Elektrizitätswerkes der Provinz, wo aber auffallenderweise kein Arbeiter gestreikt hat.

Neben diesen Betriebsstreiks glimmten in den nächsten Tagen noch ein paar kleinere Betriebsstreiks vorübergehend auf, sie wurden aber durch das blosse Erscheinen der deutschen Polizei beigelegt. Wichtiger war schon das Streiken von Landarbeitern und Händlern auf der Insel Nord-Beveland - in der Bevölkerung auch "Klein England" genannt - Dieses Eiland, von aller Welt abgeschlossen, ist natürlich mit seinen sturen, konservativen Menschen den Auslassungen des Londoner Rundfunks mehr preisgegeben, zumal dort kaum Soldaten sind. Bei einzelnen dieser Menschen ist die Angst vor einer Wiedereinziehung als Kriegsgefangene Veranlassung gewesen, auch andere mitzureissen. Das konnte festgestellt werden. Als unserc Polizei mit einzelnen Schlägen die Arbeiter wieder an die Arbeit getrieben hatte, war alles wieder ruhig. Auf der Insel Nord-Beveland und in einer Gemeinde Süd-Bevelands habe ich daraufhin die Radioapparate einziehen lassen, auch sind einige Hetzer festgenommen worden. Nach Bekanntwerden des Standrechts hat niemand mehr gestreikt. 
3. Ueberlegung lag nur bei einigen Streikenden vor, die teils diese Gelegenheit wahrnahmen, um dem Gebot der

Londoner Regierung willfährig zu sein und der Besatzung Schwierigkeiten zu machen. Ihr Ziel war „Solidarität mit London!"

teils aber auch gegen die Wiedereinziehung persönlich

prostestieren wollten. Dies waren die Mitläufer. Sie hatten als Ziel lediglich "Nicht-Einziehung der Kriegsgefangenen, da sie nach eigener Ansicht bisher immer loyal mitgearbeitet hatten."

4. Der Umfang der Streiks im Verhältnis zu den übrigen Betrieben und Dienststellen war geringfügig.

5. Im allgemeinen haben die Führer der Betriebe und Dienststellen erst auf den Druck der deutschen Polizei hin die Streikenden zur Wiederaufnahme der Arbeit veranlasst. Gleiche Versuche der niederländischen Polizei schlugen fehl, ebenso die eines Bürgermeisters.

Die Unterlassung einer Einflussnahme seitens der Betriebsführer hat deswegen geringe Bedeutung gehabt, weil wir mit unserer Polizei sofort zugegen waren. Sie hätte aber grössere Bedeutung gewinnen können, wenn - wie schon vorher gesagt — der Streik organisiert gewesen wäre. Das hatten wohl auch die Betriebsführer gehofft.

6. Möglichkeiten für die Betriebsführer, auf die Ereignisse Einfluss zu nehmen, bestanden zweifellos auch vor unserem Eingreifen, sei es durch Zureden oder einzelne polizeiliche Festnahmen.

7. Die Zusammenarbeit im deutschen Bereich funktionierte ausgezeichnet. Die zugewiesene Polizei-Komp. mit einem ausgezeichneten Komp.-Chef arbeitete vorbildlich. Die Nachrichtenmittel funktionierten. Nachrichten für Flandern und Schouwen wurden von den Polizeiposten an den Fähren abgeholt und an die Bevölkerung (durch Bürgermeister) weitergegeben. Lediglich nach Nordbeveland bekamen wir die Nachrichten (z.B. Standrecht-Plakat) zu spät. Es. ist dort nut ein N.S.B.-er. Zweckmässig wäre auch dort die Einrichtung eines deutschen Polizeipostens. Dieser müsste uns aber zusätzlich von Den Haag zugewiesen werden.

8. Die staatlichen und obrigkeitlichen Dienststellen auf niederländischer Seite haben von den Streiks entweder $z u$ spät erfahren oder wussten nicht, was sie tun sollten oder wollten vielleicht erst die weitere Entwicklung abwarten. Jedenfalls waren wir meistens eher da, um die Ruhe und Ordnung wieder herzustellen.

9. Die N.S.B.-Stellen beschränkten sich darauf, uns - allerdings frühzeitig - Mitteilung zu machen, damit wir eingreifen sollten. Von den Obleuten der N.A.F. haben wir nichts bemerkt. Bisher wurde uns ein Fall bekannt, dass der Obmann selber mitstreikte; er wurde abgesetzt.

10. Meine Vertrauensleute - die nicht zur N.S.B. gehören - berichten mir, dass die Bevölkerung zunehmend Wut auf die Emigranten-Regierung und deren Rundfunk bekommen hat. Man gibt an, den englischen Rundfunk nicht mehr hören zu wollen; ob diese Absicht von langer Dauer sein wird, bezweifle ich allerdings, denn es gibt noch genügend fanatische Elemente, die das Volk zum Abhören englischer Sender verleiten werden (Geistlichkeit, Lehrer, Aerzte, Juristen, höhere Schüler usw.; Kommunisten gibt es hier kaum!). In absehbarer Zeit ist einen Streik, wenigstens in Zeeland, nicht zu denken, die Bevölkerung hat genug davon. Versuche dazu wird die Reaktion allerdings bei passenden Gelegenheiten unternehmen.

11. Die Reaktion bildet immer noch, bezonders angesichts einer feindlichen Landung, 
eine grosse Gefahr. Es gilt daher, diese reaktionär-fanatischen Elemente zu fassen und als Geiseln festzunehmen. Die ewigen Vorstellungen der zentralen Stellen des Reichskommissariats (Rüstungsinspektion, Landwirtschaft, Schulwesen, Aerzte, Juristen usw.) zur Nicht-Inhaftierung einzelner Personen ats militärischen und ernährungspolitischen Gründen müssen aufhören. (Die einzige Stelle, die gut funktioniert, ist die Verwaltung). Der Beauftragte sitzt sozusagen an der militärischen und ernährungspolitischen Front und wird in jedem Falle dafür sorgen, dass diese Grundlagen nicht gefährdet werden. Die deutschen Zentralstellen sind m.E. von der zentralistischen Krankheit der Niederlande angesteckt und machen dann sehr oft das, was die niederländischen Zentralstellen wünschen. Deren Absicht ist aber neben der Ernährung des Volkes auch die Erhaltung eines Widerstandsapparates in den Schlüsselstellen der wirtschaftlichen, landwirtschaftlichen und erzieherischen Sektoren des niederl. Volkes, eines Widerstandsapparates, der im Falle einer feindl. Landung den Deutschen schaden und dem Feinde nutzen soll.

Das Volk ist hier gewöhnt und dazu erzogen, führenden Männern zu folgen, weil es keine eigene politische Meinungsbildung und auch die N.S.B, nicht den Willen und die geistige Fähigkeit diese zu schaffen, hat.

Das Herz der Mehrheit des seeländischen Volkes ist bei den Deutschen, der Verstand aber bei den Männern, die die staatliche und geistige Macht über sie hatten und noch deshalb haben, weil das Volk noch nicht an einen Sieg Deutschlands glaubt. Vernunft aber kennt das Volk nicht.

Die N.S.B. kann wohl die staatliche Macht ausüben, damit ist zweifellos schon viel gewonnen, nicht aber die geistig-seelische wie die N.S.D.A.P. bei uns in Deutschland, denn dazu fehlen den Funktionären jegliche Grundlagen. Also müssen wir Deutschen auch diese geistig seelische Macht rücksichtslos zerbrechen.

Middelburg, den 11.5.1943.

M ünzer,

Beauftragter Zeeland.

\title{
49. Rapport van de Beauftragte voor de provincie Drente, d.d. 13-5-1943
}

\author{
Assen, den 13. Mai 1943.
}

An

den Reichskommissar für die besetzten niederl. Gebiete, Herrn Reichsminister Dr. Se y s s In q u a r t,

Den Haag.

Betr.: Erfahrungsbericht über die Zeit des Ausnahmezustandes und des Polizeistandrechts.

Wenn wir heute so ziemlich am Abschluss der Zeit des Polizeistandrechts stehen und gerade in den letzten Tagen die Möglichkeit hatten, uns in Ruhe die Frage vorzulegen, was wohl die Ursachen dieses plötzlichen Streiks gewesen sind, so können wir 2 besonders wichtige Momente feststellen: 
1. Die niederländische Bevölkerung hat bei verschiedenen Anlässen versucht, den Anordnungen der Besatzungsmacht nicht Folge zu leisten. Diese Versuche sind teilweise nicht ganz ohne Erfolg gewesen. Ich denke hierbei besonders an die Aerzte- und Studentenaktionen. Diese kleinen Erfolge sind von dem englischen Sender ausgenutzt worden und man hat die niederländische Bevölkerung dazu aufgefordert, sich weiterhin in jeder Weise passiv zu verhalten und sich auch dem Aufruf zum Arbeitseinsatz nach Deutschland $\mathrm{zu}$ widersetzen.

2. Der Aufruf des Wehrmachtbefehlshabers in den Niederlanden war in seiner Fassung viel $z u$ eng. Die Bevölkerung hätte unbedingt gleichzeitig wissen müssen, welche ehemaligen Soldaten von der Rückführung in die Kriegsgefangenschaft freigestellt würden. Ich bin der Ansicht, dass, da nur ein verhältnismässig geringer Prozentsatz von der Rückführung betroffen wird, der weitaus grösste Teil nicht mehr das geringste Interesse an irgendwelchen Gegenmassnahmen gehabt hätte.

Schon in den frühen Morgenstunden des 30.4. war der Streik von Overijssel nach der Provinz Drenthe übergesprungen. Zuerst der Milchstreik der Gemeinde De Wijk, einige Stunden später Streik der Torfarbeiter in der Gemeinde Odoorn und gegen Mittag der Streik des Postamtes Meppel sowie in den Nachmittagsstunden der Streik sämtlicher Firmen und Geschäfte der gleichen Stadt. Ich habe dann noch vom Haag aus veranlasst, wo ich zu einer wichtigen Sitzung bei der Rüstungsinspektion war, sämtliche grossen Firmen und Bürgermeister anzurufen und ihnen zu sagen, dass sie persönlich für die Ruhe und Ordnung und für die sofortige Beendigung des Streiks verantwortlich wären. Sollten sie dazu nicht in der Lage sein, so sähe ich mich veranlasst, den Ausnahmezustand auch für die Provinz Drenthe $z u$ erwirken.

Ich selbst hatte auf dem Nachhauseweg vom Haag, ehrlich gesagt, noch nicht daran geglaubt, dass schon am nächsten Morgen tausende von Bauern an dem Streik zur Nichtablieferung der Milch teilnähmen. - Ueber die Ursachen berichte ich später.

Am 1. Mai kamen dann jedoch Meldungen über Meldungen herein und zwar über Weigerung von Milchabgabe, Streik in den Molkereien, Sabotagefälle, wie z.B. Schienen von einer Kleinbahn entfernt, Telefonleitung durchgeschnitten, Brücken offen gedreht und Streiks in den Kartoffelmehlfabriken. Auch in der Torfindustrie im Südosten von Drenthe griff der Streik in grossem Masse um sich. In der Meierei Nijeveen bei Meppel wurden in der Nacht vom 30.4. zum 1.5. 2000 Liter Rahm und einige Maschinen vernichtet. Die Untersuchungen sind noch im Gange.

Das Polizeistandrecht, das gleichzeitig mit dem 1. Maj für die Provinz Drenthe erklärt wurde, konnte erst in den späten Nachmittagsstunden durch Plakatanschlag und teilweise zur gleichen Zeit durch die Presse der Bevölkerung mitgeteilt werden. Ich glaube, hier sagen zu müssen, dass der Sonnabendnachmittag und der Sonntag für die Uebersicht, ob gearbeitet oder nicht gearbeitet würde, ausserordentlich ungünstig waren, da verschiedene Molkereien $z$.B. am Sonnabendnachmittag und Sonntags aus kirchlichen Gründen nie gearbeitet haben. Dazu kommt, dass auch ein grosser Teil der Bauern am Sonntag die Milch nicht zur Ablieferung bringt, sondern erst am Montagmorgen mit der Montagmilch zusammen. Trotzdem habe ich er für notwendig gehalten, dass ein Teil der Sonntags nicht arbeitenden Molkereien ihren Betrieb aufnahm, damit die Milch, die schon am Sonnabend gemolken wurde, zur Verarbeitung kam.

In der Nacht vom 2. auf 3.5. erhielten wir dann die Meldung, dass in Elp, Gemeinde Westerbork, 5 Bauernhöfe und in der Gemeinde Gieten 1 Bauernhof brannten. Es handelte sich um Höfe von deutschfreundlichen Familien und ein Hof war der Besitz eines NSBers. Gegen 4 Uhr am 3.5. erhielten wir dann noch die Nachricht, dass die grosse Torfstreufabrik in Klazienaveen, Gemeinde Emmen, angezündet sei. 
Diese Brände, die weithin sichtbar waren. haben in den nachfolgenden Stunden nochmals die Streikbewegung auf den Höhepunkt gebracht. Durch rücksichtsloses Eingreifen in den frühen Morgenstunden bis zum Montagmittag ist es uns dann gelungen, in Drenthe die Ruhe und Ordnung wieder herzustellen.

Vom Sonnabend bis einschliesslich Montag wurden 85 Personen festgenommen und $z u$ einem Teil dem Polizeistandgericht in Groningen zugeführt. 40 Festgenommene werden heute noch vom Sicherheitsdienst verhört und bearbeitet, um dem ordentlichen Gericht vorgeführt zu werden. Durch das Polizeistandgericht wurden 4 Todesurteile bereits vollstreckt. Ausserdem wurden 5 Männer, die sich der Festnahme durch die Flucht entziehen wollten, erschossen und 2 verletzt.

Zu Ihren einzelnen Fragen, sehr geehrter Herr Reichsminister, darf ich wie folgt Stellung nehmen:

1. Welches sind die Hintergttïnde des Streiks?

Ich darf hier auf meine ersten beiden Punkte verweisen und noch dazu vermerken, dass die Bauern für sich eine Ausnahme erwartet hatten. Verschiedene erklärten mir, dass sie selbst und ihre Söhne doch für die Ernährung stets alles getan und sich zum grössten Teil nicht politisch betätigt hätten. Sie hätten erwartet, dass man ihre Arbeit, die ja auch letztenendes für die Besatzungsmacht wichtig sei, mit der Freistellung ihrer Männer anerkennen würde.

2. Was war die unmittelbane Veranlassung, von wo ist er ausgegangen und in welcher Weise hat er sich verbreitet:

Ich habe festgestellt und auch bestätigt bekommen, dass die Streikbewegung von Overijssel schon in den frühen Morgenstunden des Freitags nach Drenthe gekommen ist und hier in einem verhältnismässig schnellen Tempo aufgenommen wurde. Es ist auch bekannt, dass sich in den letzten Tagen fremde Elemente in grösserer Zahl in der Provinz aufgehalten und dass diese den Streik gerade bei den Bauern forciert haben. Verschiedene Batuern erklärten mir, dass sie von ihnen nicht bekannten Radfahrern aufgefordert worden seien, in den Streik zu treten. Man habe nicht nur die Milch nicht abliefern sollen, sondern es war auch die Aufforderung ergangen, Raps- und Kornfelder abzumähen und damit der Vernichtung preiszugeben. Das letztere ist in Drenthe nicht zur Durchführung gekommen.

Zur Verbreitung haben dann bestimmt noch das Telefon und die ausländischen Sender mitgeholfen.

Man kann auch wohl davon sprechen, dass die Stimmung des grössten Teiles der Bevölkerung von ca. 10 \% Hetzern ausgenützt worden ist, in der Annahme, dass nach dem wilden Streik auch der Generalstreik für die ganzen Niederlande folgen würde. Ich glaube auch, dass man aufgrund der schnellen Verbreitung von einer guten Organisation sprechen kann.

Wir dürfen auch nicht vergessen, dass die Kirche in letzter Zeit eine sehr aggressive Haltung angenommen hat und ihren Anhängern jede positive politische Mitarbeit in unserem Sinne verbietet.

3. Welche Uleberlegung veranlasste die Streikenden zu ihrer Handlung und welche Ziele verfolgten sie?:

Wie ich schon in Punkt 1 sagte, waren die Niederländer in ihrer Haltung durch verschiedene Teilerfolge gestärkt worden und glaubten nun, dass sie durch einen Streik auch die Rückführung der Soldaten in die Kriegsgefangenschaft verhindern könnten. Ich glaube allerdings nicht, dass sie $z \mathfrak{u}$ solchen Handlungen hingerissen worden wären, wenn sie gewusst hätten, dass wir solche scharfen Massnahmen treffen würden. Ich habe 
auch über diesen Punkt mit einigen Bauern gesprochen, die geflohen waren und mir nach ihrer Rückkehr erklärten, dass sie mit ruhiger Ueberlegung anders gehandelt hätten. Sie seien aber in den ersten Stunden über die Bekanntmachung des Wehrmachtbefehlshaber sehr aufgebracht gewesen.

Mann kann deshalb auch sagen, dass sie mit einer Art kindlicher Naivität in die ernste Situation hineingestolpert sind. Sie haben sich vollkommèn ungeschickt benommen und glaubten, sie würden ihren Dickkopf auch in diesen Dingen durchsetzen. Als allerdings die ersten Schüsse fielen, sind sie bis auf einige wenige wie die Hasen gelaufen. Diese wenigen waren Rädelsführer oder kirchlich fanatisch eingestellte Menschen.

4. Welchen Ulmfang nahm der Streik im Verhältnis zu den übrigen Betrieben und Dienststellen ihres Tätigkeitsbereiches ein?:

Der Streik der Behörden und öffentlichen Betriebe konnte zum grössten Teil verhindert werden. Einige kleine Streiks waren schon am Sonnabendmittag beigelegt. Der Streik in der Provinz Drenthe hatte hauptsächlich die Bauern, Landarbeiter und Arbeiter der Torfindustrie erfasst. In den Städten Assen, Hoogeveen und Beilen ist es überhaupt nicht zu einem Streik gekommen, obwohl ich es gerade in diesen Orten erwartet hätte.

5. Welchen Einfluss hat die Führung der Betriebe und Dienststellen genommen bezw. welche Bedeutung hatte die Unterlassung einer Einflussnahme?:

Bevor das Polizeistandrecht in der Provinz Drenthe bekannt wurde, hatten nur verhältnismässig wenig Betriebsführer und Behördenleiter versucht, den Streikenden entgegenzutreten. Man wollte angeblich abwarten, $z u$ welchen Gegenmassnahmen die Besatzungsmacht schreiten würde. Man wollte von sich aus auch im ersten Augenblick möglichst wenig unternehmen, um nicht so sehr den Eindruck zu erwecken, dass man im Grunde genommen gegen einen Streik sei. Man fürchtete die Wut der Bevölkerung. Als meine Dienststelle aber die telefonische Aufforderung an Betriebsführer und Behördenleiter gegeben hatte, änderte sich das Bild, da man jetzt sagen konnte, „wir haben einen Auftrag von der Besatzungsmacht und wir wollen verhindern, dass das Polizeistandrecht eingeführt wird." Bei diesen Männern hätte man vielleicht auch eine andere Haltung erwarten können, wenn wir in den Vormonaten hier und da etwas schärfer angepackt hätten. Ich habe aber festgestellt, dass die Betriebs - und Behördenleiter schon Initiative ergreifen, wenn wir sie für die Folgen persönlich verantwortlich machen. Ich habe dies besonders bei den Bürgemeistern wahrgenommen.

6. Welche Möglichkeiten bestanden für Sie selbst, auf den Lauf der Ereignisse Einfluiss zu nehmen?:

Bevor das Polizeistandrecht in Drenthe erklärt wurde, habe ich mit meinen Mitarbeitern, mit der Ordnungspolizei und dem Sicherheitsdienst dafür gesorgt, dass alle notwendigen Massnahmen schnellstens in der Provinz durch Bürgemeister, Behörden und Vertrauensleute bekannt wurden und dass uns gleichzeitig laufend Meldungen aus allen Teilen der Provinz zugingen. Die Meldungen wurden zentral bei der Ordnungspolizei entgegengenommen und in kurzen Stichworten schriftlich festgelegt.

Ich habe vor der Verhängung des Polizeistandrechts die Dienststelle nicht verlassen, sondern meine Referenten hier und da hinbeordert. Erst mit dem Eintreten des Polizeistandrechts habe ich es für notwendig gehalten, selbst mit in die Provinz hinauszufahren, um mir ein persönliches Bild zu machen und gleichzeitig der Bevölkerung und besonders den Bürgermeistern und anderen führenden Männern der Provinz zu zeigen, dass wir nicht nur in normalen Zeiten vollkommene Ruhe und Sicherheit bewahren, sondern dass wir auch dann unsere Anweisungen und Befehle erteilen können, wenn es einmal schärfer hergeht. Daneben war es notwendig, dass die Männer des Polizeiregiments Todt Leute zur Verfügung hatten, die die Provinz kannten und auch wussten, wie die Menschen in der Provinz Drenthe anzufassen sind. 
7. Wie funktionierte die Zusammenarbeit im deutschen Bereich und in welcher Weise funktionierten die Nachtichtenmittel für Sie zu den Zentralen bezw. welche Möglichkeit Bestand, Nachtrichten an die Bevölkerung weiterzugeben?:

Die Zusammenarbeit in deutschen Bereich zwischen Sicherheitsdienst, dem Chef des Sicherungsbereiches und meiner Dienststelle war ausgezeichnet. Es standen uns für die Provinz Drenthe nur rund 30 Mann des Polizeiregimentes Todt zur Verfügung. Man ersieht daraus, dass nicht die Zahl ausschlaggebend ist, sondern dass man sich auch mit wenigen Leuten bei der nötigen Härte und Rücksichtslosigkeit in solcher Zeit durchsetzen kann. Wir haben schwierige Fälle zusammen durchgesprochen und dann gehandelt. Es wurden auch Erfahrungen mit dem SD und der Polizei der beiden nördlichen Provinzen ausgetauscht und nach Möglichkeit alle Dinge telefonisch erledigt.

Der Fernschreiber nach Den Haag bezw. von Den Haag war sehr überlastet, sodass wir von hier aus schwer Meldungen nach dem Haag geben konnten. Es dürfte vorteilhaft sein, das bei kommenden Fällen die Möglichkeit gegeben wird, zu jeder Stunde, auch nachts, Meldungen telefonisch durchzugeben.

Die Nachrichten der Bevölkerung zu übermitteln, stiess auf verschiedene Schwierigkeiten.

a) Die Plakatierung des Polizeistandrechts konnte erst bis in die späten Nachmittagsstunden des Sonnabends in der Provinz durchgeführt werden. Es wird notwendig sein, die Plakate in der Provinz selbst herzustellen, damit nicht die Zeit des Transportes vom Haag nach hier verloren geht. Die Austeilung der Plakate muss durch die Marechaussee vor sich gehen, die dann allerdings Benzin für die Motorräder zur Verfügung haben muss. Vielleicht lässt es sich ermöglichen, für einen Sonderfall etwas Benzin beim Polizeioffizier der Provinz zu belassen.

b) Die Presse kommt in der Provinz Drenthe ausserordentlich langsam zur Verteilung, da die Zeitungen erst mit dem Zug und dann noch mit Autobussen bezw. mit Fahrrädern befördert werden müssen. Eine schnellere Verteilung dürfte auch in ernsten Zeiten auf Grund der schlechten Verkehrsverhältnisse nicht möglich sein.

c) Lautsprecheranlagen stehen nur in kleinstem Masse zur Verfügung. Ich werde aber darauf hinarbeiten, diese $z \mathfrak{u}$ vergrössern, damit man wenigstens in einigen Städten die Bekanntgabe durch Lautsprecher vornehmen kann. Es wäre auch zu prüfen, ob man über Lautsprecheranlagen den Distributieapparat einschalten kann, damit auf diesem Wege ein grosser Teil der Bevölkerung laufend über Radionachrichten Kenntnis erhält. $Z u$ wünschen wäre es auch, dass wir in der ländlichen Provinz einen Lautsprecherwagen zur Verfügung hätten, der auch in die entlegensten Dörfer die Nachrichten und notwendigen Bekanntmachungen schnellstens bringen kann. Sollte ein Lautsprecherwagen nicht zur Verfügung stehen, so wäre $z u$ überlegen, ob man eine solche Anlage nicht in einen Wagen, der zu unserer Dienststelle gehört, einbauen kann.

d) Die Bekanntmachungen der Urteile des Standgerichtes müssen nicht für die 3 Nordprovinzen in Groningen gedruckt werden, sondern in jeder Provinz für sich, damit auch diese Plakate durch die Marechaussee schnellstens angeschlagen werden. Ich habe eine gut funktionierende Druckerei bereits schon dem Sonderbeauftragen für die Niederlande genannt und darf hierbei nochmals darum bitten, uns das Klischee eines Hoheitszeichens zur Verfügung $z u$ stellen, damit dieses sofort zur Hand ist.

8. Wie waren der Einsatz und das Verhalten der hier in Frage kommenden staatlichen Dienststellen und obrigkeitlichen Stellen aut niederländischer Seite?:

Der Einsatz der niederländischen Polizei, besonders der Marechaussee kann im Grossen und Ganzen als gut bezeichnet werden. Die Männer der Marechaussee haben teilweise sehr gut gearbeitet, wenn sie im Rücken die deutsche Ordnungspolizei hatten. Auf sich alleine 
angewiesen, wurde es einzelnen Marechausseebeamten schwer gemacht, sich voll für uns einzusetzen, da sie fürchteten, von der Masse der Bevölkerung falsch beurteilt zu werden. Ich kann aber betonen, dass der niederländischen Kriminalbeamte de Kruiff glänzend mitgearbeitet hat und dass es seiner Initiative zu danken ist, dass wir sehr schnell den Brandstifter von 5 Bauernhöfen fassen konnten. Ich habe in einem Sonderbericht auch darum gebeten, ihn vorzugsweise $z \mathfrak{u}$ befördern.

Der Vizepräsident des Landgerichts in Assen, Herr Baron von Imhoff, hat unsere Arbeit auch sehr unterstützt. Der grösste Teil der Bürgermeister hat auch nach Kräften versucht, Einfluss auf die Bevölkerung $z \mathfrak{u}$ nehmen, um den Streik niederzuschlagen. Ich habe allerdings 4 Bürgermeister an den Sonderbeauftragten für die Niederlande gemeldet und gebeten, diese zu entlassen. Der Sonderbeauftragte hat bereits zugestimmt.

Die Zusammenarbeit mit dem Kommissar der Provinz war als sehr lose zu bezeichnen, da ich aufgrund der Erfahrungen der letzten Monate nicht die Gewissheit hatte, dass meine Wünsche der Zeit entsprechend schnellstens erledigt würden. Ich kann auch feststellen, dass der Provinz-Voedselkommissar in Drenthe gut mitgearbeitet hat und die örtlichen Bürohalter telefonisch dazu aufforderte, bei der Niederschlagung des Streiks mitzuwirken. Der Voedselkommissar erklärte mir, dass diese verhältnismässig gute Mitarbeit in den ersten Tagen auf das scharfe Anfassen von ca. 20 Bürohaltern vor einigen Wochen durch meine Dienststelle zurückzuführen sei.

9. Wie war das Verhalten bezw. der allfallige Einsatz der politischen Parteien und threr Mitglieder und Formationen?:

Die Führung der NSB ist in der Provinz Drenthe nicht in Erscheinung getreten, da der Distriktleiter Dieters zur Waffen-SS eingerückt ist und sein Stellvertreter angeblich in Groningen tätig war.

Ein grösserer Teil der NSB, besonders der WA und der SS, hat sich den NSB- und gut gerichteten Bürgermeistern sowie meiner Dienststelle zur Verfügung gestellt. Ich kann wohl sagen, dass dieses Zurverfügungstellen aus eigener Initiative entstand und zeigte, dass diese Männer auch in ernsten Tagen $z u$ uns stehen.

Ganz ausgezeichnet hat der Landstand bei mir mitgearbeitet. Der Provinzbauernführer hatte gute Verbindungen mit seinen Ortsbauernführern, die Meldungen hereingaben und auch Weisungen von mir über den Provinzbauernführer zur Kenntnis nahmen.

Die Niederländische Arbeitsfront hat, soweit es ihr möglich war, auch gut mitgearbeitet und versucht, Einfluss auf den Lauf der Dinge zu nehmen.

Ich werde bei einem wiederkehrenden Fall diese beiden Organisationen sowie den NVD noch mehr benutzen, um Weisungen möglichst schnell in die Provinz zu bringen.

10. Unter welchen Eindruck stieht nunmehr die niederländische Bevölkerung tücksichtlich des Streikes und im Hinblick auf die Wiederholung einer solchen Aktion?:

Die Drenthsche Bevölkerung ist im Augenblick sehr zurückhaltend. Sie hat zu einem Teil vielleicht nicht aus Schlechtigkeit an dem Streik teilgenommen und geglaubt, dass man uns von der Rückführung der Kriegsgefangenen, soweit sie der Landbevölkerung angehören, abbringen könne. Ich glaube, sagen $z u$ dürfen, dass die Landbevölkerung zum grössten Teil inaktiv geblieben wäre, wenn man in der Bekanntmachung gesagt hätte, dass die Ernährungswirtschaft usw. freigestellt bleibt.

11. Welche Schlussfolgerungen ziehen Sie aus diesen Ereignissen füt den Fall keiner feindlichen Landung?:

Es sei dahingestellt, wie sich die Bevölkerung verhalten hätte, wenn auf den Höhepunkt des Streiks ein Landungsversuch unternommen worden wäre oder man gar durch Flugzeuge Waffen abgeworfen hätte. Ich glaube, dass wir dann mit einem sehr harten Widerstand $z u$ rechnen gehabt haben würden. 
In diesem Zusammenhang ist es sehr zu begrüssen, dass die Beschlagnahme der Radioapparate durchgeführt wird. Die getroffenen Massnahmen zur Unterdrückung der Streikbewegung haben der Bevölkerung gezeigt, dass wir undanks unserer friedlichen Bemühungen, um die Niederländer $z u$ einer besseren und gesünderen Einsicht $z u$ bringen, auch hart und unerbittlich sein können. Er würde dem Verständnis der Niederländer zugute kommen, wenn in Zukunft in unserer Politik klar und deutlich zum Ausdruck käme, wie die Stellung der Niederländer im europäischen Raum gedacht ist.

Gerade in den letzten Tagen hat mir der Bauernführer noch einmal versichert, dass die Bauern in den Niederlanden niemals um etwas gebeten wurden, oder sogar noch eine Belohnung für den Anbau besonders notwendiger Produkte erhalten haben. Die Bauern sind es gewohnt, Anordnungen und Befehle entgegenzunehmen.

Abschliessend darf ich Sie noch daron in Kenntnis setzen, dass die Nichtablieferung der Milch für die Provinz Drenthe folgende Verluste ergeben hat:

Die Ablieferung von Vollmilch in 3 normalen Tagen betrug rund 1050000 Liter. Am 1., 2. und 3. Mai, also in den 3 Tagen des Streiks, wurden nur 747000 Liter Milch zur Ablieferung gebracht. Das bedeutet einen Verlust von rund 303000 Liter Milch oder von rund $10000 \mathrm{~kg}$ Butter bei einem durchschnittlichen Fettgehalt von 3,3 bis 3,4\%.

S e $11 \mathrm{~m}$ e r.

50. Rapport van de Beauftragte voor de provincie Friesland, d.d. 14-5-1943

Leeuwarden, den 14. Mai 1943.

An den

Herrn Reichskommissar für die

besetzten niederländischen Gebiete

Den $\mathrm{Ha}$ ag.

Betr.: Erfahrungsbericht über die Streikfrage.

Bezug: Fernschreiben Nr. 5739 vom 10. Mai d.Js.

In der Nacht vom 29. zum 30. April d.Js. erfolgte in Leeuwarden ein Eisenbahnsabotageversuch. An 30.4.43 waren Teilstreiks der Behörden und einzelner grösserer Betriebe in Leeuwarden sowie Unruhen in vereinzelten Gemeinden auf dem Lande festzustellen.

Dadurch, dass die Bevölkerung in der Stadt Wasser hamsterte und die Läden leer kaufte, versagten zeitweilig die Wasserleitungen, obwohl beim Werk, wie sich nachher feststellte, überall gearbeitet wurde. Durch einen grösseren Teilstreik bei der einzigen Tageszeitung der Provinz konnte diese am 30.4. nicht erscheinen, sodass niemand von der Verkündung des Standrechts in den 4 Provinzen unmittelbar etwas erfuhr. 
Am 1.5. war die Streikbewegung in der Stadt fast ganz erledigt, während sie auf dem Lande sich an diesem Tage ausbreitete. Die Verkündung des Standrechts für Friesland konnte erst in der Stadt am 1.5. am Mittag, auf dem Lande z.T. erst in den Abendstunden erfolgen und auf den 4 friesischen Inseln, wo das Standrecht an sich nicht nötig gewesen wäre, erst am 2. bezw. 3.d.Mts.

Am 3.5.d.Js. war auf dem Lande beinah von einem Gesamtmilchstreik zu sprechen. Auch erfolgten in mehreren Gemeinden grössere Zusammenrottungen. Durch das energische Eingreifen der Polizeistreifen ging dann auch der ländliche Streik vom 3.5. abends ab zurück. um schliesslich mit Ablauf des 3.5. völlig aufzuhören.

$Z u$ den einzelnen Fragen nehme ich wie folgt Stellung:

Zu 1: Durch die Hetzsendung der fremden Sender und die Mundpropaganda war eine gewisse Unruhe schon vorher vorhanden. Bereits seit Wochen wurde in Flugblättern gegen einen Arbeitseinsatz in Deutschland gehetzt, insbesondere aber auch sogar gegen die Ausgabe der Freistellungsscheine durch die örtlichen Bürohalter des Ernährungskommissar. Vielleicht hätte sich der Streik vor allem auf dem Lande vermeiden lassen, wenn bei der Bekanntmachung über die Rückführung der Kriegsgefangenen auf die zahlreichen Ausnahmen sofort hingewiesen worden wäre. Insbesondere hätte mindestens einige Wochen vorher durch Mundpropaganda über den Landstand und Ernährungskommissar darauf hingewiesen werden müssen, dass die Freistellungsscheine in der Landwirtschaft grundsätzlich auch für die Kriegsgefangenen gelten würden. Als Anlage lege ich eine Stellungnehme eines deutschfreundlichen zuverlässigen Friesen bei. ${ }^{1}$ )

$\mathrm{Zu}$ 2: Die unmittelbare Veranlassung war die Bekanntmachung des WBN. über die Kriegsgefangenen. Eine Zentrale hat sich nicht ermitteln lassen, wohl aber besteht die Vermutung, dass z.Tl. von marxistischer Seite zum Streik auf dem Lande gehetzt worden ist. $\mathrm{Ob}$ ein Teil der Grossbauern, die sich am Streik positiv beteiligt haben, von der reformierten Geistlichkeit aufgehetzt worden ist, ist wohl möglich, hat aber an keiner Stelle nachgewiesen werden können.

$\mathrm{Zu}$ 3: Irgendeine Ueberlegung und ein gestecktes Streikziel waren weder bei den kleinen Behördenstreiks noch bei den Bauern- und Landarbeiterstreiks zu erkennen. Während und nach den Streiktagen habe ich mit vielen Männern vom Lande gesprochen und eigentlich überall meine eigene Auffassung bestätigt gefunden, dass es nichts sinnloseres gäbe, als diese Bauernstreiks. Gerade die für die Besatzungsmacht entscheidenden Einrichtungen wie Post (hier abgesehen von einem Teilstreik der Telefonistinnen am 30.4), Eisenbahn und die wichtigen Versorgungsbetriebe haben sich an dem Streik hier überhaupt nicht beteiligt.

Zu 4: In der Landwirtschaft sollen am 3.5. vielleicht $1 / 10$ am Streik beteiligt gewesen sein, an den anderen Tagen aber wohl nur noch $1 / 3$ bis $2 / 3$. Bei den staatlichen und kommunalen Dienststellen haben am 30.4. insgesamt vielleicht $1 / 4$ gestreikt.

Zu 5: Bei dem mehr oder minder allgemeinen Landwirtschaftsstreik konnten auch die vernünftigen deutschfreundlichen Bauern nichts ausrichten. Bei den Behörden war allerdings die Einflussnahme des Behördenleiters oft nicht zu verkennen. Während energische Persönlichkeiten auch am 30.4. jeden Streik $z \mathfrak{u}$ verhindern wussten, war bei anderen Dienststellen, z.B. der Verkehrsinspektion, der Einfluss des Behörden-

1) De Bijlage werd hier niet afgedrukt. 
leiters in negativer Hinsicht auch zu erkennen. Aehnliches dürfte bei dem Totalstreik am 30.4. beim Voedselkommissar auch zu gelten haben.

Zu 6: Durch Einflussnahme auf die Behördenleiter, Androhung entsprechender Massnahmen und Mitteilung von der Verhängung des Standrechts konnte eine Eindämmung der Streiklust erzielt werden. Auch haben die Aufrufe der Bürgermeister von Leeuwarden und Leeuwarderadeel, die von mir angeregt waren, sicherlich dazu beigetragen. dass hier alles ruhig blieb. Auch die hiesige Presse konnte schon am 1.5. durch mündliche Besprechungen entsprechend beeinflusst werden.

Zu 7: Die Zusammenarbeit im deutschen Bereich war hier durchweg ausgezeichnet, insbesonders funktionierten die Nachrichtenmittel zu allen Dienststellen gut. Die Aufklärung der Bürgermeister wurde dadurch erschwert, dass Telegramme des Kommissars der Provinz, die mit mir abgesprochen waren, eine Beförderungszeit von 4-5 Stunden benötigten. Die Veröffentlichung der Urteile des Standgerichts hätte z.Tl. noch einen Tag früher durch die Presse erfolgen können, wenn das Gericht nicht $z$ u sehr überlastet gewesen wäre.

$\mathrm{Zu}$ 8: Der Einsatz und das Verhalten der staatlichen und kommunalen Dienststellen von niederländischer Seite waren durchweg gut, bis auf einzelne Bürgermeister, die zu weiche Persönlichkeiten waren. In einzelnen Gemeinden hätten nach Ansicht der hier eingesetzten Polizeikräfte die niederländischen Polizeikräfte wesentlich energischer vorgehen müssen. Es wurden hierfür zu Unrecht die Bürgermeister verantwortlich gemacht. Von einem Eingreifen des Landespolizeipräsidenten in Groningen war hier nichts $z u$ bemerken.

Ein Brandstiftungsversuch in einem Arbeitsdienstlager und ein Eisenbahnsabotageversuch in der Gemeinde Achtkarspelen wurden durch die fraglichen Bürgermeister erst nach etwa 10 Stunden hierher gemeldet, da sie selber nicht vorher über die Vorfälle durch ihre Gendarmerie unterrichtet worden war.

Zu 9: NSB. und NSDAP. trat als solche nicht in Erscheinung. Einzelne Mitglieder der NSB. haben zur Unterrichtung der Polizeistreifen mit mehr oder minder sachlichen Angaben beigetragen.

$\mathrm{Zu}$ 10: Die deutschfeindlichen Kreise sollen diesen Streik als eine Art Generalstreik betrachtet haben und ist im Falle einer Landung sicherlich mit der Möglichkeit einer Wiederholung $z u$ rechnen.

$\mathrm{Zu}$ 11: Im Landungsfall müsste sofort das Standrecht und die völlige Strassensperre für die Dauer der Verdunkelung eingeführt werden. Bei grösseren Streikfällen und einzelnen Sabotageversuchen müsste dann strafweise die Sperrstunde gemeinde oder provinzweise noch mehr ausgedehnt werden.

Es wäre zu prüfen, wie man beim richtigen Generalstreik durch einzelne zuverlässige Leute Eisenbahn-, Post- und Versorgungsbetriebe wenigstens teilweise in Betrieb halten könnte. Mit einem neuen Generalstreik der Landwirtschaft rechne ich eigentlich nicht, da die Bauern doch wohl überall das sinnlose gerade dieses Streikes eingesehen haben. 


\section{Rapport van de Beauftragte voor de provincie Groningen, d.d. 14-5-1943}

Groningen, 14. Mai 1943.

An den

Herrn Reichskommissar für die besetzten niederländischen Gebiete.

Reichsminister Dr. Se ys $\sim$ In quart

Den Haag

Betr.: Erfahrungsbericht über die Streiktage.

Bezug: Fernschreiben vom 10. Mai 1943, Nr. 5739.

Die Streiktage zeigten hier folgendes Bild: Die Bekanntgabe des Wehrmachtbefehlshabers traf die Niederländer - auch politisch - ganz unvorbereitet. Ein abgewogenes Urteil war bei ihnen ohnehin nicht zu erwarten. Infolgedessen verdichtete sich ihre länger angesammelte, allgemeine Ablehnung der deutschen Massnahmen aus diesem Anlass, welcher sehr weite Kreise der Bevölkerung berührte, zu einer Arbeitsniederlegung. Die Niederländer glaubten im allgemeinen, dass alle ehemaligen Soldaten sehr bald in die Kriegsgefangenschaft überführt werden würden, und dass deshalb eine Fortsetzung der Arbeit an ihrem jetzigen Arbeitsplatz sowieso keinen Wert mehr habe. Hinzu kam der Wunsch, ihrem Protest Ausdruck zu geben, und dadurch vielleicht die Besatzungsmacht zur Zurücknahme dieser Anordnung zu veranlassen. Eine Vorbereitung zu dieser Arbeitsniederlegung war nur insoweit vorhanden, als die Widerstandskreise und die beständig unheilvoll wirkenden Feindsender wiederholt auf den Streik: hingewiesen hatten.

Die Gesamtlage war nicht so, dass im Anfang ein noch dazu organisierter Streikwille vorhanden gewesen wäre. Vielmehr bemächtigten sich die Widerstandskreise erst hinterher dieser akut nicht von ihnen herbeigeführten Situation allgemeiner Unlust, indem sie versuchten, die Neigung zur Arbeitseinstellung zu aktivieren und zum Generalstreik auswachsen zu lassen. Das gelang ihnen indes nur teilweise. Dort, wo die marxistisch verseuchte Landbevölkerung (Landarbeiter und die ihnen nahestehenden Kleinbauern) im Gemenge mit völlig roten Fabrikarbeitern vorzugsweise wohnt (also in der südöstlichen und in der südwestlichen Ecke der Provinz), trat nunmehr der organisierte Streikwille zutage. Es zeigte sich dabei, dass auch Teile der Grossbauern diesmal von sich aus die Landarbeiter zur Arbeitseinstellung veranlassten. "Rotfront" und "Reaktion" spielten aus ganz verschiedenen Motiven hier zusammen. $\mathrm{Zu}$ diesen rein politischen Gruppen stiessen auf dem Lande politisch-kirchliche Landarbeiter und Bauern, welche infolge der offenen und versteckten Hetze der kalvinistischen Kirche den Zeitpunkt des Handelns ebenfalls für gekommen ansahen.

Die aus diesen Motiven und aus diesen Kreisen ausgelöste Streikbewegung zeigte das übliche Bild: Zusammenrottungen, kleinere Gewalttaten, Belästigungen von Nichtstreikenden, Nichtablieferung der Milch, Ausgiessen der zur Molkerei fahrenden Milch durch Jugendliche, Behinderung der Milchfahrer. An zwei Stellen fand auch ein Barrikadenbau auf der Landstrasse statt, um den Omnibus- und Molkereifahrbetrieb zu hindern. In keinem Fall jedoch haben die Streikenden Schusswaffen bei sich gehabt oder solche gebraucht. Brandstiftungen sind in der Provinz Groningen nicht vorgekommen, wohl aber Misshandlungen von NSB-Bürgermeistern, Telefondrahtzerschneidungen, Beschädigunen der Eisenbahngeleise.

Die Arbeitsniederlegung begann am Freitag, dem 30. April 1943, in der Stadt Groningen und in den hauptsächlichsten Industrieorten (Delfzijl, Veendam, Appingedam, Hoogkerk). Hier war die Arbeitsniederlegung breiter angelegt als auf dem flachen Lande. Am Sonn- 
abend, dem 1. Mai 1943, wurde jedoch in diesen Orten die Arbeit schon wieder in der Breite aufgenommen, um dann etwa um $10 \mathrm{Uhr}$ abermals teilweise aufgegeben $z$ u werden, zumal das Polizeistandrecht um diese Zeit hier noch nicht galt, und zumal die Arbeit an diesem Sonnabend ohnehin in vielen Betrieben um 12 Uhr zu endigen pflegt. Demgegenüber begann die Arbeitsniederlegung auf dem Lande eigentlich erst am Sonnabend, datuerte dafür aber länger: Sonnabend, Sonntag, Montag und teilweise Dienstag. In der Stadt und in den stadtähnlichen Gemeinden war die Arbeitsniederlegung praktisch auf den Freitagnachmittag und teilweise noch auf dem Sonnabendvormittag beschränkt. Indes bleibt festzuhalten, dass sowohl in der Stadt als auch auf dem Lande die Arbeitseinstellung längst nicht ueberall erfolgte. Auf dem Lande blieben ganze Gebietsteile von der Arbeitseinstellung verschont, in der Stadt beteiligten sich höchstens $20 \%$ an der Arbeitseinstellung. Das Bezeichnende dieses Streikes war, dass sein Schwergewicht in den ländlichen Gebietsteilen lag und von ländlichen Kreisen geführt wurde, die ich soeben näher skizziert habe.

Die öffentlichen Werke (Gas, Wasser, Elektrizität, Strassenbahn, Autobus, Strassenreinigung) waren in der Stadt und in der Provinz Sonnabend in Betrieb mit einer vorübergehenden Störung der Strassenbahn, während am Freitag nur beim Gaswerk die Arbeitsniederlegung halbtags erfolgte. Ein Teil der Behörden und öffentlichen Dienststellen, vor allem die PTT und die Distributionsämter, zeigten Neigung zur Arbeitsniederlegung, die sich ebenfalls auf den Freitagnachmittag beschränkte.

$Z_{\mathrm{u}}$ den Ursachen dieses Streikes gehört neben dem Erörterten auch die Tatsache, dass die Niederländer infolge der schwankenden Haltung der deutschen Besatzungspolitik in den letzten Jahren sich nicht klar darüber waren, wie weit sie eigentlich gehen könnten, wo mit anderen Worten die Grenze wäre, die man nicht ohne Gefahr für Leib oder Leben überschreiten dürfe. Die Besatzungsbehörde ist meist recht langmütig gewesen, hatte es mit Anordnungen und Androhungen oftmals auch da bewenden lassen, wo gleichbleibende Festigkeit nötig gewesen wäre, wohingegen sie zwischenzeitlich in ihren Methoden recht abrupt hart gewesen war. Die Bevölkerung wollte daher bei diesem Streikanfall durchaus nicht glauben, dass nun wider Erwarten ernst gemacht und durchgegriffen würde. Soweit hatten sich in der vergangenen Zeit die immer wiederholten Androhungen und die nicht durchgeführten Anordnungen der Besatzungsbehörde ausgewirkt, dass man sich nicht vorstellen konnte, dass man jetzt gleich $z u$ Beginn scharf eingreifen würde. In dieser Beziehung sei aus der letzten Zeit erinnert an: Nichteingetretene Folgen bei der Ermordung führender NSBer; die wiederholt hin- und hergehende und bekanntgewordene Auffassung, ob überhaupt und wie der Arbeitseinsatz der Studenten erfolgen soll; die langwierigen Erörterungen, ob und welche Loyalitätserklärungen die Studenten abgeben sollten; die Behandlung der friesischen Sprachfrage und in der Breite die bei jedem einzelnen Fall des Aufrufes zum Arbeitseinsatz ausdrücklich angekündigten "schärfsten Massnahmen" im Falle des Nichterscheinens des Aufgerufenen, die aber in den letzten Monaten praktisch überhaupt in keinem einzigen Fall eintraten.

Die eingesetzten - geringen - Polizeikräfte erledigten ihre Aufgabe hervorragend gut mit grösster Ruhe und ebensolcher Umsicht unter Führung des Kommandeurs Major Mechels. Sie waren von Anfang an in jedem Augenblick Herr der Situation. Ihnen, dem Leiter des Standgerichtes und dem guten Zusammenwirken aller Deutschen und der führenden niederländischen Dienststellen (Landespolizeipräsident, Kommissar der Provinz, Bürgermeister der Stad Groningen, Ernährungskommissar) ist, es zu danken, dass der Streik gleich nach Beginn in sich zusammenbrach, und dass die verbliebenden wenigen Unruheherde in kürzester Frist beseitigt wurden. Durch das Standgericht zum Tode verurteilt wurden in der Provinz Groningen 9 Männer; bei den Zusammenrottungen wurden 23 Personen getötet und 13 verletzt.

Es war allenthalben zu beobachten, dass überall dort in privaten und öffentlichen Betrieben die Arbeitsniederlegung entweder schon gar nicht erfolgte oder nur kurze Zeit dauerte, wo 
der Leiter des Betriebes energisch zugriff und die Fortsetzung der Arbeit einfach verlangte. Die Arbeiter, welche diese feste Führung nicht erfuhren, verliessen kurzer Hand die Arbeitsstätte, fanden sich dann aber bald wieder ein, wenn von ihnen schriftlich oder mündlich die Wiederaufnahme der Arbeit verlangt wurde.

Meinerseits habe ich selbstverständlich sehr scharf auf Fortsetzung der Arbeit hingewirkt. Auf den öffentlichen Sektor durch unzweideutige Aufforderung zur Weiterarbeit, die durch den Kommissar der Provinz und den Bürgermeister der Stadt weitergegeben wurde. Auf den landwirtschaftlichen Sektor durch die straffe Anspannung des ganzen Apparates des Ernährungskommissars, welcher den ganzen Sonntag über - bei gleichzeitig von mir angeordnetem werktäglichen Telefon- und Telegrafenverkehr - in allen Landgemeinden auf die Molkereien, landwirtschaftlichen Fabriken und Bauern im Sinne sofortiger Wiederaufnahme der Arbeit am Montagmorgen hinwirkte. Auf den gewerblichen Sektor, indem ich in der Nacht vom Sonnabend auf Sonntag die Leiter der grösseren gewerblichen Betriebe in den gefährdeten Orten von mir aus persönlich anrufen liess mit dem eindeutigen Hinweis, dass die volle Arbeit am Montag wieder aufzunehmen sei, dass die Fabrikleitung den Sonntag unter allen Umständen $z u$ einer dahingehenden persönlichen Aufforderung an jeden einzelnen Arbeiter und Angestellten zu benutzen habe, dass mir bis Montagmorgen 8 Uhr die volle Wiederaufnahme der Arbeit zu melden und bis Montagmorgen 10 Uhr die nicht zur Arbeit Erschienenen den Bürgermeistern listenmässig $z u$ bezeichnen wären. Dabei habe ich ausdrücklich und sehr scharf betont, dass andernfalls sowohl die Fabrikleitung als auch die Gefolgschaft vor das Standgericht gezogen würden. - Ueberdies habe ich im Einverständnis mit allen Beteiligten an jedem Tag zweimal die in dieser Sache führenden Männer der Provinz (Kommandeur des Sicherungsbereiches, Leiter der hiesigen Aussenstelle des SD, Ordnungspolizei, Standrichter, Landespolizeipräsident, Kommissar der Provinz, Bürgermeister der Stadt Groningen, Kreisgeschäftsführer der NSDAP) in kameradschaftlicher Weise zu einer Lagebesprechung zusammengeführt, um eine rasche gemeinsame Orientierung aller dieser Dienststellen und ein gemeinsames Zusammenwirken sicherzustellen. Da der Postverkehr arbeitete, die Zeitungen erschienen und auch die Druckereien zur Verfügung standen, war die Möglichkeit der Verständigung mit der Zentrale und der Bevölkerung gegeben. Die Ortsbehörden hatten zweimal am Tag telegrafisch Lageberichte an den Provinzkommissar zu geben.

Das Verhalten der niederländischen Behörden war mit Ausnahme des Kommissars der Provinz, des Bürgermeisters der Stadt und der NSB-Bürgermeisters auf dem Lande zunächst zurückhaltend und zaghaft. Als die niederländischen Dienststellen aber scharf angewiesen wurden, gingen sie meist mit, um die Arbeitseinstellung $z u$ überwinden. Die NSB und ihre Unterorganisationen haben ebenfalls überall dort, wo sie es konnten, auf die Fortsetzung der Arbeit hingewirkt. Die sozialen Vormänner haben $z u$ einem Teil gut gearbeitet, zu einem andern Teil versagt. Es zeigte sich weitgehendst, dass der Einfluss des NSB und ihrer Unterorganisationen auf die nicht der NSB angeschlossene Bevölkerung ausserordentlich gering ist. Der Einsatz der NSB und ihrer Formationen war weder nötig, noch zweckmässig. Nur beim Gaswerk in Groningen hat die Technische Nothilfe dafür gesorgt, dass infolge des Fortlaufens der Gefolgschaft das Werk vor Schaden bewahrt wurde. Die Hilfspolizei war freudig beim Einsatz, indes etwas unruhig und unüberlegt.

Die Bevölkerung ist jetzt äusserlich ruhig, innerlich aber auch infolge der neueren Massnahmen (Meldepflicht, Fortführung der Studenten, Radiowegnahme), einigermassen erregt. Jetzt betrachtet sie den Streik ziemlich allgemein als töricht und aussichtslos. Die Arbeiter sehen ein, dass sie wie stets die Dummen gewesen sind, während sich die Hetzer im Ernstfall im Verborgenen gehalten haben. Eine Wiederholung des Streikes wird die Bevölkerung nicht so ohne weiteres mitmachen, nachdem sie das scharfe Zupacken der Polizei kennengelernt hat. Im Falle einer feindlichen Landung wird sie vorsichtiger und vielleicht nicht so kopflos sein, jedoch dem Feind jeden möglichen Vorschub leisten. 
Als zunächst zu ziehende Folgerungen würde ich nachbenannte Punkte in Vorschlag bringen:

1. Die Ermittlungen nach den hauptsächlichsten Streikhetzern müssen mit Energie weitergeführt werden mit dem Ziel, diese möglichst abzuurteilen und auf jeden Fall festzusetzen. In erster Linie die Marxisten, aber ebenso die politisierenden und hetzenden Geistlichen sowie die Reaktionäre, alle, soweit sie an diesem Streik sich irgendwie aktiv beteiligt haben.

Die ehemaligen Leiter der marxistischen Fachverbände, die grösstenteils mit Pension ausgestattet sind und jetzt untätig und hetzend im Lande umherlaufen, müssen entweder als Geisel verhaftet oder zusammengefasst ausserhalb der Niederlande zur Arbeit eingesetzt werden.

2. Die aus dem Streik noch laufenden an die deutschen Gerichte überwiesenen Strafsachen müssen in kürzester Frist zum Abschlussurteil gebracht werden, da sie sonst ihre Wirkung verfehlen.

3. Der besonders empfindliche Verkehrs- und Ernährungsapparat (Post, Telegraf, Telefon, Distributionsämter, Ernährungskommissar) bedarf einer sofortigen Ueberprüfung in Bezug auf Leitung und Gefolgschaft. Die nicht eindeutig klaren Leute müssten ersetzt werden. Die am Streik beteiligten Gefolgschaftsangehörigen aus diesen Betrieben müssten fristlos entlassen werden.

Die Eisenbahn, der man jetzt in Arbeiterkreisen die Schuld am verlorenen Streik gibt, bedarf laufend ganz besonders einer Durchprüfung und Aufsicht.

4. Die leitenden Posten in der Verwaltung bis hin zum Bürgermeister müssen beschleunigt mit geeigneten NSBern besetzt werden. Auch dort sollte man eine Aenderung eintreten lassen, wo dies ohne ein ausführliches "Sündenregister" vom Beauftragten gemeinsam mit dem Kommissar der Provinz für nötig gehalten wird. Dabei möchte man der provinziellen Beurteilung etwas mehr Bedeutung beimessen als bisher. Bei der Neubesetzung sollte man den grossgermanisch denkenden NSBern den Vorzug geben vor den dietschdenkenden faschistischen NSBern.

Die jetzt amtierenden NSB-Bürgermeister müssten die Erlaubnis erhalten, eine Waffe (unsichtbar) zu tragen.

5. Der Benachrichtigungsapparat der NSB und ihrer Nebenorganisationen, sowie die sofortige Mobilisierungsmöglichkeit von Männern aus nationalsozialistischen Kreisen (Schutz der Bürgermeister usw.) müsste sofort überprüft und auf Leistung gebracht werden. Beides war nicht in Ordnung.

6. In den hauptsächlichst gefährdeten Gemeinden müsste eine Ueberprüfung der Polizeistärken stattfinden. Die neuerdings eingeführte Vereinzelung der Polizeikräfte ist für solche Fälle weniger günstig als die früher übliche Zusammenziehung der Polizeikräfte auch auf dem Lande.

7. Deutscherseits sollte man auch eine Lehre aus diesem Gesamtfall ziehen: Ausserhalb der NSB, ihrer Nebenorganisationen und der Germanischen SS wird man sich jetzt kaum verlässliche Freunde erwerben können, die auch im Ernstfall für die deutschen Interessen eintreten. Werbungsmassnahmen dieser Art haben keinen Wert und werden lediglich als Schwäche ausgelegt. Die Besatzungsbehörde sollte sich deshalb auf diejenigen: Massnahmen beschränken, welche für den günstigen Kriegsablauf unbedingt nötig sind, und gleichzeitig darauf achten, dass die getroffenen Anordnungen auch in jedem Fall wirklich durchgeführt werden. Anordnungen, die man doch praktisch nicht durchführen kann oder will, sollten besser überhaupt nicht getroffen worden. Es müsste mehr noch als bisher dafür gesorgt werden, dass den Niederländern bei so tief einschneidenden Massnahmen von autorisierter Seite aus rechtzeitig die nötigen Erläuterungen gegeben werden.

Schliesslich sollte man der NSB nicht mehr Aufgaben freigeben, als sie erledigen kann. Wenn man beispielsweise die Schaffung des Landstandes und seine Handhabung auf sich wirken lässt, so kommt man zu dem Ergebnis, dass diese Seite der NSB-Tätigkeit in dieser 
Form ziemlich bedeutungslos geblieben ist. Ebenso hat die Aerztekammer sehr viel unnützen Widerstandswillen gefördert, ohne hinreichende positive Gegenwerte einzubringen.

Einen weiteren Bericht gemäss dem letzten Absatz des dortigen Fernschreibens werde ich nach Abstimmung mit den übrigen deutschen Stellen in Kürze folgen lassen.

Con ring.

\section{Rapport van de Beauftragte voor de provincie Limburg, d.d. 14-5-1943}

An den

Herrn Reichskommissar für die

besetzten niederländischen Gebiete,

Herrn Reichsminister Dr S e y s-Inquart,

Den Haag

Betr.: Erfahrungsbericht für die Provinz Limburg.

Bezug: Dortiges Fernschreiben Nr. 5739 vom 10.5.43.

$\mathrm{Da}$ ich einige Zeit vor dem Streik bereits im Reich weilte und auch während des Streiks nicht in der Provinz Limburg gewesen bin, kann ich meinerseits kaum eine eigene Stellungnahme zu den Vorfällen abgeben. Das, was ich aus Berichten, und Erzählungen entnommen habe, lässt einwandfrei erkennen, dass die erste Bekanntmachung des Wehrmachtbefehlshabers über die Rückführung der ehemaligen Kriegsgefangenen in die Gefangenschaft den Streik ausgelöst hat. Vielleicht wäre es nicht zum Streik gekommen, wenn die gleiche Bekanntmachung die Möglichkeit von Befreiungen der verschiedenen Berufsgruppen von Kriegsgefangenen enthalten hätte. Diese Meinung wird von sehr vielen Deutschen und Niederländern vertreten. Unter Berücksichtigung der gesamten politischen, ernährungsmässigen und wirtschaftlichen Lage des niederländischen Volkes, sowie unserer eigenen militärischen Lage, konnte es nach meiner persönlichen Meinung auch zum Streik kommen, wenn der Aufruf zur Rückführung der niederländischen Soldaten in die Kriegsgefangenschaft alles das enthalten hätte, was jetzt in $\mathrm{hhm}$ vermisst wird. Die dauernde Beeinflüssung durch die äusseren und inneren politischen Gegner hatte eine Stimmung im Volke herbeigeführt, die bei einem bestimmten Anlass zu einer Entladung führen musste. So hörte ich von Niederländern, die sofort nach dem Anschlag der Bekanntmachung des WBN zwischen lesenden Gruppen gestanden haben und dort deren Bemerkungen hörten, dass es bei ihnen in demselben Augenblick feststand, dass es $z u$ irgend welchen Unruhen kommen würde.

\section{Zu Punkt 1:}

Die Hintergründe für den Streik sind nach meiner Meinung rein politische und volkliche. Die Streikenden haben sicherlich angenommen, durch ihren Einsatz für die Freiheit ihres eigenen Volkes etwas zu tun. Es ist auch bezeichnend, dass im oberen Teil der Provinz das Gerücht umging, die Engländer seien bereits in Amsterdam gelandet. 


\section{Zu Punkt 2:}

Der unmittelbare Anlass für den Streik waren diejenigen Arbeiter, auf die sich die Bekanntmachung des WBN bezog und die in die Kriegsgefangenschaft abgeführt wurden. Ihnen fehlte von dieser Stunde an jegliches Interesse für die Arbeit. Durch sie begann das sogenannte Abbröckeln der eigentlichen Schichten. Die Streikbewegung hat in Limburg bei den Zechen ihren Anfang genommen, in Sonderheit Zeche "Maurits".

\section{Zu Punkt 3:}

Die Ueberlegungen, die zum Streik geführt haben, habe ich bereits eingangs dargelegt. Dass den Streikenden ein weiteres Ziel vor Augen geschwebt hat, als bereits unter Punkt 1 angeführt, kann ich mir nicht vorstellen.

\section{Zu Punkt 4-9:}

kann ich vor mir aus wegen meiner Abwesenheit keine Stellung nehmen. Zu Punkt 9 glaube ich doch sagen zu müssen, dass der NSDAP., NSB. und NAF., den Berichten und Rücksprachen zufolge, ein grosser Dank 'für ihren Einsatz gebührt.

\section{Zu Punkt 10:}

Wenn auch ein kleiner Teil des niederländischen Volkes den Streik verurteilt, - hierbei handelt es sich um Nationalsozialisten und jene, die nicht mitgestreikt haben, - so glaube ich doch, dass der grösste Teil der Bevölkerung stolz darauf ist, der besetzenden Macht den einheitlichen Willen vor Augen geführt zu haben. Nunmehr zeigt sich die Bevölkerung uns gegenüber kühl, ablehnend und man kann sagen hochmütig. Ich kann mir hierüber ein gutes Bild machen, weil ich einige Wochen abwesend war und nun wieder in der Bevölkerung stehe. Es ist mir auch verschiedentlich mitgeteilt worden, dass wir jetzt von Niederländern abgelehnt werden, die bereits vor dem 10.5.40 und auch nachher, im gewissen Sinne zu uns gestanden haben. $\mathrm{Zu}$ einem nochmaligen Streik wird es nach meinen bisherigen Feststellungen nicht mehr kommen, es sei denn, dass die von unseren Gegnern lang erwartete Invasion Wahrheit wird.

\section{Zu Punkt 11:}

Wie bereits unter Punkt 10 erwähnt, müssen wir damit rechnen dass das niederländische Volk bei einer feindlichen Landung von See her und aus der Luft die Feindtruppen als seine Befreier ansieht und gewillt ist, sich ihnen zur Verfügung zu stellen. Wer da von den Niederländern nicht mithilft, wird von den anderen genau so als Abseitsstehender und Landesverräter angesehen werden, wie das im kleinen bei dem Streik am 30.4.43 der Fall war. Die Möglichkeiten über das Hinausgehen des Beginnens sind in Limburg aber sehr gering. Die in Limburg vorhandenen militärischen Kräfte einschl. der Tausende von Schutzgruppenmännern, werden ohne weiteres in der Lage sein, die gelandeten feindlichen Truppen und die inneren Gegner zusammenzuschlagen. Hinzu kommt die Nähe des Reiches. Als notwendig erachte ich in den kommenden Monaten die Zusammenschweissung aller Reichsdeutschen. Die NSB. hat dafür zu sorgen, dass die niederländischen Nationalsozialisten fest zusammengefügt werden. Die innere Stärke muss beiden nationalsozialistischen Gruppen die Kraft des Deutschen Reiches und der Achsenmächte geben. Hierfür ist eine kluge und entsprechende Propaganda notwendig und verantwortlich. Es ist nicht so wichtig, immer wieder auf den mächtigen Atlantikwall hinzuweisen, als auf die Angriffskraft unserer Armeen. Es steht einwandfrei fest, dass unsere Gegner nicht mehr 1:100 an den deutschen Sieg glauben. Unsere Aufgabe muss es daher sein, die Siegesgewissheit unserer reichsdeutschen und niederländischen Kameraden $z \mathfrak{u}$ stärken.

Um $z u$ verhüten, dass es noch einmal wieder zu einem Streik in den Niederlanden kommt, bei dem doch nur das niederländische Volk der Leidtragende ist, glaube ich, den Vorschlag 
machen $z u$ müssen, ein Plakat mit einem entsprechenden Text $z \mathfrak{u}$ entwerfen, drucken zu lassen und dasselbe allen Betrieben und offentlichen Verwaltungen in mehreren Exemplaren in einer versiegelten Rollenpackung zuzustellen. Diese Rollen sind auf ein Stichwort des Herrn Reichskommissars hin zu öffnen und die Plakate, die die Bevölkerung in der schärfsten Form vor Unruhen und Streiks warnen, anzuschlagen. Eine derartige Massnahme wird nach meiner Meinung entsprechenden Erfolg haben.

Schmidt.

\section{Rapport van de Beauftragte voor de provincie Noord-Brabant, d.d. 14-5-1943}

Herzogenbusch-Vught, 14. Mai 1943.

Betr.: Erfahrungsbericht über die Streiktage.

Bezug: Ihr Fernschreiben 5739 vom 10.5.1943.

1. Da die Niederländer vom politischen Geschehen und seinen Folgen so gut wie keine Vorstellung haben, ist der eigentliche Grund für diesen Streik meines Erachtens in dem Willen zu suchen, der Besatzungsmacht einmal die Zähne zu zeigen. Man rechnete hierbei stark auf "Hilfe von draussen" und das Gerücht, das am Sonntag in Maastricht umlief, nach welchem nunmehr, d.h. nachdem der Streik zusammengebrochen sei, die englische Luftwaffe die Schachtanlagen bombardieren würde, ist hierfür geradezu bezeichnend.

2. Die Veranlassung bildete zweifellos die nicht gerade geschickt abgefasste Anordnung des W.B.N. Damit war der Gegenseite die von ihr lange und dringend gewünschte Basis gegeben, da von dieser Anordnung praktisch fast jede niederländische Familie betroffen schien. Ausgegangen ist die Streikbewegung vom Bergbaurevier in Süd-Limburg, da hier die Zusammenballung der Menschen am stärksten ist und griff dann auf die anderen Gebiete über. Die Verbreitung erfolgte durch Mundpropaganda (Radfahrer, kath. Geistliche, Telefon usw.) Einen wichtigen Faktor bildete in diesem Zusammenhang auch das Gas, dessen Ausbleiben geradezu alarmierend wirkte, da dadurch ja praktisch die Wirksamkeit des Streiks demonstriert wurde.

3. Wenn man überhaupt von Ueberlegung oder Ziel sprechen kann, so sollte dieser Streik eine Demonstration gegen die Verschickung von Niederländern nach Deutschland sein. Dieser Widerstand war ja auch von der katholischen Kirche in allen möglichen Variationen propagiert worden. Ein auch nur im Bereich des Möglichen liegendes unmittelbares Ziel war meines Erachtens nicht vorhanden.

4. Während der Streik die Provinz Süd-Limburg bereits am Freitag fast restlos erfasst hatte; blieb er in Nordbrabant zunächst nur auf die Philipswerke beschränkt. Aber auch hier konnte man eine ausgesprochene Streiklust nicht feststellen, was schon daraus hervorgeht, dass am Freitag noch die Belegschaft zur Arbeit erschienen ist, obwohl das Ausbleiben des Gases eine geregelte Fortführung des Betriebes schon nicht mehr zuliess. Erst am Montag spitze sich dann auch hier die Lage $z u$. 
5. Die Betriebsführer standen der Streikbewegung mit gemischten Gefühlen gegenüber. Auf der einen Seite freuten sie sich als Niederländer über die Schwierigkeiten, die der Besatzungsmacht daraus entstanden, auf der anderen Seite waren sie klug genug, um einzusehen, dass diese Auseinandersetzung mit einem völligen Misserfolg enden würde, deren Kosten von ihnen persönlich zu tragen wären. Auf der einen Seite wollten sie zwar an und mit den Deutschen Geld verdienen, auf der anderen Seite aber auch nicht als Landesverräter geiten.

Die Abteilungschefs, die Ingenieure, Techniker, kurz alles das, was man als Leitende Angestellte $z u$ bezeichnen pflegt, waren dagegen sehr aktiv, aber auch wieder klug genug. sich nicht allzusehr in den Vordergrund zu schieben.

6. Die Einflussmöglichkeiten waren natürlich für die Sonderbeauftragten örtlich sehr verschieden. Diese waren a) durch die Gegenspieler auf niederländischer Seite und b) durch die Zusammenarbeit der deutschen Dienststellen bedingt. Allgemein kann man aber sagen, dass die Macht der Sonderbeauftragten in keinem Verhältnis zu ihrer Herausstellung durch Presse und Plakate stand.

Eine grössere Schwierigkeit bereitete ausserdem der Mangel an aktiven, politisch geschulten Kräften im Stabe des Beauftragten. Vor allem wirkte sich dies auf den wirtschaftlichen Sektor aus, auf dem gerade die brennendsten Probleme an uns herantraten. Ich halte es daher für unumgänglich notwendig, dass jedem Beauftragten sobald als möglich ein erfahrener Wirtschaftsreferent zugegeben wird, der aber Soldat gewesen sein muss, damit er auch die nötige Härte mitbringt. Das wäre meines Erachtens eine dankbare Tätigkeit für viele kriegsversehrte Offiziere. Ausserdem müsste man diese Gelegenheit benutzen, um sämtlichen Reichs- und Parteistellen klarzumachen, dass die Niederlande keinen Erholungsaufenthalt sondern Kriegsgebiet darstellen.

7. Die Zusammenarbeit auf dem deutschen Sektor war in beiden Provinzen ausgezeichnet. Wir erlebten hier ein aus der Not geborenes Zusammenrücken aller Deutschen, ganz gleich, wie sie sonst $z \mathrm{u}$ den Tagesproblemen standen und stehen.

Der Telefon- und Fernschreibverkehr funktionierte - abgesehen von der durch die Ueberlastung zwangsläufig bedingten Blockierung - gut. Am Sonntag war die Telefonverbindung nach Den Haag durch starkes Rauschen in der Leitung gestört, sodass wir $z$ war im Haag gut zu verstehen waren, während dies hier unten nur mit grösster Mühe möglich war.

8. Das Verhalten der niederländischen staatlichen Stellen war örtlich sehr verschieden. Besondere Beachtung verdient die klare und eindeutige Haltung des Provinzkommissars Graf D'Ansembourg, dem es mit unserer Unterstützung in verhältnismässig kurzer Zeit gelang, die Gemeindebehörden wieder in Gang zu bringen. In Nordbrabant ist es auf diesem Sektor verhältnismässig ruhig geblieben, was schon aus der kleinen Zahl von 3 Gemeinden hervorgeht, in denen vorübergehend der Dienstbetrieb eingestellt wurde. Der Provinzkommissar van Rijckevorsel ist viel zu klug, um sich auf eine solche unsichere Sache einzulassen. Dazu bewegt er sich immer auf der Linie des Generalsekretärs Frederiks und wird auch mit diesem stehen und fallen. Ich hatte dem Provinzkommissar allerdings noch, bevor ich nach Maastricht abfuhr, keinen Zweifel darüber gelassen, was man auf niederländischer Seite $z u$ erwarten habe, wenn man hier mit dem Feuer spielen wolle.

Besondere Aufmerksamkeit müssen wir aber den Distributieämtern widmen. Hier muss unter allen Umständen eine starke personelle Auswechslung vorgenommen werden. Zumindest aber muss die Leitung dieser Aemter zuverlässigen NSB-Mitgliedern übertragen werden, da die Erfahrung gezeigt hat, dass oft ein einzelner Mann mit etwas Initiative in der Lage war, den ganzen Betrieb zusammenzuhalten. Hinzu kommt, dass gerade bei den Distributieämtern verhältnismässig viele frühere Gewerkschaftsfunktionäre untergekommen sind. Bei dem starken Publikumsverkehr ist natürlich bei der Empfänglichkeit der Niederländer in solchen Augenblicken (z.B. Ablehnung eines Bezugscheines) eine starke Beeinflüssungsmöglichkeit gegeben. 
9. Wie mir der Sozialreferent Vogt, Maastricht, ausdrücklich bestätigte, war die Haltung der NSB-Mitglieder auf den Schachtenlagen einwandfrei. Sie haben - bis auf wenige Ausnahmen - nicht nur nicht gestreikt, sondern darüberhinaus sich der Ausdehnung des Streiks aktiv widersetzt. So haben z.B. zwei NSB-Mitglieder, der Aufseher v. d. Meenen und der Chef der Zeichenabteilung v. Kooten, erheblich dazu beigetragen, dass die Kokerei der Schachtanlage "Maurits" intakt geblieben ist.

In Nordbrabant war der Distriktsleiter Stoetzer mit einem kleinen Stabe nach Herzogenbusch gekommen und stellte auch sofort seinen ganzen sonstigen Apparat (einschliesslich der W.A.) zur Verfügung. Die Groepsleider haben sich zum Teil bei der Nachrichtenübermittlung hervorgetan, wenngleich hierbei oft ein leichter $\mathrm{Zug}$ zur Uebertreibung festzustellen war.

Aber man muss die Dinge sehen, wie sie sind: Der NSB fehlt natürlich hier ebenso die Erfahrung wie der Gegenseite. Ein Generalstreik in Deutschland hätte bei der auf solche Dinge geschulten Arbeiterschaft auf beiden Seiten andere Auswirkungen gehabt.

10. Die Haltung der niederländischen Bevölkerung ist so unsicher geworden, dass sie noch nicht begriffen hat, was geschehen ist. Ich möchte die Niederländer mit Kindern vergleichen, die zwar oft gehört haben, dass man mit zufällig gefundenen Munitions- und Sprengstücken nicht spielen soll, die es aber doch nicht lassen können, daran herumzuhämmern und zu klopfen, um dann entsetzt und fassungslos sehen zu müssen, wie dieses so harmlos aussehende Ding losgeht und einige Kameraden zerreisst.

Der Schrecken, den die niederländische Bevölkerung erfasst hat, ist also noch nicht überwunden und die widerspruchslose Hinnahme der nachfolgenden Verordnungen bestätigt dies ja nur. Bei der oberflächlichen Art des Niederländern muss man allerdings damit rechnen, dass dieser Eindruck ebenso schnell verwischt wird, wie er gekommen ist.

Während man aber vorher den Streik nur als eine Art Generalprobe ansah, für das, was dann kommen sollte, hat heute auch bei der Intelligenz eine tiefe Ernüchterung und eine etwas realere Betrachtung der Dinge Platz gegriffen. Auf der anderen Seite darf man natürlich auch nicht ausser acht lassen, dass durch dieses harte Zuschlagen der Hass stark vermehrt wurde. Diesen Schichten müssen wir daher in Zukunft unsere besondere Aufmerksamkeit widmen.

11. Wie die Niederländer sich nach diesen Ereignissen im Falle einer feindlichen Landung verhalten werden, lässt sich heute noch nicht annähernd übersehen; denn dieses harte Zufassen hat bei den Niederländern 1.) grosse Furcht vor deutschen Sicherungs- bezw. Vergeltungsmassnahmen, 2.) aber auch ein noch grösseres Verlangen „befreit zu werden" hervorgerufen. Die Niederländer werden sich nach meiner Meinung, d.h. so lange noch kein greifbarer Erfolg für die Gegenseite zu verzeichnen ist, zurückhalten. Wenn das Landungsmanöver aber auch nur einen örtlichen oder zeitlichen Erfolg haben sollte, dann müssen wir mit einem Massenaufstand, der alle Gebiete umfasst, rechnen. Wir müssen daher dafür sorgen, dass in allen lebenswichtigen Betrieben an führender Stelle zuverlässige Elemente sind. Wir dürfen uns dabei auch nicht durch Sachlichkeitserwägungen - wie sie uns als Deutschen liegen - irreführen lassen. Es ist $z$.B. in der jetzigen Situation gar nicht so entscheidend, ob ein Bürgermeister nun auch die letzten Ausführungsbestimmungen des niederländischen Gemeinderechts kennt, sondern es genügt, - wie dieses einmal an anderer Stelle drastisch zum Ausdruck gebracht wurde wenn der Bürgermeister seinen Namen schreiben kann. Hauptsache ist es, dass dieser Mann ungefähr die nationalsozialistische Idee begriffen hat und dann weiss, worauf es in entscheidender Stunde ankommt. Und es ist z.B. besser, einem W.-Betrieb einen Adjunktdirektor beizugeben, der zwar vielleicht keine Bilanz lesen kann, der aber, wenn es sein muss, mit vorgehaltener Pistole Betriebsführer und Gefolgschaft zur Arbeit zwingt. Hier muss die NSB zwei Dinge klar sehen: Einmal, dass uns weniger mit solchen Leuten gedient ist, die versorgt werden wollen oder müssen, zum anderen, dass sie sich jetzt den früheren NSDAP-Mitgliedern gegenüber toleranter verhält. In unserer Lage können wir uns einen solchen Bruderkrieg nicht leisten. 
Abschliessend würde ich es für gut halten, jetzt zwar jeden Widerstand, wann und wo er sich auch immer gezeigt haben mag, zu brechen. Das ist jetzt ein Aufwaschen. Aber wir dürfen auch nicht alle Niederländer in einen Topf werfen und müssen mehr denn je versuchen, die uns gegenüberstehende Einheitsfront aufzuteilen, dadurch, dass wir verschiedene Berufsgruppen oder auch meinetwegen Konfessionsgemeinschaften verschieden behandeln. Die Zulassung von Rundfunkgeräten bietet hier eine willkommene Gelegenheit. Wir werden dann vielleicht dahin kommen, dass es in Zukunft in den Niederlanden 3 Gruppen gibt: NSB-er, Radiobesitzer und, um den Ausdruck noch einmal $z u$ gebrauchen, Antis. Wenn wir dann noch durch Hunger bezw. durch Sonderzuweisungen noch eine vierte Gruppe schaffen könnte, dann würden wir unserem Ziel schon ein Stück nähergekommen sein.

Im übrigen werde ich weisungsgemäss die mit dem Streik zusammenhängenden Ereignisse noch einmal gemeinsam mit allen zuständigen deutschen Dienststellen überprüfen und Ihnen darüber Bericht erstatten.

Him merich.

\section{Rapport van de Beauftragte voor de provincie Overijssel, d.d. 15-5-1943}

An den

Zwolle, den 15. Mai 1943.

Herrn Reichskommissar für die besetzten niederl. Gebiete,

Den Haag.

Bett.: Erfahrungsbericht über die Streikbewegung in der Provinz Overijssel.

Bezug: Dort. FS. Nr. 5739 vom 10.5.43.

Durch die Massnahmen des totalen Kriegseinsatzes ist schon seit längerer Zeit eine umfangreiche Missstimmung in weiten Kreisen der Bevölkerung festzustellen. Die militärischen Rückschläge in Russland und Afrika, die durch den englischen Rundfunk aufgebauscht verbreitet wurden, hatten zur Folge, dass ausser den niederländischen Nationalsozialisten niemand mehr an einen deutschen Sieg glaubt.

Diese Stimmung wurde durch Hetzsendungen des englischen Rundfunks, in denen zum Widerstand gegen die deutschen Massnahmen aufgefordert wurde und wird, noch verstärkt bezw. ausgenutzt. Gerüchtweise wurde hier und da auch schon verbreitet, dass eine Rückführung aller ehemaligen Angehörigen der niederländischen Wehrmacht in die Kriegsgefangen-

1) Betekent: In Vertretung. De gemachtigde voor Noord-Brabant, Thiel, bevond zich toentertijd in militaire dienst. 
schaft geplant sei. Bezeichnend ist, dass auch die wiederholten Bombardierungen niederländischer Städte mit Verlusten der holländischen Bevölkerung in diesen Kreisen nur zur Folge hatten, dass man sagte: „Wenn die Deutschen nicht da wären, würden auch die Bombardierungen nicht stattfinden."

Ein reales politisches Denken über das Schicksal Europas; im besonderen der Niederlande bei einem evtl. Sieg der Alliierten einschliesslich Sowjetrussland ist nur bei einem verschwindend geringen Teil bemerkbar.

Die Bekanntmachung des Wehrmachtbefehlshabers betr. Kriegsgefangenschaft wurde am Donnerstag, dem 29.4., kurz vor 12,00 Uhr durch FS zur Veröffentlichung an die Zeitungen durchgegeben.

Ich bin der Meinung, dass ein kleiner Kreis von Aktivisten nur auf diese Bekanntgabe wartete, um in Aktion treten zu können, da schon kurz nach Beendigung der Mittagspause in der Zeit zwischen 14-15 Uhr in den Rüstungswerken Stork, Dikkers, Heemaf usw. ein Totalstreik ausbrach, der in der Zeit bis 17,00 Uhr die gesamte Industrie in der Twente erfasste.

Bemerkenswert ist die Tatsache, dass in der deutschen Abteilung der Rüstungsfirma Hazemeijer in Hengelo am Donnerstag keine Streikbewegungen festzustellen waren. Die Belegschaft von über 1000 Mann arbeitete reibungslos bis zum Feierabend durch. Erst am Freitagmorgen wurde die Arbeit nicht aufgenommen. Auch dieses dürfte als Beweis dafür dienen, dass eine unbekannte Organisation besteht, die in den holländischen Betrieben ungestört ihre Massnahmen treffen konnte, während sie sich bei der unter deutscher Leitung stehenden Firma Hazemeijer scheinbar nicht traute.

Bei vielen deutschen Stellen bestand oder besteht die Meinung, dass dieser Streikausbruch eine spontane Kundgebung als Antwort auf die Bekanntmachung des Wehrmachtbefehlshabers sei. Ich halte dieses aber für ausgeschlossen, da

1. eine solche einmütige Haltung von über 20.000 Arbeitern und Arbeiterinnen innerhalb von 2-3 Stunden ohne Organisation nicht hergestellt werden kann;

2. die Nachricht über die Bekanntmachung auf legalem Wege zeitigstens gegen 17,00 Uhr an die Bevölkerung gelangen konnte, weil erst gegen 17,00 Uhr damit begonnen wird, der Leserschaft die Zeitungen zuzustellen.

Die m.E. nicht sehr glückliche Form der Bekanntmachung, die keinerlei Ausnahmen enthielt, gab der Streikorganisation vollen Wind in ihre Segel. Wäre z.B. darin sofort zum Ausdruck gebracht worden, dass die Angehörigen der Rüstungsindustrie usw. von der Rückführung in die Gefangenschaft ausgeschlossen sind, so wäre es bestimmt schwieriger gewesen, einen Streik in solchem Ausmasse herbeizuführen.

Schon am Donnerstag in der Zeit zwischen 16,30 und 17,00 Uhr griff der Streik auf einige städtische Behörden in der Twente über, deren Angehörige ihre Arbeitsplätze verliessen, ohne ihre Bürgermeister bezw. Behördenleiter zu benachrichtigen.

Der Streikausbruch und die Ankündigung eines Generalstreiks verbreitete sich mit Windeseile über die gesamte Provinz. Eine Streikpsychose trat dadurch ein, dass in den grösseren Städten der Provinz Overijssel bei Bekanntwerden des Gerüchtes über einen bevorstehenden Generalstreik die Einwohnerschaft begann, Wasser zu hamsteren, d.h. alle verfügbaren Gefässe mit Wasser füllte, sodass die Reservoire der Wasserwerke in kurzer Zeit geleert waren und die Wasserversorgung trotz Weiterarbeit in den Werken eine Zeitlang nicht funktionierte. Es wurde dadurch selbstverständlich allgemein vermutet, dass der Generalstreik auch in den lebenswichtigen Betrieben bereits ausgebrochen sei. 
Am Freitagmorgen konnte man in der Provinz Overijssel fast von einem hundertprozentigen Streik sprechen. Ausser der niederländischen Eisenbahn und wenigen städtischen und staatlichen Aemtern streikte fast alles, auch die Geschäftsleute hielten am Freitagvormittag durchweg ihre Läden geschlossen.

Während meiner Ansicht nach ein unbekannter Aktivistenkreis die Absicht hatte,

1. der Besatzungsmacht durch Ausfall der Produktion und allgemeine Unruhen Schaden $z \mathbf{u}$ bereiten;

2. festzustellen, wie sich die gesamte Bevölkerung in einem derartigen Falle verhalten würde,

war die Masse der Bevölkerung nur Herde, die über die Absichten ihrer Haltung sich selbst nicht im klaren war. Die einen glaubten, durch den Streik die Rückführung in die Kriegsgefangenschaft verhindern $z u$ können; andere waren aufgrund von Gerüchten der Meinung, der Engländer würde mit einer Invasion eingreifen, und ein weiterer grosser Teil beteiligte sich nur aus Solidaritätspflicht oder Zwang heraus, um nicht als schlechte Niederländer $z \mathbf{u}$ gelten.

Interessant war die Feststellung bei der Landbevölkerung, deren Streikbeteiligung nur im Nichtabliefern ihrer Milch an die Molkereien bestand, und die teilweise von der Bekanntmachung des Wehrmachtbefehlshabers, also von den eigentlichen Gründen des Streikausbruches, noch gar nichts wussten.

Die Betriebsführer sahen dem Ausbruch des Streiks tatenlos zu und ich bin überzeugt wenn der grösste Teil von ihnen vielleicht auch nicht unmittelbar an dem Streikausbruch mitschuldig war - , dass sie sich doch über die Schwierigkeiten, die der Besatzungsmacht entstanden, freuten. Diese Passivität der Betriebsführerschichten hatte zur selbstverständlichen Folge, dass die Belegschaften glauben mussten, es geschähe alles in vollem Einverständnis $z$ wischen Arbeitnehmern und Arbeitgebern.

In Betrieben, die bei dem Streik besonders unangenehm aufgefallen sind, z.B. Stork in Hengelo, schlage ich vor, deutsche Wehrwirtschaftsführer als Betriebsführer kommissarisch einzusetzen oder die Werke für Kriegsdauer überhaupt zu beschlagnahmen. Ausserdem halte ich es für angebracht, die Arbeitsfront massgeblich an der Menschenführung in den Betrieben einzuschalten.

Bei Eintreffen der Nachricht vom Streikausbruch begab ich mich sofort in das Streikgebiet der Twente und hielt Besprechungen mit den Bürgermeistern ab. Bei diesen ersten Zusammenkünften am Donnerstagabend erreichte ich immerhin, dass die lebenswichtigen Betriebe (Gas-, Wasser - und Elektrizitätswerke) nicht einen Augenblick zum Stillstand kamen. Am zweiten Streiktage hielt ich wiederum Bürgermeister- sowie Betriebsführerappelle $a b$, bei welchen ich die Bürgermeister und Betriebsführer aufforderte, unverzüglich dafür Sorge zu tragen, dass ihre städtischen Betriebe bezw. ihre Werke wieder in Gang kämen. Bei den Bürgermeistern hatte ich auch bis auf wenige Ausnahmen, die sich aufgrund ihrer mangelnden Persönlichkeit nicht durchsetzen konnten, vollen Erfolg. Die Betriebsführer gaben sich auch, nachdem ich sie auf den Ernst der Lage hingewiesen hatte, die redlichste Mühe, ihren Betrieb bezw. ihre Belegschaft wieder zum Arbeiten $z u$ bringen.

Da die Provinz Overijssel noch immer ohne Kommissar ist, und der stellvertr. Kommissar solchen ernsten Situationen absolut nicht gewachsen ist, konnte ich mich der Provinzialbehörden nicht bedienen, sondern musste alle Verhandlungen selbst führen und Anordnungen zum grossen Teil allein erteilen. Eine möglichst umgehende Besetzung des Kommissarpostens ist unbedingt erforderlich.

Am Sonnabend, den 1.5., arbeiteten die staatlichen und kommunalen Behörden und Dienst- 
stellen wieder voll. Die Industrie hatte zum grossen Teil bis mittags 12,00 Uhr ihre Tätigkeit auch wieder aufgenommen. Nur in vereinzelten Orten lieferten die Bauern noch keine Milch ab. Ich machte die Bürgermeister dafür verantwortlich, dass sie mit eigenen Nachrichtenmitteln für eine sofortige Milchablieferung zu sorgen hätten, was ihnen auch hundertprozentig gelang. Eine ganze Anzahl von Molkereien arbeitete daraufhin freiwillig am Sonntag, um die spät angelieferte Milch zu verarbeiten.

Nach Bekanntwerden des Streiks wurde das I./SS-Pol. "Todt" von Arnheim nach der Twente in Marsch gesetzt und traf in den Abendstunden des Donnerstag, 29.4., in Hengelo ein. Nach Verhängung des Polizeistandrechts für die Provinz Overijssel am Freitag, dem 30.4., teilte der Kommandeur des Bataillons, Hauptmann Ne y, den nunmehrigen Sicherungsbereich Overijssel in Sicherungsbezirke ein, sodass die gesamte Provinz Overijssel mit Polizeitruppen, wenn auch nur sehr schwach, doch immerhin besetzt war. Die Führung sowie das Auftreten der Mannschaften waren hervorragend. Dieser Haltung und dem energischen Auftreten der Polizeitruppen ist es zu verdanken, dass die Aufruhrbewegung so schnell und verhältnismässig unblutig niedergeschlagen werden konnte.

Sogleich nach Verhängung des Standrechts und meiner Bestellung zum Sonderbeauftragten verlegte ich vorübergehend meinen Dienstsitz nach Hengelo, wo ich in der Dienststelle der Kreisleitung der NSDAP. Zimmer für mich, den Kommandeur des Sicherungsbereichs sowie für den SD zur Verfügung gestellt bekam. Diese Zusammenlegung erleichterte die Arbeit ganz bedeutend. Die Zusammenarbeit darf ich als vorbildlich bezeichnen.

Von meiner Dienststelle in Zwolle nach der Kreisleitung der NSDAP. in Hengelo bestand schon immer direkter Telefonanschluss. Zur schnellen und reibungslosen Nachrichtenübermittlung liess ich aber noch eine zweite Leitung nach der Kreisleitung in Hengelo freimachen, sodass alle Befehle bezw. Meldungen von Den Haag sowie von allen anderen Dienststellen ohne Verzögerung übermittelt werden konnten. Die Nachrichtenübermittlung an die Bevölkerung erfolgte durch Plakataushang und durch Lautsprecherwagen, von denen einer in der Stadt Hengelo vorhanden war und ein zweiter vom Arbeitsbereich der NSDAP. zur Verfügung gestellt wurde.

Die niederländische Polizei tat wohl im grossen und ganzen ihre Pflicht. Ihr Auftreten der Bevölkerung gegenüber war aber meistens ziemlich schlapp. Es ist anzunehmen, dass ein Teil von ihnen Sympathie für die Streikenden hatte, wenn sie es auch nicht offen zeigten.

In den letzten Tagen konnte wiederholt festgestellt werden, dass niederländische Polizei bei Feststellung von Uebertretung der Sperrstunde vor allem gegen deutschfreundliche Niederländer vorging.

Eine grosse Unterstützung fand ich beim Arbeitsbereich der NSDAP., Kreis Overijssel, der seine Parteigenossen restlos der Streikbekämpfung zur Verfügung stellte.

Erfreulich war auch das Verhalten der NSB., die bei dieser Gelegenheit zeigte, dass sie bereit ist, auf deutscher Seite durch dick und dünn zu gehen. Der Distriktsleiter bot mir seinen gesamten Parteiapparat einschliesslich WA zum Einsatz an. Es brauchte aber nicht darauf zurückgegriffen zu werden. Ausserordentlich wertvoll war die Nachrichtenübermittlung seitens der Parteigenossen des Arbeitsbereichs der NSDAP. und der Dienststellen der NSB. Erwähnen möchte ich, dass sich auch die Funktionäre der NSB., denen man gewisse deutschfeindliche Tendenzen nachsagt, offen $z \mathfrak{u}$ uns bekannten.

Ich habe den Eindruck, dass uns die niederländische Bevölkerung eine derartig konsequente Niederkämpfung der Streikbewegungen nie zugetraut hat. Sie hält sich z.Zt. genauestens an 
die bestehenden Bestimmungen. Wie ich durch vertrauenswürdige Mitteilungen erfahren habe, ist die Arbeitsleitung in den Betrieben augenblicklich grösser als vor dem Streik. Ebenso ist eine erfreuliche Zunahme in der Milchablieferung festzustellen.

Ich bin allerdings der Ansicht, dass wir uns trotz dieser Tatsachen nicht darüber hinwegtäuschen dürfen, dass vor allem bei einer evtl. feindlichen Landung die Bevölkerung je nach Art der Beeinflüssung von feindlicher Seite oder von Führern bereit sein wird, passiven und evtl. auch aktiven Widerstand entgegenzusetzen.

Ich gestatte mir, die Ansicht zu äussern, dass mehr als bisher die leitenden Behördenstellen mit vertrauenswürdigen nationalsozialistischen Männern besetzt werden müssten, da in einem Ernstifalle doch nur auf diese absolut Verlass ist.

Ausserdem halte ich es für angebracht, wenn meiner Dienststelle eine Lautsprecheranlage, eingebaut in einem PKW., zur Uebermittlung von Verhaltungsmassregeln und Befehlen an die Bevölkerung zugeteilt würde.

Weidlich.

\section{Rapport van de Beauftragte voor de provincie Gelderland, d.d. 15 5 1943}

An den

Arnhem, den 15. Mai 1943

Reichskommissar f. d. b. n. Gebiete,

Herrn Reichsminister Dr. Se y s s-In qua r t,

Den Haag.

Betr.: Erfahrungsbericht - Streiktage.

Bezug: Fernschreiben 5739 vom 10.5.1943.

\section{Verlaut:}

Donnerstag, den 29.4, waren bei der Bevölkerung sichtbare Anzeichen grosser Erregung bemerkbar. Es stellte sich heraus, dass die in der Presse verkündete Rückführung in die Kriegsgefangenschaft des niederländischen Heeres von 1940 direkter Anlass war.

Von Overijssel zugehende Mitteilungen über dort ausgebrochene Streiks grösseren Umfangs veranlassten mich $z u$ erhöhter Aufmerksamkeit und Benachrichtigung der deutschen Dienststellen in der Provinz. Der Kreisleiter des Arbeitsbereichs, der Distriktleiter der NSB. sowie der Leiter der niederländischen Polizei wurden aufmerksam gemacht, damit evtl. erste Anzeichen eines Uebergreifens des Streiks auf die Provinz Gelderland mir schnellstens gemeldet würden. Gegen Abend lief die Mitteilung über Arbeitsniederlegung von ca. 500 Arbeitern in der Gemeinde Ulft ein. Der Betriebsdirektor der fraglichen Firma wurde energisch angefasst und angewiesen, noch am Abend durch vervielfältigte Schreiben seine Arbeiter auf die ernsten Folgen eines Streiks aufmerksam zu machen. Sofortiges Eingreifen wurde angekündigt, falls 
nicht am nächsten Morgen volle Wiederaufnahme der Arbeit eine halbe Stunde nach Betriebsanfang gemeldet werden könnte. Freitagmorgen wurde 100\%-ige Arbeitsaufnahme mitgeteilt.

Zwischen 9 und 10 Uhr (30.4.43) erreichten mich stets zahlreicher werdende Berichte über Arbeitsniederlegung von Betrieben nach anfänglich vollzähligem Erscheinen der Belegschaften. Es wuchs $z \mathfrak{u}$ einer Lawine an. Die Unmenge von eingehenden Angaben konnte über die zur Verfügung stehende Telefonapparatur nicht verarbeitet werden, zumal diese noch teilweise versagte. Stündlicher Meldedienst durch Boten wurde für die niederländische Polizei angeordnet, auch mit der NSB. und NAF. eine entsprechende Vereinbarung getroffen, damit Ueberblick über das Geschehene in der Provinz gewährleistet blieb.

$\mathrm{Da}$ in Arnheim und in der Provinz der Streik auf Behörden, städtische Betriebe, Telefonämter usw. übergriff, waren alle Anzeichen eines sich entwickelnden Generalstreiks vorhanden. Herrn Generalkommissar Rauter telefonisch zu erreichen stiess auf Schwierigkeiten. Um ein restloses Ausschalten der städtischen Betriebe in Arnheim mit den damit verbundenen Folgen $z u$ vermeiden, wandte ich mich an Obersturmbannführer Fortenbacher des SS.Ers.Batl. "Germania", zwecks Abstellen einiger Männer zur Sicherung der Wasser-, Elektrizitäts- und Gaswerke der Stadt Arnheim. (Das in Arnheim stationierte Batl. des Polizeiregiments "Todt" war in der Nacht vom 29. zum 30.4. nach Overijssel zum Einsatz gebracht). Ein späteres Telefonat mit Herrn Generalkommissar Rauter bestätigte, dass das SS.Ers.Batl. "Germania" als Sicherungstruppe für die Provinz eingesetzt werden konnte.

Um die Flutwelle der an Stärke zunehmenden Streikbewegung zu kehren, beschloss ich durch persönliches Eingreifen bei den Behörden und Gemeindebetrieben der Stadt Arnheim sowie der Kunstseidefabriken Arnheim/Ede (ca. 2.500 Mann Belegschaft) Wiederaufnahme der Arbeit schnellstens durchzusetzen und somit ein Beispiel zu stellen.

Bürgermeister und Direktion wurden zu Eilbesprechungen herbeigerufen, auf ihre Pflichten hingewiesen und Ratschläge für ihr Handeln, die Streikenden zur Wiederaufnahme der Arbeit zu bewegen, erteilt.

Die Erregung der Bevölkerung wuchs immer mehr, auch trat das Streikbild äusserlich in Erscheinung. Alle Strassenbahnwagen fuhren in die Remise zurück. Auf der Strasse wurde u.a. ein Wagen mit Stroh der Wehrmacht angezündet.

Noch am Morgen gelang es jedoch, eine rückläufige Bewegung auszulösen. Der erste Strassenbahnwagen wurde in Betrieb gesetzt. Am Nachmittag fuhr die Strassenbahn vollzählig, obgleich manche Schwierigkeiten zu überwinden waren. So wurde z.B. ein Strassenbahnwagen durch die Bevölkerung umgeworfen.

Die städtischen Betriebe konnten langsam auf vollen Arbeitsgang gebracht werden. Bei den Kunstseidefabriken nahm die Zahl der an die Arbeitsplätze zurückkehrenden Arbeiter stetig $z$ u.

Soweit möglich waren an die Stellen der Streikbewegung in der Provinz den zuständigen Bürgermeistern und Betriebsführern telefonisch Anweisung gegeben, wobei ich sie zu energischem Handeln aufforderte. $\mathrm{Zu}$ besonderen Brennpunkten in der Provinz wurden Referenten gesandt, um die getroffenen Massnahmen zu überprüfen.

Die bereits für die Gemeindebetriebe Arnheim eingesetzte Technische Nothilfe in Verbindung mit dem deutschen Ingenieurstab schickte Sonderkommandos in die Provinz, wo Streikbewegungen in lebenswrichtigen Gemeindebetrieben gemeldet wurden. Nach einer $\mathrm{Be}-$ 
sprechung mit dem Kommissar der Provinz, Baron van Heemstra, sandte dieser ein Rundschreiben an die Bürgermeister, worin er diese auf den Ernst der Lage hinwies und aufforderte, mit allen ihnen zur Verfügung stehenden Mitteln einzuschreiten.

In den abends erschienenen Zeitungen wurde das Standrecht verkündet. Plakatierung konnte in der Nacht vom 30.4. zum 1.5. durchgeführt werden. Samstag, 1.5., zeigte sich in zunehmendem Masse Wiederaufnahme der Arbeit. Die Beamtenschaft war überall in der Provinz vollzählig erschienen.

Sonntag, 2.5., zeigte ein normales Strassenbild. Die Sicherungskräfte sowie niederländische Polizei waren angewiesen, nur bei deutlich sichtbaren Demonstrationen einzuschreiten und von der Waffe Gebrauch zu machen. Dieser Massnahme ist es zu danken, dass in der Provinz auf der Strasse niemand verwundet oder getötet wurde.

In Erwartung der Urteile des tagenden Standgerichts Gelderland wurde eine Druckerei in Bereitschaft gehalten. Drei Stunden nach Eintreffen der Bestätigung der Urteile konnten die Plakate dem bereitgestellten Verteilerapparat der SS. und Maréchaussee übergeben werden.

Montag, 3.5., trafen nur noch von 3 Stellen Streikmeldungen aus der Provinz ein. Mit Sonderkommandos wurden diese Fälle beseitigt.

Eine Brandstiftung im Justizgebäude Arnheim konnte nach kräftiger Bekämpfung durch die Feuerwehr mit allen Mitteln (Magirusleiter) auf einen Dachstuhlbrand beschränkt werden.

Das Standgericht hatte insgesamt 23 Todesurteile ausgesprochen. In viermaliger Auflage erfolgte Bekanntgabe an die Bevölkerung durch Plakatierung in der gesamten Provinz.

$Z_{u}$ den gestellten Fragen ist $z u$ sagen:

$\mathrm{Zu}$ 1.) Allgemeine Erregung über befürchtete Massnahmen des erhöhten Arbeitseinsatzes. Diese und durch den englischen Sender aufgeputschte Stimmung bildeten günstigen Nährboden.

Zu 2.) Die Bekanntmachung des W.B.N. traf die Niederländer wie ein Schlag, zumal keine Ausnahmen angekündigt waren. Ausgangspunkt des Streiks war das Industriegebiet in Overijssel. Tatsachenberichte aus Overijssel, welche sich von Mund $z u$ Mund durch Telefon, durch Reisende usw., wellenförmig verbreiteten, zeigten den Leuten erst, dass ein Streik überhaupt möglich war, und wirkten ansteckend.

$\mathrm{Zu}$ 3.) In erster Linie war es ein Ausdruck des Protestes, hinter dem die stille Hoffnung stand, durch allgemeine Arbeitsniederlegung Durchführung der deutschen Massnahmen $z u$ erschweren evtl. unmöglich $z u$ machen. In vielen Kreisen war man überzeugt, auf Grund früherer Erfahrungen, dass deutscherseits bei wachsenden Schwierigkeiten Zurückziehung der getroffenen Massnahmen erfolgen würde.

$\mathrm{Zu}$ 4.) Freitagmorgen bis zum Einsetzen der Gegenmassnahmen streikten schätzungsweise $50-60 \%$ der Belegschaften der Privatindustrie, $40-50 \%$ der Beamtenschaft.

$\mathrm{Zu}$ 5.) Behördenleiter und Betriebsführer haben sich mit wenigen Ausnahmen aus eigenem Antrieb nicht der Streikwelle energisch entgegengestellt. Dass dieses mit grosser Aussicht auf Erfolg wohl durchgeführt werden konnte, haben die Tatsachen später bewiesen. Wenn sie energisch auf ihre Pflichten aufmerksam gemacht wurden, haben die Leiter der Behörden und Betriebe durchweg gut reagiert und tatkräftig gehandelt. Es wirkte sich günstig aus, dass jeweils bei den Behörden und Fabriken das Führen 
einer Liste mit genauer Zeitangabe der Wiederaufnahme der Arbeit jeder Person zur späteren Ueberprüfung verlangt wurde und die Leiter persönlich hierfür $z \mathrm{u}$ haften hatten. Der Direktion der Kunstseidefabriken wurde der Lautsprecherwagen zur Verfügung gestellt, damit am Samstagmittag die Arbeiter zum Antreten der Nachtschicht aufgefordert werden konnten. Einer guten Zusammenarbeit mit der Direktion war es $z \mathfrak{u}$ danken, dass in diesem führenden Betriebe eine schnelle Wiederaufnahme der Arbeit erfolgte und kein Gefolgschaftsmitglied vor das Standgericht kam.

$\mathrm{Zu}$ 6.) Eilbesprechungen mit zur Dienststelle beorderten Behörden- und Betriebsleitern, Anweisung über Telefon oder durch Boten mit Benutzung des Nachrichtennetzes des Arbeitsbereichs, der NSB., NAF. usw. ergaben über Erwarten grosse Einflussmöglichkeiten.

Zu 7.) Die Zusammenarbeit im deutschen Bereich war sehr gut. Das Uebergreifen des Streiks auf die Telefonverstärkerstation machte die Telefonverbindung nach auswärts zeitweilig unmöglich, bis die getroffenen Gegenmassnahmen auch dort Wiederaufnahme der Arbeit auslösten. Eine sofort in Bereit gestellte Druckerei konnte jeweils 3 Stunden nach Textaufgabe die für die Bevölkerung benötigten Plakate liefern.

$\mathrm{Zu}$ 8.) Der Apparat der staatlichen und obrigkeitlichen Dienststellen liess sich, wenn man die Herren energisch anfasste und jeweils persönlich verantwortlich stellte, gut bespielen. Ein Mangel an Nachrichtenübermittlungsmöglichkeiten machte sich für den Kommissar der Provinz bemerkbar. Der Verteilerapparat der Maréchausee musste eingeschaltet werden. Schnellste Durchgabedauer an alle Bürgermeister 11 Stunden.

$\mathrm{Zu}$ 9.) Verbindung mit dem Kreisinspekteur des Arbeitsbereichs wurde aufgenommen. Die Notwendigkeit des Einsatzes von Parteigenossen ergab sich nur für den Ingenieurstab, welcher mit der Technischen Nothilfe gemeinsam eingeschaltet wurde. Der Distriktsleiter der NSB stellte sich mit seinen Männern zur Verfügung. Die WA, erschien ohne Aufforderung in Uniform und leistete vor allem in abgelegenen Gebieten gute Dienste. Verschiedene nationalsozialistische Bürgermeister bedienten sich der WA.

$Z u$ 10.) Man ist durchweg überzeugt, dass ein Streik, der nicht zur Unterstützung einer Landung durchgeführt wird, zwecklos ist. Die grosse Enttäuschung war, dass die Eisenbahner nicht mitstreikten. Man nimmt an, dass dieses bei einer Landung der Engländer wohl der Fall sein wird! Der Streik der Eisenbahner soll dann das Signal zum Generalstreik werden.

$Z u$ 11.) Ich zweifele nicht daran, dass im Ernstfalle nicht nur mit einer neuen Streikwelle, sondern auch mit Aufständen in den nicht stark gesicherten Gebieten gerechnet werden muss.

Für den Fall einer Wiederholung eines Streiks, welcher nicht im Zusammenhang mit einer Landung steht, müsste vorgesorgt werden, dass der jetzt erstandene Abwehrapparat schneller in Aktion treten kann. Ein Sicherheitskommandeur für jede Provinz, der auf seine Aufgabe mit einem Mobplan vorbereitet ist, müsste dauernd angewiesen sein. In Zusammenarbeit mit den Beauftragten könnte bei den ersten Anzeichen einer Streikbewegung eingegriffen werden, damit Lokalisierung auf alle Fälle möglich ist.

Telefon- und Telegrafennetz müssten für den ausschliesslichen Dienstgebrauch umgeschaltet werden können. In Dienststellen, welche unter Bewachungsschutz gestellt werden, empfiehlt es sich, jeweils den Leiter als Geisel festzuhalten.

Für die Eisenbahn gilt das gleiche. Zusätzlich könnte man in Utrecht schlagartig bei Ausbrechen eines Eisenbahnerstreiks die Verwaltungsgebäude besetzen und die Beamten als 
Geisel festhalten, wovon dann den Eisenbahnern Mitteilung zu machen wäre. Die Niederländer sind fortlaufend $z u$ belehren, dass auch ohne Verkündung des Standrechts auf Streik in Kriegszeiten die Todesstrafe steht. In verstärktem Masse wären die Betriebsleiter durch die Niederländische Arbeitsfront anzusprechen und auf ihre Führungspflichten aufmerksam zu machen.

Der Ausbau der Technischen Nothilfe ist zu fördern mit Schwerpunkt der Aufrechterhaltung der lebenswichtigen städtischen Betriebe.

I.V.

Brandes ${ }^{1}$.

\section{Rapport van de Beauftragte voor de provincie Utrecht, d.d. 15-5-1943}

15. Mai 1943.

An den

Herrn Reichskommissar für die

besetzten niederländischen Gebiete,

Reichsminister Dr. S e y s s-In q u a r t,

Den Haag.

Betr.: Fernschreiben 5739 vom 10.5.43 16 UThr.

Der Ablauf der Ereignisse während der Streiktage war folgender:

Am 30. April 1943 gegen Mittag gingen die ersten Nachrichten über ausgebrochene bezw. versuchte Streiks ein. Gegen 16 Uhr wurde in folgenden Orten gestreikt:

Ut rech t: $\quad$ Verkehrsinspektion

Nederlandsche Spoorwegen-Verwaltung

Fernmeldeamt

„GEBRUR" (Gas-, Elektrizitäts-, Autobus- und Radio-Betriebe)

„PUEM" (Provinziale Utrechtsche Elektrizitäts-Maatschappij)

„LUBRO" Brotfabrik.

Versucht wurde der Streik im Elektrizitätswerk „PEGUS”. - In den Nederlandschen Spoorwegen wurde der Streik ebenfalls versucht, zum Teil wurde Sitzstreik durchgeführt.

Amersfoort: Getreide-Packlager Gerritsen

De Bilt: Wehrmachtsbetrieb Wenten

Apparatefabrik van Doorn

Metallwarenfabrik Meijer en Greeven.

Versucht wurde der Streik in der Geflügel- und Eier-Zentrale.

Bilthoven: $\quad$ Firma ,Inventum".

IJ sselstein: 6 Möbelfabriken.

1) De gemachtigde voor Gelderland, Schneider, bevond zich in militaire dienst. 
Zeist:

Abcoude:

Veenendaal:

Rheenen:

Woudenberg:
Die Belegschaft des Gaswerkes.

Die Gefolgschaft der Amsterdamschen Ballast-Maatschappij.

10 Fabriken und die gesamte Gemeindeverwaltung.

Teilweise die Beamtenschaft.

Der Bürgermeister selbst war abwesend und das Gemeindehaus geschlossen. Es war jedoch nicht genau festzustellen, ob die Beamten das Gemeindehaus ebenfalls verlassen hatten.

Nachdem ich die betreffenden Bürgermeister angerufen hatte, wurde in den meisten Fällen die Arbeit sofort wieder aufgenommen. Der Rest nahm die Arbeit am Sonnabend wieder auf, nachdem SS-Kommandos dazu aufgefordert hatten.

Damit war in der Provinz Utrecht die ganze Streikbewegung im grossen und ganzen überhaupt erledigt. Ab Montag arbeiteten wieder sämtliche Betriebe und Verwaltungen.

$\mathrm{Zu}$ den in obengenannten Fernschreiben gestellten Fragen nehme ich wie folgt Stellung:

\section{Zur Frage: Welches sind die Hintergründe des Streikes?}

Sie sind in der allgemeinen Opposition gegen alle Massnahmen der Besatzungsmacht zu suchen, einer Opposition, die von London aus ständig aufrecht erhalten und geschürt wird für alle Fälle.

2. Zur Frage: Was war die unmittelbare Veranlassung, von wo aus hat er sich verbreitet und in welcher Weise?

Als unmittelbare Veranlassung muss die Bekanntmachung des Wehrmachtbefehlshabers bezeichnet werden. Sie ist jedoch nicht die Ursache des Streikwillens selber, sondern nur die Auslösung des seit langem bestehenden Streikwillens. Es gibt demzufolge auch keinen bestimmten Ausgangspunkt, genau so wenig, wie man von bewusster, systematischer Ausdehnung sprechen kann. In dem sprungweisen zusammenhanglosen Aufflattern des Streiks ist zu erkennen, dass dem Streik keine Führung zugrunde lag, sondern dass er in gewissem Sinne spontan ausbrauch. Führung war nur jeweils in Streikorten, aber auch nicht in allen, festzustellen. Der Streik wurde besonders von der Seite der Halbwüchsigen getragen. Es ist beobachtet worden, dass die Aeltern versuchten, sich den Jungen entgegenzustellen. Für die Jungen war es scheinbar der sehnlichst erwartete Augenblick, ihr Heldentum unter Beweis zu stellen. In den Orten, wo eine grössere Anzahl von Betrieben streikte, war klar zu erkennen, dass die Betriebe nicht zum gleichen Zeitpunkt, sondern nach einander in den Streik traten. Die Feststellung, dass in einem Betrieb der Streik begann, war für den nächsten das Signal, und so weiter für den folgenden, zum Streik.

Nur bei der Eisenbahn hatte ein 24-jähriges Mädel den Versuch unternommen, durch Absendung eines Telegramms die gesamten Eisenbahnstellen zu veranlassen, den Betrieb stillzulegen. Nach ihrer Verhaftung blieb sie bis auf den heutigen Tag dabei, dass diese Handlung völlig aus eigenem Entschluss entstand.

Bei den Behörden mag das Telefon als Vermittler eine gewisse Rolle gespielt haben. Die Art des Streikausbruches ist jedoch ein Zeichen dafür, dass er für den vorliegenden Fall nicht bewusst organisiert und ausgerufen worden ist. Die halbwüchsigen und unreifen Burschen glaubten nun den Zeitpunkt für gekommen. Einwürfe, dass der gleichzeitige Ausbruch in Den Helder und in Limburg ein Zeichen für den organisierten Streik gewesen sei, ist meines Erachtens nicht stichhaltig. Dies hätte sich in den gleichen Berufen auswirken müssen. Es ist nur ein Zeichen dafür, dass die Bereitschaft zum Streik bezw. Widerstand überall bestanden hat. 
3. Zur Frage: Welche Ueberlegung veranlasste die Streikenden zu ihrer Handlung und welche Ziele verfolgten sie?

Wenn bestimmte Ueberlegungen dem Streik zugrunde gelegen haben, dann höchstens bei denen, die in die Kriegsgefangenschaft zurückgehen müssen und die, wie an verschiedenen Stellen laut wurde, noch sagten: Wenn ich sowieso in Kriegsgefangenschaft muss, dann brauche ich ja bis dahin nicht mehr zu arbeiten.

Für die jungen Burschen war die Niederlegung der Arbeit dieser Männer Zeichen genug zur Ingangsetzung ihres Heldentums. - In der Bahn wurden Bemerkungen von jungen Leuten gehört, die darauf hinaus liefen, nun sei die Zeit gekommen, irgend etwas anzustellen. Dass der Streik im allgemeinen erst um die Mittagszeit ausbrach, hat seine Ursache wahrscheinlich darin, dass die Betriebsgefolgschaften erst in der Frühstückspause Gelegenheit hatten, zu der Anordnung des Wehrmachtbefehlshabers und den Abwehrmassnahmen Stellung zu nehmen. Sonstige Ueberlegungen haben nach den Beobachtungen dem Streik und den damit verbundenen Handlungen nicht zugrunde gelegen. Es ist auch wohl kaum ein bestimmtes Ziel verfolgt worden, als höchstens das in den Niederlanden allgemein gesetzte, nämlich die Massnahmen der Besatzungsmacht, sofern sie mit dem eigenen Wunsche nicht übereinstimmen, soweit wie möglich in ihrer Durchführung zu hemmen bezw. hinauszuzögern.

4. Zur Frage: Welchen Ulmfang nahm der Streik im Verhältnis zu den übrigen Betrieben und Dienststellen ihres Tätigkeitsbereiches ein?

Im Verhältnis zu den übrigen Betrieben und Dienststellen innerhalb meines Dienstbereiches war der Umfang des akuten Streiks fast bedeutungslos.

5. Zur Frage: Welchen Einfluss hat die Führung der Betriebe und Dienststiellen genommen bezw. welche Bedeutung hatte die Unterlassung einer Einflussnahme?

Bei einigen wenigen Dienststellen und Betrieben wurde von der Leitung sofort dem Streik entgegengetreten. Z.B. von der Generaldirektion der Niederländischen Eisenbahn, von dem Direktor von Waterstaat und dem Direktor des Elektrizitätserzeugungswerkes "PEGUIS". Die Betriebsführer der streikenden Betriebe in Veenendaal haben auf meinen Anruf hin gleichfalls noch am Freitag ihre Belegschaft zum Abbruch des Streiks mit Erfolg aufgerufen. Man kann also sagen, dass dort, wo von der Führung bewusst gegen den Streik vorgegangen wurde, die Gefolgschaft auch sofort den Streik abgebrochen hat. Bis zum Sonnabend haben sich die Streiks überall dort gehalten, wo seitens der Führung nichts getan wurde, weil, wie z.B. bei den Elektrizitätsverteilungsbetrieben „PUEM" und „GEBRUR" in Utrecht angeblich nichts getan werden konnte. Die Streiklust war nach den Beobachtungen im gesamten Volk nicht sehr gross, deshalb waren die Streiks dort am erfolgreichsten, wo seitens der Betriebsführung keine ernsthafte Einflussnahme versucht wurde. Und sie waren dort am wenigsten bezw. überhaupt nicht erfolgreich, wo seitens der Betriebsführung sofort energisch Einfluss genommen wurde.

6. Zur Frage: Welche Möglichkeiten bestanden für Sie selbst auf den Lauf der Ereignisse Einfluss zu nehmen?

Ich habe durch telefonischen Anruf der Bürgermeister bezw. Dienststellenleiter oder durch persönliche Rücksprachen versucht, auf den Gang der Ereignisse Einfluss zu nehmen. Dies ist auch im allgemeinen in positivem Sinne gelungen. Im übrigen standen mir über den Kommandeur des Sicherungsbereiches Polizei bezw. SS für die Fälle zur Verfügung, wo der Dienststellenleiter behauptete, selbst nicht mächtig genug zu sein. Ebenso stand mir ein Lautsprecherwagen zur Verfügung. Da jedoch die Streiks und Zusammenrottungen umgehend beseitigt werden konnten, brauchte der Lautsprecherwagen nicht erst in Tätigkeit $z u$ treten. Die Zusammenrottungen waren im übrigen, abgesehen von einem Fall in Hilversum, so wenig politisch bedeutungsvoll, dass sich aus ihnen die Notwendigkeit des Einsatzes des Lautsprecherwagens nicht ergab. 
7. Zur Frage: Wie funktionierte die Zusammenarbeit im deutschen Bereich und in welcher Weise funktionierten die Nachrichtenmittel für Sie zu den Zentralen bezw. welche Möglichkeit bestand, Nachrichten an die Bevölkerung weiterzugeben?

Die Zusammenarbeit im deutschen Bereich war gut. Ich habe die Dienststellenleiter cier deutschen Dienststellen sofort zusammengerufen und die Lage mit ihnen durchgesprochen, ebenso Massnahmen zum Schutze der deutschen Dienststellen ergriffen.

Desgleichen fand noch am ersten Tage des Ausnahmezustandes eine Besprechung mit dem Kommandeur des Sicherungsbereiches statt, die ebenfalls erfolgreich war. Eine Stockung in der Nachrichtenübermittlung ist nicht eingetreten. Zur Verfügung stand: Telefon, Presse, Lautsprecherwagen und Post.

8. Zur Frage: Wie war der Einsatz und das Verhalten der hier in Frage kommenden staatlichen Stellen und obrigkeitlichen Dienststellen aut niederländischer Seite? Der Einsatz und das Verhalten der staatlichen und obrigkeitlichen Dienststellen auf niederländischer Seite war verschieden. Zum Teil wurde sofort gegen die Streikbewegung angegangen, zum Teil aber liess man den Streik laufen und bemühte sich erst nach entsprechender Aufforderung durch den Beauftragten bezw. den Kommandeur des Sicherungsbereiches.

Ich möchte jedoch nicht behaupten, dass die Dienststellenleiter, die sofort gegen die Streikbewegung angingen, abgesehen von den NSBern, dies aus einer inneren positiven Haltung der Besatzungsmacht gegenüber getan haben, sondern ich glaube vielmehr, dass daran mangels einer zentralen Leitung der Streikbewegung keine einheitliche Auffassung vorhanden war, und dass die weniger Mutigen bezw. Leichtsinnigen die Zeit für nicht gekommen hielten.

9. Zur Frage: Wie wat das Verhalten bezw. der allfällige Einsatz der politischen Parteien und ihrer Mitglieder und Formationen?

Ein Einsatz weder der NSDAP, der NSB oder der Formationen war nicht notwendig, da die Streikbewegung fast umgehend niedergeschlagen werden konnte. Es kann also über ein Verhalten nicht berichtet werden.

10. Zur Frage: Unter welchem Eindruck steht nunmehr die niederländische Bevölkerung hinsichtlich des Streiks und im Hinblick auf die Wiederholung einer solchen Aktion?

Die Bevölkerung ist zur Zeit ziemlich niedergeschlagen. Der Mut zum Streik ist bei aller Bereitschaft dazu sehr gering. Der Versuch zum Streik ist kläglich zusammengebrochen.

Die Meinung im Volk geht dahin, dass der Streik eine grosse Torheit war und es käme doch nichts dabei heraus. Es sieht auch nicht so aus, als wenn grosse Lust zur Wiederholung eines Streiks vorhanden wäre. Das konsequente Durchgreifen seitens der Kommandeure der Sicherungsbereiche hat erheblich dazu beigetragen, das niederländische Volk von dem Wahn zu befreien, dass wir es nicht wagen würden, mit den letzten Mitteln vorzugehen.

Seitens der Wehrmacht wurden zwar wegen dieses Vorgehens Bedenken geäussert, aber es war trotzdem das allein Richtige.

11. Zur Frage: Welche Schlussfolgerungen ziehen Sie aus diesen Ereignissen für den Fall einer feindlichen Landung?

Im Falle einer feindlichen Landung werden sicherlich wieder hier und dort Unruhen aufflackern, aber sie werden sehr wahrscheinlich genau so uneinheitlich sein, wie die vorhergegangenen. Ich bin sogar der Ansicht, dass im allgemeinen erst einmal der Erfolg der Landung gegenüber den deutschen Verteidigungskräften abgewartet werden wird. Das 
Volk weiss nunmehr, dass es jedem Versuch zur Unruhe mit seinem eigenen Leid und Leben zahlen muss. Für einen Wiederholungsfall halte ich es für dringend notwendig, dass mehr als bisher die leitenden Personen in Behörden, Dienststellen, soweit sie nicht absolut sicher erscheinen, gegen zuverlässige Kräfte ausgewechselt werden. Hierbei dürfte weniger auf $100 \%$ ige Fachkenntnisse als auf politische Zuverlässigkeit Wert gelegt werden. Beispiel: Im Elektro-Erzeugungswerk "PEGUS" in Utrecht wurde von der Rüstungsinspektion angestrebt, anstelle des eingesetzten Direktors (NSBer), der als Schwachstrom-Ingenieur angeblich ungenügend sein sollte, den Direktor Drunings vom Elektrizitätswerk „PUEM" einzusetzen, da er als Starkstromfachmann die grössere Gewähr für das Funktionieren des Werkes, vor allen Dingen in einem Ernstfalle, bieten sollte. Der NSBer hat den Streik im Erzeugungsbetrieb mit Erfolg verhindert. Herr Brunings dagegen ist angeblich in seinem Betriebe dazu nicht in der Lage gewesen. Folgerung: Es kommt also nicht auf die 100\%igen Fachkräfte an, sondern auf Männer, die in einer solchen Situation der Belegschaft gegenüber ihren Mann stellen. - Es ist gewiss leichter, mit eingearbeiteten Fachkräften $z u$ arbeiten, soweit sie jedoch politisch nicht zugleich zuverlässig sind, versagen sie ja gerade in dem Augenblick, wo es eigent lich auf sie ankommt. Es ist deshalb Zeit, dass wir den Weg der Bequemlichkeit endlich verlassen.

Im übrigen dürfte die rechtzeitige erneute Verhängung des Standrechts im Falle einer Landung die inneren Aufstandsversuche von vornherein sofort lähmen.

Besonders unsinniges Verhalten der Streikenden ist hier nicht festzustellen gewesen, es sei dann, dass die halbwüchsigen Burschen glaubten, durch herausfordernde Blicke und ein ebensolches Benehmen ihren Mut kund $z u$ tun.

$M$ üller $-R$ einert.

\section{Rapport van de Beauftragte voor Amsterdam (Noord-Holland), d.d. 15-5-1943}

Amsterdam, den 15. Mai 1943.

An den

Reichskommissar für die besetzten niederländischen Gebiete,

Herrn Reichsminister Dr. S e y s s - In q u a r t,

Den Haag.

Betr.: Erfahrungsbericht für die Stadt Amsterdam und die Provinz Nord-Holland über die Streiktage.

Nach Veröffentlichung der Bekanntmachung des Wehrmachtbefehlshabers über die Rückführung der Angehörigen der ehemaligen niederländischen Wehrmacht in die Kriegsgefangenschaft setzte ein Sturm auf die Zeitungskioske ein. Die Bevölkerung geriet in eine gewisse Nervosität; die Anordnung des Wehrmachtbefehlshabers wurde überall lebhaft diskutiert; 
die Stimmung war gedrückt. Von der Rüstungsinspektion lief die Meldung ein, das nach Bekanntwerden der Massnahmen des Wehrmachtbefehlshabers in einige Betrieben die Arbeiter zeitweise ihre Arbeitsplätze verlassen und in Gruppen dieses Ereignis besprochen hätten. Im Laufe des Donnerstags (29.4.) ist es in der Provinz Nord-Holland und in der Stadt Amsterdam nirgends $z u$ Arbeitsverweigerungen oder Streiks gekommen. Auch in der Nacht zum 30.4. blieb alles ruhig.

Am Vormittag des 30.4. liefen alsdann aus der Provinz Nord-Holland und auch aus Amsterdam die ersten Nachrichten über Streiks ein. U.a. streikten in IJmuiden die Belegschaft des Hochofenwerks von etwa 2.300 Arbeitern, in Amsterdam die Werkspoor mit etwa 2.200 Arbeitern, die Papierfabrik v. Gelder in Velsen mit 600 Arbeitern. Die Gesamtzahl der streikenden Personen in der Provinz Nord-Holland mit der Stadt Amsterdam belief sich am Mittag des 30.4. auf etwa 10.000 Arbeitern und Arbeiterinnen, darunter waren etwa 2.000 Arbeiter aus landwirtschaftlichen und gärtnerischen Betrieben. In den Energie- und anderen öffentlichen Versorgungsbetrieben wurde weitergearbeitet; desgl. in den Fokkerwerken in Amsterdam. $\mathrm{Zu}$ öffentlichen Zusammenrottungen oder Kundgebungen war es nirgends gekommen.

Nach Verhängung des Polizeistandrechts über die Provinz Nord-Holland trat in Erkenntnis des Ernstes der Lage eine gewisse Ernüchterung ein; in vielen Betrieben wurde die Arbeit wieder aufgenommen.

Am Sonnabendvormittag war der Streik bis auf das Hochofenwerk, die Papierfabrik und die Plattengiesserei in Velsen-IJmuiden sowie einige sonstige Betriebe im wesentlichen eingestellt. Neue Streikmeldungen liefen jedoch ein aus einigen ländlichen Bezirken in NordHolland mit landwirtschaftlichen und gärtnerischen Betrieben; insbesondere aus der Gemeinde Andijk und auch aus dem Wieringermeerpolder. Gegen Abend des 1.5. war der Streik infolge der polizeistandrechtlichen Massnahmen allgemein gebrochen bis auf einige Streikherde in ländlichen Gemeinden. Auch dort wurde die Arbeit im Laufe des Sonntag-Montag in vollem Umfange wieder aufgenommen.

Bemerkenswert ist die Tatsache, dass in öffentlichen Betrieben und Dienststellen keine Arbeitsverweigerungen vorgekommen sind; alle Beamten und Angestellten des öffentlichen Dienstes haben ihre Amtsgeschäfte wahrgenommen.

Im einzelnen ist über die Streiktage folgendes zu berichten:

1. Die Ursachen des Streiks sind insbesondere darin zu suchen, dass in der niederländischen Bevölkerung infolge der letzten Massnahmen (Arbeitseinsatz nach Deutschland, zunehmende Verknappung der Lebensmittel usw.) seit längerer Zeit eine starke Spannung und Erregung bestand; hinzu kommt vor allem die fortgesetzte Verhetzung durch den englischen Rundfunk sowie die umfangreiche Verteilung von Flugblättern kommunistischen Inhalts.

2. Die unmittelbare Veranlassung des Streiks war die Bekanntmachung des Wehrmachtbefehlshabers vom 29.4. Infolge des Inhalts der Bekanntmachung bestand die Auffassung, dass sofort alle Angehörigen der ehemaligen niederländischen Wehrmacht (Berufssoldaten und Reservisten) in die Kriegsgefangenschaft zurückgeführt würden; auch war am 29.4. noch nichts davon verlautbart, dass Befreiungen und sonstige Ausnahmen für Rüstungs-, landwirtschaftliche Betriebe usw. möglich sind. Eine Rolle spielte weiter der Umstand, dass die Niederländer eine gewisse Abneigung gegen alles Militärische haben und sich ausserdem sehr ungern von ihrer Familie trennen. 
3. Durch den Streik wollten die beteiligten Kreise m.E. einen Protest gegen die letzten Massnahmen der Besatzungsmacht zum Ausdruck bringen. Sie glaubten, dadurch einen Druck auf die deutsche Regierungsgewalt auszuüben. Ich habe nicht den Eindruck gewonnen, dass eine einheitliche Streikleitung bestand, abgesehen vielleicht von Velsen und IJmuiden, wo sicherlich eine kommunistische Führung vorhanden war. Auf dem Lande wurde im allgemeinen lediglich aus Sympathie mitgestreikt.

Wenn in der Provinz Nord-Holland und in der Stadt Amsterdam der Streik sich nicht allgemein ausgebreitet hat, so ist dieses auch wohl mit darauf zurückzuführen, dass die Bevölkerung sich noch der Folgen der Streiktage des Jahres 1941 bewusst war und im Gegensatz zu den nördlichen Provinzen bereits viel mehr in die Realität des Krieges einbezogen ist.

4. Im Vergleich $z u$ den in der Provinz Nord-Holland und in der Stadt Amsterdam vorhandenen Betrieben und Dienststellen hat der Streik einen verhältnismässig geringen Umfang gehabt; besonders ist in Amsterdam und Haarlem der Streik auf ganz wenige Betriebe beschränkt geblieben.

5. und 6 .

Als Sonderbeauftragter habe ich mit den Direktoren und Betriebsleitern der grösseren am Streik beteiligten Betriebe Verbindung aufgenommen und dieselben unter Hinweis auf die polizeistandrechtlichen Folgen aufgefordert, alles zu tun, um eine Wiederaufnahme der Arbeit in ihren Betrieben durchzusetzen. In IJmuiden und Velsen ist dadurch zweifellos erreicht, dass noch im Laufe des Sonnabend der Streik abgebrochen wurde und die Hochöfen wieder in Betrieb kamen. Ich bin überzeugt, dass in vielen Betrieben der Streik von vornherein hätte unterbunden werden können, wenn die Betriebsführung von sich aus sofort energischer vorgegangen wäre und nicht erst meine Aufforderung abgewartet hätte.

Auf die ländliche Bevölkerung hat auf meine Veranlassung der Niederländische Landstand durch seine Ortsbauernführer einen beruhigenden Einfluss ausgeübt. Während der kritischen Stunden war ich persönlich zusammen mit dem SD. und dem Standgericht in IJmuiden und habe dort auf die Direktion der streikenden Betriebe eingewirkt. Auch die sofortige Verhaftung der Rädelsführer und Hetzer hat ihren Eindruck nicht verfehlt; am Spätnachmittag des 1.5. waren bereits in allen Gemeinden die Urteile des Standgerichts durch Anschlag bekanntgegeben, wodurch eine starke Ernüchterung eintrat.

7. Mit allen in Frage kommenden deutschen Dienststellen (SD., Kommandeur des Polizeistandgericht, NSDAP.) stand ich im engsten und besten Einvernehmen. Die Nachrichtenmittel zu den Zentralen funktionierten im allgemeinen gut. Eine Verzögerung bei der Durchgabe von Fernschreiben entstand dadurch, dass mein Fernschreiber als Nebenstelle an den Fernschreiber des Polizeibataillons in Amsterdam angeschlossen ist und diese Stelle oft durch eigene Nachrichtenübermittlung auf längere Zeit besetzt war. Die Nachrichten an die Bevölkerung wurden meistens durch Mund-Propaganda weitergegeben. Die schnelle Herausbringung von Plakaten war dadurch gewährleistet, dass ich bereits vorher eine Druckerei mit Personal sichergestellt hatte.

8. Die staatlichen und gemeindlichen Dienststellen haben von vornherein gut mitgearbeitet. Der Kommissar der Provinz und die Bürgermeister der Städte Amsterdam und Haarlem haben sich nach Besprechung mit mir stark für die Verhinderung und Aufhebung von Streiks eingesetzt. Auch die Bürgermeister der kleineren Gemeinden wurden von mir für die Aufrechterhaltung der Ruhe und Ordnung und Unterdrückung des Streiks persönlich verantwortlich gemacht. Wenn es in der Provinz Nord-Holland im allgemeinen ruhig geblieben ist, so ist dieses nicht zuletzt auf das Verhalten der Bürgermeister zurückzuführen. Besonders zu erwähnen ist noch der Einsatz der Amsterdam'er und Haarlem'er Polizei, die in diesen Tagen eine einwandfreie Haltung gezeigt haben. 
9. Die NSB. und ihre Mitglieder haben sich im allgemeinen in diesen Tagen Zurückhaltung auferlegt und sind nicht besonders in Erscheinung getreten. In der Gemeinde Enkhuizen hat die WA, zeitweilig auf Veranlassung des Bürgermeisters als Hilfspolizei Dienst getan und für Ruhe und Ordnung gesorgt. Der Nederl. Landstand hat mit meiner Dienststelle eng zusammengearbeitet.

10. Die niederländische Bevölkerung hat infolge der strengen polizeilichen Massnahmen erkannt, dass ein Streik zwecklos ist, und eingesehen, dass sie mit derartigen Demonstrationen gegenüber der Besatzungsmacht nicht durchkommt und nichts erreicht. Z.Zt. ist mit einer Wiederholung des Streiks nicht zu rechnen. Die standgerichtlichen Urteile und deren Vollstreckung haben eine abschreckende Wirkung gehabt.

11. Im Falle einer feindlichen Landung ist nach meiner Auffassung mit einem Generalstreik zu rechnen. Die niederländische Bevölkerung wird sich in einem solchen Falle m.E. $z \mathrm{u}$ unüberlegten Handlungen hinreissen lassen und die feindlichen Kampfhandlungen unterstützen.

Als Vorbeugungsmassnahme erscheint es mir besonders notwendig, die Betriebsführer der einzelnen Betriebe anzuhalten, ihre Pflichten zu erfüllen und sie persönlich für die Ruhe und Ordnung und Weiterführung der Arbeit im Betriebe verantwortlich zu machen. Ausserdem muss in solchen Fällen von vornherein mit schärfsten Massnahmen durchgegriffen werden. Eine wesentliche Rolle spielt in solcher Lage auch die Haltung der Bürgermeister, sodass als Gemeindeleiter nur noch solche Personen am Platze sind, die auf Grund ihrer politischen Einstellung im Ernstfall die Gewähr einer zuverlässigen Zusammenarbeit mit der Besatzungsmacht bieten.

Dr. Sch roeder.

\section{Rapport van de Beauftragte voor de provincie Zuid-Holland, d.d. 17-5-1943}

Den Haag, den 17. Mai 1943.

An

den Herrn Reichskommissar für die besetzten niederländischen Gebiete.

Betr.: Erfahrungsbericht über die Streikbewegung in Südholland.

Die Streikbewegung, die ihren Ausgang am 29.4.1943 von den östlichen Provinzen Limburg, Brabant, Groningen und Nachbarprovinzen genommen hatte, ergriff die Provinz Südholland in den Vormittagsstunden des 30.4.1943. Sie entstand im Haag durch Bekanntwerden und Verbreiten der über PTT. aus Amsterdam kommenden Berichte über den Streikbeginn in Zwolle, Enschede und hauptsächlich Hengelo. Im Norden der Provinz begann sie in Alphen 
a. d. Rijn in der Druckerei von Samson, die von Utrecht die Streiknachrichten empfangen hatte. Im Südosten streikte zuerst der Betrieb Johann de Witt in Dordrecht, eine Tochtergesellschaft der Philippswerke in Eindhoven, sodass die Beeinflussung von dort vermutet werden muss. In Dordrecht haben ferner auch Schüler des dortigen Technikums die Streikparolen aus Brabant und dem Osten des Landes empfangen und in die verschiedensten industriellen Betriebe der Stadt getragen. Es dehnte sich dann der Streik auf die Umgebung von Dordrecht aus und ergriff, teils auch wieder direkt von Brabant her beeinflusst, östlich Dordrecht die industriellen, insbesondere die Werftbetriebe von Leerdam, Gorinchem, Hardinxveld und Sliedrecht; nördlich und nordwestlich Dordrechts die Betriebe in Alblasserdam, Lekkerkerk, Krimpen a. d. Lek, Krimpen a. d. IJssel, Ridderkerk und Barendrecht. Zuletzt, teilweise erst am 1.5.1943, wurden die südholländischen Inseln von der Streikbewegung berührt.

Im Haag traten zunächst einige Unterbetriebe der PTT., nämlich das Zentralmagazin und die Zentralwerkstatt mit zusammen 400 von 600 Leuten in Streik, ferner das überwiegend mit weiblichen Kräften besetzte Postscheck und Giroamt mit 400 von 2160 Personen, während die Hauptverwaltung mit einer Belegschaft von 2000 durch klare Weisungen der Leitung trotz anfänglicher Spannung bei der Arbeit gehalten werden konnte. In der Stadt selbst entstand unter dem Publikum zeitweise eine gewisse Unruhe, sodass auch Strassenbahnen am Weiterfahren verhindert wurden und Strassenbahnführer den weiteren Dienst verweigerten. In der gewerblichen Wirtschaft streikten im Bezirk Gross-Den Haag die Radiofabrik v. d. Heem (Erres-Radio), ein Rüstungsbetrieb mit 90 v.H. der Belegschaft, ferner einige andere Betriebe mit wesentlich geringeren Ziffern. Von den für die Ernährung wichtigen Betrieben streikten im Haag die Molkereiproduktenzentrale mit ungefähr 200 Mann, ferner Teile des Ernährungsdepartements und des Distributiebüros. Von den sonstigen öffentlichen Dienststellen und Betrieben stellten Teile der Zentrale der Staatsminen, des Statistischen Reichsamts, des Reichskohlenbüros, des Standesamts, des Einwohnermeldeamts, des Wohlfahrtsamts und der Verwaltung des provinzialen Waterstaat die Arbeit ein.

In Leiden blieben die städtischen Dienststellen und Betriebe voll in Arbeit; es streikten einige gewerbliche Betriebe zu 100 v. H., andere mit etwa zwei Drittel der Belegschaft und wieder andere überhaupt nicht. In dem sich westlich und nördlich Leidens erstreckenden Blumenzwiebelgebiet war zwar die Stimmung gespannt und nervös und es wurde auch in Hillegom am Sonntagabend (2.5.) anlässlich kleiner Zusammenrottungen durch die Polizei von der Schusswaffe Gebrauch gemacht, aber die Streikbeteiligung war nur sehr gering. Das Schwerwiegendste war, dass am Freitagsmorgen (30.4.) die Molkerei in Hillegom es unterliess, die Milch von den Bauern zu holen. Oestlich Leiden, in Alphen und Umgebung, schloss sich zunächst die ganze Industrie dem Streik in der Druckerei Samson an. Dank des sehr entschlossenen Einwirkens des Bürgermeisters Colyn in Alphen wurde aber schon am 30.4.1943 nachmittags fast überall wieder gearbeitet.

Gouda blieb vom Streik völlig unberührt. Nur in dem Postamt wurde von einem Teil der Belegschaft einige Stunden gestreikt. Verhältnismässig ruhig blieben auch die vorwiegend landwirtschaftlichen Gebiete des zwischen Leiden und Gouda gelegenen Rynlandes, des von dort aus sich südlich auf Rotterdam hin erstreckenden Schielandes und der süd- und südöstlich von Gouda gelegenen Krimpener-Waand.

Dagegen wurde die sich hieran weiter südlich anschliessende Alblasser-Waard sowohl in ihren industriellen als auch landwirtschaftlichen Betrieben stark von der Streikbewegung erfasst. Bei den industriellen Betrieben handelt es sich hier vor allem um die mittleren und kleinen Werftbetriebe, in den oben bereits genannten, an Merwede, Noord und Lek gelegenen Gemeinden, die sich von Gorinchem über Dordrecht bis Krimpen a. d. Lek und Krimpen a. d. IJssel erstrecken. Ein Hauptzentrum des Streiks war hier die Merwedewerft in Hardinxveld, von deren Belegschaft auch einige standrechtlich erschossen wurden. Unter den Bauern 
zeigte sich hier der stärkste Widerstand in einem bei einer Molkerei in Giessen-Nieuwkerk entstandenen Aufruhr, dessen beide Rädelsführer ebenfalls standrechtlich erschossen worden sind. Eine ähnliche, wenn auch schwächere Streikhaltung wie in der Alblasser-Waard trat auch in dem westlich sich anschliessenden Teile der Insel IIsselmonde in Erscheinung, mit Zwijndrecht als industriellen und Barendrecht als landwirtschaftlichen Mittelpunkt.

Wie schon der grösste Teil der Rotterdamer Wirtschaft, so enthielten sich auch fast alle am "Neuen Wasserweg" in Schiedam, Vlaardingen und Maassluis gelegenen Betriebe, insbesondere die dort liegenden grösseren Werften, restlos des Streiks. Auch auf den südholländischen Inseln (ausser dem eben erwähnten östlichen Teile der Insel IJsselmonde) entwickelte sich der dort erst spät begonnene Streik nicht zu besonders beachtlicher Stärke.

Sehr erheblich war dagegen wiederum die Streikbeteiligung in dem nördlich der Städte des Neuen Wasserwegs gelegenen Gemüsezuchtgebiet des Westlandes und Delfilandes bis einschliesslich Pijnacker und der grösseren Industrie des Stadt Delft. Es streikten, von de Lier und Noordwijk ausgehend, im ganzen Gebiet die grosse Mehrheit der vielen hundert grösseren und kleineren Gemüsebaubetriebe mit Besitzern und Arbeitern. Begünstigt wurde der Streik weiter dadurch, dass die Veilingsvorstände (Gemüseauktionen), ausser des Vorstandes der Veiling Loosduinen, nicht rechtzeitig Ernstliches unternahmen, um die Gärtner zur Anlieferung von Gemüse anzuhalten, sondern sich direkt passiv verhielten. In Pijnacker und Naaldwijk stellten auch die örtlichen Bürohalter des Provinzialernährungskommissars mit ihrem Personal die Arbeit ein. In Delft haben insgesamt 11 industrielle Betriebe, darunter auch die drei grössere, nämlich Gist- en Spiritusfabrik, Oliefabrik Calvé und Nederlandsche Kabelfabrik, in der übergrossen Mehrzeit ihrer Belegschaften gestreikt. Der SD Rotterdam hat hier, wie bei den Werften in Dordrecht und Umgebung, eine Anzahl Streikender festgenommen.

Bei dem Streik in den ländlichen Gebieten ging es im wesentlichen um die Verweigerung der Milchlieferung durch die Erzeuger oder des Abholens und Verarbeitens der Milch durch die Molkereien. Stellenweise wurde die Milchlieferung auch durch das Publikum verhindert. wie überhaupt der Milchtransport am meisten ins Stocken geriet. Um keine Milch umkommen $\mathrm{zu}$ lassen, ist sie in mehreren Bezirken zu Käse verarbeitet worden. Ich habe den Eindruck, dass in der Milchwirtschaft die Streikaktivität grösstenteils von den Molkereien und ihrem Personal - auch ihrem Führerpersonal - ausging und dass die Mblkereien dabei auch in Verbindung zueinander getreten sind.

In den öffentlichen Dienststellen und Betrieben wurden folgende Streikfälle festgestellt:

a) Ernährungsverwaltung:

In den Haag streikte das Ernährungsdepartement, in den Gemeinden Alphen, Schoonrewoerd, Delft, Naaldwijk, Pijnacker und Peursum streikte das Personal der örtlichen Bürohalter des Provinzialernährungskommissars, wobei sich in Delft, Naaldwijk und Pijnacker auch die Bürohalter selbst beteiligten. In Den Haag, Alblasserdam, Papendrecht, Alphen, Sliedrecht, Hardinxveld und Numansdorp streikten auch die Distributiebüros.

b) Gemeindeverwaltung:

In Den Haag streikten ein Teil des Personals des Standesamts, des Wohlfahrtsamtes und des Distributiebüros. Einer vom Bürgermeister durch die Abteilungschefs gerichteten Aufforderung zur Arbeitsaufnahme haben am 1.5. vormittags alle Streikenden Folge geleistet bis auf 10, die bereits entlassen sind. Weitere Streikfälle wurden in den Gemeindeverwaltungen Voorburg, Dordrecht, Sliedrecht, Hardinxveld, Giessendam, Schoonrewoerd, Alphen und Gorinchem festgestellt. In Alphen und Gorinchem bewirkten die Bürgermeister Colyn und van Houten, die am 30.4 .43 vormittags dienstlich 
abwesend waren, dass nachtmittags alles wieder normal arbeitete. In den übrigen Gemeindeverwaltungen war der Streik am 1.5.43 mittags beendet.

c) Reichs und Provinzialvenwaltung:

Von den übrigen öffentlichen Dienststellen und Betrieben streikten in Den Haag das Reichskohlenbüro, das Statistische Reichsamt, die Zentrale der Staatsminen, der provinziale Waterstaat, das Postscheck - und Giroamt, und die Postämter in Gouda, Dordrecht, Delft und 's-Gravenzande. Ab 1. Mai 1943 wurde aber auch hier wieder normal gearbeitet. In einer Anzahl der vorgenannten Dienststellen dauerte der Streik nur wenige Stunden.

Die weite Verbreitung des Streiks am 30.4.1943 ist wesentlich mit darauf zurückzuführen, dass an diesem Tage der Oranje-Sender die allgemeine Streikparole ausgab. Mit der Verkündung des Standrechts am 1.5.43 ist der Streik überall in der Provinz schnell zurückgegangen. Im wesentlichen verharrten nur einige Belegschaften oder Teile von ihnen in den beiden Hauptstreikzentren, in der Gegend Dordrecht-Alblasserwaard und im Westland im Streik. Am 3. Mai ging auch dort der Streik zu Ende. Die 10 in der Provinz vollstreckten Todesurteile betrafen 4 Fälle aus Rotterdam und 6 aus dem Streikgebiet Dordrecht-Alblasserwaard. $Z u$ Aufruhr ähnliche Handlungen ist es in der Provinz nur in Giessen-Nieuwkerk in dem von mir erwähnten Falle gekommen, in dem 2 Rädelsführer des Aufruhrs an der dortigen Molkerei zum Tode verurteilt worden sind.

$\mathrm{Zu}$ den Fragen über die Ursachen des Streiks und die Folgerungen, die aus ihm zu ziehen sind, habe ich folgendes zu sagen:

Zu 1) Die Hintergründe des Streiks liegen in der allgemeinen Hochspannung, die sich in den letzten Monaten bei dem ungeschichtlichen Denken fast aller Schichten des Volkes durch falsche Siegeshoffnungen und eine systematische Hetze immer mehr gesteigert hatte, Der Oranje- und der englische Sender und die Flugblatt- und sonstige Innenpropaganda hatte den Widerstandswillen gegen die Massnahmen der Besatzungsmacht an alle Kreise des Volkes, insbesondere Arbeiter, Studenten und Beamte, immer wieder herangetragen, weiter aufgestachelt und gewissermassen zur Ehrensache jedes braven „Vaterländers” gemacht. Es bedurfte nur eines, allerdings kräftigen Funkens, um diese Spannung zur Entladung zu bringen.

$Z_{u}$ 2) und 3) Dieser Funke wurde die am 29.4.43 verkündete Anordnung des Wehr» machtbefehlshabers über die Rückführung der entlassenen niederländischen Soldaten in die Kriegsgefangenschaft. Die Erregung darüber war eine ausserordentlich grosse, vor allem in der Masse des Volkes, bei den Arbeitern und Bauern und den kleinen Leuten des Mittelstandes. Der sogenannte Gebildete wusste bei sich, dass es sich um eine völkerrechtlich zulässige Massnahme handelte; wenn er einmal nach Deutschland musste, ging er schliesslich noch lieber als Kriegsgefangener wie als Arbeiter hin; schlechte Behandlung in der Kriegsgefangenschaft fürchtete er nicht ernstlich. Dagegen empfand der kleine Mann, der sich über die rechtliche Seite der Sache wenig oder gar keine Gedanken macht, mit seiner ganzen Umgebung, Frau und Kindern, das Verbringen in die Kriegsgefangenschaft als eine schwere Last, als eine Existenzbedrohung für sich und seine Familie und zum grossen Teile auch, persönlich aufrichtig, als ein ihm angetanes, unverdientes Unrecht. In seinem durchweg unsoldatischen Empfinden und bei dem von früher gepflegten Pacifismus ist ihm das Gefangenerund damit das Wiedersoldatwerden an sich schon arg wider den Strich; die ihm durch die Hasspropaganda einfiltrierten Verleumdungen auch des deutschen Heeres liessen ihn vielfach die gleich in Umlauf gesetzten Gerüchte, dass die Gefangenen evtl. auch als kämpfende Soldaten verwendet werden sollten, glauben und versetzten ihn und seine Familie in Schrecken. Bei sich oder Arbeitskameraden hatte er es erlebt, dass der Uebergang in ein Arbeitsverhältnis bei einem deutschen oder niederländischen Rüstungsbetrieb eine empfind- 
liche, eigentlich schon nicht mehr tragbare Lohnkürzung gebracht hatte. Die ihm nun weiter drohende Kürzung seines Einkommens bis auf den Kriegsgefangenensold verursachte ihm drückende Sorgen um die Zukunft seiner Familie. Der selbständige kleine Bauer und Gärtner wurde von der Sorge befallen, dass sein Betrieb, der als Familienbetrieb ganz von seiner Arbeit abhängig ist, eingehen würde. Diese Leute sagten sich selbst und sprachen es öfter aus: Wir haben doch nun als Bauern, Gärtner oder Arbeiter - und für viele stimmt das ja 3 Jahre lang auch für Deutschland treu und brav gearbeitet und unsere Pflicht getan. $\mathrm{Da}$ haben wir solche "Strafe" nicht verdient. Das erzeugte weithin auch seine subjektiv ehrliche Entrüstung. Nach der Formulierung der ersten Bekanntmachung des Wehrmachtbefehlshabers, die über Umfang und Zeitpunkt der Rückführung keine Angaben enthielt, hatte man allgemein mit der sofortigen Durchführung gerechnet. Dadurch entstand eine so tiefe Niedergeschlagenheit und Mutlosigkeit, dass darüber der Arbeitswille erlahmte. So verliess zunächst mancher der direkt Betroffenen seine Arbeit oder blieb von ihr fern, um sich mit dieser Tatsache irgendwie zurechtzufinden und auf ihre Folgen sich und seine Familie vorzubereiten. Im ganzen aber entstand unter dem Einfluss von äusserem alter und neuer Hetze und innerem akuten Druck eine Gesamtstimmung, aus der heraus das Gros der Menschen ohne viel Ueberlegung sagte: „Nu is het maat vol: Wir streiken". Die Streikenden werden wohl daran gedacht haben, der besetzenden Macht ihren Protest zeigen zu wollen, auch vielleicht eine Aufhebung oder Milderung der Massnahme zu erreichen. Aber klare Ziele haben sie m.E. nicht gehabt. Natürlich haben sich die professionellen Hetzer gleich der Sache angenommen, um aus ihr an Widerstand $z u$ machen, was herauszuholen war. Aber klare Ziele haben m.E. auch die nicht verfolgt. Eine eigentliche Streikleitung war nicht vorhanden. Der Streik ging ja auch nicht von der alten Streikzentrale Amsterdam, sondern vom Osten aus. Dies nach meinem Dafürhalten aus dem Grunde, weil der Osten im ganzen noch besser zu essen hat und bisher vom Kriege noch weniger gespürt hat als der Westen. Das Ereignis wirkte im Osten erschütternder. Im Westen ist das Schicksalhafte des Krieges zwar auch noch nicht ins Bewusstsein, aber doch schon weithin ins Unterbewusstsein der Menschen eingegangen. Charakteristisch ist in diesem Zusammenhang, dass die 3 Grossstädte am ruhigsten geblieben sind und dass die Werft- und Rüstungsarbeiter Rotterdams und der übrigen Städte am Neuen Wasserweg, die von ihren 24 Gulden die Woche mit ihrer Familie zu leben haben, die die Luftzerstörungen der Engländer um sich sehen und zeitweise täglich in die Luftschutzkeller müsen, sozusagen überhaupt nicht gestreikt, dass das aber wohl die Werftarbeiter im Dordrechter Gebiet getan haben, die noch über ländliche Hilfsqueilen verfügen und wenig Fliegerangriffe gehabt haben, und die Westlandsgärtner. denen es noch besser geht.

$Z_{u}$ 4) Die Frage nach dem Umfang des Streikes im Verhältnis zu den übrigen Betrieben und Dienststellen meines Tätigkeitsbereiches glaube ich mit der übersichtlichen Darstellung im Anfang meines Berichts ausreichend beantwortet zu haben.

Zu 5) Die Möglichkeit des Einflusses der Führer war bei diesem Streik besonders gross, weil bei ihm ein Gegensatz zwischen Arbeitgeber und Arbeitnehmer nicht bestand, eine zielweisende Streikparole von Arbeitnehmerseite nicht gegeben war und daher die Gefolgschaften einer klaren charakterfesten Weisung weithin zugänglich waren. Wo die Führung eine Einflussnahme unterliess, gaben sich die Gefolgschaften meist der allgemeinen Stimmung hin und streikten, bis sie durch Verkündung des Standrechts und seine schlagartige Wirksamkeit zur Vernunft gebracht wurden. Wo aber die Führung ihre moralische Kraft einsetzte und die Leute auf die Unsinnigkeit des Streikes deutlich hinwies, hatte das im allgemeinen sofort Erfolg. Beispielsweise ging beim Rotterdamschen Bankverein hier im Haag die zum Streik aufbrechende Angestelitenschaft gleich wieder an ihre Arbeit, als Herr Woltersom den vordersten Streikenden sagte: „Sie können gehen, dann aber für immer." In Leiden, wo eine ganze Reihe von industriellen Betrieben, teilweise mit voller Belegschaft, die Arbeit niederlegten, streikte in der Textilfabrik Kranz kein Mensch, nachdem einer der 
Inhaber die Leute klar an die Arbeit gewiesen hatte. In Delft, wo allgemein gestreikt wurde, blieben die Leute in der bekannten Fayencefabrik auf Einwirkungen des Leiters am Freitag in der Arbeit, kehrten dann allerdings unter dem Druck fremder Arbeiter am 1.5. morgens zu ihr nicht zurück. In der grossen Gist- und Spiritusfabrik blieben auf Aufforderung des Betriebsleiters soviele Arbeiter im Betrieb, dass die Produktion fortgesetzt werden konnte. Der Direktion (van Leeuwen), die mir das mit Stolz mitteilte, habe ich erklärt, dass die Leute alle geblieben wären, wenn sie (die Direktion) sich hinter den Betriebsleiter gestellt und die Leute ernstlich zur Arbeit befohlen hätten. In Dordrecht, wo auch das Gros der Betriebe streikte, blieben die Leute der Gasmesserfabrik auf Einwirkung des Betriebsführers an der Arbeit, ebenso in Zwijndrecht, dessen industrielle Betriebe auch allgemein streikten, die Belegschaft der chemischen Fabrik van Epenhuijzen, nachdem sie von dem der N.S.B. angehörenden Direktor van Epenhuijzen ernstlich dazu angehalten war. Desgleichen kehrten die am Freitag streikenden Arbeiter der elektrotechnischen Betriebe in Slikkerveer und die der Asphaltfabriken in Krimpen a. d. IJssel und Dordrecht, die dem N.S.B.er Gips gehören, auf schriftliche bezw. mündliche Aufforderung der Betriebsführer am Samstag zur Arbeit zurück. Aehnliche Erfolge hatten der Chef der P.T.T. im Haag bei seiner Hauptverwaltung und die Bürgermeister in Alphen, Gorinchem und 's-Gravenzande bei städtischen und anderen Betrieben.

$Z u$ 6) Während ich selbst von Freitag, den 30.4., 11 Uhr, bis Sonnabend, den 1.5., 11 Uhr, als stellvertretender Sonderbeauftragter für Nordholland in Amsterdam tätig sein musste, und dort sofort die persönliche Verbindung mit allen massgebenden deutschen und niederländischen Polizeistellen und dem Oberbürgermeister in Amsterdam und dem Kommissar der Provinz: in einer gemeinsamen Besprechung der Lage aufgenommen und mit ihnen vor allem ein genaues Meldewesen festgelegt hatte, habe ich noch am gleichen Tage von Amsterdam aus meinen ersten Referenten im Haag, Amtsrat Kerkhoff, über den Kommissar der Provinz die Bürgermeister in Südholland zur Wachsamkeit und dreimal täglichen Lageberichten auffordern lassen. Ausserdem nahm Amtsrat Kerkhoff sofort mit den Bürgermeistern und den Vertrauenspersonen in den einzelnen, vor allem den vom Streik besonders getroffenen Gebieten der Provinz Fühlung auf. Das hat die Bürgermeister grössenteils zum persönlichen Einsatz, Einflussnahme auf Betriebe, besonderen Bekanntmachungen und dergl. veranlasst. Nach meiner Rückkehr habe ich diese Einflussnahme und die Besprechungen mit massgeblichen Vertretern der verschiedenen Wirtschaftszweige fortgesetzt.

Zu 7) Die Zusammenarbeit im deutschen Bereich, insbesondere mit dem S.D., funktionierte gut. Mit diesem wurden alle Meldungen ausgetauscht. Unmittelbar nach meinem Wiedereintreffen im Haag habe ich das gemeinsame Vorgehen mit dem Kommandeur des Sicherungsbereiches Südholland und dem Vorsitzenden des Polizeistandgerichtes besprochen. An den Verhancilungen des Polizeistandgerichts in Rotterdam am Montag, den 3.5., habe ich persön lich teilgenommen; auch in den Beratungen war ich zugegen. Die normalen Nachrichtenmittel waren, von Einzelfällen abgesehen, nicht gestört, aber Ueberbeanspruchung verzögerte häufig die Verbindungen. Nachrichten an die Bevölkerung konnten durch Bekanntmachungen der Bürgermeister gegeben werden.

$Z u$ 8) Der Einsatz der alten Bürgermeister wurde, von einigen Ausnahmen, wie z.B. in Alphen, abgesehen, erst durch Einwirkungen von hier aus aktiv. Die N.S.B.-Bürgermeister haben sich durchweg bewährt.

$Z_{u}$ 9) Die Kringleiter der N.S.B. haben ihre Distriktsleiter im allgemeinen gut informiert; einzelne von ihnen und einige Ortsgruppenleiter haben auch sachgemäss mit Bürgermeistern zusammengearbeitet und auf Betriebe eingewirkt. Das gleiche gilt von Vertretern des Landstandes und der N.A.F. Es muss aber hier darauf hingewiesen werden, dass ein nicht unbeträchtlicher Teil von Mitgliedern der N.S.B., auch solche, die sonst ein gutes Verständnis 
für die Massnahmen der deutschen Besatzungsmacht aufbringen, von der Schockwirkung der Verordnung des Wehrmachtbefehlshabers mit erfasst worden sind und noch heute über deren Sinn insofern in Zweifeln leben, als sie befürchten, dass damit die bisherige Politik des Reichskommissars aufgegeben und das normale Kriegsverhältnis zwischen den beiden Völkern wiederhergestellt sei.

Zu 10) und 11) Das schnelle und scharfe, aber doch sachlich und zeitlich auf das Notwendige beschränkte Durchgreifen der deutschen Besatzungsmacht gegenüber dem Streik hat seinen Eindruck auf die niederländische Bevölkerung nicht verfehlt. Der Eindruck wird m.E. so nachhaltig sein, dass sich so leicht eine solche Aktion nicht wiederholen wird. Andererseits ist aber die Grundstimmung des Volkes noch so von verhaltenem Hass auf den Boden ungeschichtlichen Denkens erfüllt, dass m.E. im Falle einer feindlichen Landung oder eines ähnlich schweren Ereignisses mit jeder Unsinnigkeit, auch mit der Wiederholung eines Streikes, gerechnet werden muss. Es muss daher m.E. alles getan werden, was möglich ist, um die Grundstimmung der Niederländer bei Freunden und Feinden von uns in unserem Sinne zu verbessern, und was sonst geeignet ist, durch inneren oder äusseren $Z$ wang, die Menschen von der Wiederholung eines Streikes abzuhalten, oder, wenn dieser ausgebrochen ist, ihn wieder schnellstens niederzuschlagen.

Dazu zähle ich:

a) Zur inneren Aufrichtung und Stärkung unserer Freunde und Niederschlagung einer neu aufgekommenen niederländischen feindlichen Propaganda, eine deutliche für die Oeffentlichkeit bestimmte Erklärung von massgeblicher Stelle, dass das Verbringen der niederländischen früheren Soldaten in Kriegsgefangenschaft nicht, wie unsere Feinde es auslegen, ein klares Feindschaftsverhältnis zwischen dem deutschen und dem niederländischen Staat und seinen Angehörigen herstellen soll, sondern dass sie nur eine von Lage und Zeit geforderte militärische Notwendigkeit darstellt, durch die das vom Reichskommissar immer wieder betonte politische Endziel, Herstellung einer brüderlichen Gemeinschaft unserer beiden Völker in einem germanischen Staatenbunde, nicht geändert werden soll.

b) Ausfüllen der durch die Wegnahme der Radios entstandenen Lücke in der Versorgung der Holländer mit Nachrichten durch verkehrte deutsche und N.S.B.-Propaganda aller, aber seriöser Art. Dabei müssen Märchen, wie das neulich verbreitete, dass die Fleisch- und Butterrationen infolge des Streikes hätten gekürzt werden müssen, vermieden werden. Der Holländer ist $z u$ nüchtern, hat auch unter sich zu viele Sachverständige, als dass er so etwas glaubte. Mit solchen unsachlichen Meldungen nehmen wir uns selbst nur die Glaubwürdigkeit. Beim Holländer wirkt nur eine ernsthaft auf die Dinge eingehende Propaganda. Für eine solche ist er aber auch durchaus empfänglich.

c) In Zukunft müssen meines Erachtens bei Verkündung so eingreifender Massnahmen, wie sie die Gefangensetzung der früheren Soldaten darstellt, gleichzeitig in der Anordnung oder in Sonderartikein die Erleichterungen bekanntgegeben werden, die zu gewähren man von vornherein bereit ist. Dass man das im vorliegenden Falle unterlassen hat, hat zweifellos wesentlich zur Verstärking der Erregung und des Streikes beigetragen. Schon das Bekanntwerden der ersten Ausnahmen am 30.4. hat zur Entspannung beigetragen. Die verspätete Bekanntgabe der Befreiungsmöglichkeiten hatte aber auch noch den weiteren grossen Nachteil, dass man die Befreiungen jetzt vielfach für sich als einen Erfolg des Streikes reklamiert, wie beim Aerztestreik, auf den man zum Vergleich hinweist. Je weiter wir uns seitlich von dem Ereignis entfernen, umsomehr wird die gegnerische Propaganda die Befreiungen dem Widerstande als Erfolg anrechnen. Es wäre zu wünschen, dass auch die ursprünglichen Forderungen gegenüber den Aerzten durchgesetzt würden.

d) Den Einzelheiten des Streikes muss meines Erachtens allgemein so weit nachgegangen werden, dass man möglichst viele auch nicht strafrechtlich Verantwortliche feststellt. Diesen 
muss ihre Verantwortung so vorgehalten werden, dass sie sich in einem kommenden Falle unter Beobachtung fühlen. Ich beabsichtige daher, in nächster Zeit zum Beispiel die ganzen Veilingvorstände der Provinz mit dem Provinzialernährungskommissar zu besonderen Versammlungen $z u$ laden und sie, eingehend auf bestimmte Vorfälle, auf ihre Verantwortung hinzuweisen. Ebenso denke ich demnächst den Beirat der neuen Handelskammer der Provinz, dem auch alle Führer der Fachgruppen der gewerblichen Wirtschaft angehören, zusammentreten zu lassen und den Herren anhand von festgehaltenen Einzelfällen deutlich zu machen, dass es nur an dem Willen und dem Einsatz der moralischen Kraft des Betriebsführers gelegen habe, ob ihre Gefolgschaften streikten oder nicht, und dass wir daraus in Zukunft unsere Konsequenzen ziehen werden.

Ueber die Ablösung von Bürgermeistern, die sich als unzuverlässig erwiesen haben, stehe ich mit dem S.D. in Ueberlegungen. Eine entsprechende Vorlage wird in Kürze erfolgen.

e) Es hat sich bei dem Streik herausgestellt, dass zu viele unserer Gegner noch Telephone und Autos und Benzin haben und unseren Freunden diese Verbindungsmittel vielfach fehlen. Ueber die Zuteilung dieser Mittel verfügen zu sehr die niederländischen und deutschen Wirtschafts- und Verkehrsstellen. Durch stärkere Einschaltung der politischen Stellen muss sichergestellt werden, dass im Ernstfalle unsere Freunde und nicht unsere Gegner die Nachrichten- und Verkehrsmittel in der Hand haben.

Sch webel.

\section{Stimmungsbericht aus den Niederlanden d.d. 10-5-1943 1)}

Den Haag, den 10. Mai 1943.

\section{Reaktionen auf die Bekanntmachungen der Deutschen Wehrmacht in den Niederlanden:}

An den Streiks der vergangenen Woche - so schreibt einer unserer Gewährsleute - haben insgesamt mindestens eine halbe Million arbeitender niederländischer Männer und Frauen teilgenommen. Es war jedenfalls die grösste Streikaktion, die sich je in den Niederlanden ereignete. Es ist falsch, eine derartige Volksbewegung als ,unbedeutend" zu bezeichnen, wie dies in einem Artikel vom 3. Mai im "Algemeen Handelsblad” der Fall war. Es trifft auch nicht $z u$, dass diese Aktionen durch das "Eingreifen der Polizei" gebrochen wurde, wie es in einigen offizielen Bekanntmachungen hiess. Es steht vielmehr fest, dass die Streiks grösstenteils aus eigener Initiative beendet wurden, und zwar ehe von einem polizeilichen Auftreten die Rede war. Man wollte protestieren, und als man glaubte, dass dieser Protest deutlich genug zum Ausdruck gekommen war, nahm man die Arbeit wieder auf. Wenn die Autoritäten die Bedeutung einer solchen Aktion unterschätzen, besteht die Gefahr, dass man weitere Fehler begeht, die später vielleicht zu unangenehmen Ueberraschungen Anlass geben dürften. Obwohl

1) Bijlagen 59 en 60 zijn Stimmungsberichte, die ten behoeve van verschillende Duitse instanties een beeld poogden te geven van de stemming in Nederland; zij werden vermoedelijk door ambtenaren van het Generalkommissariat z.b.V. opgesteld. 
man andererseits die Bedeutung der Aktion nicht überschätzen darf (wie dies bei den Salonbolschewisten der Fall ist, die hierin einen revolutionären Umsturzversuch erblicken), dürften die Ereignisse wichtig genug sein, um die Frage zu stellen, was die eigentlichen Motive des Wehrmachtbefehlshabers waren, als er mit der erneuten Kriegsgefangenschaft der Mitglieder der ehemaligen niederländischen Wehrmacht ein derartig grosses Risiko auf sich nahm, eine Frage, die in politischen Kreisen lebhaft besprochen wird. Die Begründung in der ersten Bekanntmachung des Wehrmachtbefehlshabers, nämlich dass „einzelne Mitglieder der ehemaligen niederländischen Wehrmacht durch ihr feindseliges Auftreten das in sie gestellte Vertrauen verletzt hätten", wird allgemein als nicht ausschlaggebend angesehen. Für das Benehmen einiger Einzelpersonen lässt man nicht eine ganze Armee (insgesamt mindestens 350000 Mann) büssen. Ulebrigens wird am Schluss der Bekanntmachung gesagt, dass man diese Massnahmen ausschliesslich den „Hetzern" zu verdanken habe, die durch ihr verbrecherisches Auftreten diese Massnahmen notwendig gemacht hätten. Wer wird unter diesen „Hetzern" verstanden? In politischen Kreisen nimmt man allgemein an, dass General Christiansen sich durch den Ton der jüngsten Rundfunksendungen der niederländischen Regierung in London und vor allem durch die letzte Ansprache der Königin, die sich angeblich ziemlich scharf geäussert hat, gereizt gefühlt habe. Man kann jedoch nicht annehmen, dass aus solchen impulsiven Reaktionen derartige für die öffentliche Ruhe und Ordnung so gefährliche Massnahmen getroffen werden und man sucht darum nach anderen Motiven. Allgemein herrscht hier die Ansicht, dass die Deutschen Angst haben vor einer Invasion und aus diesem Grunde soviel wehrfähige Männer als möglich aus den Niederlanden entfernen wollen. Manche dagegen nehmen an, dass die Deutschen inländische Widerstandsaktionen befürchteten und deshalb zu dieser Massnahme schritten. Letzteres erscheint jedoch nicht sehr annehmbar, weil dies für die Deutschen auf die Dauer nur eine Verschiebung der Schwierigkeiten bedeuten würde: die Millionen feindselig eingestellter Ausländer, die heute bereits in Deutschland sind, werden sich bei der ersten Gelegenheit sicherlich als ein schwieriges Problem erweisen. Man kann sich kaum vorstellen, dass deutscherseits dieses Problem ohne Notwendigkeit erschwert wird. So bleibt also die Auffassung, dass die Verordnung mit den zu erwartenden alliierten Offensiven in Zusammenhang steht. Der gänzlich unerwartete Augenblick, an dem die Bekanntmachung veröffentlich wurde, dürfte auf die Dringlichkeit der Angelegenheit hindeuten, mit anderen Worten auf die Tatsache, dass man die Offensive noch im Laufe dieses Sommers erwartet. Selbstverständlich wird diese Argumentierung stark durch die Wunschträume niederländischer Politiker und Intellektueller beeinflusst - wie man immer versucht ein schwer erklärliches Ereignis mit einer möglichen baldigen angloamerikanischen Invasion in Verbindung zu bringen.

\section{In Erwartung newer Konflikte:}

Unser Gewährsmann erachtet es als selbstverständlich, dass zu den Daten, an denen den Aufrufen des Wehrmachtbefehlshabers entsprochen werden muss, neue Konflikte zu erwarten sind.

An erster Stelle ist bekanntlich das Berufspersonal der niederländischen Wehrmacht unter dem Offiziersrang an der Reihe. Diese Gruppe muss sich in drei Teilen stellen, nämlich am 7., 10. und 13. Mai. Dieses untergeordnete Berufspersonal uinfasst im ganzen ungefähr 20.000 Mann. Zieht man die Ausnahmen (Polizei, Brandwehr, Luftschutz, Verwaltungsbeamte etc.) $\mathrm{ab}$, dann verbleiben noch wenigstens 10.000 Mann, die sich $z \mathrm{u}$ den angegebenen Tagen in Kriegsgefangenschaft begeben müssen. Die grosse Frage ist nun die: werden sie sich melden? Allenthalben wird die Parole ausgegeben: nicht melden. Die Argumentierung für diese Parole ist die, dass die Deutschen keine Kriegsgefangenen ,einberufen" dürfen, dass sie sie jedoch, nachdem sie sie erst freigelassen haben, aufs neue "gefangennehmen" müssen, d.h. die in Frage kommenden müssen sich holen lassen; und diejenigen, die befürchten, dass sie dabei Gefahr laufen, müssen „,verschwinden”. Man will damit aufs neue und immer wieder gegen diese Massnahmen protestieren und es den deutschen Machthabern so schwierig 
wie möglich machen in der Hoffnung, die Durchführung dieser Massregel zu sabotieren oder zum wenigsten so lange wie möglich hinauszuschieben. Es wird erwartet, dass viele Niederländer dieser Parole Folge leisten werden. Für Angehörige des Berufspersonals, die noch Wartegeld beziehen, werden bereits Stiftungen gegründet (vor allem in protestantischkirchlichen und katholischen Kreisen), um ihnen evtl. finanziell zu helfen, wenn sie genötigt würden, sich "unsichtbar" $z \mathfrak{u}$ machen. Dieses Spiel wird sich wahrscheinlich bei allen folgenden Aufrufen wiederholen. Wie gross der Prozentsatz der sich Nichtmeldenden sein wird, ist schwer vorherzusagen; aber die niedrigste Schätzung ist doch noch $50 \%$. Zweifellos haben die während der Streiks erlassenen und vollzogenen Todesurteile Eindruck auf die Bevölkerung gemacht; doch haben sie den Hass und die Verbitterung nur vergrössert sofern das wenigstens noch möglich war. Auf jeden Fall wäre es falsch zu erwarten, dass $N$ ein freies Volk, erzogen in jahrhundertelanger Rechtstradition, sich durch Gewalt für immer einschüchtern liesse. Die Praxis hat im Gegenteil schon bewiesen, dass jeder weitere Ausbruch des Widerstandes schärfer und ausgebreiteter wird. Auch wenn also vorläufig die aüssere Ruhe und Ordnung wiederhergestellt sind, wird man in Zukunft doch mit schärferen Konflikten rechnen müssen, um so mehr als die Zahl derjenigen, die wenig oder nichts mehr $z u$ verlieren hat (oder $z u$ haben meint), täglich wächst.

Schliesslich ist in diesem Zusammenhang die Feststellung wichtig, wie wenig Einfluss Woudenberg's Organisation (die Niederländische Arbeitsfront) besitzt. Am Tage der Bekanntmachung wurde von den Leitern der Arbeitsfront behauptet, dass unter den Arbeitern alles „,ruhig" sei, während bereits zehntausend streikten. Nirgendwo ist es diesen Leitern oder ihren Vertretern in den Betrieben (den sozialen Vormännern) gelungen, einen Streik aufzuhalten oder wenigstens abzuschwächen. Die Arbeitsfront war einfach ohnmächtig, und keine einzige Gruppe von Arbeitern hat Anordnungen von dieser Seite befolgt. Wie ganz anders hätte dies sein können, wenn die Deutschen sich den niederländischen Verhältnissen einigermassen angepasst hätten und mit der niederländischen Fachbewegung $z u$ einer Uebereinstimmung gekommen wären!

Eine Bemerkung noch betreffs der Ratschläge, die von London aus durch die Regietung Gerbrandy bei dieser Gelegenheit gegeben wurden. Es wäre eine starke Ueberschätzung des Einflusses von Seiten der Londoner Radiopropaganda, wenn man annähme, dass darin die Hauptursache der Streikbewegung zu suchen sei. Gewiss gibt es Kreise, die sich genau nach den von London ausgegebenen Parolen richten. Die Bedeutung dieser Kreise braucht nicht unterschätzt zu werden; fest steht jedoch, dass die grosse Masse sich von den Londoner Instruktionen kaum etwas zu Herzen nimmt. Die meisten Niederländer hören nach den Meldungen, weil sie über den eigenen Sender die Berichte nur von einer Seite vernehmen. Auch kommt es den Gefühlen vieler entgegen, wenn sie eine scharfe Kritik an den Deutschen aussprechen hören; weiter jedoch reicht das Interesse für die Londoner Propaganda bei der übergrossen Mehrheit nicht. Man hört sogar die Meinung (und sie wurde bei dieser Gelegenheit wieder öffentlich ausgesprochen), dass man in London lieber keine Instruktionen bezüglich der Innenpolitik, von der man doch nicht unterrichtet sei, geben solle. Schliesslich steht fest, dass kein einziger Aufruf in London zum Streik aufgefordert hat, während dieser doch gerade die typische Form war, in der sich der Widerstand hier im Lande äusserte. Sofern nicht im Volke selbst der Widerstandsgeist lebte und wenn nicht durch Massnahmen in diesem Lande die Opposition geweckt würde, dann würde keine einzige Anweisung aus London, wie zwingend sie auch formuliert sei, die Ursache von Ereignissen sein können, wie man sie in den letzten Tagen erlebt hat.

\section{Die Streiks:}

Die Bekanntmachungen des Wehrmachtbefehlshabers in den Niederlanden, General der Flieger Fr. Christiansen vom 29. und 30. April, denenzufolge die Mitglieder der ehemaligen niederländischen Wehrmacht sofort als Kriegsgefangene abzuführen sind, haben im ganzen 
niederländischen Volk eine starke Empörung hervorgerufen. Die früher oft gemachten Voraus sagen, dass in einem gewissen Augenblick die angesammelte Erbitterung in allgemeinen Widerstandsaktionen zum Ausdruck kommen würde, haben sich in den vergangenen Tagen bewahrheitet, und $z$ war in einer Weise, die die Autoritäten in manchen Fällen vollkommen überraschte.

Dieser Widerstand kam im ganzen Lande in einer Reihe direkter und spontaner Streiks zum Ausdruck, die sich zwar in Umfang und Intensität unterschieden, jedoch alle das deutliche Ziel verfolgten, gegen die Bekanntmachungen des Wehrmachtbefehlshabers zu protestieren. Wo unser Gewährsmann in verschiedenen Teilen des Landes in der Lage war, nähere Untersuchungen durchzuführen, hat er feststellen können, dass es nirgendwo die $\mathrm{Ab}$ sicht war, den Streik durchzusetzen bis in bestimmte Forderungen eingewilligt sein würde. Bis auf einige lokalen Ausnahmen seien, wie er berichtete, überhaupt keine bestimmten Streikforderungen formuliert worden und nach verhältnismässig kurzer Zeit sei die Arbeit wieder aufgenommen worden, ohne der Polizei Gelegenheit zu hartem Eingreifen zu geben. Ob es bei einer späteren Gelegenheit genauso gehen werde, sei zweifelhaft.

Ferner sei ihm, wie beim Amsterdamer Streik im Februar 1941 der spontane Charakter der Aktion aufgefallen. Von einer gut vorbereiteten Organisation oder zielbewussten Führung sei nicht die Rede gewesen, wenn es auch selbstverständlich gewesen sei, dass manche Leute versucht hätten, sich dieser Streiks zu ,bemächtigen”. Im allgemeinen seien diese Versuche jedoch gescheitert: die Beteiligten entschieden in den meisten Fällen selbst, in welchem Augenblick sie die Arbeit wieder aufnehmen würden. Hätte es aber eine Organisation und Führung gegeben, so wären die Folgen dieser spontanen. Ausbrüche nicht $z u$ übersehen gewesen. Zwar habe es hier und da eine gewisse "geistige" Vorbereitung gegeben, und es sei zu erwarten, dass an dieser "geistigen" Vorbereitung in Zukunft noch intensiver gearbeitet werde.

Ueber die Haltung des Eisenbahnpersonals berichtet unser Gewährsmann ferner: Im niederländischen Volk herrsche grosse Enttäuschung und teils sogar Erbitterung über die passive Haltung des niederländischen Eisenbahnspersonals. Tatsächlich hätten in vielen Fällen die Arbeiter und Beamten die Arbeit wieder aufgenommen, als sie gehört hätten, dass das Eisenbahnpersonal nicht streike. Wenn das Eisenbahnpersonal, das hierzulande tatsächlich eine Schlüsselposition einnimmt, mitgemacht hätte, wären die deutschen Autoritäten in eine äusserst schwierige Lage geraten.

Fest stehe, dass beim niederen Eisenbahnpersonal eine gewisse Neigung zum Streik bestanden hätte, die hier und da auch zum Ausdruck gekommen sei. Die Führung der Eisenbahnen in Utrecht sei jedoch der Meinung gewesen, dass ,der geeignete Augenblick noch nicht gekommen sei". Sie hätten sich Dritten gegenüber auf Rundfunk-Ratschläge der niederländischen Regierung berufen. In diesen sei allerdings $z u$ passivem Widerstand gegen die Bekanntmachungen angeregt (Nichtanmeldung und Verweigerung der Mitarbeit bei der Ausführung von Aufrufen der Deutschen Wehrmacht), aber gleichzeitig vor aktivem Widerstand gewarnt worden. Und als aktiven Widerstand betrachtete die Eisenbahnführung einen Streik. Der Grossteil des Publikums weise diese Argumentierung zurück; man weise nachdrücklich daraufhin, dass die Regierung in London sich zwar nicht für „,bewaffneten Widerstand" erklärte, jedoch ausdrücklich angeordnet habe, dass die Behörden sich weigern sollten, die Entschlüsse der Deutschen Wehrmacht auszuführen, so das ein Streik des Eisenbahnpersonals bestimmt am Platz gewesen wäre. Ihrerseits behaupte die Leitung der Eisenbahnen aber, sie müsse ihre Kräfte für "den entscheidenden Augenblick" - vor allem im Falle einer Invasion - bewahren. Verantwortliche Gewerkschaftler unterschrieben diese Meinung. Sie behaupteten dass sich jetzt jedenfalls klar herausgestellt habe, was die Deutschen im Falle einer Invasion zu erwarten hätten. Ihrer Meinung nach sei es gut, dass das Eisenbahnpersonal dann noch imstande sei, als "vollständige Reservekraft" aufzutreten. 


\section{Weitere Konflikte:}

Ein anderer Gewährsmann schreibt:

Die Nachwehen der Streiks waren noch nicht beendet und täglich wurden noch Todesurteile gefält, als eine neue Verordnung viele Familien in Aufregung versetzte. Es handelt sich hierbei um die Verordnung vom 5. Mai, die alle männlichen Studenten niederländischer Universitäten (abgesehen von denjenigen, die die bekannte Loyalitätserklärung gezeichnet haben) aufrief, sich am nachfolgenden Tag (6. Mai) bei den angewiesenen SS - und PolizeiInstanzen „zwecks Einschaltung in den Arbeitseinsatz" zu melden. Mit ,unbegrenzten Strafen" wurden diejenigen bedroht, die sich der Anmeldepflicht entziehen würden. Diese Verordnung hat besonders die Empörung des niederländischen Publikums durch die Bestimmung geweckt, dass Eltern und Vormunde für das verpflichtete Erscheinen der Aufgerufenen mitverantwortlich seien und dass sie durch die Sicherheitspolizei bestraft werden können, ohne dass sie als Mitschuldige, Helfer oder Anstifter überführt $z u$ werden brauchen. Das Publikum ist der Meinung, dass diese Verordnungen gegen "Arier" noch weiter gehen als die gegen die Juden. Von "Judenhelfern" muss noch immer festgestellt werden, dass sie tatsächlich gesuchten Juden Hilfe geleistet haben; aber Eltern und Vormunde gesuchter Studenten können auch bestraft werden, wenn sie nicht zur Weigerung angespornt oder anderweitig Hilfe bei der Umgehung der Verordnung geleistet haben. Das ist ein Beispiel von „Gesetzgebung", wie man es in einem kultivierten Staat auch in Kriegszeit nicht für möglich gehalten hätte. Dieser neue Aufruf, kurz nach der Widerstandsaktion gegen die Einberufung der Kriegsgefangenen, ist ausserdem ein typisches Beispiel des völligen Mangels an Takt und Psychologie seitens der Besatzungsautoritäten. Dies ist das Urteil eines jeden gemässigten Niederländers, den ich hierüber sprach.

Inzwischen fürchteten manche Kreise, dass die Bedrohung gegen Eltern und Vormunde die meisten Studenten wohl veranlassen würde, sich $z u$ melden. Die Zahlen von Amsterdam zeigen jedoch, dass diese Furcht unbegründet war: Am 6. Mai kamen nach genauer Angabe 612 von 3600 Amsterdamer Studenten dem Aufruf nach: das heisst also, dass bedeutend weniger als $20 \%$ der Studenten auf Grund der Drohungen in der Verordnung nachgegeben haben. Ziffern aus anderen Orten sind noch nicht bekannt; aber man nimmt an, dass diese $20 \%$ kaum irgendwo überschritten sein dürften und dass in vielen Fällen die Zahlen noch kleiner sein werden. So hätten, lautet die Ansicht, die Deutschen Behörden sich also wieder neue Lasten und Sorgen auf den Hals geholt: man müsse nun, aus Prestigegründen, viel Zeit und Energie aufwenden, um diejenigen, die sich nicht angemeldet haben, $z u$ suchen, abzuholen und zu strafen - und das, während am 7. Mai neue Schwierigkeiten durch die verpflichteten Anmeldungen der ersten Gruppe Kriegsgefangener, von denen viele, wie man weiss, nicht erschienen sind, entstanden sein dürften.

Unterdessen sind standrechtlich weiterhin in erschreckend schnellem Tempo eine Reihe von Todesurteilen ausgesprochen und vollzogen worden. Die Urteile werden jetzt nur in den Lokalblättern veröffentlicht, so dass man in dem einen Teil des Landes nicht weiss, wie schlimm es im anderen aussieht. Nach Mitteilung unseres Gewährsmannes wurden in Gelderland und Overijssel in der vergangenen Woche 28 Todesurteile vollzogen, im Limburg 30, in Groningen und Friesland 40. Im ganzen sind öffentlich bereits mehr als 130 Hinrichtungen erfolgt, und inzwischen dürfte die Zahl schon wieder erheblich gestiegen sein. Hierbei ist nicht die grosse Anzahl Personen einbegriffen, die bei Konflikten an Ort und Stelle ums Leben gekommen ist. Besonders in Friesland und Groningen scheint diese hoch zu sein. Aus Friesland kommen Berichte von zahlreichen Toten in Leeuwarden und in der Provinz; eine Reihe von Städtern und Bauern ist hier in Gefechten mit der Polizei und mit N.S.B.ern getötet worden. Friesische Bauern haben Bauernhöfe in Brand gesteckt, Mitglieder der N.S.B. angegriffen, Autoritäten misshandelt. Dasselbe hat sich in Groningen und Limburg zugetragen. Aus allen eingehenden Berichten spricht ein bitterlich ernster Widerstand der Bevölkerung 
gegen das weiterhin zunehmende Wegführen der wehrbaren niederländischen Männer und allenthalben sieht man welche Bedeutung das Publikum diesem allem beimisst. Dass man allmählich in das gefährliche Stadium kommt, in dem Terror-Verordnungen und Todesurteile am laufenden Band nicht mehr genügend sind, um den Widerstand gänzlich zu unterdrücken, lässt das Misslingen des Aufrufs an die Studenten erkennen und wird sich ferner bei den folgenden Aufrufen an die niederländische Wehrmacht zeigen. Und wohin kommt es mit dem Deutschen Regime, fragt man in politischen Kreisen, wenn das bis jetzt erfolgreich angewandte System von Erschiessungen und Einschüchterung nicht mehr hilft?

\section{Kritik an London;}

Neben dem wachsenden Hass und der Erbitterung gegen die deutschen Massnahmen und die NSB (die, ob sie will oder nicht, für die jüngsten. Massnahmen mitverantwortlich gemacht wird) übt das Publikum ausserdem Kritik aus am Eisenbahnpersonal und der niederländischen Regierung in London. Man habe erwartet, dass von England aus jede Widerstandsaktion, wozu man selber ausgerufen hatte, tatkräftig unterstützt werden würde. Man sieht zwar ein, dass bei ähnlichen Streikaktionen nicht sofort mit einer Invasion gerechnet werden kann, andererseits hätte man aber auf schwere Bombenangriffe auf Eisenbahnen usw. gehofft. Soweit ist es bereits mit einem Grossteil des niederländischen Volkes gekommen, dass es bereit ist, die schwersten Luftangriffe auf eigenes Gebiet zu dulden, wenn es sich nur deutlich herausstellt, dass sie als Unterstützung inländischer Widerstandsaktionen anzusehen sind. Selbstverständlich spielt die aussenpolitische Lage hierbei eine grosse Rolle. Man rechnet damit, dass im Laufe dieses Sommers "grosse Dinge" geschehen werden und in seiner Ungeduld greift man diesen Ereignissen vor. Ausserdem stehen manche Niederländer - vor allem in bürgerlichen und intellektuellen Kreisen — auf dem Standpunkt, dass es töricht sein würde, jetzt gehorsam nach Deutschland $z u$ gehen, wenn in einigen Monaten doch ,die grosse Schlacht beginnt".

\section{Die N.S.B.:}

Dass auch die N.S.B. sich durch den Verlauf der Dinge nicht wohl fühlt, geht aus einer Erklärung hervor, die durch Mussert auf der ersten Seite von „Volk en Vaderland"1) abgedruckt wurde. Hierin erklärt Mussert u.a., dass er die erneute Kriegsgefangenschaft der Mitglieder der ehemaligen niederländischen Wehrmacht erst aus der Bekanntmachung des Wehrmachtbefehlshabers erfahren habe und darüber im Augenblick noch keinen Kommentar dargeben könne. Mit anderen Worten, der Leiter der NSB legt Wert darauf, seinen Mitgliedern mitzuteilen, dass die Sache ohne ihn abgehandelt wurde und ferner, dass er nicht damit einverstanden ist, denn sonst hätte er schon eine Betrachtung darüber geben können.

Ausserdem treffen aus dem Innern des Landes allerhand Gerüchte ein (im Moment allerdings schwierig zu kontrollieren) über NSB-er, die sich angeblich mit dem Auftreten des Publikums einverstanden erklärt haben. Jedenfalls steht fest, dass der Einfluss der NSB nirgendwo im Lande auch nur so gross gewesen ist, dass sie imstande war, ihre Stimme. gegen diese Widerstandsaktionen hören zu lassen.

Schlieslich verlautet noch, dass an vielen Stellen hierzulande durch NSB-er und deutsche Beamte intensiv daran gearbeitet wird, den Strom der Todesurteile einzudämmen. Offensichtlich befürchten viele Nationalsozialisten, - Niederländer und Deutsche - die ziemlich isolierte Posten bekleiden, dass die Bevölkerung diese Todesurteile noch vor Kriegsende an ihnen rächen wird, ehe sie Gelegenheit haben, sich in Sicherheit zu bringen.

1) No. van 7 Mei 1943 . 


\section{Die Lebensmittelversorgung:}

$\mathrm{Z}_{\mathrm{u}}$ allen diesen Schwierigkeiten kommt noch die Knappheit an Lebensmitteln, vor allem an Butter, Käse, Fleisch und Zucker. Auf eine diesbezügliche Frage unseres Gewährsmannes an einen Ernährungsverständigen in Amsterdam antwortete dieser, die Tatsache dass man jetzt doppelt so lang mit der Ration Butter und Fleisch auskommen müsse, sei keineswegs allein auf die Streikaktion der Bauern zurückzuführen. Seiner Ansicht nach sei die Butterposition bereits so schlecht, dass die Produktion nicht mehr ausreiche. Man habe diese Gelegenheit denn auch einfach ergriffen, um den Bauern die Schuld zu geben: so komme man über eine schwierige Zeit hinweg und gebe anderen die Schuld. Ausserdem sei die Sache ziemlich durchsichtig: wenn ein Tag Streik eine derartige Stockung in der Butterrationierung verursachen könnte, würde sich das Publikum fragen, wo denn alle Butter bleibe, die normal an anderen Tagen produziert werde, wenn 24 Stunden Sabotage schon eine derart grosse Lücke in die Produktion schlage.

Mit Butter und Käse wird es schwierig bleiben, auch nachdem diese Verlängerungsperiode vorbei sein wird, und zwar aus dem einfachen Grunde, weil man zuviel Butter (bezw. zuviel Vieh) aus Holland herausgezogen hat.

Die Gemüseversorgung hat tatsächlich durch die Streiks eine Stockung erfahren, und zwar weil es sich hier um täglich angeführte Artikel handelt. Diese Stockung wurde jedoch bereits behoben.

Hinsichtlich der Kartoffel- und Gemüseversorgung brauche man in Amsterdam, wie der oben erwähnte Nahrungssachverständige betont haben soll, vorläufig keine Angst zu haben. Auch die Brotration werde nicht herabgesetzt worden, wenn man wenigstens die Vorräte und Massnahmen unangerührt lässt.

\section{Stimmungsbericht aus den Niederlanden d.d. 20-5-1943}

Den Haag, den 20. Mai 1943.

\section{Anmeldungspflicht: stetige Unruhe.}

Die Unruhe unter der niederländischen Bevölkerung ist, gemäss Bericht eines unserer Gewährsleute, durch die Verordnung des Reichskommissars vom 8. Mai ds. Js., nach der alle männlichen Bewohner der besetzten niederländischen Gebiete im Alter von 18 bis 35 Jahren zur Anmeldung bei den verschiedenen provinzialen Arbeitsbüros verpflichtet werden, womöglich noch gestiegen (sie umfasst jetzt noch mehr Gruppen der Bevölkerung). Und schon laufen in offiziellen Kreisen Gerüchte um, dass die Altersgrenze nach oben bis zu 45 oder 50 Jahren erhöht werden solle; ein diesbezüglicher Erlass sei innerhalb einiger Wochen zu erwarten.

Für den grössten Teil des Publikums bedeutete diese Verordnung „,sofortiger Abtransport nach Deutschland", und darum äusserte sich auch sogleich heftiger Widerstand in allen 
Schichten der Bevölkerung. Hier und da haben die Behörden bekanntgegeben, dass vorläufig nur von einer Anmeldung die Rede sei in der Absicht, eine Inventarisierung der zur Verfügung stehenden Arbeitskräfte zu ermöglichen. Das ist natürlich nur ein schwacher Trost, weil ein jeder wohl begreift, dass man mit dieser Inventarisierung schliesslich keine anderen Absichten als Abführung nach Deutschland haben kann. Freistellungen betreffen hauptsächlich behördliches und halbbehördliches Personal (incl. Eisenbahnen und P.T.T.). Weiterhin noch abgerechnet einige Personen aus der Lebensmittelversorgung, kommt man jedoch nach den Statistiken zu einer Gesamtzahl von 500.000 Mann, die unter die Arbeitsverordnung fallen. Zugerechnet $z \mathfrak{u}$ denen, die bereits in Deutschland arbeiten und die laut Verordnungen der vergangenen Woche noch "gehol"" werden müssen, ergibt sich die Totalenanzahl von einer Million Mann, die dann in Deutschland leben und arbeiten müssen. Wenn man diese Pläne in der Tat zur Ausführung bringen könnte bei einer relativ noch langen Dauer des Krieges, würde eine derartige starke Herausziehung der wehrhaften Männer nicht weniger als eine Katastrophe für das eigene niederländische Volksleben bedeuten. Kein Wunder dass man sich in politischen Kreisen über diese Verordnungen ausserordentlich besorgt zeigt, dass man von London aus eine heftige Kampagne dagegen unternommen hat und das man auch in führenden N.S.B.-Kreisen über den Verlauf der Sache deprimiert ist.

Es sei schon, meint man, so oft und von allen Seiten über die Tatsache geschrieben worden, dass die Deutschen die gröbsten politischen und psychologischen Fehler hinsichtlich der Behandlung anderer Völker machten, dass eine Beweisführung hier überflüssig werde. Die Tatsache selbst stehe nun wohl unumstösslich fest. Dennoch bleibe es ein Rätsel, warum all diese Verordnungen und Massnahmen so schnell aufeinander folgen mussten, um so mehr als die Durchführung derselben bisher zum grossen Teil einen Fehlschlag bedeutete, dessen Nachteile (Unruhe, Hetze, Energieverschwendung, Sabotage etc.) nicht im entferntesten die Vorteile aufwögen. Von den Studenten stehe nun fest, dass ungefähr $75 \%$ nicht erschienen sei. Von den Berufsmilitären hätten sich nur ungefähr 5-600 in Amersfoort gemeldet (von den ungefähr 600 Unteroffizieren der kolonialen Reserve nur 3); infolge der gewährten Ausnahmen kann die Gesamtzahl derer, die sich zu melden hatten, nicht genau angegeben werden; aber eine niedrige Schätzung gibt 2000 als total an, so dass auch von dieser Gruppe ungefähr $75 \%$ nicht gekommen ist. Im ganzen genommen handle es sich hier allein schon um 12000 Männer, die "geholt" oder, wenn man will, "gefangen" werden müssten. Die Todesurteile folgen noch immer aufeinander, und die Verfolgungen und Verhaftungen im ganzen Land werden fortgesetzt; unter den Arrestanten befinden sich jetzt viele Fabrikanten wie die Van Heeks in Twenthe, Philips in Eindhoven und verschiedene Betriebsleiter der Limburger Bergwerke.

Immer dringender wird also die Frage, warum man jetzt mit diesen Verordnungen, die jedesmal wieder neue Schwierigkeiten verursachen, eine so katastrophale Eile hat. Und die Antwort wird in politischen Kreisen immer einstimmiger gegeben: die Deutschen hätten Eile, weil bald grosse Dinge geschehen würden, weil sie Todesängste vor Invasionen in grossem Massstab hätten, weil sie im Hinblick darauf alle wehrhaften Männer aus den besetzten Gebieten wegnähmen um so wenig möglich Gefahr im Rücken zu haben oder um über Millionen von Geiseln in Deutschland zu verfügen, wenn es nicht so glatt gehe etc, etc.

\section{Wehrmacht gegen bürgerliche Verwaltung:}

Diesen Auffassungen wird durch die hartnäckigen Gerüchte Nahrung gegeben, dass diese ganzen Verordnungen, im besonderen die Verordnung bezüglich des Zurückführens der Kriegsgefangenen, völlig und ausschliesslich das Werk des Wehrmachtbefehlshabers, General Christiansen, sei. Er habe im Auftrag des Führer-Hauptquartiers gehandelt, ohne Rücksprache mit dem Reichskommissar, der übrigens im Ausland gewesen sei, als die Verordnung verkündet wurde. General Christiansen habe hiermit, so wird in deutschen Kreisen behauptet. der bürgerlichen Regierung ein Ende zu machen versucht, wenigstens habe er die Möglichkeit 
schaffen wollen, in Zukunft unter Umgehung der Niederländischen Regierung handeln $z u$ können. Teilweise ist ihm das gelungen. In N.S.B.-Kreisen herrsche eine deprimierte Stimmung, weil man fühlt, dass auf diese Weise Musserts Einfluss auf die niederländischen Regierungsangelegenheiten unmöglich gemacht wird (während ihm gerade in dieser Hinsicht noch vor kurzem die schönsten Versprechen gegeben wurden). Man bemerke infolgedessen auch eine starke Neigung bei Mussert und einer Anzahl seiner engsten Mitarbeiter (vor allem Professor Carp), stärker mit den vielgeschmähten „Antis" anzubinden, jedenfalls sich so viel wie möglich „,niederländisch" zu halten, um für die Zukunft noch zu retten, was zu retten ist.

Nach Aeusserung unseres Gewährsmannes hat die Niederländische Regierung in London in sehr scharfen Worten und Warnungen sich an das behördliche Personal gerichtet. Sofern es auf irgendeine Weise an der Durchführung dieser Verordnungen mitwirke, werde dies von der niederländischen Regierung als Landesverrat angesehen werden und die verantwortlichen Personen würden in der Zukunft dafür bestraft werden. Dies gelte dann vor allem für die Leiter der betreffenden Büros und für die Bürgermeister. In der Tat kommt für viele dieser Regierungsbeamten eine äusserst schwierige Zeit. Rein juristisch gesehen, könnte sich Deutschland hinsichtlich der Kriegsgefangenen eventuell noch auf internationale Konventionen berufen, so dass auch die Regierungsbeamten dies eventuell könnten. Aber was den Aufruf aller Männer gemäss der jüngsten Verordnung betrifft, stehe wohl fest, das im Internationalen Recht keine Basis dafür zu finden sei, was übrigens für den grössten Teil der getroffenen Massregeln gilt. Wie dem auch sei: das Publikum hat nicht das geringste Interesse an juristischen Spitzfindigkeiten. Und damit werden die Regierungsbeamten Rechnung halten müssen.

In den Kreisen der Kommunisten und „Illegalen" herrsche kaum verborgene Freude über den Lauf der Dinge in der letzten Zeit. Vor allem bei den Illegalen, bei weitem die wichtigste Gruppe, da sie Leute aus allen Kreisen der Bevölkerung umfasst, zeige sich eine fieberhafte Aktivität. Man versucht die verbitterte Stimmung des Publikums auszunutzen, um die deutschfeindliche Stimmung noch zu verschärfen, und es ist eine Tatsache, dass sie ein willigeres Ohr als je zuvor finden. Die Anzahl derer, die fühlen, dass sie so gut wie nichts mehr $z u$ verlieren haben, hat in den letzten Wochen stark zugenommen, und vor allem unter diesen Männern sind die neuen Anwärter auf illegales Handeln zu suchen. Und sie werden auch gefunden; denn mit ihren Massregeln der letzten Wochen, teilt unser Gewährsmann mit, hätten die Deutschen diese Eingruppierung aufs stärkste gefördert.

Es scheine das Schicksal der Deutschen zu sein, dass sie psychologische Fehler begehen, selbst wenn sie versuchen, Gutes zu tun. So hat man jetzt dem niederländischen Eisenbahnpersonal mitgeteilt, dass sie die Wahl hätten zwischen 125 Gramm echtem Kaffee oder 50 Gramm echtem Tee, weil sie am 1. Mai gearbeitet haben. Sie werden also als die "weissen Schafe" angesehen, die eine Belohnung dafür erhalten, dass sie mit den "schwarzen Schafen" (den Streikenden) nicht mitgetan haben. Man kann sich denken, wie die anderen Arbeiter hierauf reagieren. Aber auch der grösste Teil des Eisenbahnpersonals fühlt sich hierdurch beleidigt. Es wäre besser gewesen, über die ganze Sache zu schweigen. Durch diese Verteilung guter Gaben an Menschen, die sich grösstenteils doch schon schämten, versagt zu haben, reizt man den Widerstand, den man zu hemmen beabsichtigte. So hat man durch dieses Geschenk viele Eisenbahnarbeiter dem Gedanken an Streik näher als je gebracht!

\section{Die Stimmung in der N.S.B.t}

Einer unserer Gewährsleute schreibt: Mehrfach verlautet, dass die Stimmung unter den alten Mitgliedern der N.S.B. in letzter Zeit beinahe verzweifelt sein soll. Ueber die Affäre Dr. van Genechten laufen viele Gerüchte um. Die Richtigkeit der Behauptungen ist allerdings. schwierig zu kontrollieren. Aus manchen Auslassungen von Mussert selbst erhält man jeden- 
falls den Eindruck, dass auch er in mancher Hinsicht enttäuscht wurde. In dem letzten Wochen soll er oft die Worte gebrauchen, "dass es nun einmal keinen anderen Weg gäbe", woraus manche Niederländer schliessen, dass er über den eingeschlagenen Weg nicht sehr zufrieden ist. Es gehört jedoch zur Aufgabe eines Politikers, das Notwendige zu tun, wenn dies auch nicht angenehm ist. An sich braucht in der Einsicht über diese harte Notwendigkeit kein Symptom der Enttäuschung gesehen $z u$ werden.

Ueber die Stimmung unter den alten Mitgliedern der N.S.B. brachte unser Gewährsmann folgendes in Erfahrung:

1. Mr. van Vessem, der seinerzeit die N.S.B. in der Ersten Kammer vertrat, hat sich immer wieder geweigert, während der Besatzungszeit einen Posten zu bekleiden. Zu Ende des Jahres 1940 hatte unser Gewährsmann eine Unterredung mit ihm. Aus dieser ging hervor, dass Mr. van Vessem schon damals Fehler in der N.S.B. und bei vielen ihrer Anhänger gesehen hat, im grossen ganzen sich jedoch mit der von Mussert verfolgten Politik einverstanden erklärte. Damals sei er noch sehr beeindruckt gewesen von den Tagen, die er im Mai $1940 \mathrm{im}$ Gefängnis verbracht habe. Kürzlich jedoch soll er einem Bekannten gegenüber seinem Herzen in den Worten Luft gemacht haben: "So haben wir es nie gewollt". "Wir strebten einen vollkommenen niederländischen Nationalsozialismus an und was wir jetzt bekommen ist eine Gleichschaltung der germanischen Völker". Auch soll er sich über Mangel an Energie und Uebersicht bei Mussert beklagt haben.

2. Ein junger N.S.B.-er, der van Genechten auf seiner letzten Reise nach Deutschland begleitete, äusserte sich über das Nervenleiden v. Genechtens. Im Anschluss an die erwähnte Reise habe sich erst das Leiden eingestellt. Als Wirtschaftssachverständiger habe v. Genechten feststellen müssen, dass Deutschland nicht lange mehr durchhalten könne: in zahlreichen Gesprächen mit Deutschen - fast durchweg Mitglieder der N.S.D.A.P. - habe er ausserdem jedesmal erfahren müssen, dass das Volk den Krieg allmählich als eine $z u$ schwere Last empfinde und dass schliesslich sogar das Vertrauen zum Führer verloren zu gehen drohe. Vor allem soll ein Gespräch mit dem Bürgermeister von Wien einen tiefen Eindruck auf ihn gemacht haben.

3. Ein junger N.S.B.-er, der einen wichtigen Posten in der Jugendorganisation der Partei bekleidet, soll sich an einen Professor, der zwar selber kein Nationalsozialist ist, jedoch als deutschfreundlich gilt und als Grossniederländer einen gewissen Einflus auf die Jugend ausübt, mit der Frage gewandt haben, ob er seinen Treueid auf Mussert nicht zurücknehmen könnte. Der Professor habe ihm abgeraten, weil er der Ansicht sei, der junge Mann könne seinen Idealen besser dienen, wenn er im Parteiverband bliebe und dort die wohlwollenden Elemente weiterhin unterstütze. Der junge Mann sei denn auch in der Partei geblieben, obwohl er sich darin eigentlich nicht mehr am Platz fühle.

4. Ein Arzt in einem Krankenhaus einer grösseren Stadt hierzulande soll von einem NSB-er-Patienten, einem der ältesten Mitglieder der Partei, erzählt haben, der sich über den Verlauf der Dinge im Lande und in der Partei bitter beklagt habe. Der Arzt äusserte hierzu: „Nach der Stimmung dieses Mannes zu urteilen, gibt es wohl keine Niederländer, die geistig mehr leiden als die ehrlichen idealistischen NSB-er aus den ersten Jahren der Bewegung".

Weiter laufen immer mehr Gerüchte über eine Krisis innerhalb der N.S.B. um. In einem Journalistenkreis soll bereits erzählt worden sein, dass Mussert die Auflösung seiner Partei ernsthaft in Erwägung ziehe. Der Leitartikel von Mr. Carp in „Volk en Vaderland"1) unter dem Titel „Das Urteil der Geschichte" machte den Eindruck einer Bestätigung dessen, was in letzter Zeit über die NSB erzählt wurde. Carp weist auf die Aehnlichkeit zwischen der jetzigen Lage und der zu Ende des 18. Jahrhunderts hin, als die Niederlande durch revolutionäre französische Armeen besetzt wurden. Vor allem wird die Parallele zwischen Schimmel-

1) No. van $7 \mathrm{Mei} 1943$. 
penninck und Mussert lebhaft besprochen. Schimmelpenninck, so heisst es, habe die Unabhängigkeit des Landes retten wollen, wenn er auch die neuen Grundsätze der französischen Revolution einführen wollte. Durch seinen eigenen Mitarbeiter verraten musste er jedoch den Kampf aufgeben. Die Niederlande wurden sodann als Königreich Holland unter Führung des Bruders Napoleons Frankreich einverleibt. Im allgemeinen erblickt man in diesem Absatz eine Parallele zur jetzigen Lage. Auch Mussert, so heisst es, werde durch manche seiner Mitarbeiter verraten und schliesslich gezwungen werden zugunsten einer direkten deutschen Verwaltung den Platz zu räumen. Mussert wird also von zwei Seiten angegriffen. Einerseits durch die Anhänger einer ausgesprochenen niederländischen Richtung in der Partei, wobei der alte grossniederländische Gedanke einen gewissen Einfluss ausübt, und andererseits durch die Anhänger einer radikal-deutschen Richtung, die sich dann der niederländischen SS anschliessen. $\mathrm{Zu}$ der ersten Gruppe soll Ruiter gehören, eine der leitenden Persönlichkeiten in Amsterdam der, wie verlautet, aus der Partei getreten ist.

\section{Niederländische Reaktion auf die Verordnung über Einziehung von Rundfunkgeräten:}

\section{Zum nebenbezeichnetem Thema macht unser Gewährsmann folgende Ausführungen:}

In der eindrucksvollen Verordnungsreihe der letzten Zeit nimmt die Verfügung des Reichskommissars vom 13.5.1943, betreffend Einziehung von Rundfunkgeräten im besetzten niederländischen Gebiet beim Publikum einen so bedeutsamen Platz ein, dass man gründlicher Sabotageversuche sicher sein kann. Der Preis alter Apparate aus zweiter oder dritter Hand, die durch den Käufer eingeliefert werden sollen mit der Absicht den eigenen Apparat behalten zu können, ist bereits erheblich gestiegen. Ausserdem sind hier und da schon "Nachrichtendienste" organisiert worden, die das Publikum gegen eine kleine Vergütung für Papierkosten usw. über die wichtigsten Rundfunkmeldungen aus dem Ausland informieren sollen. Die Tatsache, dass von der Verordnung nur die hier ansässigen Deutschen und NSB-er (vielleicht auch einige Journalisten) freigestellt werden, zeige, wie uns unser Gewährsmann die Meinung des Publikums zusammenfasst, wohl sehr deutlich, dass man von der antideutschen Stimmung des ganzen niederländischen Publikums überzeugt ist. Allgemein erblicke man darin die Einsicht über das völlige Scheitern der deutschen Propaganda in einem Lande, das man neben Norwegen am liebsten für die Deutsche Sache gewonnen hätte.

Von politischer Seite glaube man ferner in dieser Massnahme eine gewisse Furcht seitens der deutschen Besatzung erblicken zu können, Angst vor einer baldigen Invasion der Alliierten. Tatsächlich könne man diese und ähnliche Verordnungen keineswegs als einen Beweis von Kraft auffassen. Vor allem hierdurch nehme das Publikum die Sache ziemlich ruhig auf. Die Hoffnung auf baldige entscheidende Ereignisse würde nur verstärkt.

\section{Widerstand gegen Anmeldungspflicht:}

Unser Gewährsmann berichtet folgendes:

Die scharfe Rundfunksprache, die Königin Wilhelmina an einem der Ostertage über den Londoner Sender hielt, wird zusammen mit den bereits früher erwähnten Erklärungen der niederländischen Regierung, worin Beamten und Behörden anheimgestellt wird, gegen die jüngsten Massnahmen der Besatzungsbehörden so aktiv und zweckmässig wie irgendmöglich Widerstand zu leisten, in weiten Kreisen verbreitet.

Zweifellos üben diese Anregungen Einfluss aus, aber wenn sie nicht gemacht würden, würde der Widerstand des niederländischen Publikums doch nicht nachlassen. Der Widerstand geht weiter und umfasst alle Kreise. Drohungen mit Todesstrafen und Massenhinrichtungen (den letzten Mitteilungen auf der Pressekonferenz zufolge sollen angeblich in den vergangenen zwei Wochen mehr als 400 Todesurteile ausgesprochen und vollzogen worden sein, wozu dann noch einige Hunderte von Toten kommen, die ohne Urteil erschossen wurden), haben 
nicht mehr die gewünschte Auswirkung, jedenfalls nicht eine derart grosse Auswirkung, dass sie den Widerstand brechen können. Zwar besteht viel Meinungsverschiedenheit über die Form des Widerstandes. So ziehen manche Leute es vor, jede Anmeldung und Eintragung prinzipiell $z \mathfrak{u}$ unterlassen, was auch die Folgen sein mögen, während andere wieder auf dem Standpunkt stehen, dass man so lange wie möglich mit Freistellungen ("Ausweise") arbeiten müsse, auch wenn man kein Vertrauen darin hege, weil man damit die Leute "so lange wie möglich aus den Händen der Deutschen halten kann". Dieser letzte Standpunt wird voraussichtlich von der Mehrheit befolgt werden, jedenfalls so lange dies Vorteile in Form von Freistellungen bietet. Wie man angeblich beim Publikum glaubt soll auch bei den Deutschen Autoritäten eine ziemlich grosse Verwirrung hinsichtlich der Ausführung sämtlicher Verordnungen herrschen. So sei z.B. kürzlich auf der Pressekonferenz bestätigt worden, dass die Anmeldung noch nicht die Verschickung um jeden Preis nach Deutschland bedeute. Es bestehe die Absicht, einen vollständigen Ueberblick über die verfügbaren Arbeitskräfte zu bekommen ,um dadurch eine bessere Arbeitsverteilung zustandebringen zu können". Einige Journalisten hätten sich auf Beispiele aus den letzten Tagen berufen, denenzufolge Männer, die sich angemeldet hatten, innerhalb 2 oder 3 Tage nach Deutschland abreisen mussten, während in einigen Fällen sogar die Identitäts- und Stammkarte abgegeben werden musste, um die Inhaber auf diese Weise zu zwingen. Der Sprecher der Pressekonferenz habe diese Absicht jedoch in Abrede gestellt und obige Mitteilung bestätigt. Selbstverständlich komme diese Verwirrung bei den Autoritäten dem Verlauf der Sache nicht zugute. So verlautet, dass in Naarden, wo man an einem Tag 300 Anmeldungen erwartet habe, nur 6 Leute erschienen seien, in Hilversum nur 37 von 450 usw. Auch hier müsse die deutsche Polizei also wieder herangezogen werden, während sie sowieso bereits mit dem Einholen nichtwilliger Studenten (von denen sich jetzt imsgesamt 4300 gemeldet hätten, so dass nach Abzug derjenigen, die sich schon direkt meldeten, noch 7000 bis 8000 fehlen dürften), ehemaliger Mitglieder der Wehrmacht, entflohener Juden und sabotierender Inhaber von Rundfunkempfangsanlagen zu tun hätte. Was letzteres anbetreffe, so könne man wohl sagen, dass davon speziell ,der kleine Mann" betroffen werde, der oft jahrelang gespart habe, um einen guten Radioapparat kaufen zu können und jetzt nicht über die Mittel verfüge, sich einen „Ersatz" anzuschaffen. Jedenfalls stehe fest, dass eine Zeit politischer Verfolgungen anbrechen werde, wie dies in den Niederlanden sogar in den Zeiten von Herzog Alba und Napoleon nicht der Fall gewesen sei. 
SUMMARY 
Strikes broke out on three occasions during the German occupation of the Netherlands. In February of 1941 the population of Amsterdam and a few other cities stopped work in protest against the persecution of the Jews. In April-May 1943, strikes broke out in many parts of the country to protest against the decree by virtue of which members of the former Dutch army were compelled to register to be brought back to Germany in captivity. On September the 17th 1944, railway workers stopped work on instructions given by the Netherlands Government in London.

These three strikes have been made the subject of research which was carried out by the Netherlands State Institute for War Documentation. The present book dealing with the second of these strikes is the first result of the work. It is based on investigations made during the period ranging from the autumn of 1946 to the spring of 1948. Most of the material was obtained by questioning the most important witnesses of the strike movement and sifting the evidence obtained. In addition, many documents were collected from German and Dutch sources. The entire work was carried out under the responsability of Dr P. J. Bouman, Professor of Sociology at the State University of Groningen. The origin of the strike in Eastern Overijsel (just on the German irontier) was investigated separately by $\mathrm{Mr}$ B. A. Sijes, a research-associate of the State Institute.

Part I: General Survey; Part II: The strikes in the Provinces; Conclusions (pp. 7-188)

\section{Author: Dr P. J. Bouman}

Shortly after the occupation of the Netherlands in May 1940, Hitler, certain of victory in Europe, believed it advisable to make a gesture by which he hoped to gain the sympathy of the people of Holland. The Dutch army, with the exception of the officers, was demobilized in June 1940. Conditions, however, by no means returned to normal. The burden of the occupation made itself felt in an ever-increasing degree; the German authorities courted the support of collaborators more openly and it became obvious that the role allotted to the Netherlands was that of active collaboration on part of the Dutch people in the German war economy.

The feeling of embitterment grew more intense from year to year. In February 1941, the population of Amsterdam demonstrated against the measures taken against the Jews by means of a token strike. Everywhere in the country small groups were formed for the organization of illegal resistance. The German police, particularly the Sicherheitsdienst, however, worked 
quickly and effectively. On the surface everything appeared to be quiet, but there was a strengthening under-current of tension. During the first months of 1943 a nervous tendency of growing impatience became quite perceptible amongst all classes of the population. The German defeat at Stalingrad could no longer be concealed, R.A.F. raids on the cities of Western Germany became heavier, the situation in North Africa swung in favour of the Allies, and Churchill plainly hinted in his speeches that the war was about to take a new turn.

An acute shortage of labour compelled the Germans to recruit new groups of workers from the occupied territories. In February 1943 "razzias" were organized for that purpose in various towns of Holland. District Labour Exchanges were ordered to control all engagements and dismissals. On March 11 th 1943, a decree was issued ordering all students to sign a declaration of loyalty and declare their willingness to work in Germany on completion of their studies. It seemed as if the Germans desired to provoke one conflict after another; on March 24th 1943, the Dutch medical profession laid down their functions as a protest against the increasing German pressure brought to bear upon their organization. It was not known at that time, however, that far more severe measures were in abeyance.

Documents captured in Berlin show that as far back as February 13th 1943, Himmler had submitted proposals to the Fïhrer to reintern the Dutch army (about 300.000 men) which had been set free in 1940. The main objective of this measure was to recruit additional labour for the German war industry. The possibility of invasion by the Allies was not altogether overlooked; the leaders of the German army were afraid of a revolt in the rear of the German troops required for the defence of the coast.

The German authorities in the Netherlands, particularly the Reichs-Commissioner Seyss-Inquart and the Commissioners-General Rauter and Fischböck were not enthusiastic over Himmler's plans. They feared political unrest and disorganization of the Dutch industrial system. The Führer, however, followed Himmler's advice and a proclamation was drafted which the German military commander in the Netherlands, General Christiansen, published under his name on Thursday April 29th 1943.

The order for the re-internment of the former Dutch army as p.o.w. was an unexpected blow to the already nervous population, and a tendency to active resistance was the inevitable result. The organisation of the illegal movement, however, had not developed sufficiently to proceed to open revolt. Moreover, it was obvious that such action should take place only at the moment of the Allied invasion. When matters were considered quite dispassionately, only one conclusion could be reached, that every form of open resistance was at that moment premature. But the spontaneous reactions of the masses could not be halted; the only possible demonstration was a general strike.

"Spontaneous strikes" is the correct term to be used when referring to the wave of strikes which, with no previous organisation, broke out on Thursday 
afternoon, April 29th 1943, in the Twente district and spread rapidly over the province of Overijsel. The spontaneity of the movement can be demonstrated by the fact that on Friday morning, April 30th, work was stopped in many parts of the country without any consultation having taken place between various strike leaders.

It is interesting to examine the variety of movements in the different regions. A detailed report of the events during the strike days of the end of April and beginning of May 1943 can serve as a contribution to our knowledge of the history of the occupation; but it also gives some insight into the character of the Dutch people, the contrasts between urban and rural districts, the richly varied social life and the great variety of regional characteristics. Sociologists and social psychologists may perhaps draw conclusions from the reactions of particular groups described in this book (with many notes on the socialpsychological influence of rumour). We also believe that valuable data have been collected on the relations between the masses and their leaders. Were the reactions indeed so spontaneous as they appeared to be at first sight?

It has already been pointed out that the strikes developed among certain groups belonging to specific industries. Sociology teaches, however, that each group has its specific group-norms and cannot act without leadership. In point of fact, this rule applied to most of the spontaneous strikes in the April-May days of 1943, as the personal prestige of leading personalities exerted its influence on the collective activities of the masses. It is true that they did not organize the strikes as such, but a few words of approval, a slight encouragement, an example ostentatiously given were generally sufficient to ensure the solidarity of the group.

As far as we may speak of leadership, it should be said that in many cases this was only of an informal nature. The old trade unions and political parties had been dissolved and most agricultural associations were in a state of disintegration. Only the churches had been able to keep themselves intact. Further, co-operative societies, social clubs and sporting clubs were centres of contact. Religious groups in many cases had their connections with certain formally dissolved political organisations. Very often they acted as a screen for young illegal organisations. It was therefore hardly possible to determine later on whether the leadership of certain spontaneous strikes had emanated from religious, political or illegal groups. Moreover, the leadership, in this phase of the resistance movement, was limited more to approval and encouragement than to careful organization of strikes. Those who had been able to continue their organisational activities through the positions they held were themselves quite surprised by the fierce reactions of the population. Confronted with the fact that the people could no longer be kept in check, most of them showed sufficient sense of responsibility to warn the public to proceed carefully. All efforts had to be directed to prevent wholesale massacre.

When reviewing the complicated problem of leaders and followers, of organisation and spontaneity during the April-May strikes, it should be borne 
in mind that any strike action or strike suggestion was influenced by the conditions of the organisations in the factories. The workers of average-sized establishments, particularly where trade union influence was strong, could more readily manifest their group solidarity. Leaders of local branches of unions which had been dissolved, usually still held an authoritative position though informally. When the general position was discussed in the light of General Christiansen's decree, the local leaders were in a better position to give concrete advice than were those holding positions in religious societies or in the former political parties.

By means of an extensive inquiry, completed by data obtained through verbal interviews, a fairly accurate picture has been obtained of the motives which led to the outbreak of the strike. The history of the expansion of the stoppage can be found in detail in the archives of the German Sicherheitsdienst which are fairly complete as far as the events during the strike days are concerned. There are many instances, however, where the documents contradict one another.

It was not mere chance that the strike movement started in Twente (East Overijsel) and in the metal industry (N.V. Gebr. Stork \& Co, Hengelo). In that part of the country there exists a tendency to act collectively. It is true that the population has the reputation of being fairly docile, but when it becomes irritated it is apt to turn obstinate and stubborn. Moreover, the structure of the Twente industrial plants - establishments of an average size with a fairly powerful group-solidarity amongst their workers - lends itself easily to mass demonstrations at short notice.

The rumour of the strike in Hengelo was spread throughout the district by the many workers who lived in adjacent towns or villages.

The telephone also helped materially to make the strike known in other industrial towns of the Twente district. Everywhere there was a resurgence of the sentiment of solidarity and the population very quickly expressed sympathy with the demonstration of resistance of the Hengelo workers. Before the afternoon was over the workers of a large number of firms in Almelo, Enschede, Borne, Oldenzaal, Nijverdal, Haaksbergen, Rijssen and Vriezenveen had also stopped work.

Travellers passing throught the railway stations in Twente gave further publicity to events in the Twente industrial district. On Thursday afternoon the first strike was also declared in $Z$ wolle. There were similar signs of unrest in Eastern Gelderland and in the industrial districts of Central Gelderland. At Kampen and neighbouring places the illegal groups acting under the auspices of the Reformed Church came into action. It is true that at the famous Philips Works in Eindhoven the employees did not leave the factories on Thursday afternoon, but "sit down" strikes were reported to have occurred in various departments and demonstrated the increasing tension among the staff. The 
agitation in the mining district of South Limburg was also very strong and on Thursday night the possibility of strike action was the subject of general discussion.

That evening the rumour of the strikes in Twente had spread practically throughout the country. Many workers who still hesitated on Thursday after noon must have decided in the course of the evening that the moment had come to sabotage the orders of the Germans. Here and there small illegal groups distributed leaflets calling upon the workers to stop work. Where there was still some hesitation, there was a tendency to go to the factories or the shops on Friday morning for further consultation. The rural population did not react so quickly, they did not receive the news of the "general strike" until Friday, though the strike was by no means "general" nor did it become so during the following days.

The difference in strength between the various strikes was of some benefit to the occupying power. It enabled the German police authorities to divide their attention over the most threatened districts. On Thursday they took forcible means to repress the movement in Twente. Experience had taught them that large masses of the population could be held in check by a single deterring example. It was noticeable, however, that the Sicherheitspolizei was not ready on April 29th 1943 to counter the first attempts at resistance. Rauter, the Higher SS- and Police Leader, complained to Christiansen at a later period 1) that the proclamation, which on Thursday afternoon had been made known by the telex-news-service to the daily press, was a badly drafted and incomplete document. Why had no special exemptions been provided for and why had Rauter not been consulted as to the time of the publication?

It was also most peculiar that Reichskommissar Seyss-Inquart was not in the country when General Christiansen's decree was issued. He was travelling in Germany and at the critical moment his exact whereabouts were not even known. In consequence, the full responsibility for the maintenance of order fell upon Rauter.

The Germans depended a great deal upon the speedy suppression of the resistance movement. Should the strike spread to a nationwide extent, there was a danger of this from of sabotage extending outside the Dutch frontiers. The workers of Belgium and France might declare their solidarity with the Dutch strikers. Denmark also could not be trusted. And in Germany itself no absolute reliance could be placed on the Catholics in Westphalia where the illegal movement under Bishop Von Galen, of Münster, appeared to gain in strength. If part of Western Europe were in a state of ferment, it might encourage the Allies to accelerate the invasion.

Rauter consequently decided on the same Thursday evening that an S.S. Regiment should move from Arnhem to Hengelo. These troops were instructed to act with vigour pending the proclamation of the "Standrecht" (state of

1) During the examination of Rauter and Christiansen in prison, it was shown once more how strong had been the conflicting forces within the Third Reich. 
emergency). If possible, reinforcements would be sent from Westphalia. Twente lay within easy reach of troops coming from various directions.

The illusion that the strike might be confined to Twente was shattered, however, by reports which arrived on Friday morning in German police headquarters at The Hague. Telegrams received during the course of that morning became hourly more alarming; strikes were reported in certain mines of South Limburg, strikes at Eindhoven, and in other industrial towns of Brabant, strikes in places along the Merwede and the Noord, in the industrial district of NorthHolland, in Arnhem, in Central Gelderland, in Friesland, in practically all parts of the country with the exception of Amsterdam (where work was stopped in a few factories only). There were practically no disturbances in The Hague, Rotterdam, Utrecht and Haarlem.

Rauter was fully aware of the fact that he had not sufficient troops at his disposal to patrol the entire country. He also realised that in the circumstances he could expect little support from the Dutch National Socialist Movement. Only military force, mass arrests and death sentences might intimidate the population.

After Rauter had obtained a more or less general view of the confused situation, he proclaimed on Friday 30th April the "Standrecht" for the provinces of Overijsel, Limburg, North-Holland and Gelderland, i.e., for the four provinces from which the most alarming reports had come in.

Every disturbance of public order, which included the stoppage of the usual activities of the population, was to be punished most severely. Even before the proclamation of the "Standrecht" in a number of provinces - soon to be extended to the whole country - had become known, the strike movement had further developed. After the first mass arrests and the first death sentences there was some hesitation in many districts. The three charts added to this book indicate how the strikes developed in the first phases of the movement, how they dwindled in strength from Saturday, 1st of May, and how they continued on Monday, May 3rd only in a few districts where the population was exceptionally stubborn.

When studying the events in the various provinces the question arose why in some towns and rural districts there were very few strikes or perhaps none at all. It greatly reassured the Germans that the population of the largest cities continued to work. The Amsterdam workers had already given vent to their feelings during the strike of February 1941. In the ensuing years the intensified measures against the Jews had created a paralyzing impotence amongst all classes of the population. Rotterdam had been devastated and torn asunder, and many of her inhabitants had been evacuated to the suburbs. Apart from this, the port, generally the centre of labour agitation, was already at a standstill. A number of the former dockers had been given jobs in the construction of defence lines in the neighbourhood of the Hook of Holland. The Hague, the centre of German bureaucracy, was under more control than 
any other city, and little opportunity arose for demonstrative resistance. Utrecht had very few large industrial establishments but was characterized by a population which had never shown much persistent energy. The town was important, however, as the centre of the railway-system.

The fact that the railwaymen did not participate in the strikes presumably contributed much to break the illusion that the strike would develop into a real nation-wide movement. Everywhere the strikers followed keenly the activities of the railways. On Friday morning April 30th it was still said everywhere that the railwaymen would stop work in the course of the day. It was presumed that consultations would first have to take place before there was any action. When, however, on Saturday morning the 1st of May, the trains continued to run normally, it became evident that the strike would not take on a nationwide character. Many considered this to be a reason for discontinuing the stoppage.

There were many complaints about the lack of leadership on part of the Dutch Government in London. "Radio Oranje", the voice of the Dutch Government, did not appear to be sufficiently informed and its broadcasts again and again lagged behind events. Moreover, the advice given to go into hiding and thus prevent being made a prisoner-of-war, was not a practical solution for all concerned.

One of the greatest difficulties that hampered the study of events on Friday 30 April, was the very rapid growth of the strike movement in the rural districts. In industrial enterprises it was possible almost without exception to fix the exact time when work was stopped. The situation, however, was quite different in farming districts where the men sometimes did not go to work in the fields but continued to do certain work in the stables and sheds. After all, cattle had to be milked and the farm could never close down altogether. In many districts, particularly in the dairy regions, the stopping of the transport of milk to the dairy factories was the most pronouced demonstration of resistance. Here and there the April-May strike of 1943 is even now referred to as the "milk strike".

The position in the villages was often very confused, as people in rural districts are not as familiar with the strike weapon as they are in industry and commerce. Patrols of German soldiers passing through the villages made the population realise how critical the situation was. Wherever there were victims, the local inhabitants vividly recount many particulars of the events. For the rest, the strikes in rural districts remain too vague to reconstruct and to give a clear picture of them. Even eye-witnesses in most cases can give no details of the date when the strikes began, nor how they developed and how and when they came to an end. The material available only allowed a rough sketch to be made of the development of the strikes in all parts of the Netherlands.

Immediately after the proclamation of the police "standrecht" - this had 
occurred earlier in Twente - the Germans began to hit hard. They were determined at all costs to suppress the strike, even by mass-executions. On the 1st of May 1943 the "Standrecht" was extended to the entire country and the "Beauftragten", i.e. Seyss-Inquart's provincial deputies, received special powers to maintain order. On Friday the atmosphere in the headquarters of the "Sicherheits"-police was still rather tense, but in the course of the day it became clear that the measures taken were making themselves felt. The absence of disturbances in the large cities and the failure of the railwaymen to join the strike allowed the Germans to concentrate all their forces in the isolated strike centres.

On Friday April 30th burgomasters and directors of factories in Twente were made responsible for the resumption of work. The "Beauftragte" in the province of Overijsel demanded that normal conditions should be restored on Saturday morning. He was convinced that the strike movement had started at the instigation of a few strike leaders and he urged that the strike should be ended as quickly it had commenced. When it became evident on Saturday morning that his orders had not been obeyed, a number of people were shot. There was wild shooting in the streets, factory directors were arrested and other methods of intimidation used which made the population realise that worse was to follow if resistance continued.

Many arrests took place at Eindhoven during the Saturday and this was also the case in other industrial towns of Brabant, though there were no executions. The German police preferred first to exert pressure upon the burgomasters and factory owners.

In South Limburg the Germans had the advantage that in the well-organised mining industry, a State enterprise, they could make the leading personalities directly responsible for a continuation of the strike. The position was not so clear at Maastricht and in Central Limburg where the Catholic clergy (particularly in Roermond), in collaboration with various illegal groups, had encouraged the strike movement in the first instance; at a later stage they recommended more caution. Generally speaking, it may be said that the clergy of Limburg had shown themselves more active during the strike-days than the clergy of Brabant, who had persisted much longer in playing a waiting game.

The German police in Delft tried to obtain the names of the strikers. Mass arrests took place on Saturday. Along the Merwede and the Noord police sections from Rotterdam operated on Friday and by intimidation succeeded in getting some shifts of workers to resume work. Most of the strikers, however, remained at home on Saturday. After the proclamation of the "Standrecht" on the 1st of May, the German police, under the leadership of the notorious "Kriminalsekretär" Hoffmann from Rotterdam, decided in favour of the reprisals. Many managers of factories and workers were arrested at $Z_{w i j n-}$ drecht, Kinderdijk, Alblasserdam, Bolnes and other places. It should be added that in this district strong resistance was offered by directors and managers, who in most cases refused to hand over lists of names of their staffs. 
In the strike area of Velzen-Wormerveer-Krommenie, the German police concentrated attention on Krommenie, where they suspected there was communist agitation. On Saturday afternoon, twelve workers were dragged from their homes and taken to Amsterdam, where they were tried by the "Standgericht" (Emergency Court). 80 people were arrested on the 1st of May in Velsen and Beverwijk, but only 10 of them were tried. Though it became clear that there would be victims the Germans hinted that a number of the arrested persons might still be saved if the workers would give proof of their good intentions by working a few hours extra on the Saturday afternoon. Most of the workers concerned were thereupon prepared to abandon their rebellious attitude.

In Arnhem and in the smaller industrial places of Central Gelderland the German police at first acted with great brutality. In these places too the numerous arrests and great pressure on directors and managers of industrial enterprises gave rise to the belief that further resistance would be smothered in blood. Many people wer due to appear before the "Standgericht" of Gelderland. Small wonder then that most of the strikers preferred not to run the risk of being arrested on Monday morning.

In the peat districts of the northern Netherlands the proclamation of the "Standgericht" on Saturday May 1st made a great impression on the inhabitants. On Friday many workers had been arrested in Oude-Pekela and NieuwePekela. The "Sicherheitspolizei" sent patrols from Groningen (a strong German detachment had been stationed in the provincial capital) to all the villages where workers were on strike. A circumstance which complicated the situation in this district (as in others) was the traditional May Day celebration. The German police had given warning, however, that this could not be an excuse to remain away from work on Saturday morning. On Saturday and Sunday discussions took place between representatives of various groups of strikers and between directors of industrial factories and leaders of the workers. Generally speaking, the Germans were prepared to accept the promise that work would be resumed on Monday morning, May 3rd.

In Friesland the strike on Saturday assumed the character of a strong emotional popular movement. In no other district of the Netherlands was there a similar degree of solidarity. The whole province was permeated by an atmosphere of agitation and excitement. It was consequently extremely difficult for the German police to handle the situation as it was obvious that patrolling the villages made very little impression.

In other agricultural districts of Holland the same feelings were demonstrated, though very often no particular centres of resistance could be designated. On the chart which shows the position on the 1st of May only three shades of strike intensity are marked. The intensity of resistance was still more difficult to define in the rural districts. When comparing the charts for April 30th and May 1st, we see that the strike movement had diminished on Saturday (compared with the preceding day), particularly in South Holland 
and in the "Achterhoek" of Gelderland. In many regions which have been given the same shade on both charts, differences may well have existed. Generally speaking, the rural strikes were more intense on Saturday May 1st than on Friday April 30th.

The proclamation of the "Standrecht", first in Overijsel, Limburg, NorthHolland and Gelderland and later on in the remaining provinces, was the most effective means of intimidating the population. Announcements in the papers and over the radio, as well as by posters, informed the public that a continuation of the strike would be punished without mercy. The German police chiefs were sufficiently experienced to know that serious threats are a wedge between those who hesitate and those who are firmly resolved.

It cannot be denied that the Germans showed a certain degree of moderation in applying the provisions of the emergency laws. They soon freed a fairly large number of arrested persons who had continued to strike after the proclamation of the "Standrecht". Many of them were sent to the concentration camp of Vught for a few months, and a minority heard the death sentence passed against them. The leaders of the emergency courts fully realised that the police had only made an arbitrary choice out of the hundreds of thousands of "criminals". They knew at the same time that the task entrusted to them was to set deterring examples. The immediate publication of the sentences was of the greatest importance; the public had to learn that the German police would stop at nothing. In fact the publication of a number of death sentences on Sunday May 2nd (generally by means of posters) contributed to a large extent to the creation of an atmosphere of despondency, a feeling that nothing could be done against force.

From this summary of events on April 30th and May 1st it will be clear that in certain districts hundreds of thousands of workers, farmers and civil servants stopped work on those two days. The public services struck in larger numbers on April 30th than on May 1st. It was easier to exert pressure on civil servants than on other groups of the population and their action was less spontaneous than that of the great masses who bore less responsibility. Moreover, the intellectuals realised sooner that the strike had primarily to be given the character of a demonstration, and that it could not be drawn out indefinitely, there being no question of real solidarity on a nation-wide scale. On Saturday afternoon of May 1st most of the strikers were fairly convinced that the most sensible thing to do was to resume work on Monday morning. Meanwhile, many expressions were heard of embittered and unyielding obstinacy. The attitude of the strikers depended more on the mentality of the group than upon the individual.

If the manner in which the strikes were initiated on Thursday and Friday and the methods of resistance during these critical days give some insight into the character of the various groups of the population in their regional 
diversity, their collective behaviour during the next days of the strike makes these characteristics stand out still more prominently.

Viewed from a standpoint of social psychology, the first attempts at resistance might be regarded as a touchstone for the spontaneity of the reactions amongst various classes of the population in their geographical dispersion. After the proclamation of the "Standrecht" and after the first terrorism aimed at intimidating the people, the great varieties in the degrees of embitterment and of inclination to offer further resistance became discernible.

Social psychology which lacks the possibility of conducting experiments in laboratoria only seldom possesses sufficient material to carry out comparative studies of mass behaviour. From our description of the strike events in the eleven provinces it may be determined to what extent regional character, group-temperament and group-links of those concerned contributed to the nature of the resistance offered to Christiansen's order. Still more interesting is the collective behaviour during the second phase. When the first demonstrative phase was over the time had come to make a choice between submission (recognising that the strike had in fact failed) and further resistance.

The extent of the mass activities demonstrating the triumph of "persistence in spite of everything" is indicated on the third chart (position on Monday May 3rd). In the first place it should be observed that the rural districts acted later than the urban population and that on this account alone they showed a tendency to continue their resistance. Moreover in the isolated agricultural districts, for instance in North-Beveland (Zeeland), advantage was taken of the absence of German troops. Some strikes in the agricultural districts were prolonged out of mere carelessness. It also happened that illegal groups had obtained the leadership and encouraged the continuation of the strikes. However, it is by no means a question of chance that on Monday May 3rd the strikes in Friesland were still in full progress, especially in the Calvinist communities of North Friesland. Neither is it a question of chance that a large part of the map of North-West Brabant is coloured: strikes were going on in that part of the country on the 5th and 6th, and even on the 7th of May. Neither could the inhabitants of Vaassen, Epe and Heerde (Gelderland), of Haaksbergen and Genemuiden (Overijsel), of Slochteren (Groningen) and of certain peat districts yield easily to German oppression.

When consulting the three charts, it should be borne in mind that they show certain gaps and inevitable inaccuracies. Premature conclusions should not be drawn. Knowledge of local conditions is essential, for instance, to explain the passive attitude of the population of certain communities. This remark applies inter alia to the islands of Zeeland, burdened as they were under a heavy German occupation, and for the whole dune district from Cadzand to Den Helder and the Wadden islands, where part of the population had been evacuated and wide stretches of ground had been turned into military defence lines. It was hardly possible to start a strike in these regions. 
After the numerous arrests which took place on Saturday morning and afternoon, May 1st 1943, and after the carrying out of the first death sentences, the "Sicherheitspolizei" felt sure that the larger part of the strikers would resume work on Monday morning. They counted on the possibility, however, that they might have to deal with isolated cases but these would be easier to handle than resistance by anonymous masses.

Sunday May 2nd could be used to intensify the policy of intimidation to the utmost and speed up the resumption of work on Monday morning. During the whole of that day there was great activity in all German quarters.

According to an order issued by Headquarters of the German Sicherheitspolizei, on May 1st, and addressed to all "Aussenstellen", special control had to be made on Sunday during all church services. Great care was taken, however, as the people knew that spies were apt to be around. Moreover, the clergy realised that it would not serve any useful purpose to fan the flames. They sometimes chose texts referring to times of distress but no one considered himself called upon to stimulate the continuation of resistance after the proclamation of the "Standrecht".

The German courts which commenced their task on Saturday, continued their trials at great speed. Sentences of death were in most cases immediately carried out and published. By means of posters and wireless announcements giving the names of the victims, the public had to be convinced of the gravity of the situation. Everywhere active patrolling was kept up and many instances of haphazard shooting took place. Fear and dismay were also spread by numerous arrests during the early hours of Saturday and Sunday.

On Monday morning May 3rd the various measures taken were reviewed by the Germans in order to ascertain whether they had led to the required results. In general, the German police had no reason for complaint. Consequently, they could confine their attention to isolated cases of resistance. This explains the large number of victims during the continuation of the strikes after Sunday; near Haaksbergen in Overijsel, in Marum (Groningen) and elsewhere people were shot at random. Here and there the Germans shot a number of workers in the factory yards by way of demonstration. Similar acts of terrorism and the publication of a large number of death sentences by the special courts did not fail to make a deep impression. In spite of this, however, the population of certain parts of the country, in particular of Friesland and the Nort-West corner of North-Brabant, refused to be intimidated. Only after the 7th of May when more than 80 death sentences had been carried out and about 60 persons had been killed by random shooting was order restored.

The conqueror could now show himself in all his power. On May 7th a new order on forced labour was published in all papers. All men from the age of 18 to 35 , in so far as they were not prisoners-of-war, had to register with one of the district labour exchanges. A few days later, on May 13th 1943, there followed an order confiscating all radio sets. 


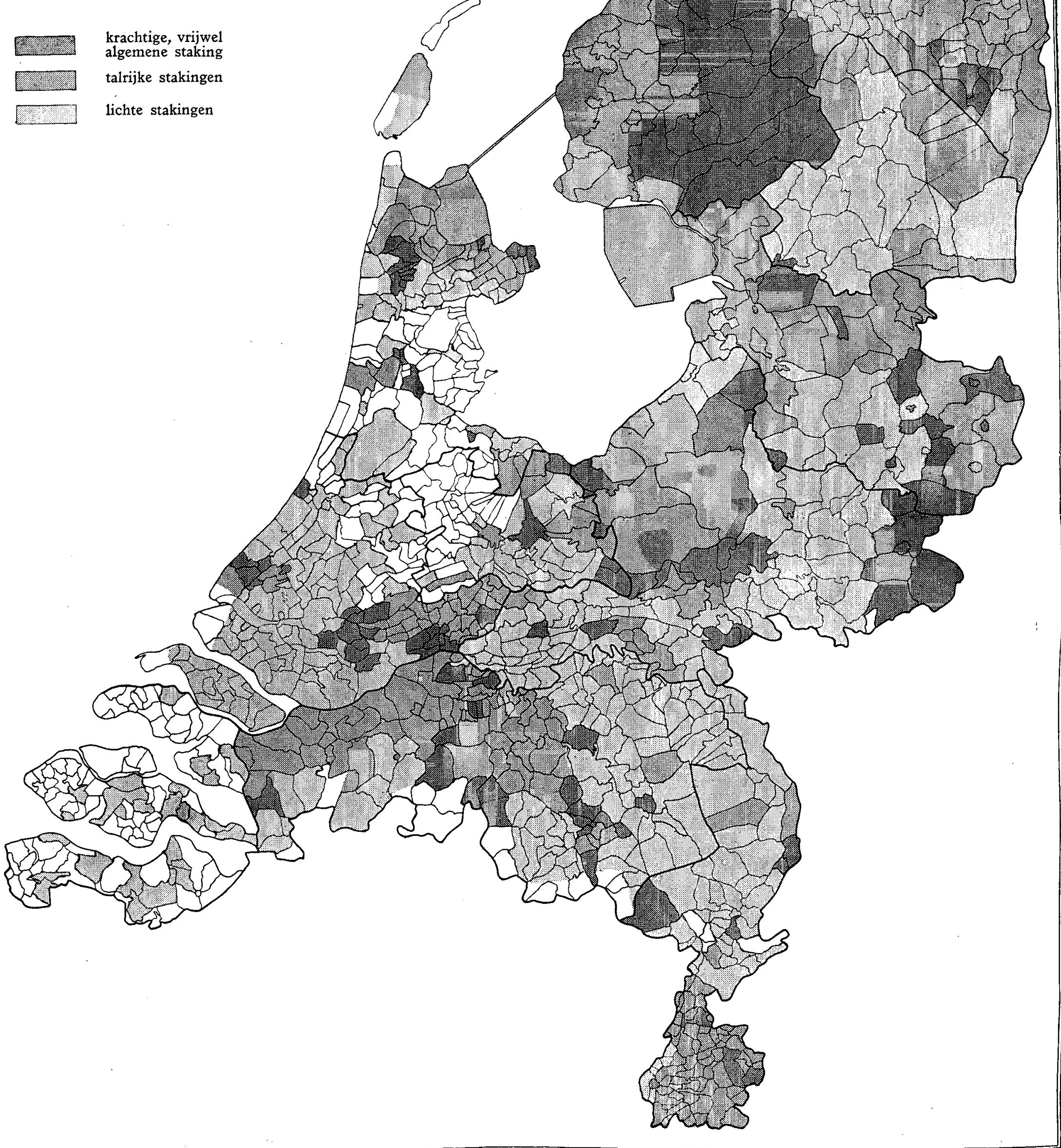


krachtige, vrijwel algemene staking

talrijke stakingen

2. lichte stakingen

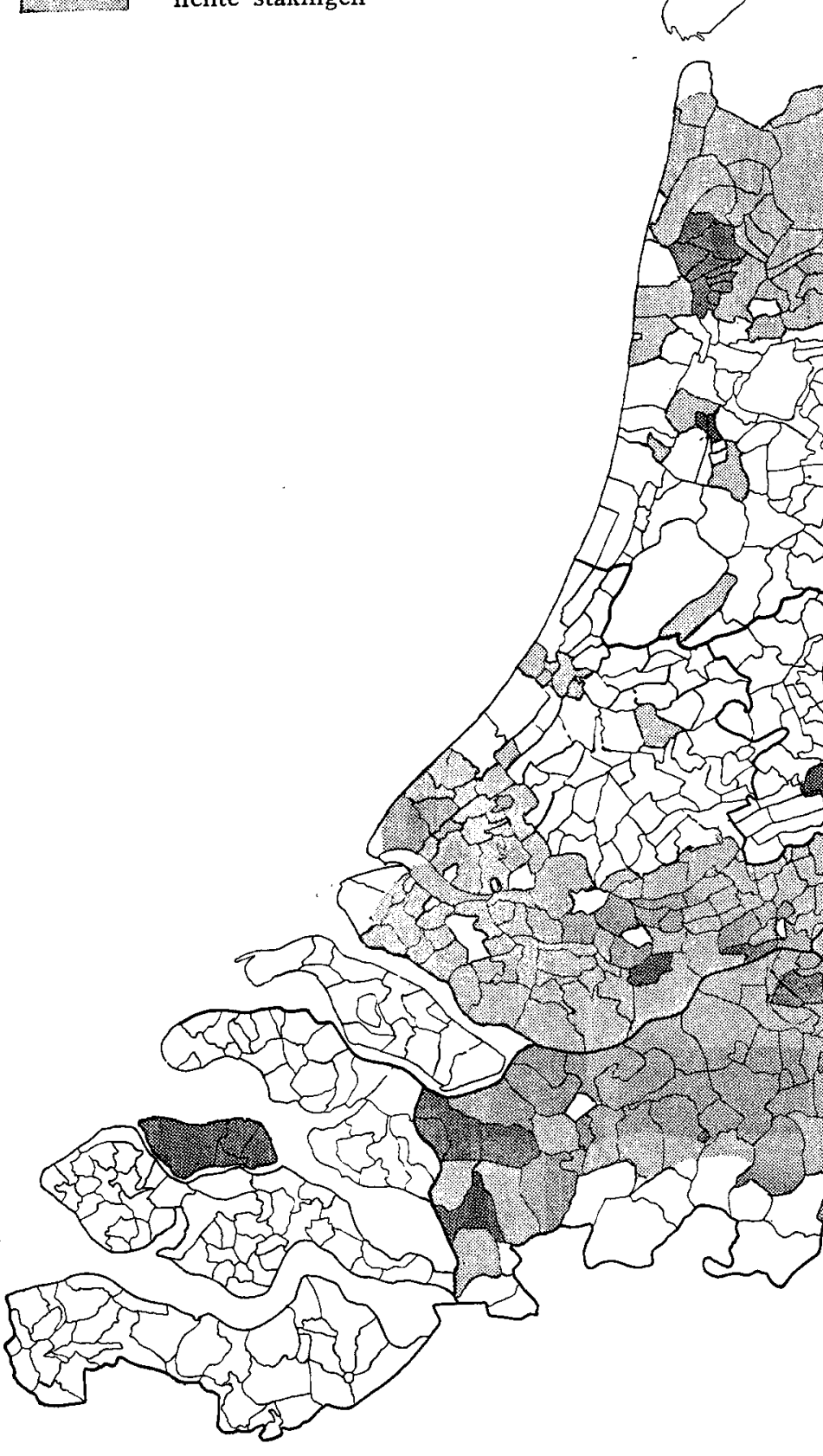

织

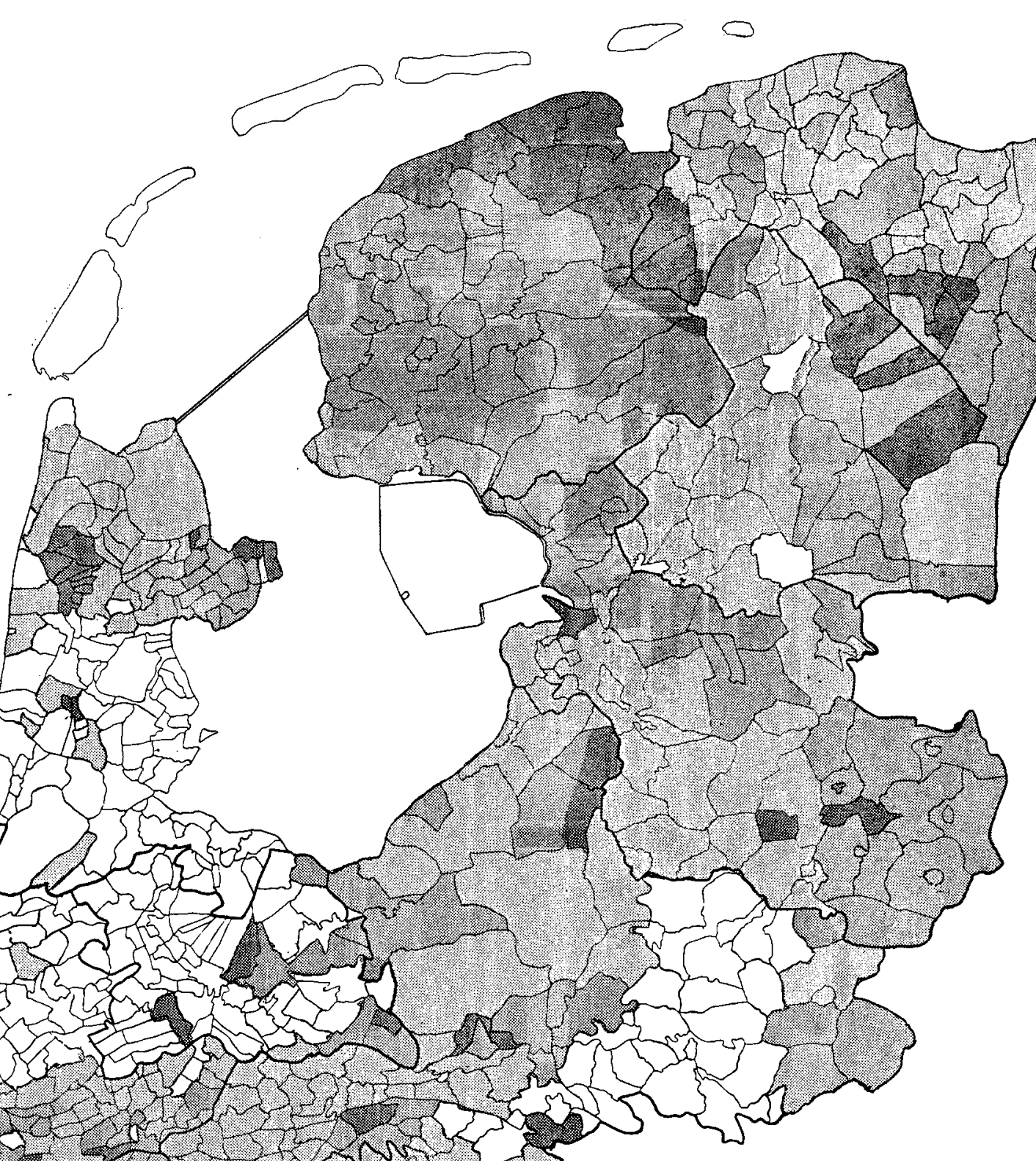


Did all this mean that the strike movement had been a complete failure? On the surface this might seem to be the case but in reality it was the turning point in the history of the resistance movement in the Netherlands. The population had learned the dangers of insufficiently organized open resistance. The urge for organized illegal resistance, however, was strengthened. The activities became more resolute, there was greater willingness to give hospitality to those who had gone into hiding, particularly in the rural districts. It also proved to be of great importance in that people had learned to know one another. During the days of the strike, personalities capable of giving leadership had come to the fore; unreliable elements had been uncovered, and here and there traitors had been detected. Forged into a solid mass, the people of Holland looked forward to the decisive days when the German power would crumble under the blows of the Allied armed forces.

Appendix I: The mechanism of the outbreak of the strike in Eastern Holland (pp. 191-296)

Author: B. A. Sijes

Even before the outbreak of the strike in "Twente" (an industrial district in the Eastern part of the Netherlands) the population had in various ways given expression to their feelings of hostility against the German occupation of the country. The workers and the employers vented their feelings by resisting the attempts to Nazify their unions. The farmers sabotaged the compulsory deliveries of cattle and grain, whilst members and leaders of many cultural organisations which had been in existence in Twente before the war preferred to continue their activities in an illegal way rather than collaborate with the Germans.

Though the strike outbreak on April 29th 1943, may for many have come quite suddenly - even for the strikers in Twente - investigations have shown that the most important precondition for this action had been gradually developing. It was to be sought in the fact that the existing social distinctions had been subordinated to the general desire of giving expression in one way or another to the feeling of dissatisfaction prevailing among all classes of the population.

All this needed time to ripen; the tendency, however, to understand and to listen to one another became perceptible fairly quickly in Twente. This tendency was expressed by illegal meetings (as early as in 1941) where workers, intellectuals and employers met together. Farmers and townsfolk - a distinction which actually is not very sharp in Twente - established closer contact because the city dwellers could buy for moderate prices butter, milk and grain. Further enquiries have shown that an attempt had been made, with the assistance of the management of two large machine factories in Twente, to organise a nation-wide strike - following the example of the 
anti-pogrom strike of February 1941 - and thus halt the increasing deportation of workers to Germany. .

This does not mean that all social groups in Twente, each of them led by their own considerations, moved in accord to common action against the Germans. The lack of mutual confidence which had prevailed for so many years, particularly amongst the textile workers and their employers, had not disappeared in the short space of three years. The collaboration of the employers in the deportations of: workers to Germany - though under compulsion of the Germans - had created a great deal of ill-feeling among the workers of Twente.

The increasing pressure of the Germans on all social classes brought about more understanding, however, as they all were opposed to the same enemy. In the resistance movement which gradually developed a common enemy was created.

In consequence of the social differentiations of this growing agglomeration, the character of the resistance offered by the various groups was not identical. The employers, for instance, sabotaged the deportation of workers to Germany by measures practically all of an administrative character and by organising as badly as possible the work to be done for the Germans. The workers "went slow" and the farmers avoided - though in the initial stages not too obviously - the compulsory deliveries.

If the character of the various social groupings influenced the form of their resistance, this also determined the way in which they became involved in the strike.

When the strike broke out, the workers mostly did not seek contact with the managements of the undertakings. In those factories, however, where the employers had been consulted, the latter left the choice to their employees. In face of the active role which the workers - by the very nature of their social position - had to play in the conflict, the employer in most cases could only be a passive observer. He could not lay down his functions and thus give expression to his attitude towards the Germans. For him there were only two alternatives: to close his works or to remain at his desk.

When the workers left the factories on Thursday afternoon of April 29th 1943, they left in groups of hundreds at a time. The workers of every factory had, so to say, taken a unanimous decision when they stopped work. As the strike broke out in the three larger cities of Twente, i.e., Hengelo, Enschede and Almelo, practically simultaneously in various factories, the personnel of all these factories, once the work was stopped, constituted one great mass into which each individual worker was merged. The position of the employers, on the other hand, was quite different. For them it was impossible to submerge into the anonymity of a group. They were the men - precisely because of their small numbers - to whom the Germans could turn most easily. They could be reached quicker than the workers and could be made directly 
krachtige, vrijwel

algemene staking

talrijke stakingen

$\square$ lichte stakingen

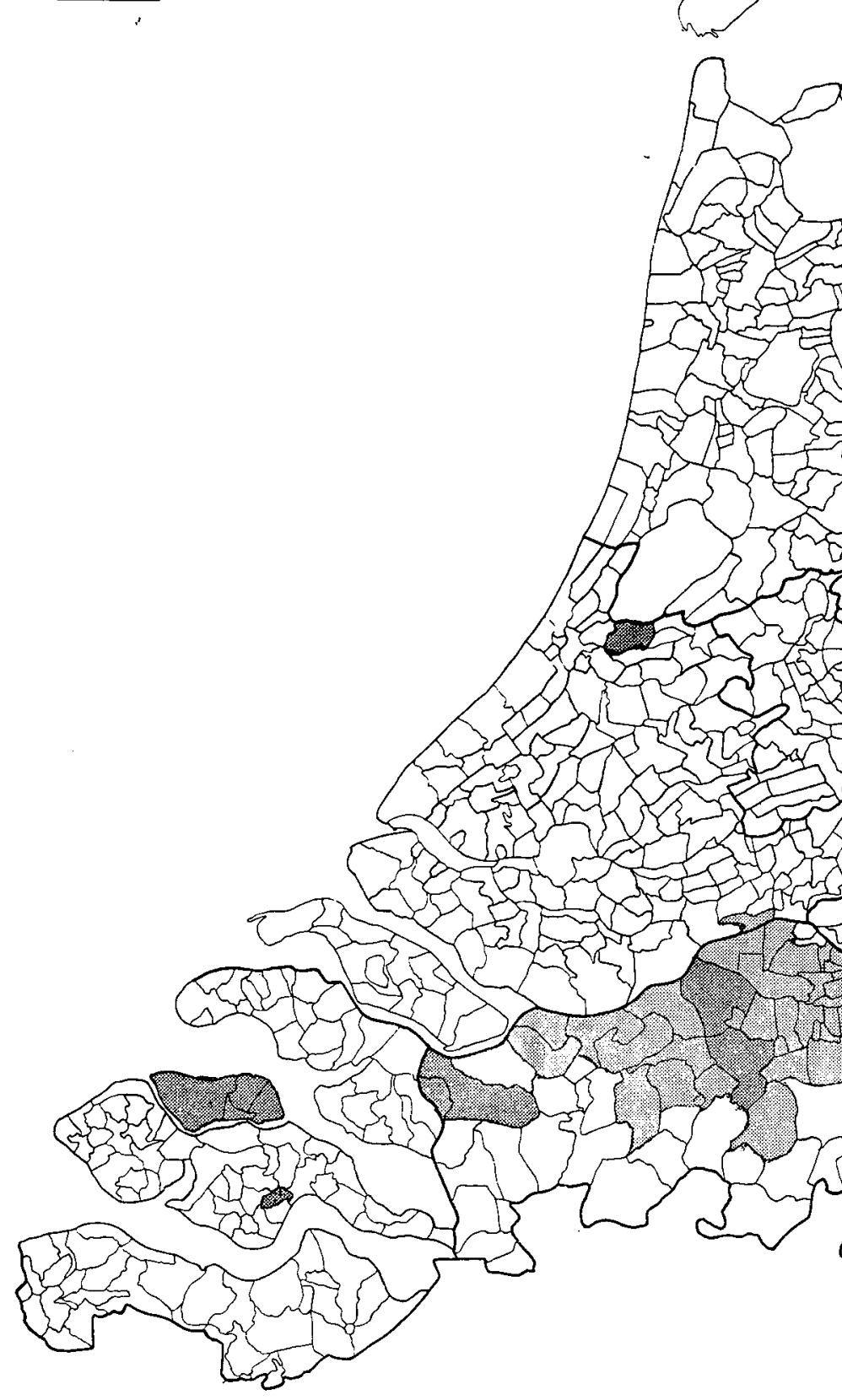


responsible not only for the fact that their workers had stopped work but equally for their return to the benches. It is true that the employers might have left their homes but this was not advisable. If they wished to extricate themselves from their vulnerable position, the only way open was to leave their homes, go into hiding and reappear when no further expansion could be given to the strike movement and when refusal to resume work would cost numerous victims. This policy was indeed followed by several employers in Almelo and Enschede.

The passive resistance of the employers may also be inferred from the fact that they did not take the initiative and urge their employees to resume work. They did not do this even though it was already clear on Friday afternoon, April 30th, that the strike had to be called off because the railwaymen did not join in. The employers did not clearly define their position until Friday night, when in the town-hall of Hengelo they were ordered under threats of punishment by a high German official to call upon their workers to resume work. The manufacturers of Enschede complied with a similar order on Friday night when they were informed that they had to supply the names of strikers.

Though the employers did not take an active part in the strike, their attitude towards the Germans was known and this influenced the decisions of the workers to take strike action.

We do not wish to create the impression that the workers leaving the factories were conscious of the attitude of their employers. When the German decree became known they wanted only one thing - to leave the factories. That hardly any discussions needed to be held was to some extent facilitated by the knowledge that the workers felt they had the backing of their employers.

However, from the moment the workers left the factories their attitude became passive. They went home and stayed home the next day or went to the farms to fetch milk. It was busy in the streets on Thursday afternoon but it was very quiet on the following Friday. Meetings or gatherings on a large scale were not held and there were no demonstrations. Discussions with many workers revealed no evidence as to what steps were taken to ascertain the position in other places. Only one man went to the west of the country to try and extend the strike movement. From this it may be inferred that the reaction of the working population of Twente was totally different from the reaction of the workers of Amsterdam during the February strike of 1941; the latter in spite of terrorism on the second day of the strike, continued to demonstrate their anti-German feelings. A similar emotional demonstration on the part of the working population of Twente was by its very nature out of the question. They fully realised, when it proved to be impossible to declare a general strike, that a refusal to resume work would engender such acts of terrorism in the Netherlands as had never been witnessed before, not even during the February strike.

When investigating the origin and the expansion of the strike it was found that hardly any attempts had been consciously made to involve other groups 
in the strike movement. For a large part this must be ascribed to the fact that the measures imposed by the Germans suddenly affected simultaneously practically all families, the very lives of sons and brothers, fiancés and husbands. To return to the state of prisoners-of-war was considered to be tantamount to being shut up in a concentration camp. Resistance against such measures did not need to be carefully prepared just because they struck everyone like a fatal blow. Those affected were already banded together in large masses in the factories and the mutual sympathy was too strong. The first hesitations in the factories where the strikes originated were turned into a mass movement, everyone laying down his tools when the rumours were confirmed. Once the example was set by the skilled workers of Twente, the wave of the strikes extended from town to town, and from village to village and it stopped only on the outskirts of the large industrial district.

The spontaneous outbreak of this strike - as it happens to be the case with all mass-movements - consequently found its origin in a number of factors which presented themselves at one and the same time. In the first place the hatred and the urge to resistance of the Dutch population had already been incited by the conduct of the Germans. Active resistance by the masses could only take place, however, when everybody was hurt at the same time and in the same way, in their most elementary sentiments and when those personalities who could give the impetus to open resistance were present in old-established and well-tried communities.

It was the "technical" conditions which rendered it possible for the strike to spread in barely $21 / 2$ hours throughout the entire district of Twente. In Hengelo where the strike commenced, the most important factories stand very close to one another. A large number of the workers employed in Hengelo lived in two other industrial towns (Enschede and Almelo). Of the workers employed in these towns many again had their homes in other smaller factory towns and even in the rural communities. When the strike broke out it was therefore possible to set an apparatus into motion which necessarily led to the extension of the strike even into the rural communities. Finally, it should be recorded that the telephone operators of the factories gave great publicity to the outbreak of the stoppage.

In Hengelo the workers resumed work on Saturday morning May 1st 1943; no one had yet been shot. Some shooting by the Germans had taken place, but the first victims only fell when the masses of the workers were on their way to resume work. Here it cannot be said, as far as Hengelo is concerned, that work was resumed only after acts of terrorism by the Germans. There was a widespread opinion among the metal workers that there was no point in striking unless the strike could be extended.

Hengelo had not only given the sign to strike, it was also the starting point for the resumption of work.

Two other groups participated in the strike movement, the farmers and 
dairy factory workers. The latter group played a significant part in the extension of the strike in the rural communities, as they caused the dairy factories to close down. These factories are an important centre in rural regions. All farmers having dealings with the factories meet one another there every day. The readiness of the individual to resist could only gradually find its orientation among the farming population during the strike, and only then when one single command could be made applicable for the entire field of activity of the dairy factory. This command was given when the dairy factory workers stopped work. By this action a large number of farmers found themselves in the same position, thereby turning the individual desire to resist into a demonstration of unanimous action. As many dairy factories were idle, there was no milk for the population. People nonetheless needed milk and they went to fetch it from the farmers, which, given the geographical position of the towns affected, did not raise any great difficulties. A consequence of this direct contact was the reciprocal stimulation of the will to participate in the strike movement on part of farmers and workers. In this way unity was established which surpassed by far the unanimity among the city strikers. The dairy factories played the role of a connecting link and succeeded in creating one single action of resistance in which the rural and urban population participated equally.

It was for this reason that the attempts of the Germans to break the strike in the rural part of Twente was directed not so much against the farmer as against the management of the dairy factories. Great pressure was brought to bear to make the farmers resume their deliveries of milk. When these attempts achieved success, the strike in the rural part of Twente soon collapsed.

\section{Appendix II: Documents on the strikes}

$$
\text { (pp. 299-434) }
$$

Most of the documents printed in annex II have been supplied to the authors by the Netherlands State Institute for War Documentation. Some others have been supplied to the State Institute by the US 7771 Document Centre Berlin, the Office of the Chief of Counsel for War Crimes, Berlin Branch, and the Political Investigation Department of the Police, The Hague.

All documents are printed in their original language. A few footnotes have been added by the State Institute for War Documentation.

The following documents have been selected for publication:

1. Letter from the Commander of the German Security Police to his Berlin superiors, Jan. 1st 1943.

2. Telex-message from the Reichsführer-SS H. Himmler to his deputy in the Netherlands, H. A. Rauter, February 10 th 1943.

3. Letter from the Reichs-Commissioner, Dr A. Seyss-Inquart, to the Reichsführer-SS H. Himmler, February 15th 1943. 
4. Notes of a meeting held in the Reichs-Chancellory Berlin, February 22nd 1943.

5. Notes of a meeting held in the Reichs-Chancellory Berlin, February 22nd 1943 (extended version).

6. Notes written by the Commander of the German Security Police The Hague, February 26th 1943.

7. Note written by an official of the Reichs-Chancellory Berlin, March 1 st 1943.

8. Report in the Deutsche Allgemeine Zeitung, March 3rd 1943.

9. Two telex-messages from Commissioner-General F. Schmidt to all provincial deputies of the Reichs-Commissioner, March 5th 1943.

10. Telex-message from Commissioner-General F. Schmidt to Gauleiter F. Sauckel, March 22nd 1943.

11. Telex-message from Commissioner-General F. Schmidt to Gauleiter F. Sauckel, April 12th 1943.

12. Telex-message from Commissioner-General F. Schmidt to Gauleiter F. Sauckel, April 16th 1943.

13. Note from the German Foreign Office, April 17th 1943.

14. Telex-message from the Reichs-Commissioner Dr A. Seyss-Inquart to Dr H. H. Lammers, April 19th 1943.

15. Telex-message from the Reichs-Commissioner Dr A. Seyss-Inquart to Dr H. H. Lammers, April 22nd 1943.

16. Telex-message from Ambassador $\mathrm{K}$. Ritter to the German Foreign Office, Berlin, April 24th 1943.

17. Telegram from Ambassador K. Ritter to the German Foreign Office, Berlin, April 24th 1943.

18. Circular letter from the German Military Commander in the Occupied Netherlands, April 26th 1943.

19. Proclamation of the German Military Commander in the occupied Netherlands, General F. Christiansen, April 29th 1943.

20. Telex-message from the Higher SS- and Police Leader The Hague, H. A. Rauter to the Reichsführer-SS H. Himmler, April 29th 1943.

21. Telex-message from Dr R. Brandt, Himmler's private secretary, to the Higher SS- and Police Leader The Hague, H. A. Rauter, April 30th 1943.

22. Notes from the Office of the Commander of the German Security Police, The Hague, April 30th 1943.

23. Telex-message from the Commander of the German Security Police to all offices in the Netherlands of the German Security Police, April 30 th 1943.

24. Staff-order issued by General K. M. Demelhuber, commander of the Waffen-SS in the Netherlands, April 30th 1943.

25. Telex-message from W. W. Dittmar, Press Counsellor of the Reichs- 
Commissioner to all pressassistants attached to the provincial deputies of the Reichs-Commissioner, April 30th 1943.

26. Telex-message from the Commander of the German Security Police, The Hague, Dr W. Harster to the Reichssicherheitshauptamt April 30th 1943.

27. Proclamation of the German Military Commander in the occupied Netherlands, General F. Christiansen, April 30th 1943.

28. Proclamation of the Reichs-Commissioner, Dr A. Seyss-Inquart, May 1st 1943.

29. Report drawn up by the Amsterdam Office of the Commander of the German Security Police, May 1 st 1943.

30. Telex-message from E. Deppner to all offices in the Netherlands of the German Security Police, May 1st 1943.

31. Telex-message from W. Lages, Head of the Amsterdam office of the German Security Police, to the Commander of the German Security Police, The Hague, May 2nd 1943.

32. Telex-message from the Commander of the German Security Police, The Hague to the Reichssicherheitshauptamt, May 2nd 1943.

33. Telex-message from the Head of the Rotterdam Office of the German Security Police to the Commander of the German Security Police, The Hague, May 3rd 1943.

34. Telex-message from the Commander of the German Security Police, Dr W. Harster, to the Reichssicherheitshauptamt, May 3rd 1943.

35. Telex-message from the Commander of the German Security Police, Dr W. Harster, to the Reichssicherheitshauptamt, May 3rd 1943.

36. Telex-message from Commissioner-General F. Schmidt to all provincial deputies of the Reichs-Commissioner, May 3rd 1943.

37. Letter from the Head of the Apeldoorn office of the Netherlands Labour Front to the Leader of the Labour Front in the province of Gelderland, May 3rd 1943.

38. Letter from the Head of the Rotterdam Office of the German Security Police, H. Wölk, to the Commander of the German Security Police, Dr W. Harster, May 4th 1943.

39. Telex-message from the Commander of the German Security Police, The Hague, Dr W. Harster, to the Reichssicherheitshauptamt, May 4th 1943.

40. Report of the Head of the Amsterdam Office of the German Security Police, W. Lages, May 1943.

41. Telex-message from the Commander of the German Security Police, The Hague, to the Reichssicherheitshauptamt. May 7th 1943.

42. Telex-message from Commissioner-General F. Schmidt to all provincial deputies of the Reichs-Commissioner, May 12 th 1943.

43. Report from A. A. M. Stoetzer, Leader of the Netherlands National Socialist movement in the province of North-Brabant. 
44. Telex-message from the Reichsführer-SS H. Himmler to H. A. Rauter, May 9th 1943.

45. Report of the Commander of the German Security Police, The Hague, May 12th 1943.

46. Report of the Commander of the German Security Police, The Hague, May 13th 1943.

47. Telex-message from the Reichs-Commissioner, Dr A. Seyss-Inquart, to all provincial deputies, May 10th 1943.

48. Report of Seyss-Inquart's deputy for the province of Zeeland, May, 11th 1943.

49. Report of Seyss-Inquart's deputy for the province of Drente, May 13th 1943.

50. Report of Seyss-Inquart's deputy for the province of Friesland, May 14th 1943.

51. Report of Seyss-Inquart's deputy for the province of Groningen, May 14th 1943.

52. Report of Seyss-Inquart's deputy for the province of Limburg, May 14th 1943.

53. Report of Seyss-Inquart's deputy for the province of North-Brabant, May 14th 1943.

54. Report of Seyss-Inquart's deputy for the province of Overijsel, May 15th 1943.

55. Report of Seyss-Inquart's deputy for the province of Gelderland, May 15th 1943.

56. Report of Seyss-Inquart's deputy for the province of Utrecht, May 15th 1943.

57. Report of Seyss-Inquart's deputy for the town of Amsterdam and the province of North-Holland, May 15th 1943.

58. Report of Seyss-Inquart's deputy for the province of South-Holland, May 17th 1943.

59. A German general survey of the situation in the Netherlands, May 10th 1943.

60. A German general survey of the situation in the Netherlands, May 20th 1943.

\section{Maps}

Three maps have been added to the volume (to be found at the inside of the bookcover); they give a survey of the intensity of the strikes in the various communal districts (.,gemeenten") of Holland April the 30st, Saturday May 1st and Monday May 3rd 1943. 
REGISTER VAN GEOGRAFISCHE NAMEN 
AALSMEER - 183

Aalten - 76, 77

Abcoude - 177, 410

Achterhoek. Gelderse - 22, 30, 56, 69, 75, 76,77

Achtkarspelen - 100, 108, 391

Achttienhoven - 172

Aduard - 112

Afrika (Noord) - 40, 401

Akkrum - 103

Alblasserdam - 29, 36, 156,163, 165, 351, 417,418

Alblasserwaard - 161, 163, 168, 170, 417, 418,419

Alkemade - 170, 178, 182, 183, 185

Alkmaar - 365

Almelo - 21, 51-53, 63, 64, 195, 198, 202. $208,230,231,233-235,237-244,258$ e.v., 270, 273, 278, 283,286, 292, 293

Almkerk - 146, 162, 163

Alphen aan de Rijn - 167, 416, 418

Alteveer - 85

Ambt-Delden - 53, 198, 237 e.v.

Ameide - 168

Ameland - 104

Amerongen - 172, 176

Amersfoort - 70, 176, 244, 336, 409, 430

Ammerzode - 80

Amstenrade - 124

Amsterdam - 23, 25, 26, 29, 60, 70, 84, $178,179,180,183,206-208,228,230$, $244,288,325,327-329,331,339-341$. $344,357,358,360,363,364,368,374$, 376, 413 e.v., 427, 429, 433

Andijk - 178, 184, 185, 414

Anna Paulowna - 185

Annen - 88

Apeldoorn - 31, 58, 68, 69, 70, 346, 347, 348

Appelscha - 101

Appingedam - 112, 392

Arcen - 131

Arkel - 161

Arnhem - 23, 26, 30, 58, 61, 65, 71-75, $79,80,154,196,273,282,285,286,288$, $289,290,294,329,331,346,404,406,407$

Assen - 82-84, 386, 388

Assendelft - 180, 340

Avegoor-Ellecom - 72, 73

Axel - 150

BAARDERADEEL - 103

Baarn - 175, 226, 249

Baflo - 111

Barendrecht - 168, 170, 417, 418
Barradeel - 97

Barsbeek - 57

Bathmen - 56

Bedum - 112

Beegden - 130

Beek - 145

Beemster - 183

Beerta - 114

Beilen - 84, 385

België - 23, 130

Bellingwolde - 118, 187

Beneden-Leeuwen - 78

Bennekom - 177

Benschop - 177

Bentheim - 206

Berchtesgaden - 325, 326

Bergambacht - 168

Bergen op Zoom - 140, 142

Berkel - 169

Berlijn - 36, 37, 302, 306, 308, 312, 322 , $344,345,356,370$

Best - 138, 143, 144

Betuwe (Neder-) - 78, 79, 80

Beusichem - 80

Beverwijk - 29, 181, 339

Bierum - 111

Biervliet - 150

Biesbosch- 146

't Bildt - 97, 98

Bilt, De - 175, 409

Bilthoven - 175, 409

Bladel - 145

Blaricum - 183

Boekelo - 53, 236, 239, 241, 279

Bohemen-Moravië, Protectoraat - 309

Bolnes - 29, 36, 163, 164

Bolsward - 104

Bontebok - 102

Borger - 90

Born - 128

Borne - 21, 52, 64, 198, 233, 234, 235, 236, 237, 239, 240, 242, 252, 262 e.v., 279, 280

Bornerbroek - 237, 239, 240. 280

Boskoop - 170

Boterdiep - 112

Bovenkarspel - 184, 185

Boven-Knijpe - 162

Boven-Leeuwen - 78

Bovensmilde - 88

Boxtel - 145

Breda - 36, 139, 140, 141

Brekken, De - 102

Breugel - 145

Breukelen-Nijenrode - 172 
Broek op Langendijk - 185

Broek in Waterland - 183

Broeierd, Den - 65

Brunssum - 122, 128

Brussel - 309

Buitenpost - 35, 100

Bunnik - 172

Bunschoten - 175

CADZAND - 33

Callantsoog - 183

Coevorden - 54, 82, 83

Colijnsplaat - 150, 151

Crooswijk - 154

Culemborg - 79

DALFSEN - 55, 56

Dantumadeel - 99

Dedemsvaart - 55, 82

Delden $-52,66,231,234,237,239,240$, 250, 275

Delfland - 418

Delft $-25,29,153,155,157,182,418$, 419,421

Delfzijl - 111, 113, 392

Denekamp - 53, 66, 198, 237, 238, 241, 243 , $276,277,279,280,283$

Denemarken - 23

Deventer - 58-60, 283

Didam - 75

Diepenheim - 56, 198

Dieren - 73

Diever - 88

Dinxperloo - 88

Dodewaard - 80

Doesburg - 75, 77

Doetinchem - 77

Doezum - 108

Dokkum - 35, 98, 99, 109

Doniawerstal - 103

Dongen - 143

Doorn - 172

Doorwerth - 26,73

Dordrecht - 152, 153, 157-160, 182, 351, $417-419,421$

Drachten - 101

Drenthe - 31, 106, 329, 338, 344, 383 e.v.

Drentse Punt - 84

Dreumel - 80

Driebergen - 172

Drunen - 145

Druten - 79

Düsseldorf - 327, 329

Duisburg - 162

Duitsland - 23, 24, 38, 54, 79, 93, 136, 206, $226,230,242,243,265,291,303,304$, $307-312,318,319,343,376,424,430$, 432

Dwingelo - 88
ECHT - 129, 130

Echten - 103

Edam - 183

Ede - 74, 75, 176, 406

Eelde - 84

Eemnes - 172

Eenrum - 111

Eerbeek - 73

Ees - 108

Eethen - 146

Eext - 89

Eexterzandvoort - 89

Egmond-Binnen - 183

Eibergen - 76, 77

Eigelshoven - 128

Eindhoven - 22, 23, 25, 29, 35, 36, 134, $136-140,143,144,157,304,345,374,417$

Elburg - .70

Elp - 87, 88, 384

Elst - 80

Emmen - 82-84, 384

Emmer Erfscheidenveen - 82

Engeland - 323

Enkhuizen - 178, 185, 416

Enschede - 21, 49, 52, 54, 58, 62, 63, 65, $195,198,202,204,208,209,219-221$, $231-244,247,248,254$ e.v., 266, 268, $272,279,282,283,285,292,293,416$

Enter - 235

Epe - 26, 33, 68, 69, 70, 348

Eursinge - 81

Exloo - 90, 91

Eysden - 124, 128

Ezinge - 110

FERWERADEEL - 99

Finland - 378

Finsterwolde - 114

Foxhol - 114

Franeker - 96

Frankrijk - 23, 433

Fries-Groningse Grensgebied - 106-108

Friese Palen - 109

Friesland $-7,23,26,30-33,106,107$, 133, 329, 345, 356, 358, 389 e.v., 427

GAASTERLAND - 103

Gasselte - 90

Geersdijk - 150

Gelderland - 23, 30, 35, 67, 77, 80, 327, $331,334,344,345,405$ e.v.

Geldermalsen - 79

Geldrop - 143, 144

Gemert - 143

Genemuiden - 33, 35, 57, 58

Giessen-Nieuwkerk - 161, 168, 418, 419

Giessendam-Neder-Hardinxveld - 160, 418

Gieten - 87, 89, 90, 341, 384

Giethoorn - 57

Gilze-Rijen - 143, 145 
Glanerbrug - 65, 195, 243

Goeree-Overflakkee - 171, 351, 352

Goes - 149, 381

Goirle - 143

Gooi, Het - 183

Goor - 52, 198, 205, 216, 231, 233, 234, $236,237,239,241,272,278,279$

Gorinchem - 146, 160-163, 355, 381, 417, 418

Gorredijk - 101, 103

Gouda - 167, 169, 351, 355, 417, 419

Graft - 183

Gramsbergen - 55, 82

's-Gravenhage - 23, 24, 26, 33, 71, 84, 136, $154,155,159,182,206,248,302,303$, $329,334,337,342,344,360,381,382$, $384,387,399,404,417,418$

's-Gravenpolder - 149

s-Gravenzande - 29, 169, 419

Greonterp - 103

Gronau - 53, 54, 205, 242

Groningen - 26, 30, 31, 33, 34, 85, 88-90, $100,105-113,115,117,118,288,329$, $334,338,342,345,385,387,388,392-$ $396,416,427$

Grootebroek - 184

Grootegast - 108

Grouw - 103

Grijpskerk - 110

HAAG, Den - zie 's-Gravenhage

Haaksbergen - 21, 31, 33, 34, 52, 53, 64, $65,198,216,233-241,243,267,268$, $279,281,283$

Haar, De - 109

Haaren - 138, 145

Haarlem - 23, 182, 206, 365, 415

Haarlemmermeer - 183

Halen - 130

Haisteren - 135, 147

Ham, Den - 55

Hamburg - 329

Harbrinkshoek - 235

Hardenberg - 55

Harderwijk - 70

Hardinxveld - 36, 160, 161, 162, 351, 355, 417,418

Haren (Gr) - 106

Harenkarspel - 185

Harlingen - 96

Hasselt - 57

Hattum - 69

Haulerwijk - 108

Havelte - 86

Heemse - 55

is Heer Abtskerke - 149

's Heer Arendskerke - 149

Heer-Hugowaard - 185

Heerde $-26,33,67,68,69$

s-Heerenhoek - 149
Heerenveen - 93, 101

Heerlen - 25, 120-122, 126, 128

Heerlerheide - 124, 128

Heeze - 145

Heiloo - 185

Heithuizen - 130

Helder, Den - 33, 182, 410

Hellendoorn - 55, 56, 198, 234, 237, 239 . $241,250,269-271,280$

Helmond - 25, 134, 139, 140, 143

Helvoirt - 145

Hemelumer Oldephaert - 103

Hendrik Ido Ambacht - 165

Hengelo - 21, 23, 34, 47-53, 57, 59-67, $71,83,117,134,182,195,196,198$, $202-212,219$ e.v., $227,230-232,234-$ 237,239 e.v. $248,251-253,255,257$, $258,263-270,272,273,276-288,292$, $293,295,325,328-331,334,402-404$, 416

Hennaarderadeel - 103

Herten - 129

's-Hertogenbosch - 139,140,146, 228, 328

Herwijnen - 80

Heusden - 145

Hevea-dorp - 73, 75

Hillegom - 170, 417

Hilvarenbeek - 143, 145

Hilversum - 183,310,330, 411, 434

Hindeloopen - 103

Hoedekenskerke - 149

Hoek van Holland - 26, 167

Hoekse Waard - 171

Hoenkoop - 177

Hogeland, Het - 111

Holwerd - 98

Hondsrug- 86,88

Hoogeloon - 145

Hoogeveen - 82-85, 385

Hoogezand - 26, 35, 113-115, 117

Hooghalen - 82

Hoogkarspel - 185

Hoogkerk - 111, 392

Hoogsoeren - 282, 285, 288

Hoogwoud - 185

Hoorn - 183, 185

Hoornaar - 161, 162, 168

Horn - 130

Horst - 131

Houten- 177

Huissen - 80

Hulst - 381

Hijken - 82

JAPAN - 38

Jisp - 183

Joure - 103

Julianakanaal - 128, 129

Jutphaas - 172 
KAATSHEUVEL - 143

Kampen - 22, 57, 58, 59

Kamperland - 150

Kamperzeedijk - 57

Kantem - 111

Kapelle - 149

Kats - 150

Katwijk - 170

Kerkrade - 128

Kinderdijk - 29, 36, 163, 165, 166

Klazinaveen - 88, 384

Klimmen - 128

Kloosterburen - 111

Klundert - 145

Kockengen - 172

Kollumerland - 99, 100

Kommerzijl - 110

Koog aan de Zaan - 180

Kortgene - 150

Koudum - 103

Krimpen aan de Lek - 168, 417

Krimpen aan de IJssel - 168, 417, 421

Krimpenerwaard - 168, 417

Krommenie - 29, 31, 178-181, 339, 363366

Kuinre - 57

Kwadijk - 183

Kwintsheul - 168

LAND VAN ALTENA - 36, 145, 146, 161

Land van Maas en Waal - 77, 78

Landsmeer - 183

Lange Watering - 169

Langstraat - 36, 143, 145

Laren - 183

Leek - 107, 110

Leens - 110

Leerdam - 161, 351, 355, 417

Leersum - 172

Leeuwarden - 94-101, 104, 228, 357, 389, 391,427

Leeuwarderadeel - 391

Leiden - 167, 417, 420

Leidschendam - 169

Lek - 417

Lekkerkerk - 168, 417

Lemmer - 96, 103

Lemsterland - 103

Leusden - 176

Lexmond - 168

Lichtenvoorde - 76, 77

Lier, De - 29, 168, 169, 418

Limburg - 22, 23, 25, 29, 30, 35, 92, 136, $327,334,338,344,345,350,356,378$, $396-398,410,416$

Linne - 130

Lochem - 75, 77

Loenen - 73, 172

Loenersloot - 172

Loosdrecht - 172
Loosduinen - 418

Lopik - 176

Loppersum - 111

Losser - 52, 198, 233, 234, 235, 237, 239. 241

MAARSSEN - 177

Maartensdijk - 176

Maasbracht - 128, 130

Maasland - 169

Maassluis - 167, 418

Maastricht - 25, 29, 35, 119, 123-128, 327, $329,331,334,398-400$

Made - 146

Markelo - 198, 231, 234, 237, 239, 241, 250 , 279,283

Marrum (Fr) - 99

Marum (Gr) - 31, 108, 109

Medemblik - 185

Menaldumadeel - 97

Meppel - 57, 82-84, 384

Merwede - 23, 25, 29, 157, 160, 417

Metslawier - 99, 100

Middelburg - 149, 381

Middelie - 183

Middelstum - 112

Midwolde - 110, 114

Mierlo - 374

Millingen - 77

Moerdijk - 135

Monnikendam - 183

Monster - 169

Montfoort - 172

Münster- 23, 61

Muiden - 183

Munnikeburen $(\mathrm{Fr})$ - 35, 101

Muntendam - 116

Musselkanaal - 118

Mijdrecht - 177

NAALDWIJK - 29, 169, 355, 418

Naarden - 434

Neede - 76,77

Neer - 130

Niawier - 99, 100

Niekerk - 110

Niers - 131

Nieuw-Amsterdam - 83

Nieuw-Buinen - 82, 83, 89, 90

Nieuw-Kruislant - 99

Nieuw-Vosmeer - 145, 147

Nieuwedijk - 146

Nieuwendijk - 163

Nieuwe Pekela - 26, 30, 116, 117

Nieuwe Schans - 118

Nieuwe Waterweg - 420

Nieuwolde - 114

Nichtevecht - 172

Noord - 23, 25, 29, 157, 163, 417

Noord-Bergum - 35, 100 
Noord-Beveland - 32, 148, 150, 151, 381

Noord-Brabant - 7, 23, 29, 31, 33, 35, 329, $331,334,338,344,372,398-401,416,417$

Noordbroek - 114

Noordeloos - 168

Noord-Holland - 23, 25, 26, 30, 36, 78, 103, $148,327,334,338,350,357,358,360$, $363,367,368$

Noordhorn - 107

Noord-Oostpolder - 56

Noorwegen - 308, 433

Nordhorn - 53, 204, 240, 243

Norg - 85

Nunspeet $-69,70$

Nijeveen - 84, 384

Nijkerk - 70

Nijmegen - 66, 77, 79

Nijverdal - 21, 52, 65, 230, 233, 269, 270, 285

ODOORN - 82, 90, 384

Odijk - 172

Oisterwijk - 143, 145

Oldambt - 113

Oldehove - 107, 110

Oldekerk - 110

Oldenzaal - 21, 52, 54, 64, 195, 198, 231$234,236,237,239-244,264$ e.v., 276 , 279,284

Olst - 56

Ommen - 55

Onstwedde - 118

Oostdongeradeel - 99

Oosterend - 103

Oosterhesselen - 88

Oosterhout - 146, 147

Ooster-Nijkerk - 99, 100

Oostzaan - 183

Ootmarsum - 198, 237, 239, 241, 243, 279

Opende - 108

Opeinde - 100

Oplee - 145

Opperdoes - 185

Opsterland - 101

Oss - 143

Oterleek - 185

Ottersum - 131

Ouddorp - 184

Oude Bildtzij 1 - 98

Oudega - 102

Oude Niedorp - 185

Oudenrijn - 175

Oude Pekela - 26, 30, 116, 117

Oude Tonge - 171, 351

Oude Wetering - 170

Oud-Vossemeer - 148

Overijssel - 23, 28, 30, 53-56, 59, 60, 66, $76,82,326,327,334,338,344,356,358$, 384,401 e.v.
PANNERDEN - 76

Papendrecht - 418

Parijs - 309

Peize - 85

Pernis - 153

Pesse - 81, 88

Peursum - 168, 418

Poeldijk - 169

Polsbroek - 176

Purmerend - 182

Purmerland - 183

Putten - 70

Pijnacker - 169, 418

RAALTE - 55, 56, 269

Rauwerderhem - 103

Reitdiep - 107

Renkum - 26, 35, 73

Renswoude - 172

Rheden - 72, 73

Rhenen - 172, 176, 177, 410

Ridderkerk - 164, 165, 417

Roden - 85, 108

Rodenrijs - 169

Rodeschool - 111

Roelofsarendsveen - 170

Roermond - 29, 124, 128, 129

Rolde - 88

Roosendaal - 140, 143

Roozenburg - 171

Rosmalen - 145

Rossum - 237, 239, 241, 279

Rotterdam - 23, 25, 26, 29, 153, 154, 155 , $159-165,182,206,288,314,329,338$, $342,344,349,352,355,360,418,421$

Ruinen - 88

Ruurlo - 75

Ruwiel - 172

Rijnland - 417

Rijssen - 21, 53, 65, 198, 233-237, 239, $240,245,271-273,279$

SAASVELD - 237, 239, 279

Salland - 55

Santpoort - 181

Sappemeer - 115

Sassenheim - 170

Schaesberg - 128

Schagen - 185

Scharmer - 34, 113, 115, 117

Scharwoude - 185

Scheemda - 114

Schelluinen - 162, 168

Scherpenzeel - 70, 175

Schie, De - 156

Schiebroek - 355

Schiedam - 152,153,167, 206, 352, 418

Schieland - 417

Schiermonnikoog - 104

Schinnen - 128 
Schinveld - 128

Schiphol - 326

Schoonebeek - 82

Schoonhoven - 354, 355

Schoonrewoerd - 418

Schouwen-Duiveland - 149

Schouwenzijl - 110

Schijndel - 143

Sellingen - 118

Simpelveld - 128

St. Annaparochie - 97, 98

St. Jacobiparochi - 97, 98

St. Maarten - 185

St. Odilliënberg - 130

St. Pancras - 185

Sittard - 127-129

Sleen - 88

Sliedrecht - 153, 160,161, 417, 418

Slikkerveer - 164, 421

Slochteren - 33, 34, 113

Sloten - 103

Smallingerland - 100

Smilde - 88

Sneek - 102, 104

Soest - 172

Son - 145

Sowjet-Rusland - 401, 402

Spakenburg - 175

Spanbroek - 185

Sprang-Capelle - 143

Spijk - 111

Stad-Delden - 198

Stadskanaal - $117,1,8$

Stampersgat - 142

Staphorst - 57

Stavoren - 96, 103

Stedum - 111

Steeg, De - 72

Steenbergen - 85, 135, 142, 147

Steenwijk - 57

Steenwijkerwold - 57

Stein - 128

Stellingwerven, De - 101

Stevensweerd - 130

Stompetoren - 185

Stoutenburg - 176

Straatsburg - 326

Stroobos - 100, 110

Suameer - 35, 100

Surhuisterveen - 100

Susteren - 129

Swalmen - 130

TEGELEN - 130

Ten Boer - 112

Ter Apel - 118

Terborg - 77

Terheyden - 145

Termunten - 108

Terneuzen - 150, 381
Terschelling - 104

Texel - 185

Thesinge - 112

Tholen - 148

Tiel - 78, 79

Tielerwaard - 80

Tienhoven - 172

Tilburg - 140,143,147, 329

Tolbert - 107, 110

Treebeek - 122

Trimunt, Duitse stelling - 34, 109, 110

Tubbergen - 66, 198, 214,234, 235, 237 , $239,241,279,280$

Twekkelo - 235

Twente $-7,20-23,25,26,28,34,47-49$, $52,53,59-61,65-67,71,75-77,92$, $94,114,136,141,154,158,176,195$, $200-204,207,210,402-404$

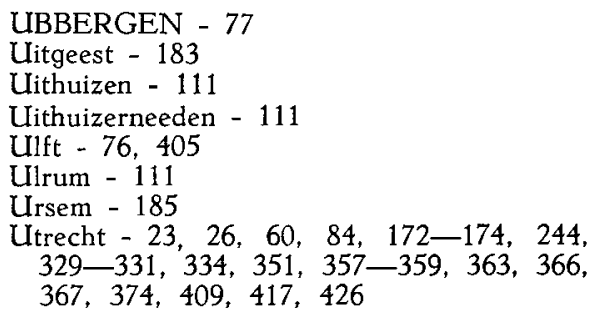

VAALS - 124

Vaassen - 26, 33, 35, 67-70, 348

Valkenswaard - 137, 143, 144

Valthermond - 82, 83, 90,91

Vecht - 54

Veendam - 26, 116, 117, 392

Veenendaal - 172, 175, 176, 410

Veenhuizen - 185

Veenkoloniën, Groninger - 105, 114, 115, 118

Velsen-IJmuiden - 25, 29, 178, 179, 181, $183,206,357,360,363-365,367,369$, 414,415

Visvliet - 110

Velp - 73

Veluwe $-22,23,26,30,67,69,70-72$, $74,75,77$

Venlo - 130, 131

Venray - 131

Vinkeveen - 172

Vlaardingen - 167, 418

Vlagtwedde - 118

Vledder - 86

Vlieland - 104

Vlissingen - 149

Vlodrop - 130

Vogelwaarde - 150

Vollenhove - 57

Voorburg - 155, 170, 418

Voorhei (Oosterhout) - 146, 147 
Voorne-Putten - 171

Vorden - 75

Vreeswijk - 172

Vries - 84

Vriezenveen - $21,52,53,65,66,198,233-$ $237,239,241,245,273-275,279$

Vrouwenparochie - 98

Vijfheerenlanden - 168

WAALWIJK - 143

Wadden eilanden - 33

Wageningen - 74

Wamel - 78

Wanneperveen - 57

Wapenveld - 69

Wapserveen - 86

Warffum - 111

Warmenhuizen - 184, 185

Wedde - 118

Weerselo - 52, 198, 231, 234, 237, 239, 241, $277,279,280$

Weert - 130

Weesp - 183

Werken, De - 146

Werkendam - 161, 163

Werkhoven - 172

Wervershof - 185

Westdongeradeel - 99

Westerbork - 384

Westerkwartier - 106, 107, 110, 118

West-Europa - 23

Westfalen - 23, 61

Westland - 25, 29, 168, 170, 355, 418, 419

Wetzens - 99

Wezep - 69

Wierden - 53, 54, 66, 198, 234, 235, 237$242,279,280$

Wieringen - 185,360

Wieringermeerpolder - 358, 362, 363, 414

Wieringerwaard - 185

Wildervank - 26, 116, 117

Willemstad - 145

Willeskop - 172, 177

Wilnis - 177

Wilp, De - 100, 101, 108, 109

Winkel - 185

Winschoten - 116, 187

Winsum - 111

Winterswijk - 76

Wissenkerke - 150, 151

Wognum - 185

Wolvega - 101

Wonseradeel - 97

Workum - 103
Wormerveer - 25, 29, 178, 180

Woudenberg - 410

Woudstreek, De (Fr) - 93, 100, 101

Wijhe - 56

Wijk - 138, 145, 146

Wijk bij Duurstede - 172, 176

Wijk, De - 82, 384

Wijlre - 128

Wijmbritseradeel - 102

IJMUIDEN zie: Velsen-Iymuiden

IJssel - 58

IJsselmonde - 163, 168, 170, 418

IJsselmuiden - 57

IJsselstein - 176, 409

ZAANDAM - 180, 181, 374

Zaanstreek - 357, 358, 360

Zaltbommel - 79

't Zand - 111

Zandeweer - 111

Zeeland - 33, 324, 334, 381 e.v.

Zeerijp - 111

Zeeuwsch-Vlaanderen - 150

Zegveld - 177

Zeist - 175, 410

Zenderen - 236

Zevenaar - 76, 77

Zevenhuizen - 107, 108

Zierikzee - 381

Zoeterwoude - 170

Zonnemaire - 149

Zoutkamp - 110

Zuid-Beveland - 149, 381

Zuidbroek - 114, 117

Zuiderdiep - 105

Zuiderzee - 103

Zuid-Holland - 7, 25, 30, 78, 134, 135, 349, 356, 416 e.v.

Zuid-Horn - 107

Zuidlaren - 84

Zuid-Limburg, zie Limburg

Zuidwolde - 82

Zuilen - 174

Zuna - 236

Zutphen - 77

Zwaluwe, Hoge/Lage - 145

Zwartewater - 57

Zwartsluis - 57

Zweelo - 88

Zwolle - 21, 57-60, 69, 154, 196, 200, 201, $213-215,217,246,247,281,283,289$, 294

Zwijndrecht - 29, 162, 166, 167, 418, 421 
REGISTER VAN PERSONEN EN INSTELLINGEN 
ABERSON'S IJzerfabriek - 56

Abonné Sigarenfabriek - 137

A.B.T.B., landbouwvereniging - 276

Abteilung Marine - 303

Academisch Ziekenhuis Groningen - 106

Adema, H. - 99

Aecherlin, A., burgemeester van Zwijndrecht - 166, 167

Aerodyne - 183

Ago-fabrieken - 118

Agrarisch Front - 57

Akkermans, D. J., bedrijfsleider - 164

A.K.U. (Alg. Kunstzijde Unie) - 26, 71, 72, $74,80,406,408$

Alba, hertog van - 434

Albarda, Ir. J. W., minister van Waterstaat $1940-1943-40$

Alberts, Houthandel - 149

"Alblas", Zuurstoffabriek, De - 165

Alg. Handelsblad - 423

Alg. Ned. Bond van Textielarb. - 209

Alkmaarse IJzer- en Metaalgieterij - 182, 365

Allmann, A., vertegenw. Beauftragte Overijssel - 217, 246, 247, 289

Almelose Confectiefabriek v/h Smits \& Co $52,233,259,261$

Almelose Coöp. Melkinrichting - 241, 259

Aluminiumfabriek - 130

Aluminium Wals- en Persbedrijven - 175

„Amelko", melkconcern - 354,355

Amilko, Zuivelfabriek - 176

Amrok - 183

Amsterd. Ballast Mij. - 177, 410

Amsterdamse Bank - 94

Amsterdamse Droogdok-Mij. - 178, 358, 364,365

Apeld. Cartonnagefabriek - 347

Apeldoornse Coöp. Fabriek van Zuivelproducten - 70, 347

Apeldoornse Machinefabriek - 70, 347

Apeldoornse Messenfabriek - 347

Apitz, Dr. G. A., Leiter der Hauptabteilung Soziale Verwaltung - 303, 379

A.R. (Anti-Revolutionnaire Partij) - 59

Arbeitseinsat $z-15,19,37,303,304,307$, $309,321,361,362,376,377,378,384$, $390,393,407,414,427$

Arck's Beschuitfabriek - 69

Aribo, I., pianist - 203

Arlt, Dr A., SS-richter - 287, 329, 331

Artsenkamer - 13, 396

Asbroek, J. H., fabrieksarb. - 65

Asphaltfabriek - 421
Asselberg's IJzerindustrie Handel Mij. - 142

Assent Kanters, Fa. J. v .d. - 143

Assies, B. - 109

Atlantik-Wall - 148, 170

„Aurora”, Coöp. Zuivelfabriek - 185

Aussendienststelle Amsterdam - 339, 341, 342, 357 e.v.

Aussendienststelle Arnhem - 285, 287

Auswärtiges Amt - Zie: Ministerie van Buitenlandse Zaken, Berlijn

Ausweise - 24, 266, 276, 371, 434

Avarès, directeur Stork - 224, 229

Avest, J. W. ter, opperwachtmeester gemeentepolitie Hengelo - 282, 283

BAAN-HOFMAN, Machinefabriek - 161

Backer, Mr. A. J., Commissaris der provincie N.-Holland - 415, 421

Bakhuis' Vleeswarenfabriek - 56

Bakker, H., landbouwer - 85, 86

Bakker, Ir. J., mijningenieur - 125

Bakovenbouw - 158

„Bamshoeve”, Katoenspinnerij - 220, 233, 255,258

Barends, W., fabrieksarbeider - 65

Bartels, M., chef belastingkantoor - 126

Bata-fabrieken - 138, 144

Bataafse Petroleum Mij. - 153

„Batavier, De", bontweverij - 76

Beatrix, Prinses - 39

Beauftragte des Reichskommissars - 25 , $28,37,134,150,159,313-315,327,332$, $338,346,368,370,379$

Beauftragte des Reichskommissars in Drenthe - 383 e.v., 389

Beauftragte des Reichskommissars in Friesland - 98, 389 e.v.

Beauftragte des Reichskommissars in Gelderland - 405 e.v.

Beauftragte des Reichskommissars in Groningen - 110, 392-396

Beauftragte des Reichskommissars in Limburg - 396-398

Beauftragte des Reichskommissars in NoordBrabant - 134

Beauftragte des Reichskommissars in NoordHolland - 413 e.v.

Beauftragte des Reichskommissars in Overijssel, Zie: Weidlich, K.

Beauftragte des Reichskommissars in Utrecht - 409 e.v.

Beauftragte des Reichskommissars in Zeeland - 381 e.v. 
Brouwerij "De Drie Hoefijzers" - 141

Bruch, gemachtigde voor de mijnbouw $120,122,124,125$

Brugge, J. B. ter, econ. techn. adviseur - 259

Bruininga, H. R., burgemeester van Roden 85

Bruinsma, M. - 101

Bruyne, J. de, burgemeester van Werkendam - 163

Bruyning, A. T., hoofdinspecteur van politie Enschede - 257, 283

Buiscar, fabriek - 70, 348

Bureau Coördinatie v. d. Pol. Recherche Afd. 's-Gravenhage - 302

Bureau Opsporing Oorlogsmisdaden (Sub. Commissie Zwolle) - 196, 200, 201, 281,287

Burgerl. Stand - 155

Buvy, fabriek - 183

Bijl, A. v. d., arts - 170

„Bijto", drukkerij - 185

CALLENBACH, Uitgeverij en drukkerij te Nijkerk - 70

Calvé-fabrieken - 156, 418

Campagne, T., fabrieksarbeider - 79

Capitulatie, Mei 1940 - 318, 322, 324

Carisborg, bruinkoolbedrijf - 122

Carp, Mr. Dr. J., hoofd afd. bestuurszaken der N.S.B. - 431, 432

Casablanca-conferentie - 14

Cate, Mr. H. J. F. ten - 203, 229, 245

Cate Hzn $\mathcal{E}$ Co, $H$. ten $-52,233,259,260$

"Ceder", Houtwarenfabriek - 144

Centr. Bureau voor de Statistiek - 155. 417,419

C.C.D. (Centrale Controle Dienst) - 124, $126,127,128,129,131,133,144,212$, 214,373

Centr. Suiker Mij. - 142

Chamotte-Unie - 79

Charbon, H. B., directeur postkantoor - 160

Chefintendant des WBN - 310, 311

Chemische fabriek Rhenen - 176

Christelijk Nat. Vakverbond - 200, 210, 215

Christiansen, General der Flieger F., Wehrmachtbefehlshaber in den Niederlanden 7, 16 e.v., 21 e.v., 32, 37, 39, 40, 47, 60, $86,105,120,127,136,158,164,182,184$, $195,248,251,284,309,310,314,316$, $320,322-325,334-337,342,350,352$, $353,359,370-373,377,378,384,410-$ $414,424,425,428,430$

Churchill, W. S., eerste minister van Engeland - 14

Cirkel, Staalmeubelfabr. - 179, 365

Cocosfabriek, Ned. - 347

Colijn, P. A., burgemeester van Alphen a/d Rijn - 417, 418, 421
Commissaris voor niet-commerciële Verenigingen en Stichtingen - 211, 215

Communistische Partij Nederland - 26, $31,83,90,138,178,179,180,339,360$, $369,373,376,382,414,431$

Concentratiekampen, Duitse - 70, 78, 89, 116,305

Concentratiekamp Amersfoort - 116

Concentratiekamp Dachau - 112

Concentratiekamp Ommen - 271, 378

Concentratiekamp Vught - 31, 55, 57, 62, $64,68,70,72,77,79,84,89,97,102$, $112,116,146,147,149,151,153,157$, $162,164,165,167,253,258,263,266$, $271,276,361$

"Concertvereniging", Hengelose - 48, 203, 216

Conring, Dr. H., Beauftragte Groningen $110,338,392-396$

Coöp. Aardappelmeelfabriek - 88

Coöp. Landbouwersbank en Handelsver. 83

Coöp. Zuivelfabriek, Ter Apel - 118

Coöp. Zuivelfabriek, Assen - 84

Coöp. Zuivelfabriek, Bedum - 112

Coöp. Zuivelfabrieken in Friesland - 102

Coöp. Zuivelfabriek, Sleen - 88

Corps Mariniers - 353

Cort van der Linden, Mr. P. W. J. H., burgemeester van Groningen - 393, 394

Courant, Nieuwe Apeldoornse - 70, 347, 348

Courant, Nieuwe Hengelose - 219

Courant, Prov. Overijsselse en Zwolse - 59

Croll, fabrieksdirecteur - 219

Cultuur-Technische Dienst - 269

D. A. M. BIERBEDRIJF - 112

Dagblad van Noord-Holland - 182

Dam, Prof. Dr. J. van, secr.-generaal departement van Opvoeding, Wetenschappen en Kultuurbescherming - 303

Dam, Dr. R. J. van, lid illegale "Trouw"groep - 58,59

Daems. J. H. T., burgemeester van Roosendaal - 140

Davelaar, fabrieksarbeider - 175

Dekker, Mej. G. - 118

Dekker, Fa. J. - 181

Demelhuber, K. M., SS-Gruppenführer, commandant van de Waffen-SS in Nederland - 330, 332

Deppner, E., Regierungsrat - 340

Deurloo, J., fabrieksknecht - 164

Deutsche Allgemeine Zeitung - 16, 312

Deutsche Zeitung i. d. Niederlanden - 328

Diepenbrock \& Reigers, ijzergieterij - 76

Diepgrond, K.K.-man - 271

Diertens, G. J. - 109

Dieters, G., districtleider NSB in Drenthe 388 
Beauftragte des Reichskommissars in ZuidHolland - 158, 416 e.v.

Bedrijfsschap voor Eieren en Pluimvee - 175

Bedrijfsschap Zuivel - 154, 155

Beek, W. van, fabr. arb. - 138

Beets, Ir. C., directie-secretaris Storkfabrieken - 217, 218, 223, 252

Beiersdorf, F., SS-Obersturmbannführer Kommandeur Sicherungsbereich Utrecht 329

Bekker, P. J. E., burgemeester van OudeTonge - 351

Belderok, G. J. H., administrateur Staatsmijnen - 125, 126

Bella, S. de la, secretaris N.V.V. - 207, 208

Bendien's Confectiefabrieken - 51, 64, 230, $231,233,261$

Bendien, Tj. - 261

Berends, A., commissaris van politie Enschede - 257, 285

Bergen, S. van, landbouwer - 85

Berghuizen Papierfabriek - 69

Berkelmans Schoenfabriek - 143

Berkfabrieken in Kampen - 58, 59

Bernichel, Hauptmann, Kommandeur Sicherungsbereich Limburg - 329

Bestuurdersbond, Enschedese - 208, 209

Bestuurdersbond, Hengelose - 209

„Betondak”, fabriek - 161

"Betuwe", Maatschappij De - 79

Beukema, fabriek - 115

Beunder, J. J., hoofdred. Twents Nieuwsblad - 221

„Bever" Conservenfabriek - 181

Bevolkingsregister - 417

Beyma, Jhr. Mr. J. M. van, burgemeester van Leeuwarden - 391

Beynes, Rijtuigenfabriek - 182

"Biesbosch", Scheepswerf en Machinefabriek - 158, 159

Bisschop, Mr. E. G., burgemeester van s-Gravenzande - 421

Blaey, J. W. de, arbeider - 162

Blank, H., fabr. arb. - 180,340

Bleeker, J., burgemeester van Dordrecht $159,160$.

Blikfabrieken, Verenigde - 29, 156, 179 , $339,358,364,365$

Bloemers, H. P. J., burgemeester van Arnhem - 71

Blok van Heyst, Fa. - 143

Blonk, Dr. A., ,Fabrieken en Mensen” - 48

Blütge, Oberleutnant, Ortskommandant Goeree-Overflakkee - 171, 351

Blijdenstein $\mathcal{E}$ Co $-52,233,254,255,257$. 258

Böhmer, Oberst, Kommandeur Sicherungsbereich Sïd-Holland - 329

Boekelose Coöp. Stoomzuivelfabriek - 241

Boekelose Stoomblekerij - 232, 258
Boele, Scheepswerf en Machinefabriek - 164

Boelstra, J. J., politiepresident Rotterdam 159

Boening, Dr., Leiter Hauptabteilung Soziale Verwaltung - 304

Boer, A. de - 101

Boer, B. de, directeur Zuivelfabriek - 238

Boer, K. de, burgemeester van Hardinxveld - 162

Boer, Thomas de, fabriek - 140

Boerma, Prof. Dr. W. E. en G. H. L. Zeegers „Bevolkings verschuivingen..." - 152

Bohnhoff, Chemische fabriek - 347

Boogerd, J., chemicus - 124, 129

Boot, fabrieksarbeider - 223

Bootsma, J., visser - 103

Borghouts, Drukkerij - 153

Borghuis, J. A., bedrijfsleider textielfabriek 270

Bormann, M., Reichsleiter - 316

„Borne", Coöp. Stoomzuivelfabriek en Melkinrichting - 237, 263

Borst, Confectiefabriek Fa. Ger. - 220

Bos, B. H., fabrieksarbeider - 65

Bos, H., illegale werker - 88

Bos, J. ten, fabriek - 233

Bosch, L., inspecteur van belastingen - 101

Boschker, Lederfabriek Fa. - 76

Bottinga, J., gemeente-secretaris - 247

Boulanger, Dr., SS-Richter - 287, 327, 329

Bouman's Meubelfabrieken - 153

Bouman, M., controleur C.C.D. - 124, 127, 129

Bouman, Prof. Dr. P. J., hoogleraar te Groningen - 92

Bouman, W. H. - 7

Bouwman, H. W., drukker - 153

Bouwman, W., lid illegale organisatie - 70

Braat, Kon. Fabriek - 156

Brandes, A., biz. gevolmachtigde voor Gelderland - 338, 409

Brandt, Dr. R., secretaris van ReichsführerSS Himmler - 326

Brasser, C., bedrijfsleider - 64

Brasser, J. A., fabrieksarbeider - 262

Brasser, P., hoofdinspecteur van politie Almelo - 260

Bredemeyer, Metaalwarenfabriek G. - 183

Brink, H. G. - 263

Brocades-Stheeman, Pharmaceut. fabr. 83,84

Broek, Ir. H. J. v. d., hoofdredacteur RadioOranje - 38-40, 42

Broere, M., burgemeester van Enkhuizen 416

Broeze, G. J., onderwijzer-hoefsmid - 269, 271

Brons' Motorenfabriek - 112

Brishuis' Trailerfabriek - 183

Brouwer, L., controleur C.C.D. - 124, 127 
Dikkers $\&$ Co, Metaalbedrijf G. - 50, 206, $216,222,224,229,232,248,285,291,402$

„Dinkelland”, Coöp. Zuivelfabriek - 241

"Dinteloord", Coöp. Vlasfabriek - 142

"Dinteloord", Suikerfabriek - 142

Diocesane R. K. Werkliedenverbonden - 141

Directie van de Noordoostpolderwerken 56,59

Directoraat-Generaal v. d. Politie - 198, $282,285-287,289,290$

Distributiedienst - 122, 129

Dittmar, W. W., perschef v. d. Rijkscommissaris - 332

Document Center, 7771 U.S. - 302

„Dolphia", klooster - 65, 268

Domela Nieuwenhuis, F. - 98

"Dongen", Stoomwasserij, De - 143

Doolaard, A. den (pseud. van C. Spoelstra) - 40, 41

Doorn, Apparatenfabriek van - 175, 409

Doornbosch, J. - 109

Doornbosch, K. - 109

Dordrechtsche Asphaltfabriek - 158

Dordtsche Metaalindustrie Johan de Witt 157, 158

Douma, Gebr., houtzagerij - 56

Douwe Egberts, fabriek - 103

Driessen, Herman, textielfabriek - 77

Drift, Ir. J. B. v. d., hoofdingenieur Staatsmijnen - 123,124, 126

Drunings, directeur P.U.E.M. - 413

Ducroo \& Brauns, werf - 358, 364

Duintjer's Radiatorenfabriek - 117

„Dulder”, Coöp. Zuivelfabriek - 241

Dussen, Mr. J. Ae. H. J. v. d., burgemeester Hengelo - 202

Dutch Button Works - 77

Duursma, H., burgemeester van Slochteren $-113$

Dijk, F. van, kruidenier - 99

Dijkhof, H., functionaris N.V.V. - 217, 218

Dijksterhuis, P. R., directeur Philips - 138

Dijkstra, Mej. J. - 101

Dijkstra, P., fabrieksarbeider - 74

EBELS, E. H., provinciaal voedselcommissaris in Groningen - 393

Eci (Electro-Chemische Industrie) - 129

Eckhard, kampleider van Ommen - 271

Edah, fabriek - 139

Eekhof, J. A., burgemeester van Denekamp $-276$

„Eendracht”, Coöp. Zuivelfabriek De, Eext - 89

„Eendracht”, Coöp. Zuivelfabriek De, Rossum - 241

„Eendracht”, Coöp. Zuivelfabriek, Tubbergen - 241, 280

„Eendracht”, Stroocartonfabriek De - 112
Eerdemans Jzn, Fabriek van Melkproducten - 235

Eerste Kamer der Staten-Generaal - 432

Eertink, fabrieksbaas - 223

Eftgè, E., Oberbereichsleiter - 304

Egger $\mathcal{E}$ Cie., Holl. Zwitserse Borduurfabriek - 260

„Eibergen”, Stoomzuivelfabriek - 76

Eibergse Stoomblekerij - 76

Eilander, H., fabrieksarbeider - 68

Eilers, J. G., fabrieksarbeider - 138

Eisenga, J., onderwijzer - 101, 103

Ekker-Stork, Mevr. A. J., bestuurslid „Groene Kruis" - 211

Electro Motoren Fabriek - 158

Electro-Smit, fabriek - 164

Elesva, staalwarenfabriek - 347

Elzinga, J. - 100

Emmen, W., fabrieksarbeider - 83

Emmerloot, C. van, fabrieksarbeider - 78

„Energie", bruinkoolbedrijf - 122

„Engel", Oliefabriek De - 180

Enka - 26, 71, 176

,Enkes", Kogellagerfabriek - 155

Enthoven, Pletterij - 156

Enting, G., veehouder - 89

Epenhuyzen, van, directeur Chem. fabriek 421

Erdtsieck, H. G. - 248

Es, C. van, directeur afd. Soc. Zaken Almelo - 202, 208, 209, 210, 218

Esselink, G. W. H., burgemeester van Marrum, gem. Ferwerderadeel - 99

Eternit v/h Martinit - 66, 233, 277, 278

„Etna", IJzergieterijen en Emailleerfabr. 141

FABER, A., veehouder - 111

Fabriek van Electrische Apparaten v/h F. Hazemeyer $\mathcal{E}$ Co - 227, 231, 232, 254, 285

Fabrikanten-Vereniging, Enschede - 215, 256

Fahrenholtz, H. J., SS-Obersturmbannführer $-311$

Februari-staking 1941, Amsterdam - 178. $179,180,182,185,196,198,206,228$, 248, 291, 294, 360, 376, 415, 426

Feenstra, J. E., commandant Marechaussee gewest Arnhem - 285

Fefap, elastiekfabriek - 146

Feldmeyer, H. J., voorman Germaanse SS in Nederland - 334

Fenstra's Meubelfabrieken - 176

Ficher $\mathcal{E}$ Wap, fabriek - 275

Figee fabriek - 182

Fischböck, Dr. H., commissaris-generaal voor economie en financiën - 15, 16, 306, 309, 312

Fokkens, D., landbouwer - 100

Fokkerfabrieken - 368

Fordfabrieken - 368 
Fortenbacher, W., SS-Obersturmbannführer, Kommandeur Sicherungsbereich Gelderland - 329, 331, 407

Franeker Landbouw coöp. - 96

Frank, arts - 211

Frankruiter, S., melkventer - 106

Frederiks, A. L., student - 66

Frederiks, Dr. K. J., secretaris-generaal departement van Binnenlandse Zaken 314, 399

Frico (Friese Coöp. Zuivelcentrale) - 94, 95

"Friesland", Coöp. Condensfabriek - 94

Fristho, Meubelfabriek - 96

Führererlass - 15, 306, 311, 312, 318, 322, 359

Furck, Kommandeur Sicherungsbereich Tilburg - 329

Fijnagel, W., fabrieksarbeider - 79

GALEN, C. A. Graf von, bisschop van Münster - 23

Garde \& Co's, Drukkerij, Van de - 79

Gasmeterfabriek - 421

Gazelle-Rijwielfabriek - 73

Gebrur, Electriciteitsbedrijf - 409, 411

Geel, D. van, burgemeester van Marum 109

Geelkerken, C. van, plaatsvervangend leider NSB - 315

Gelder's Papierfabrieken, van - 26, 70, 73, $181,347,358,364,365,414$

Gelderen, Kruiwagenfabriek, Firma Johan van - 161

„Gelderland", Papierfabriek - 77

Gelderman, H., fabrieksdirecteur - 265

Gelderman, H. P. - 215

Geelderman \& Zoon, H. P. - 52, 64, 232, $233,264,265,266$

Gelria, Schoenfabriek - 76

Gembo, Chemische fabriek - 116

Gemeente Gasbedrijf, Groningen - 106

Gemeentelijke Gasfabriek, Leeuwarden - 94

Gemeente Gas-, Electr.-, Autobusbedrijf, Utrecht - 173, 175

Gemeentel. Lichtbedrijven, Leeuwarden - 94

Gemeentelijke waterleiding, Almelo - 259

Gemeentelijke waterleiding, Hengelo- 245

Gend E Loos, Van - 71, 140, 225

Genechten, Prof. Mr. Dr. R. van, commissaris der provincie Zuid-Holland - 431, 432

Generalbevollmächtigte für den Arbeitseinsatz in den Niederlanden - 14

Gerards, Ir. E. J., mijningenieur - 125

Gerbrandy, Prof. Mr. P. S., Minister-President 1940-1945 - 38, 40, 41, 425

Germaanse SS in Nederland - 334, 388, 395,433

"Germania", SS-Ersatz Batl. - 406

Gero-fabriek - 175
Gerritsen's Graanhandel en Pakhuizen 175,409

Gesink \& Zoon - 183

Geuvers, J. H., fabrieksarbeider - 65

Geval, J., arbeider scheepswerf - 165

Gewestelijk Arbeidsbureau - 48, 205, 206, 269, 314

Gielen, Ir. Ch., directeur textielfabriek - 262

Gielen, J. C. W., fabrieksarbeider - 138

Giessen, C. v. d., arbeider - 162

Gils, A. J. A. van, burgemeester van Made 146

Gimborn's Inktfabrieken - 76

Gimpels, Zeepfabriek - 183

Gips, directeur asphaltfabriek - 421

Gispen, fabriek - 79

Gist- en Spiritusfabriek - 156, 157, 418, 421

„Glanerbrug", Meubelfabriek - 258

Glas, J. - 109

Goedhart, F., oprichter van illegale blad "Het Parool" - 14

Goering, H., fabrieksarbeider - 268

Goering, H., Reichsmarschall - 65

Gorkum \& Co's Uitg. bedrijf, van - 84

Gorter, K., fabrieksarbeider - 83

Goudse Melkinrichting - 355

Gramsch, Ministerial Direktor - 307

Gran, SS-Obersturmführer - 331

Grasso, Machinefabrieken - 139, 140

Griesenbeck, SS-Obersturmführer - 331

Grinten, Chemische fabriek, L. van der 130

"Groene Kruis", Het, afd. Hengelo - 48, $196,203,204,211,212$

Grond-Mij. - 185

Groot, Ir. C. F. A. de, directeur WillemSophia mijnen - 125

Groot, J. de, fabrieksarbeider - 166

Groot $\mathcal{E}$ van Vliet, Scheepswerf de - 164

Grüne Polizei - 57, 61, 62, 104, 157, 161, $162,178,205,243,251,252,260,261$, $262,263,267,270$

Gruyter's fabrieken, P. de - 139, 140

Gijzelaars - 381, 383, 395

Gijzelaarskamp Haaren - 211

Gijzelaarskamp St. Michielsgestel - 126, 138,271

H.A.V. Bank - 153, 167

Haaften, Dr. B. ten, arts - 211

„Haaksbergen", Coöp. Zuivelfabriek - 241

Haandrikman, G., hoofdconducteur Nederlandse Spoorwegen - 264

Haardt, Mr. W. L., jurist Philipsfabrieken 138

Haasse, G. B., SS-Sturmbannführer - 342

Hälwes, Major der Ordnungspolizei - 329

Härt1, Dr. E., SS-Richter Sturmbannführer $287,327,329$ 
Haex, Mr. A., directie Staatsmijnen - 122, 124,125

Hagen, Dr., plaatsvervanger van M. Stompe, Oberregierungsrat - 327

Haka, Sigarenfabrieken - 143

Halberg's Machinefabriek en Scheepswerf 130

Halbertsma's Fabrieken - 103

Halm, B., opperluitenant SS - 264

Hamer, J. G., burgemeester van Genemuiden $-57,58$

Hamstra, Gebr. - 183

Hansa-Programm - 303

Hansen, Dr., SS-Richter - 329

Hardick \& Seckel, Firma - 219

Harkema, A. - 112

Harster, Dr. W., Befehlshaber der Sicherungspolizei und des SD - 281, 285, 286, $288,289,303,310,311,327,329,330$, $333,336,341,342,344,345,349,356$, 357,375

Hartekamp, H., loopjongen - 252

Harteveld, W. A. van, gemeente-secretaris Alkemade - 170

Hartholt, A. - 109

Harthold, D. - 109

Hartholt, H. - 109

Hartstra, Dr. H., voorzitter "Groene Kruis", Hengelo - 196, 211

Hasselbeke, A., leider distributiebureau Tubbergen - 66

Hauptabteilung Ernährung und Landwirtschaft - 371

Hauptabteilung Soziale Verwaltung - 303, $304,310,311,378,379$

Havelaar, A., timmerman - 158

Haveneth, J. H., Kriminalsekretär - 339, 340

„Haverkate", Café, Hengelo - 62, 263

Hazemeyer's Fabriek van Signaal-apparaten $-51,61,219,227,232,248,254$, 402

Heeg, T., burgemeester van Nieuwe-Pekela $-116$

Heek \& Co., van - 52, 63, 204, 230-233, $254,256,258,430$

Heek \& Zoon, Textiel Mij. L. van - 23'

Heem, Radiofabriek van der - 155, 417

Heemaf $-51,61,67,206,216,226,229$, $232,252,402$

Heemstra, Mr. S. Baron van, Commissaris der Provincie Gelderland - 407

Heinemann, L., SS-Obersturmführer - 287

Hekkert, Mej. G. - 174

Hellwich, Dr. W., chef Dienststelle für soziale Verwaltung - 206, 207, 215

„Helmond", Schroefboutenfabriek - 139

Hema - 139

Hendriks, L. H., fabrieksarbeider - 78

Hendrikse, Th. S. - 181
Hengelose Coöp. Melkinrichting - 237, 239, 241,279

Herik, J. v .d., ambtenaar - 166, 167, 168

Hermjohannes, SS-Scharführer - 285

„Hero" Fabrieken - 36, 141, 142

Herrmann, O., Regierungsdirektor - 326, 327,328

Herwalts, Tassenfabriek - 76

"Hevea", Verenigde Nederlandse Rubberfabriek - 26, 35, 73, 74

Hey, H., fabrieksarbeider - 340

Heymans, Prof. Dr. G., psycholoog - 93

Heyst, Radiatorenfabriek van der - 155

Hille's Brood- en Beschuitfabriek - 181

Himmerich, F., biz. Beauftragte in NoordBrabant - 327, 338, 401

Himmler, H., Reichsführer SS - 15, 22, 25 , $36,37,286,305,306,317,325,326$, 375,370

Hirschfeld, Dr. H. M., secr.-gen. departement van Handel, Nijverheid en Scheepvaart - 125,126

Hitler, A. - 15, 18, 136, 284, 306, 322, $323,324,377$

Hiweg - 347

Höfkens, Ververij - 276

Höhere SS- und Polizeiführer, Zie: Rauter, H. A.

Hoen, P. 't, Zie: Goedhart, F.

Hof, J. P., "Friese dialectgeografie" - 107

Hoffmann, J. W., hoofd van de SD te Rotterdam - 29, 135, 161, 162, 165, 166, 167

Hofnar, Sigarenfabrieken - 143

"Holland" Machinefabriek - 160

"Holland" Textielfabriek - 219

„Holland" IJzerfabriek en Constructiewerkplaats - 142

Holland-Nautic fabriek - 182

„Hollandia" Schoenfabriek - 143

"Hollandia" Stijfselfabriek - 77

Hollandse Constructiewerkplaatsen - 167

Hollandse Kunstzijde Industrie - 36, 141

Holst, Prof. Dr. G., directeur Philipsfabrieken -138

Holterman, G. J., fabrieksarbeider - 65

Hommel, W. A., drukker - 153

Hommen, B. H., gemeentesecretaris Oldenzaal - 264, 266

Hoogkamp, J. A., burgemeester van Veendam - 117

Hoogland, Prof. Ir. J. G. - 204, 205, 225 , 249,251

Hoogland, J. L., landbouwer - 98

Hoogovens, Kon. Ned. - 181, 358, 364, 365, 414,415

„Hoop", Scheepswerf De - 160

Hoopen \& Zoon, A. J. ten - 76

Hoopen $\mathcal{E}$ Zoon, D. J. ten - 65, 267, 268

Horst $\&$ Co, ter $-52,65,233,269,271-273$

Houten, C. J .van, Fabrieken - 183 
Houten, J. G. van, burgemeester van Gorinchem - 352, 418, 421

Houtkoper, P. - 181

Houtum \& Palm, fabriek - 347

H.T.M., Haagse Tramweg Mij. - 155

Hudson, Sigarenfabriek - 140

Huifkar, Sigarenfabriek De - 140

Huizing, L., landbouwer - 89

Hulshof, Leder- en Metaalwarenfabriek - 76

Hummel, bestuurslid N.V.V. - 209

Huninks, Vleeswarenfabriek - 56

ILLEGALE PERS - 204, 205, 374, 381, 414 Illegaliteit - 80,81, 85, 88,91,93, 95, 101, $110,120,126-129,135,137,140,142$, $148,150,157,158,160,165,167,178$, $179,187,188,196,199,203,204,210$, $212,291,360,373,376,381,431$

Imborg, G., fabrieksarbeider - 15

Imhoff, Mr. A. W. Baron van, vice-president arrondissementsrechtbank te Assen - 388 "Industrie", IJzergieterij - 35, 67, 347, 348 Inspecteur-Generaal der Mijnen - 122, 125 Intercommunale waterleiding - 94

„Inventum", Fabriek - 175, 409

JANNINK \& ZOON, G. - 52, 232, 233, 258

Jansen, J. F., wachtmeester staatspolitie 274

Jansen, J. H., bestuurder „Mercurius" - 209

Jansen $\mathcal{E}$ Tilanus, Fabrieken - 52, 65, 66, $233,234,273-275$

Jansen de Wit, Firma, Kousenfabriek - 143

Janssen, Scheepswerf - 79

Jasneva v/h Jasper's Sigarenfabriek - 137

Jochems, W. J., landbouwer - 185

Johan de Witt, Fabriek, dochteronderneming Philipsfabrieken - 417

Jolink, Broodbakkerij - 347

Jong, E. de - 109

Jong, Joh., Kardinaal de - 13

Jong, Drs. L. de, chef Rijksinstituut voor Oorlogsdocumentatie - 8, 42, 201

Jong $\mathcal{E}$ van Dam, kant- en kousenfabriek $51,225,232$

Jonge Poerink \& Co., Draadvlechterij - 262

Jongsma, A. G., burgemeester van Krommenie - 180,339

Jonker, Ds. J. H. - 163

Jordaan, J. G. H., directeur textielfabriek 267, 268

Jordaan $\mathcal{E}$ Zoons, textielfabriek - 34, 52, $64,65,233,267,268$

Juetting, Dr. W., Oberregierungsrat - 314, 379

Juliana, Prinses - 38, 39, 40, 336, 343, 349

KABELFABRIEK, NEDERL., Delft - 156, 418
Kärgel, Major, Kommandeur Sicherungsbereich N.-Holland - 329, 339

Kalkfabriek v/h van Dijk \& Co. - 158

Kalksteenfabriek - 161

Kamer van Koophandel, Hengelo - 232

Kampen, G. van, fabrieksarbeider - 78

Kampen, van, bestuurslid N.V.V. - 209, 218,219

Kamping, R., veehouder - 89

Karhof, N. J., "Noord-Beveland in bezettingstijd" - 150

"Katastrophen Einsatz" - 243

Katoenfabriek v/h Arntz. Jannink \& Co. 66, 216, 278

Kauer, SS-Untersturmführer - 331

Kaune, Kriminalsekretär - 339, 340

Keitel, W., veldmaarschalk, chef van het Oberkommando der Wehrmacht - 16, 17, $307,309,318,319$

"Keizerskroon", Hotel De - 263

Kempe, Dr. G. T., „Criminaiteit in Drenthe" $-82$

Kempen, P. van, fabrieksarbeider - 138

Kerkhoff, Ph., Amtsrat - 421 •

Kersemakers \& Zoon, C. - 137

Kersten, W., fabrieksarbeider - 164

Keus, Ir. H. I., directeur Heemaf - 61, 226, $227,248,251$

Kieft, H., onderwijzer - 260

Kiewiet, J. - 101

Kiewit, J, de, commies Nederlandse Spoorwegen - 242

Kleefman, E. en H., fabrieksarbeiders - 113

Klein Busink \& Zoon, J. - 347

Kley, K. van der, "Het Drentse Volks-

karakter" - 86

Klinkbeil, SD-er - 139

Klinkenberg, F. D. G., burgemeester van Putten - 70

Klinkenberg, Fabriek - 181

Klinknagel en Schroefboutenfabriek $\mathrm{v} / \mathrm{h}$ Joh. Smit - 164

„Klok" De, Zeepfabriek - 69

Klokman, G. J., „Ned. Volkskarakters" - 75

Kloos \& Zonen's werkplaatsen - 165

Kneuterdijk, Paleis, Persafdeling Rijkscommissariaat - 327

Knipscheer, C. W., fabrieksarbeider - 74

Knolle, F., SS-Obersturmbannführer - 285, 311,370

Koek, Dr. H. C., zenuwarts - 93

Koekoek, Meubelfabriek Firma - 176

Koenemans, Exportbedrijf - 115

Kohrmeyer, Fr. - 281

Kok, C. S. de, scheepswerfarbeider - 162

Kok, H. de, fabrieksarbeider - 79

Koninklijke Metaalwarenfabriek v/h Daalderop \& Zoon - 79

Koninklijke Nederlandse Fabriek van Wollen dekens v/h G. C. Zaalberg - 167 
Koninklijke Nederlandse Katoenspinnerij $50,216,224,229,232$

Koninklijke Nederlandse Zoutindustrie - 51, 225,232

Koninklijke Oldenzaalse Stoomweverij v/h J. Molkenboer Jr - 64, 231, 233, 264, 265

Koninklijke Stoomblekerij Nijverdal - 65, 269

Koninklijke Stoomweverij Nijverdal - 52, $65,230,233,269,270,274$

Koninkrijk Holland - 433

Koopmans Meelfabrieken - 94

Kooten, van, afd.-chef Staatsmijn Maurits 400

Kootstra, L. - 162

Kooymans, gewestelijk politiepresident N.Brabant - 374

Kort, Fa. A. en J. de - 143

Koster, Mr. J. D., burgemeester van Heerde - 69

Kramer, J., fabrieksarbeider - 340

Kranz, Textielfabriek - 420

Kremer, L., directeur Oranje-Nassaumijnen - 125

Kritzinger, K., staatssecretaris van de Rijkskanselarij te Berlijn - 15, 306, 308

Krole Jzn., J., burgemeester van Vriezeveen - 273, 274

"Kroon", Lederfabriek de - 143

Kruiff, de, rechercheur, 388

Kruisinga, J. C. M., notaris - 273, 274

Kruyff, M. G. de, burgemeester van Franeker -96

Kruyt, Prof. Dr. J. P., „De Noord-Hollanders" - 183

Krijgsgevangenkampen $-305,318,319,376$

Krijgsgevangenschap Nederlands Leger $321-325,333-336,342-348,349,352-$ $354,357,371,372,375-377,381,384$, $385,390,396,401,402,405,410,413$, $419,424,425,428$

Kuile $\& \mathrm{Zn}$., N. ter - 52, 232, 257, 258

Kultuurkamer - 48, 203

Kupers, E., voorzitter N.V.V. - 207, 208

Kuperus, G. H., burgemeester 't Bildt - 98

"Kwatta" N.V. Stoomchocolade- en Cacao. fabriek - 141

LAGES, W., Aussendienststellenleiter van Sipo en SD, Amsterdam - 341, 357, 369

Lambooy Klunder, fabriek - 139

Lammers, Dr. H. H., chef der Rijkskanselarij te Berlijn - 320

Lamprecht, Vize-Admiral bij Rüstungs-inspektion te Baarn - 249

"Landbouw" Zuivelfabriek, De - 167

"Landbouw en Maatschappij" - 87

Landbouwhogeschool - 74

Landbouwproefstation Maastricht - 127

Landelijke Raad van Verzet - 13
Land-Oorlog Reglement - 204

Landstand - 31, 130, 132, 135, 144, 147, $215,361,372,388,395,415,416,421$

Landwacht-Nederland - 13, 315

Lautermans, K., „De Betuwenaars" - 78

Ledeboer, H. B. N., directeur van Heek $\mathcal{E}$ Co. - 204, 215

Lederwaren- en kettingkastenfabriek - 76

Leer, W. van, burgemeester van Leerdam 351

„Leerdam" Glasfabriek - 161

Leeuwarder Papierwarenfabriek - 94, 95

Leeuwarder Textiel Mij. - 52, 233, 260

Leeuwen, Ir. W. H. van, directeur Gist- en Spiritusfabriek - 421

Leininga, O. - 116

Lels, B. J. M., directeur Fa. Vroege - 165

Lemmeren, Joh. van, fabrieksarbeider - 180, 340

Leppersfabrieken - 73

Levensverzekering Mij., Algemene Friese 44

Leyden, Weverij van - 365

Leyenaar, K. - 7, 94

Lies, L. van, voorman - 225

Liese, Generalbevollmächtigte für den Arbeitseinsatz in den Niederlanden - 14

Liese, Verwalter Philips Fabrieken - 136

Lieshout, G. C., directeur Oranje-Nassaumijnen - 125

Ligtenberg, Gebr. - 143

Limburg, J., leider afd. N.A.F. Apeldoorn 348

Lindeboom, G. C., arts - 205

Lips' Brandkasten- en Slotenfabriek - 158

Loeff, Drukkerij en Uitgeverij v/h M. J. van der - 49, 51, 221, 230

Loep, Ir. F. M., bedrijfsingenieur - 62,66 , $253,254,287,293$

Loever, D., arbeider - 162

Lonneker, Coöp. Melkinrichting en Zuivelfabriek - 237, 241

Loon, P. van, fabrieksarbeider - 340

Lorentz, Untersturmführer - 254

Louwes, Ir. S. L., directeur-generaal van de voedselvoorziening - 375

Lubro-Broodfabrieken - 173, 409

Lucas, H., opperwachtmeester staatspolitie $-283$

Lucifersfabrieken, Ver. Holl. - 141

Luyt, Fa. - 179

MAALDRINK, Mr. E. D., burgemeester van

Wierden - 277

Maas, C. van de - 204

Maas, Ir. H. A., burgemeester van Helmond - 139

Machinefabriek v/h H. J. Koopman - 160

Machinefabriek v/h Rogier, Nerincx, Richter - 142 
Made \& de Vries, Machinefabriek v. d. 103

Maljers, Fa. - 149

Manen, J., van de R.K.-vakbeweging - 120

„'t Mannetje", Kistenfabriek - 156

Mantey, Oberleutnant - 328

Marchant et d'Ansembourg, M. V. E. H. J. M., Graaf de, Commissaris der Provincie Limburg - 399

„Markelo", Coöp. Zuivelfabriek - 241, 279

Markusse, A., Drukkerij - 150

Markusse, A. G. M. en M. - 151

"Marne"-autobusdienst - 110

Mastenbroek, G., fabrieksarbeider - 340

Mayer, Kapitän-Leutnant - 246, 249

Mechels, Major, Kommandeur Sicherungsbereich Groningen, Friesland, Drenthe 329,393

Meenen, v. d., opzichter - 400

Meertens, Dr. P. J., „Nederl. Volkskarakters" - 75, 78, 119, 183

Meihuizen-Boon's Glucosefabriek - 114

Meldepflichtverordnung - 16, 309, 378

Menko, N. J., fabriek - 52, 232, 257, 258

"Mercurius", Alg. Bond v. Handels- en Kantoorbedienden - 209

"Merwede", Scheepswerf De - 160, 162

Metaalbond - 216

"Meteoor", Betonfabriek De - 72

Meyer $\mathcal{E}$ Groen, Metaalwarenfabriek - 175, 409

Meyers, Scheepswerf - 79

Mignot $\mathcal{E}$ de Block - 138

Ministerie van Buitenlandse Zaken te Berlijn $-17,37,318,319,321,322$

Möllers, van de Schutzpolizei - 340

Monchy, D. W. de - 203

Moonen, Drs L., secretaris Bisdom Roermond - 128

Mous, Ir. J., directeur Staatsmijnen - 124, 125,126

Müller, Oberstleutnant - 327

Müller, F. E., burgemeester van Rotterdam - 352, 353

Müller, L. von, van de Staf van General Christiansen - 324

Müller, SS-Hauptsturmführer - 311

Müller Lehning, H. W., commissaris voor niet-commercieele verenigingen en stichtingen - 211, 215

Müller-Reinert, B., Oberbereichtsleiter, biz. bevollmächtigte Utrecht - 338, 413

Mulder, G., typograaf - 151

Munter, H. C., fabrieksarbeider - 74

Münzer, W., Beauftragte in Zeeland - 150, $338,381,383$

Mussert, Ir. A. A., leider Nationaal-Socialistische Beweging in Nederland - 40, $204,305,312,334,343,353,361,428$, 431 e.v.
Mutsaers, Wollenstoffenfabriek. Fa. A. N. $-140$

Mijnen - 25, 29, 35, 120, 123, 128, 141, 157,326

Domaniale mijn - 123, 124

Emma - 121-125

Hendrik - 122-124, 126, 128

Juliana - 123, 124

Laura - 123, 124

Maurits - 120-125, 397, 400

Oranje-Nassau - 123, 124, 128

Wilhelmina - 122-124, 126, 128

Willem Sophie - 124

N.A.F. (Nederlands Arbeidsfront) - 31, 49, $135-137,200,201,203,207,215,216$, $217,218,219,253,291,346,348,371$, $372,382,388,397,403,406,408,409$, 421,425

Napoleon - 433, 434

N.A.S. (Nat. Arbeids Secretariaat) - 98

Nationaal Comité tot Verzet - 13, 93, 95

Nationale Levensverzekeringsbank - 153

N.S.B.- (ers) - 23, 37, 51, 55, 58, 70, 72, $81,85,87,88,89,90,96,99,100,108$, $116,127,130,135,137,140,143,146$, $149,155-159,161,162,166,169,207$, $211,218,227,243,247,257,272,274$, $276,283,305,312,314,315,334,336$, $342,343,346,350,352,353,360,361$, $371,372,374,376,379,382,383,388$, $391,392,393,394,395,397,399,400$, $401,404,405,406,408,412,413,416$, $421,422,427,428,431$ e.v.

N.S.D.A.P. - 247, 383, 391, 393, 397, 400, $404,412,415,432$

N.S.F. (Nationaal Steun Fonds) - 188

N.S.N.A.P. - 350

"Nedalo", Lonneker Apparatenfabriek 219,227

"Nederland", Stikstofverbindingsindustrie 158

Nederlandse Arbeidsdienst - 24, 303, 337

"Nederland's fier protest", illegaal rapport van Dr. R. J. van Dam - 58

Nederlandse Dok Mij. - 178, 364, 365

Nederlandse Heide Mij. - 176

Nederlandse Instrumenten Compagnie - 130

Nederlandse Leger - 305, 306, 312, 314, $317-319,321-324,333-336,342,348-$ $353,357,362,370,376,377,384,401$

Nederlandse Regering te Londen - 27, 31, $36,37,38$ e.v., $85,86,96,111,135,375$, $376,381,424-426,428,431,433$

Nederlandse Seintoestellenfabriek - 183

Nederlandse Spoorwegen - 27, 73, 76, 77, $84,110-112,136-138,173,186,223$, $242-244,249,259,267,269,271,273$, $282,283,293,295$ 
N.V.V. - 49, 75, 200, 203, 206, 207, 208, $209,210,215,217-219$

Nederlandse Volksdienst - 212, 371, 388

„Neerlandia", Melkfabriek - 183

"Neerlandia", Zuivelfabriek - 185

Nelis, Dr. H., SS-Sturmbannführer - 287

Nemef, Slotenfabriek - 347

Neurdenburg, M. G., bedrijfsleider - 64

Ney, W., Hauptmann, Kommandant Sicherungsbereich Overijsel - 250, 253, 281, $288,329,404$

Niehaus $\mathcal{E}$ van der Berg, Machinefabriek 153

Nieuwe Amsterdamse Leder Mij. - 143

Nieuw-Buiner Glasfabriek v/h Meursing \& Co. -83

Nieuwenhuisen, A. M., burgemeester van Schoonhoven - 355

Nieuwkoop, N. van - 181

Nieuwold, P., fabrieksarbeider - 115

Nitsch, R., Major Sicherheitspolizei - 285, 289

Nitz, Major der Rüstungsinspektion 310,311

Nolte, Dr. L., Verwalter Philips-fabrieken 136, 138

Noo, H. P. de, stationschef - 181

„Nooit Gedacht”, Coöp. Stoomzuivelfabriek Hellendoorn - 241, 280

"Nooit Gedacht", R.K. Coöp. Stoomzuivelfabriek Ootmarsum - 241

„Noord", Werf De - 165

Noord-Hollandse Machinehandel - 180

Noord-Nederlandse Machinefabriek - 116

Noppen, G. van, boekhouder - 165

Norel, W. v., fabrieksarbeider - 68

Nova-autobussen - 347

„Nijverheid", N.V. Stoomweverij - 220

OBERKOMMANDO DER WEHRMACHT (OKW) - 16, 17, 308, 309, $312,316-319,321,371$

O.D. (Ordedienst) - 135, 142, 150

Odink $\mathcal{E}$ Koenderink, J. P. - 64, 216, 267, 268

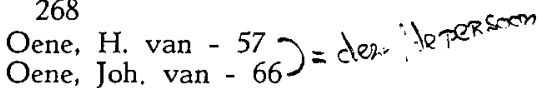

Oerlemans Klompenfabriek, Fa. H. - 143

Oeseburg, G., arts - 90

Offenberg, F., fabrieksarbeider - 339

Office of Chief of Counsel for War Crimes, Berlin Branch - 302

Oisterwijkse Textielindustrie - 143

Okkinga, P., directeur zuivelfabriek - 112

Oliefabrieken, Verenigde - 166

Oltwater, J., fabrieksarbeider - 65

Ommeren, Verffabriek van - 71

Omta, A., burgemeester van Oldehove - 110

„Ons Belang", Veilingsvereniging - 111
"Ons Belang”, Coöp. Stoomzuivelfabriek en Melkinrichting - 238, 273

„Ons Belang", Zuivelfabriek - 241

Oonk, J. H., burgemeester van Haaksbergen $-267$

Oorlogsdocumentatie, Rijksinstituut voor $7,8,27,66,121,196,198,201,204$, $205,214,221,223,232,302$

Oosterbaan, Ir. W., provinciaal voedselcommissaris in Friesland - 391

Oostwoud-Fabrieken - 96

Op Korte Golf, Illegaal blad - 48, 196, 204

Oranjeboombrouwerij - 153

Ordnungspolizei - 259, 268, 281, 323, 329, $334,339,344,345,358,365,366,386$, 387,394

Organon - 143

O.T., Organisation Todt -378

Ots, H. R. - 116

Overduin, Ds. M. - 163

Overijsels Landbouwblad - 215

Overijselse Landbouw Mij. - 214, 215

PADMOS, portier - 157

Palthe's Textielveredelingsbedrijven - 51, $63,64,233,258,259,261,273$

„Panter" Sigarenfabriek - 174

Parkzicht, Hotel - 207

„Parool, Het", illegaal blad - 14

Patent en Kristalsodafabriek - 129

Paulen, Ir. A., directeur Staatsmijn - 125

Peeze Binkhorst, H. C. M., burgemeester van Hellendoorn - 269

„Pegus" Electriciteitsbedrijf - 409, 411, 413

Penn \& Bauduin, Fa. - 158, 160

Pessink, B., fabrieksarbeider - 72

Peters, G., fabrieksarbeider - 74

Pette, Chocoladefabriek - 180

Philips, Dr. A. F. - 136

Philips, Ir. F. - 138

Philips, Gloeilampenfabriek - 22, 25, 35, $36,134,136-139,157,304,328,344$, $345,374,398,430$

Picus Houtindustrie - 137

Piekhaar, D., bestuurslid "Groene Kruis" 211

Piesbergen, Dr. H., Regierungspräsident 314

Plaatijzer Industrie - 347

Plaatwellerij, De - 181, 365

Plekker, S. L. A., burgemeester van Haarlem - 415

Poel, Dr. Alb. van de -7

Pol, J. A., slager - 117

Polet, F. - 100

Polizeistandrecht, $Z_{\text {ie: }}$ Standrecht

Pope's Metaaldraadlampenfabriek - 130

„Porceleyne Flesch, De" - 156, 157, 421

Posma, A., bedrijfsleider - 125

Post, J. - 81, 83 
Postcheque- en Girodienst - 154, 155, 417, 419

Postema, J., veehouder -85

P.T.T. - 73, 86, 105, 106, 127, 129, 130 , $136,137,143,146,155-158,167,176$, $, 228,248,351,356,374,393,395,408$, $416,417,430$

P.R.A. (Politieke Recherche Afdeling) 196, 287

Prakke, Gebr. - 76

Princenhage, fabriek - 141

Prins, Scheepshelling - 71

Prins Visser, A. J., directeur Kloos \& Zoon $-165$

„Prinses”, Zuivelfabriek De - 185

Proper, H., fabrieksarbeider - 68

Protestantse Kerkgenootschappen - 74, 75, $96,98,199$

Gereformeerde Kerk - 58, 83, 90, 101, 111, $168,376,392$

Christelijke Gereformeerde Kerk - 75, 171

Provinciaal Electriciteitsbedrijf Friesland 94

Prov. Geld. Electriciteits Mij. - 74

Prov. Utrechtse Elec. Mij. - 173

Provinciale Waterstaat Z. Holland - 417, 419

PUEM, Pro. Utr. Elec. Mij. - 409, 411, 413

Pijpers, J., lid illegale organisatie -70

QUADVLIEG, J. M. Z., fabrieksarbeider 74

RAAD VAN ARBEID - 127, 130

Raad van Bestuur in Arbeidszaken - 215, 216

Raaymakers Textielfabriek, J. A. - 143

Rademakers IJzergieterij - 153

Radiodistributiecentrale, Almelo - 261

Radio-Hilversum - 38, 40

Radio-Oranje - 27, 38, e.v., 95, 96, 120 , $138,142,376,381,382,401,414,419$, 424,433

Ramie-Uunion - 232, 255, 258

Randwijk's Grafische Machine- en Materialenhandel - 158

Rappard, Mr. L. R. J. Ridder van, burgemeester van Gorinchem - 352, 381

Rauter, H. A., commissaris-generaal voor het veiligheidswezen $-15,16,22,23,24$, $36,37,124,126,155,159,250,271,281$, $282,284,286-290,305,306,317,323-$ $331,334,338,341,353,358,361,366$, $368,369,375,377,378,406$

Rawi-Matrassenfabriek - 116

Recter, Dr. C. G., chef soc. afd. H. ten Cate $\mathcal{E}$ Co. - 259

Reekum, Techn. Bur. Van - 347

Rees, Scheepswerf van - 161

Reesink $\mathcal{E}$ Co., H. J. - 77

Reichsbahn - 243
Reichsernährungsministerium - 308

Reichssicherheitshauptamt - 303, 333, 344, $345,356,365,370,377$

Reineveld, Fabriek van - 156, 157

Reinierse, fabrieksarbeider - 141

Remerij, B. - 104

Renner, offizier Grüne Polizei - 162

Reus, C. de, fabrieksemployé - 73

Reydon, Mr. H., secr.-gen. dept. van Volksvoorlichting en Kunsten - 305

Ribbentrop, J. von, minister van Buitenlandse Zaken - 321, 322

Richy, H., inspecteur van politie - 283

Riet, F. L. v. d. - 109

Rietveld, L. C., commissaris voor de belangen van de voormalige Nederlandse weermacht - 334, 337

Rigtersbleek v/h G. J. van Heek \& Zn. $52,219,233,257,258$

Ritter, K., Botschafter z.b.V., Auswärtiges Amt - 17, 321, 322, 323

Ritter, Dr. P. H., „De Utrechtenaren” - 173

Rocarto's Cartonnagefabriek - 70, 347

Rode Kruis, Duitse - 90

Rommel, E., veldmaarschalk - 13

Romijn, Mr. Dr. A. J., burgemeester van Winschoten - 187

Ronner, G. - 99

R.K. geestelijkheid - 78, 129, 368, 373, 376, 398

R.K. Herderlijk Schrijven - 376

R.K. Jonge Boerenstand - 132, 144, 147, 374

R.K. Ned. Boeren- en Tuindersbond - 132, 144

R.K. Staatspartij - 59

R.K. Werklieden Verbond 132, 200, 210, 215

Roorda, Tj., afd. chef Stork's Fabrieken 206, 223, 229, 294

Roskam, E. J., boerenleider - 215, 389

Ross, W., Beauftragte voor Friesland $98,338,389,391$

Ross van Lennep, Ir. D. P. - 122, 124, 125,126

Rossum, W. van, fabrieksarbeider - 115

"Rotterdammer" De, Zie: Broek, Ir. H. J. v. d.

Rotterdamse Bankvereniging - 420

Rotterdamse Droogdok Mij. - 152

Rotterdamse Verzekering-Societeiten - 153

Roukens, Dr. W., ,De Limburgers" - 119

Rückert, J. J. G. E., burgemeester van Enschede - 256

Rüstungsbetrieb - 246

Rüstungsinspektion - $60,159,179,217,226$, $246,249,303,308,310,311,324,368$, $371,381,383,384,413,414$

Rüstungsministerium - 308

Ruiter, G. J., directeur-generaal van de landbouw - 433 
Russchen, J., landbouwer - 101

Ruyters, B., controleur C.C.D. - 124, 127

Rijckevorsel, Jhr. Mr. Dr. A. B. G. M. van, Commissaris der Provincie Noord-Brabant $-399$

Rijkhoff, Th. - 180, 340

Rijksbelastingsdienst (Limburg) - 126

Rijksbureau voor Chemische producten - 155

Rijkscommissaris voor het bezette Nederlandse gebied Zie: Seyss-Inquart, Dr. A.

Rijksinstituut voor Oorlogsdocumentatie $Z$ ie: Oorlogsdocumentatie, Rijksinstituut voor

Rijkskanselarij, Berlijn - 306, 308, 312

Rijkskolenbureau - 155, 417, 419

Rijkszuivelcentrale - 155

„Rijn", Scheepswerf De - 158

Rijpma, Mevr. M. E. - 212

Rijwiel Industrie v/h F. en J. van Werven 83,84

SS Zie: Waffen-SS

"Salland", Zuivelfabriek - 55

Samel, B., Hauptsturmführer - 328

"Samenwerking", Coöp. Stoomzuivelfabriek $-241,280$

"Samenwerking", Coöp. Zuivelfabriek - 168

Samsom, Drukkerij - 417

Santvliet, S. van - 138

Sark, W. Th. J. van, fabrieksarbeider - 65

Sauckel, F., Generalbevollmächtigte für den Arbeitseinsatz - 16, 303, 304, 307, 311, $315,316,317,320,321,378$

Savelsberg, R., electro-monteur - 124

Schadee, commissaris van politie Gouda 351

Schatz, luitenant van de Ordnungspolizei 268,281

Scheepsbouwkundig Proefstation - 74

Scheepswerven v/h H. H. Bodewes - 77

"Schelde", Scheepswerf De - 149

Scheps, J. H., oprichter illegaal blad „Op Korte Golf" - 48, 196, 204, 205, 210, 291

Schilte \& Zonen's Houthandel - 176

Schimmelpenninck, R. J., raadspensionnaris $-432$

Schlüter, Dr. K., Landgerichtsrat - 326, 327,328

Schmidt, F., General-kommissar z.b.V. $37,303,304,312,313,315-317,320$, $330,332,346,370,379$

Schmidt, W, Beauftragte Limburg - 398

Schmidt \& Z Z., Tricotagefabriek A. - 117

Schmitt, Instrumentenfabriek - 175

Schneider, Dr, E., Beauftragte Gelderland 409

Schoenfabriek v/h W. Lourijse \& Zoon - 143

Schoenmakerij, Centrale - 347

Schokbeton, Fabriek - 166

Scholten, lid fabriekskern - 223
Scholten E Zn., J. F. - 52, 231, 232, 254 , 257, 258

Scholtens, Mr. H. W. J., burgemeester van Weerselo - 277

Scholtens concern - 114, 115

Scholtenshuis, Bureau SD te Groningen $100,105,106,108,109,110,112$

Schouten, Ir. J. W. - 177

Schouwenburg. H., chef de bureau - 265

Schröder, Dr. W., Beauftragte Overijssel $217,218,327,338$

Schuemann, M., Kreisleiter - 315, 371

Schuhmacher, bedrijfsleider - 68

Schwebel, Dr. E. A., Beauftragte ZuidHolland - 158, 416 e.v., 327, 338

Schweitzer, W. J. B., directeur van de Mijnen "Laura" en "Vereniging"

$\mathrm{SD}$ zie: Sicherheitsdienst

S.D.A.P. - 59, 71, 75, 99

Sellmer, H., Beauftragte Drenthe - 389

"Servo", Chemische Fabriek Delden - 66, 275

Seyss-Inquart, Dr. A., Rijkscommissaris voor het bezette Nederlandse gebied - 15, 22,

$23,25,37,120,155,207,210,222,305$, $306,307,308,309,312,314,317,319$, $320,321,323,325,326,327,334,337$, $346,358,360,361,362,371,376,377$, $379,380,398,422,429,430,433$

Sicherheitsdienst - 31, 85, 105, 106, 109$111,115,117,123-127,130,134,135$, $138-142,144,146,147,153,161,162$, $164-167,175,247,266,284,285,290$, $331,334,366,367,369,370,374,381$, $385,386,387,393,404,415,418,421$, 423

Sicherheitspolizei - 22, 25, 28, 30, 31, 33, $34,35,62,65,153,254,265,266,273$, $281,282,284,285,287,290,329,330$, $331,334,339,344,345,351,358,366$, $369,370,377,387$

Sicherungsbereiche - 281, 329, 331, 334, $358,365,387,404,411,412,421$

Sichtermann, Mr. M., burgemeester van Almelo - 260, 261

Sietsma, J. T. -70

Sikkinga, A. - 109

Slootmans, C., „De Westbrabanders" - 133, 145

Slort, M., lid illegale organisatie - 70

Slotboom, H. - 63, 256.

Sluis, Gebr., Zaadhandel - 185

Sluis, T. van der, zangeres - 203

Smaalen, W. F. G. L. van, bedrijfsleider 167

Smeets, Drukkerijen - 130

Smid, J. - 101

Smit, J. J., directeur drukkerij - 221

Smit \& Zoon, drukkerij H. L. - 49, 221, 222

Smit, Scheepswerf J. \& K. - 165 
Smit, W. J., fabrieksarbeider - 166

Smit $\&$ Co's machinefabriek - 165

Smit $\mathcal{E} Z$ Zn., Scheeps- en Werktuigbouw 165

Smits, H., directeur confectiefabriek - 261

Snoeven \& Hooymakers, Fa. - 143

Sondereinsatzaktion (S.E.-aktion) - 310

Sonderkommando SS - 79

Spanner, Prof. Dr. H., afd. Staatsrecht v. h. Rijkscommissariaat - 327

„Spectrum”, Ververij en Blekerij - 139

.Sphinx", Aardewerkfabriek De - 127

"Spinspan", fabriekskrant - 263

Spitzen, Mr. D. G. W., secretaris-generaal dept. van Waterstaat - 125,126

Spoor, Mosterdfabriek, W. A. - 79

Spoorwegen, Nederlandse - 136, 137, 138, $173,186,359,370,395,403,408-411$, $426,428,430,431$

Spoorijzer, Delft - 156

Sprössing, ingenieur van Stork - 246

Spruyt $\mathcal{E}$ Co. - 77

Staaldraadkabelfabriek v/h J. C. den Haan $-161$

Staargaard, C. F., Commissaris der provincie Groningen - 393, 394

Staatsmijnen Zie: Mijnen

Stadsreinigingsdienst Groningen - 106

Stampe, M., Oberregierungsrat - 327

Standrecht - 22, 28, 29, 32, 61, 64, 72, 73, $75,79,85,90,111,123,146,153,160$, $162,179,181,247,250,256,260,263$, $265,267,269,271,272,277,278,286$, $287,325,327,328,330,332,334,337$, $338,342,349,351,352,358,359,362$, $363,367,378,381,383,384,385,387$, $390,391,393,404,407,409,413,414$, 419

Standgericht $-29,30-33,35,66,68,69$, $72,73,78,79,88,90,106,110,125$, $138,146,180,266,271,277,284,287$, $288,293,327,329,330,331,334,344$, $345,355,357,358,366,369,385,387$, $391,393,407,415,421$

Steeg, J. ter, directeur Zuivelfabriek - 273, 274

Steggink, G. J., loco-burgemeester van Hengelo - 246, 247, 283

Steinmeyer, J. B. J. - 63, 256

Stekelenburg, G., bedrijfsleider - 164

Stel, Sj., groenteverkoper - 100

"Ster", Borstelfabriek De - 347

"Ster", Veevoederfabriek De - 180

Sterenborg, Schoenfabriek, Fa. H. B. - 76

Stimmungsberichte - 37, 423 e.v.

Stoel- en meubelfabriek v/h Gebr. van Rooyen - 176

Stoetzer, A. A. M., districtsleider NSB in Noord-Brabant - 372, 400
Stokman, Dr. S., „Verzet Ned. Bisschoppen" - 212

Stoomhamer, Timmerfabriek De - 176

Stoomspinnerijen en Weverijen $\mathrm{v} / \mathrm{h} \mathrm{S}$. J. Spanjaard - 52, 64, 217, 233, 262, 263, 264

Stoomwasserij $\mathrm{v} / \mathrm{h} \mathrm{H}$. C. Timmers - 161

Stork, C. F., directeur Machinefabriek $62,218,253$

Stork, F. G., bedrijfsleider - 217, 246, 248, 254

Stork $\mathcal{E}$ Co., Koninklijke Weefgoederenfabriek, C. T. -232

Stork $\mathcal{E}$ Co., Machinefabriek Gebr. - 21, $47,48,50,51,60,67,117,134,182,202$, $206,207,218,219,222-26,228,230$, $232,246,247,249,253,254,262,269$, $285,287,291,293,294,402,403$

Strafgevangenis Scheveningen - 70, 277

Strating, $H$., bedrijfsingenieur - 181

Strobel. M., hoofd Duitse Politie, Maastricht $-123,124,125$

Struycken, Mr., hoofd soc .dienst HKI - 142

Studentenaanmelding / Loyaliteitsverklaring $-361,372,378,393,427,428,430$

Stiihler, Dr. C., Regierungs Vize-Präsident 327

Stuurmans, bedrijfsleider - 340

Sijes, B. A., wetenschappelijk medewerker van het Rijksinstituut voor Oorlogsdocumentatie $-7,21,49,66$

Sijthoff's Uitg. Mij., A. W. - 167

TAAI, O., wachtmeester Rijkspolitie - 284

Tabak, K., bestuurder textielarbeidersbond 210,218

Taminio's Jamfabriek - 80

Technische Noodhulp - 394

Teeuw, C. ,onderwijzer - 161

Tempelaars, M., mijnwerker - 124

Terpstra, R., landarbeider - 100

Terwindt, Arntz en Holdus - 139

Terwindt, Steenfabriek - 79

Textiel Bij. v/h Gebr. Driesen - 77

Thiel, R., Beauftragte Noord-Brabant 134, 401

Thana, E., fabrieksarbeider - 113

Thomassen, Machinefabriek - 72

Thomsen, SS-Hauptsturmführer - 285, 286, 287

Thijn, Ir. G. A., provinciaal voedselcommissaris in Drenthe - 388

Tilanus, N. C., directeur textielfabriek - 273

"Timtur", Schoenfabriek - 143

Tjolkens, J., fabrieksarbeider - 72

"Todt" Polizeiregiment - 387, 404

Togt, W. v. d., bedrijfsleider - 167

Tomado-fabriek - 166

Toonkunst, Mij. tot Bevordering der - 203

Toussaint, S. H., mijnwerker - 124 
Trachsler, E., bedrijfsleider - 265

Tricot-fabriek - 144

Tricot-, Kapok- en Verenfabriek v/h Scholl, Engberts en Scholle - 233

Tricotagefabrieken - 130

Trip, B., landbouwer - 90, 341

"Trouw"-groep, illegale organisatie -58

"Tubantia", Spinnerij - 232, 255, 258

Twenthe, Reisbureau te Enschede - 54, 242,243

"Twenthe", Stoomspinnerij - 52, 233

Twents Centraal Station voor electrische stroomlevering - 225, 226, 232, 249

T.E.T. (Twentse Elec. Tramweg Mij.) $54,233,243,255$

Twentse Kabelfabriek N.V. - 65, 267

Twents Nieuwsblad - 221

Twentse Textielfabrikanten Vereniging -

T 216

Twijnstra's Oliefabrieken, U. - 103

"Tijd", Oliefabriek De - 180

Tijl, Erven, Uitgeverij - 59

UEBERFALLKOMMANDO - 61, 251

"Unique", Handschoenenfabriek - 143

VAART, G. v. d. - 109

"Valk", Margarinefabriek, De - 183

Valk, S. L. v. d., directeur postkantoor 157

Varvik, H. W. - 62, 252

Vasbinder, W., burgemeester van Bellingwolde - 187

Veen, K. van, fabrieksarbeider - 339

Veen, M. van, burgemeester van Enschede 202

Veer, van der, fabriek - 139, 140

Veer, E. A. van der, kantoorbediende -66

Veer, W. A. van der, boekdrukker - 66, 340

Velden, Gloeilampenfabriek, Gebr. v. d. - 77

Velden, Klompenfabriek, Gebr. v. d. - 144

Velo, Wasmachinefabriek - 168

Vennink, Mej. E. G., telefoniste - 248

Verenigde Chemische Fabriek - 153

Verenigde Jouster Drukkerijen - 103

Verhoef, A. L. - 162

Verhoeven, P. J., fabrieksarbeider - 138

Verkennis, W. A., bedrijfsleider - 157

Verordnungblatt für die besetzten niederländischen Gebiete - 307

Versteeg, J. A., fabrieksarbeider - 73

Versteeg, IJzergieterij - 160

"Verwachtiñg", Coöp. Zuivelfabriek - 185

Verwey de Winter - 228, 248

Vessem, Mr. A. J. van, gemachtigde voor rechtskundige aangelegenheden der NSB 432

Völckers, Dr. C., bijz. gevolmachtigde Rotterdam - 338
„Victoria”, Biscuit- en Chocoladefabriek 158

Vincent, J., zangeres - 203

$V$ is, Gebr. - 185

Visser, G., districtsleider N.V.V. - 210, 218

Vitrite Works, De - 149

Vlam, J. B. - 206, 209

Vliet, Ir. J. van, mijningenieur - 125

Vliet Azn., A. van, directeur scheepswerf 164

„Vlijt”, Meelfabriek, De - 180

Vogel, E. O., Untersturmführer - 328

Vogelenzang, Kalkzandsteenfabriek - 176

"Volharding", Melkinrichting De, Hengelo $236,237,238,241$

"Volharding", Coöp. Zuivelfabriek, Denekamp - 241, 276

"Volharding", Touwfabriek De - 116

"Volk en Vaderland", Weekblad der NSB - 353, 428, 432

Volkshuis, R.K., Heerlen - 120

Voorlichtingsdienst, Nederlandse, te Londen - 39

"Vooruit", Scheepswerf - 185

Voorwinde, A., hoofd bureau Sociale Zaken Philips - 136, 137

Vos van Steenwijk, Mr. Dr. R. H. Baron de, Commissaris der provincie Drenthe - 388

Voûte, E. J., burgemeester van Amsterdam 415,421

Vredenburg, W., fabrieksarbeider - 340

Vreeswijk, Ir. D. W. van, lid directie Papierfabriek - 73

"Vreugde en Arbeid" - 216, 291

"Vriendenkring", Bierbrouwerij De - 131

Vries, A. de, c.s., Nederlandse Volkskarakters" - 75, 81, 83

Vries, B. de, landbouwer - 102

Vries, K. de, smidsknecht - 99

Vries, J. C. de, directeur Philips-fabrieken - 138

Vries Reilingh, Dr. de, arts - 212

Vries Robbé \& Co., De - 160, 161

Vriezema, B. K. - 112

Vroeg-in-de-wei, functionaris N.A.F. - 136

Vroom \& Dreesman - 139

Vruchten- en conservenfabriek - 181

"Vrije Volk, Het", illegaal blad - 120

"Vulcanus", IJzergieterij - 35, 67, 68, 347. 348

WAARD Sr., G. S. de, keurmeester 166,168

"Waarheid", De, illegaal blad - 158

Waffen-SS - 13, 61, 69, 72, 73, 79, 98, $159,175,180,247,264,282,289,329-$ $331,334,344,358,366,369,388,407$, 410,411

Wal, S. de - 109 
Waldkötter, G. A., inspecteur van politie $247,282,283$

Walraven, wnd. politiepresident Arnhem 285,290

Walraven, J., fabrieksarbeider - 78

Waltz, luitenant Grüne Polizei - 270

Warlimont, General W., van OKW 321,322

Wasserschutzpolizei - 159

Wassink, Confectiefabriek - 277

Waterstaat - 129

"Wato"-fabriek - 54, 242

"Weddehoen", Coöp. Zuivelfabriek - 237, 241

Weeme \& Zn., ter - 76

W.A. (Weerafdeling der NSB) - 59, 379, $388,400,404,408,416$

"Weerselo", Coöp. Stoomzuivelfabriek 241,280

Weermacht, Duitse - 117, 306, 310, 311, $312,324,378$

Weidlich, K., Beauftragte des Reichskommissars voor Overijsel - 60, 61, 64, $217,246,247,248,251,252,260,261$, $270,273,277,284,289,293,338,405$

Weima, F. - 100

Weimar, W., fabrieksarbeider - 74

"Welgelegen", Scheepswerf - 96

Wendt, Dr., SS-Richter - 329, 341, 342

Wenten, weermachtsbedrijf - 409

Werf, G. v. d. - 112

Werf Jan Smit Czn. - 165

Werkspoor - 174, 178, 358, 363, 364, 414

Werner, Mej. E. - 140

Werts, G. van, fabrieksarbeider - 138

Werven, H. J. van, fabrieksarbeider - 68

Westerman, Confectiefabriek, Fa. - 76

"Wetri", Tricotagefabriek, De - 183

Weyenborg, G. J., fabrieksarbeider - 62, 252

Wibbelink, Expeditiebedrijf - 278

Wickel, Legationsrat - 37

Wientjes, Hotel - 215

Wier, J. v .d. - 109

Wier, U. v. d. - 109

Wierdense Export slachterij - 66, 267, 277

Wieringen, Ds E. van - 163

Wiersma, G. - 180, 340

Wiersma, J. P., „De Friezen” - 93

Wildeboer, J. L., agent van politie - 232

Wilhelmina, Koningin - 335, 343, 349, 376. 424,433

Wilkens Meihuizen $\mathcal{E}$ Co. - 117

Willard, Tapijtweverij - 183

Willem II, Sigarenfabriek - 143

Wilton, Scheepsb. Mij. - 153

.Wim", geheim agent - 43
Wimmer, Dr. F., commissaris-generaal voor bestuur en justitie - 326, 338

Wingerden, Kopergieterij, Fa. van - 161

WinkeIman, Generaal H. G. - 318

Wit, Th. de - 215

„Wit-Gele Kruis" - 212

Withold's Mandenmakerij - 56

Witkamp, Kennemer Machinefabriek - 181

Witte, B. de, landbouwer - 103

Wöhrman, Fa. - 77

Wölk, H., hoofd Aussendienststelle Rotterdam van Sipo en de SD - 141, 342, 343, 349,355

Woerden, Fa. van, kaashandel - 103

Woerlee, C. - 223

Woltersom, Mr. H. L., directeur van de Rotterdamse Bank - 420

Woud, A., zangeres - 203

"Woudbloem", De, Coöp. Aardappelmeelfabriek - 34,113, 115

Woudenberg, H. J., leider N.A.F. - 49, 207, $208,209,210,215,218,219,425$

Woudstra, M., melkventer - 106

Wuelisch, General H. H. von, chef staf General Christiansen - 316, 325, 372

Wuyster, J. A., commisaris van politie. Hengelo - 247, 282

Wijffels, Ir. F. C. M., inspecteur-generaal der mijnen - 122, 125

Wijker, J. - 181

Wijlens, A. B., fabrieksarbeider $-65,268$

Wijman, A., fabrieksarbeider - 78

Wijnen, W. van, directeur Goudse Melkinrichting - 355

IJKEMA, A., burgemeester van OosterNijkerk, gem. Oost-Dongeradeel - 100

IJpma, J., „Ned. Volkskarakters” - 170

ZADELFABRIEK v/h van der Kloot Meyburg - 73

Zalsman, Drukkerij, Fa. - 58

Zande, Fa. v. d., Meelfabriek - 78

Zand'vliet, S. van, fabrieksarbeider - 146

Zeeuw, W, burgemeester van Rijssen 272,273

Zeppelin, Nettenfabriek van - 347

Zetten, D. van, fabrieksarbeider - 79

Zomer \& Keuning's Uitg. Mij., Gebr. - 74

Zoutziederij $\mathrm{v} / \mathrm{h}$ Kolff $\mathcal{E}$ Vis -153

Zuidema, J., melkventer - 106

"Zuiden", Cartonnagefabriek, Het - 139

Zuivelbank, Coöp. - 94

,Zutphen", Ind. Mij. - 77

Zwaan, Fa. M. - 143

Zijlstra, J. - 99

Zijlstra's Meubelfabriek - 103 